\title{
Catalytic Enantioselective Boryl and Silyl Substitution with Trifluoromethyl Alkenes: Scope, Utility, and Mechanistic Nuances of Cu-F $\beta$-Elimination
}

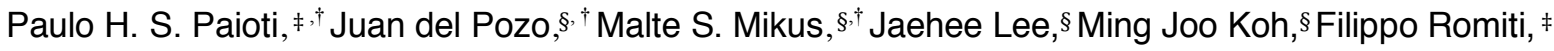 \\ Sebastian Torker, $*, \neq$ and Amir H. Hoveyda*,§,

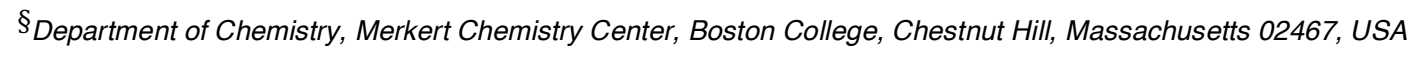 \\ ¥ Supramolecular Science and Engineering Institute, University of Strasbourg, CNRS, 67000 Strasbourg, France
}

email: amir.hoveyda@bc.edu or ahoveyda@unistra.fr;

sebastiantorker@gmail.com (for computational work)

\section{Supporting Information. Part I. Experimental}

\section{Table of Contents}

1. General 2

2. Reagents

3. Synthesis and Characterization of Representative Trifluoromethyl-Substituted

Alkenes

3.1. Aryl-substituted alkenes

3.2. Alkyl-substituted alkenes

4. Optimization Studies for Boryl and Silyl Substitutions .

4.1. Evaluation of various reaction parameters in boryl substitutions..................................... 7

4.2. Evaluation of ligands for enantioselective boryl substitution ......................................... 7

4.3. Evaluation of ligands for enantioselective silyl substitution .........................................

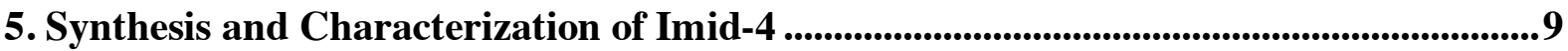

6. Procedures and Characterization of Allylic Substitution Products ...............................11

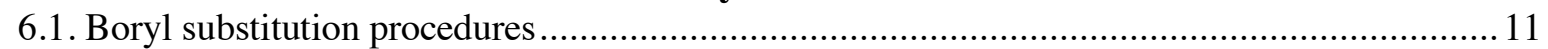

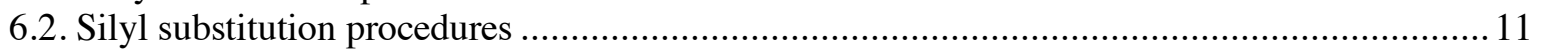

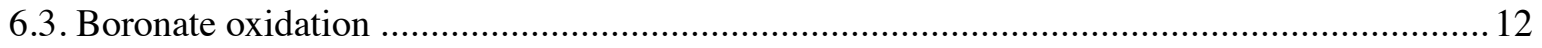

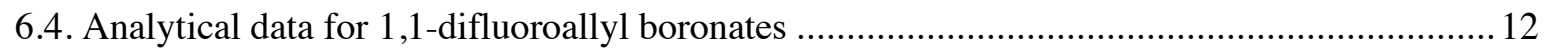

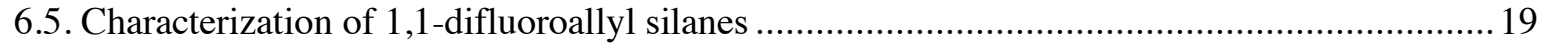

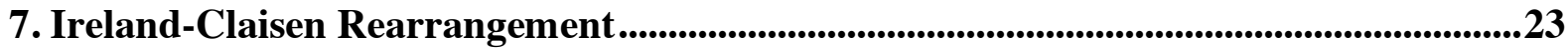

8. Gram-Scale Catalytic Enantioselective Boryl Substitution and Subsequent Addition to Aldehyde and Catalytic Diastereoselective Boryl Substitution ...........................................26

9. Trapping of the $\mathrm{Cu}$-alkyl Intermediate with $\mathrm{D}_{2} \mathrm{O}$...................................................................27

10. Synthesis and Characterization of $\mathrm{Cu}-\mathrm{Alkyl}$ and $\mathrm{Cu}-\mathrm{Allyl}$ Complexes.........................28 


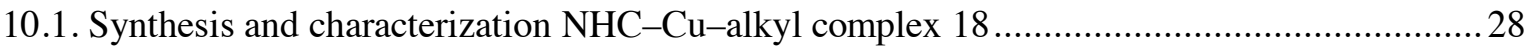

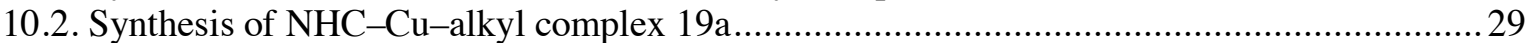

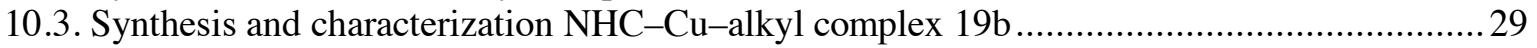

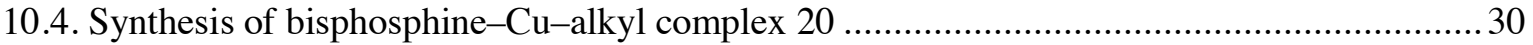

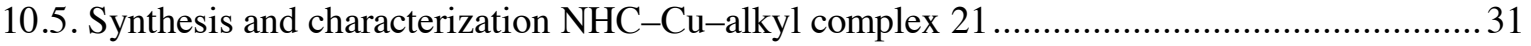

11. Investigation of the Resting State of the Catalytic Cycle ................................................31

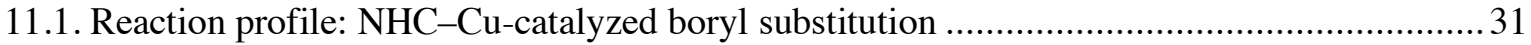

11.2. Reaction profile: Bisphosphine-Cu-catalyzed boryl substitution......................................... 32

12. Studies Regarding the Rate of $\mathrm{Cu}-\mathrm{F}$ $\beta$-Elimination ....................................................33

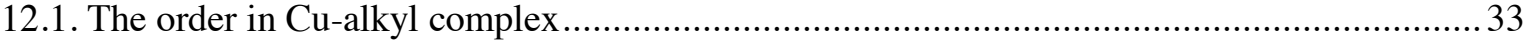

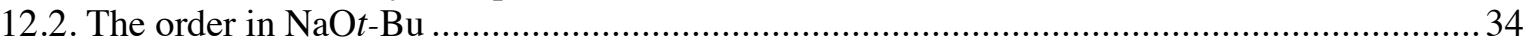

12.3. The order in $\mathrm{MeOH}$

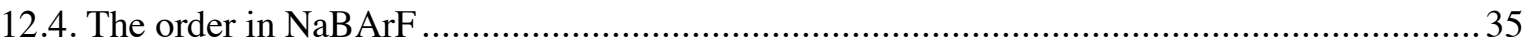

13. Studies on the $\mathrm{Cu}-\mathrm{F}$ Elimination of $\mathrm{Cu}$-Alkyl Complexes ...............................................36

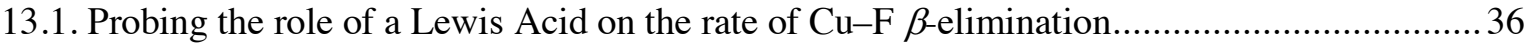

13.2. Probing the role of a Lewis base on the rate of $\mathrm{Cu}-\mathrm{F} \beta$-Elimination ..................................... 36

14. Transmetallation of Boronates with $\mathrm{CuOt}$-Bu Complexes ..........................................36

14.1. Reactions of 10a with bisphosphine-CuOt-Bu and $\mathrm{NHC}-\mathrm{CuOt}$-Bu complexes ........................36

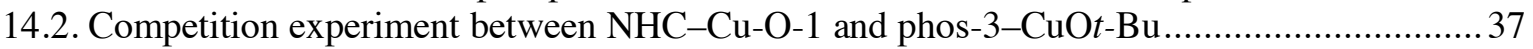

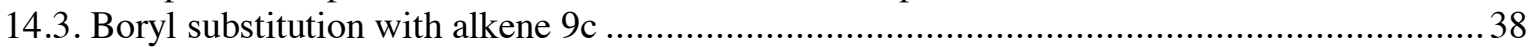

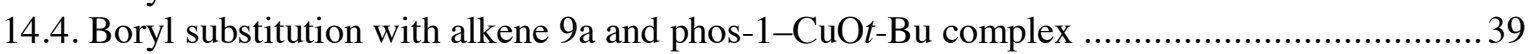

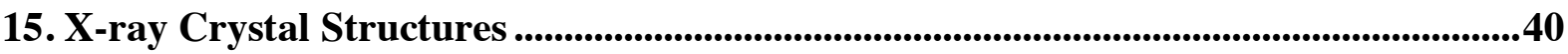

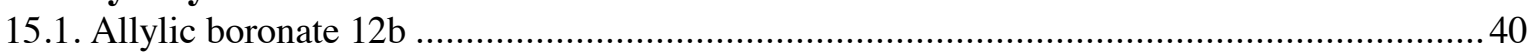

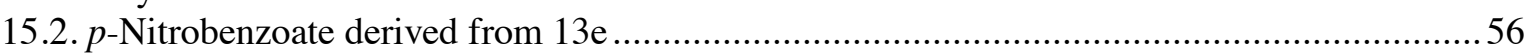

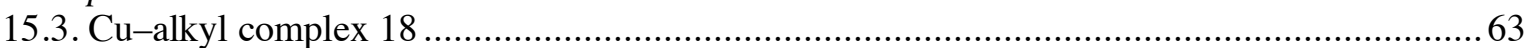

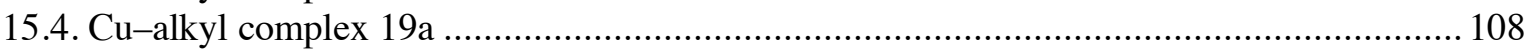

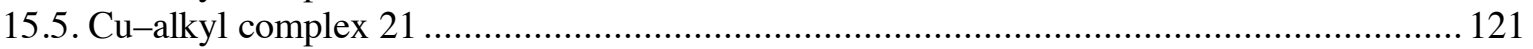

16. NMR Spectra .............................................................................................................................................143

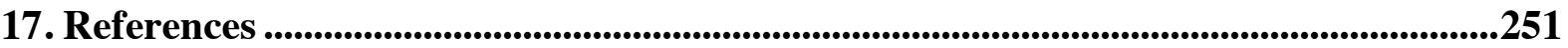

\section{General}

Infrared (IR) spectra were recorded on a Bruker FT-IR Alpha (ATR mode) spectrophotometer, $v_{\max }$ in $\mathrm{cm}^{-1}$. Bands are characterized as broad (br), strong (s), medium (m), and weak (w). ${ }^{1} \mathrm{H}$ NMR spectra were recorded on Varian Unity INOVA 400 (400 MHz), 500 (500 MHz), or 600 $(600 \mathrm{MHz})$ spectrometers. Chemical shifts are reported in ppm from tetramethylsilane with the solvent resonance as the internal standard $\left(\mathrm{CDCl}_{3}: \delta 7.27 \mathrm{ppm}\right)$. Data are reported as follows: chemical shift, integration, multiplicity $(\mathrm{s}=$ singlet, $\mathrm{d}=$ doublet, $\mathrm{t}=$ triplet, $\mathrm{q}=$ quartet, $\mathrm{pent}=$ pentet, $\mathrm{m}=$ multiplet, $\mathrm{br}=$ broad, app = apparent), and coupling constants $(\mathrm{Hz}) .{ }^{13} \mathrm{C} \mathrm{NMR}$ spectra were recorded on Varian Unity INOVA 400 (100 MHz), 500 (125 MHz), or 600 (150 $\mathrm{MHz}$ ) spectrometers with complete proton decoupling. Chemical shifts are reported in ppm from tetramethylsilane with the solvent resonance as the internal standard $\left(\mathrm{CDCl}_{3}: \delta 77.23\right.$ ppm). ${ }^{19} \mathrm{~F}$ NMR spectra were recorded on a Varian Unity INOVA $400(376 \mathrm{MHz})$ and 600 (564 $\mathrm{MHz}$ ). Chemical shifts are reported in ppm with $\alpha, \alpha, \alpha$-trifluorotoluene as an external or internal standard (-63.72 ppm). ${ }^{31} \mathrm{P}$ NMR spectra were recorded on a Varian Unity INOVA 
$400(161 \mathrm{MHz})$ and $600(242 \mathrm{MHz})$. Chemical shifts are reported in ppm with $85 \% \mathrm{H}_{3} \mathrm{PO}_{4}$ in $\mathrm{H}_{2} \mathrm{O}$ as an external standard $(\delta 0.0 \mathrm{ppm})$. Data are reported as follows: chemical shift, integration, multiplicity $(\mathrm{s}=$ singlet, $\mathrm{d}=$ doublet, $\mathrm{t}=$ triplet, $\mathrm{q}=$ quartet, pent $=$ pentet, $\mathrm{m}=$ multiplet, br $=$ broad, app = apparent), and coupling constants $(\mathrm{Hz})$. High-resolution mass spectrometry was performed on a JEOL AccuTOF DART (positive mode) or an Advion Expression CMS (ESI+ or ESI-) at the Boston College Mass Spectrometry Facility. Enantiomeric ratios were determined by HPLC analysis (high-performance liquid chromatography) with a Shimadzu chromatograph [Chiral Technologies Chiralcel AZ-H (4.6 x $250 \mathrm{~mm}$ ), Chiral Technologies Chiralcel OC-H (4.6 x $250 \mathrm{~mm})$, Chiral Technologies Chiralcel OD-H (4.6 x $250 \mathrm{~mm})$, Chiral Technologies Chiralcel OJ-H (4.6 x $250 \mathrm{~mm}$ ), Chiral Technologies Chiralcel OZ-H (4.6 x $250 \mathrm{~mm})$, or Chiral Technologies Chiralpak AD-H (4.6 x $250 \mathrm{~mm})$ ] in comparison with authentic racemic samples. Specific rotations were measured on a Rudolph Research Analytical Autopol IV Polarimeter. Melting points were measured on a Thomas Hoover capillary melting point apparatus and are uncorrected. Unless otherwise noted, reactions were carried out with distilled and degassed solvents under an atmosphere of dry $\mathrm{N}_{2}$, oven- $\left(135^{\circ} \mathrm{C}\right)$ or flame-dried glassware, and standard dry box or vacuum-line techniques. Hexane, toluene, diethyl ether, benzene and dichloromethane were purified under a positive pressure of dry argon by a modified Innovative Technologies purification system through a copper oxide and alumina column. Tetrahydrofuran (Aldrich) was purified by distillation from sodium benzophenone ketyl immediately prior to use. All work-up and purification procedures were carried out with reagent grade solvents (purchased from Fisher Scientific) under air.

\section{Reagents}

Bis(pinacolato)diboron $\left[\mathbf{B}_{2}(\mathbf{p i n})_{2}\right]$ : purchased from Frontier Scientific, Inc., recrystallized from pentane and dried under vacuum prior to use.

2,2'-bis(diphenylphosphino)-1,1'-binaphthyl [rac-binap]: purchased from Strem and used as received.

1,3-Bis(2,4,6-trimethylphenyl)imidazolinium chloride: purchased from Aldrich and used as received.

2'-Bromo-2,6-dimethoxybiphenyl: purchased from Aldrich and used as received.

3-Bromobenzonitrile: purchased from Aldrich and used as received.

1-Bromo-2,4,6-trifluorobenzene: purchased from Oakwood and used as received.

Cesium Fluoride: purchased from Strem and used as received.

Copper(I) chloride: purchased from Strem and used as received.

1-(3-Dimethylaminopropyl)-3-ethylcarbodiimide Hydrochloride: purchased from Advanced Chemtech and used as received.

4-Dimethylaminopyridine: purchased from Advanced Chemtech and used as received.

$N, N$-Dimethylformamide: purchased from Acros and used as received.

(Dimethylphenylsilyl)boronic Acid Pinacol Ester [PhMe2SiB(pin)]: purchased from TCI Chemicals and used as received.

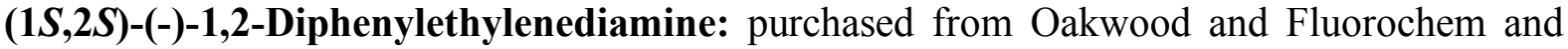
used as received. 
Ferrocene Carboxylic Acid: Purchased from Alfa and used as received.

Lithium tert-butoxide: purchased from Strem and used as received.

Iodine: purchased from Alfa aesar and used as received.

4-Iodoanisole: purchased from Aldrich and used as received.

1-Iodonaphthalene: purchased from Aldrich and used as received.

Potassium tert-butoxide: purchased from Strem and used as received.

Sodium tert-butoxide: purchased from Aldrich and used as received.

Triisopropylsilyl Trifluoromethanesulfonate: purchased from TCI America, distilled over $\mathrm{CaH}_{2}$ prior to use.

(E)-Trimethyl-(3,3,3-trifluoroprop-1-enyl)silane: purchased from TCI America and used as received.

(E)-4,4,4-trifluorobut-2-en-1-ol: purchased from Oakwood chemicals and used as received.

$\alpha, \alpha, \alpha$-Trifluorotoluene: purchased from Aldrich and used as received.

Tris(2,4,6-trimethylphenyl)phosphine: purchased from Alfa aesar and used as received.

Tris(dibenzylideneacetone)dipalladium: purchased from Strem and used as received.

Trifluoromethyl(1,10-phenanthroline) copper(I): purchased from Strem and used as received.

1-(tert-Butyl)-4-iodobenzene: purchased from Aldrich and used as received.

3. Synthesis and Characterization of Representative Trifluoromethyl-Substituted Allkenes

\subsection{Aryl-substituted alkenes}

Scheme S1. Synthesis of Aryl-Substituted Trifluoromethyl Alkenes

a. Catalytic cross-coupling with alkenyl silanes and aryl iodides:

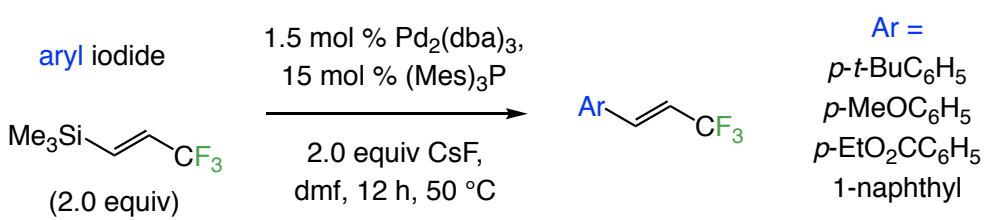

b. Catalytic cross-coupling with a carboxylic acid and an aryl bromide:

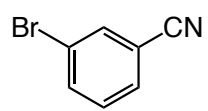

(2.0 equiv)<smiles>C=C(C(=O)O)C(F)(F)F</smiles>

$10 \mathrm{~mol} \% \mathrm{Pd}(\mathrm{OAc})_{2}$,

$$
1.0 \text { equiv Cul }
$$

2.0 equiv $\mathrm{K}_{2} \mathrm{CO}_{3}$,

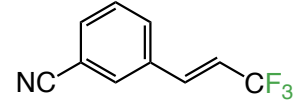

$\mathrm{nmp}, 15 \mathrm{~h}, 130^{\circ} \mathrm{C}$

c. Cross-coupling with a carboxylic acid and metal sulfonates:

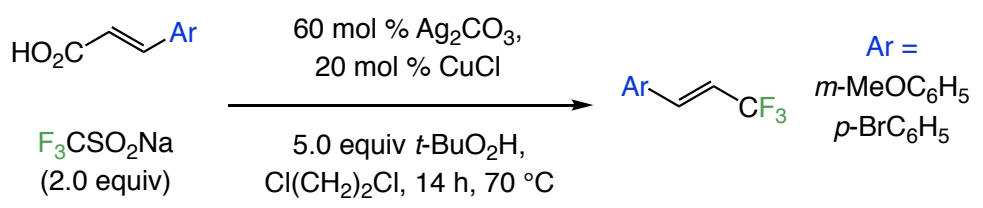

(E)-1-(tert-Butyl)-4-(3,3,3-trifluoroprop-1-en-1-yl)benzene $(97 \% \quad E), \quad(E)-1-m e t h o x y-4-$ (3,3,3-trifluoroprop-1-en-1-yl)benzene ( $98 \% E)$, ethyl (E)-4-(3,3,3-trifluoroprop-1-en-1- 
yl)benzoate $(98 \% E)$ and $(\boldsymbol{E})-\mathbf{1 - ( 3 , 3 , 3 - t r i f l u o r o p r o p - 1 - e n - 1 - y l ) n a p h t h a l e n e ~}(87 \% E)$ were synthesized according to a previously reported procedure. ${ }^{1}$ To facilitate isolation of $(\boldsymbol{E})-1-$ (3,3,3-trifluoroprop-1-en-1-yl)naphthalene, the unpurified reaction mixture was allowed to stir for $1 \mathrm{~h}$ in an equal mixture of $\mathrm{CH}_{2} \mathrm{Cl}_{2}$ and $30 \%$ aqueous $\mathrm{H}_{2} \mathrm{O}_{2}$ (to oxidize (Mes) ${ }_{3} \mathrm{P}$ ) prior to silica gel chromatography, resulting in some $E$-to- $Z$ isomerization (97:3 to 87:13 $E: Z)$.

(E)-3-(3,3,3-Trifluoroprop-1-en-1-yl)benzonitrile $(92 \% E)$ was synthesized based on a reported procedure. ${ }^{2} \mathrm{R} f=0.65$ (hexanes:EtOAc 70:30; $\mathrm{UV} / \mathrm{KMnO}_{4}$ stain). ${ }^{1} \mathrm{H} \mathrm{NMR}\left(\mathrm{CDCl}_{3}\right.$, $600 \mathrm{MHz}): \delta 7.73(\mathrm{~s}, 1 \mathrm{H}), 7.68(\mathrm{t}, J=7.9 \mathrm{~Hz}, 1 \mathrm{H}), 7.52(\mathrm{t}, J=7.8 \mathrm{~Hz}, 1 \mathrm{H}), 7.13(\mathrm{dd}, J=16.2$, $2.3 \mathrm{~Hz}, 1 \mathrm{H}), 6.27(\mathrm{dq}, J=16.1,6.3 \mathrm{~Hz}, 1 \mathrm{H}) ;{ }^{13} \mathrm{C} \mathrm{NMR}\left(\mathrm{CDCl}_{3}, 150 \mathrm{MHz}\right): \delta 135.7(\mathrm{q}, J=6.7$ $\mathrm{Hz}), 134.9,133.3,131.7,131.1,130.1,123.2$ (q, $J=267.9 \mathrm{~Hz}), 118.8$ (q, $J=34.2 \mathrm{~Hz}), 118.2$, 113.7; ${ }^{19} \mathrm{~F} \mathrm{NMR}\left(\mathrm{CDCl}_{3}, 376 \mathrm{MHz}\right): \delta-63.87$ (dd, $\left.J=6.4,2.2 \mathrm{~Hz}\right)$; HRMS (DART-TOF) m/z: $[\mathrm{M}+\mathrm{H}]^{+}$Calcd for $\mathrm{C}_{10} \mathrm{H}_{7} \mathrm{~F}_{3} \mathrm{~N}^{+}:$198.0525, Found: 198.0515.

(E)-1-methoxy-3-(3,3,3-trifluoroprop-1-en-1-yl)benzene $(>98 \% \quad E)$ was synthesized according to a reported procedure. ${ }^{3} \mathrm{R} f=0.60$ (hexanes:EtOAc 95:5; UV/KMnO 4 stain). ${ }^{1} \mathrm{H}$ NMR $\left(\mathrm{CDCl}_{3}, 400 \mathrm{MHz}\right): \delta 7.32(\mathrm{t}, J=7.9 \mathrm{~Hz}, 1 \mathrm{H}), 7.13(\mathrm{dq}, J=16.2,2.2 \mathrm{~Hz}, 1 \mathrm{H}), 7.06$ (dt, $J=7.7,1.3 \mathrm{~Hz}, 1 \mathrm{H}), 6.98(\mathrm{t}, J=2.1 \mathrm{~Hz}, 1 \mathrm{H}), 6.94(\mathrm{ddd}, J=8.2,2.6,0.9 \mathrm{~Hz}, 1 \mathrm{H}), 6.20(\mathrm{dq}, J$ $=16.1,6.5 \mathrm{~Hz}, 1 \mathrm{H}), 3.85(\mathrm{~s}, 3 \mathrm{H}) ;{ }^{13} \mathrm{C} \mathrm{NMR}\left(\mathrm{CDCl}_{3}, 150 \mathrm{MHz}\right): \delta 160.2,137.9,135.0,130.2$ (q, $J=9.2 \mathrm{~Hz}), 123.7$ (q, $J=267.3 \mathrm{~Hz}), 120.3$ (q, $J=8.9 \mathrm{~Hz}), 116.0,112.9$ (q, $J=9.0 \mathrm{~Hz})$, 55.5; ${ }^{19} \mathrm{~F} \mathrm{NMR}\left(\mathrm{CDCl}_{3}, 376 \mathrm{MHz}\right): \delta-63.36(\mathrm{dd}, J=6.6,2.1 \mathrm{~Hz}) ; \mathrm{HRMS}$ (DART-TOF) $\mathrm{m} / \mathrm{z}$ : $[\mathrm{M}+\mathrm{H}]^{+}$Calcd for $\mathrm{C}_{10} \mathrm{H}_{10} \mathrm{~F}_{3} \mathrm{O}^{+}: 203.0678$, Found: 203.0676 .

(E)-1-Bromo-4-(3,3,3-trifluoroprop-1-en-1-yl)benzene $\quad(>98 \% \quad E)$ was synthesized according to a previously reported procedure. ${ }^{3}$

\subsection{Alkyl-substituted alkenes}

Scheme S2. Synthesis of Alkyl-Substituted Trifluoromethyl Alkenes

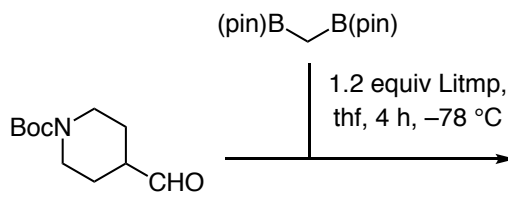

1. 4.0 equiv $\mathrm{HB}($ pin) $10 \mathrm{~mol} \% \mathrm{Cp}_{2} \mathrm{ZrHCl}, \mathrm{Et}_{3} \mathrm{~N}$,

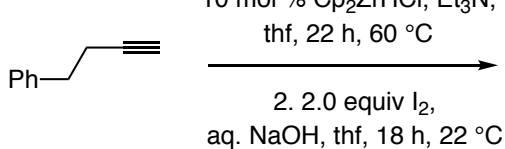

1. 4.0 equiv $\mathrm{HB}$ (pin), $10 \mathrm{~mol} \% \mathrm{Cp}_{2} \mathrm{ZrHCl}, \mathrm{Et}_{3} \mathrm{~N}$,

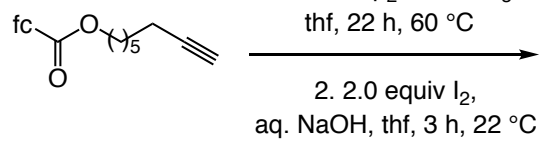

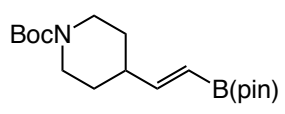

$56 \%$ yield

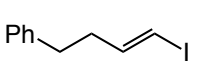

$56 \%$ overall yield

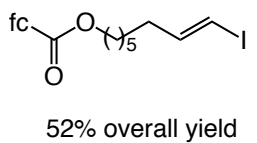

1. 2.0 equiv $\mathrm{I}_{2}$, aq. $\mathrm{NaOH}$, thf, $3 \mathrm{~h}, 22^{\circ} \mathrm{C}$

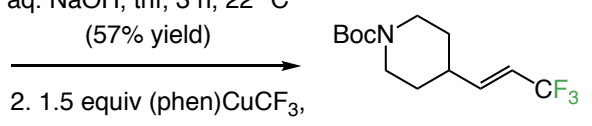
dmf, $23 \mathrm{~h}, 50^{\circ} \mathrm{C}$ (81\% yield)
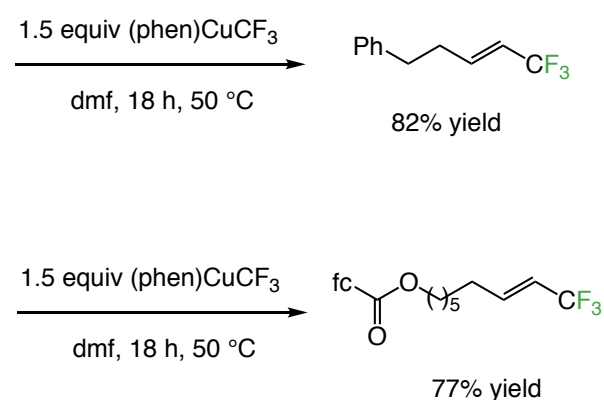
tert-Butyl-(E)-4-(3,3,3-trifluoroprop-1-en-1-yl)piperidine-1-carboxylate $(>98 \% \quad E)$ was synthesized according to a reported procedure. ${ }^{4}{ }^{1} \mathrm{H} \mathrm{NMR}\left(\mathrm{CDCl}_{3}, 600 \mathrm{MHz}\right): \delta 6.32(\mathrm{dd}, J=$ 16.2, $5.3 \mathrm{~Hz}, 1 \mathrm{H}), 5.60$ (dq, J = 12.9, $6.2 \mathrm{~Hz}, 1 \mathrm{H}), 4.14$ (bs, 2H), 2.75 (bs, 2H), 2.25 (bs, 1H), 1.83-1.59 (m, 2H), $1.46(\mathrm{~s}, 9 \mathrm{H}), 1.37-1.19(\mathrm{~m}, 2 \mathrm{H}) ;{ }^{13} \mathrm{C} \mathrm{NMR}\left(\mathrm{CDCl}_{3}, 150 \mathrm{MHz}\right): \delta 154.9$, $143.8(\mathrm{q}, J=6.3 \mathrm{~Hz}), 123.3(\mathrm{q}, J=267.8 \mathrm{~Hz}), 117.6(\mathrm{q}, J=34.9 \mathrm{~Hz}), 79.8,42.9,38.2,30.8$, 28.6; ${ }^{19} \mathrm{~F} \mathrm{NMR}\left(\mathrm{CDCl}_{3}, 376 \mathrm{MHz}\right): \delta-64.02(\mathrm{~d}, J=6.2 \mathrm{~Hz}$ ); HRMS (DART-TOF) $\mathrm{m} / \mathrm{z}$ : $[\mathrm{M}+\mathrm{H}]^{+}$Calcd for $\mathrm{C}_{13} \mathrm{H}_{21} \mathrm{~F}_{3} \mathrm{NO}_{2}{ }^{+}: 280.15189$, Found: 280.15171 .

(E)-(5,5,5-Trifluoropent-3-en-1-yl)benzene was synthesized according to a previously reported procedure. ${ }^{4,5}$

(E)-9,9,9-Trifluoronon-7-en-1-yl ferrocenecarboxylate was synthesized according to a reported procedure. ${ }^{4,5}{ }^{1} \mathrm{H} \mathrm{NMR}\left(\mathrm{CDCl}_{3}, 400 \mathrm{MHz}\right): \delta 6.39(\mathrm{dtd}, J=16.0,7.0,2.3 \mathrm{~Hz}, 1 \mathrm{H})$, $5.68-5.57(\mathrm{~m}, 1 \mathrm{H}), 4.81(\mathrm{t}, J=1.9 \mathrm{~Hz}, 2 \mathrm{H}), 4.39(\mathrm{t}, J=2.0 \mathrm{~Hz}, 2 \mathrm{H}), 4.23(\mathrm{t}, J=6.6 \mathrm{~Hz}, 2 \mathrm{H})$, $4.21(\mathrm{~s}, 4 \mathrm{H}), 2.24-2.14(\mathrm{~m}, 2 \mathrm{H}), 1.74(\mathrm{dt}, J=14.0,6.6 \mathrm{~Hz}, 2 \mathrm{H}), 1.53-1.37(\mathrm{~m}, 6 \mathrm{H}) ;{ }^{19} \mathrm{~F}$ NMR $\left(\mathrm{CDCl}_{3}, 376 \mathrm{MHz}\right): \delta-63.93$ (bs).

Allylic ethers were prepared by routine procedures and with a commercially available allylic alcohol.

(E)-1-Methoxy-4-((4,4,4-trifluorobut-2-en-1-yl)oxy)methyl)benzene (98\% $E)$ : ${ }^{1} \mathrm{H}$ NMR $\left(\mathrm{CDCl}_{3}, 600 \mathrm{MHz}\right): \delta 7.28(\mathrm{~d}, J=8.5 \mathrm{~Hz}, 2 \mathrm{H}), 6.91(\mathrm{~d}, J=8.5 \mathrm{~Hz}, 2 \mathrm{H}), 6.44$ (dtt, $J=15.6,4.2$, $2.1 \mathrm{~Hz}, 1 \mathrm{H}), 6.00-5.93(\mathrm{dqt}, J=15.7,6.7,2.1 \mathrm{~Hz}, 1 \mathrm{H}), 4.52(\mathrm{~s}, 2 \mathrm{H}), 4.14-4.05(\mathrm{~m}, 2 \mathrm{H}), 3.83$ $(\mathrm{s}, 3 \mathrm{H}) ;{ }^{13} \mathrm{C} \mathrm{NMR}\left(\mathrm{CDCl}_{3}, 150 \mathrm{MHz}\right): \delta 159.7,136.8(\mathrm{q}, J=6.3 \mathrm{~Hz}), 129.8,129.6,123.3(\mathrm{q}, J$ $=267.8 \mathrm{~Hz}), 118.9(\mathrm{q}, J=33.8 \mathrm{~Hz}), 114.1,72.8,67.7,55.5 ;{ }^{19} \mathrm{~F} \mathrm{NMR}\left(\mathrm{CDCl}_{3}, 564 \mathrm{MHz}\right): \delta-$ $64.28\left(\mathrm{dq}, J=5.6,2.6 \mathrm{~Hz}\right.$ ); HRMS (DART-TOF) $\mathrm{m} / \mathrm{z}$ : $[\mathrm{M}]^{+\bullet}$ Calcd for $\mathrm{C}_{12} \mathrm{H}_{13} \mathrm{~F}_{3} \mathrm{O}_{2}{ }^{+}: 246.0862$, Found: 246.0862 .

(E)-tert-Butyldiphenyl((4,4,4-trifluorobut-2-en-1-yl)oxy)silane $(98 \% E):{ }^{1} \mathrm{H}$ NMR $\left(\mathrm{CDCl}_{3}\right.$, $600 \mathrm{MHz}): \delta 7.73(\mathrm{dt}, J=8.0,1.4 \mathrm{~Hz}, 4 \mathrm{H}), 7.55-7.38(\mathrm{~m}, 6 \mathrm{H}), 6.52-6.43(\mathrm{~m}, 1 \mathrm{H}), 6.21-6.10$ $(\mathrm{m}, 1 \mathrm{H}), 4.43-4.12(\mathrm{~m}, 2 \mathrm{H}), 1.16(\mathrm{~s}, 9 \mathrm{H}) ;{ }^{13} \mathrm{C} \mathrm{NMR}\left(\mathrm{CDCl}_{3}, 150 \mathrm{MHz}\right): \delta 139.1$ (q, $J=6.2$ $\mathrm{Hz}), 135.7,133.1,130.2,128.1,123.8$ (q, $J=267.4 \mathrm{~Hz}), 117.5$ (q, $J=34.0 \mathrm{~Hz}), 62.2,27.0$, 19.5; ${ }^{19} \mathrm{~F} \mathrm{NMR}\left(\mathrm{CDCl}_{3}, 564 \mathrm{MHz}\right): \delta-63.77$ (dq, $J=6.0,2.6 \mathrm{~Hz}$ ); HRMS (DART-TOF) m/z: $[\mathrm{M}+\mathrm{H}]^{+}$Calcd for $\mathrm{C}_{20} \mathrm{H}_{24} \mathrm{~F}_{3} \mathrm{OSi}^{+}:$365.1543, Found: 365.1538 .

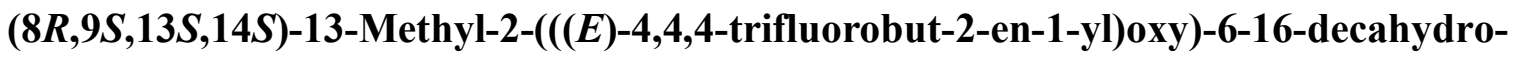
17H-cyclopenta[a]phenanthren-17-one $(>98 \% E)$ was synthesized according to a previously reported procedure. ${ }^{6}{ }^{1} \mathrm{H} \mathrm{NMR}\left(\mathrm{CDCl}_{3}, 600 \mathrm{MHz}\right): \delta 7.23(\mathrm{~d}, J=8.6 \mathrm{~Hz}, 1 \mathrm{H}), 6.73(\mathrm{dd}, J=8.6$, $2.8 \mathrm{~Hz}, 1 \mathrm{H}), 6.67(\mathrm{~d}, J=2.8 \mathrm{~Hz}, 1 \mathrm{H}), 6.56(\mathrm{ddq}, J=15.8,4.0,2.0 \mathrm{~Hz}, 1 \mathrm{H}), 6.07$ (dtt, $J=15.3$, $5.9,1.6 \mathrm{~Hz}, 1 \mathrm{H}), 4.63(\mathrm{~d}, J=3.1 \mathrm{~Hz}, 2 \mathrm{H}), 2.94-2.84(\mathrm{~m}, 2 \mathrm{H}), 2.52(\mathrm{dd}, J=19.1,8.7 \mathrm{~Hz}, 1 \mathrm{H})$, $2.41(\mathrm{dt}, J=14.0,3.6 \mathrm{~Hz}, 1 \mathrm{H}), 2.27$ (td, $J=10.7,4.3 \mathrm{~Hz}, 1 \mathrm{H}), 2.20-2.11(\mathrm{~m}, 1 \mathrm{H}), 2.11-2.00$ (m, 2H), 2.00-1.93 (m, 1H), 1.69-1.56 (m, 3H), 1.56-1.40 (m, 3H), $0.92(\mathrm{~s}, 3 \mathrm{H}) ;{ }^{13} \mathrm{C}$ NMR $\left(\mathrm{CDCl}_{3}, 150 \mathrm{MHz}\right): \delta 221.0,156.2,138.3(\mathrm{q}, \mathrm{J}=6.3 \mathrm{~Hz}), 135.4,133.2,126.7,123.1(\mathrm{q}, J=$ $266.4 \mathrm{~Hz}), 119.5$ (q, $J=34.0 \mathrm{~Hz}), 115.0,112.3,65.9,50.6,48.2,44.2,38.5,36.1,31.8,29.9$, 26.7, 26.1, 21.8, 14.1; ${ }^{19} \mathrm{~F}$ NMR $\left(\mathrm{CDCl}_{3}, 376 \mathrm{MHz}\right): \delta-64.36$ (dq, $\left.J=5.4,2.7 \mathrm{~Hz}\right)$; HRMS (DART-TOF) $\mathrm{m} / \mathrm{z}:[\mathrm{M}+\mathrm{H}]^{+}$Calcd for $\mathrm{C}_{22} \mathrm{H}_{26} \mathrm{~F}_{3} \mathrm{O}_{2}{ }^{+}: 379.1879$, Found: 379.1854 . 


\section{Optimization Studies for Boryl and Silyl Substitutions}

\subsection{Evaluation of various reaction parameters in boryl substitutions}

The background (uncatalyzed) reaction was evaluated with 11a $(>98 \% E), \mathrm{B}_{2}(\text { pin) })_{2}, \mathrm{NaO} t-\mathrm{Bu}$ and $\mathrm{CuCl}$ (Scheme S3). Without any ligand, ent-12a was not detected in toluene, whereas there was $24 \%$ conv in thf. We find that enantioselectivity is inversely proportional to the amount of thf present. This is likely due to more prevalent uncatalyzed reaction in the more polar medium. Scheme S3. Impact of Competitive Background Reaction and Medium
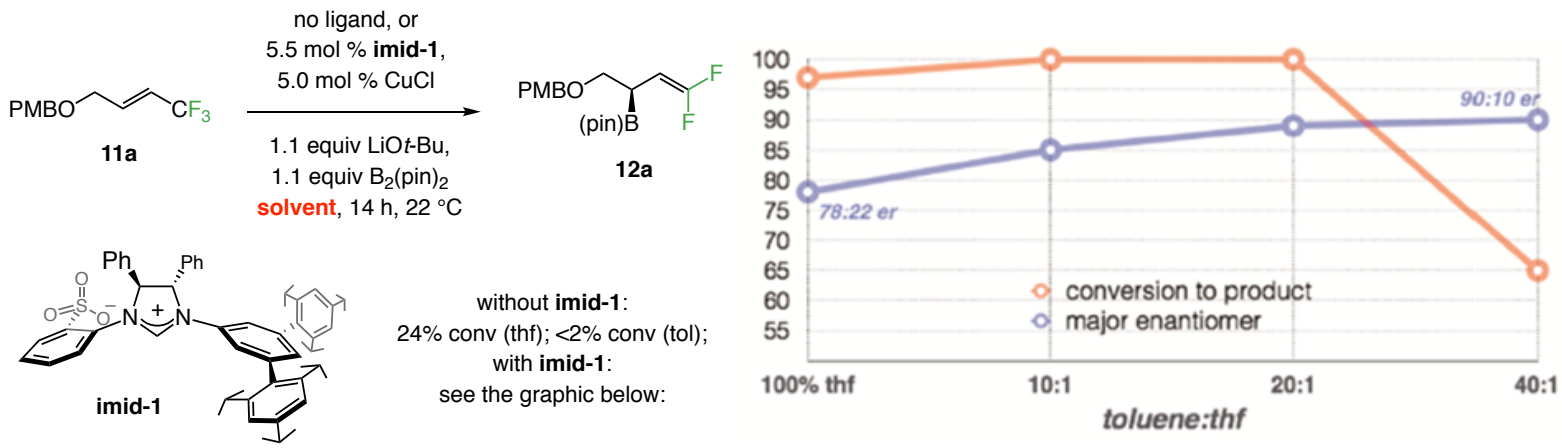

Table S1. Evaluation of Various Metal Alkoxides ${ }^{a}$

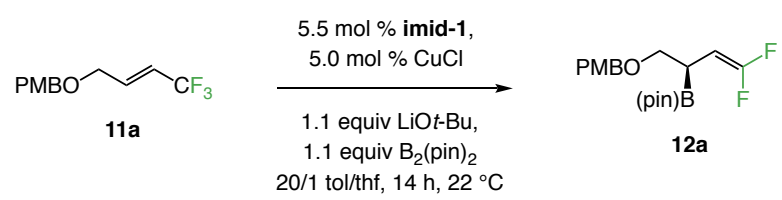

\begin{tabular}{ccccc|}
\hline entry & metal alkoxide & conv (\%) & yield (\%) & er \\
\hline 1 & NaOt-Bu & $>98$ & 80 & $89: 11$ \\
2 & NaOMe & 66 & 62 & $60: 40$ \\
3 & LiOt-Bu & $>98$ & 82 & $91: 9$ \\
4 & KOMe & 68 & 50 & nd \\
\hline 5 & KOt-Bu & $>98$ & $<30$ & na \\
6 & $\mathrm{Mg}(\mathrm{Ot}-\mathrm{Bu})_{2}$ & $<2$ & na & na \\
\hline 7 & $\mathrm{NaOPh}$ & $<2$ & na &
\end{tabular}

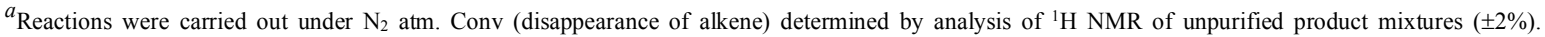
Enantioselectivity was determined by HPLC analysis $( \pm 1 \%)$. See the Supporting Information for details.

\subsection{Evaluation of ligands for enantioselective boryl substitution}

Although reactions with sulfonate-bearing imid-1 were appreciably enantioselective (91:9 er with 11a), er values were significantly lower with other substrates (Scheme S4). 
Scheme S4. Reactions of Different Substrated with Catalyst Derived from Imid-1 ${ }^{a}$

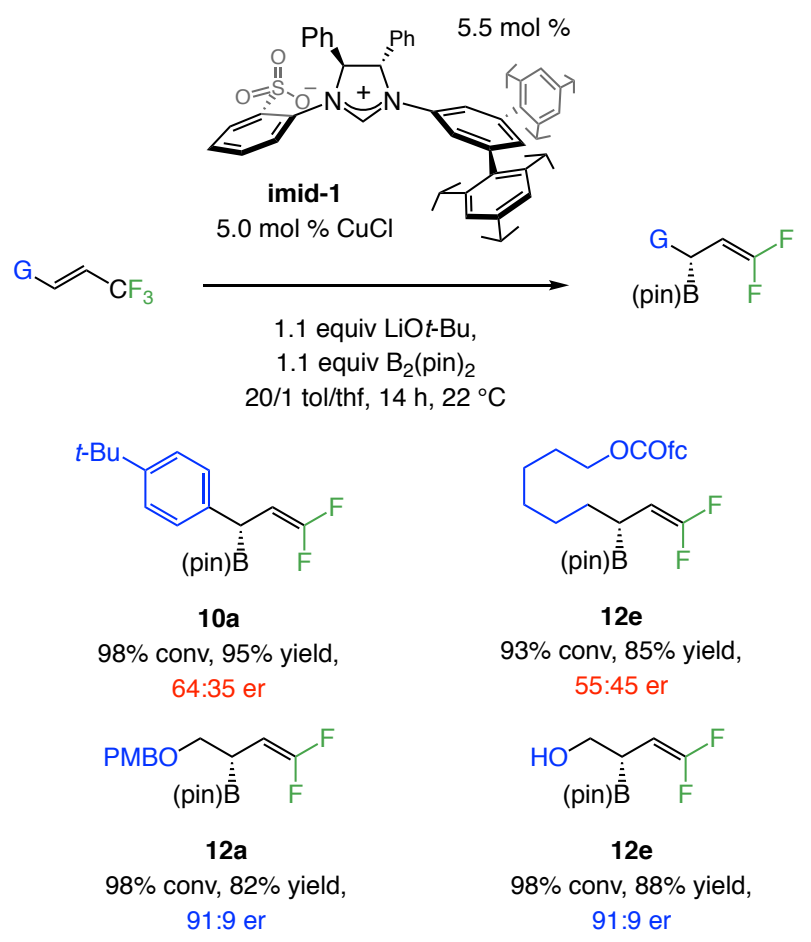

In search of a more generally applicable chiral ligand, we performed screening studies with aryl-substituted alkene 9a (Scheme S5). As a result, imid-4 and imid-S9 were identified as optimal. Because imid-4 was slightly superior to imid-S9 in the reactions with aliphatic alkenes, we chose to use it in the ensuing investigations.

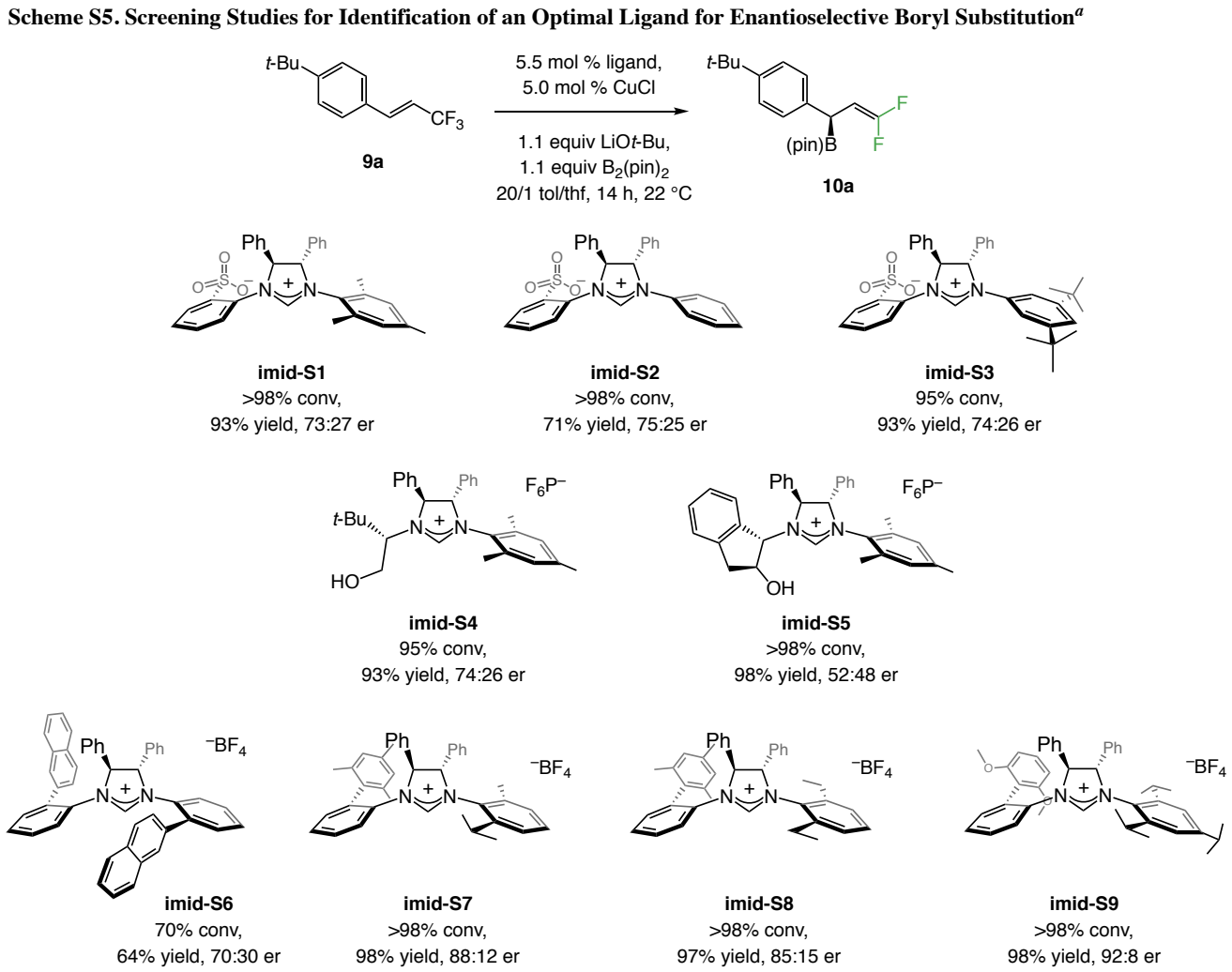

${ }^{a}$ Reactions were carried out under $\mathrm{N}_{2}$ atm. Conv (disappearance of alkene) and diastereoselectivity were determined by analysis of ${ }^{1} \mathrm{H}$ NMR of unpurified product mixtures $( \pm 2 \%)$. Yields correspond to purified products $( \pm 5 \%)$. Enantioselectivity was determined by HPLC analysis $( \pm 1 \%)$. 


\subsection{Evaluation of ligands for enantioselective silyl substitution}

Ligand screening for enantioselective silyl substitution was performed with alkene 9a, under the conditions originally optimized for the boryl substitution (Scheme S6). Because of the more sizeable silyl moiety, the size of a ligand played a more significant role on reaction efficiency. The NHC-Cu complex derived from imid-3 was identified as optimal.

Scheme S6. Screening Studies for Identification of an Optimal Ligand for Enantioselective Silyl Substitution
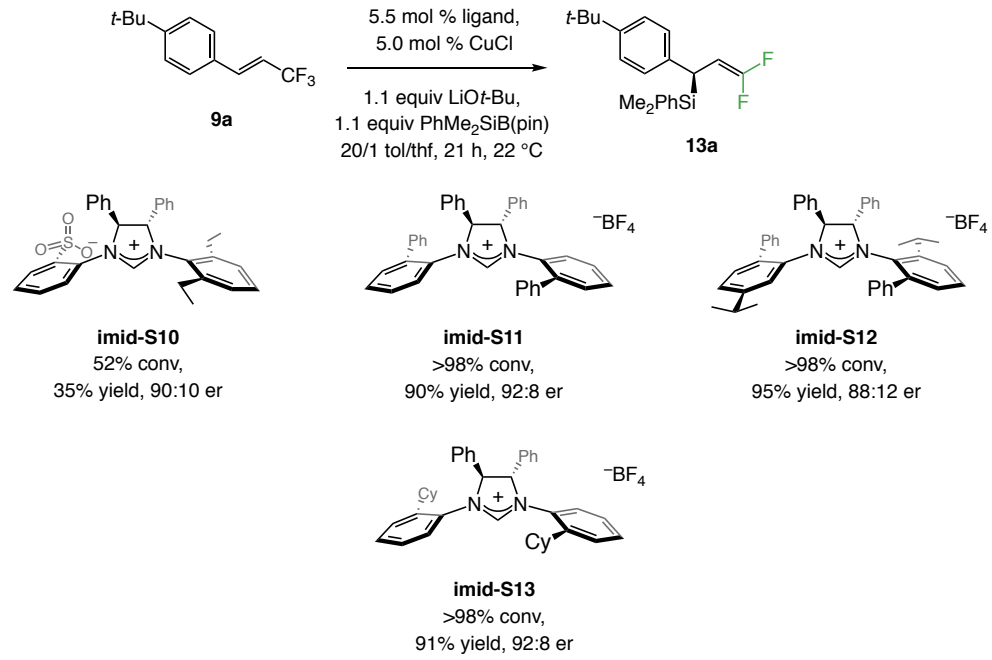

${ }^{a}$ Reactions were carried out under $\mathrm{N}_{2}$ atm. Conv (disappearance of alkene) and diastereoselectivity were determined by analysis of ${ }^{1} \mathrm{H}$ NMR of unpurified product mixtures $( \pm 2 \%)$. Yields correspond to purified products $( \pm 5 \%)$. Enantioselectivity was determined by HPLC analysis $( \pm 1 \%)$.

\section{Synthesis and Characterization of Imid-4}
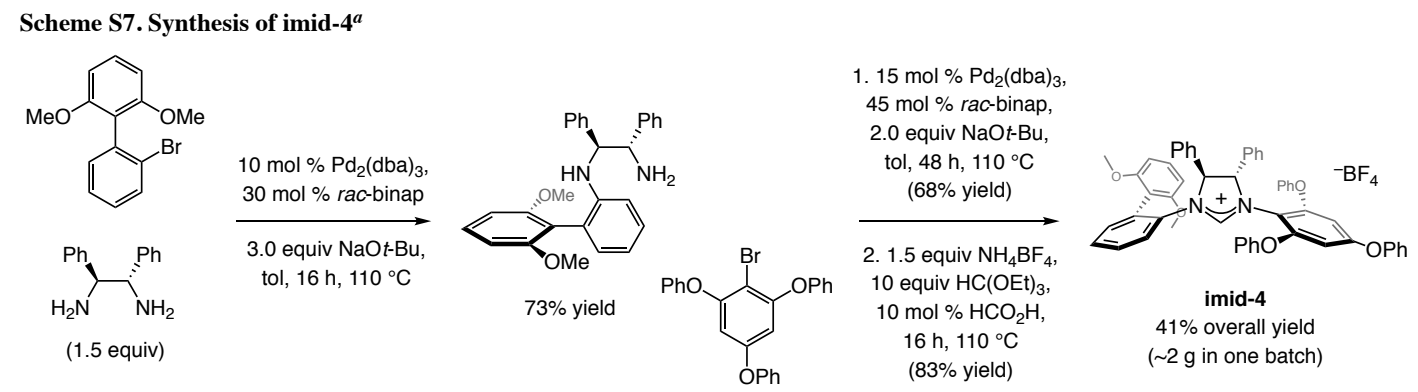

${ }^{a}$ Reactions were carried out under $\mathrm{N}_{2}$ atm. Yields correspond to purified products $( \pm 5 \%)$

((2-Bromobenzene-1,3,5-triyl)tris(oxy))tribenzene: Phenol (6.03 g, 63.99), 1-bromo-2,4,6trifluorobenzene $(3.0 \mathrm{~g}, 14.22 \mathrm{mmol})$ and $\mathrm{K}_{2} \mathrm{CO}_{3}(9.83 \mathrm{~g}, 71.10 \mathrm{mmol})$ were placed in an ovendried $100 \mathrm{~mL}$ round-bottom flask, which was then capped with a septum, evacuated and filled with $\mathrm{N}_{2} . \mathrm{N}$-methyl-2-pyrrolidine $(25 \mathrm{~mL})$ was added through syringe and the septum was replaced by a glass stopper. The mixture was allowed to stir for $20 \mathrm{~h}$ at $180{ }^{\circ} \mathrm{C}$, after which it was allowed to cool to $22^{\circ} \mathrm{C}$ and washed with EtOAc $(100 \mathrm{~mL})$ and $\mathrm{H}_{2} \mathrm{O}(100 \mathrm{~mL})$. The organic layer was washed with $\mathrm{H}_{2} \mathrm{O}(2 \times 50 \mathrm{~mL})$ with an aqueous solution of $2 \mathrm{M} \mathrm{NaOH}(2 \times 50 \mathrm{~mL})$, dried over $\mathrm{MgSO}_{4}$, filtered, and the volatiles were removed to afford brown oil, which was purified by silica gel chromatography (100:0-98:2 hexanes:EtOAc) to give the desired product as white solid (3.33 g, 54\% yield). $\mathrm{R} f=0.65$ (hexanes:EtOAc 90:10; UV/KMnO 4 stain). ${ }^{1} \mathrm{H}$ NMR $\left(\mathrm{CDCl}_{3}, 400 \mathrm{MHz}\right): \delta 7.36(\mathrm{dd}, J=8.6,7.4 \mathrm{~Hz}, 4 \mathrm{H}), 7.33-7.26(\mathrm{~m}, 2 \mathrm{H}), 7.17-7.08(\mathrm{~m}$, $5 \mathrm{H}), 7.08-7.02(\mathrm{~m}, 2 \mathrm{H}), 6.95(\mathrm{~d}, J=3.5 \mathrm{~Hz}, 2 \mathrm{H}), 6.39$ (s, 2H). 
$(1 S, 2 S)-N^{1}-\left(2^{\prime}, 6^{\prime}\right.$-Dimethoxy-[1,1'-biphenyl]-2-yl)-1,2-diphenylethane-1,2-diamine: In an $\mathrm{N}_{2}$-filled glove box, an oven-dried 10 dram vial containing a stir bar was charged with $\mathrm{Pd}(\mathrm{dba})_{2}$ (0.49 g, $0.853 \mathrm{mmol})$, rac-binap (1.59 g, $2.56 \mathrm{mmol}), \mathrm{NaO} t$-Bu (2.46 g, $25.58 \mathrm{mmol}),(1 S, 2 S)$ diphenylethylenediamine (2.72 g, $12.80 \mathrm{mmol}), 2^{\prime}$-bromo-2,6-dimethoxybiphenyl (2.5 g, 8.53 mmol). Toluene $(8.5 \mathrm{~mL})$ was added to the mixture and the vial was sealed (electrical tape) and removed from the glove box. The solution was allowed to stir $16 \mathrm{~h}$ at $110{ }^{\circ} \mathrm{C}$, after which it was passed through celite and washed with $\mathrm{CH}_{2} \mathrm{Cl}_{2}(30 \mathrm{~mL})$. After removal of the volatiles, the yellow oil was purified by silica gel chromatography (100:0-50:50 hexanes:Et $\left.{ }_{2} \mathrm{O}\right)$ to give the desired compound as yellow solid (2.65 g, $73 \%$ yield). $\mathrm{R} f=0.40$ (EtOAc, streak, UV/KMnO 4 stain). ${ }^{1} \mathrm{H}$ NMR $\left(\mathrm{CDCl}_{3}, 400 \mathrm{MHz}\right): \delta 7.45$ (t, $\left.J=8.3 \mathrm{~Hz}, 1 \mathrm{H}\right), 7.32-7.26(\mathrm{~m}, 6 \mathrm{H}), 7.20-7.10$ (m, 4H), 7.09-6.95 (m, 4H), 6.78 (dd, $J=8.4,4.9 \mathrm{~Hz}, 2 \mathrm{H}), 6.66$ (t, $J=7.4 \mathrm{~Hz}, 1 \mathrm{H}), 6.23$ (d, $J$ $=8.1 \mathrm{~Hz}, 1 \mathrm{H}), 4.88(\mathrm{~d}, J=6.8 \mathrm{~Hz}, 1 \mathrm{H}), 4.51(\mathrm{dd}, J=6.8,3.9 \mathrm{~Hz}, 1 \mathrm{H}), 4.24(\mathrm{~d}, J=3.9 \mathrm{~Hz}, 1 \mathrm{H})$, 3.81 (s, 3H), 3.67 (s, 3H). (S,S)-Imid-4: In an $\mathrm{N}_{2}$-filled glove box, an oven-dried 10 dram vial containing a stir bar was charged with $\mathrm{Pd}(\mathrm{dba})_{2}(0.36 \mathrm{~g}, 0.618 \mathrm{mmol})$, rac-binap (1.15 g, 1.89 $\mathrm{mmol}), \mathrm{NaO} t$-Bu $(0.79 \mathrm{~g}, 8.25 \mathrm{mmol})$, ((2-bromobenzene-1,3,5-triyl)tris(oxy))tribenzene (1.79 g, $4.12 \mathrm{mmol})$, and $(1 S, 2 S)-\mathrm{N}^{1}-\left(2^{\prime}, 6^{\prime}\right.$-dimethoxy-[1,1'-biphenyl]-2-yl)-1,2-diphenylethane-1,2diamine $(1.75 \mathrm{~g}, 4.12 \mathrm{mmol})$. Toluene $(4.1 \mathrm{~mL})$ was added and the vial was sealed (electrical tape) and then removed from the glove box. The mixture was allowed to stir for $48 \mathrm{~h}$ at 110 ${ }^{\circ} \mathrm{C}$, after which it was allowed to cool to $22{ }^{\circ} \mathrm{C}$ and then was passed through celite and washed with $\mathrm{CH}_{2} \mathrm{Cl}_{2}(30 \mathrm{~mL})$. After removal of the volatiles, the resulting yellow oil was purified by silica gel chromatography (100:0-80:20 hexanes:EtOAc) to afford the desired bis-arylamine as yellow solid (2.17 g, 68\% yield). $\mathrm{R} f=0.50$ (hexanes:EtOAc 80:20; $\mathrm{UV} / \mathrm{KMnO}_{4}$ stain). ${ }^{1} \mathrm{H}$ $\operatorname{NMR}\left(\mathrm{CDCl}_{3}, 400 \mathrm{MHz}\right): \delta 7.32-7.24(\mathrm{~m}, 5 \mathrm{H}), 7.22-7.16(\mathrm{~m}, 2 \mathrm{H}), 7.13-7.01(\mathrm{~m}, 6 \mathrm{H}), 6.99$ $6.91(\mathrm{~m}, 7 \mathrm{H}), 6.81-6.74(\mathrm{~m}, 5 \mathrm{H}), 6.70-6.62(\mathrm{~m}, 2 \mathrm{H}), 6.62-6.57(\mathrm{~m}, 2 \mathrm{H}), 6.54(\mathrm{dd}, J=8.4,0.9$ $\mathrm{Hz}, 1 \mathrm{H}), 6.26(\mathrm{dt}, J=7.5,1.2 \mathrm{~Hz}, 1 \mathrm{H}), 6.20(\mathrm{~s}, 2 \mathrm{H}), 5.01-4.93(\mathrm{~m}, 1 \mathrm{H}), 4.59(\mathrm{~d}, J=4.0 \mathrm{~Hz}$, $2 \mathrm{H}), 4.53(\mathrm{~d}, J=11.1 \mathrm{~Hz}, 1 \mathrm{H}), 3.66(\mathrm{~s}, 3 \mathrm{H}), 3.53(\mathrm{~s}, 3 \mathrm{H})$.

The diamine $(2.14 \mathrm{~g}, 2.75 \mathrm{mmol}), \mathrm{NH}_{4} \mathrm{BF}_{4}(0.43 \mathrm{~g}, 4.13 \mathrm{mmol})$, triethyl orthoformate $(4.6 \mathrm{~mL}$, $27.5 \mathrm{mmol})$, formic acid ( $11 \mu \mathrm{L}, 0.28 \mathrm{mmol}, 0.1$ equiv) were placed in a sealed tube containing a stir bar and the vessel was sealed with a Teflon cap. The mixture was allowed to stir for $16 \mathrm{~h}$ at $110^{\circ} \mathrm{C}$, after which the volatiles were removed under reduced pressure, and the yellow oil was dissolved in $\mathrm{CH}_{2} \mathrm{Cl}_{2}(5 \mathrm{~mL})$ and purified by silica gel chromatography (50:50-100:00 hexanes: $\mathrm{CH}_{2} \mathrm{Cl}_{2}$ followed by 50:50-100:00 hexanes:EtOAc) to give yellow solid, which was dissolved in the minimum amount of $\mathrm{CH}_{2} \mathrm{Cl}_{2}$ and recrystallized by the addition of hexanes (vigorous stirring). The precipitate was allowed to sit for one minute and filtered in a sintered funnel and triturated twice $\left(\mathrm{CH}_{2} \mathrm{Cl}_{2}: \mathrm{Et}_{2} \mathrm{O} 20: 80\right)$. The resulting solid was dried in vacuo $\left(\mathrm{P}_{2} \mathrm{O}_{5}\right)$ for $16 \mathrm{~h}$ to afford imid-4 as light yellow solid (2.00 g, $83 \%$ yield). $\mathrm{R} f=0.15$ (EtOAc, streaking; $\mathrm{UV} / \mathrm{KMnO}_{4}$ stain); ${ }^{1} \mathrm{H}$ NMR $\left(\mathrm{CDCl}_{3}, 600 \mathrm{MHz}\right): \delta 9.14(\mathrm{~s}, 1 \mathrm{H}), 7.46-7.04(\mathrm{~m}, 28 \mathrm{H}), 6.99$ (t, $J$ $=7.4 \mathrm{~Hz}, 1 \mathrm{H}), 6.89(\mathrm{~d}, J=8.0 \mathrm{~Hz}, 1 \mathrm{H}), 6.85(\mathrm{~d}, J=7.6 \mathrm{~Hz}, 2 \mathrm{H}), 6.68(\mathrm{~d}, J=8.4 \mathrm{~Hz}, 1 \mathrm{H}), 6.50$ (d, $J=8.4 \mathrm{~Hz}, 1 \mathrm{H}), 5.98$ (s, 1H), 5.82 (d, $J=7.0 \mathrm{~Hz}, 1 \mathrm{H}), 5.00$ (d, $J=7.1 \mathrm{~Hz}, 1 \mathrm{H}), 3.69$ (s, $3 \mathrm{H}), 3.39$ (s, 3H).; ${ }^{13} \mathrm{C} \mathrm{NMR}\left(\mathrm{CDCl}_{3}, 150 \mathrm{MHz}\right): \delta 159.3,158.9,158.2,157.5,155.6,154.7$, 136.0, 135.9, 133.5, 132.5, 131.8, 130.7, 130.5, 130.0, 129.9, 129.5, 129.3, 129.2, 129.1, 128.1, 125.5, 124.2, 120.7, 119.3, 115.1, 109.5, 105.2, 104.6, 101.4, 75.1, 74.8, 56.6, 55.8; HRMS (DART-TOF) m/z: [M+H] $]^{+}$Calcd for $\mathrm{C}_{23} \mathrm{H}_{29} \mathrm{SiF}_{2} \mathrm{O}_{3}{ }^{+}: 419.1849$, Found: 419.1841 . 


\section{Procedures and Characterization of Allylic Substitution Products}

\subsection{Boryl substitution procedures}

With $\mathrm{NHC}-\mathrm{Cu}$ complexes: In a $\mathrm{N}_{2}$-filled glove box, an oven-dried 2-dram vial containing a magnetric stir bar was charged with $\mathrm{CuCl}(1.0 \mathrm{mg}, 0.010 \mathrm{mmol})$, imidazolinium salt $(0.011$ mmol, $5.5 \mathrm{~mol} \%)$, LiOt-Bu $(17.8 \mathrm{mg}, 0.222 \mathrm{mmol})$. thf $(100 \mu \mathrm{L})$ and toluene $(1.0 \mathrm{~mL})$ were added and the solution was allowed to stir for $1 \mathrm{~h}$. A solution of $\mathrm{B}_{2}(\mathrm{pin})_{2}(56.4 \mathrm{mg}, 0.222 \mathrm{mmol})$ and $\mathrm{F}_{3} \mathrm{C}$-substituted alkene $(0.202 \mathrm{mmol})$ in toluene $(1.0 \mathrm{~mL})$ was added to the mixture containing the catalyst. The vial was sealed (electrical tape) and removed from the glove box, and the mixture was allowed to stir for $14 \mathrm{~h}$, after which it was passed through a short plug of silica gel $\left(3 \mathrm{~cm} \times 1 \mathrm{~cm}\right.$; eluted with $\left.\mathrm{Et}_{2} \mathrm{O}\right)$. Removal of the volatiles in vacuo, and purification of the resulting residue by silica gel chromatography afforded the desired 1,1-difluoroallyl boronates.

With bisphosphine-Cu complexes: In a $\mathrm{N}_{2}$-filled glove box, an oven-dried 2-dram vial containing a magnetric stir bar was charged with $\mathrm{CuCl}(1.0 \mathrm{mg}, 0.010 \mathrm{mmol})$, bisphosphine (0.011 mmol), LiOt-Bu (17.8 mg, $0.222 \mathrm{mmol}), \mathrm{B}_{2}$ (pin) $)_{2}(56.4 \mathrm{mg}, 0.222 \mathrm{mmol})$. thf $(100 \mu \mathrm{L})$ and toluene $(1.0 \mathrm{~mL})$ were added and the solution was allowed to stir for $5 \mathrm{~min}$. A solution of the $\mathrm{F}_{3} \mathrm{C}$-substituted alkene $(0.202 \mathrm{mmol}, 1.0$ equiv) in toluene $(1.0 \mathrm{~mL})$ was added to the original catalyst solution. The vial was sealed (electrical tape) and removed from the glove box, and the mixture was allowed to stir for $14 \mathrm{~h}$, after which it was passed through a short plug of silica gel $\left(\left(3 \mathrm{~cm} \times 1 \mathrm{~cm}\right.\right.$; eluted with $\left.\mathrm{Et}_{2} \mathrm{O}\right)$. Removal of the volatiles in vacuo, and purification of the resulting residue by silica gel chromatography afforded the desired 1,1-difluoroallyl boronates.

\subsection{Silyl substitution procedures}

With $\mathrm{NHC}$-Cu complexes: In a $\mathrm{N}_{2}$-filled glove box, an oven-dried 2-dram vial with a magnetic stir bar was charged with $\mathrm{CuCl}(1.0 \mathrm{mg}, 0.010 \mathrm{mmol})$, imidazolinium salt $(0.011 \mathrm{mmol}), \mathrm{LiO} t$ $\mathrm{Bu}(17.8 \mathrm{mg}, 0.222 \mathrm{mmol})$. After this, thf $(100 \mu \mathrm{L})$ and toluene $(1.0 \mathrm{~mL})$ were added and the mixture was allowed to stir for $1 \mathrm{~h}$. A solution of $\mathrm{PhMe}_{2} \mathrm{SiB}$ (pin) $(60.6 \mu \mathrm{L}, 0.222 \mathrm{mmol})$ and the $\mathrm{F}_{3} \mathrm{C}$-substituted alkene $(0.202 \mathrm{mmol})$ in toluene $(1.0 \mathrm{~mL})$ were then added to the initial catalyst solution. The vial was sealed (electrical tape) and removed from the glove box, and the mixture was allowed to stir for $14 \mathrm{~h}$, after which it was passed through a short plug of silica gel ( $\left(3 \mathrm{~cm} \times 1 \mathrm{~cm}\right.$; eluted with $\left.\mathrm{Et}_{2} \mathrm{O}\right)$. Removal of the volatiles in vacuo, and purification of the resulting residue by silica gel chromatography afforded the desired 1,1-difluoroallyl boronates.

With bisphosphine-Cu complexes: In a $\mathrm{N}_{2}$-filled glove box, an oven-dried 2-dram vial containing a magnetric stir bar was charged with $\mathrm{CuCl}(1.0 \mathrm{mg}, 0.0101 \mathrm{mmol})$, bisphosphine (0.011 mmol), $\mathrm{LiO} t$-Bu (17.8 mg, $0.222 \mathrm{mmol})$, and a magnetic stirring bar. $\mathrm{PhMe}_{2} \mathrm{SiB}$ (pin) $(60.6 \mu \mathrm{L}, 0.222 \mathrm{mmol})$ in thf $(100 \mu \mathrm{L})$ and toluene $(1.0 \mathrm{~mL})$ were added and the mixture was allowed to stir for $5 \mathrm{~min}$. A solution of the $\mathrm{F}_{3} \mathrm{C}$-substituted alkene $(0.202 \mathrm{mmol}, 1.0$ equiv) in dry toluene $(1.0 \mathrm{~mL})$ was added to the solution of the catalyst. The vial was sealed (electrical tape) and removed from the glove box, and the mixture was allowed to stir for $14 \mathrm{~h}$, after which it was passed through a short plug of silica gel $\left(3 \mathrm{~cm} \times 1 \mathrm{~cm}\right.$; eluted with $\left.\mathrm{Et}_{2} \mathrm{O}\right)$. Removal of the volatiles in vacuo, and purification of the resulting residue by silica gel chromatography afforded the desired 1,1-difluoroallyl boronates. 


\subsection{Boronate oxidation}

The mixture recovered after the short plug of silica gel and removal of the volatiles was directly subjected to oxidation conditions. thf $(1.0 \mathrm{~mL} / 0.1 \mathrm{mmol}$ substrate $), \mathrm{pH}=7.0$ phosphate buffer solution $\left(1.0 \mathrm{~mL} / 0.1 \mathrm{mmol}\right.$ substrate), and $\mathrm{NaBO}_{3} \bullet 4 \mathrm{H}_{2} \mathrm{O}\left(5.0\right.$ equiv) were added at $22^{\circ} \mathrm{C}$. The solution was allowed to stir vigorously for $2 \mathrm{~h}$, after which $\mathrm{Et}_{2} \mathrm{O}(5 \mathrm{~mL})$ and brine $(5 \mathrm{~mL})$ were added and the mixture was transferred to a separatory funnel. The layers were separated, and the aqueous portion was washed with $\mathrm{Et}_{2} \mathrm{O}(2 \mathrm{~mL})$. The organic layers were combined, dried over $\mathrm{MgSO}_{4}$, filtered through cotton, concentrated and the remaining residue was purified by silica gel chromatography (hexanes:EtOAc with $1 \%$ of $\mathrm{Et}_{3} \mathrm{~N}$ ).

\subsection{Analytical data for 1,1-difluoroallyl boronates}

(R)-2-(1-(4-(tert-Butyl)phenyl)-3,3-difluoroallyl)-4,4,5,5-tetramethyl-1,3,2-dioxaborolane (10a): colorless oil. $\mathrm{R} f=0.65$ (hexanes:EtOAc 90:10; UV/KMnO 4 stain). IR (neat): 2965 (m), 1739 (s), 1510 (w), 1466 (w), 1363 (s), 1326 (s), 1292 (m), 1268 (m), 1256 (m), 1197 (s), 1108 (m), $914(\mathrm{~s}), 571(\mathrm{~m}), 521(\mathrm{~m}) \mathrm{cm}^{-1} ;{ }^{1} \mathrm{H} \mathrm{NMR}\left(\mathrm{CDCl}_{3}, 400 \mathrm{MHz}\right): \delta 7.30-7.29(\mathrm{~m}, 2 \mathrm{H}), 7.15$ (d, $J=8.0 \mathrm{~Hz}, 2 \mathrm{H}), 4.55$ (ddd, $J=25.2,10.0,2.4 \mathrm{~Hz}, 1 \mathrm{H}), 3.23$ (d, $J=10.4 \mathrm{~Hz}, 1 \mathrm{H}), 1.30$ (s, 9H), $1.24(\mathrm{~s}, 6 \mathrm{H}), 1.23(\mathrm{~s}, 6 \mathrm{H}) ;{ }^{13} \mathrm{C} \mathrm{NMR}\left(\mathrm{CDCl}_{3}, 100 \mathrm{MHz}\right): \delta 156.0(\mathrm{t}, J=285.4 \mathrm{~Hz}), 148.7$, $137.7(\mathrm{t}, \mathrm{J}=2.3 \mathrm{~Hz}), 127.6,125.7,84.0,79.4$ (dd, $J=22.8,20.5 \mathrm{~Hz}), 34.5,31.5,25.1$ (bs), 24.7; ${ }^{19} \mathrm{~F}$ NMR (376 MHz, $\left.\mathrm{CDCl}_{3}\right): \delta-90.37(\mathrm{~d}, J=46.6,1 \mathrm{~F}),-92.12(\mathrm{dd}, J=47.0,25.9 \mathrm{~Hz}$, 1F); HRMS (DART-TOF) m/z: $\left[\mathrm{M}+\mathrm{NH}_{4}\right]^{+}$Calcd for $\mathrm{C}_{19} \mathrm{H}_{31} \mathrm{BNF}_{2} \mathrm{O}_{2}{ }^{+}$: 354.2410, Found: 354.2412. Specific rotation: $[\alpha]_{\mathrm{D}}{ }^{20}-21.63\left(c\right.$ 2.64, $\left.\mathrm{CH}_{2} \mathrm{Cl}_{2}\right)$ for an enantiomerically enriched sample of 92:8 er favoring the $(R)$-enantiomer. Enantiomeric purity was determined by HPLC analysis in comparison with authentic racemic material (92:8 er shown; OZ-H column, 100\% hexanes, $0.3 \mathrm{~mL} / \mathrm{min}, 220 \mathrm{~nm})$. $(R)$-enantiomer: $\mathrm{t}_{\mathrm{r}}=14.1 \mathrm{~min},(S)$-enantiomer: $\mathrm{t}_{\mathrm{r}}=15.1 \mathrm{~min}$.

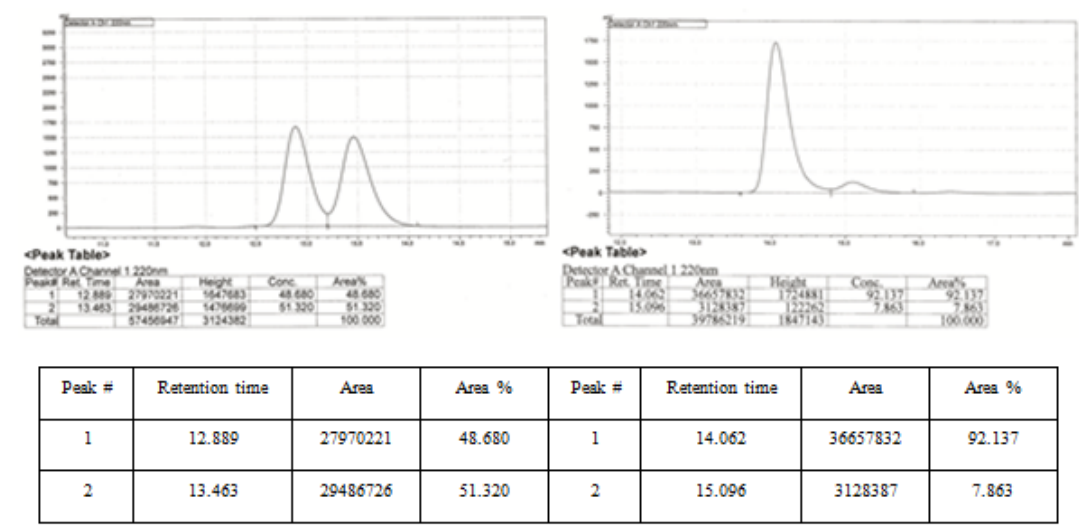

(R)-2-(3,3-Difluoro-1-(naphthalen-1-yl)allyl)-4,4,5,5-tetramethyl-1,3,2-dioxaborolane

(10b): colorless oil. $\mathrm{R} f=0.62$ (hexanes:EtOAc 90:10; $\mathrm{UV} / \mathrm{KMnO}_{4}$ stain). IR (neat): 2979 (m), 1739 (s), 1510 (s), 1372 (m), 1323 (s), 1167 (w), 1138 (s), 966 (m), 798 (s) cm ${ }^{-1}$; ${ }^{1} \mathrm{H}$ NMR $\left(\mathrm{CDCl}_{3}, 600 \mathrm{MHz}\right): \delta 8.09(\mathrm{~d}, J=8.4 \mathrm{~Hz}, 1 \mathrm{H}), 7.86(\mathrm{~d}, J=7.4 \mathrm{~Hz}, 1 \mathrm{H}), 7.72(\mathrm{dd}, J=7.2,2.2$ $\mathrm{Hz}, 1 \mathrm{H}), 7.52$ (t, $J=8.1 \mathrm{~Hz}, 1 \mathrm{H}), 7.48$ (t, $J=8.1 \mathrm{~Hz}, 1 \mathrm{H}), 7.44-7.39$ (m, 2H), 4.74 (ddd, J = 25.2, 9.8, $2.4 \mathrm{~Hz}, 1 \mathrm{H}), 3.88(\mathrm{~d}, J=9.8 \mathrm{~Hz}, 1 \mathrm{H}), 1.22(\mathrm{~s}, 6 \mathrm{H}), 1.20(\mathrm{~s}, 6 \mathrm{H}) ;{ }^{13} \mathrm{C} \mathrm{NMR}\left(\mathrm{CDCl}_{3}\right.$, $150 \mathrm{MHz}): \delta 156.1(\mathrm{t}, J=286.2 \mathrm{~Hz}), 137.6,134.3,131.8,129.1,127.0,126.0,125.9,125.7$, 125.6, 124.1, 84.3, $79.2(\mathrm{dd}, J=23.01,22.8 \mathrm{~Hz}), 24.8,24.7,24.2(\mathrm{bs}) ;{ }^{19} \mathrm{~F}$ NMR (564 MHz, $\mathrm{CDCl}_{3}$ ): major isomer (restricted rotation around benzylic $\mathrm{C}-$ naphthalene bond) $\delta-88.7$ (dd, $J$ 
$=45.6,2.4 \mathrm{~Hz}),-89.7(\mathrm{dd}, J=45.5,25.3 \mathrm{~Hz})$, minor isomer $\delta-88.86(\mathrm{~d}, J=45.4 \mathrm{~Hz}),-90.11$ (dd, $J=45.4,25.2 \mathrm{~Hz}$ ); HRMS (DART-TOF) $\mathrm{m} / \mathrm{z}$ : $[\mathrm{M}+\mathrm{H}]^{+}$Calcd for $\mathrm{C}_{19} \mathrm{H}_{22} \mathrm{BF}_{2} \mathrm{O}_{2}{ }^{+}$: 331.1675, Found: 331.1672; Specific rotation: $[\alpha]_{\mathrm{D}}{ }^{20}-22.35$ (c 2.0, $\mathrm{CH}_{2} \mathrm{Cl}_{2}$ ) for an enantiomerically enriched sample of 92:8 er favoring the $(R)$-enantiomer. Enantiomeric purity was determined by HPLC analysis in comparison with authentic racemic material (92:8 er shown; OD-H column, 99.8:0.2 hexanes: $i-\mathrm{PrOH}, 0.1 \mathrm{~mL} / \mathrm{min}, 220 \mathrm{~nm})$. $(S)$-enantiomer: $\mathrm{t}_{\mathrm{r}}=$ 52.4 min, $(R)$-enantiomer: $\mathrm{t}_{\mathrm{r}}=57.0 \mathrm{~min}$.
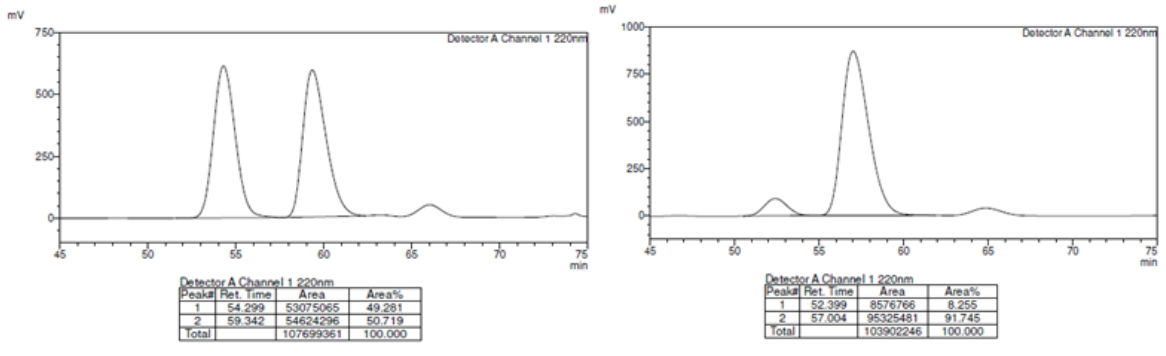

\begin{tabular}{|c|c|c|c|c|c|c|c|}
\hline Peak \# & Retention time & Area & Area \% & Peak \# & Retention time & Area & Area \% \\
\hline 1 & 54.299 & 53075065 & 49.281 & 1 & 52.399 & 8576766 & 8.255 \\
\hline 2 & 59.342 & 54624296 & 50719 & 2 & 57.004 & 95325481 & 91.745 \\
\hline
\end{tabular}

\section{(R)-2-(3,3-Difluoro-1-(3-methoxyphenyl)allyl)-4,4,5,5-tetramethyl-1,3,2-dioxaborolane}

(10d): colorless oil. $\mathrm{R} f=0.65$ (hexanes:EtOAc 90:10; $\mathrm{UV} / \mathrm{KMnO}_{4}$ stain). IR (neat): 2976 (m), 1739 (s), 1597 (m), 1465 (m), 1367 (m), 1325 (s), 1292 (m), 1259 (s), 1153 (s), 1123 (s), 1047 (m), $967(\mathrm{~m}), 913(\mathrm{~m}), 848(\mathrm{~s}) \mathrm{cm}^{-1} ;{ }^{1} \mathrm{H} \mathrm{NMR}\left(\mathrm{CDCl}_{3}, 400 \mathrm{MHz}\right): \delta 7.20$ (t, J = $\left.7.9 \mathrm{~Hz}, 1 \mathrm{H}\right)$, $6.82(\mathrm{~d}, \mathrm{~J}=8.4 \mathrm{~Hz}, 1 \mathrm{H}), 6.78(\mathrm{t}, \mathrm{J}=2.1 \mathrm{~Hz}, 1 \mathrm{H}), 6.73(\mathrm{ddd}, \mathrm{J}=8.3,2.6,0.9 \mathrm{~Hz}, 1 \mathrm{H}), 4.58$ (ddd, $\mathrm{J}=25.2,10.1,2.3 \mathrm{~Hz}, 1 \mathrm{H}), 3.80(\mathrm{~s}, 3 \mathrm{H}), 3.23(\mathrm{~d}, \mathrm{~J}=10.1 \mathrm{~Hz}, 1 \mathrm{H}), 1.23(\mathrm{~s}, 6 \mathrm{H}), 1.22(\mathrm{~s}, 6 \mathrm{H})$. ${ }^{13} \mathrm{C} \mathrm{NMR}\left(\mathrm{CDCl}_{3}, 150 \mathrm{MHz}\right): \delta 160.0,156.1(\mathrm{t}, J=285.5 \mathrm{~Hz}), 142.6,129.7,120.5,113.8$, 111.6, 84.2, $79.1(\mathrm{dd}, \mathrm{J}=23.1,20.4 \mathrm{~Hz}), 55.4,26.0(\mathrm{bs}), 24.8 .{ }^{19} \mathrm{~F} \mathrm{NMR}\left(564 \mathrm{MHz}, \mathrm{CDCl}_{3}\right): \delta$ $-89.21\left(\mathrm{~d}, J=46.3 \mathrm{~Hz}\right.$ ), -90.53 (d, $J=25.2 \mathrm{~Hz}$ ); HRMS (DART-TOF) m/z: [M+H] ${ }^{+}$Calcd for $\mathrm{C}_{16} \mathrm{H}_{22} \mathrm{BF}_{2} \mathrm{O}_{3}{ }^{+}: 311.1625$, Found: 311.1624 . Specific rotation: $[\alpha]_{\mathrm{D}}{ }^{20}-29.60\left(c 0.5, \mathrm{CDCl}_{3}\right)$ for an enantiomerically enriched sample of 95:5 er favoring the $(R)$-enantiomer. Enantiomeric purity was determined by HPLC analysis in comparison with authentic racemic material (95:5 er shown; OJ-H column, 99.5:0.5 hexanes: $i-\mathrm{PrOH}, 0.5 \mathrm{~mL} / \mathrm{min}, 220 \mathrm{~nm})$. $(R)$-enantiomer: $\mathrm{t}_{\mathrm{r}}$ $=9.7 \mathrm{~min},(S)$-enantiomer: $\mathrm{t}_{\mathrm{r}}=10.6 \mathrm{~min}$.
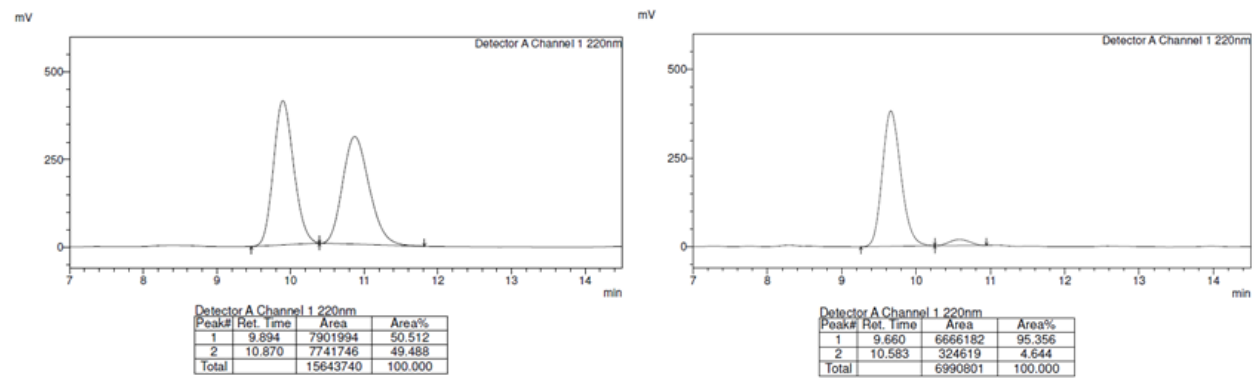

\begin{tabular}{|c|c|c|c|c|c|c|c|}
\hline Peak \# & Retention time & Area & Area \% & Peak \# & Retention time & Area & Area \% \\
\hline 1 & 9.894 & 7901994 & 50.512 & 1 & 9.660 & 6666182 & 95.356 \\
\hline 2 & 10.870 & 7741746 & 49.488 & 2 & 10.583 & 324619 & 4.644 \\
\hline
\end{tabular}




\section{(R)-2-(3,3-Difluoro-1-(4-methoxyphenyl)allyl)-4,4,5,5-tetramethyl-1,3,2-dioxaborolane}

(10e): colorless oil. $\mathrm{R} f=0.60$ (hexanes:EtOAc 90:10; UV/KMnO 4 stain). IR (neat): $2979(\mathrm{~m})$, 1740 (s), 1510 (s), 1464 (w), 1361 (m), 1329 (s), 1246 (s), 1036 (m), 915 (m), 850 (m) cm c $^{-1}$ ${ }^{1} \mathrm{H} \mathrm{NMR}\left(\mathrm{CDCl}_{3}, 400 \mathrm{MHz}\right): \delta 7.15(\mathrm{~d}, J=8.5 \mathrm{~Hz}, 2 \mathrm{H}), 6.84(\mathrm{~d}, J=8.5 \mathrm{~Hz}, 2 \mathrm{H}), 4.55(\mathrm{ddd}, J$ = 25.3, 10.0, $2.4 \mathrm{~Hz}, 1 \mathrm{H}), 3.79(\mathrm{~s}, 3 \mathrm{H}), 3.19(\mathrm{~d}, J=10.1 \mathrm{~Hz}, 1 \mathrm{H}), 1.23(\mathrm{~s}, 6 \mathrm{H}), 1.22(\mathrm{~s}, 6 \mathrm{H})$; ${ }^{13} \mathrm{C} \mathrm{NMR}\left(\mathrm{CDCl}_{3}, 100 \mathrm{MHz}\right): \delta 158.0,156.1(\mathrm{t}, J=284.5 \mathrm{~Hz}), 133.0,129.0,114.3,84.1,79.6$ $(\mathrm{dd}, \mathrm{J}=21.8,20.1 \mathrm{~Hz}), 55.4,24.8,24.8 . ;{ }^{19} \mathrm{~F} \mathrm{NMR}\left(564 \mathrm{MHz}, \mathrm{CDCl}_{3}\right):-89.56(\mathrm{dd}, J=47.0$, $2.2 \mathrm{~Hz}$ ), -90.88 (dd, $J=46.7,25.4 \mathrm{~Hz}$ ); HRMS (DART-TOF) m/z: $[\mathrm{M}+\mathrm{H}]^{+}$Calcd for $\mathrm{C}_{16} \mathrm{H}_{22} \mathrm{BF}_{2} \mathrm{O}_{3}{ }^{+}: 311.1625$, Found: 311.1630 ; Specific rotation: $[\alpha]_{\mathrm{D}^{20}}-32.01\left(c\right.$ 1.0, $\left.\mathrm{CDCl}_{3}\right)$ for an enantiomerically enriched sample of 94:6 er favoring the $(R)$-enantiomer. Enantiomeric purity was determined by HPLC analysis in comparison with authentic racemic material (94:6 er shown; OJ-H column, 99.5:0.5 hexanes: $i-\mathrm{PrOH}, 0.5 \mathrm{~mL} / \mathrm{min}, 220 \mathrm{~nm})$. $(S)$-enantiomer: $\mathrm{t}_{\mathrm{r}}=$ $11.0 \mathrm{~min},(R)$-enantiomer: $\mathrm{t}_{\mathrm{r}}=10.0 \mathrm{~min}$.

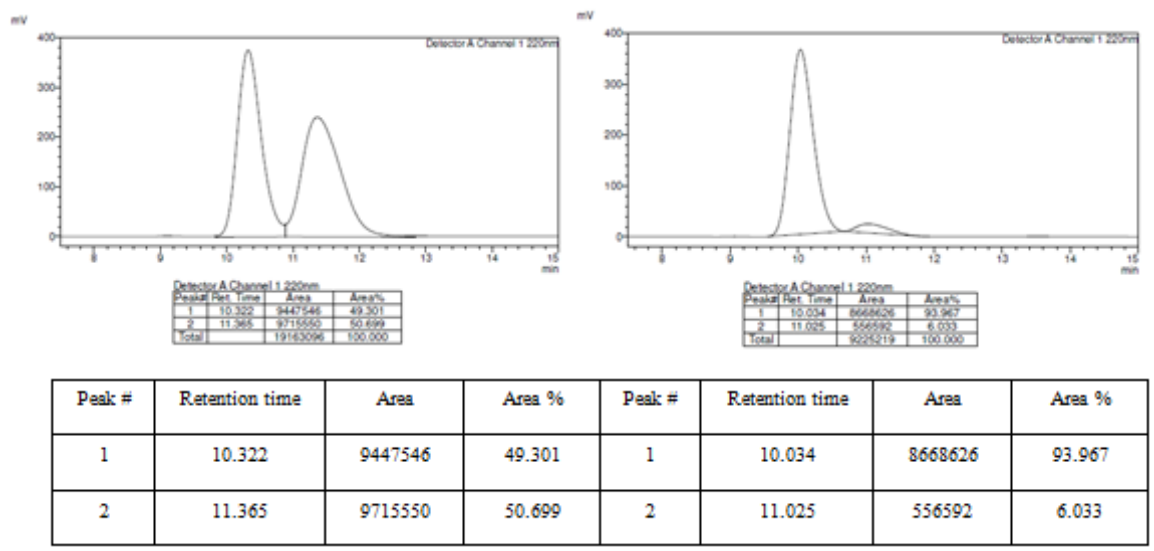

(R)-2-(1-(4-Bromophenyl)-3,3-difluoroallyl)-4,4,5,5-tetramethyl-1,3,2-dioxaborolane

(10f): colorless oil. $\mathrm{R} f=0.70$ (hexanes; $\mathrm{UV} / \mathrm{KMnO}_{4}$ stain). IR (neat): 2977 (m), 1739 (s), 1486 (m), 1328 (s), 1137 (s), 1123 (s), 1072 (m), 1010 (m), 967 (m), 915 (m), 849 (m) cm ${ }^{-1}$; ${ }^{1} \mathrm{H}$ NMR (CDCl, $500 \mathrm{MHz}): \delta 7.40(\mathrm{~d}, J=8.4 \mathrm{~Hz}, 2 \mathrm{H}), 7.10$ (d, $J=8.4 \mathrm{~Hz}, 2 \mathrm{H}), 4.55$ (ddd, $J=$ $25.1,10.0,2.2 \mathrm{~Hz}, 1 \mathrm{H}), 3.20(\mathrm{~d}, J=10.0 \mathrm{~Hz}, 1 \mathrm{H}), 1.22(\mathrm{~s}, 6 \mathrm{H}), 1.21(\mathrm{~s}, 6 \mathrm{H}) ;{ }^{13} \mathrm{C} \mathrm{NMR}\left(\mathrm{CDCl}_{3}\right.$, $125 \mathrm{MHz}$ ): $\delta 156.3(\mathrm{t}, J=290.6 \mathrm{~Hz}), 140.1,131.8,129.7,119.9,84.3,78.7$ (dd, $J=22.1,20.1$ $\mathrm{Hz}), 25.4$ (bs), 24.8, 24.7; ${ }^{19} \mathrm{~F}$ NMR (470 MHz, $\left.\mathrm{CDCl}_{3}\right): \delta-88.63(\mathrm{~d}, J=44.8 \mathrm{~Hz}),-89.81$ (dd, $J=44.6,25.0 \mathrm{~Hz}$ ); HRMS (DART-TOF) $\mathrm{m} / \mathrm{z}$ : $[\mathrm{M}+\mathrm{H}]^{+}$Calcd for $\mathrm{C}_{15} \mathrm{H}_{19} \mathrm{BF}_{2} \mathrm{O}_{2} \mathrm{Br}^{+}$: 359.0624 , Found: 359.0620. Specific rotation: $[\alpha]_{\mathrm{D}}{ }^{20}-28.40\left(c 0.4, \mathrm{CH}_{2} \mathrm{Cl}_{2}\right)$ for an enantiomerically enriched sample of 95:5 er favoring the $(R)$-enantiomer. Enantiomeric purity was determined by HPLC analysis in comparison with authentic racemic material (95:5 er shown; OJ-H column, $100 \%$ hexanes, $0.5 \mathrm{~mL} / \mathrm{min}, 220 \mathrm{~nm})$. $(R)$-enantiomer: $\mathrm{t}_{\mathrm{r}}=12.7 \mathrm{~min},(S)$-enantiomer: $\mathrm{t}_{\mathrm{r}}=10.0 \mathrm{~min}$. 

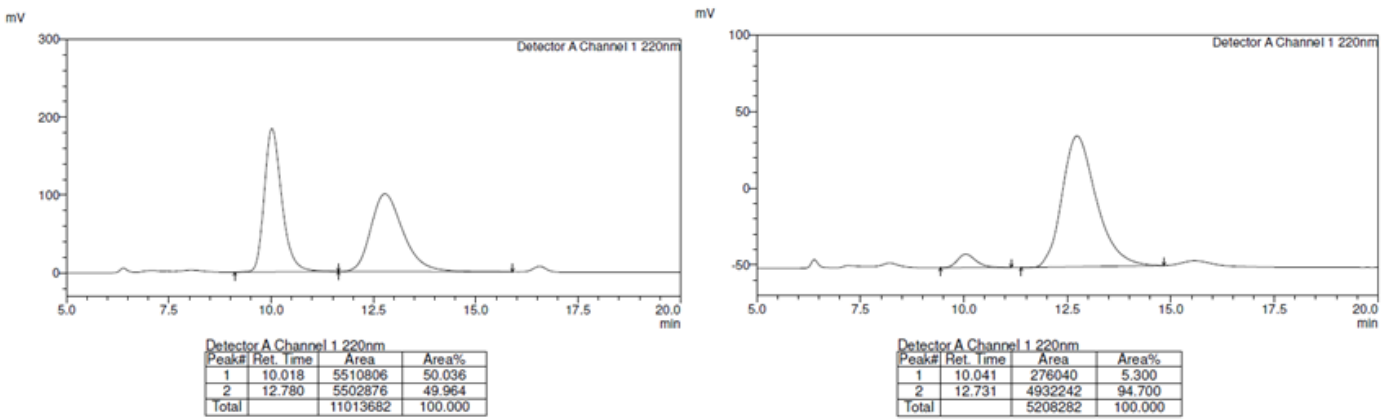

\begin{tabular}{|c|c|c|c|c|c|c|c|}
\hline Peak \# & Retention time & Area & Area \% & Peak \# & Retention time & Area & Area \% \\
\hline 1 & 10.018 & 5510806 & 50.036 & 1 & 10.041 & 276040 & 5.300 \\
\hline 2 & 12.780 & 5502876 & 49.964 & 2 & 12.731 & 4932242 & 94.700 \\
\hline
\end{tabular}

(R)-2-(4,4-Difluoro-1-((4-methoxybenzyl)oxy)but-3-en-2-yl)-4,4,5,5-tetramethyl-1,3,2-

dioxaborolane (12a): $\mathrm{R} f=0.38$ (hexanes:EtOAc 10:1; UV/KMnO 4 stain). IR (neat): $2979(\mathrm{w})$, 2928 (w), 2855 (w), 1742 (m), 1613 (w), 1513 (m), 1465 (w), 1371 (s), 1325 (s), 1245 (s), 1142 (s), 1089 (s), 1036 (s), 819 (s), 677 (w), 515 (w) cm ${ }^{-1} ;{ }^{1} \mathrm{H}$ NMR $\left(\mathrm{CDCl}_{3}, 500 \mathrm{MHz}\right): \delta 7.25$ (d, $J=8.5 \mathrm{~Hz}, 2 \mathrm{H}), 6.86(\mathrm{~d}, J=8.5 \mathrm{~Hz}, 2 \mathrm{H}), 4.43$ (dt, $J=18.0,12.0 \mathrm{~Hz}, 2 \mathrm{H}), 4.27$ (ddd, $J=26.0$, 9.5, 2.5 Hz, 1H), 3.80 (s, 3H), $3.53(\mathrm{~d}, J=6.5 \mathrm{~Hz}, 2 \mathrm{H}), 2.22$ (q, $J=7.0 \mathrm{~Hz}, 1 \mathrm{H}), 1.23(\mathrm{~s}, 12 \mathrm{H})$; ${ }^{13} \mathrm{C} \mathrm{NMR}\left(\mathrm{CDCl}_{3}, 100 \mathrm{MHz}\right): \delta 159.2,156.3(\mathrm{dd}, J=283.8,283.0 \mathrm{~Hz}), 130.7,129.2,113.8$, 83.9, 77.0 (dd, $J=23.5,20.5 \mathrm{~Hz}), 72.6,71.0(\mathrm{t}, J=3.0 \mathrm{~Hz}), 55.4,24.9,24.8,20.7(\mathrm{bs}) ;{ }^{19} \mathrm{~F}$ $\operatorname{NMR}\left(376 \mathrm{MHz}, \mathrm{CDCl}_{3}\right): \delta-89.56(\mathrm{~d}, J=47.8,1 \mathrm{~F}),-91.49$ (dd, $\left.J=47.8,25.9 \mathrm{~Hz}, 1 \mathrm{~F}\right)$; HRMS (DART-TOF) $\mathrm{m} / \mathrm{z}$ : $\left[\mathrm{M}+\mathrm{NH}_{4}\right]^{+}$Calcd for $\mathrm{C}_{18} \mathrm{H}_{29} \mathrm{BF}_{2} \mathrm{O}_{4} \mathrm{~N}^{+}$: 372.2152, Found: 372.2178 ; Specific rotation: $[\alpha]_{\mathrm{D}}{ }^{20}-1.18\left(c 2.13, \mathrm{CHCl}_{3}\right)$ for an enantiomerically enriched sample of 91:9 er favoring the $(S)$-enantiomer. Enantiomeric purity was determined by HPLC analysis of the alcohol product after oxidation in comparison with authentic racemic material (AD-H column, 98:2 hexanes: $i-\mathrm{PrOH}, 0.3 \mathrm{~mL} / \mathrm{min}, 220 \mathrm{~nm})$. $(S)$-enantiomer: $\mathrm{t}_{\mathrm{r}}=77.4 \mathrm{~min},(R)$-enantiomer: $\mathrm{t}_{\mathrm{r}}$ $=95.7 \mathrm{~min}$.
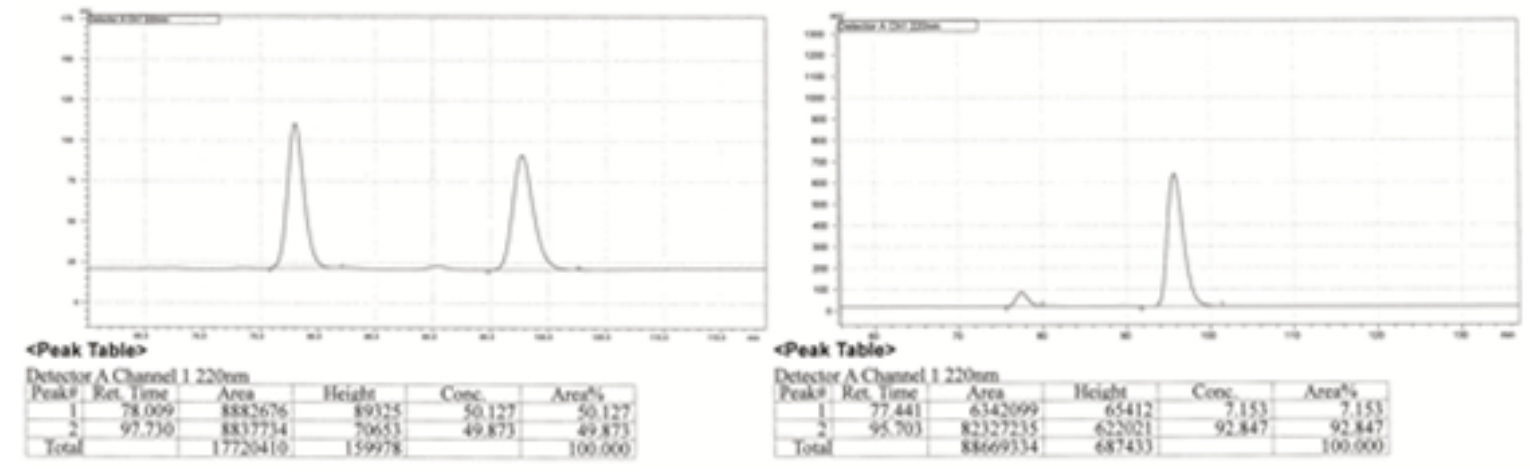

\begin{tabular}{|c|c|c|c|c|c|c|c|}
\hline Peak $\#$ & Retention time & Area & Area \% & Peak $\#$ & Retention time & Area & Area \% \\
\hline 1 & 78.009 & 8882676 & 50.127 & 1 & 77.441 & 6342099 & 7.153 \\
\hline 2 & 97.730 & 8837734 & 49.873 & 2 & 95.703 & 82327235 & 92.847 \\
\hline
\end{tabular}




\section{(S)-2-(1,1-Difluoro-5-phenylpent-1-en-3-yl)-4,4,5,5-tetramethyl-1,3,2-dioxaborolane}

(12b): white solid. Melting point: 50-52 ${ }^{\circ} \mathrm{C}$; IR (neat): 2977 (w), 2926 (w), 1738 (s), 1600 (w), 1454 (s), 1372 (s), 1363 (s), 1211 (s), 1156 (s), 1142 (s), 670 (m), 441 (s) cm ${ }^{-1} ;{ }^{1} \mathrm{H}$ NMR $\left(\mathrm{CDCl}_{3}, 400 \mathrm{MHz}\right): \delta 7.29-1.26(\mathrm{~m}, 2 \mathrm{H}), 7.19-7.16(\mathrm{~m}, 3 \mathrm{H}), 4.20$ (ddd, $J=26.0,10.4,2.8 \mathrm{~Hz}$ ), $2.71-2.64(\mathrm{~m}, 1 \mathrm{H}), 2.57(\mathrm{ddd}, J=13.7,10.6,5.8,1 \mathrm{H}), 1.92-1.83(\mathrm{~m}, 2 \mathrm{H}), 1.72-1.62(\mathrm{~m}, 1 \mathrm{H})$, $1.56(\mathrm{~s}, 12 \mathrm{H}) ;{ }^{13} \mathrm{C} \mathrm{NMR}\left(\mathrm{CDCl}_{3}, 100 \mathrm{MHz}\right): \delta 156.3(\mathrm{t}, J=284.6 \mathrm{~Hz}), 142.3,128.6,128.5$, $125.9,83.7,78.9(t, \mathrm{~J}=21.2 \mathrm{~Hz}), 35.3,33.2,24.9,18.5(\mathrm{bs}) ;{ }^{19} \mathrm{~F} \mathrm{NMR}\left(376 \mathrm{MHz}, \mathrm{CDCl}_{3}\right): \delta-$ $90.01(\mathrm{~d}, J=48.9 \mathrm{~Hz}, 1 \mathrm{~F}),-92.15$ (dd, $J=48.9,24.4 \mathrm{~Hz}, 1 \mathrm{~F})$; HRMS (DART-TOF) $\mathrm{m} / \mathrm{z}$ : $[\mathrm{M}+\mathrm{H}]^{+}$Calcd for $\mathrm{C}_{17} \mathrm{H}_{24} \mathrm{BF}_{2} \mathrm{O}_{2}{ }^{+}: 309.1832$, Found: $309.1823 ;[\alpha]_{\mathrm{D}}{ }^{20}-1.20\left(c\right.$ 2.07, $\left.\mathrm{CH}_{2} \mathrm{Cl}_{2}\right)$ for an enantiomerically enriched sample of 92:8 er favoring the $(S)$-enantiomer. Enantiomeric purity was determined by HPLC analysis in comparison with authentic racemic material (92:8 er shown; OJ-H column, 100\% hexanes, $0.3 \mathrm{~mL} / \mathrm{min}, 220 \mathrm{~nm})$. $(S)$-enantiomer: $\mathrm{t}_{\mathrm{r}}=26.1 \mathrm{~min}$, $(R)$-enantiomer: $\mathrm{t}_{\mathrm{r}}=24.7 \mathrm{~min}$.
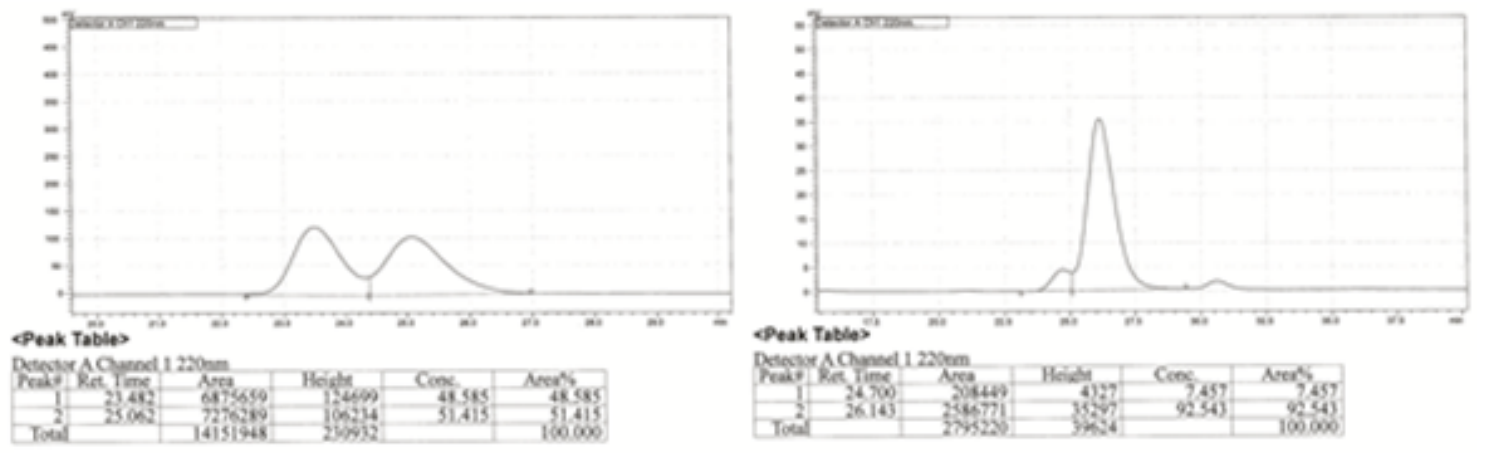

\begin{tabular}{|c|c|c|c|c|c|c|c|}
\hline Peal: $=$ & Retention time & Area & Area \% & Peak $\#$ & Retention time & Area & Area $\%$ \\
\hline 1 & 23.482 & 6875659 & 48.585 & 1 & 24.700 & 208449 & 7.457 \\
\hline 2 & 25.062 & 7276289 & 51.415 & 2 & 26.143 & 2586771 & 92.543 \\
\hline
\end{tabular}

(S)-9,9-Difluoro-7-(4,4,5,5-tetramethyl-1,3,2-dioxaborolan-2-yl)non-8-en-1-yl

ferrocenecarboxylate (12c): colorless oil. IR (neat): 2986 (w), 2933 (w), 2879 (w), 1738 (m), 1712 (s), 1461 (m), 1372 (m), 1326 (m), 1274 (s), 1108 (s), 407 (s) cm ${ }^{-1}$; ${ }^{1} \mathrm{H} \mathrm{NMR} \mathrm{(CDCl}{ }_{3}$, $400 \mathrm{MHz}$ ): $\delta 4.80(\mathrm{t}, J=2.0 \mathrm{~Hz}, 2 \mathrm{H}), 4.38(\mathrm{t}, J=2.0 \mathrm{~Hz}, 2 \mathrm{H}), 4.21-4.17(\mathrm{~m}, 7 \mathrm{H}), 4.14$ (ddd, J $=15.1,10.6,2.8 \mathrm{~Hz}, 1 \mathrm{H}), 1.83(\operatorname{app~q}, J=8.4 \mathrm{~Hz}, 1 \mathrm{H}), 1.71(\operatorname{app~p}, J=6.4 \mathrm{~Hz}, 2 \mathrm{H}), 1.46-1.31$ $(\mathrm{m}, 8 \mathrm{H}), 1.23(\mathrm{~s}, 12 \mathrm{H}) ;{ }^{13} \mathrm{C} \mathrm{NMR}\left(\mathrm{CDCl}_{3}, 100 \mathrm{MHz}\right): \delta 171.9,156.1(\mathrm{t}, J=284.6 \mathrm{~Hz}), 83.6$, 79.1 (t, $J=21.2 \mathrm{~Hz}$ ), 71.7, 71.3, 70.2, 69.8, 64.4, 31.0 (t, $J=2.2 \mathrm{~Hz}), 29.3,29.0,28.8,26.1$, 25.2, 24.8, 18.5 (bs); ${ }^{19} \mathrm{~F}$ NMR (470 MHz, $\left.\mathrm{CDCl}_{3}\right): \delta-90.58(\mathrm{~d}, J=49.8 \mathrm{~Hz}, 1 \mathrm{~F}),-92.87$ (dd, $J=51.2,26.3 \mathrm{~Hz}, 1 \mathrm{~F}$ ); HRMS (DART-TOF) $\mathrm{m} / \mathrm{z}$ : $[\mathrm{M}+\mathrm{H}]^{+}$Calcd for $\mathrm{C}_{26} \mathrm{H}_{36} \mathrm{BF}_{2} \mathrm{FeO}_{4}{ }^{+}$: 517.2019, Found: 517.2025; specific rotation: $[\alpha]_{\mathrm{D}}{ }^{20}-1.76$ (c 3.25, $\mathrm{CH}_{2} \mathrm{Cl}_{2}$ ) for an enantiomerically enriched sample of 90:10 er favoring the $(S)$-enantiomer. Enantiomeric purity was determined by HPLC analysis of the alcohol product after oxidation in comparison with authentic racemic material (90:10 er shown; AD-H column, 98:2 hexanes:i-PrOH, $0.3 \mathrm{~mL} / \mathrm{min}$, $220 \mathrm{~nm}) .(S)$-enantiomer: $\mathrm{t}_{\mathrm{r}}=215.0 \mathrm{~min},(R)$-enantiomer: $\mathrm{t}_{\mathrm{r}}=208.2 \mathrm{~min}$. 

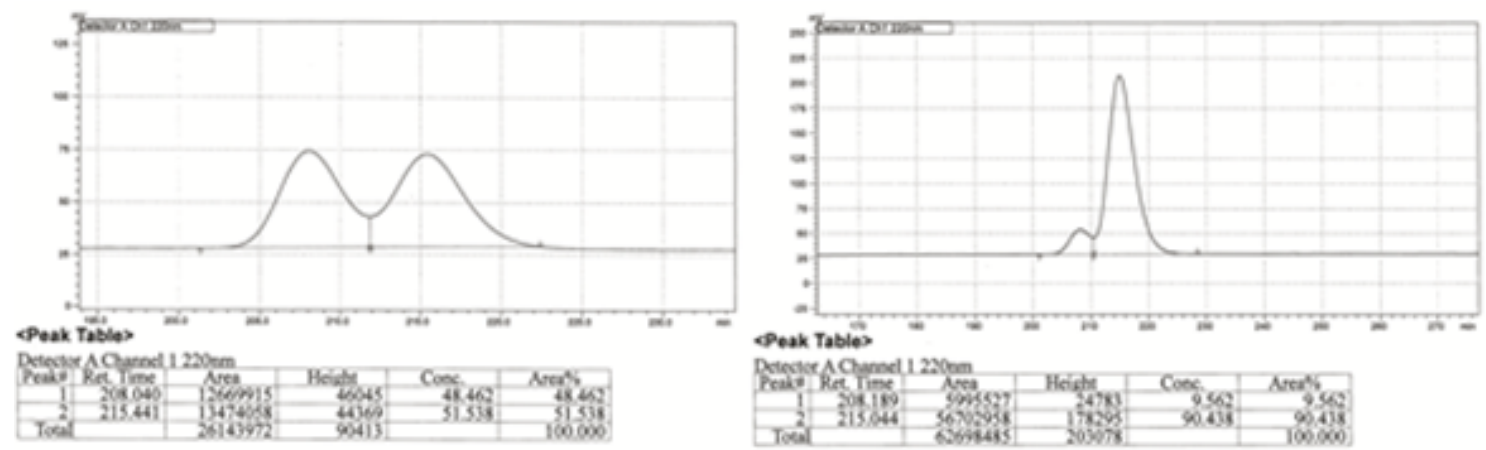

问

\begin{tabular}{|c|c|c|c|c|c|c|c|}
\hline Peak $\#$ & Retention time & Area & Area \% & Peal $\#$ & Retention time & Area & Area \% \\
\hline 1 & 208.040 & 12669915 & 48.462 & 1 & 208.189 & 5995527 & 9.562 \\
\hline 2 & 215.441 & 13474058 & 51.538 & 2 & 215.044 & 56702958 & 90.438 \\
\hline
\end{tabular}

(R)-tert-Butyl((4,4-difluoro-2-(4,4,5,5-tetramethyl-1,3,2-dioxaborolan-2-yl)but-3-en-1yl)oxy)diphenylsilane (12d): colorless oil. $\mathrm{R}_{f}=0.58$ (20:1 petroleum ether:Et $\left.{ }_{2} \mathrm{O}\right)$; IR (neat): 2978 (w), 2931 (w), 2858 (w), 1741 (m), 1427 (w), 1372 (m), 1324 (m), 1252 (m), 1141 (m),

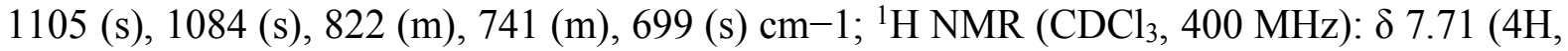
$\mathrm{ddt}, J=5.9,3.9,1.7 \mathrm{~Hz}), 7.48-7.35(6 \mathrm{H}, \mathrm{m}), 4.31(1 \mathrm{H}, \mathrm{ddd}, J=25.9,10.4,2.5 \mathrm{~Hz}), 3.85-3.74$ $(2 \mathrm{H}, \mathrm{m}), 2.17(1 \mathrm{H}, \mathrm{dt}, J=11.5,6.2 \mathrm{~Hz}), 1.27(12 \mathrm{H}, \mathrm{s}), 1.07(9 \mathrm{H}, \mathrm{s}) ;{ }^{13} \mathrm{C} \mathrm{NMR}\left(\mathrm{CDCl}_{3}, 101\right.$ MHz): $\delta 156.4(\mathrm{t}, J=285.8 \mathrm{~Hz}), 135.8,133.8,129.7,127.8,127.7,83.8,76.8(\mathrm{t}, J=22.2 \mathrm{~Hz})$, $65.0(\mathrm{t}, J=2.7 \mathrm{~Hz}), 27.0,25.0,24.9,22.9$ (bs), 19.4; ${ }^{19} \mathrm{~F} \mathrm{NMR}\left(\mathrm{CDCl}_{3}, 376 \mathrm{MHz}\right): \delta-88.66$ $(\mathrm{d}, J=47.4 \mathrm{~Hz}),-90.79(\mathrm{dd}, J=47.4,25.9 \mathrm{~Hz}) ;{ }^{11} \mathrm{~B} \mathrm{NMR}\left(\mathrm{CDCl}_{3}, 128 \mathrm{MHz}\right): \delta 35.3 ; \mathrm{HRMS}$ (ESI-TOF) $\mathrm{m} / \mathrm{z}$ : Calcd for $\mathrm{C}_{26} \mathrm{H}_{36} \mathrm{O}_{3} \mathrm{BF}_{2} \mathrm{Si}[\mathrm{M}+\mathrm{H}]^{+}$: 473.2490, Found: 473.2474; specific rotation: $[\alpha]_{\mathrm{D}}{ }^{20}-8.6\left(c\right.$ 1.0, $\mathrm{CHCl}_{3}$ ) for an enantiomerically enriched sample of 93:7 er. Enantiomeric purity was determined by HPLC analysis of the alcohol product after oxidation in comparison with authentic racemic material (93:7 er shown; AD-H column, 99.5:0.5 hexanes: $i$-PrOH, $0.5 \mathrm{~mL} / \mathrm{min}, 220 \mathrm{~nm})$. (S)-enantiomer: $\mathrm{t}_{\mathrm{r}}=40.9 \mathrm{~min},(R)$-enantiomer: $\mathrm{t}_{\mathrm{r}}=44.4$ $\min$.
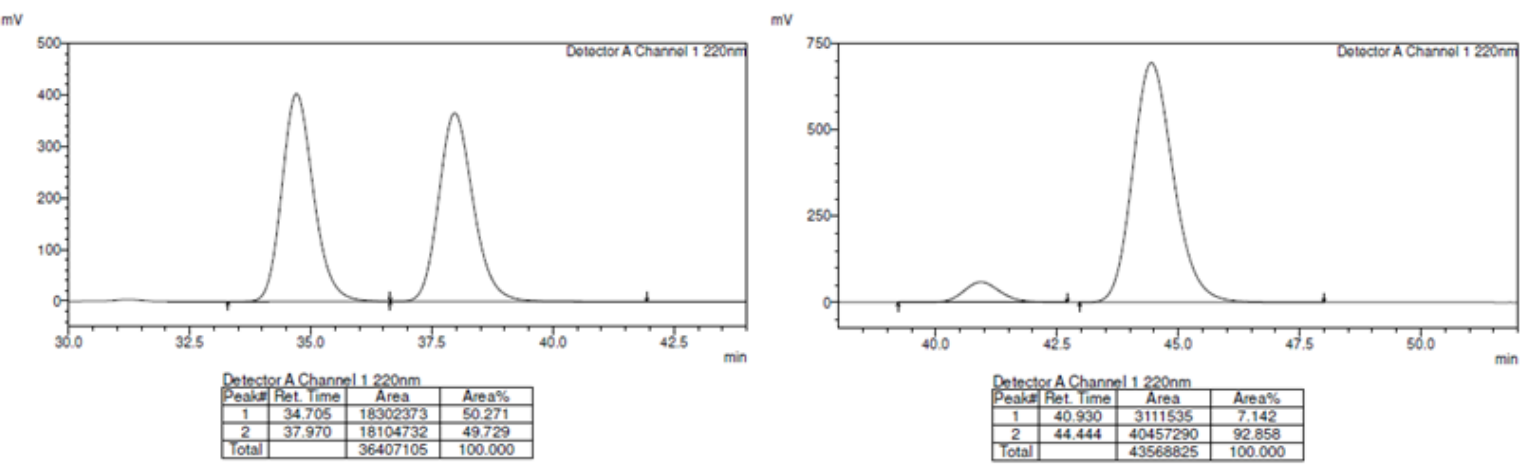

\begin{tabular}{|c|c|c|c|c|c|c|c|}
\hline Peak \# & Retention time & Area & Area \% & Peak \# & Retention time & Area & Area \% \\
\hline 1 & 34.705 & 18302373 & 50.271 & 1 & 40.930 & 3111535 & 7.142 \\
\hline 2 & 37.970 & 18104732 & 49.729 & 2 & 44.444 & 40457290 & 92.858 \\
\hline
\end{tabular}


(R)-4,4-Difluoro-2-(4,4,5,5-tetramethyl-1,3,2-dioxaborolan-2-yl)but-3-en-1-ol

(12e): colorless oil. IR (neat): 2981 (w), 2885 (w), 1741 (s), 1470 (s), 1372 (s), 1239 (m), 1215 (m), 1141 (s), $1110(\mathrm{~m}), 1052(\mathrm{~m}), 487(\mathrm{w}) \mathrm{cm}^{-1} ;{ }^{1} \mathrm{H} \mathrm{NMR}\left(\mathrm{CDCl}_{3}, 400 \mathrm{MHz}\right): \delta 4.24$ (ddd, $J=$ 26.4, 10.8, $2.8 \mathrm{~Hz}, 1 \mathrm{H}), 3.69$ (t, $J=6.4 \mathrm{~Hz}, 2 \mathrm{H}), 2.15-2.09(\mathrm{~m}, 1 \mathrm{H}), 1.91(\mathrm{t}, J=6.0 \mathrm{~Hz}, 1 \mathrm{H})$, $1.26(\mathrm{~s}, 12 \mathrm{H}) ;{ }^{13} \mathrm{C} \mathrm{NMR}\left(\mathrm{CDCl}_{3}, 100 \mathrm{MHz}\right): \delta 159.7(\mathrm{t}, J=286.2 \mathrm{~Hz}), 84.1,76.0(\mathrm{dd}, J=22.7$, $20.5 \mathrm{~Hz}), 63.7$ (t, $J=3.1 \mathrm{~Hz}), 24.9,24.8,23.0(\mathrm{bs}) ;{ }^{19} \mathrm{~F} \mathrm{NMR}\left(376 \mathrm{MHz}, \mathrm{CDCl}_{3}\right): \delta-88.62(\mathrm{~d}$, $J=46.2 \mathrm{~Hz}, 1 \mathrm{~F}),-90.77$ (dd, $J=46.2,25.9 \mathrm{~Hz}, 1 \mathrm{~F}$ ); HRMS (DART-TOF) m/z: [M+H] ${ }^{+} \mathrm{Calcd}$ for $\mathrm{C}_{10} \mathrm{H}_{18} \mathrm{BF}_{2} \mathrm{O}_{3}{ }^{+}$: 235.1312, Found: 235.1322; specific rotation: $[\alpha]_{\mathrm{D}^{20}}-10.81$ (c 1.64, $\mathrm{CH}_{2} \mathrm{Cl}_{2}$ ) for an enantiomerically enriched sample of 83:17 er, favoring the $(R)$-enantiomer. Enantiomeric purity was determined by HPLC analysis of the alcohol product synthesized after PMB protection of the homopropargylic alcohol (HPLC trace contains PMBtrichloroacetimidate impurities) and oxidation of the allylic boronate in comparison with authentic racemic material (AD-H column, 98:2 hexanes:i-PrOH, $0.3 \mathrm{~mL} / \mathrm{min}, 220 \mathrm{~nm}$ ). $(S)$ enantiomer: $\mathrm{t}_{\mathrm{r}}=76.1 \mathrm{~min},(R)$-enantiomer: $\mathrm{t}_{\mathrm{r}}=94.9 \mathrm{~min}$.

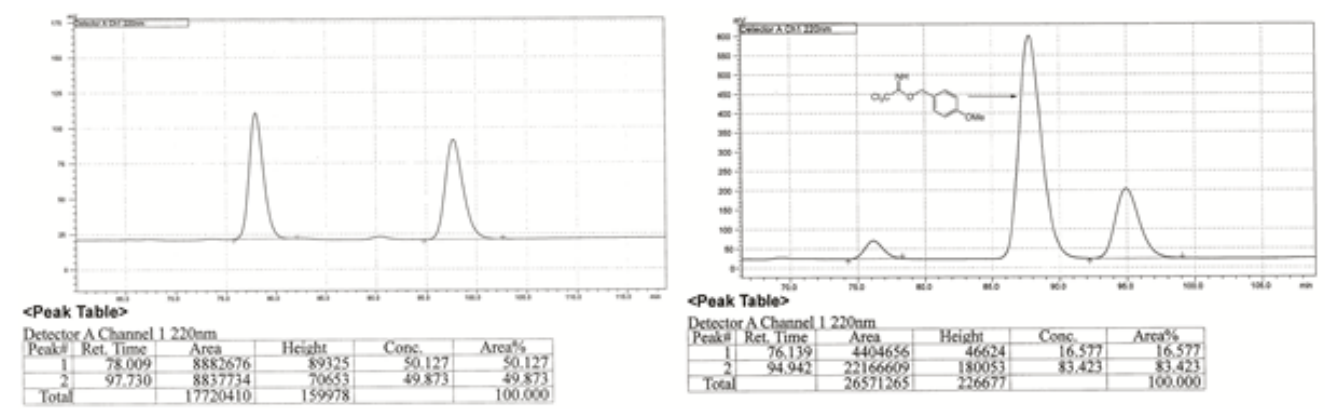

\begin{tabular}{|c|c|c|c|c|c|c|c|}
\hline Peak $\#$ & Retention time & Area & Area $\%$ & Peal \# & Retention time & Area & Area \% \\
\hline 1 & 78.009 & 8882676 & 50.127 & 1 & 76.139 & 4404656 & 16.577 \\
\hline 2 & 97.730 & 8837734 & 49.873 & 2 & 94.942 & 22166609 & 83.423 \\
\hline
\end{tabular}

\section{tert-Butyl-(S)-4-(3,3-difluoro-1-(4,4,5,5-tetramethyl-1,3,2-dioxaborolan-2-yl)allyl)}

piperidine-1-carboxylate (12f): colorless oil. IR (neat): 2977 (w), 2931 (w), 1738 (s), 1692 (s), 1421 (w), 1364 (m), 1326 (m), 1251 (w), 1163 (m), 1141 (m), 1105 (s), 972 (w), 909 (w), $850(\mathrm{~m}), 770(\mathrm{w}) \mathrm{cm}^{-1} ;{ }_{1}^{1} \mathrm{H} \mathrm{NMR}\left(\mathrm{CDCl}_{3}, 400 \mathrm{MHz}\right): \delta 4.20-4.00(\mathrm{~m}, 2 \mathrm{H}), 4.12(\mathrm{ddd}, J=25.3$, $11.1,2.6 \mathrm{~Hz}, 1 \mathrm{~h}), 2.74-2.57$ (m, 2H), $1.74(\mathrm{dd}, J=10.5,7.4 \mathrm{~Hz}, 1 \mathrm{H}), 1.68-1.55(\mathrm{~m}, 2 \mathrm{H}), 1.45$ $(\mathrm{s}, 9 \mathrm{H}), 1.24(\mathrm{~s}, 9 \mathrm{H}), 1.27-1.04(\mathrm{~m}, 2 \mathrm{H}) ;{ }^{13} \mathrm{C} \mathrm{NMR}\left(\mathrm{CDCl}_{3}, 125 \mathrm{MHz}\right): \delta 156.5(\mathrm{t}, J=284.7$ $\mathrm{Hz}$ ), 155.0, 83.8, 79.4, 77.1 (t, J=42.0 Hz), 44.7 (bs), $43.8(\mathrm{bs}), 37.8$ (t, $J=2.4 \mathrm{~Hz}), 31.8$ (bs), 31.1 (bs), 28.7, 25.0, 24.9; ${ }^{19} \mathrm{~F}$ NMR (376 MHz, $\left.\mathrm{CDCl}_{3}\right): \delta-88.16(\mathrm{~d}, J=47.7 \mathrm{~Hz}),-91.20(\mathrm{dd}$, $J=47.7,25.3 \mathrm{~Hz}) ;{ }^{11} \mathrm{~B}$ NMR $\left(\mathrm{CDCl}_{3}, 128 \mathrm{MHz}\right): \delta 35.8$; HRMS (ESI-TOF) m/z: $[\mathrm{M}+\mathrm{H}]^{+}$ Calcd for $\mathrm{C}_{19} \mathrm{H}_{33} \mathrm{BF}_{2} \mathrm{NO}_{4}{ }^{+}$: 388.2465 , Found: 388.2452; Enantiomeric purity was determined by HPLC in comparison with authentic racemic material (94:6 er shown; AD-H column, 96:4 hexanes: $i$-PrOH, $0.5 \mathrm{~mL} / \mathrm{min}, 220 \mathrm{~nm})$. $(S)$-enantiomer: $\mathrm{t}_{\mathrm{r}}=24.9 \mathrm{~min},(R)$-enantiomer: $\mathrm{t}_{\mathrm{r}}=25.9$ $\min$. 


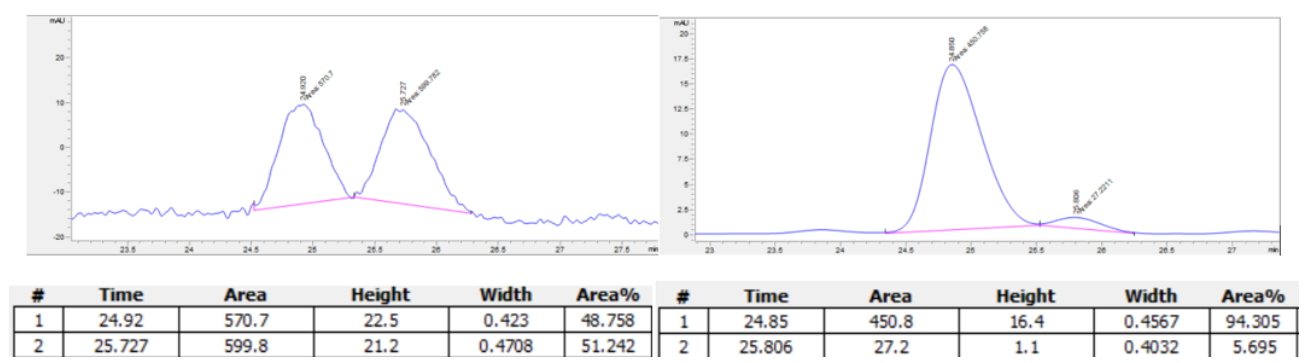

\begin{tabular}{|c|c|c|c|c|c|}
\hline Retention Time & Area & Area $\%$ & Retention Time & Area & Area $\%$ \\
\hline 24.920 & 570.7 & 48.758 & 24.850 & 450.8 & 94.305 \\
\hline 25.727 & 599.8 & 51.242 & 25.806 & 27.2 & 5.695 \\
\hline
\end{tabular}

\subsection{Characterization of 1,1-difluoroallyl silanes}

(R)-(1-(4-(tert-Butyl)phenyl)-3,3-difluoroallyl)dimethyl(phenyl)silane (13a): colorless oil. $\mathrm{R} f=0.51$ (hexane, $\mathrm{UV} / \mathrm{KMnO}_{4}$ stain). IR (neat): 2960 (m), 2868 (w) 1736 (s), 1513 (m), 1261 (m), $1177(\mathrm{~m}), 832(\mathrm{~m}), 810(\mathrm{~m}), 699(\mathrm{~m}), 469(\mathrm{w}) \mathrm{cm}^{-1},{ }^{1} \mathrm{H} \mathrm{NMR}\left(\mathrm{CDCl}_{3}, 400 \mathrm{MHz}\right): \delta 7.42-$ $7.29(\mathrm{~m}, 5 \mathrm{H}), 7.22(\mathrm{~d}, \mathrm{~J}=8.4 \mathrm{~Hz}, 2 \mathrm{H}), 6.82(\mathrm{~d}, J=8.4 \mathrm{~Hz}, 2 \mathrm{H}), 4.54(\mathrm{ddd}, J=22.7,11.9,4.0$ $\mathrm{Hz}, 1 \mathrm{H}), 3.14(\mathrm{dd}, J=11.9,2.2 \mathrm{~Hz}, 1 \mathrm{H}), 1.30(\mathrm{~s}, 9 \mathrm{H}), 0.29(\mathrm{~s}, 3 \mathrm{H}), 0.28(\mathrm{~s}, 3 \mathrm{H}) ;{ }^{13} \mathrm{C}$ NMR $\left(\mathrm{CDCl}_{3}, 100 \mathrm{MHz}\right): \delta 155.4(\mathrm{t}, J=284.6 \mathrm{~Hz}), 148.1,137.9,136.3,134.4,134.1,129.5,127.8$, 127.0, 125.3, $78.6(\mathrm{t}, \mathrm{J}=21.5 \mathrm{~Hz}), 34.5,31.6,30.8,-3.7,-4.3,-4.8 ;{ }^{19} \mathrm{~F} \mathrm{NMR}\left(\mathrm{CDCl}_{3}, 376\right.$ MHz): $\delta-90.27$ (ddd, $J=48.2,3.8,2.2 \mathrm{~Hz}, 1 \mathrm{~F}),-90.53$ (dd, $J=48.1,22.6 \mathrm{~Hz}, 1 \mathrm{~F}$ ); HRMS (DART-TOF) m/z: [M+NH$]^{+}$Calcd for $\mathrm{C}_{21} \mathrm{H}_{30} \mathrm{SiF}_{2} \mathrm{~N}^{+}: 362.2110$, Found: 362.2128; specific rotation: $[\alpha]_{\mathrm{D}}{ }^{20}-25.59\left(c 0.5, \mathrm{CH}_{2} \mathrm{Cl}_{2}\right)$ for an enantiomerically enriched sample of 95:5 er favoring the $(R)$-enantiomer. Enantiomeric purity was determined by HPLC analysis in comparison with authentic racemic material (OD-H column, 100:0 hexanes:i-PrOH, 0.7 $\mathrm{mL} / \mathrm{min}, 220 \mathrm{~nm}) .(S)$-enantiomer: $\mathrm{t}_{\mathrm{r}}=6.8 \mathrm{~min},(R)$-enantiomer: $\mathrm{t}_{\mathrm{r}}=7.4 \mathrm{~min}$.
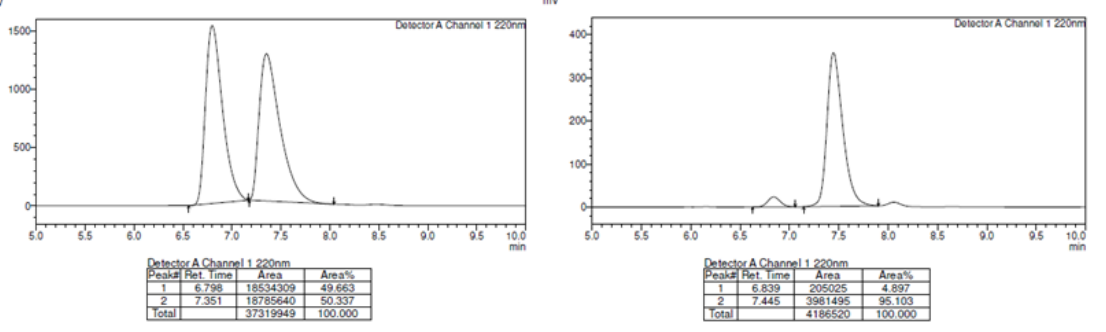

\begin{tabular}{|c|c|c|c|c|c|c|c|}
\hline Peak \# & Retention time & Area & Area $\%$ & Peak \# & Retention time & Area & Area \% \\
\hline 1 & 6.798 & 18534309 & 49.663 & 1 & 6.839 & 205025 & 4.897 \\
\hline 2 & 7.351 & 18785640 & 50.337 & 2 & 7.445 & 3981495 & 95.103 \\
\hline
\end{tabular}

(R)-(3,3-Difluoro-1-(4-methoxyphenyl)allyl)dimethyl(phenyl)silane (13b): colorless oil. $\mathrm{R} f$ $=0.60$ (hexanes:EtOAc 95:5; UV/KMnO 4 stain). IR (neat): 2957 (w), 2835 (w) 1736 (s), 1510 (m), 1246 (s), 1177 (m), $832(\mathrm{~m}), 810(\mathrm{~m}), 701(\mathrm{~m}), 648(\mathrm{w}) \mathrm{cm}^{-1} ;{ }^{1} \mathrm{H} \mathrm{NMR}\left(\mathrm{CDCl}_{3}, 400 \mathrm{MHz}\right)$ : $\delta$ 7.41-7.30 (m, 5H), 6.8-6.71 (m, 4H), 4.49 (ddd, $J=21.8,11.8,4.9 \mathrm{~Hz}, 1 \mathrm{H}), 3.78(\mathrm{~s}, 3 \mathrm{H})$, $3.10(\mathrm{dd}, J=11.8,2.0 \mathrm{~Hz}, 1 \mathrm{H}), 0.28(\mathrm{~s}, 3 \mathrm{H}), 0.27(\mathrm{~s}, 1 \mathrm{H}) ;{ }^{13} \mathrm{C} \mathrm{NMR}\left(\mathrm{CDCl}_{3}, 150 \mathrm{MHz}\right): \delta$ $157.5,155.4(\mathrm{t}, J=284.9 \mathrm{~Hz}), 136.2,134.4,133.1,129.6,128.7,128.2,127.8,78.7(\mathrm{t}, J=21.7$ 
$\mathrm{Hz}), 55.4,30.3,30.3,25.2,-4.4,-4.7 . ;{ }^{19} \mathrm{~F} \mathrm{NMR}\left(\mathrm{CDCl}_{3}, 376 \mathrm{MHz}\right): \delta-90.17(\mathrm{ddd}, J=47.8$, 4.9, $2.0 \mathrm{~Hz}$ ), $-90.38(\mathrm{ddd}, J=47.9,21.7 \mathrm{~Hz})$; HRMS (DART-TOF) $\mathrm{m} / \mathrm{z}$ : $\left[\mathrm{M}+\mathrm{NH}_{4}\right]^{+}$Calcd for $\mathrm{C}_{18} \mathrm{H}_{24} \mathrm{~F}_{2} \mathrm{NOSi}^{+}$: 336.1590 , Found: 336.1591 ; specific rotation: $[\alpha]_{\mathrm{D}}{ }^{20}-32.45\left(c\right.$ 2.0, $\left.\mathrm{CH}_{2} \mathrm{Cl}_{2}\right)$ for an enantiomerically enriched sample of 97:3 er favoring the $(R)$-enantiomer. Enantiomeric purity was determined by HPLC analysis in comparison with authentic racemic material (OD$\mathrm{H}$ column, 100:0 hexanes: $i-\mathrm{PrOH}, 0.7 \mathrm{~mL} / \mathrm{min}, 220 \mathrm{~nm}) .(S)$-enantiomer: $\mathrm{t}_{\mathrm{r}}=18.6 \mathrm{~min},(R)-$ enantiomer: $t_{r}=15.9$ min.
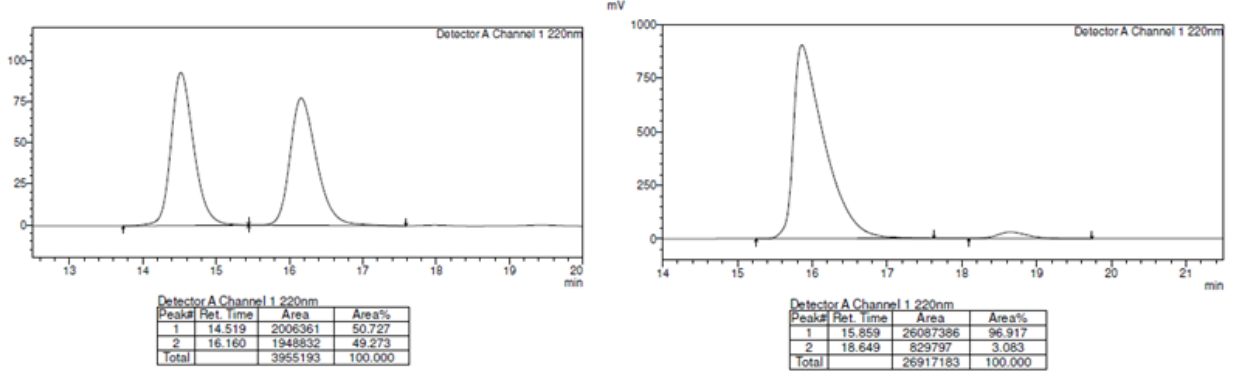

\begin{tabular}{|c|c|c|c|c|c|c|c|}
\hline Peak \# & Retention time & Area & Area \% & Peak \# & Retention time & Area & Area \% \\
\hline 1 & 14.519 & 2006361 & 50.727 & 1 & 15.859 & 26087386 & 96.917 \\
\hline 2 & 16.160 & 1948832 & 49.273 & 2 & 18.649 & 829797 & 3.083 \\
\hline
\end{tabular}

(R)-3-(1-(Dimethyl(phenyl)silyl)-3,3-difluoroallyl)benzonitrile (13c): colorless oil. $\mathrm{R} f=$ 0.72 (hexanes:EtOAc 80:20; UV/KMnO4 stain). IR (neat): 2957 (w), 2228 (m), 1735 (s), 1596 (w), $1427(\mathrm{~m}), 1261$ (s), $1115(\mathrm{~m}), 1076(\mathrm{w}), 893(\mathrm{w}), 812$ (s), $698(\mathrm{~m}), 474(\mathrm{~m}) \mathrm{cm}^{-1} ;{ }^{1} \mathrm{H}$ NMR $\left(\mathrm{CDCl}_{3}, 600 \mathrm{MHz}\right): \delta 7.42-7.36(\mathrm{~m}, 2 \mathrm{H}), 7.33(\mathrm{t}, J=7.4 \mathrm{~Hz}, 2 \mathrm{H}), 7.25(\mathrm{qd}, J=4.5,2.9 \mathrm{~Hz}$, $3 \mathrm{H}), 7.07-7.00(\mathrm{~m}, 2 \mathrm{H}), 4.49$ (ddd, $J=22.8,11.6,2.9 \mathrm{~Hz}, 1 \mathrm{H}), 3.17$ (dd, $J=11.6,2.2 \mathrm{~Hz}, 1 \mathrm{H}$ ), $0.30(\mathrm{~s}, 3 \mathrm{H}), 0.29$ (s, 3H). ${ }^{13} \mathrm{C} \mathrm{NMR}\left(\mathrm{CDCl}_{3}, 150 \mathrm{MHz}\right): \delta 155.8(\mathrm{t}, J=286.3 \mathrm{~Hz}), 142.9,134.8$, 134.3, 131.7, 130.6, 130.2, 129.1, 129.0, 128.1, 119.1, 112.4, 77.4 (dd, J = 23.3, 21.1 Hz), 31.6, -4.8, -5.0. ${ }^{19} \mathrm{~F}$ NMR (564 MHz, $\left.\mathrm{CDCl}_{3}\right): \delta-88.35$ (dt, $\left.J=43.6,2.6 \mathrm{~Hz}\right),-88.57(\mathrm{dd}, J=43.8$, $22.9 \mathrm{~Hz}$; HRMS (DART-TOF) $\mathrm{m} / \mathrm{z}$ : $[\mathrm{M}+\mathrm{H}]^{+}$Calcd for $\mathrm{C}_{18} \mathrm{H}_{18} \mathrm{SiNF}_{2}{ }^{+}$: 314.1171, Found: 314.1192; specific rotation: $[\alpha]_{\mathrm{D}^{20}}-30.19\left(c\right.$ 1.0, $\left.\mathrm{CHCl}_{3}\right)$ for an enantiomerically enriched sample of 97:3 er favoring the $(R)$-enantiomer. Enantiomeric purity was determined by HPLC analysis in comparison with authentic racemic material (97:3 er shown; OD-H column, 100\% hexanes, $1.0 \mathrm{~mL} / \mathrm{min}, 220 \mathrm{~mm})$. $(R)$-enantiomer: $\mathrm{t}_{\mathrm{r}}=49.8 \mathrm{~min}$, $(S)$-enantiomer: $\mathrm{t}_{\mathrm{r}}=35.6 \mathrm{~min}$.
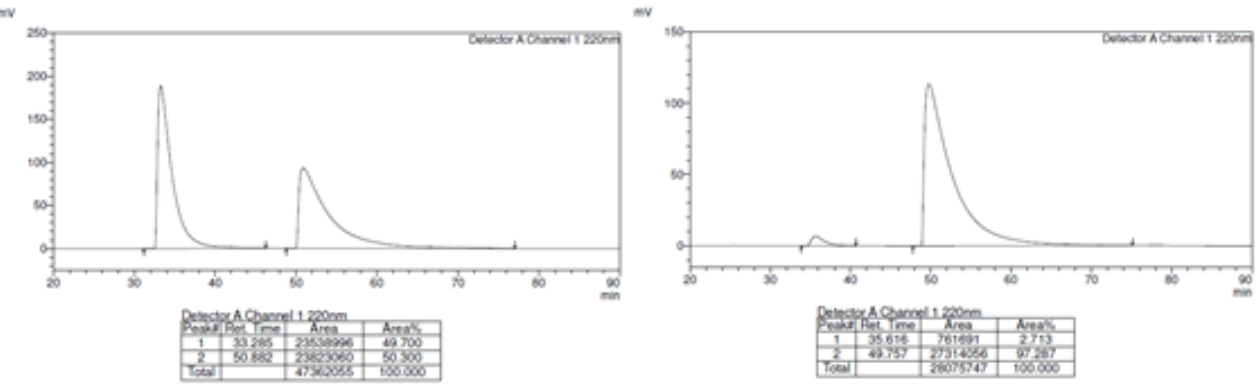

\begin{tabular}{|c|c|c|c|c|c|c|c|}
\hline Peal; $\#$ & Retention time & Area & Area \% & Pealk $\#$ & Retention time & Area & Area \% \\
\hline 1 & 33.285 & 23538996 & 49.700 & 1 & 35.616 & 761691 & 2.713 \\
\hline 2 & 50.882 & 23823060 & 50.300 & 2 & 49.757 & 27314056 & 97.287 \\
\hline
\end{tabular}


(R)-(4,4-Difluoro-1-((4-methoxybenzyl)oxy)but-3-en-2-yl)dimethyl(phenyl)silane (13d): colorless oil. $\mathrm{R} f=0.25$ (hexanes:EtOAc 90:10; $\mathrm{UV} / \mathrm{KMnO}_{4}$ stain). IR (neat): 3349 (bm), 2956 (w), 1734 (s), 1428 (m), 1345 (w), 1249 (s), 1178 (w), 1044 (m), 809 (s), 698 (s) cm ${ }^{-1} ;{ }^{1} \mathrm{H}$ NMR $\left(\mathrm{CDCl}_{3}, 400 \mathrm{MHz}\right): 7.57-7.48(\mathrm{~m}, 2 \mathrm{H}), 7.43-7.38(\mathrm{~d}, J=6.3 \mathrm{~Hz}, 3 \mathrm{H}), 4.08$ (ddd, J = 25.0, 11.4, $2.7 \mathrm{~Hz}, 1 \mathrm{H}), 3.76$ (ddd, $J=10.8,4.3,1.9 \mathrm{~Hz}, 1 \mathrm{H}), 3.54$ (t, $J=10.4 \mathrm{~Hz}, 1 \mathrm{H}), 2.17$ (t,

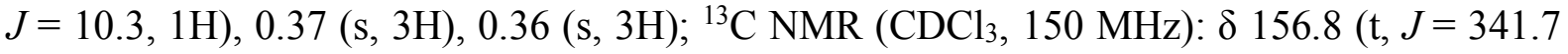
$\mathrm{Hz}), 136.3,134.0,133.2,129.7,128.2,77.0$ (t, $J=25.7 \mathrm{~Hz}), 63.2,27.9$ (t, $J=1.8 \mathrm{~Hz}),-4.0,-$ 4.7; ${ }^{19} \mathrm{~F} \mathrm{NMR}\left(\mathrm{CDCl}_{3}, 376 \mathrm{MHz}\right): \delta-87.18(\mathrm{~d}, J=48.3 \mathrm{~Hz}),-90.84(\mathrm{dd}, J=48.1,25.0 \mathrm{~Hz}$; HRMS (ESI-TOF) m/z: $[\mathrm{M}+\mathrm{H}]^{+}$Calcd for $\mathrm{C}_{12} \mathrm{H}_{17} \mathrm{SiF}_{2} \mathrm{O}^{+}$: 243.1011, Found: 243.1017; Enantiomeric purity was determined by HPLC analysis in comparison with authentic racemic material (94:6 er shown; OD-H column, 97:3 hexanes: $\mathrm{PrOH}, 1.0 \mathrm{~mL} / \mathrm{min}, 220 \mathrm{~nm})$. (R)enantiomer: $t_{\mathrm{r}}=10.9 \mathrm{~min},(S)$-enantiomer: $\mathrm{t}_{\mathrm{r}}=9.4 \mathrm{~min}$.

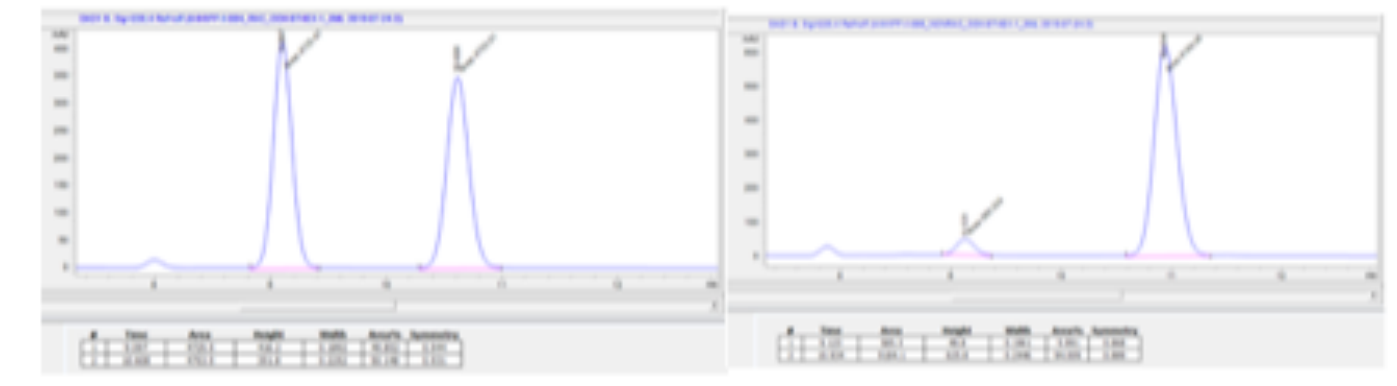

\begin{tabular}{|c|c|c|c|c|c|}
\hline Retention Time & Area & Area\% & Retention Time & Area & Area\% \\
\hline 9.097 & 4725.5 & 48.852 & 9.123 & 585.3 & 5.991 \\
\hline 10.608 & 4753.5 & 50.148 & 10.934 & 9184.1 & 94.009 \\
\hline
\end{tabular}

(R)-(4,4-Difluoro-1-((4-methoxybenzyl)oxy)but-3-en-2-yl)dimethyl(phenyl)silane (13e): colorless oil. $\mathrm{R} f=0.50$ (hexanes:EtOAc 90:10; $\mathrm{UV} / \mathrm{KMnO}_{4}$ stain). IR (neat): 2955 (w), 2851 (w) $1736(\mathrm{~m}), 1612(\mathrm{w}), 1513(\mathrm{~m}), 1246$ (s), 1089 (m) 1036 (m), 813 (s), 700 (m), 469 (w) $\mathrm{cm}^{-1} ;{ }^{1} \mathrm{H} \mathrm{NMR}\left(\mathrm{CDCl}_{3}, 400 \mathrm{MHz}\right): \delta 7.48(\mathrm{dd}, J=7.7,1.8 \mathrm{~Hz}, 2 \mathrm{H}), 7.43-7.30(\mathrm{~m}, 3 \mathrm{H}), 7.20$ $(\mathrm{d}, \mathrm{J}=8.6 \mathrm{~Hz}, 2 \mathrm{H}), 6.87(\mathrm{~d}, J=8.6 \mathrm{~Hz}, 2 \mathrm{H}), 4.39(\mathrm{~d}, J=11.6 \mathrm{~Hz}, 1 \mathrm{H}), 4.31(\mathrm{~d}, J=11.6 \mathrm{~Hz}$, $1 \mathrm{H}), 4.15$ (ddd, J = 25.4, 11.2, $2.8 \mathrm{~Hz}, 1 \mathrm{H}), 3.82$ (s, 3H), 3.49 (ddd, $J=9.4,4.4,1.6 \mathrm{~Hz}, 1 \mathrm{H}$ ), $3.42(\mathrm{t}, J=8.8 \mathrm{~Hz}, 1 \mathrm{H}), 2.22-2.12(\mathrm{~m}, 1 \mathrm{H}), 0.33(\mathrm{~s}, 6 \mathrm{H}) ;{ }^{13} \mathrm{C} \mathrm{NMR}\left(\mathrm{CDCl}_{3}, 150 \mathrm{MHz}\right): \delta 159.3$, 156.0 (t, $J=284.0 \mathrm{~Hz}), 136.9,134.1,130.7,129.5,128.0,113.9,77.9$ (t, $J=21.9 \mathrm{~Hz}), 72.4$,

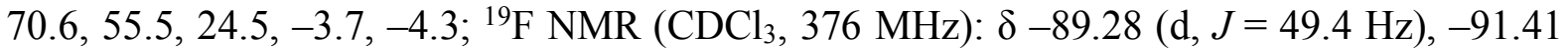
(dd, $\mathrm{J}=50.5,25.4 \mathrm{~Hz}$ ); HRMS (DART-TOF) $\mathrm{m} / \mathrm{z}$ : $\left[\mathrm{M}+\mathrm{NH}_{4}\right]^{+}$Calcd for $\mathrm{C}_{20} \mathrm{H}_{28} \mathrm{SiF}_{2} \mathrm{O}_{2} \mathrm{~N}^{+}$: 380.1852, Found: 380.1844; specific rotation: $[\alpha]_{\mathrm{D}}{ }^{20}-5.60$ (c 1.0, $\mathrm{CH}_{2} \mathrm{Cl}_{2}$ ) for an enantiomerically enriched sample of $94: 6$ er favoring the $(R)$-enantiomer. Enantiomeric purity was determined by HPLC analysis in comparison with authentic racemic material (ODH column, 100:0 hexanes:i-PrOH, $1.0 \mathrm{~mL} / \mathrm{min}, 220 \mathrm{~nm})$. $(S)$-enantiomer: $\mathrm{t}_{\mathrm{r}}=60.5 \mathrm{~min},(R)$ enantiomer: $\mathrm{t}_{\mathrm{r}}=49.4 \mathrm{~min}$. 

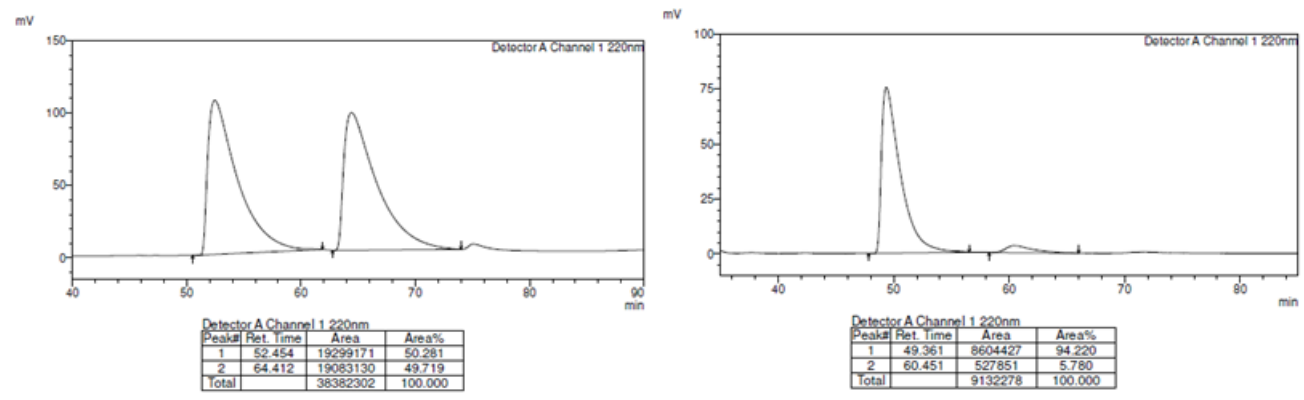

\begin{tabular}{|c|c|c|c|c|c|c|c|}
\hline Peak \# & Retention time & Area & Area \% & Peak \# & Retention time & Area & Area \% \\
\hline 1 & 52.454 & 19299171 & 50.281 & 1 & 49.361 & 8604427 & 94.220 \\
\hline 2 & 64.412 & 19083130 & 49.719 & 2 & 60.451 & 527851 & 5.780 \\
\hline
\end{tabular}

(8R,9S,13S,14S)-2-(((R)-2-(Dimethyl(phenyl)silyl)-4,4-difluorobut-3-en-1-yl)oxy)-13methyl-6,7,8,9,11,12,13,14,15,16-decahydro-17H-cyclopenta[a]phenanthren-17-one

(13f): white solid. $\mathrm{R} f=0.35$ (hexanes:EtOAc 90:10; UV/KMnO 4 stain). IR (neat): 2928 (w), 2864 (w) 1736 (s), 1609 (w), 1499 (m), 1249 (s), 1189 (m), 1114 (m), 1057 (m), 814 (s), 701 (m), $653(\mathrm{w}) \mathrm{cm}^{-1}$; The ${ }^{1} \mathrm{H}$ NMR, ${ }^{13} \mathrm{C}$ NMR and ${ }^{19} \mathrm{~F}$ NMR signals for both diastereomers overlap in $\mathrm{CDCl}_{3}$, thus diastereomeric ratio was not be determined by analysis of NMR spectra. ${ }^{1} \mathrm{H} \mathrm{NMR}$ $\left(\mathrm{CDCl}_{3}, 600 \mathrm{MHz}\right): \delta 7.55(\mathrm{dd}, J=7.7,1.7 \mathrm{~Hz}, 2 \mathrm{H}), 7.44-7.35(\mathrm{~m}, 3 \mathrm{H}), 7.18(\mathrm{~d}, J=8.5 \mathrm{~Hz}$, $1 \mathrm{H}), 6.63(\mathrm{dd}, J=8.5,2.7 \mathrm{~Hz}, 1 \mathrm{H}), 6.56(\mathrm{~d}, J=2.7 \mathrm{~Hz}, 1 \mathrm{H}), 4.23(\mathrm{ddd}, J=25.3,11.3,2.6 \mathrm{~Hz}$, $1 \mathrm{H}), 4.01-3.96(\mathrm{~m}, 1 \mathrm{H}), 3.94-3.89(\mathrm{~m}, 1 \mathrm{H}), 2.93-2.84(\mathrm{~m}, 2 \mathrm{H}), 2.59-2.47(\mathrm{~m}, 1 \mathrm{H}), 2.45-2.35$ (m, 1H), 2.34-2.22 (m, 2H), 2.20-2.11 (m, 1H), 2.09-1.94 (m, 3H), 1.69-1.39 (m, 6H), 0.93 $(\mathrm{s}, 3 \mathrm{H}), 0.42(\mathrm{~s}, 6 \mathrm{H}) \cdot ;{ }^{13} \mathrm{C} \mathrm{NMR}\left(\mathrm{CDCl}_{3}, 100 \mathrm{MHz}\right): \delta 221.1,156.9(\mathrm{t}, J=284.5 \mathrm{~Hz}), 156.2$, $137.9,136.6,134.1,133.25,132.4,129.6,128.1,126.5,114.9,112.4,77.4$ (t, $J=22.5 \mathrm{~Hz}$ ), $68.8,50.6,48.2,44.2,38.5,36.1,31.8,29.8,26.7,26.1,24.3,21.8,14.0,0.2,-3.7,-4.3 ;{ }^{19} \mathrm{~F}$ NMR $\left(\mathrm{CDCl}_{3}, 564 \mathrm{MHz}\right): \delta-88.79(\mathrm{dd}, J=48.6,2.7 \mathrm{~Hz}),-90.69(\mathrm{ddd}, J=49.0,25.3,3.0$ $\mathrm{Hz}$ ); HRMS (DART-TOF) m/z: [M+H] ${ }^{+}$Calcd for $\mathrm{C}_{30} \mathrm{H}_{37} \mathrm{~F}_{2} \mathrm{O}_{2} \mathrm{Si}^{+}$: 495.2525, Found: 495.2546; specific rotation: $[\alpha]_{\mathrm{D}^{20}}+54.58\left(c 2.0, \mathrm{CH}_{2} \mathrm{Cl}_{2}\right)$ for a diastereomeric sample of 93:7 dr. specific rotation: $[\alpha]_{\mathrm{D}}{ }^{20}+67.18\left(c 2.0, \mathrm{CH}_{2} \mathrm{Cl}_{2}\right)$ for a diastereomeric sample of 50:50 dr. Diastereomeric ratio was determined by HPLC analysis in comparison with authentic material synthesized with achiral NHC ligand (OJ-H column, 99:1 hexanes:i-PrOH, $0.5 \mathrm{~mL} / \mathrm{min}, 220 \mathrm{~nm}$ ). Major diastereomer: $t_{r}=77.3 \mathrm{~min}$, minor diastereomer: $t_{r}=105.6 \mathrm{~min}$.
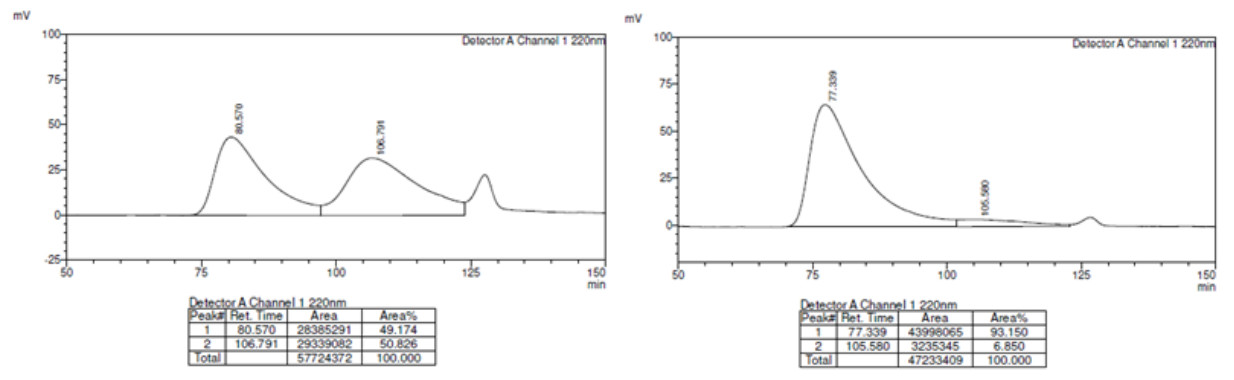

\begin{tabular}{|c|c|c|c|c|c|c|c|}
\hline Peak \# & Retention time & Area & Area \% & Peak \# & Retention time & Area & Area \% \\
\hline 1 & 80.570 & 28385291 & 49.174 & 1 & 77.339 & 43998065 & 93.150 \\
\hline 2 & 106.791 & 29339082 & 50.826 & 2 & 105.580 & 3235345 & 6.850 \\
\hline
\end{tabular}


tert-Butyl-(S)-4-(1-(dimethyl(phenyl)silyl)-3,3-difluoroallyl)piperidine-1-carboxylate

(13g): colorless oil. $\mathrm{R} f=0.53$ (hexane:EtOAc 90:10; UV/KMnO 4 stain). IR (neat): $2976(\mathrm{w})$, 2853 (w), 1732 (s), 1692 (s), 1426 (m), 1251 (m), 1166 (s), 816 (m), 701 (m), 649 (w) cm c $^{-1}$ ${ }^{1} \mathrm{H} \mathrm{NMR}\left(\mathrm{CDCl}_{3}, 400 \mathrm{MHz}\right): \delta 7.52-7.46(\mathrm{~m}, 2 \mathrm{H}), 7.41-7.34(\mathrm{~m}, 3 \mathrm{H}), 4.08-3.99(\mathrm{~m}, 2 \mathrm{H}), 4.04$ (ddd, $J=19.5,9.4,2.3 \mathrm{~Hz}, 1 \mathrm{H}), 2.63-2.45(\mathrm{~m}, 2 \mathrm{H}), 1.76(\mathrm{ddd}, J=12.4,5.5,2.7 \mathrm{~Hz}, 1 \mathrm{H}), 1.57-$ $1.40(\mathrm{~m}, 3 \mathrm{H}), 1.44(\mathrm{~s}, 9 \mathrm{H}), 1.33-1.18(\mathrm{~m}, 1 \mathrm{H}), 1.17-1.02(\mathrm{~m}, 1 \mathrm{H}), 0.34(\mathrm{~s}, 3 \mathrm{H}), 0.33(\mathrm{~s}, 3 \mathrm{H})$; ${ }^{13} \mathrm{C} \mathrm{NMR}\left(\mathrm{CDCl}_{3}, 150 \mathrm{MHz}\right): \delta 156.3(\mathrm{t}, J=284.2 \mathrm{~Hz}), 154.9,137.7,133.9,129.5,128.1,79.5$, $76.7(\mathrm{t}, J=20.5 \mathrm{~Hz}), 37.2,32.9,28.7,-2.8,-3.6 . ;{ }^{19} \mathrm{~F} \mathrm{NMR}\left(\mathrm{CDCl}_{3}, 470 \mathrm{MHz}\right): \delta-88.31(\mathrm{~d}$, $\mathrm{J}=49.4 \mathrm{~Hz}$ ), $-91.93\left(\mathrm{dd}, J=48.9,24.2 \mathrm{~Hz}\right.$ ); HRMS (DART-TOF) $\mathrm{m} / \mathrm{z}:[\mathrm{M}+\mathrm{H}]^{+}$Calcd for $\mathrm{C}_{21} \mathrm{H}_{32} \mathrm{~F}_{2} \mathrm{NO}_{2} \mathrm{Si}^{+}$: 396.2154, Found: 396.2141; specific rotation: $[\alpha]_{\mathrm{D}}{ }^{20}-12.60\left(c\right.$ 2.0, $\left.\mathrm{CH}_{2} \mathrm{Cl}_{2}\right)$ for an enantiomerically enriched sample of 96:4 er favoring the $(S)$-enantiomer. Enantiomeric purity was determined by HPLC analysis in comparison with authentic racemic material (OD$\mathrm{H}$ column, 98:2 hexanes: $i-\mathrm{PrOH}, 0.7 \mathrm{~mL} / \mathrm{min}, 220 \mathrm{~nm})$. $(S)$-enantiomer: $\mathrm{t}_{\mathrm{r}}=7.5 \mathrm{~min},(R)-$ enantiomer: $\mathrm{t}_{\mathrm{r}}=7.1 \mathrm{~min}$.
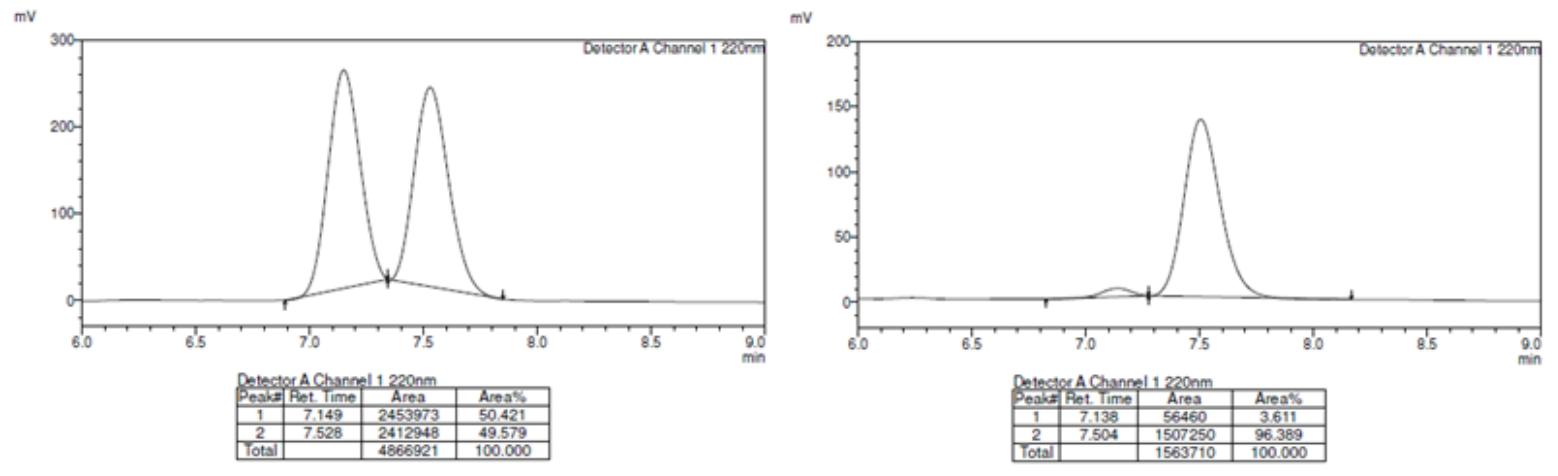

\begin{tabular}{|c|c|c|c|c|c|c|c|}
\hline Peak \# & Retention time & Area & Area \% & Peak \# & Retention time & Area & Area \% \\
\hline 1 & 7.149 & 2453973 & 50.421 & 1 & 7.136 & 56460 & 3.611 \\
\hline 2 & 7.528 & 2412948 & 49.579 & 2 & 7.504 & 1507250 & 96.389 \\
\hline
\end{tabular}

\section{Ireland-Claisen Rearrangement}

(R)-1-((tert-Butyldiphenylsilyl)oxy)-4,4-difluorobut-3-en-2-ol (secondary alcohol derived from allyl boronate 12d): In a $\mathrm{N}_{2}$-filled glove box, an oven-dried 8-dram vial containing a stir bar was charged with $\mathrm{CuCl}$ (4.4 mg, $0.04 \mathrm{mmol}$ ), imid-4 (42.7 mg, $0.05 \mathrm{mmol})$, $\mathrm{LiO} t$-Bu (78.2 $\mathrm{mg}, 0.98 \mathrm{mmol})$. thf $(0.3 \mathrm{~mL})$ and $\alpha, \alpha, \alpha$-trifluorotoluene $(3.0 \mathrm{~mL})$ were added and the mixture was allowed to stir for 1 hour. A solution of $\mathrm{B}_{2}(\operatorname{pin})_{2}(0.248 \mathrm{~g}, 0.976 \mathrm{mmol})$, (E)-tButyldiphenyl((4,4,4-trifluorobut-2-en-1-yl)oxy)silane (0.324 g, $0.89 \mathrm{mmol})$, and dry $\alpha, \alpha, \alpha$ trifluorotoluene $(3.0 \mathrm{~mL})$ was added to the initial catalyst solution. The vial was sealed (electrical tape) and removed from the glove box, and the mixture was allowed to stir for $21 \mathrm{~h}$, after which it was passed through a short plug of silica gel $\left(4 \mathrm{~cm} \times 2 \mathrm{~cm}\right.$; eluted with $\left.\mathrm{Et}_{2} \mathrm{O}\right)$. Removal of the volatiles in vacuo afforded $12 \mathrm{~d} .{ }^{1} \mathrm{H}$ and ${ }^{19} \mathrm{~F}$ NMR analysis of the unpurified mixture indicated $95 \%$ conv (see Table $\mathrm{S} 2$ for optimization studies). The colorless oil residue was dissolved in thf $(8.0 \mathrm{~mL})$ and a solution of $\mathrm{pH}=7.0$ buffer $(8.0 \mathrm{~mL})$ was added; this was followed by the addition of $\mathrm{NaBO}_{3} \bullet 4 \mathrm{H}_{2} \mathrm{O}(0.683 \mathrm{~g}, 4.44 \mathrm{mmol})$ followed by vigorous stirring for $2 \mathrm{~h}$ at $22{ }^{\circ} \mathrm{C}$. At this point, the mixture was diluted with $\mathrm{Et}_{2} \mathrm{O}(2 \mathrm{~mL})$ and brine $(2 \mathrm{~mL})$. 
After aqueous wash (with $\mathrm{Et}_{2} \mathrm{O}$ ) the organic layers were combined, dried over $\mathrm{MgSO}_{4}$, filtered, and the volatiles were removed to give colorless oil which was purified by silica gel chromatography $\left(100: 0 \rightarrow 30: 1\right.$ gradient of hexanes:EtOAc with $1 \%$ of $\left.\mathrm{Et}_{3} \mathrm{~N}\right)$ to afford the desired secondary allylic alcohol as colorless oil $(0.261 \mathrm{~g}, 81 \%$ overall yield). Colorless oil. $\mathrm{R} f$ $=0.55$ (80:20 hexanes:EtOAc; $\mathrm{UV} / \mathrm{KMnO}_{4}$ stain). IR (neat): $3417(\mathrm{bm}), 3072(\mathrm{w}), 2931(\mathrm{w})$, 1742 (m), 1427 (w), 1110 (s), 924 (m), 700 (s), 504 (s) cm $\mathrm{cm}^{-1} ;{ }^{1} \mathrm{H} \mathrm{NMR}\left(\mathrm{CDCl}_{3}, 500 \mathrm{MHz}\right): \delta$ $7.66(\mathrm{~d}, J=6.7 \mathrm{~Hz}, 4 \mathrm{H}), 7.48-7.38(\mathrm{~m}, 6 \mathrm{H}), 4.51-4.44(\mathrm{~m}, 1 \mathrm{H}), 4.32(\mathrm{ddd}, J=24.6,9.2,2.2$ $\mathrm{Hz}, 1 \mathrm{H}), 3.68(\mathrm{dd}, J=10.2,3.7 \mathrm{~Hz}, 1 \mathrm{H}), 3.57(\mathrm{dd}, \mathrm{J}=10.2,7.1 \mathrm{~Hz}, 1 \mathrm{H}), 2.60-2.56(\mathrm{~d}, J=3.8$ $\mathrm{Hz}, 1 \mathrm{H}), 1.09$ (s, 9H); ${ }^{13} \mathrm{C} \mathrm{NMR}\left(\mathrm{CDCl}_{3}, 150 \mathrm{MHz}\right): \delta 157.3(\mathrm{t}, J=289.8 \mathrm{~Hz}), 135.7,133.0$, 130.2, 128.1, $79.0(\mathrm{dd}, J=21.8,17.7 \mathrm{~Hz}), 67.6,66.0,27.0,19.5 ;{ }^{19} \mathrm{~F} \mathrm{NMR}\left(\mathrm{CDCl}_{3}, 376 \mathrm{MHz}\right)$ : $\delta-84.9(\mathrm{~d}, J=36.0 \mathrm{~Hz}),-85.4(\mathrm{dd}, J=35.8,24.4 \mathrm{~Hz})$; HRMS (DART-TOF) m/z: $[\mathrm{M}+\mathrm{H}]^{+}$ Calcd for $\mathrm{C}_{20} \mathrm{H}_{25} \mathrm{SiF}_{2} \mathrm{O}_{2}{ }^{+}$: 363.1586, Found: 363.1597; specific rotation: $[\alpha]_{D}{ }^{20}-10.21$ (c 5.0, $\mathrm{CH}_{2} \mathrm{Cl}_{2}$ ) for an enantiomerically enriched sample of 94:6 er favoring the $(R)$-enantiomer. Enantiomeric purity was determined by HPLC analysis in comparison with authentic racemic material (AD-H column, 99.5:0.5 hexanes: $i$-PrOH, $0.5 \mathrm{~mL} / \mathrm{min}, 220 \mathrm{~nm}$ ). $\left(S\right.$ )-enantiomer: $\mathrm{t}_{\mathrm{r}}=$ $43.3 \mathrm{~min},(R)$-enantiomer: $\mathrm{t}_{\mathrm{r}}=47.0 \mathrm{~min}$.

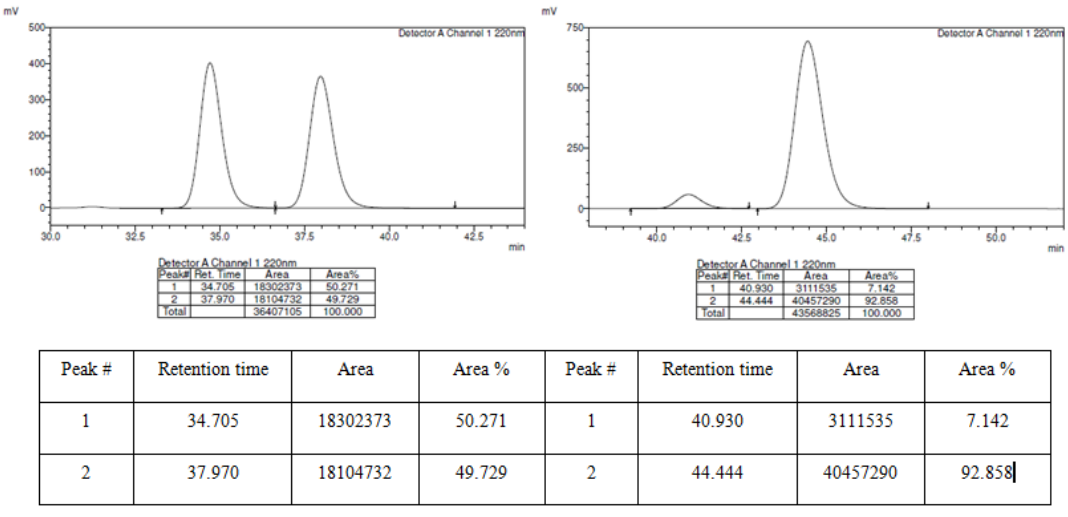

(R)-1-((tert-Butyldiphenylsilyl)oxy)-4,4-difluorobut-3-en-2-yl propionate (16): Alcohol S1 (0.240 g, $0.664 \mathrm{mmol})$, dmap (81.1 $\mathrm{mg}, 0.664 \mathrm{mmol})$, and EDC $\cdot \mathrm{HCl}(190.7 \mathrm{mg}, 0.995 \mathrm{mmol})$ were added to an oven-dried $10 \mathrm{~mL}$ round-bottom flask, which was subsequently capped with a septum. The flask was twice evacuated and back-filled with $\mathrm{N}_{2}$, after which $\mathrm{CH}_{2} \mathrm{Cl}_{2}(3.3 \mathrm{~mL})$ and propionic acid $(74.2 \mu \mathrm{L}, 0.995)$ were added and the mixture was allowed to stir for $3 \mathrm{~h}$. The reaction was then quenched by the addition of $\mathrm{CH}_{2} \mathrm{Cl}_{2}(5 \mathrm{~mL})$ and $\mathrm{H}_{2} \mathrm{O}(5 \mathrm{~mL})$. After aqueous wash (with $\mathrm{CH}_{2} \mathrm{Cl}_{2}$ ), the organic layers were dried over $\mathrm{MgSO}_{4}$, filtered and the volatiles were removed in vacuo to afford an yellow oil, which was purified by silica gel chromatography $\left(100: 0 \rightarrow 50: 1\right.$ hexanes:EtOAc with 1\% of $\left.\mathrm{Et}_{3} \mathrm{~N}\right)$ to afford 16 as colorless oil (0.252 g, 91\% yield). Colorless oil. $\mathrm{R} f=0.75$ (hexanes:EtOAc 80:20; UV/KMnO 4 stain). IR (neat): 3072 (w), 2932 (w), 1750 (s), 1742 (s), 1428 (w), 1111 (s), 931 (m), 700 (s), 504 (s) $\mathrm{cm}^{-1} ;{ }^{1} \mathrm{H} \mathrm{NMR}\left(\mathrm{CDCl}_{3}, 400 \mathrm{MHz}\right): \delta$ 7.68-7.64 (m, 4H), 7.47-7.37 (m, 6H), 5.61-5.55 (m, $1 \mathrm{H}), 4.40$ (ddd, $J=24.4,9.6,1.8 \mathrm{~Hz}, 1 \mathrm{H}), 3.77$ (dd, $J=10.8,5.9 \mathrm{~Hz}, 1 \mathrm{H}), 3.71$ (dd, $J=11.3$, $4.5 \mathrm{~Hz}, 1 \mathrm{H} 1 \mathrm{H}), 2.30(\mathrm{qd}, J=7.6,3.1 \mathrm{~Hz}, 2 \mathrm{H}), 1.13(\mathrm{t}, J=7.6 \mathrm{~Hz}, 3 \mathrm{H}), 1.06(\mathrm{~s}, 9 \mathrm{H}) ;{ }^{13} \mathrm{C}$ NMR $\left(\mathrm{CDCl}_{3}, 150 \mathrm{MHz}\right): \delta 173.6,157.7(\mathrm{t}, J=292.0 \mathrm{~Hz}), 135.8,133.4,130.0,128.0,76.9(\mathrm{dd}, J=$ $25.0,17.6 \mathrm{~Hz}), 68.0,65.3,27.8,26.9,19.5,9.2 ;{ }^{19} \mathrm{~F} \mathrm{NMR}\left(\mathrm{CDCl}_{3}, 376 \mathrm{MHz}\right): \delta-82.47(\mathrm{dd}, J$ $=30.8,24.4 \mathrm{~Hz}),-84.02(\mathrm{~d}, J=30.7 \mathrm{~Hz})$; HRMS (DART-TOF) $\mathrm{m} / \mathrm{z}:[\mathrm{M}+\mathrm{H}]^{+}$Calcd for 
$\mathrm{C}_{23} \mathrm{H}_{29} \mathrm{SiF}_{2} \mathrm{O}_{3}{ }^{+}: 419.1849$, Found: 419.1855; specific rotation: $[\alpha]_{D}{ }^{20}+5.99\left(c 2.0, \mathrm{CH}_{2} \mathrm{Cl}_{2}\right)$ for an enantiomerically enriched sample of $93: 7$ er favoring the $(R)$-enantiomer.

(R,E)-6-((tert-Butyldiphenylsilyl)oxy)-3,3-difluoro-2-methylhex-4-enoic acid (17): Compound 16 (20.3 mg, $0.049 \mathrm{mmol})$ was added to an oven-dried conical $5 \mathrm{~mL}$ flask containing a magnetic stirring bar and capped with a rubber septum. Compound $\mathbf{1 6}$ was then azeotroped with benzene $(3 \times 0.3 \mathrm{~mL})$ under high vacuum. The reaction flask was placed under argon atmosphere (balloon). $\mathrm{CH}_{2} \mathrm{Cl}_{2}(0.05 \mathrm{~mL}), \mathrm{Et}_{2} \mathrm{O}(0.1 \mathrm{~mL})$, freshly distilled $\mathrm{Et}_{3} \mathrm{~N}(27.0 \mu \mathrm{L}$, $0.194 \mathrm{mmol}$ ) and triisopropylsilyl triflate (freshly distilled; $39.2 \mu \mathrm{L}, 0.145 \mathrm{mmol}, 3.0$ equiv) were added and the reaction was allowed to stir at $22^{\circ} \mathrm{C}$ for $21 \mathrm{~h}$ (see Table S3 for optimization). The reaction was quenched by the addition of $\mathrm{Et}_{2} \mathrm{O}(3.0 \mathrm{~mL})$ and $\mathrm{H}_{2} \mathrm{O}(2.0 \mathrm{~mL})$ and transferred to a separatory funnel. The aqueous layer was extracted with $\mathrm{Et}_{2} \mathrm{O}(2 \times 2.0 \mathrm{~mL})$ and the organic layers were combined, dried over $\mathrm{MgSO}_{4}$, filtered and concentrated under reduced pressure to deliver an oil which was taken to the next step without further purification. ${ }^{1} \mathrm{H}$ and ${ }^{19} \mathrm{~F}$ NMR analysis at this stage revealed a 10:90 ratio of starting material:TIPS-ester $(90 \%$ conv to Ireland-Claisen product). $\mathrm{Et}_{2} \mathrm{O}(0.5 \mathrm{~mL}), \mathrm{MeOH}(1.0 \mathrm{~mL})$ and $\mathrm{H}_{2} \mathrm{O}(0.5 \mathrm{~mL})$ were added to the corresponding TIPS-ester, followed by $\mathrm{K}_{2} \mathrm{CO}_{3}$ (67.0 mg, $0.49 \mathrm{mmol}, 10$ equiv). The mixture was allowed to stir rapidly at $22{ }^{\circ} \mathrm{C}$ for $30 \mathrm{~min}$. The reaction was quenched by the addition of aqueous solution of $1 \mathrm{M} \mathrm{HCl}$ (until $\mathrm{pH}=3$ ) and the volatiles were removed in vacuo. After aqueous wash $\left(\mathrm{CH}_{2} \mathrm{Cl}_{2} ; 3 \times 3 \mathrm{~mL}\right)$ the organic layers were combined, dried over $\mathrm{MgSO}_{4}$, filtered and concentrated under reduced pressure to afford an yellow oil, which was purified by silica gel chromatography (50:1-2:1 hexanes:EtOAc) to furnish 17 as colorless oil (13.5 $\mathrm{mg}, 67 \%$ overall yield). Colorless oil; $\mathrm{R} f=0.15$ (hexanes:EtOAc $60: 40 ; \mathrm{UV} / \mathrm{KMnO}_{4}$ stain). IR (neat): 3040 (bm), 2930 (w), 2857 (w), 1716 (s), 1684 (s), 1428 (m), 1112 (s), 702 (s), 504 (s) $\mathrm{cm}^{-1} ;{ }^{1} \mathrm{H} \mathrm{NMR}\left(\mathrm{CDCl}_{3}, 600 \mathrm{MHz}\right): \delta 7.67(\mathrm{~d}, J=6.8 \mathrm{~Hz}, 4 \mathrm{H}), 7.49-7.33(\mathrm{~m}, 6 \mathrm{H}), 6.26-6.06$ $(\mathrm{m}, 2 \mathrm{H}), 4.30(\mathrm{~s}, 2 \mathrm{H}), 3.16-3.06(\mathrm{~m}, 1 \mathrm{H}), 1.34(\mathrm{~d}, J=7.3 \mathrm{~Hz}, 3 \mathrm{H}), 1.08(\mathrm{~s}, 9 \mathrm{H}), ;{ }^{13} \mathrm{C} \mathrm{NMR}$ $\left(\mathrm{CDCl}_{3}, 150 \mathrm{MHz}\right): \delta 178.1,138.1(\mathrm{t}, J=8.5 \mathrm{~Hz}), 137.7,135.4,132.0,130.0,123.6(\mathrm{t}, J=25.2$ $\mathrm{Hz}), 64.8,49.3,31.9$ (t, $J=93.5 \mathrm{~Hz}), 29.0,21.5,13.8 . ;{ }^{19} \mathrm{~F} \mathrm{NMR}\left(\mathrm{CDCl}_{3}, 376 \mathrm{MHz}\right): \delta-97.56$ $(\mathrm{d}, J=246.7 \mathrm{~Hz}),-100.41\left(\mathrm{dt}, \mathrm{J}=246.6,12.0 \mathrm{~Hz}\right.$ ); HRMS (DART-TOF) m/z: $[\mathrm{M}+\mathrm{H}]^{+} \mathrm{Calcd}$ for $\mathrm{C}_{23} \mathrm{H}_{29} \mathrm{SiF}_{2} \mathrm{O}_{3}{ }^{+}: 419.1849$, Found: 419.1841; specific rotation: $[\alpha]_{\mathrm{D}}{ }^{20}-62.65\left(c 1.0, \mathrm{CH}_{2} \mathrm{Cl}_{2}\right)$ for an enantiomerically enriched sample of 88:12 er favoring the $(R)$-enantiomer. Enantiomeric purity was determined by HPLC analysis in comparison with authentic racemic material (AZH column, 99.5:0.5 hexanes: $i$ - $P r O H, 0.5 \mathrm{~mL} / \mathrm{min}, 220 \mathrm{~nm})$. $(S)$-enantiomer: $\mathrm{t}_{\mathrm{r}}=23.2 \mathrm{~min},(R)-$ enantiomer: $t_{r}=21.6$ min.
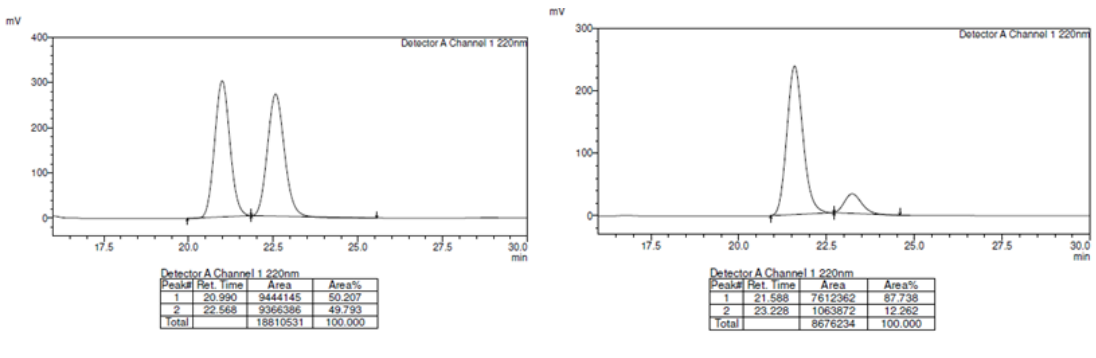

\begin{tabular}{|c|c|c|c|c|c|c|c|}
\hline Peak \# & Retention time & Area & Area \% & Peak \# & Retention time & Area & Area \% \\
\hline 1 & 20.990 & 9444145 & 50.207 & 1 & 21.588 & 7612362 & 87.736 \\
\hline 2 & 22.566 & 9366386 & 49.793 & 2 & 23.228 & 10633872 & 12.262 \\
\hline
\end{tabular}




\section{Gram-Scale Catalytic Enantioselective Boryl Substitution and Subsequent Addition to} Aldehyde and Catalytic Diastereoselective Boryl Substitution

(R,E)-8-((tert-Butyldiphenylsilyl)oxy)-5,5-difluoro-2-methyloct-6-en-4-ol (14): In a $\mathrm{N}_{2}$ filled glovebox, a solution of $\mathrm{CuCl}(16.0 \mathrm{mg}, 162 \mu \mathrm{mol})$, imid-4 (157 mg, $178 \mu \mathrm{mol})$ and $\mathrm{LiO} t$ $\mathrm{Bu}(285 \mathrm{mg}, 3.56 \mathrm{mmol})$ was added to a $20: 1$ solution of $\alpha, \alpha, \alpha$-trifluorotoluene: thf $(8.4 \mathrm{~mL})$, and the mixture was allowed to stir for $1 \mathrm{~h}$ at $22{ }^{\circ} \mathrm{C}$. A solution of $\mathrm{B}_{2}(\mathrm{pin})_{2}(903 \mathrm{mg}, 3.56 \mathrm{mmol})$ and alkene $11 \mathrm{~d}(1.18 \mathrm{~g}, 3.23 \mathrm{mmol})$ in $20: 1 \alpha, \alpha, \alpha$-trifluorotoluene:thf $(8.4 \mathrm{~mL})$ was prepared and added to the initial catalyst solution. The vessel was removed from the glovebox and the mixture was allowed to stir for $14 \mathrm{~h}$, after which the volatiles were removed to afford colorless oil, which was purified by silica gel chromatography $\left(50: 1-20: 1\right.$ petroleum ether:Et $\left.{ }_{2} \mathrm{O}\right)$ to afford the 1,1-difluoroallyl boronate 12d as colorless solid (1.24 g, $2.62 \mathrm{mmol}, 81 \%$ yield, 93:7 er). The resulting allyl boronate $\mathbf{1 2 d}(1.20 \mathrm{~g}, 2.54 \mathrm{mmol})$ was then dissolved in thf $(20 \mathrm{~mL})$; the solution was allowed to cool to- $78^{\circ} \mathrm{C}$ and $n$-BuLi (1.6 M in hexanes, $\left.1.75 \mathrm{~mL}, 2.79 \mathrm{mmol}\right)$ was added, and the mixture was allowed to stir for $15 \mathrm{~min}$ at $-78^{\circ} \mathrm{C}$. Trifluoroacetic anhydride $(0.42 \mathrm{~mL}, 3.05 \mathrm{mmol})$ was then added dropwise and the mixture was allowed to stir for $30 \mathrm{~min}$ at $-78{ }^{\circ} \mathrm{C}$. Isovaleraldehyde $(0.42 \mathrm{~mL}, 3.81 \mathrm{mmol})$ was added $\left(\right.$ at $\left.-78{ }^{\circ} \mathrm{C}\right)$, and the mixture was allowed to warm to $22{ }^{\circ} \mathrm{C}$ and stir for $16 \mathrm{~h}$ at $22{ }^{\circ} \mathrm{C}$. The reaction was quenched by the addition of saturated aqueous solution of $\mathrm{NaHCO}_{3}(20 \mathrm{~mL})$ and washed with $\mathrm{Et}_{2} \mathrm{O}(3 \times 20 \mathrm{~mL})$. The combined organic layers were washed with brine $(20 \mathrm{~mL})$, dried over $\mathrm{MgSO}_{4}$, filtered, and concentrated under reduced pressure to afford yellow oil, purification of which by silica gel chromatography (20:1-10:1 petroleum ether: $\left.\mathrm{Et}_{2} \mathrm{O}\right)$ afforded the $\mathbf{1 4}$ as a colorless oil (1.06 $\mathrm{g}$, 2.45 mmol, 96\% yield, 97:3 Z:E, 92.5:7.5 er). Colorless oil. $\mathrm{R}_{f}=0.21$ (petroleum ether: $\mathrm{Et}_{2} \mathrm{O}=$ 10:1); IR (neat): 3435 (w), 2956 (m), 2931 (m), $2858(\mathrm{~m}), 1684(\mathrm{w}), 1590(\mathrm{w}), 1471(\mathrm{~m}), 1427$

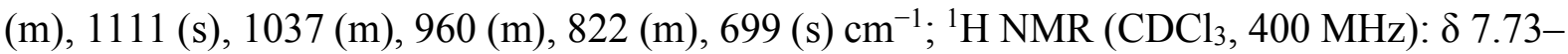
$7.67(4 \mathrm{H}, \mathrm{m}), 7.51-7.37(6 \mathrm{H}, \mathrm{m}), 6.24(1 \mathrm{H}, \mathrm{d}, J=15.7 \mathrm{~Hz}), 6.12-5.97(1 \mathrm{H}, \mathrm{m}), 4.33(2 \mathrm{H}, \mathrm{dq}$, $\mathrm{J}=5.4,3.2 \mathrm{~Hz}), 3.87(1 \mathrm{H}, \mathrm{q}, J=9.2 \mathrm{~Hz}), 1.98-1.84(2 \mathrm{H}, \mathrm{m}), 1.47(1 \mathrm{H}, \mathrm{ddd}, J=14.0,10.3,4.4$ Hz), $1.37(1 \mathrm{H}, \mathrm{ddd}, J=14.0,9.8,2.7 \mathrm{~Hz}), 1.11(9 \mathrm{H}, \mathrm{s}), 1.01(3 \mathrm{H}, \mathrm{d}, J=6.6 \mathrm{~Hz}, 1 \mathrm{H}), 0.96(3 \mathrm{H}$, $\mathrm{d}, J=6.6 \mathrm{~Hz}) ;{ }^{13} \mathrm{C} \mathrm{NMR}\left(\mathrm{CDCl}_{3}, 101 \mathrm{MHz}\right): \delta 136.3(\mathrm{t}, J=8.4 \mathrm{~Hz}), 135.6,133.4,133.3,130.0$, 127.9, $122.3(\mathrm{t}, J=244.1 \mathrm{~Hz}), 120.9(\mathrm{t}, J=25.5 \mathrm{~Hz}), 72.1(\mathrm{t}, J=29.4 \mathrm{~Hz}), 62.9,39.1(\mathrm{t}, J=$ $1.8 \mathrm{~Hz}), 26.9,24.4,23.8,21.5,19.4 ;{ }^{19} \mathrm{~F} \mathrm{NMR}\left(\mathrm{CDCl}_{3}, 377 \mathrm{MHz}\right): \delta-107.2(\mathrm{dt}, J=244.1$, $10.5 \mathrm{~Hz}$ ), -109.1 (dt, $\mathrm{J}=244.1,9.6 \mathrm{~Hz}$ ); HRMS (ESI-TOF) $\mathrm{m} / \mathrm{z}$ : Calcd for $\mathrm{C}_{25} \mathrm{H}_{34} \mathrm{O}_{2} \mathrm{~F}_{2} \mathrm{SiNa}$ $[\mathrm{M}+\mathrm{Na}]^{+}: 455.2188$, Found: 455.2173 ; specific rotation: $[\alpha]_{\mathrm{D}}{ }^{20}-24.8\left(c 1.0, \mathrm{CHCl}_{3}\right)$ for an enantiomerically enriched sample of 92.5:7.5 er. Enantiomeric purity was determined by HPLC analysis in comparison with authentic racemic material (Chiralcel OD-H column, 99:1 hexanes/i-PrOH, $0.5 \mathrm{~mL} / \mathrm{min}, 220 \mathrm{~nm})$. $(S)$-enantiomer: $\mathrm{t}_{\mathrm{r}}=14.4 \mathrm{~min},(R)$-enantiomer: $\mathrm{t}_{\mathrm{r}}=13.0$ min.
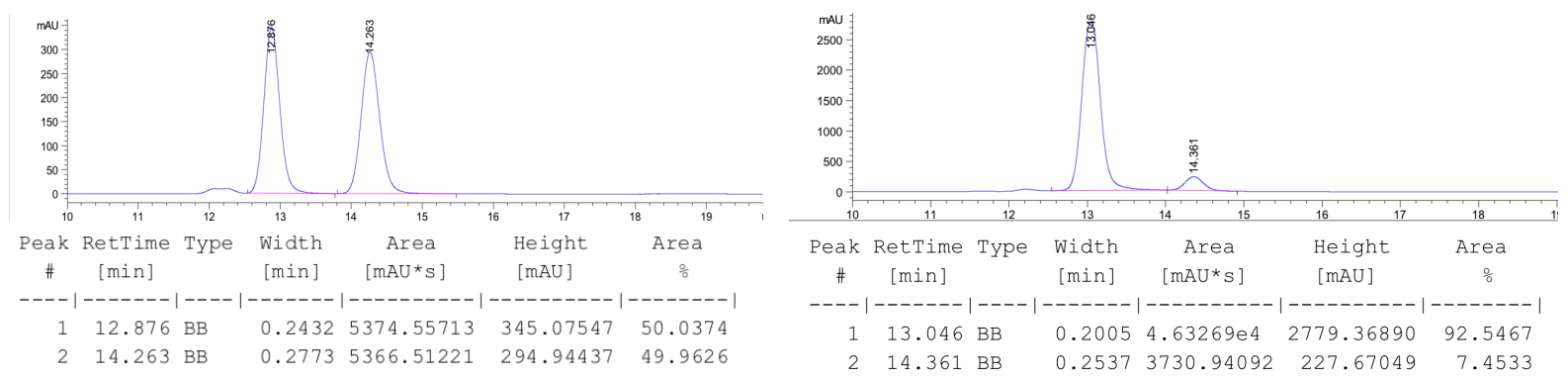


\begin{tabular}{|c|c|c|c|c|c|}
\hline Retention Time & Area & Area\% & Retention Time & Area & Area\% \\
\hline 12.876 & 5374.55713 & 50.0374 & 13.046 & 46326.62982 & 92.5467 \\
\hline 14.263 & 5366.51221 & 49.9626 & 14.361 & 3730.94092 & 7.4533 \\
\hline
\end{tabular}

\section{$(4 R, 7 S, Z)-8-(($ tert-Butyldiphenylsilyl)oxy)-5-fluoro-2-methyl-7-(4,4,5,5-tetramethyl-}

1,3,2-dioxaborolan-2-yl)oct-5-en-4-ol (15): In a $\mathrm{N}_{2}$-filled glove box, an oven-dried roundbottomed flask containing a magnetic stir bar was charged with $(\boldsymbol{S}, \boldsymbol{S})$-phos-3 $(70 \mathrm{mg}, 138$ $\mu \mathrm{mol}), \mathrm{CuCl}(12.4 \mathrm{mg}, 125 \mu \mathrm{mol}), \mathrm{LiO} t-\mathrm{Bu}(150 \mathrm{mg}, 3.75 \mathrm{mmol})$ and toluene $(15 \mathrm{~mL})$. The mixture was allowed to stir for $10 \mathrm{~min}$ at $22{ }^{\circ} \mathrm{C}$, after which a solution of $\mathrm{B}_{2}$ (pin) $(700 \mathrm{mg}$, $2.75 \mathrm{mmol})$ and $14(1.08 \mathrm{~g}, 2.50 \mathrm{mmol})$ in toluene $(10 \mathrm{~mL})$ was added. The mixture was allowed to stir for $14 \mathrm{~h}$ and then the volatiles were removed in vacuo to afford colorless oil. Purification by silica gel chromatography (9:1 to $4: 1$ petroleum ether:Et $\left.t_{2} \mathrm{O}\right)$ afforded $\mathbf{1 5}$ as colorless oil (1.11 g, $2.05 \mathrm{mmol}, 82 \%$ yield, 98:2 Z:E, >98:2 ds). Colorless oil. $\mathrm{R}_{f}=0.18$ (petroleum ether: $\mathrm{Et}_{2} \mathrm{O}=4: 1$ ); IR (neat): $3446(\mathrm{w}), 2956(\mathrm{~m}), 2929(\mathrm{~m}), 2857(\mathrm{~m}), 1702(\mathrm{w})$, 1472 (m), 1360 (m), 1324 (m), 1143 (s), 1106 (s), 1080 (s), 965 (m), 822 (m), 734 (m) cm c $^{-1}$ ${ }^{1} \mathrm{H} \mathrm{NMR}\left(\mathrm{CDCl}_{3}, 400 \mathrm{MHz}\right): \delta 7.71(4 \mathrm{H}, \mathrm{d}, J=6.9 \mathrm{~Hz}), 7.47-7.34(6 \mathrm{H}, \mathrm{m}), 4.91(1 \mathrm{H}, \mathrm{dd}, J=$ $38.0,9.6 \mathrm{~Hz}), 4.11(1 \mathrm{H}, \mathrm{dt}, J=17.8,7.1 \mathrm{~Hz}), 3.83(2 \mathrm{H}, \mathrm{t}, J=5.9 \mathrm{~Hz}), 2.56-2.44(\mathrm{~m}, 0 \mathrm{H}), 1.87$ $(1 \mathrm{H}, \mathrm{bs}), 1.78(1 \mathrm{H}, \mathrm{tt}, J=7.1,6.7 \mathrm{~Hz}), 1.52(2 \mathrm{H}, \mathrm{t}, J=7.1 \mathrm{~Hz}) 1.26(12 \mathrm{H}, \mathrm{s}), 1.06(9 \mathrm{H}, \mathrm{s}), 0.93$ $(6 \mathrm{H}, \mathrm{d}, J=6.7 \mathrm{~Hz}) ;{ }^{13} \mathrm{C} \mathrm{NMR}\left(\mathrm{CDCl}_{3}, 100 \mathrm{MHz}\right): \delta 159.7(\mathrm{~d}, J=257.0 \mathrm{~Hz}), 135.8,135.7$, 134.0, 133.9, 129.6, 127.7, 104.9 (d, $\left.J_{\mathrm{C}, \mathrm{F}}=14.5 \mathrm{~Hz}\right), 83.6,69.4(\mathrm{~d}, J=29.4 \mathrm{~Hz}), 65.0,42.9$, 27.0, 24.9, 24.7 (bs), 24.6, 23.0, 22.5, 19.4; ${ }^{19} \mathrm{~F} \mathrm{NMR}\left(\mathrm{CDCl}_{3}, 377 \mathrm{MHz}\right): \delta-124.77$ (dd, $J=$ 38.0, $17.8 \mathrm{~Hz}$ ); ${ }^{11} \mathrm{~B}$ NMR $\left(\mathrm{CDCl}_{3}, 160 \mathrm{MHz}\right): \delta 35.6$; HRMS (ESI-TOF) m/z: Calcd for $\mathrm{C}_{31} \mathrm{H}_{46} \mathrm{~B} \mathrm{O}_{4} \mathrm{FSiNa}[\mathrm{M}+\mathrm{Na}]^{+}:$563.3140, Found: 563.3131.

\section{Trapping of the $\mathrm{Cu}-$ allkyl Intermediate with $\mathrm{D}_{2} \mathrm{O}$}

In a $\mathrm{N}_{2}$-filled glove box, an oven-dried 2-dram containing a stir bar vial was charged with $\mathrm{CuCl}$ (1.0 mg, $0.0101 \mathrm{mmol})$, imid-5 (6.8 mg, $0.0111 \mathrm{mmol})$, CsOAc (38.8 mg, $0.2020 \mathrm{mmol})$. Dry 1,4-dioxane $(0.5 \mathrm{~mL})$ was added and the mixture was allowed to stir for $4 \mathrm{~h}$, after which it was further charged with a solution of $\mathrm{B}_{2}(\mathrm{pin})_{2}(51.3 \mathrm{mg}, 0.202 \mathrm{mmol})$ and 11a $(24.9 \mathrm{mg}, 0.101$ mmol, 1.0 equiv) in 1,4-dioxane $(0.5 \mathrm{~mL})$. $\mathrm{D}_{2} \mathrm{O}(9.1 \mu \mathrm{L}, 0.5050,5.0$ equiv) was added to the solution containing 11a, which was then transferred by syringe to the solution containing the catalyst. The mixture was allowed to stir for $20 \mathrm{~h}$, after which it was passed through a short plug of silica gel $\left(3 \mathrm{~cm} \times 1 \mathrm{~cm}\right.$; eluted with $\left.\mathrm{Et}_{2} \mathrm{O}\right)$. Evaporation of the volatiles afforded colorless oil, which was purified by silica gel chromatography $(3 \mathrm{~cm} \times 1 \mathrm{~cm}$; eluted with 10:1 petroleum ether:Et ${ }_{2} \mathrm{O}$ ), affording $35-\boldsymbol{d}_{\mathbf{1}}(31.8 \mathrm{mg}, 0.084 \mathrm{mmol}, 84 \%$ yield) as colorless oil. The diastereomeric ratio and $\mathrm{D}: \mathrm{H}$ ratio were determined by analysis of the ${ }^{19} \mathrm{~F}$ NMR spectrum of the unpurified mixture. Racemic 35- $\boldsymbol{d}_{\mathbf{1}}$ was prepared through the use of an achiral $\mathrm{NHC}-\mathrm{Cu}$ complex (derived from SIMes $\cdot \mathrm{HCl}$; 95\% conv, 5\% 12a, 73\% yield, $>98: 2 \mathrm{dr}, 86 \% \mathrm{D}$ incorporation).

4,4,5,5-Tetramethyl-2-((2R,3R)-4,4,4-trifluoro-1-((4-methoxybenzyl)oxy)butan-2-yl-3-d)1,3,2-dioxaborolane (35- $\left.\boldsymbol{d}_{\mathbf{1}}\right)$ : colorless oil. $\mathrm{R} f=0.70$ (petroleum ether:EtOAc 70:30, 
$\mathrm{UV} / \mathrm{KMnO}_{4}$ stain). ${ }^{1} \mathrm{H}$ NMR $\left(\mathrm{CDCl}_{3}, 400 \mathrm{MHz}\right): \delta 7.26(\mathrm{dd}, J=9.6,3.2 \mathrm{~Hz}, 2 \mathrm{H}), 6.89(\mathrm{~d}, J=$ $8.5 \mathrm{~Hz}, 2 \mathrm{H}), 4.47(\mathrm{~d}, J=11.7 \mathrm{~Hz}, 1 \mathrm{H}), 4.43(\mathrm{~d}, J=11.6 \mathrm{~Hz}, 1 \mathrm{H}), 3.83(\mathrm{~s}, 3 \mathrm{H}), 3.56(\mathrm{~d}, J=6.4$ $\mathrm{Hz}, 2 \mathrm{H}), 2.40-2.23(\mathrm{~m}, 1 \mathrm{H}), 1.66(\mathrm{q}, J=6.2 \mathrm{~Hz}, 1 \mathrm{H}), 1.25(\mathrm{~s}, 6 \mathrm{H}), 1.25(\mathrm{~s}, 6 \mathrm{H}) ;{ }^{13} \mathrm{C} \mathrm{NMR}$ $\left(\mathrm{CDCl}_{3}, 100 \mathrm{MHz}\right): \delta 159.3,130.7,129.4,127.9$ (q, $\left.J=275.0 \mathrm{~Hz}\right), 113.9,84.0,72.8,70.2$, 55.5, 32.6 - $31.1(\mathrm{~m}), 25.0,24.8,19.4(\mathrm{bs}) ;{ }^{19} \mathrm{~F} \mathrm{NMR}$ (376 MHz, $\left.\mathrm{CDCl}_{3}, \mathbf{3 5}-\boldsymbol{d}_{\mathbf{1}}\right): \delta-65.02(\mathrm{~d}, J$ $=11.6 \mathrm{~Hz}),{ }^{19} \mathrm{~F}$ NMR $\left(376 \mathrm{MHz}, \mathrm{CDCl}_{3}, 35\right): \delta-64.93$ (t, $\left.J=11.3 \mathrm{~Hz}\right)$; HRMS (ESI-TOF) $\mathrm{m} / \mathrm{z}:[\mathrm{M}+\mathrm{H}]^{+}$Calcd for $\mathrm{C}_{18} \mathrm{H}_{26} \mathrm{DBF}_{3} \mathrm{O}_{4}{ }^{+}: 376.2012$, Found: 376.1983. Enantiomeric purity of 35- $\boldsymbol{d}_{\mathbf{1}}$ was determined by HPLC analysis in comparison with authentic racemic material (86:14 er shown; AD-H column, 98:2 hexanes/ $i$-PrOH, $0.6 \mathrm{~mL} / \mathrm{min}, 220 \mathrm{~nm}) .(R, R)$-enantiomer $\mathrm{t}_{\mathrm{r}}=$ $44.0 \mathrm{~min},(S, S)$-enantiomer $\mathrm{t}_{\mathrm{r}}=47.0 \mathrm{~min}$.
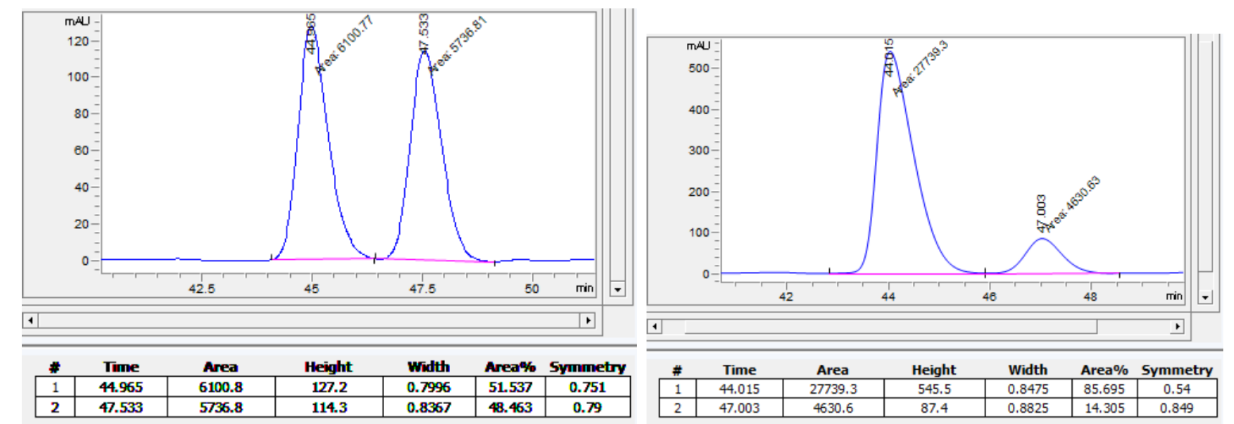

\begin{tabular}{|c|c|c|c|c|c|}
\hline Retention Time & Area & Area\% & Retention Time & Area & Area\% \\
\hline 44.965 & 6100.8 & 51.537 & 44.015 & 27739.3 & 85.695 \\
\hline 47.533 & 5736.8 & 48.463 & 47.003 & 4630.6 & 14.305 \\
\hline
\end{tabular}

\section{Synthesis and Characterization of $\mathrm{Cu}-\mathrm{Allkyl}$ and $\mathrm{Cu}-\mathrm{Allyl} \mathrm{Complexes}$}

\subsection{Synthesis and characterization NHC-Cu-alkyl complex 18}

Under a $\mathrm{N}_{2}$ atmosphere an oven-dried $8 \mathrm{~mL}$ vial equipped with a magnetic stir bar was charged with $\quad \mathrm{B}_{2}(\text { pin })_{2} \quad(42 \mathrm{mg}, 162 \mu \mathrm{mol}), \quad(E)$-tert-butyldiphenyl((4,4,4-trifluorobut-2-en-1yl)oxy)silane (11d) $(62 \mathrm{mg}, 162 \mu \mathrm{mol})$ and NHC-Cu-O-1 ${ }^{7}$ (85 mg, $\left.25 \mu \mathrm{mol}\right)$. The solids were suspended in hexanes $(5 \mathrm{~mL})$ and the suspension was allowed to stir vigorously for 2 . The resulting white suspension was filtered through a plug of celite $(4 \times 1 \mathrm{~cm})$, the solid washed with cold hexanes $(2 \mathrm{~mL})$, and benzene was added $(1 \mathrm{~mL})$. The volatiles were in vacuo, and hexanes was added and removed in vacuo (twice), affording complex $\mathbf{1 8}$ as white amorphous solid. Crystals suitable for X-ray analysis were obtained upon allowing a hexanes solution of 18 to stand for $3 \mathrm{~d}$ at $-40{ }^{\circ} \mathrm{C} .{ }^{1} \mathrm{H}$ NMR $\left(\mathrm{CDCl}_{3}, 400 \mathrm{MHz}\right): \delta 7.94-7.86(2 \mathrm{H}, \mathrm{m}), 7.82(2 \mathrm{H}, \mathrm{dd}$, $\mathrm{J}=6.5,2.9 \mathrm{~Hz}), 7.37(2 \mathrm{H}, \mathrm{dd}, J=8.6,6.7 \mathrm{~Hz}), 7.27(2 \mathrm{H}, \mathrm{dd}, \mathrm{J}=5.2,1.9 \mathrm{~Hz}), 7.08-6.97(4 \mathrm{H}$, $\mathrm{m}), 6.93(2 \mathrm{H}, \mathrm{dd}, J=7.3,1.8 \mathrm{~Hz}), 6.27(2 \mathrm{H}, \mathrm{s}), 3.62-3.48(4 \mathrm{H}, \mathrm{m}), 3.28(1 \mathrm{H}, \mathrm{dd}, J=8.8,5.2$ $\mathrm{Hz}), 2.53(4 \mathrm{H}$, dhept, $J=13.7,6.8 \mathrm{~Hz}), 2.30(2 \mathrm{H}, \mathrm{dt}, J=11.1,5.5 \mathrm{~Hz}), 1.46-1.40(2 \mathrm{H}, \mathrm{m}), 1.37$ $(6 \mathrm{H}, \mathrm{d}, J=6.9 \mathrm{~Hz}), 1.29(6 \mathrm{H}, \mathrm{d}, J=6.9 \mathrm{~Hz}), 1.21(6 \mathrm{H}, \mathrm{s}), 1.14(14 \mathrm{H}, \mathrm{d}, J=5.5 \mathrm{~Hz}), 1.10(6 \mathrm{H}$, $\mathrm{d}, J=6.9 \mathrm{~Hz}), 1.08-1.04 \mathrm{ppm}(6 \mathrm{H}, \mathrm{m}) .{ }^{13} \mathrm{C} \mathrm{NMR}\left(\mathrm{CDCl}_{3}, 151 \mathrm{MHz}\right): \delta 184.6,145.6,145.5$, 136.4 , 136.3, 135.9, 135.0, 134.6, 130.5, 129.5, 129.3, 124.2, 124.1, 122.2, 82.3, 69.8, 67.8, 35.0, 32.0, 30.3, 29.4, 29.0, 28.9, 28.4, 28.1, 27.1, 25.8, 25.7, 25.4, 25.3, 25.1, 25.0, 24.7, 24.1, 23.9, 23.1, 20.9, 19.6, 14.4 ppm. ${ }^{19} \mathrm{~F}$ NMR $\left(\mathrm{CDCl}_{3}, 376 \mathrm{MHz}\right): \delta-50.55 \mathrm{ppm}(\mathrm{d}, J=18.0 \mathrm{~Hz})$. 
Preparation of a solution of complex 18: An oven-dried $8 \mathrm{~mL}$ vial was charged with $\mathrm{B}_{2}$ (pin) $(6.5 \mathrm{mg}, 25 \mu \mathrm{mol})$ and (E)-tert-butyldiphenyl((4,4,4-trifluorobut-2-en-1-yl)oxy)silane (11d) $(9.5 \mathrm{mg}, 26 \mu \mathrm{mol})$ in a suspension in benzene- $d_{6}$. After solution became homogeneous, it was transferred to an NMR tube, which was tightly capped (septum and electrical tape). An initial ${ }^{19} \mathrm{~F}$ NMR spectrum was collected to assess shimming, after which a stock solution of IPr-Cu$\mathrm{O} t$-Bu complex $(13.0 \mathrm{mg}, 25 \mu \mathrm{mol})$ in benzene- $d_{6}$ was added by syringe. The ${ }^{19} \mathrm{~F}$ NMR spectrum was recorded within $20 \mathrm{sec}$.

\subsection{Synthesis of $\mathrm{NHC}-\mathrm{Cu}-$ alkyl complex 19a}

In a $\mathrm{N}_{2}$-filled glove box, an oven-dried NMR tube was charged with a stock solution of olefin 9c $(9 \mathrm{mg}, 25 \mu \mathrm{mol})$ and $\mathrm{PhMe}_{2} \mathrm{SiB}(\mathrm{pin})(6.5 \mathrm{mg}, 25 \mu \mathrm{mol})$ in thf $(0.7 \mathrm{~mL})$. The tube was capped with a septum and removed from the glovebox. The ${ }^{19} \mathrm{~F}$ NMR spectrum was recorded to assess shimming, after which a thf solution of NHC-Cu-O-1 (11 mg, $25 \mu \mathrm{mol}, 0.3 \mathrm{~mL})$ was added by syringe and the sample was vigorously shaken. The ${ }^{19} \mathrm{~F}$ NMR spectrum was then recorded (Scheme 8 ). Crystals suitable for X-ray crystallography were obtained upon adding hexanes to the mixture $(2 \mathrm{~mL})$ and allowing it to stand for $\sim 24 \mathrm{~h}$ at $-40{ }^{\circ} \mathrm{C}$.

Scheme S8. Reaction of an In Situ Generated $\mathrm{NHC}-\mathrm{Cu}-\mathrm{SiMe}_{2} \mathrm{Ph}$ Complex with alkene 9c

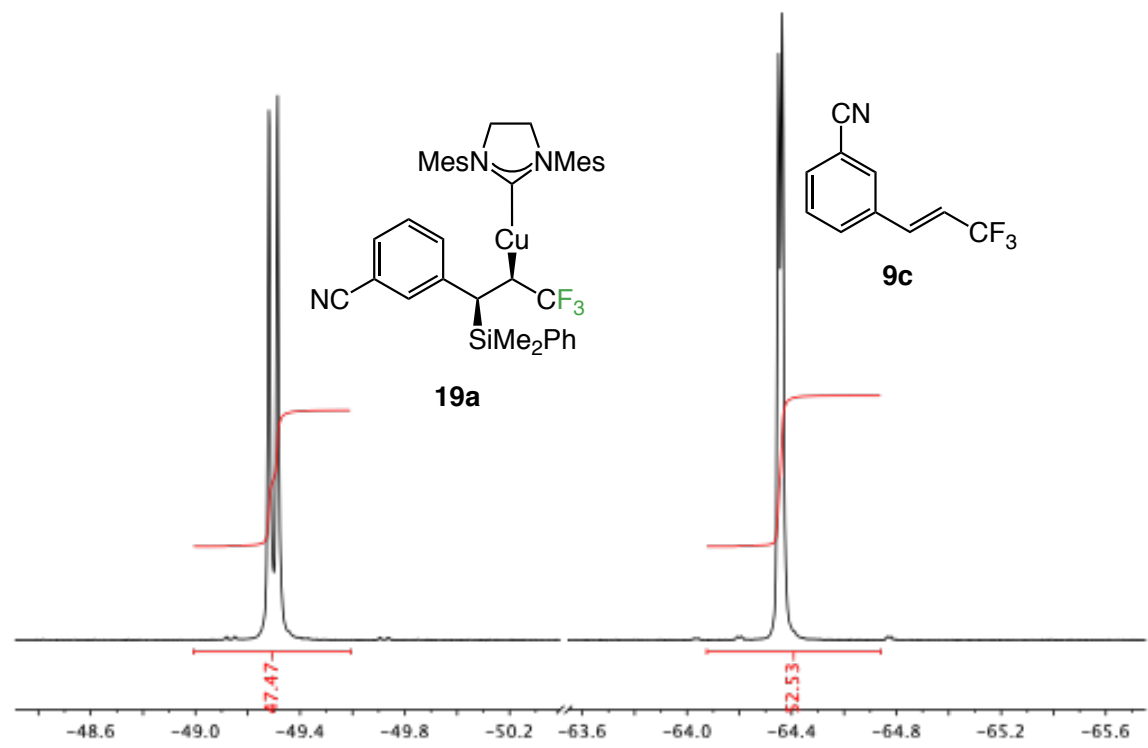

\subsection{Synthesis and characterization $\mathrm{NHC}-\mathrm{Cu}-$ alkyl complex $19 \mathrm{~b}$}

In a $\mathrm{N}_{2}$-filled glovebox, an oven-dried 2-dram vial containing a a stir bar was charged with $\mathrm{IPr}-$ $\mathrm{Cu}-\mathrm{O} t$-Bu complex $(20 \mathrm{mg}, 0.038 \mathrm{mmol})$ and $(E)$-tert-butyldiphenyl((4,4,4-trifluorobut-2-en1-yl)oxy)silane (11d) (16.6 mg, $0.046 \mathrm{mmol})$. The solids were dissolved in benzene $(1 \mathrm{~mL})$ and $\mathrm{PhMe}_{2} \mathrm{SiB}$ (pin) was added by syringe $(12.5 \mu \mathrm{L}, 0.046 \mathrm{mmol})$. The suspension was allowed to stir for $15 \mathrm{~min}$, after which the volatiles were removed to give colorless oil, which was dissolved in pentane $(0.7 \mathrm{~mL})$ and kept in the glovebox for $12-16 \mathrm{~h}$ at $-40{ }^{\circ} \mathrm{C}$, leading to the formation of colorless crystals. Flitration and removal of the volatiles in vacuo afforded $\mathrm{Cu}-$ alkyl complex 19b (33.3 mg, $0.035 \mathrm{mmol}, 92 \%$ yield). ${ }^{1} \mathrm{H}$ NMR $\left(\mathrm{C}_{6} \mathrm{D}_{6}, 600 \mathrm{MHz}\right) \delta 7.75-7.70$ $(\mathrm{m}, 2 \mathrm{H}), 7.66-7.61(\mathrm{~m}, 2 \mathrm{H}), 7.46-7.41(\mathrm{~m}, 2 \mathrm{H}), 7.25(\mathrm{t}, J=7.8 \mathrm{~Hz}, 2 \mathrm{H}), 7.23-7.10(\mathrm{~m}, 13 \mathrm{H})$, $6.34(\mathrm{~s}, 2 \mathrm{H}), 3.94(\mathrm{dd}, J=9.6,4.1 \mathrm{~Hz}, 1 \mathrm{H}), 3.65(\mathrm{dd}, J=9.6,7.3 \mathrm{~Hz}, 1 \mathrm{H}), 2.69$ (m, 4H), 1.94$1.76(\mathrm{~m}, 2 \mathrm{H}), 1.42(\mathrm{~m}, 12 \mathrm{H}), 1.15(\mathrm{~s}, 9 \mathrm{H}), 1.08(\mathrm{~m}, 12 \mathrm{H}), 0.29(\mathrm{~s}, 3 \mathrm{H}), 0.04(\mathrm{~s}, 3 \mathrm{H}) ;{ }^{13} \mathrm{C} \mathrm{NMR}$ 
$\left(\mathrm{C}_{6} \mathrm{D}_{6}, 151 \mathrm{MHz}\right) \delta 184.5,145.6,145.6,141.2,136.3,136.1,135.5,135.2,134.6,134.3,130.6$, 129.5, 129.3, 124.4, 122.7, 67.5, 29.3, 29.1, 29.0, 27.3, 24.5, 24.3, 24.2, 19.6, 14.3, -0.3, -4.2. ${ }^{19} \mathrm{~F} \operatorname{NMR}\left(\mathrm{C}_{6} \mathrm{D}_{6}, 470 \mathrm{MHz}\right) \delta-48.76(\mathrm{~d}, J=18.3 \mathrm{~Hz})$.

\subsection{Synthesis of bisphosphine-Cu-alkyl complex 20}

In a $\mathrm{N}_{2}$-filled glovebox, an oven-dried 2-dram vial equipped with a stir bar was charged with $[\mathrm{Cu}-\mathrm{O} t-\mathrm{Bu}]_{4}(2.0 \mathrm{mg}, 0.0015 \mathrm{mmol})$ and phos-3 $(11.4 \mathrm{mg}, 0.0025 \mathrm{mmol})$. The solids were dissolved in thf $(0.4 \mathrm{~mL})$ and the mixture was allowed to stir for $15 \mathrm{~min}$ at $22{ }^{\circ} \mathrm{C}$. A thf solution $(0.2 \mathrm{~mL})$ containing (E)-tert-butyldiphenyl((4,4,4-trifluorobut-2-en-1-yl)oxy)silane (11d) $(10.9 \mathrm{mg}, 0.0030 \mathrm{mmol})$ and $\mathrm{B}_{2}(\text { pin })_{2}(7.6 \mathrm{mg}, 0.0030 \mathrm{mmol})$ was added (pipette) and the mixture was transferred to a J-young NMR tube. Reaction progress was analyzed by NMR spectroscopy five min after the solutions were mixed (Scheme S9).

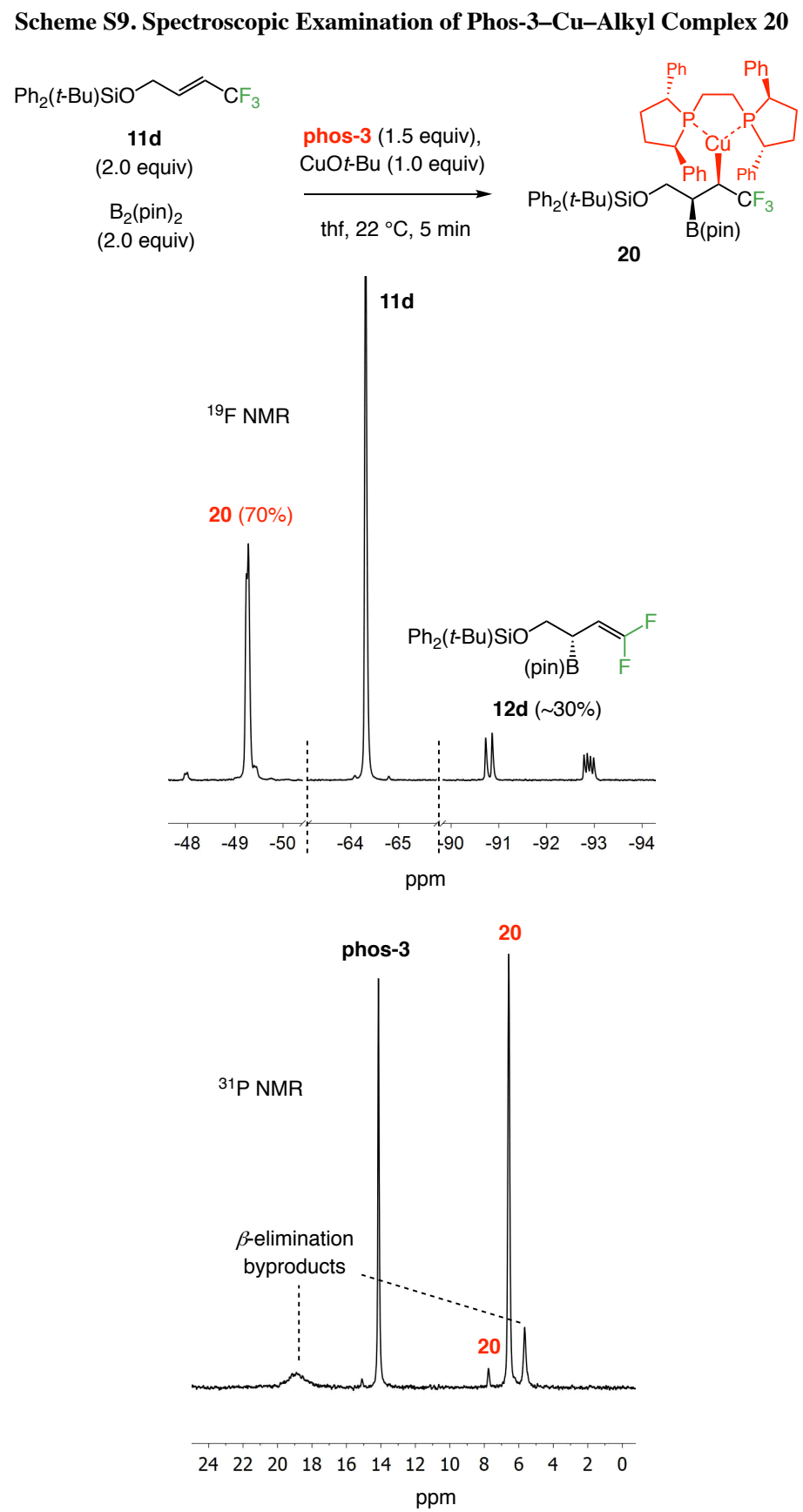


Analysis of the ${ }^{19} \mathrm{~F}$ NMR spectra revealed the formation of phos3-Cu-alkyl complex 20 and that significant $\mathrm{Cu}-\mathrm{F} \beta$-elimination had already occurred after just $5 \min (\sim 30 \%$ to 12d; Scheme S9). Further monitoring of reaction progress showed $58 \%$ conv to $\mathbf{1 2 d}$ after $30 \mathrm{~min}$ and $>98 \%$ conv after $3 \mathrm{~h}$. When the transformation was carried out in the presence of 3.0 equiv phos-3, there was no noteworthy difference in the outcome, which suggests that phosphine dissociation is probably not involved in $\mathrm{Cu}-\mathrm{F} \beta$-elimination.

\subsection{Synthesis and characterization NHC-Cu-alkyl complex 21}

In a $\mathrm{N}_{2}$-filled glovebox, an oven-dried 2-dram vial equipped with a magnetic stir bar was charged with NHC-Cu-O-1 $(20 \mathrm{mg}, 0.038 \mathrm{mmol})$ and $(E)$-tert-butyldiphenyl $((4,4,4-$ trifluorobut-2-en-1-yl)oxy)silane (11d) $(16.6 \mathrm{mg}, 0.046 \mathrm{mmol})$. The solids were dissolved in benzene $(1 \mathrm{~mL})$ and PMHS was added by syringe $(5 \mu \mathrm{L}, 0.076 \mathrm{mmol})$. The suspension was allowed to stir for $15 \mathrm{~min}$, after which the volatiles were removed in vacuo. The resulting colorless oil was dissolved in hexanes $(1.5 \mathrm{~mL})$ and kept in a glovebox freezer for $12-16 \mathrm{~h}$ at $40{ }^{\circ} \mathrm{C}$, leading to the formation of crystals suitable for X-ray ray diffraction. Flitration and removal of volatiles in vacuo afforded $\mathrm{Cu}$-alkyl complex $21(25.5 \mathrm{mg}, 0.031 \mathrm{mmol}, 82 \%$ yield). ${ }^{1} \mathrm{H}$ NMR $\left(\mathrm{C}_{6} \mathrm{D}_{6}, 600 \mathrm{MHz}\right): \delta 7.81-7.70(\mathrm{~m}, 4 \mathrm{H}), 7.28-7.17(\mathrm{~m}, 6 \mathrm{H}), 7.09(\mathrm{~d}, \mathrm{~J}=7.8$ $\mathrm{Hz}, 2 \mathrm{H}), 7.01-6.92(\mathrm{~m}, 4 \mathrm{H}), 6.17(\mathrm{~s}, 2 \mathrm{H}), 3.49$ (td, J = 9.8, $5.2 \mathrm{~Hz}, 1 \mathrm{H}), 3.32(\mathrm{td}, J=9.8,6.2$ $\mathrm{Hz}, 1 \mathrm{H}), 2.46$ (hept, $\mathrm{J}=6.9 \mathrm{~Hz}, 4 \mathrm{H}), 2.27(\mathrm{~m}, 1 \mathrm{H}), 2.08(\mathrm{~m}, 1 \mathrm{H}), 1.27(\mathrm{~d}, J=6.9 \mathrm{~Hz}, 12 \mathrm{H})$, $1.23-1.14(\mathrm{~m}, 1 \mathrm{H}), 1.10(\mathrm{~s}, 9 \mathrm{H}), 1.02(\mathrm{~d}, J=6.9 \mathrm{~Hz}, 12 \mathrm{H}) .{ }^{13} \mathrm{C} \mathrm{NMR}\left(\mathrm{C}_{6} \mathrm{D}_{6}, 151 \mathrm{MHz}\right): \delta$ $184.50,145.64,136.16,135.45,134.94,130.66,129.54,124.17,122.18,67.33,32.66,28.97$, $27.16,24.80,23.84,23.82,19.57,14.36$. The signal in the ${ }^{13} \mathrm{C}$ NMR spectrum that corresponding to $\mathrm{CF}_{3}$ was not detected likely as a result of low intensity of the ${ }^{13} \mathrm{CF}_{3}$ signals caused by $\mathrm{C}-\mathrm{F}$ coupling. ${ }^{19} \mathrm{~F}$ NMR $\left(\mathrm{C}_{6} \mathrm{D}_{6}, 564 \mathrm{MHz}\right): \delta-51.44(\mathrm{~d}, J=17.1 \mathrm{~Hz})$.

\section{Investigation of the Resting State of the Catalytic Cycle}

\subsection{Reaction profile: NHC-Cu-catalyzed boryl substitution}

In a $\mathrm{N}_{2}$-filled glovebox an oven-dried vial was charged with alkene $11 \mathrm{~d}(36.4 \mathrm{mg}, 0.100 \mathrm{mmol})$, $\mathrm{B}_{2}$ (pin) $)_{2}(28 \mathrm{mg}, 0.110 \mathrm{mmol}), \mathrm{LiO} t-\mathrm{Bu}(8.8 \mathrm{mg}, 0.110 \mathrm{mmol})$ and trifluorotoluene as the internal standard ( $14.6 \mathrm{mg}, 0.100 \mathrm{mmol}$ ). The components were dissolved in the corresponding solvent for the reaction $(20 / 1 \mathrm{tol} / \mathrm{thf}$ or thf, $0.8 \mathrm{~mL})$ and transferred to an NMR tube, which was

Scheme S10. Reaction profile for Boryl Substitution with NHC-Cu-O-1 as Catalyst Precursor
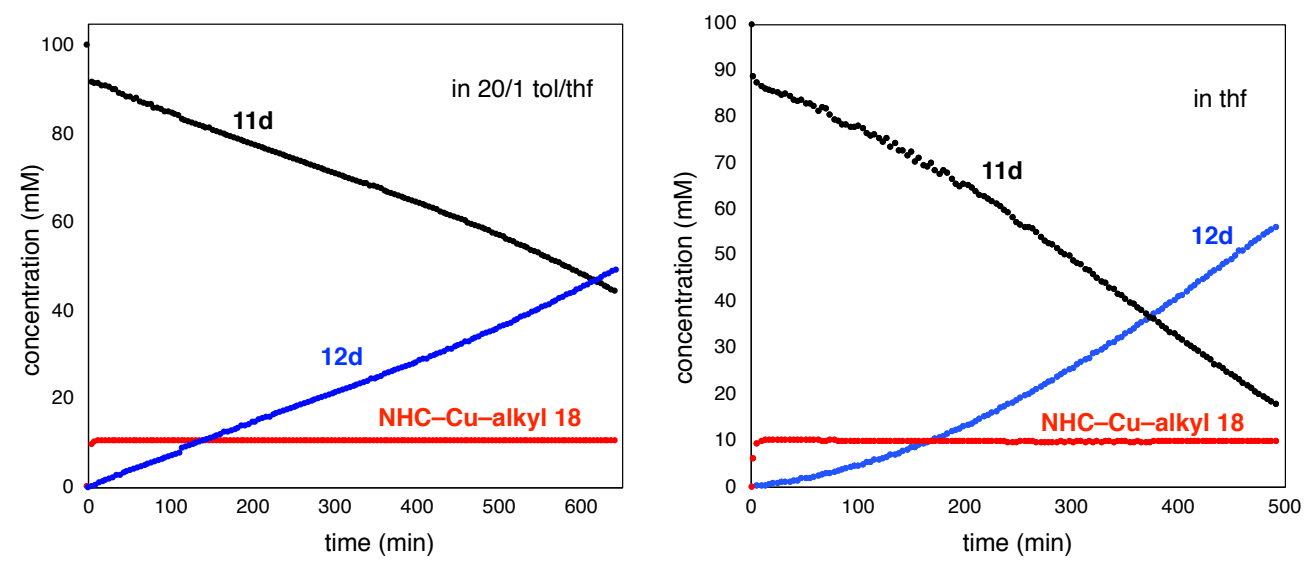
then sealed (septum and electrical tape). ${ }^{19} \mathrm{~F}$ NMR spectrum was recorded to determine the proper spectrometer settings and establish the exact initial ratio of $\mathbf{1 1 d}$ :internal standard. At this point, NHC-Cu-O-2 was added by syringe $(5.2 \mathrm{mg}, 0.010 \mathrm{mmol}$; a stock solution was prepared and used), the contents of the NMR tube were carefully mixed, and the experiment was carried out as quickly as feasible.

\subsection{Reaction profile: Bisphosphine-Cu-catalyzed boryl substitution}

In a $\mathrm{N}_{2}$-filled glovebox an oven-dried vial was charged with 11d (36.4 $\left.\mathrm{mg}, 0.100 \mathrm{mmol}\right)$, $\mathrm{B}_{2}$ (pin) 2 (28 mg, $\left.0.110 \mathrm{mmol}\right)$, LiOt-Bu $(8.8 \mathrm{mg}, 0.110 \mathrm{mmol})$, and trifluorotoluene as the internal standard $(14.6 \mathrm{mg}, 0.100 \mathrm{mmol})$. The components were dissolved in thf $(0.8 \mathrm{~mL})$ and transferred to an NMR tube, which was sealed with a septum and strip electrical tape. After the NMR probe and sample reached the temperature of the corresponding experiment $\left(-40^{\circ} \mathrm{C}\right.$ or $25^{\circ} \mathrm{C}$ ) an initial ${ }^{19} \mathrm{~F}$ NMR spectrum was recorded to establish proper spectrometer settings and determine the initial 11:internal standard ratio. Next, the tube was charged with a thf $(0.2 \mathrm{~mL})$ solution of phos-3, stored at $-78{ }^{\circ} \mathrm{C}(5.0 \mathrm{mg}, 0.010 \mathrm{mmol})$, and $\mathrm{CuCl}(1.0 \mathrm{mg}, 0.010 \mathrm{mmol})$ was added, the contents of the NMR tube were mixed, and the experiment was started in a timely manner. (In the case of the experiment conducted at $22{ }^{\circ} \mathrm{C}$, the stock solution was kept at the same temperature).

Scheme S11. Reaction profile for boryl substitution with phos-3-Cu-Ot-bu as catalyst precursor

a. Reaction profile at $-40^{\circ} \mathrm{C}$ :
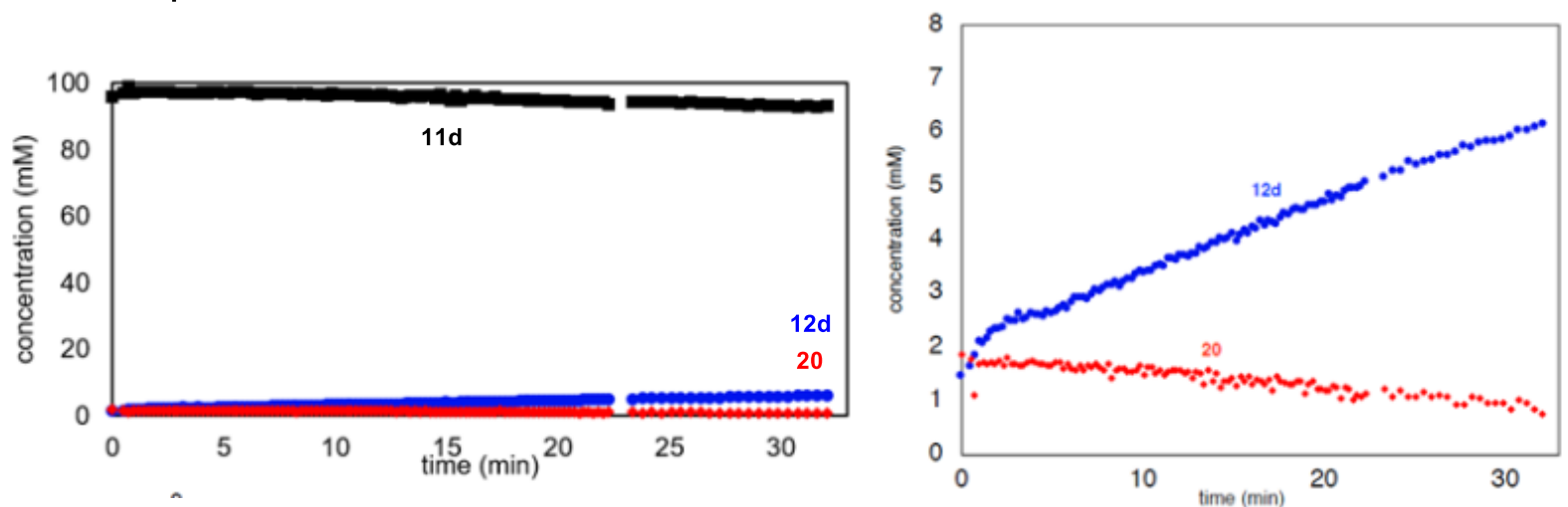

b. Reaction profile at $25^{\circ} \mathrm{C}$ :
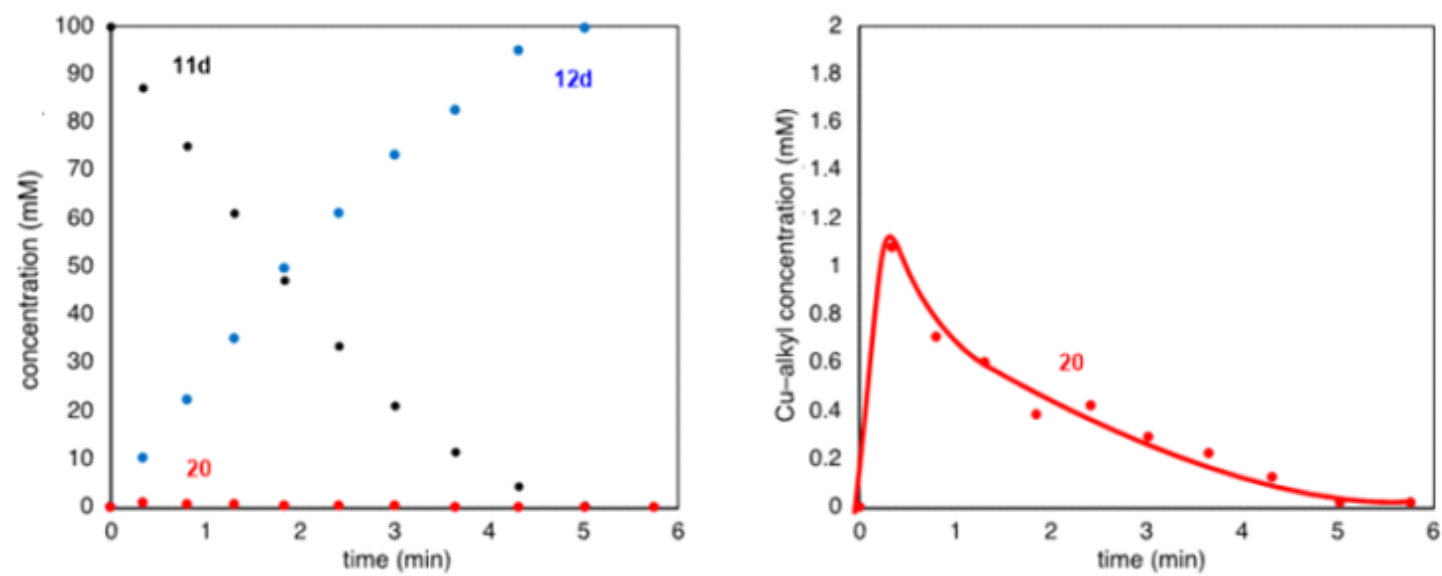


\section{Studies Regarding the Rate of $\mathrm{Cu}-\mathrm{F} \beta$-Elimination}

With metal alkoxides: An oven-dried NMR tube was charged with a stock solution of $\mathrm{Cu}-$ alkyl complex 18 and $\alpha, \alpha, \alpha$-trifluorotoluene as the internal standard, and then additional solvent was added to reach $0.5 \mathrm{~mL}$ total volume. The tube was tightly capped with (septum and electrical tape). A ${ }^{19} \mathrm{~F}$ NMR spectrum was recorded to establish proper spectrometer settings and establish the exact initial ratio of 18:internal standard. Then a stock solution of metal alkoxide was quickly added by syringe, and the tube shaken carefully to achieve proper mixing. The measurement of changes in concentration was started as expeditiously as possible, and the time lapse between addition and collection of the first spectrum was noted.

With NaBArF: We were able to secure reproducible and reliable data by preparing a stock solution of $\mathrm{NaBArF}$ and allowing the insoluble particles to settle before removing an aliquot and placing it in an NMR tube by syringe. Solvent was then added to reach total volume of 0.5 $\mathrm{mL}$. A stock solution of complex $\mathbf{1 8}$ in thf was added through the septum and a ${ }^{19} \mathrm{~F}$ NMR spectrum was recorded to establish proper spectrometer settings and determine the initial 18:internal standard ratio.

\subsection{The order in Cu-alkyl complex}

In thf: An NMR tube was charged with the appropriate amount of a stock solution of complex $18(25 \mu \mathrm{mol}, 23.5 \mathrm{mg}$, per $\mathrm{mL}$ thf) and $\alpha, \alpha, \alpha$-trifluorotoluene (internal standard; $25 \mu \mathrm{mol}$, $3.7 \mathrm{mg}$, per $\mathrm{mL}$ thf). Sufficient thf was then added until total volume $=0.6 \mathrm{~mL}$. After the tube was sealed (septum and electrical tape), a stock solution of $\mathrm{NaO} t-\mathrm{Bu}$ in thf was added $(0.1 \mathrm{~mL}$, $250 \mu \mathrm{mol} \mathrm{NaO} t-\mathrm{Bu}, 24 \mathrm{mg}$, per $\mathrm{mL}$ thf) by syringe. Reaction progress was monitored by ${ }^{19} \mathrm{~F}$ NMR within $30 \mathrm{~s}$ after the solutions were mixed. The $\mathrm{Cu}-$ alkyl concentrations investigated were: $3.57 \mathrm{mM}, 7.14 \mathrm{mM}, 14.28 \mathrm{mM}$.
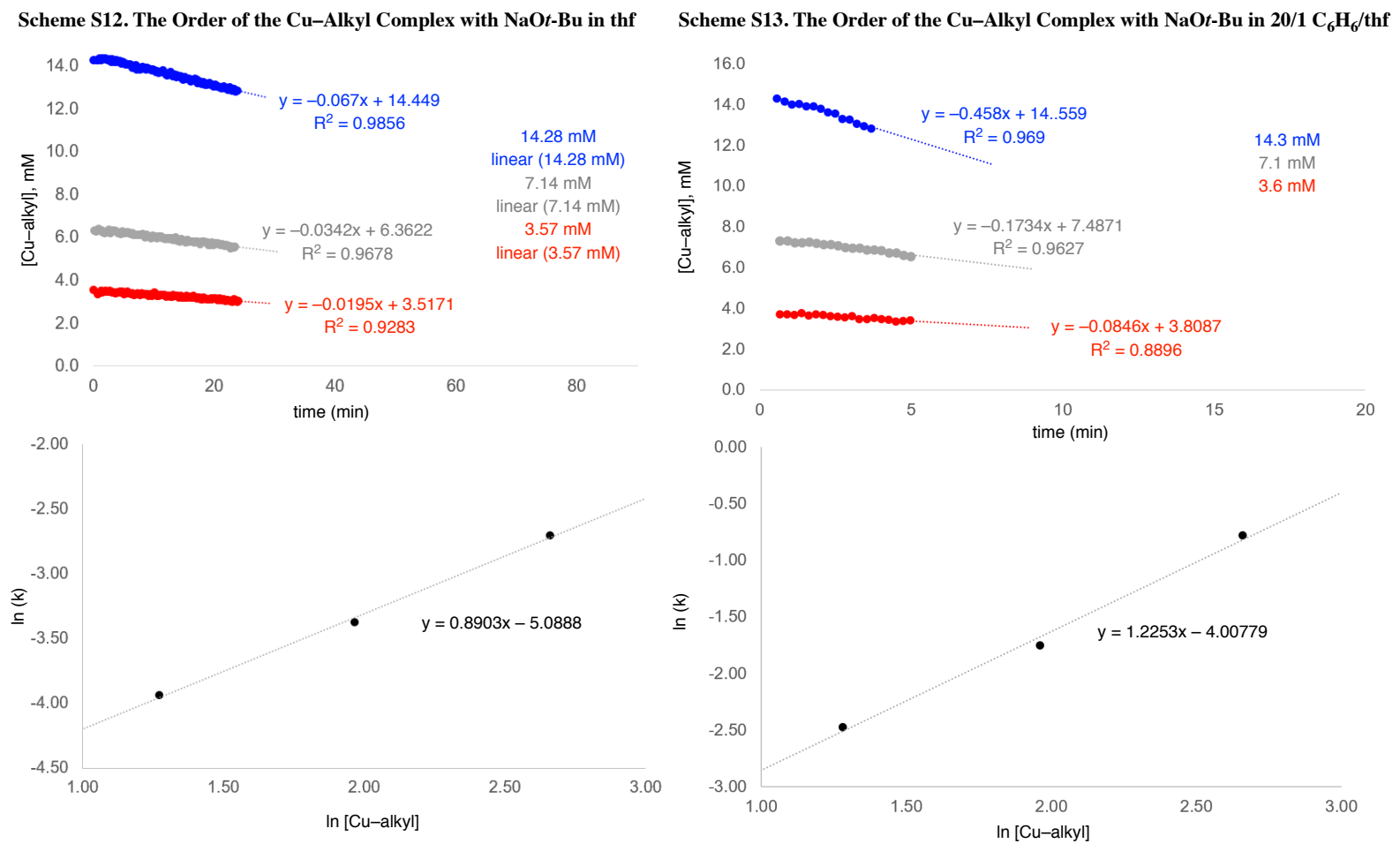

In 20/1 benzene/thf: An NMR tube was charged with the appropriate amount of a stock solution of complex $18(25 \mu \mathrm{mol}, 23.5 \mathrm{mg}$, per $\mathrm{mL}$ thf) and $\alpha, \alpha, \alpha$-trifluorotoluene (internal 
standard; $25 \mu \mathrm{mol}, 3.7 \mathrm{mg}$, per $\mathrm{mL}$ solvent mix). Sufficient thf was then added until total volume $=0.6 \mathrm{~mL}$. After the tube was sealed (septum and electrical tape), a stock solution of $\mathrm{NaO} t-\mathrm{Bu}$ in thf was added $(0.1 \mathrm{~mL}, 100 \mu \mathrm{mol} \mathrm{NaOt}$-Bu, $19.2 \mathrm{mg}$, per mL solvent mix) by syringe. Reaction progress was monitored by ${ }^{19} \mathrm{~F}$ NMR within 30 s after the solutions were mixed. The $\mathrm{Cu}-$ alkyl concentrations investigated were: $3.57 \mathrm{mM}, 7.14 \mathrm{mM}, 14.28 \mathrm{mM}$.

\subsection{The order in $\mathrm{NaOt}$-Bu}

An NMR tube was charged with $0.3 \mathrm{~mL}$ of a stock solution of complex 18 (4 $\mu \mathrm{mol}, 3.77 \mathrm{mg})$ and $\alpha, \alpha, \alpha$-trifluorotoluene (internal standard; $4 \mu \mathrm{mol}, 0.58 \mathrm{mg}$ ) in 20/1 benzene/thf. The solution was diluted with the appropriate amount of the solvent mix so the final volume $=0.7$ $\mathrm{mL}$ (after addition of $\mathrm{NaO} t$-Bu solution). The appropriate amount of a stock solution of $\mathrm{NaO} t$ $\mathrm{Bu}(200 \mu \mathrm{mol} / \mathrm{mL}$, solvent mix) was added. The tube was sealed (septum and electrical tape) and reaction progress was monitored by ${ }^{19} \mathrm{~F}$ NMR within $30 \mathrm{~s}$ after mixing of solutions. $\mathrm{NaO} t$ Bu concentrations investigated: $114 \mathrm{mM}(0.4 \mathrm{~mL}), 57.1 \mathrm{mM}(0.2 \mathrm{~mL}), 28.6 \mathrm{mM}(0.1 \mathrm{~mL})$. The same procedure was used with thf as the solvent.

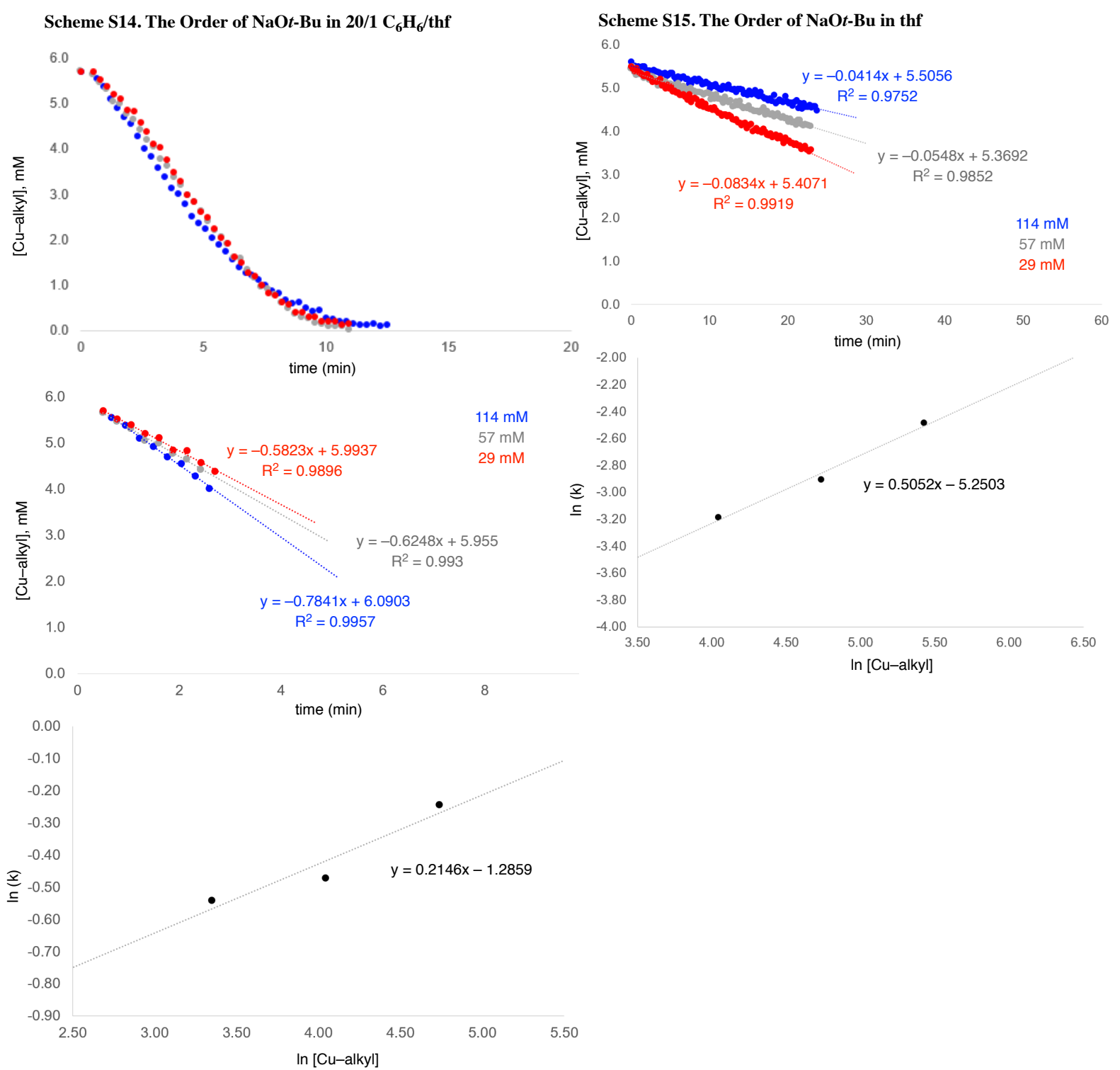

12.3. The order in $\mathrm{MeOH}$ 
An NMR tube was charged with $0.3 \mathrm{~mL}$ of a stock solution of complex 18 (4 $\mu \mathrm{mol}, 3.77 \mathrm{mg})$ and $\alpha, \alpha, \alpha$-trifluorotoluene (internal standard; $4 \mu \mathrm{mol}, 0.58 \mathrm{mg}$ ) in $20 / 1$ benzene/thf. The solution was diluted with the appropriate amount of solvent mix so that volume $=0.7 \mathrm{~mL}$ (after addition of $\mathrm{MeOH}$ solution). The appropriate amount of a stock solution of $\mathrm{MeOH}(0.25 \mathrm{M}$ in solvent mix) was added. The tube was sealed (septum and electrical tape) and reaction progress was monitored by ${ }^{19} \mathrm{~F}$ NMR within 30s after the solutions were mixed. MeOH concentrations investigated: $17.9 \mathrm{mM}(12.5 \mu \mathrm{mol}, 0.05 \mathrm{~mL}), 35.7 \mathrm{mM}(25 \mu \mathrm{mol}, 0.1 \mathrm{~mL}), 71.4 \mathrm{mM}(50 \mu \mathrm{mol}$, $0.2 \mathrm{~mL}), 142.9 \mathrm{mM}$ (100 $\mu \mathrm{mol}, 0.4 \mathrm{~mL}), 285.7 \mathrm{mM}(200 \mu \mathrm{mol}, 0.2 \mathrm{~mL})$.

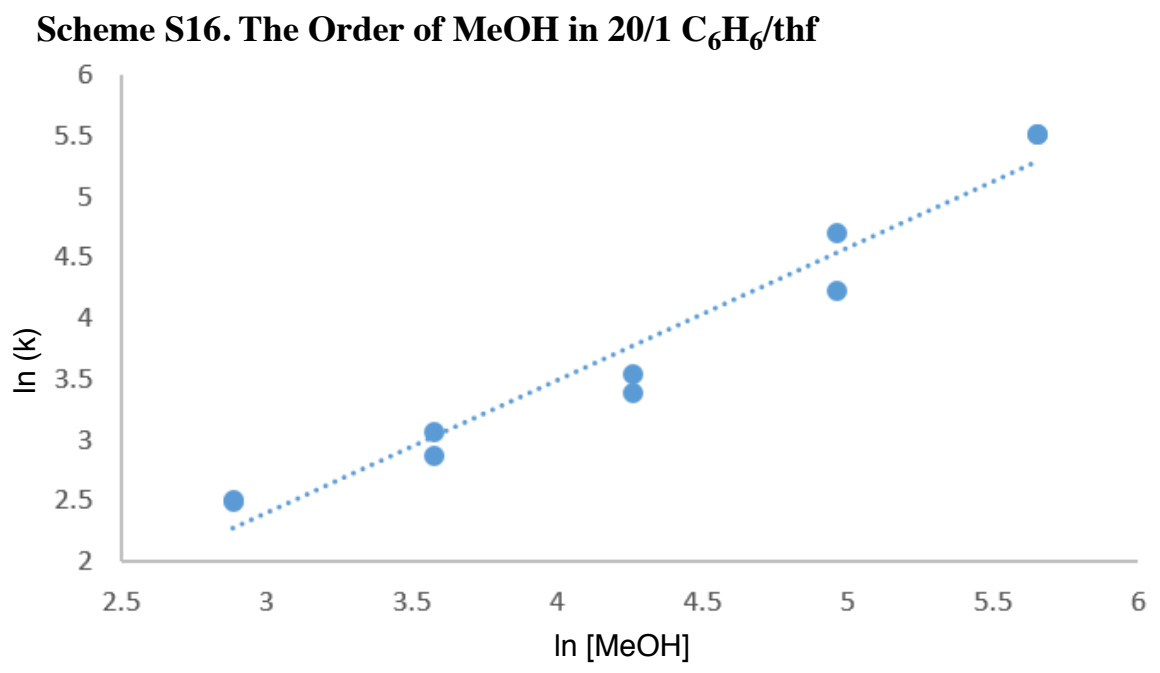

\subsection{The order in NaBArF}

An NMR tube was charged with $0.3 \mathrm{~mL}$ of a stock solution of complex 18 (4 $\mu \mathrm{mol}, 3.77 \mathrm{mg})$ and $\alpha, \alpha, \alpha$-trifluorotoluene (internal standard; $4 \mu \mathrm{mol}, 0.58 \mathrm{mg}$ ) in thf. The solution was diluted with the appropriate amount of thf so that volume $=0.7 \mathrm{~mL}$ (after addition of NaBArF solution).

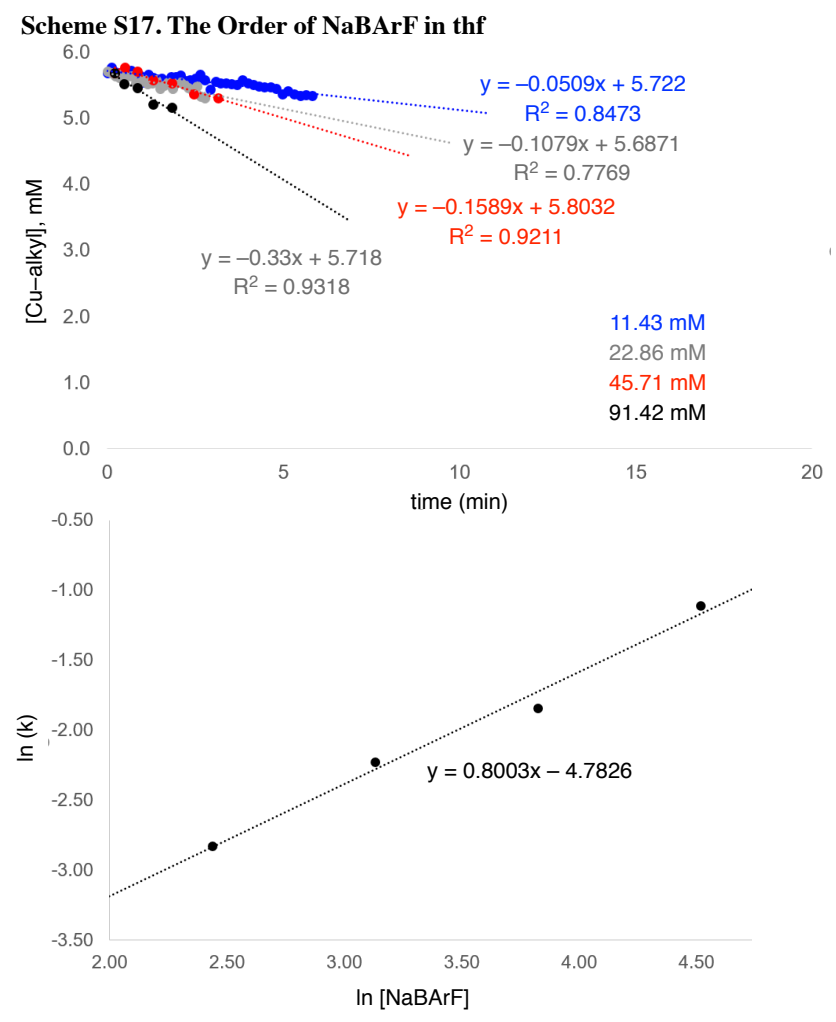


An appropriate amount of a stock solution of $\mathrm{NaBArF}(0.229 \mathrm{M}$ in thf) was added. The tube was sealed (septum and electrical tape) and reaction progress was monitored by ${ }^{19} \mathrm{~F}$ NMR within $30 \mathrm{~s}$ after the solutions were mixed. NaBArF concentrations investigated: $91.4 \mathrm{mM}, 45.7$ $\mathrm{mM}, 22.9 \mathrm{mM}$ and $11.4 \mathrm{mM}$.

\section{Studies on the Cu-F Elimination of Cu-Alkyl Complexes}

\subsection{Probing the role of a Lewis Acid on the rate of $\mathbf{C u}-\mathbf{F} \boldsymbol{\beta}$-elimination}

With NaBArF: In a $\mathrm{N}_{2}$-filled glovebox, an NMR tube was charged with a thf solution of the appropriated $\mathrm{Cu}$-based complex $(0.0057 \mathrm{mmol}$ in $0.3 \mathrm{~mL})$ and $\alpha, \alpha, \alpha$-trifluorotoluene was added as the internal standard ( $3.7 \mathrm{mg}, 0.025 \mathrm{mmol})$. The tube was sealed (septum and paraffin) and was removed from the glovebox. A solution of NaBArF (50.5 mg, 0.057, $0.3 \mathrm{~mL}$ thf) was then added by syringe and the tube was carefully shaken (manually) before being placed in a pre-shimmed spectrometer. Data were acquired by integration of an array of ${ }^{19} \mathrm{~F}$ NMR spectra (16 scans with a delay between spectra of $10 \mathrm{sec}$ ), acquired within $30 \mathrm{sec}$ after the solutions were mixed. The results of these studies are summarized in Scheme 13b in the manuscript.

\subsection{Probing the role of a Lewis base on the rate of $\mathrm{Cu}-\mathrm{F} \boldsymbol{\beta}$-Elimination}

With KOt-Bu: In a $\mathrm{N}_{2}$-filled glovebox, an NMR tube was loaded with a toluene/thf (20:1) solution of a Cu complex $(0.0057 \mathrm{mmol}$ in $0.2 \mathrm{~mL})$ and $\alpha, \alpha, \alpha$-trifluorotoluene as the internal standard (3.7 mg, $0.025 \mathrm{mmol})$. In a separate vial, a solution of $\mathrm{KO}$ - $\mathrm{Bu}(3.1 \mathrm{mg}, 0.028 \mathrm{mmol})$ was prepared in $0.4 \mathrm{~mL}$ of 20/1 toluene/thf and added by syringe. The mixture (which contains small amounts of insoluble particles) was mixed manually before being placed in pre-shimmed spectrometer. Reaction progress was monitored by ${ }^{19} \mathrm{~F}$ NMR spectroscopy. Rate constants could not be accurately determined as the reaction mixture was not homogenous. The results of these studies are summarized in Table 1 in the manuscript.

With KOt-Bu and 2,2,2-cryptand: In a $\mathrm{N}_{2}$-filled glovebox, an NMR tube was charged with a $20 / 1$ toluene/thf solution of a Cu complex $(0.0057 \mathrm{mmol}$ in $0.2 \mathrm{~mL})$ and $\alpha, \alpha, \alpha$-trifluorotoluene as the internal standard $(3.7 \mathrm{mg}, 0.025 \mathrm{mmol})$. In a separate vial, $\mathrm{KO}$ - $\mathrm{Bu}(3.1 \mathrm{mg}, 0.028 \mathrm{mmol})$ and 2,2,2-cryptand $(11.8 \mathrm{mg}, 0.031 \mathrm{mmol})$ were dissolved in $0.4 \mathrm{~mL} \mathrm{20/1}$ toluene/thf, resulting in light yellow solution, which was transferred to the NMR tube by syringe. The mixture (which contains small amounts of insoluble particles) was stirred manually before being placed in preshimmed spectrometer. Reaction progress was monitored by ${ }^{19} \mathrm{~F}$ NMR spectroscopy. The results of these studies are summarized in Table 1 in the manuscript.

With Me ${ }_{4}$ NF: In a $\mathrm{N}_{2}$-filled glovebox, an NMR tube was charged with a 20/1 toluene/thf solution a $\mathrm{Cu}$ complex $(0.0057 \mathrm{mmol}$ in $0.2 \mathrm{~mL})$ and $\alpha, \alpha, \alpha$-trifluorotoluene was added as the internal standard $(3.7 \mathrm{mg}, 0.025 \mathrm{mmol})$. A solution of $\mathrm{NMe}_{4} \mathrm{~F}(2.7 \mathrm{mg}, 0.028 \mathrm{mmol}, 0.4 \mathrm{~mL}$ $20 / 1$ toluene/thf) was added by syringe, and the mixture (conatined small amounts of insoluble particles) was stirred manually before being placed in pre-shimmed spectrometer. Reaction progress was monitored by ${ }^{19} \mathrm{~F}$ NMR spectroscopy. Rate constants could not be accurately determined as the reaction mixture was not homogenous. The results of these studies are summarized in Table 1 in the manuscript.

\section{Transmetallation of Boronates with $\mathrm{CuO} t-\mathrm{Bu}$ Complexes}

\subsection{Reactions of $10 \mathrm{a}$ with bisphosphine-CuOt-Bu and $\mathrm{NHC}-\mathrm{CuOt}$-Bu complexes}


In a $\mathrm{N}_{2}$-filled glovebox, an oven-dried 2-dram vial with a magnetic stir bar was charged with $[\mathrm{Cu}-\mathrm{Ot}-\mathrm{Bu}]_{4}(2.0 \mathrm{mg}, 0.0015 \mathrm{mmol})$ and phos-3 $(11.4 \mathrm{mg}, 0.0025 \mathrm{mmol})$. The solids were dissolved in thf $(0.4 \mathrm{~mL})$ and the solution was allowed to stir for $15 \mathrm{~min}$, after which a solution of $10 \mathrm{a}(5.0 \mathrm{mg}, 0.0015 \mathrm{mmol} .0 .2 \mathrm{~mL}$ thf) was added. The mixture was transferred to a J-young NMR tube, and reaction progress monitored by NMR spectroscopy five min after mixing.

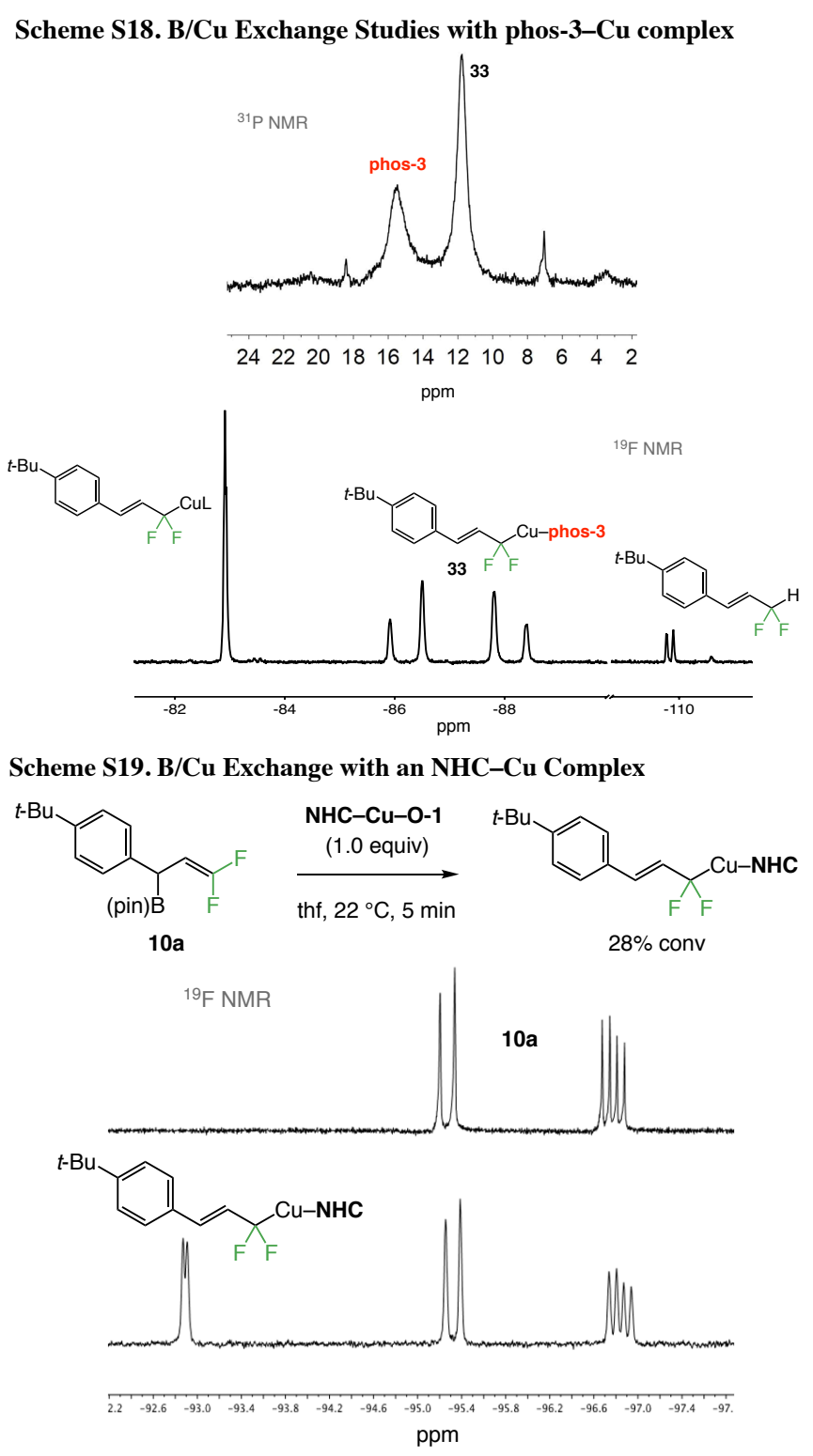

\subsection{Competition experiment between $\mathrm{NHC}-\mathrm{Cu}-\mathrm{O}-1$ and phos-3-CuOt-Bu}

In a $\mathrm{N}_{2}$-filled glovebox, an oven-dried 2-dram vial equipped with a magnetic stirring-bar was charged with $[\mathrm{Cu}-\mathrm{Ot}-\mathrm{Bu}]_{4}(2.0 \mathrm{mg}, 0.0015 \mathrm{mmol})$ and phos-3 $(11.4 \mathrm{mg}, 0.0025 \mathrm{mmol})$. The solids were dissolved in thf $(0.4 \mathrm{~mL})$ and the resulting solution was allowed to stir for $15 \mathrm{~min}$. At this time, a solution containing [1,3-bis(2,6-diisopropylphenyl)imidazol-2-ylidene]CuOt-

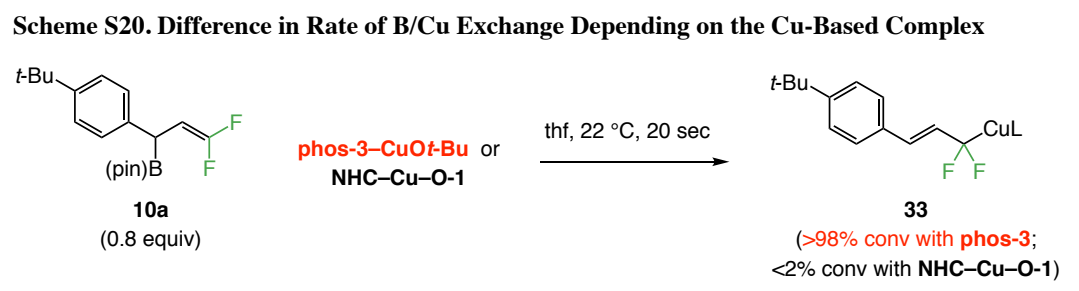


$\mathrm{Bu}$ (NHC-Cu-O-1) (4.0 mg, $0.0015 \mathrm{mmol}, 2 \mathrm{~mL}$ thf) was added and then the mixture was transferred to another vial containing $10 \mathrm{a}(4.0 \mathrm{mg}, 0.0012 \mathrm{mmol})$. The mixture was transferred to a J-young NMR tube, and reaction was analyzed by NMR spectroscopy $5 \mathrm{~min}$ after the mixing (Scheme S18). Complete conversion to $\mathbf{3 3}$ was observed, whereas signals corresponding to the reaction involving NHC-Cu-O-1 could not be detected.

\subsection{Boryl substitution with alkene 9c}

Reactions with alkene 9c were carried out according to the standard procedure (see section 6.1). Various ligands (achiral and chiral), metal alkoxides, and temperature $\left(-20,4\right.$ and $\left.22{ }^{\circ} \mathrm{C}\right)$ were tested but conversions did not reach more than $25 \%$. A mixture containing the starting material and four other compounds (see main text and spectra below) was observed in all cases, and the ratio between these compounds varied slightly depending on the condition. As expected based on the mechanistic analysis presented, the reaction with 7.0 equiv of $\mathrm{B}_{2}(\text { pin })_{2}$ and a

Scheme S21. B/Cu Exchange with the Complex Derived From NHC-Cu-O-1 (Unpurified Mixture)

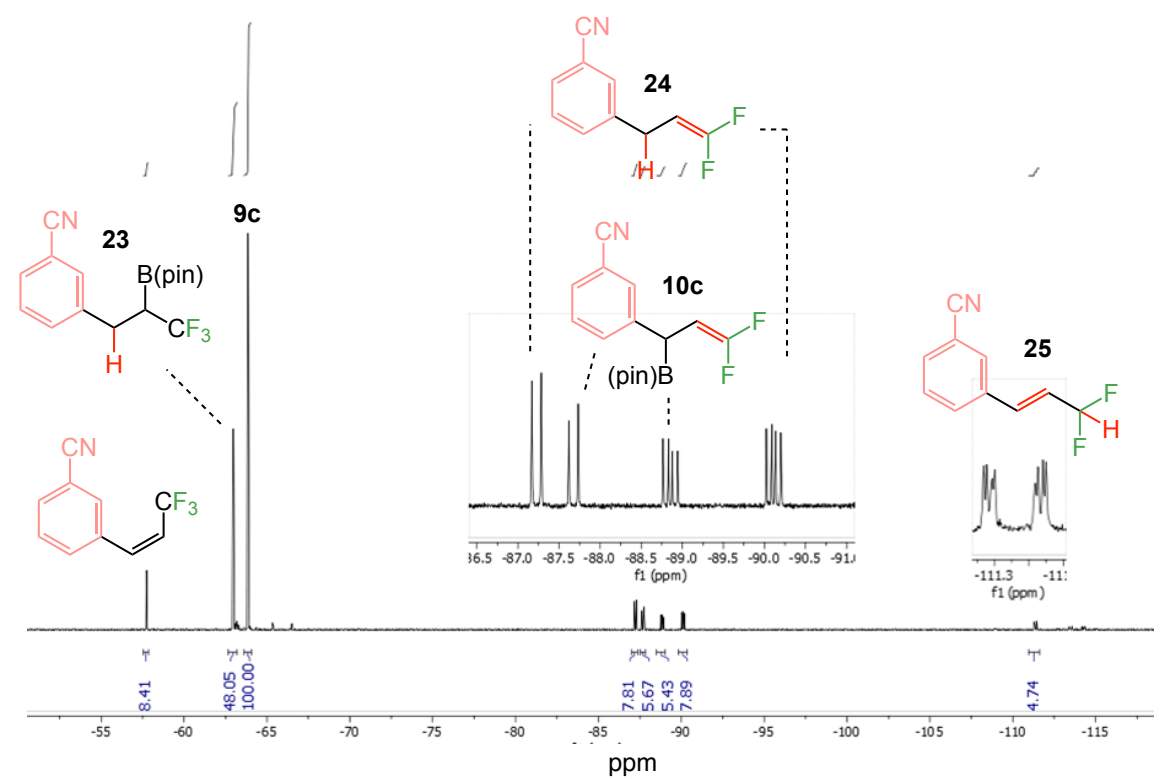

Scheme S22. B/Cu Exchange with the Complex From NHC-Cu-O-2 and Excess $\mathrm{B}_{2}(\mathrm{pin})_{2}$
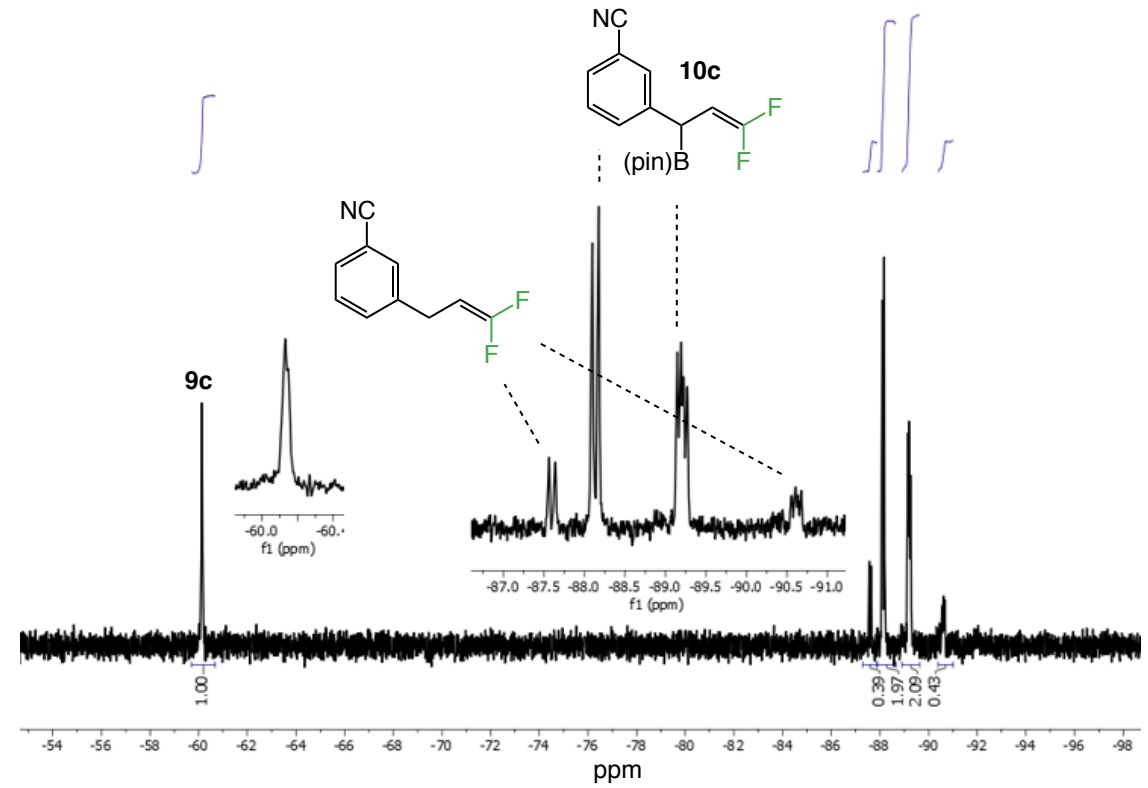
relatively bulky NHC increases conversion to desired product substantially. Excess $\mathrm{B}_{2}$ (pin) 2 favors the desired transmetallation with $\mathrm{NHC}-\mathrm{CuO} t-\mathrm{Bu}$ species (vs the undesired one involving the allyl boronate), and the bulky ligand favors the desired mode of $\mathrm{NHC}-\mathrm{CuB}$ (pin) addition to the alkene (see the discussion in section 1, part 2 the Supporting Information).

3-(3,3-Difluoro-1-(4,4,5,5-tetramethyl-1,3,2-dioxaborolan-2-yl)allyl)benzonitrile (10c): characterized as a mixture containing 23 (1:3 10c:23). Colorless oil; ${ }^{1} \mathrm{H}$ NMR $\left(\mathrm{CDCl}_{3}, 400\right.$ MHz): $\delta 7.60-7.35(\mathrm{~m}, 4 \mathrm{H}), 4.56(\mathrm{ddd}, J=24.9,10.0,2.1 \mathrm{~Hz}, 1 \mathrm{H}), 3.27(\mathrm{~d}, J=10.0 \mathrm{~Hz}, 1 \mathrm{H})$, $1.21(\mathrm{~s}, 6 \mathrm{H}), 1.21(\mathrm{~s}, 6 \mathrm{H}) .{ }^{19} \mathrm{~F}$ NMR $\left(376 \mathrm{MHz}, \mathrm{CDCl}_{3}\right): \delta-87.64(\mathrm{~d}, J=42.2 \mathrm{~Hz}),-88.82(\mathrm{dd}$, $J=42.5,24.9 \mathrm{~Hz})$.

\section{3-(3,3,3-Trifluoro-2-(4,4,5,5-tetramethyl-1,3,2-dioxaborolan-2-yl)propyl)benzonitrile}

(23): characterized as a mixture containing $10 \mathrm{c}(1: 3 \mathrm{10c}: 23)$. Colorless oil; ${ }^{1} \mathrm{H} \mathrm{NMR}\left(\mathrm{CDCl}_{3}\right.$, $400 \mathrm{MHz}$ ): $\delta$ 7.60-7.35 (m, 4H), 3.06 (dd, $J=13.8,5.4 \mathrm{~Hz}, 1 \mathrm{H}), 2.96$ (dd, $J=13.9,10.5 \mathrm{~Hz}$, $1 \mathrm{H}), 2.22$ (ddt, $J=16.7,11.4,5.9 \mathrm{~Hz}, 1 \mathrm{H}), 1.17(\mathrm{~s}, 6 \mathrm{H}), 1.13(\mathrm{~s}, 6 \mathrm{H}) ;{ }^{19} \mathrm{~F}$ NMR $(376 \mathrm{MHz}$, $\left.\mathrm{CDCl}_{3}\right): \delta-62.97(\mathrm{~d}, J=10.9 \mathrm{~Hz})$.

\subsection{Boryl substitution with alkene 9a and phos-1-CuOt-Bu complex}

This experiment is detailed in the manuscript (see Scheme 16) and were performed with 10 mol \% $\mathrm{CuCl}, 11$ mol \% phos-1, 1.1 equiv NaOMe, 1.1 equiv $\mathrm{B}_{2}$ (pin) 2 , in thf and with (or without) 2.0 equiv $\mathrm{MeOH}$.

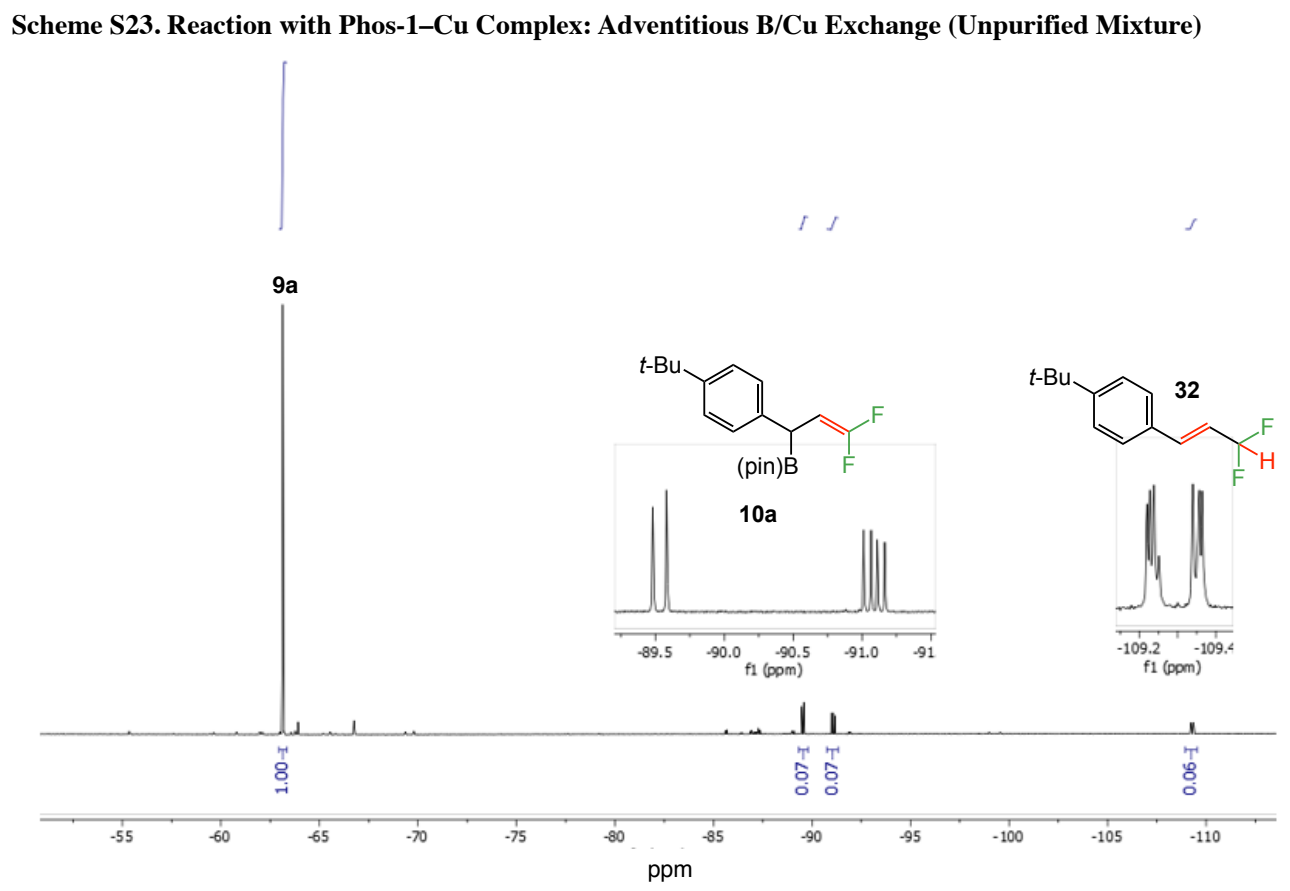

(E)-1-(tert-Butyl)-4-(3,3-difluoroprop-1-en-1-yl)benzene (32): colorless oil; $\mathrm{R}_{f}=0.58$ (petroleum ether); ${ }^{1} \mathrm{H}$ NMR $\left(\mathrm{CDCl}_{3}, 400 \mathrm{MHz}\right): \delta 7.41(\mathrm{~s}, 4 \mathrm{H}), 6.97-6.76(\mathrm{~m}, 1 \mathrm{H}), 6.25(\mathrm{td}, J$ $=64.3,5.8 \mathrm{~Hz}, 1 \mathrm{H}), 6.31-6.18(\mathrm{~m}, 1 \mathrm{H}), 1.35(\mathrm{~s}, 9 \mathrm{H}) ;{ }^{19} \mathrm{~F}$ NMR $\left(376 \mathrm{MHz}, \mathrm{CDCl}_{3}\right): \delta-109.3$ (ddd, $J=56.2,9.9,4.8 \mathrm{~Hz}, 2 \mathrm{~F}$ ). 


\section{X-ray Crystal Structures}

\subsection{Allylic boronate $12 \mathrm{~b}$}

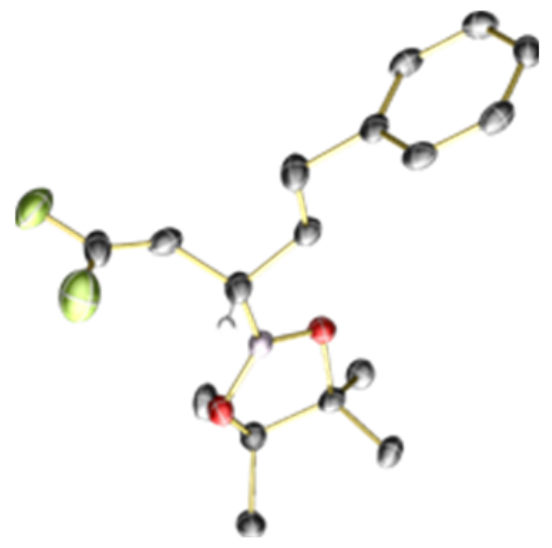

The absolute configuration of $\mathbf{1 2} \mathbf{b}$ is assigned as $(S)$. The absolute stereochemistries of other enantiomerically enriched 1,1-difluoroallyl boronates were assigned by inference. Ito and coworkers have reported the X-Ray structure for $(R)-\mathbf{1 2 b}$ and the observed parameters were nearly identical to those here. ${ }^{8}$ The specific rotation for $(R)-\mathbf{1 2 b}$ reported by Ito for $98.5: 1.5 \mathrm{er}$ sample is $[\alpha]_{\mathrm{D}}{ }^{25}+3.5\left(c 1.7, \mathrm{CHCl}_{3}\right)$, and we have measured the specific rotation for $(S)$-12b for a 92:8 er sample to be $[\alpha]_{\mathrm{D}}{ }^{20}-1.20\left(c 2.07, \mathrm{CH}_{2} \mathrm{Cl}_{2}\right)$.

Table S2. Crystal data and structure refinement for $\mathrm{C}_{17} \mathrm{H}_{23} \mathrm{BF}_{2} \mathrm{O}_{2}$

Identification code

Empirical formula

Formula weight

Temperature

Wavelength

Crystal system

Space group

Unit cell dimensions

Volume

Z

Density (calculated)

Absorption coefficient

$\mathrm{F}(000)$

Crystal size
$\mathrm{C} 17 \mathrm{H} 23 \mathrm{BF} 2 \mathrm{O} 2$

C17 H23 B F2 O2

308.16

100(2) K

$1.54178 \approx$

Triclinic

P1

$\begin{array}{ll}\mathrm{a}=8.4140(4) \approx & \alpha=102.2931(18) \infty . \\ \mathrm{b}=8.8842(4) \approx & \beta=95.7488(19) \infty . \\ \mathrm{c}=11.9257(6) \approx & \gamma=104.3562(19) \infty .\end{array}$

$832.74(7) \approx 3$

2

$1.229 \mathrm{Mg} / \mathrm{m}^{3}$

$0.766 \mathrm{~mm}^{-1}$

328

$0.420 \times 0.280 \times 0.180 \mathrm{~mm}^{3}$ 
Theta range for data collection

Index ranges

Reflections collected

Independent reflections

Completeness to theta $=67.679 \infty$

Absorption correction

Max. and min. transmission

Refinement method

Data / restraints / parameters

Goodness-of-fit on $\mathrm{F}^{2}$

Final $R$ indices $[\mathrm{I}>2 \operatorname{sigma}(\mathrm{I})]$

$\mathrm{R}$ indices (all data)

Absolute structure parameter

Extinction coefficient

Largest diff. peak and hole
5.303 to $70.308 \infty 0$

$-10<=\mathrm{h}<=10,-10<=\mathrm{k}<=10,-14<=1<=14$

11546

$5804[\mathrm{R}($ int $)=0.0350]$

$99.3 \%$

Semi-empirical from equivalents

0.7533 and 0.6486

Full-matrix least-squares on $\mathrm{F}^{2}$

$5804 / 3 / 405$

1.065

$\mathrm{R} 1=0.0556, \mathrm{wR} 2=0.1379$

$\mathrm{R} 1=0.0560, \mathrm{wR} 2=0.1384$

$-0.01(4)$

$\mathrm{n} / \mathrm{a}$

0.679 and -0.310 e. $\approx-3$

Table S3. Atomic coordinates $\left(\mathrm{x10}^{4}\right)$ and equivalent isotropic displacement parameters $\left(\AA^{2} \times 10^{3}\right)$ for $\mathrm{C}_{17} \mathrm{H}_{23} \mathrm{BF}_{2} \mathrm{O}_{2}$. U(eq) is defined as one third of the trace of the orthogonalized Uij tensor

\begin{tabular}{lcccc}
\hline & $\mathrm{x}$ & $\mathrm{y}$ & $\mathrm{z}$ & $\mathrm{U}(\mathrm{eq})$ \\
\hline $\mathrm{F}(1)$ & & & & \\
$\mathrm{F}(2)$ & $6682(3)$ & $8930(3)$ & $5449(2)$ & $41(1)$ \\
$\mathrm{O}(1)$ & $4901(3)$ & $6902(3)$ & $5704(2)$ & $45(1)$ \\
$\mathrm{O}(2)$ & $8571(3)$ & $4429(3)$ & $8153(2)$ & $23(1)$ \\
$\mathrm{B}(1)$ & $9480(3)$ & $5383(2)$ & $6621(2)$ & $22(1)$ \\
$\mathrm{C}(1)$ & $8453(4)$ & $5432(4)$ & $7437(3)$ & $22(1)$ \\
$\mathrm{C}(2)$ & $6418(4)$ & $7845(4)$ & $6065(3)$ & $28(1)$ \\
$\mathrm{C}(3)$ & $7512(4)$ & $7744(4)$ & $6892(3)$ & $24(1)$ \\
$\mathrm{C}(4)$ & $7215(4)$ & $6524(4)$ & $7589(3)$ & $24(1)$ \\
$\mathrm{C}(5)$ & $7307(4)$ & $7269(4)$ & $8894(3)$ & $24(1)$ \\
$\mathrm{C}(6)$ & $6038(4)$ & $8217(4)$ & $9164(3)$ & $28(1)$ \\
$\mathrm{C}(7)$ & $6136(4)$ & $8806(4)$ & $10460(3)$ & $25(1)$ \\
$\mathrm{C}(8)$ & $7282(4)$ & $10233(4)$ & $11094(3)$ & $26(1)$ \\
& $7384(4)$ & $10746(4)$ & $12295(3)$ & $29(1)$
\end{tabular}




\begin{tabular}{|c|c|c|c|c|}
\hline$C(9)$ & $6351(4)$ & $9830(4)$ & $12876(3)$ & $31(1)$ \\
\hline$C(10)$ & $5215(4)$ & $8412(4)$ & $12265(3)$ & $31(1)$ \\
\hline $\mathrm{C}(11)$ & $5100(4)$ & $7905(4)$ & $11062(3)$ & $28(1)$ \\
\hline$C(12)$ & $9986(4)$ & $3808(4)$ & $7902(3)$ & $22(1)$ \\
\hline$C(13)$ & $10151(4)$ & $4013(4)$ & $6651(3)$ & $22(1)$ \\
\hline$C(14)$ & $11466(4)$ & $4861(4)$ & $8812(3)$ & $26(1)$ \\
\hline$C(15)$ & $9586(4)$ & $2096(4)$ & $8021(3)$ & $28(1)$ \\
\hline$C(16)$ & 11916(4) & $4425(4)$ & $6397(3)$ & $28(1)$ \\
\hline$C(17)$ & $9054(5)$ & $2611(4)$ & $5692(3)$ & $30(1)$ \\
\hline $\mathrm{F}(3)$ & $2909(4)$ & $1352(4)$ & $4174(3)$ & $60(1)$ \\
\hline $\mathrm{F}(4)$ & $5183(3)$ & $3165(4)$ & $4924(2)$ & $56(1)$ \\
\hline $\mathrm{O}(3)$ & $1129(3)$ & $5351(3)$ & $1841(2)$ & $27(1)$ \\
\hline $\mathrm{O}(4)$ & $307(3)$ & $4596(3)$ & $3453(2)$ & $26(1)$ \\
\hline $\mathrm{B}(2)$ & $1196(4)$ & $4370(4)$ & $2567(3)$ & $24(1)$ \\
\hline$C(18)$ & $3869(5)$ & $2681(5)$ & $4086(3)$ & $38(1)$ \\
\hline$C(19)$ & $3642(4)$ & $3510(4)$ & $3315(3)$ & $32(1)$ \\
\hline$C(20)$ & $2168(4)$ & $3043(4)$ & $2380(3)$ & $29(1)$ \\
\hline$C(21)$ & $2578(4)$ & $2731(4)$ & $1144(3)$ & $26(1)$ \\
\hline $\mathrm{C}(22)$ & $3460(5)$ & $1425(5)$ & $840(3)$ & $33(1)$ \\
\hline $\mathrm{C}(23)$ & $3544(4)$ & $1007(4)$ & $-452(3)$ & $25(1)$ \\
\hline$C(24)$ & $2466(4)$ & $-383(4)$ & $-1177(3)$ & $26(1)$ \\
\hline$C(25)$ & $2478(4)$ & $-755(4)$ & $-2358(3)$ & $28(1)$ \\
\hline$C(26)$ & $3566(4)$ & $247(4)$ & $-2847(3)$ & $28(1)$ \\
\hline$C(27)$ & $4670(4)$ & $1636(4)$ & $-2133(3)$ & $30(1)$ \\
\hline$C(28)$ & $4644(4)$ & 1999(4) & $-946(3)$ & $28(1)$ \\
\hline $\mathrm{C}(29)$ & $-186(4)$ & $6119(4)$ & $2131(3)$ & $24(1)$ \\
\hline$C(30)$ & $-246(4)$ & $6032(4)$ & $3417(3)$ & $24(1)$ \\
\hline $\mathrm{C}(31)$ & $-1764(4)$ & $5086(4)$ & $1299(3)$ & $29(1)$ \\
\hline$C(32)$ & $298(5)$ & $7796(4)$ & 1936(3) & $31(1)$ \\
\hline$C(33)$ & $-1954(5)$ & $5779(5)$ & $3759(3)$ & $34(1)$ \\
\hline $\mathrm{C}(34)$ & $996(5)$ & $7426(4)$ & $4295(3)$ & $34(1)$ \\
\hline
\end{tabular}


Table S4. Bond lengths $[\AA ̊]$ and angles $[\infty]$ for $\mathrm{C}_{17} \mathrm{H}_{23} \mathrm{BF}_{2} \mathrm{O}_{2}$

\begin{tabular}{ll}
\hline $\mathrm{F}(1)-\mathrm{C}(1)$ & $1.322(4)$ \\
$\mathrm{F}(2)-\mathrm{C}(1)$ & $1.312(4)$ \\
$\mathrm{O}(1)-\mathrm{B}(1)$ & $1.372(4)$ \\
$\mathrm{O}(1)-\mathrm{C}(12)$ & $1.462(3)$ \\
$\mathrm{O}(2)-\mathrm{B}(1)$ & $1.365(4)$ \\
$\mathrm{O}(2)-\mathrm{C}(13)$ & $1.469(3)$ \\
$\mathrm{B}(1)-\mathrm{C}(3)$ & $1.589(4)$ \\
$\mathrm{C}(1)-\mathrm{C}(2)$ & $1.314(5)$ \\
$\mathrm{C}(2)-\mathrm{C}(3)$ & $1.489(4)$ \\
$\mathrm{C}(2)-\mathrm{H}(2)$ & 0.9500 \\
$\mathrm{C}(3)-\mathrm{C}(4)$ & $1.542(4)$ \\
$\mathrm{C}(3)-\mathrm{H}(3)$ & 1.0000 \\
$\mathrm{C}(4)-\mathrm{C}(5)$ & $1.534(4)$ \\
$\mathrm{C}(4)-\mathrm{H}(4 \mathrm{~A})$ & 0.9900 \\
$\mathrm{C}(4)-\mathrm{H}(4 \mathrm{~B})$ & 0.9900 \\
$\mathrm{C}(5)-\mathrm{C}(6)$ & $1.509(4)$ \\
$\mathrm{C}(5)-\mathrm{H}(5 \mathrm{~A})$ & 0.9900 \\
$\mathrm{C}(5)-\mathrm{H}(5 \mathrm{~B})$ & 0.9900 \\
$\mathrm{C}(6)-\mathrm{C}(11)$ & $1.393(5)$ \\
$\mathrm{C}(6)-\mathrm{C}(7)$ & $1.395(5)$ \\
$\mathrm{C}(7)-\mathrm{C}(8)$ & $1.394(5)$ \\
$\mathrm{C}(7)-\mathrm{H}(7)$ & 0.9500 \\
$\mathrm{C}(8)-\mathrm{C}(9)$ & $1.381(5)$ \\
$\mathrm{C}(8)-\mathrm{H}(8)$ & 0.9500 \\
$\mathrm{C}(9)-\mathrm{C}(10)$ & $1.380(5)$ \\
$\mathrm{C}(9)-\mathrm{H}(9)$ & 0.9500 \\
$\mathrm{C}(10)-\mathrm{C}(11)$ & \\
$\mathrm{C}(10)-\mathrm{H}(10)$ & \\
$\mathrm{C}(11)-\mathrm{H}(11)$ & $\mathrm{C}(15)-\mathrm{C}(14)$ \\
\end{tabular}




\begin{tabular}{|c|c|}
\hline$C(12)-C(13)$ & $1.557(4)$ \\
\hline$C(13)-C(16)$ & $1.516(5)$ \\
\hline $\mathrm{C}(13)-\mathrm{C}(17)$ & $1.524(5)$ \\
\hline $\mathrm{C}(14)-\mathrm{H}(14 \mathrm{~A})$ & 0.9800 \\
\hline $\mathrm{C}(14)-\mathrm{H}(14 \mathrm{~B})$ & 0.9800 \\
\hline $\mathrm{C}(14)-\mathrm{H}(14 \mathrm{C})$ & 0.9800 \\
\hline $\mathrm{C}(15)-\mathrm{H}(15 \mathrm{~A})$ & 0.9800 \\
\hline $\mathrm{C}(15)-\mathrm{H}(15 \mathrm{~B})$ & 0.9800 \\
\hline $\mathrm{C}(15)-\mathrm{H}(15 \mathrm{C})$ & 0.9800 \\
\hline $\mathrm{C}(16)-\mathrm{H}(16 \mathrm{~A})$ & 0.9800 \\
\hline $\mathrm{C}(16)-\mathrm{H}(16 \mathrm{~B})$ & 0.9800 \\
\hline $\mathrm{C}(16)-\mathrm{H}(16 \mathrm{C})$ & 0.9800 \\
\hline $\mathrm{C}(17)-\mathrm{H}(17 \mathrm{~A})$ & 0.9800 \\
\hline $\mathrm{C}(17)-\mathrm{H}(17 \mathrm{~B})$ & 0.9800 \\
\hline $\mathrm{C}(17)-\mathrm{H}(17 \mathrm{C})$ & 0.9800 \\
\hline $\mathrm{F}(3)-\mathrm{C}(18)$ & $1.286(6)$ \\
\hline $\mathrm{F}(4)-\mathrm{C}(18)$ & $1.329(5)$ \\
\hline $\mathrm{O}(3)-\mathrm{B}(2)$ & $1.359(4)$ \\
\hline $\mathrm{O}(3)-\mathrm{C}(29)$ & $1.470(4)$ \\
\hline $\mathrm{O}(4)-\mathrm{B}(2)$ & $1.364(4)$ \\
\hline $\mathrm{O}(4)-\mathrm{C}(30)$ & $1.469(3)$ \\
\hline $\mathrm{B}(2)-\mathrm{C}(20)$ & $1.585(4)$ \\
\hline $\mathrm{C}(18)-\mathrm{C}(19)$ & $1.322(5)$ \\
\hline$C(19)-C(20)$ & $1.491(5)$ \\
\hline C(19)-H(19) & 0.9500 \\
\hline $\mathrm{C}(20)-\mathrm{C}(21)$ & $1.531(4)$ \\
\hline $\mathrm{C}(20)-\mathrm{H}(20)$ & 1.0000 \\
\hline$C(21)-C(22)$ & $1.526(4)$ \\
\hline $\mathrm{C}(21)-\mathrm{H}(21 \mathrm{~A})$ & 0.9900 \\
\hline $\mathrm{C}(21)-\mathrm{H}(21 \mathrm{~B})$ & 0.9900 \\
\hline$C(22)-C(23)$ & $1.519(5)$ \\
\hline $\mathrm{C}(22)-\mathrm{H}(22 \mathrm{~A})$ & 0.9900 \\
\hline $\mathrm{C}(22)-\mathrm{H}(22 \mathrm{~B})$ & 0.9900 \\
\hline $\mathrm{C}(23)-\mathrm{C}(28)$ & $1.381(5)$ \\
\hline$C(23)-C(24)$ & $1.389(5)$ \\
\hline
\end{tabular}




\begin{tabular}{|c|c|}
\hline$C(24)-C(25)$ & $1.378(5)$ \\
\hline $\mathrm{C}(24)-\mathrm{H}(24)$ & 0.9500 \\
\hline$C(25)-C(26)$ & $1.376(5)$ \\
\hline $\mathrm{C}(25)-\mathrm{H}(25)$ & 0.9500 \\
\hline$C(26)-C(27)$ & $1.392(5)$ \\
\hline $\mathrm{C}(26)-\mathrm{H}(26)$ & 0.9500 \\
\hline $\mathrm{C}(27)-\mathrm{C}(28)$ & $1.387(5)$ \\
\hline $\mathrm{C}(27)-\mathrm{H}(27)$ & 0.9500 \\
\hline $\mathrm{C}(28)-\mathrm{H}(28)$ & 0.9500 \\
\hline$C(29)-C(32)$ & $1.518(5)$ \\
\hline$C(29)-C(31)$ & $1.527(5)$ \\
\hline$C(29)-C(30)$ & $1.557(4)$ \\
\hline $\mathrm{C}(30)-\mathrm{C}(33)$ & $1.510(5)$ \\
\hline$C(30)-C(34)$ & $1.520(5)$ \\
\hline $\mathrm{C}(31)-\mathrm{H}(31 \mathrm{~A})$ & 0.9800 \\
\hline $\mathrm{C}(31)-\mathrm{H}(31 \mathrm{~B})$ & 0.9800 \\
\hline $\mathrm{C}(31)-\mathrm{H}(31 \mathrm{C})$ & 0.9800 \\
\hline $\mathrm{C}(32)-\mathrm{H}(32 \mathrm{~A})$ & 0.9800 \\
\hline $\mathrm{C}(32)-\mathrm{H}(32 \mathrm{~B})$ & 0.9800 \\
\hline $\mathrm{C}(32)-\mathrm{H}(32 \mathrm{C})$ & 0.9800 \\
\hline $\mathrm{C}(33)-\mathrm{H}(33 \mathrm{~A})$ & 0.9800 \\
\hline $\mathrm{C}(33)-\mathrm{H}(33 \mathrm{~B})$ & 0.9800 \\
\hline $\mathrm{C}(33)-\mathrm{H}(33 \mathrm{C})$ & 0.9800 \\
\hline $\mathrm{C}(34)-\mathrm{H}(34 \mathrm{~A})$ & 0.9800 \\
\hline $\mathrm{C}(34)-\mathrm{H}(34 \mathrm{~B})$ & 0.9800 \\
\hline $\mathrm{C}(34)-\mathrm{H}(34 \mathrm{C})$ & 0.9800 \\
\hline $\mathrm{B}(1)-\mathrm{O}(1)-\mathrm{C}(12)$ & $106.7(2)$ \\
\hline $\mathrm{B}(1)-\mathrm{O}(2)-\mathrm{C}(13)$ & $106.6(2)$ \\
\hline $\mathrm{O}(2)-\mathrm{B}(1)-\mathrm{O}(1)$ & $113.7(3)$ \\
\hline $\mathrm{O}(2)-\mathrm{B}(1)-\mathrm{C}(3)$ & $125.3(3)$ \\
\hline $\mathrm{O}(1)-\mathrm{B}(1)-\mathrm{C}(3)$ & $121.0(3)$ \\
\hline $\mathrm{F}(2)-\mathrm{C}(1)-\mathrm{C}(2)$ & $126.6(3)$ \\
\hline $\mathrm{F}(2)-\mathrm{C}(1)-\mathrm{F}(1)$ & $108.5(3)$ \\
\hline$C(2)-C(1)-F(1)$ & $124.9(3)$ \\
\hline$C(1)-C(2)-C(3)$ & $124.9(3)$ \\
\hline
\end{tabular}




$\begin{array}{ll}\mathrm{C}(1)-\mathrm{C}(2)-\mathrm{H}(2) & 117.5 \\ \mathrm{C}(3)-\mathrm{C}(2)-\mathrm{H}(2) & 117.5 \\ \mathrm{C}(2)-\mathrm{C}(3)-\mathrm{C}(4) & 112.9(3) \\ \mathrm{C}(2)-\mathrm{C}(3)-\mathrm{B}(1) & 112.3(3) \\ \mathrm{C}(4)-\mathrm{C}(3)-\mathrm{B}(1) & 109.3(2) \\ \mathrm{C}(2)-\mathrm{C}(3)-\mathrm{H}(3) & 107.4 \\ \mathrm{C}(4)-\mathrm{C}(3)-\mathrm{H}(3) & 107.4 \\ \mathrm{~B}(1)-\mathrm{C}(3)-\mathrm{H}(3) & 107.4 \\ \mathrm{C}(5)-\mathrm{C}(4)-\mathrm{C}(3) & 114.3(2) \\ \mathrm{C}(5)-\mathrm{C}(4)-\mathrm{H}(4 \mathrm{~A}) & 108.7 \\ \mathrm{C}(3)-\mathrm{C}(4)-\mathrm{H}(4 \mathrm{~A}) & 108.7 \\ \mathrm{C}(5)-\mathrm{C}(4)-\mathrm{H}(4 \mathrm{~B}) & 108.7 \\ \mathrm{C}(3)-\mathrm{C}(4)-\mathrm{H}(4 \mathrm{~B}) & 108.7 \\ \mathrm{H}(4 \mathrm{~A})-\mathrm{C}(4)-\mathrm{H}(4 \mathrm{~B}) & 107.6 \\ \mathrm{C}(6)-\mathrm{C}(5)-\mathrm{C}(4) & 110.8(2) \\ \mathrm{C}(6)-\mathrm{C}(5)-\mathrm{H}(5 \mathrm{~A}) & 109.5 \\ \mathrm{C}(4)-\mathrm{C}(5)-\mathrm{H}(5 \mathrm{~A}) & 109.5 \\ \mathrm{C}(6)-\mathrm{C}(5)-\mathrm{H}(5 \mathrm{~B}) & 109.5 \\ \mathrm{C}(4)-\mathrm{C}(5)-\mathrm{H}(5 \mathrm{~B}) & 109.5 \\ \mathrm{H}(5 \mathrm{~A})-\mathrm{C}(5)-\mathrm{H}(5 \mathrm{~B}) & 108.1 \\ \mathrm{C}(11)-\mathrm{C}(6)-\mathrm{C}(7) & 118.1(3) \\ \mathrm{C}(11)-\mathrm{C}(6)-\mathrm{C}(5) & 120.3(3) \\ \mathrm{C}(7)-\mathrm{C}(6)-\mathrm{C}(5) & 121.6(3) \\ \mathrm{C}(8)-\mathrm{C}(7)-\mathrm{C}(6) & 121.0(3) \\ \mathrm{C}(8)-\mathrm{C}(7)-\mathrm{H}(7) & 119.5 \\ \mathrm{C}(6)-\mathrm{C}(7)-\mathrm{H}(7) & 119.5 \\ \mathrm{C}(9)-\mathrm{C}(8)-\mathrm{C}(7) & 120.0(3) \\ \mathrm{C}(9)-\mathrm{C}(8)-\mathrm{H}(8) & 120.0 \\ \mathrm{C}(7)-\mathrm{C}(8)-\mathrm{H}(8) & 120.0 \\ \mathrm{C}(10)-\mathrm{C}(9)-\mathrm{C}(8) & 119.9(3) \\ \mathrm{C}(10)-\mathrm{C}(9)-\mathrm{H}(9) & 120.1 \\ \mathrm{C}(8)-\mathrm{C}(9)-\mathrm{H}(9) & 120.1 \\ & 120.2(3) \\ \mathrm{C}(10)-\mathrm{H}(10) & 119.9 \\ & \end{array}$




\begin{tabular}{ll}
$\mathrm{C}(6)-\mathrm{C}(11)-\mathrm{C}(10)$ & $120.8(3)$ \\
$\mathrm{C}(6)-\mathrm{C}(11)-\mathrm{H}(11)$ & 119.6 \\
$\mathrm{C}(10)-\mathrm{C}(11)-\mathrm{H}(11)$ & 119.6 \\
$\mathrm{O}(1)-\mathrm{C}(12)-\mathrm{C}(15)$ & $108.2(3)$ \\
$\mathrm{O}(1)-\mathrm{C}(12)-\mathrm{C}(14)$ & $106.4(2)$ \\
$\mathrm{C}(15)-\mathrm{C}(12)-\mathrm{C}(14)$ & $110.3(3)$ \\
$\mathrm{O}(1)-\mathrm{C}(12)-\mathrm{C}(13)$ & $102.5(2)$ \\
$\mathrm{C}(15)-\mathrm{C}(12)-\mathrm{C}(13)$ & $115.3(3)$ \\
$\mathrm{C}(14)-\mathrm{C}(12)-\mathrm{C}(13)$ & $113.3(3)$ \\
$\mathrm{O}(2)-\mathrm{C}(13)-\mathrm{C}(16)$ & $108.6(3)$ \\
$\mathrm{O}(2)-\mathrm{C}(13)-\mathrm{C}(17)$ & $106.4(2)$ \\
$\mathrm{C}(16)-\mathrm{C}(13)-\mathrm{C}(17)$ & $109.9(3)$ \\
$\mathrm{O}(2)-\mathrm{C}(13)-\mathrm{C}(12)$ & $102.2(2)$ \\
$\mathrm{C}(16)-\mathrm{C}(13)-\mathrm{C}(12)$ & $115.0(3)$ \\
$\mathrm{C}(17)-\mathrm{C}(13)-\mathrm{C}(12)$ & $113.9(3)$ \\
$\mathrm{C}(12)-\mathrm{C}(14)-\mathrm{H}(14 \mathrm{~A})$ & 109.5 \\
$\mathrm{C}(12)-\mathrm{C}(14)-\mathrm{H}(14 \mathrm{~B})$ & 109.5 \\
$\mathrm{H}(14 \mathrm{~A})-\mathrm{C}(14)-\mathrm{H}(14 \mathrm{~B})$ & 109.5 \\
$\mathrm{C}(12)-\mathrm{C}(14)-\mathrm{H}(14 \mathrm{C})$ & 109.5 \\
$\mathrm{H}(14 \mathrm{~A})-\mathrm{C}(14)-\mathrm{H}(14 \mathrm{C})$ & 109.5 \\
$\mathrm{H}(14 \mathrm{~B})-\mathrm{C}(14)-\mathrm{H}(14 \mathrm{C})$ & 109.5 \\
$\mathrm{C}(12)-\mathrm{C}(15)-\mathrm{H}(15 \mathrm{~A})$ & 109.5 \\
$\mathrm{C}(12)-\mathrm{C}(15)-\mathrm{H}(15 \mathrm{~B})$ & 109.5 \\
$\mathrm{H}(15 \mathrm{~A})-\mathrm{C}(15)-\mathrm{H}(15 \mathrm{~B})$ & 109.5 \\
$\mathrm{C}(12)-\mathrm{C}(15)-\mathrm{H}(15 \mathrm{C})$ & 109.5 \\
$\mathrm{H}(15 \mathrm{~A})-\mathrm{C}(15)-\mathrm{H}(15 \mathrm{C})$ & 109.5 \\
$\mathrm{H}(15 \mathrm{~B})-\mathrm{C}(15)-\mathrm{H}(15 \mathrm{C})$ & 109.5 \\
$\mathrm{C}(13)-\mathrm{C}(16)-\mathrm{H}(16 \mathrm{~A})$ & 109.5 \\
$\mathrm{C}(13)-\mathrm{C}(16)-\mathrm{H}(16 \mathrm{~B})$ & 109.5 \\
$\mathrm{H}(16 \mathrm{~A})-\mathrm{C}(16)-\mathrm{H}(16 \mathrm{~B})$ & 109.5 \\
$\mathrm{C}(13)-\mathrm{C}(16)-\mathrm{H}(16 \mathrm{C})$ & 109.5 \\
$\mathrm{H}(16)-\mathrm{H}(16 \mathrm{C})$ & 109.5 \\
$\mathrm{H}(16 \mathrm{C})$ & 109.5 \\
$\mathrm{H}(17 \mathrm{~B})$ & 109.5 \\
\hline
\end{tabular}




$\begin{array}{ll}\mathrm{H}(17 \mathrm{~A})-\mathrm{C}(17)-\mathrm{H}(17 \mathrm{~B}) & 109.5 \\ \mathrm{C}(13)-\mathrm{C}(17)-\mathrm{H}(17 \mathrm{C}) & 109.5 \\ \mathrm{H}(17 \mathrm{~A})-\mathrm{C}(17)-\mathrm{H}(17 \mathrm{C}) & 109.5 \\ \mathrm{H}(17 \mathrm{~B})-\mathrm{C}(17)-\mathrm{H}(17 \mathrm{C}) & 109.5 \\ \mathrm{~B}(2)-\mathrm{O}(3)-\mathrm{C}(29) & 106.7(2) \\ \mathrm{B}(2)-\mathrm{O}(4)-\mathrm{C}(30) & 106.8(2) \\ \mathrm{O}(3)-\mathrm{B}(2)-\mathrm{O}(4) & 113.9(3) \\ \mathrm{O}(3)-\mathrm{B}(2)-\mathrm{C}(20) & 123.2(3) \\ \mathrm{O}(4)-\mathrm{B}(2)-\mathrm{C}(20) & 122.9(3) \\ \mathrm{F}(3)-\mathrm{C}(18)-\mathrm{C}(19) & 127.8(4) \\ \mathrm{F}(3)-\mathrm{C}(18)-\mathrm{F}(4) & 109.6(3) \\ \mathrm{C}(19)-\mathrm{C}(18)-\mathrm{F}(4) & 122.6(4) \\ \mathrm{C}(18)-\mathrm{C}(19)-\mathrm{C}(20) & 124.7(4) \\ \mathrm{C}(18)-\mathrm{C}(19)-\mathrm{H}(19) & 117.7 \\ \mathrm{C}(20)-\mathrm{C}(19)-\mathrm{H}(19) & 117.7 \\ \mathrm{C}(19)-\mathrm{C}(20)-\mathrm{C}(21) & 114.3(3) \\ \mathrm{C}(19)-\mathrm{C}(20)-\mathrm{B}(2) & 109.5(3) \\ \mathrm{C}(21)-\mathrm{C}(20)-\mathrm{B}(2) & 110.3(2) \\ \mathrm{C}(19)-\mathrm{C}(20)-\mathrm{H}(20) & 107.5 \\ \mathrm{C}(21)-\mathrm{C}(20)-\mathrm{H}(20) & 107.5 \\ \mathrm{~B}(2)-\mathrm{C}(20)-\mathrm{H}(20) & 107.5 \\ \mathrm{C}(22)-\mathrm{C}(21)-\mathrm{C}(20) & 115.3(3) \\ \mathrm{C}(22)-\mathrm{C}(21)-\mathrm{H}(21 \mathrm{~A}) & 108.5 \\ \mathrm{C}(20)-\mathrm{C}(21)-\mathrm{H}(21 \mathrm{~A}) & 108.5 \\ \mathrm{C}(22)-\mathrm{C}(21)-\mathrm{H}(21 \mathrm{~B}) & 108.5 \\ \mathrm{C}(20)-\mathrm{C}(21)-\mathrm{H}(21 \mathrm{~B}) & 108.5 \\ \mathrm{H}(21 \mathrm{~A})-\mathrm{C}(21)-\mathrm{H}(21 \mathrm{~B}) & 107.5 \\ \mathrm{C}(23)-\mathrm{C}(22)-\mathrm{C}(21) & 111.2(3) \\ \mathrm{C}(23)-\mathrm{C}(22)-\mathrm{H}(22 \mathrm{~A}) & 109.4 \\ \mathrm{C}(21)-\mathrm{C}(22)-\mathrm{H}(22 \mathrm{~A}) & 109.4 \\ \mathrm{C}(23)-\mathrm{C}(22)-\mathrm{H}(22 \mathrm{~B}) & 109.4 \\ \mathrm{C}(21)-\mathrm{C}(22)-\mathrm{H}(22 \mathrm{~B}) & 109.4 \\ & 108.0 \\ \mathrm{H}(23)-\mathrm{H}(22 \mathrm{~B})-\mathrm{C}(22) & 118.1(3) \\ & \\ \mathrm{H}(2) .8(3)\end{array}$




$\begin{array}{ll}\mathrm{C}(24)-\mathrm{C}(23)-\mathrm{C}(22) & 120.1(3) \\ \mathrm{C}(25)-\mathrm{C}(24)-\mathrm{C}(23) & 121.1(3) \\ \mathrm{C}(25)-\mathrm{C}(24)-\mathrm{H}(24) & 119.5 \\ \mathrm{C}(23)-\mathrm{C}(24)-\mathrm{H}(24) & 119.5 \\ \mathrm{C}(26)-\mathrm{C}(25)-\mathrm{C}(24) & 120.6(3) \\ \mathrm{C}(26)-\mathrm{C}(25)-\mathrm{H}(25) & 119.7 \\ \mathrm{C}(24)-\mathrm{C}(25)-\mathrm{H}(25) & 119.7 \\ \mathrm{C}(25)-\mathrm{C}(26)-\mathrm{C}(27) & 119.3(3) \\ \mathrm{C}(25)-\mathrm{C}(26)-\mathrm{H}(26) & 120.4 \\ \mathrm{C}(27)-\mathrm{C}(26)-\mathrm{H}(26) & 120.4 \\ \mathrm{C}(28)-\mathrm{C}(27)-\mathrm{C}(26) & 119.6(3) \\ \mathrm{C}(28)-\mathrm{C}(27)-\mathrm{H}(27) & 120.2 \\ \mathrm{C}(26)-\mathrm{C}(27)-\mathrm{H}(27) & 120.2 \\ \mathrm{C}(23)-\mathrm{C}(28)-\mathrm{C}(27) & 121.4(3) \\ \mathrm{C}(23)-\mathrm{C}(28)-\mathrm{H}(28) & 119.3 \\ \mathrm{C}(27)-\mathrm{C}(28)-\mathrm{H}(28) & 119.3 \\ \mathrm{O}(3)-\mathrm{C}(29)-\mathrm{C}(32) & 108.6(3) \\ \mathrm{O}(3)-\mathrm{C}(29)-\mathrm{C}(31) & 106.0(2) \\ \mathrm{C}(32)-\mathrm{C}(29)-\mathrm{C}(31) & 110.6(3) \\ \mathrm{O}(3)-\mathrm{C}(29)-\mathrm{C}(30) & 102.0(2) \\ \mathrm{C}(32)-\mathrm{C}(29)-\mathrm{C}(30) & 115.5(3) \\ \mathrm{C}(31)-\mathrm{C}(29)-\mathrm{C}(30) & 113.2(3) \\ \mathrm{O}(4)-\mathrm{C}(30)-\mathrm{C}(33) & 108.2(3) \\ \mathrm{O}(4)-\mathrm{C}(30)-\mathrm{C}(34) & 106.7(3) \\ \mathrm{C}(33)-\mathrm{C}(30)-\mathrm{C}(34) & 110.5(3) \\ \mathrm{O}(4)-\mathrm{C}(30)-\mathrm{C}(29) & 102.2(2) \\ \mathrm{C}(33)-\mathrm{C}(30)-\mathrm{C}(29) & 114.9(3) \\ \mathrm{C}(34)-\mathrm{C}(30)-\mathrm{C}(29) & 113.7(3) \\ \mathrm{C}(29)-\mathrm{C}(31)-\mathrm{H}(31 \mathrm{~A}) & 109.5 \\ \mathrm{C}(29)-\mathrm{C}(31)-\mathrm{H}(31 \mathrm{~B}) & 109.5 \\ \mathrm{H}(31 \mathrm{~A})-\mathrm{C}(31)-\mathrm{H}(31 \mathrm{~B}) & 109.5 \\ \mathrm{C}(29)-\mathrm{C}(31)-\mathrm{H}(31 \mathrm{C}) & 109.5 \\ & 109.5 \\ \mathrm{H}(32)-\mathrm{H}(32 \mathrm{~A}) & 109.5 \\ & \end{array}$




$\begin{array}{ll}\text { C(29)-C(32)-H(32B) } & 109.5 \\ \text { H(32A)-C(32)-H(32B) } & 109.5 \\ \text { C(29)-C(32)-H(32C) } & 109.5 \\ \text { H(32A)-C(32)-H(32C) } & 109.5 \\ \text { H(32B)-C(32)-H(32C) } & 109.5 \\ \text { C(30)-C(33)-H(33A) } & 109.5 \\ \text { C(30)-C(33)-H(33B) } & 109.5 \\ \text { H(33A)-C(33)-H(33B) } & 109.5 \\ \text { C(30)-C(33)-H(33C) } & 109.5 \\ \text { H(33A)-C(33)-H(33C) } & 109.5 \\ \text { H(33B)-C(33)-H(33C) } & 109.5 \\ \text { C(30)-C(34)-H(34A) } & 109.5 \\ \text { C(30)-C(34)-H(34B) } & 109.5 \\ \text { H(34A)-C(34)-H(34B) } & 109.5 \\ \text { C(30)-C(34)-H(34C) } & 109.5 \\ \text { H(34A)-C(34)-H(34C) } & 109.5 \\ \text { H(34B)-C(34)-H(34C) } & 109.5\end{array}$

Table S5. Anisotropic displacement parameters $\left(\AA^{2} \times 10^{3}\right)$ for $\mathrm{C}_{17} \mathrm{H}_{23} \mathrm{BF}_{2} \mathrm{O}_{2}$. The anisotropic displacement factor exponent takes the form: $-2 \pi^{2}\left[h^{2} a^{* 2} U^{11}+\ldots+2 h \mathbf{k} a^{*} b^{*}\right.$ $U^{12}$ ]

\begin{tabular}{lcccccc}
\hline & $\mathrm{U}^{11}$ & $\mathrm{U}^{22}$ & $\mathrm{U}^{33}$ & $\mathrm{U}^{23}$ & $\mathrm{U}^{13}$ & $\mathrm{U}^{12}$ \\
\hline $\mathrm{F}(1)$ & $51(1)$ & $40(1)$ & $42(1)$ & $19(1)$ & $10(1)$ & $20(1)$ \\
$\mathrm{F}(2)$ & $34(1)$ & $44(1)$ & $54(1)$ & $19(1)$ & $-9(1)$ & $6(1)$ \\
$\mathrm{O}(1)$ & $21(1)$ & $28(1)$ & $25(1)$ & $9(1)$ & $6(1)$ & $14(1)$ \\
$\mathrm{O}(2)$ & $23(1)$ & $24(1)$ & $23(1)$ & $7(1)$ & $4(1)$ & $12(1)$ \\
$\mathrm{B}(1)$ & $22(2)$ & $23(2)$ & $20(2)$ & $3(1)$ & $1(1)$ & $10(1)$ \\
$\mathrm{C}(1)$ & $31(2)$ & $34(2)$ & $26(2)$ & $8(1)$ & $5(1)$ & $17(2)$ \\
$\mathrm{C}(2)$ & $22(2)$ & $24(1)$ & $29(2)$ & $6(1)$ & $6(1)$ & $11(1)$ \\
$\mathrm{C}(3)$ & $23(2)$ & $30(2)$ & $23(2)$ & $7(1)$ & $2(1)$ & $14(1)$ \\
$\mathrm{C}(4)$ & $24(2)$ & $28(2)$ & $24(2)$ & $6(1)$ & $3(1)$ & $16(1)$ \\
$\mathrm{C}(5)$ & $27(2)$ & $36(2)$ & $26(2)$ & $6(1)$ & $2(1)$ & $20(2)$
\end{tabular}




\begin{tabular}{|c|c|c|c|c|c|c|}
\hline$C(6)$ & $22(2)$ & $30(2)$ & $27(2)$ & $5(1)$ & $1(1)$ & $19(1)$ \\
\hline$C(7)$ & $25(2)$ & $28(2)$ & $32(2)$ & $10(1)$ & $8(1)$ & $15(1)$ \\
\hline$C(8)$ & $24(2)$ & $29(2)$ & $33(2)$ & $2(1)$ & $-2(1)$ & $12(1)$ \\
\hline$C(9)$ & $33(2)$ & $38(2)$ & $26(2)$ & $5(1)$ & $1(1)$ & $21(2)$ \\
\hline$C(10)$ & $28(2)$ & $38(2)$ & $34(2)$ & $14(2)$ & $9(1)$ & $14(2)$ \\
\hline $\mathrm{C}(11)$ & $22(2)$ & $29(2)$ & $33(2)$ & $4(1)$ & $0(1)$ & $10(1)$ \\
\hline$C(12)$ & $20(2)$ & $25(2)$ & $24(2)$ & $6(1)$ & $4(1)$ & $12(1)$ \\
\hline$C(13)$ & $21(2)$ & $26(2)$ & $24(2)$ & $5(1)$ & $4(1)$ & $15(1)$ \\
\hline$C(14)$ & $24(2)$ & $30(2)$ & $24(2)$ & $6(1)$ & $0(1)$ & $12(1)$ \\
\hline$C(15)$ & $29(2)$ & $26(2)$ & $31(2)$ & $7(1)$ & $3(1)$ & $12(1)$ \\
\hline$C(16)$ & $25(2)$ & $39(2)$ & $28(2)$ & $12(1)$ & $10(1)$ & $15(1)$ \\
\hline$C(17)$ & $32(2)$ & $30(2)$ & $26(2)$ & $2(1)$ & $1(1)$ & $14(1)$ \\
\hline $\mathrm{F}(3)$ & $67(2)$ & $54(2)$ & $60(2)$ & $18(1)$ & $0(1)$ & $18(1)$ \\
\hline $\mathrm{F}(4)$ & $44(1)$ & $76(2)$ & $50(1)$ & $8(1)$ & $-4(1)$ & $32(1)$ \\
\hline $\mathrm{O}(3)$ & $26(1)$ & $36(1)$ & $27(1)$ & $10(1)$ & $10(1)$ & $19(1)$ \\
\hline $\mathrm{O}(4)$ & $31(1)$ & $31(1)$ & $25(1)$ & $11(1)$ & $8(1)$ & $19(1)$ \\
\hline $\mathrm{B}(2)$ & $21(2)$ & $30(2)$ & $22(2)$ & $5(1)$ & $2(1)$ & $12(2)$ \\
\hline$C(18)$ & $47(2)$ & $55(2)$ & $26(2)$ & $13(2)$ & $9(2)$ & $35(2)$ \\
\hline$C(19)$ & $23(2)$ & $37(2)$ & $36(2)$ & $4(1)$ & $3(1)$ & $12(1)$ \\
\hline $\mathrm{C}(20)$ & $34(2)$ & $36(2)$ & $27(2)$ & $12(1)$ & $6(1)$ & $24(2)$ \\
\hline$C(21)$ & $24(2)$ & $31(2)$ & $26(2)$ & $6(1)$ & $2(1)$ & $15(1)$ \\
\hline$C(22)$ & $42(2)$ & $41(2)$ & $26(2)$ & $7(1)$ & $5(1)$ & $29(2)$ \\
\hline$C(23)$ & $24(2)$ & $31(2)$ & $25(2)$ & $6(1)$ & $3(1)$ & $20(1)$ \\
\hline$C(24)$ & $21(2)$ & $27(2)$ & $37(2)$ & $12(1)$ & $7(1)$ & $14(1)$ \\
\hline$C(25)$ & $22(2)$ & $25(2)$ & $34(2)$ & $1(1)$ & $-2(1)$ & 11(1) \\
\hline$C(26)$ & $30(2)$ & $37(2)$ & $22(2)$ & $5(1)$ & $5(1)$ & $19(2)$ \\
\hline $\mathrm{C}(27)$ & $23(2)$ & $33(2)$ & $39(2)$ & $12(1)$ & $10(1)$ & $10(1)$ \\
\hline $\mathrm{C}(28)$ & $19(2)$ & $26(2)$ & $36(2)$ & $0(1)$ & $-2(1)$ & $7(1)$ \\
\hline$C(29)$ & $20(2)$ & $29(2)$ & $27(2)$ & $5(1)$ & $4(1)$ & $15(1)$ \\
\hline $\mathrm{C}(30)$ & $27(2)$ & $26(2)$ & $26(2)$ & $7(1)$ & $5(1)$ & $16(1)$ \\
\hline$C(31)$ & $27(2)$ & $33(2)$ & $28(2)$ & $5(1)$ & $-3(1)$ & $13(1)$ \\
\hline$C(32)$ & $32(2)$ & $32(2)$ & $35(2)$ & $14(1)$ & $5(1)$ & $16(2)$ \\
\hline$C(33)$ & $31(2)$ & $48(2)$ & $32(2)$ & $14(2)$ & $12(1)$ & $23(2)$ \\
\hline$C(34)$ & $41(2)$ & $33(2)$ & $24(2)$ & $1(1)$ & $-3(1)$ & $14(2)$ \\
\hline
\end{tabular}


Table S6. Hydrogen coordinates $\left(\mathrm{x}^{10^{4}}\right)$ and isotropic displacement parameters $\left(\AA^{2} \times 10^{3}\right)$ for $\mathrm{C}_{17} \mathrm{H}_{23} \mathrm{BF}_{2} \mathrm{O}_{2}$

\begin{tabular}{|c|c|c|c|c|}
\hline & $\mathrm{x}$ & $\mathrm{y}$ & $\mathrm{z}$ & $\mathrm{U}(\mathrm{eq})$ \\
\hline $\mathrm{H}(2)$ & 8573 & 8506 & 7058 & 29 \\
\hline $\mathrm{H}(3)$ & 6063 & 5806 & 7293 & 29 \\
\hline $\mathrm{H}(4 \mathrm{~A})$ & 7133 & 6400 & 9307 & 29 \\
\hline $\mathrm{H}(4 \mathrm{~B})$ & 8438 & 7992 & 9204 & 29 \\
\hline $\mathrm{H}(5 \mathrm{~A})$ & 6258 & 9143 & 8809 & 34 \\
\hline $\mathrm{H}(5 \mathrm{~B})$ & 4904 & 7523 & 8821 & 34 \\
\hline $\mathrm{H}(7)$ & 8003 & 10864 & 10701 & 31 \\
\hline $\mathrm{H}(8)$ & 8163 & 11725 & 12713 & 35 \\
\hline $\mathrm{H}(9)$ & 6423 & 10176 & 13695 & 37 \\
\hline $\mathrm{H}(10)$ & 4508 & 7779 & 12665 & 37 \\
\hline $\mathrm{H}(11)$ & 4305 & 6933 & 10649 & 34 \\
\hline $\mathrm{H}(14 \mathrm{~A})$ & 11723 & 5961 & 8719 & 38 \\
\hline $\mathrm{H}(14 \mathrm{~B})$ & 12433 & 4447 & 8712 & 38 \\
\hline $\mathrm{H}(14 \mathrm{C})$ & 11195 & 4853 & 9592 & 38 \\
\hline $\mathrm{H}(15 \mathrm{~A})$ & 9443 & 2081 & 8824 & 42 \\
\hline $\mathrm{H}(15 \mathrm{~B})$ & 10498 & 1640 & 7821 & 42 \\
\hline $\mathrm{H}(15 \mathrm{C})$ & 8557 & 1459 & 7495 & 42 \\
\hline $\mathrm{H}(16 \mathrm{~A})$ & 11900 & 4487 & 5586 & 43 \\
\hline $\mathrm{H}(16 \mathrm{~B})$ & 12437 & 3592 & 6530 & 43 \\
\hline $\mathrm{H}(16 \mathrm{C})$ & 12553 & 5460 & 6913 & 43 \\
\hline $\mathrm{H}(17 \mathrm{~A})$ & 7910 & 2367 & 5852 & 44 \\
\hline $\mathrm{H}(17 \mathrm{~B})$ & 9470 & 1669 & 5664 & 44 \\
\hline $\mathrm{H}(17 \mathrm{C})$ & 9075 & 2896 & 4942 & 44 \\
\hline $\mathrm{H}(19)$ & 4477 & 4472 & 3359 & 39 \\
\hline $\mathrm{H}(20)$ & 1408 & 2026 & 2464 & 35 \\
\hline $\mathrm{H}(21 \mathrm{~A})$ & 1530 & 2433 & 588 & 31 \\
\hline $\mathrm{H}(21 \mathrm{~B})$ & 3287 & 3743 & 1035 & 31 \\
\hline $\mathrm{H}(22 \mathrm{~A})$ & 4600 & 1798 & 1288 & 40 \\
\hline $\mathrm{H}(22 \mathrm{~B})$ & 2857 & 454 & 1063 & 40 \\
\hline
\end{tabular}




\begin{tabular}{lrrrr}
$\mathrm{H}(24)$ & 1707 & -1088 & -854 & 32 \\
$\mathrm{H}(25)$ & 1730 & -1711 & -2839 & 34 \\
$\mathrm{H}(26)$ & 3562 & -7 & -3662 & 34 \\
$\mathrm{H}(27)$ & 5437 & 2333 & -2457 & 36 \\
$\mathrm{H}(28)$ & 5400 & 2949 & -463 & 34 \\
$\mathrm{H}(31 \mathrm{~A})$ & -1578 & 5028 & 495 & 44 \\
$\mathrm{H}(31 \mathrm{~B})$ & -2680 & 5562 & 1442 & 44 \\
$\mathrm{H}(31 \mathrm{C})$ & -2045 & 4004 & 1428 & 44 \\
$\mathrm{H}(32 \mathrm{~A})$ & 1373 & 8405 & 2416 & 46 \\
$\mathrm{H}(32 \mathrm{~B})$ & -549 & 8338 & 2153 & 46 \\
$\mathrm{H}(32 \mathrm{C})$ & 382 & 7728 & 1114 & 46 \\
$\mathrm{H}(33 \mathrm{~A})$ & -2694 & 4772 & 3267 & 50 \\
$\mathrm{H}(33 \mathrm{~B})$ & -2397 & 6671 & 3658 & 50 \\
$\mathrm{H}(33 \mathrm{C})$ & -1879 & 5730 & 4575 & 50 \\
$\mathrm{H}(34 \mathrm{~A})$ & 1091 & 7174 & 5055 & 50 \\
$\mathrm{H}(34 \mathrm{~B})$ & 614 & 8393 & 4356 & 50 \\
$\mathrm{H}(34 \mathrm{C})$ & 2084 & 7611 & 4039 & 50 \\
\hline & & & & \\
\hline
\end{tabular}

Table S7. Torsion angles [œ] for $\mathrm{C}_{17} \mathrm{H}_{23} \mathrm{BF}_{2} \mathrm{O}_{2}$

$\begin{array}{lc}\mathrm{C}(13)-\mathrm{O}(2)-\mathrm{B}(1)-\mathrm{O}(1) & 10.7(3) \\ \mathrm{C}(13)-\mathrm{O}(2)-\mathrm{B}(1)-\mathrm{C}(3) & -169.5(3) \\ \mathrm{C}(12)-\mathrm{O}(1)-\mathrm{B}(1)-\mathrm{O}(2) & 8.7(4) \\ \mathrm{C}(12)-\mathrm{O}(1)-\mathrm{B}(1)-\mathrm{C}(3) & -171.2(3) \\ \mathrm{F}(2)-\mathrm{C}(1)-\mathrm{C}(2)-\mathrm{C}(3) & -0.6(5) \\ \mathrm{F}(1)-\mathrm{C}(1)-\mathrm{C}(2)-\mathrm{C}(3) & 179.8(3) \\ \mathrm{C}(1)-\mathrm{C}(2)-\mathrm{C}(3)-\mathrm{C}(4) & -116.7(3) \\ \mathrm{C}(1)-\mathrm{C}(2)-\mathrm{C}(3)-\mathrm{B}(1) & 119.2(3) \\ \mathrm{O}(2)-\mathrm{B}(1)-\mathrm{C}(3)-\mathrm{C}(2) & -11.1(4) \\ \mathrm{O}(1)-\mathrm{B}(1)-\mathrm{C}(3)-\mathrm{C}(2) & 168.7(3) \\ \mathrm{O}(2)-\mathrm{B}(1)-\mathrm{C}(3)-\mathrm{C}(4) & -137.2(3) \\ \mathrm{O}(1)-\mathrm{B}(1)-\mathrm{C}(3)-\mathrm{C}(4) & 42.6(4) \\ \mathrm{C}(2)-\mathrm{C}(3)-\mathrm{C}(4)-\mathrm{C}(5) & 60.1(4) \\ \mathrm{B}(1)-\mathrm{C}(3)-\mathrm{C}(4)-\mathrm{C}(5) & -174.1(3) \\ \mathrm{C}(3)-\mathrm{C}(4)-\mathrm{C}(5)-\mathrm{C}(6) & 176.1(3)\end{array}$




\begin{tabular}{|c|c|}
\hline$C(4)-C(5)-C(6)-C(11)$ & $-93.5(4)$ \\
\hline$C(4)-C(5)-C(6)-C(7)$ & $84.8(4)$ \\
\hline $\mathrm{C}(11)-\mathrm{C}(6)-\mathrm{C}(7)-\mathrm{C}(8)$ & $-0.2(4)$ \\
\hline$C(5)-C(6)-C(7)-C(8)$ & $-178.6(3)$ \\
\hline$C(6)-C(7)-C(8)-C(9)$ & $0.6(5)$ \\
\hline $\mathrm{C}(7)-\mathrm{C}(8)-\mathrm{C}(9)-\mathrm{C}(10)$ & $-0.3(5)$ \\
\hline$C(8)-C(9)-C(10)-C(11)$ & $-0.3(5)$ \\
\hline$C(7)-C(6)-C(11)-C(10)$ & $-0.4(5)$ \\
\hline$C(5)-C(6)-C(11)-C(10)$ & $178.0(3)$ \\
\hline$C(9)-C(10)-C(11)-C(6)$ & $0.7(5)$ \\
\hline $\mathrm{B}(1)-\mathrm{O}(1)-\mathrm{C}(12)-\mathrm{C}(15)$ & $-145.0(3)$ \\
\hline $\mathrm{B}(1)-\mathrm{O}(1)-\mathrm{C}(12)-\mathrm{C}(14)$ & $96.5(3)$ \\
\hline $\mathrm{B}(1)-\mathrm{O}(1)-\mathrm{C}(12)-\mathrm{C}(13)$ & $-22.7(3)$ \\
\hline $\mathrm{B}(1)-\mathrm{O}(2)-\mathrm{C}(13)-\mathrm{C}(16)$ & $-145.8(3)$ \\
\hline $\mathrm{B}(1)-\mathrm{O}(2)-\mathrm{C}(13)-\mathrm{C}(17)$ & $96.0(3)$ \\
\hline $\mathrm{B}(1)-\mathrm{O}(2)-\mathrm{C}(13)-\mathrm{C}(12)$ & $-23.8(3)$ \\
\hline $\mathrm{O}(1)-\mathrm{C}(12)-\mathrm{C}(13)-\mathrm{O}(2)$ & $28.0(3)$ \\
\hline $\mathrm{C}(15)-\mathrm{C}(12)-\mathrm{C}(13)-\mathrm{O}(2)$ & $145.4(3)$ \\
\hline $\mathrm{C}(14)-\mathrm{C}(12)-\mathrm{C}(13)-\mathrm{O}(2)$ & $-86.2(3)$ \\
\hline $\mathrm{O}(1)-\mathrm{C}(12)-\mathrm{C}(13)-\mathrm{C}(16)$ & $145.5(3)$ \\
\hline$C(15)-C(12)-C(13)-C(16)$ & $-97.2(3)$ \\
\hline $\mathrm{C}(14)-\mathrm{C}(12)-\mathrm{C}(13)-\mathrm{C}(16)$ & $31.2(4)$ \\
\hline $\mathrm{O}(1)-\mathrm{C}(12)-\mathrm{C}(13)-\mathrm{C}(17)$ & $-86.2(3)$ \\
\hline $\mathrm{C}(15)-\mathrm{C}(12)-\mathrm{C}(13)-\mathrm{C}(17)$ & $31.1(4)$ \\
\hline $\mathrm{C}(14)-\mathrm{C}(12)-\mathrm{C}(13)-\mathrm{C}(17)$ & $159.5(3)$ \\
\hline $\mathrm{C}(29)-\mathrm{O}(3)-\mathrm{B}(2)-\mathrm{O}(4)$ & $-11.5(4)$ \\
\hline $\mathrm{C}(29)-\mathrm{O}(3)-\mathrm{B}(2)-\mathrm{C}(20)$ & $166.6(3)$ \\
\hline $\mathrm{C}(30)-\mathrm{O}(4)-\mathrm{B}(2)-\mathrm{O}(3)$ & $-8.2(4)$ \\
\hline $\mathrm{C}(30)-\mathrm{O}(4)-\mathrm{B}(2)-\mathrm{C}(20)$ & $173.7(3)$ \\
\hline $\mathrm{F}(3)-\mathrm{C}(18)-\mathrm{C}(19)-\mathrm{C}(20)$ & $0.6(6)$ \\
\hline $\mathrm{F}(4)-\mathrm{C}(18)-\mathrm{C}(19)-\mathrm{C}(20)$ & $-178.2(3)$ \\
\hline $\mathrm{C}(18)-\mathrm{C}(19)-\mathrm{C}(20)-\mathrm{C}(21)$ & $-118.2(4)$ \\
\hline $\mathrm{C}(18)-\mathrm{C}(19)-\mathrm{C}(20)-\mathrm{B}(2)$ & $117.5(4)$ \\
\hline $\mathrm{O}(3)-\mathrm{B}(2)-\mathrm{C}(20)-\mathrm{C}(19)$ & $111.3(4)$ \\
\hline $\mathrm{O}(4)-\mathrm{B}(2)-\mathrm{C}(20)-\mathrm{C}(19)$ & $-70.8(4)$ \\
\hline
\end{tabular}


$\mathrm{O}(3)-\mathrm{B}(2)-\mathrm{C}(20)-\mathrm{C}(21)$

$\mathrm{O}(4)-\mathrm{B}(2)-\mathrm{C}(20)-\mathrm{C}(21)$

$\mathrm{C}(19)-\mathrm{C}(20)-\mathrm{C}(21)-\mathrm{C}(22)$

$\mathrm{B}(2)-\mathrm{C}(20)-\mathrm{C}(21)-\mathrm{C}(22)$

$\mathrm{C}(20)-\mathrm{C}(21)-\mathrm{C}(22)-\mathrm{C}(23)$

$\mathrm{C}(21)-\mathrm{C}(22)-\mathrm{C}(23)-\mathrm{C}(28)$

$\mathrm{C}(21)-\mathrm{C}(22)-\mathrm{C}(23)-\mathrm{C}(24)$

$\mathrm{C}(28)-\mathrm{C}(23)-\mathrm{C}(24)-\mathrm{C}(25)$

$\mathrm{C}(22)-\mathrm{C}(23)-\mathrm{C}(24)-\mathrm{C}(25)$

$\mathrm{C}(23)-\mathrm{C}(24)-\mathrm{C}(25)-\mathrm{C}(26)$

$\mathrm{C}(24)-\mathrm{C}(25)-\mathrm{C}(26)-\mathrm{C}(27)$

$\mathrm{C}(25)-\mathrm{C}(26)-\mathrm{C}(27)-\mathrm{C}(28)$

$\mathrm{C}(24)-\mathrm{C}(23)-\mathrm{C}(28)-\mathrm{C}(27)$

$\mathrm{C}(22)-\mathrm{C}(23)-\mathrm{C}(28)-\mathrm{C}(27)$

$\mathrm{C}(26)-\mathrm{C}(27)-\mathrm{C}(28)-\mathrm{C}(23)$

$\mathrm{B}(2)-\mathrm{O}(3)-\mathrm{C}(29)-\mathrm{C}(32)$

$\mathrm{B}(2)-\mathrm{O}(3)-\mathrm{C}(29)-\mathrm{C}(31)$

$\mathrm{B}(2)-\mathrm{O}(3)-\mathrm{C}(29)-\mathrm{C}(30)$

$\mathrm{B}(2)-\mathrm{O}(4)-\mathrm{C}(30)-\mathrm{C}(33)$

$\mathrm{B}(2)-\mathrm{O}(4)-\mathrm{C}(30)-\mathrm{C}(34)$

$\mathrm{B}(2)-\mathrm{O}(4)-\mathrm{C}(30)-\mathrm{C}(29)$

$\mathrm{O}(3)-\mathrm{C}(29)-\mathrm{C}(30)-\mathrm{O}(4)$

$\mathrm{C}(32)-\mathrm{C}(29)-\mathrm{C}(30)-\mathrm{O}(4)$

$\mathrm{C}(31)-\mathrm{C}(29)-\mathrm{C}(30)-\mathrm{O}(4)$

$\mathrm{O}(3)-\mathrm{C}(29)-\mathrm{C}(30)-\mathrm{C}(33)$

$\mathrm{C}(32)-\mathrm{C}(29)-\mathrm{C}(30)-\mathrm{C}(33)$

$\mathrm{C}(31)-\mathrm{C}(29)-\mathrm{C}(30)-\mathrm{C}(33)$

$\mathrm{O}(3)-\mathrm{C}(29)-\mathrm{C}(30)-\mathrm{C}(34)$

C(32)-C(29)-C(30)-C(34)

C(31)-C(29)-C(30)-C(34)
$-15.3(5)$

162.6(3)

$58.3(4)$

$-177.8(3)$

170.2(3)

$75.4(4)$

$-102.7(4)$

$-0.7(4)$

177.5(3)

$0.0(5)$

$0.7(5)$

$-0.8(5)$

$0.7(5)$

$-177.6(3)$

$0.1(5)$

147.0(3)

$-94.1(3)$

24.6(3)

144.4(3)

$-96.8(3)$

22.8(3)

$-28.4(3)$

$-145.9(3)$

85.0(3)

$-145.2(3)$

97.2(4)

$-31.8(4)$

86.1(3)

$-31.4(4)$

$-160.4(3)$ 


\section{2. $p$-Nitrobenzoate derived from $13 e$}

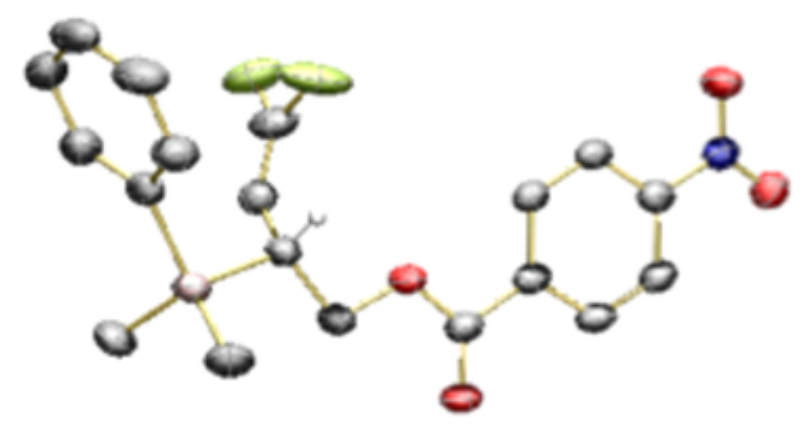

The absolute configuration of is assigned as $(R)$. This compound was recrystallized in pentane at $-20{ }^{\circ} \mathrm{C}$ over the course of two days.

Table S8. Crystal data and structure refinement for $\mathrm{C}_{19} \mathrm{H}_{19} \mathrm{~F}_{2} \mathrm{NO}_{4} \mathrm{Si}$

\begin{tabular}{ll}
\hline Identification code & $\mathrm{C}_{19} \mathrm{H}_{19} \mathrm{~F}_{2} \mathrm{NO}_{4} \mathrm{Si}$ \\
Empirical formula & $\mathrm{C}_{19} \mathrm{H}_{19} \mathrm{~F}_{2} \mathrm{NO}_{4} \mathrm{Si}$ \\
Formula weight & 391.44 \\
Temperature & $100(2) \mathrm{K}$ \\
Wavelength & $1.54178 \AA$ \\
Crystal system & Orthorhombic \\
Space group & $\mathrm{P} 2{ }_{1} 2{ }_{1}$ \\
Unit cell dimensions & $\mathrm{a}=6.6591(3) \AA$ \\
& $\mathrm{b}=7.0377(3) \AA$ \\
& $\mathrm{c}=41.6610(16) \AA$ \\
Volume & $1952.43(14) \AA^{3}$ \\
Z & 4 \\
Density (calculated) & $1.332 \mathrm{Mg} / \mathrm{m}^{3}$ \\
Absorption coefficient & $1.450 \mathrm{~mm}{ }^{-1}$ \\
F(000) & 816 \\
Crystal size & $0.220 \times 0.110 \mathrm{x} 0.080 \mathrm{~mm}{ }^{3}$ \\
Theta range for data collection & 2.121 to $66.737^{\circ}$ \\
Index ranges & $-7<=\mathrm{h}<=7,-8<=\mathrm{k}<=5$, \\
Reflections collected & $-45<=1<=49$ \\
Independent reflections & 7946 \\
Completeness to theta $=67.679^{\circ}$ & $97.4 \%$ \\
Refinement method & $3429[\mathrm{R}(\mathrm{int})=0.0346]$ \\
Data / restraints / parameters & $3429 / 0 / 246$ \\
Goodness-of-fit on F2 & 1.047 \\
Final R indices [I $>2 \sigma(\mathrm{I})]$ & $\mathrm{R} 1=0.0388, \omega \mathrm{R} 2=0.1000$ \\
\hline
\end{tabular}




\begin{tabular}{ll}
\hline $\mathrm{R}$ indices (all data) & $\mathrm{R} 1=0.0422, \omega \mathrm{R} 2=0.1025$ \\
Absolute structure parameter & $0.03(3)$ \\
Extinction coefficient & $\mathrm{n} / \mathrm{a}$ \\
Largest diff. peak and hole & 0.236 and -0.213 e $\AA^{-3}$ \\
\hline
\end{tabular}

Table S9. Atomic coordinates $\left(\mathrm{x}^{4} \mathbf{0}^{4}\right)$ and equivalent isotropic displacement parameters $\left(\AA^{2} \times 10^{3}\right)$ for $\mathrm{C}_{19} \mathrm{H}_{19} \mathrm{~F}_{2} \mathrm{NO}_{4} \mathrm{Si}$. $\mathrm{U}(\mathrm{eq})$ is defined as one third of the trace of the orthogonalized $\mathrm{U}^{\mathrm{ij}}$ tensor

\begin{tabular}{|c|c|c|c|c|}
\hline & $\mathrm{x}$ & $\mathrm{y}$ & $\mathrm{z}$ & $\mathrm{U}(\mathrm{eq})$ \\
\hline $\operatorname{Si}(01)$ & $2380(1)$ & $4089(1)$ & $3341(1)$ & $40(1)$ \\
\hline $\mathrm{O}(1)$ & $3624(4)$ & $4928(3)$ & $4300(1)$ & $45(1)$ \\
\hline $\mathrm{O}(2)$ & $3786(4)$ & $2285(3)$ & $4602(1)$ & $52(1)$ \\
\hline $\mathrm{F}(1)$ & $6562(4)$ & $9409(3)$ & $3698(1)$ & $75(1)$ \\
\hline $\mathrm{O}(3)$ & $4047(4)$ & $8288(3)$ & $5922(1)$ & $51(1)$ \\
\hline $\mathrm{O}(4)$ & $3666(5)$ & $10705(3)$ & $5611(1)$ & $57(1)$ \\
\hline$F(2)$ & $3402(4)$ & $9294(3)$ & $3800(1)$ & $93(1)$ \\
\hline $\mathrm{N}(1)$ & $3854(4)$ & $8986(4)$ & $5656(1)$ & $44(1)$ \\
\hline$C(5)$ & $3809(5)$ & $5340(4)$ & $4855(1)$ & $40(1)$ \\
\hline $\mathrm{C}(9)$ & $3812(5)$ & $8512(4)$ & $5071(1)$ & $39(1)$ \\
\hline$C(7)$ & $3853(5)$ & $5778(4)$ & $5428(1)$ & $44(1)$ \\
\hline$C(6)$ & $3834(5)$ & $4593(4)$ & $5165(1)$ & $44(1)$ \\
\hline $\mathrm{C}(8)$ & $3837(5)$ & $7718(4)$ & $5377(1)$ & $40(1)$ \\
\hline$C(14)$ & $1645(5)$ & $6135(4)$ & $3076(1)$ & $42(1)$ \\
\hline$C(11)$ & $3753(5)$ & $3993(4)$ & $4579(1)$ & $42(1)$ \\
\hline$C(10)$ & $3800(4)$ & $7301(4)$ & $4811(1)$ & $38(1)$ \\
\hline$C(2)$ & $3191(5)$ & $5195(4)$ & $3737(1)$ & $39(1)$ \\
\hline$C(1)$ & $3472(6)$ & $3785(4)$ & $4010(1)$ & $45(1)$ \\
\hline$C(3)$ & $4996(5)$ & $6434(4)$ & $3698(1)$ & $44(1)$ \\
\hline$C(19)$ & $2984(7)$ & $6956(5)$ & $2860(1)$ & $56(1)$ \\
\hline$C(4)$ & 4993(6) & $8254(5)$ & $3731(1)$ & $57(1)$ \\
\hline $\mathrm{C}(15)$ & $-291(6)$ & $6903(5)$ & $3090(1)$ & $53(1)$ \\
\hline$C(13)$ & $149(6)$ & $2557(4)$ & $3418(1)$ & $51(1)$ \\
\hline$C(12)$ & $4481(6)$ & $2744(5)$ & $3149(1)$ & $51(1)$ \\
\hline$C(17)$ & $469(8)$ & $9189(5)$ & $2686(1)$ & $66(1)$ \\
\hline$C(16)$ & $-865(7)$ & $8420(5)$ & $2899(1)$ & $64(1)$ \\
\hline$C(18)$ & $2395(8)$ & $8483(5)$ & $2666(1)$ & $66(1)$ \\
\hline
\end{tabular}

Table S10. Bond lengths $[\AA ̊]$ and angles $\left[^{\circ}\right]$ for $\mathrm{C}_{19} \mathrm{H}_{19} \mathrm{~F}_{2} \mathrm{NO}_{4} \mathrm{Si}$

$\mathrm{Si}(01)-\mathrm{C}(13)$ $1.864(3)$ 


\begin{tabular}{|c|c|}
\hline $\mathrm{Si}(01)-\mathrm{C}(12)$ & $1.868(4)$ \\
\hline $\mathrm{Si}(01)-\mathrm{C}(14)$ & $1.878(3)$ \\
\hline $\mathrm{Si}(01)-\mathrm{C}(2)$ & $1.905(3)$ \\
\hline $\mathrm{O}(1)-\mathrm{C}(11)$ & $1.336(4)$ \\
\hline $\mathrm{O}(1)-\mathrm{C}(1)$ & $1.456(4)$ \\
\hline $\mathrm{O}(2)-\mathrm{C}(11)$ & $1.206(4)$ \\
\hline $\mathrm{F}(1)-\mathrm{C}(4)$ & $1.331(5)$ \\
\hline $\mathrm{O}(3)-\mathrm{N}(1)$ & $1.221(4)$ \\
\hline $\mathrm{O}(4)-\mathrm{N}(1)$ & $1.230(4)$ \\
\hline $\mathrm{F}(2)-\mathrm{C}(4)$ & $1.318(5)$ \\
\hline $\mathrm{N}(1)-\mathrm{C}(8)$ & $1.465(4)$ \\
\hline$C(5)-C(10)$ & $1.393(4)$ \\
\hline$C(5)-C(6)$ & $1.393(5)$ \\
\hline$C(5)-C(11)$ & $1.493(5)$ \\
\hline$C(9)-C(10)$ & $1.379(4)$ \\
\hline$C(9)-C(8)$ & $1.390(4)$ \\
\hline $\mathrm{C}(9)-\mathrm{H}(9)$ & 0.9500 \\
\hline$C(7)-C(6)$ & $1.376(5)$ \\
\hline$C(7)-C(8)$ & $1.381(4)$ \\
\hline $\mathrm{C}(7)-\mathrm{H}(7)$ & 0.9500 \\
\hline $\mathrm{C}(6)-\mathrm{H}(6)$ & 0.9500 \\
\hline$C(14)-C(19)$ & $1.391(5)$ \\
\hline$C(14)-C(15)$ & $1.399(5)$ \\
\hline $\mathrm{C}(10)-\mathrm{H}(10)$ & 0.9500 \\
\hline$C(2)-C(3)$ & $1.494(5)$ \\
\hline$C(2)-C(1)$ & $1.519(4)$ \\
\hline $\mathrm{C}(2)-\mathrm{H}(2)$ & 1.0000 \\
\hline $\mathrm{C}(1)-\mathrm{H}(1 \mathrm{~A})$ & 0.9900 \\
\hline $\mathrm{C}(1)-\mathrm{H}(1 \mathrm{~B})$ & 0.9900 \\
\hline$C(3)-C(4)$ & $1.289(5)$ \\
\hline $\mathrm{C}(3)-\mathrm{H}(3 \mathrm{~A})$ & 0.9500 \\
\hline$C(19)-C(18)$ & $1.401(5)$ \\
\hline $\mathrm{C}(19)-\mathrm{H}(19)$ & 0.9500 \\
\hline$C(15)-C(16)$ & $1.386(5)$ \\
\hline $\mathrm{C}(15)-\mathrm{H}(15)$ & 0.9500 \\
\hline $\mathrm{C}(13)-\mathrm{H}(13 \mathrm{~A})$ & 0.9800 \\
\hline $\mathrm{C}(13)-\mathrm{H}(13 \mathrm{~B})$ & 0.9800 \\
\hline $\mathrm{C}(13)-\mathrm{H}(13 \mathrm{C})$ & 0.9800 \\
\hline $\mathrm{C}(12)-\mathrm{H}(12 \mathrm{~A})$ & 0.9800 \\
\hline $\mathrm{C}(12)-\mathrm{H}(12 \mathrm{~B})$ & 0.9800 \\
\hline
\end{tabular}




\begin{tabular}{|c|c|}
\hline $\mathrm{C}(12)-\mathrm{H}(12 \mathrm{C})$ & 0.9800 \\
\hline$C(17)-C(16)$ & $1.367(6)$ \\
\hline$C(17)-C(18)$ & $1.378(7)$ \\
\hline $\mathrm{C}(17)-\mathrm{H}(17)$ & 0.9500 \\
\hline $\mathrm{C}(16)-\mathrm{H}(16)$ & 0.9500 \\
\hline $\mathrm{C}(18)-\mathrm{H}(18)$ & 0.9500 \\
\hline$C(13)-\operatorname{Si}(01)-C(12)$ & $112.19(16)$ \\
\hline$C(13)-\operatorname{Si}(01)-C(14)$ & $109.73(16)$ \\
\hline $\mathrm{C}(12)-\mathrm{Si}(01)-\mathrm{C}(14)$ & $109.45(16)$ \\
\hline $\mathrm{C}(13)-\mathrm{Si}(01)-\mathrm{C}(2)$ & $108.16(16)$ \\
\hline $\mathrm{C}(12)-\mathrm{Si}(01)-\mathrm{C}(2)$ & $111.43(16)$ \\
\hline$C(14)-\operatorname{Si}(01)-C(2)$ & $105.68(13)$ \\
\hline $\mathrm{C}(11)-\mathrm{O}(1)-\mathrm{C}(1)$ & $117.0(2)$ \\
\hline $\mathrm{O}(3)-\mathrm{N}(1)-\mathrm{O}(4)$ & $123.0(3)$ \\
\hline $\mathrm{O}(3)-\mathrm{N}(1)-\mathrm{C}(8)$ & $118.4(3)$ \\
\hline $\mathrm{O}(4)-\mathrm{N}(1)-\mathrm{C}(8)$ & $118.6(3)$ \\
\hline$C(10)-C(5)-C(6)$ & $119.8(3)$ \\
\hline$C(10)-C(5)-C(11)$ & $121.8(3)$ \\
\hline$C(6)-C(5)-C(11)$ & $118.4(3)$ \\
\hline$C(10)-C(9)-C(8)$ & $118.1(3)$ \\
\hline $\mathrm{C}(10)-\mathrm{C}(9)-\mathrm{H}(9)$ & 120.9 \\
\hline $\mathrm{C}(8)-\mathrm{C}(9)-\mathrm{H}(9)$ & 120.9 \\
\hline$C(6)-C(7)-C(8)$ & $118.5(3)$ \\
\hline $\mathrm{C}(6)-\mathrm{C}(7)-\mathrm{H}(7)$ & 120.8 \\
\hline $\mathrm{C}(8)-\mathrm{C}(7)-\mathrm{H}(7)$ & 120.8 \\
\hline$C(7)-C(6)-C(5)$ & $120.5(3)$ \\
\hline $\mathrm{C}(7)-\mathrm{C}(6)-\mathrm{H}(6)$ & 119.7 \\
\hline $\mathrm{C}(5)-\mathrm{C}(6)-\mathrm{H}(6)$ & 119.7 \\
\hline$C(7)-C(8)-C(9)$ & $122.6(3)$ \\
\hline $\mathrm{C}(7)-\mathrm{C}(8)-\mathrm{N}(1)$ & $118.7(3)$ \\
\hline $\mathrm{C}(9)-\mathrm{C}(8)-\mathrm{N}(1)$ & $118.7(3)$ \\
\hline$C(19)-C(14)-C(15)$ & $117.3(3)$ \\
\hline$C(19)-C(14)-\operatorname{Si}(01)$ & $122.0(3)$ \\
\hline$C(15)-C(14)-S i(01)$ & $120.7(3)$ \\
\hline $\mathrm{O}(2)-\mathrm{C}(11)-\mathrm{O}(1)$ & $124.2(3)$ \\
\hline $\mathrm{O}(2)-\mathrm{C}(11)-\mathrm{C}(5)$ & $124.8(3)$ \\
\hline $\mathrm{O}(1)-\mathrm{C}(11)-\mathrm{C}(5)$ & $111.1(2)$ \\
\hline$C(9)-C(10)-C(5)$ & $120.5(3)$ \\
\hline $\mathrm{C}(9)-\mathrm{C}(10)-\mathrm{H}(10)$ & 119.7 \\
\hline
\end{tabular}




\begin{tabular}{|c|c|}
\hline $\mathrm{C}(5)-\mathrm{C}(10)-\mathrm{H}(10)$ & 119.7 \\
\hline$C(3)-C(2)-C(1)$ & $111.3(3)$ \\
\hline$C(3)-C(2)-\operatorname{Si}(01)$ & $111.8(2)$ \\
\hline$C(1)-C(2)-\operatorname{Si}(01)$ & $114.6(2)$ \\
\hline $\mathrm{C}(3)-\mathrm{C}(2)-\mathrm{H}(2)$ & 106.1 \\
\hline $\mathrm{C}(1)-\mathrm{C}(2)-\mathrm{H}(2)$ & 106.1 \\
\hline $\mathrm{Si}(01)-\mathrm{C}(2)-\mathrm{H}(2)$ & 106.1 \\
\hline $\mathrm{O}(1)-\mathrm{C}(1)-\mathrm{C}(2)$ & $105.6(2)$ \\
\hline $\mathrm{O}(1)-\mathrm{C}(1)-\mathrm{H}(1 \mathrm{~A})$ & 110.6 \\
\hline $\mathrm{C}(2)-\mathrm{C}(1)-\mathrm{H}(1 \mathrm{~A})$ & 110.6 \\
\hline $\mathrm{O}(1)-\mathrm{C}(1)-\mathrm{H}(1 \mathrm{~B})$ & 110.6 \\
\hline $\mathrm{C}(2)-\mathrm{C}(1)-\mathrm{H}(1 \mathrm{~B})$ & 110.6 \\
\hline $\mathrm{H}(1 \mathrm{~A})-\mathrm{C}(1)-\mathrm{H}(1 \mathrm{~B})$ & 108.8 \\
\hline$C(4)-C(3)-C(2)$ & $124.6(3)$ \\
\hline $\mathrm{C}(4)-\mathrm{C}(3)-\mathrm{H}(3 \mathrm{~A})$ & 117.7 \\
\hline $\mathrm{C}(2)-\mathrm{C}(3)-\mathrm{H}(3 \mathrm{~A})$ & 117.7 \\
\hline$C(14)-C(19)-C(18)$ & $120.8(4)$ \\
\hline $\mathrm{C}(14)-\mathrm{C}(19)-\mathrm{H}(19)$ & 119.6 \\
\hline $\mathrm{C}(18)-\mathrm{C}(19)-\mathrm{H}(19)$ & 119.6 \\
\hline$C(3)-C(4)-F(2)$ & $125.2(4)$ \\
\hline$C(3)-C(4)-F(1)$ & $126.5(4)$ \\
\hline$F(2)-C(4)-F(1)$ & $108.3(3)$ \\
\hline$C(16)-C(15)-C(14)$ & $121.8(4)$ \\
\hline $\mathrm{C}(16)-\mathrm{C}(15)-\mathrm{H}(15)$ & 119.1 \\
\hline $\mathrm{C}(14)-\mathrm{C}(15)-\mathrm{H}(15)$ & 119.1 \\
\hline $\mathrm{Si}(01)-\mathrm{C}(13)-\mathrm{H}(13 \mathrm{~A})$ & 109.5 \\
\hline $\mathrm{Si}(01)-\mathrm{C}(13)-\mathrm{H}(13 \mathrm{~B})$ & 109.5 \\
\hline $\mathrm{H}(13 \mathrm{~A})-\mathrm{C}(13)-\mathrm{H}(13 \mathrm{~B})$ & 109.5 \\
\hline $\mathrm{Si}(01)-\mathrm{C}(13)-\mathrm{H}(13 \mathrm{C})$ & 109.5 \\
\hline$H(13 A)-C(13)-H(13 C)$ & 109.5 \\
\hline $\mathrm{H}(13 \mathrm{~B})-\mathrm{C}(13)-\mathrm{H}(13 \mathrm{C})$ & 109.5 \\
\hline $\mathrm{Si}(01)-\mathrm{C}(12)-\mathrm{H}(12 \mathrm{~A})$ & 109.5 \\
\hline $\mathrm{Si}(01)-\mathrm{C}(12)-\mathrm{H}(12 \mathrm{~B})$ & 109.5 \\
\hline $\mathrm{H}(12 \mathrm{~A})-\mathrm{C}(12)-\mathrm{H}(12 \mathrm{~B})$ & 109.5 \\
\hline $\mathrm{Si}(01)-\mathrm{C}(12)-\mathrm{H}(12 \mathrm{C})$ & 109.5 \\
\hline $\mathrm{H}(12 \mathrm{~A})-\mathrm{C}(12)-\mathrm{H}(12 \mathrm{C})$ & 109.5 \\
\hline $\mathrm{H}(12 \mathrm{~B})-\mathrm{C}(12)-\mathrm{H}(12 \mathrm{C})$ & 109.5 \\
\hline$C(16)-C(17)-C(18)$ & $120.1(4)$ \\
\hline $\mathrm{C}(16)-\mathrm{C}(17)-\mathrm{H}(17)$ & 119.9 \\
\hline $\mathrm{C}(18)-\mathrm{C}(17)-\mathrm{H}(17)$ & 119.9 \\
\hline
\end{tabular}




\begin{tabular}{ll}
\hline $\mathrm{C}(17)-\mathrm{C}(16)-\mathrm{C}(15)$ & $119.9(4)$ \\
$\mathrm{C}(17)-\mathrm{C}(16)-\mathrm{H}(16)$ & 120.0 \\
$\mathrm{C}(15)-\mathrm{C}(16)-\mathrm{H}(16)$ & 120.0 \\
$\mathrm{C}(17)-\mathrm{C}(18)-\mathrm{C}(19)$ & $120.1(4)$ \\
$\mathrm{C}(17)-\mathrm{C}(18)-\mathrm{H}(18)$ & 119.9 \\
$\mathrm{C}(19)-\mathrm{C}(18)-\mathrm{H}(18)$ & 119.9 \\
\hline
\end{tabular}

Table S11. Anisotropic displacement parameters $\left(\AA^{2} \times 10^{3}\right)$ for $\mathrm{C}_{19} \mathrm{H}_{19} \mathrm{~F}_{2} \mathrm{NO4Si}$. The anisotropic displacement factor exponent takes the form: $-2 \pi^{2}\left[h^{2} a^{2} U^{11}+\ldots+2 h k\right.$ a b $\left.\mathbf{U}^{12}\right]$

\begin{tabular}{|c|c|c|c|c|c|c|}
\hline & $\mathrm{U}^{11}$ & $\mathrm{U}^{22}$ & $\mathrm{U}^{33}$ & $\mathrm{U}^{23}$ & $\mathrm{U}^{13}$ & $\mathrm{U}^{12}$ \\
\hline $\operatorname{Si}(01)$ & $51(1)$ & $26(1)$ & $42(1)$ & $-1(1)$ & $-1(1)$ & $0(1)$ \\
\hline $\mathrm{O}(1)$ & $67(1)$ & $26(1)$ & $42(1)$ & $5(1)$ & $-3(1)$ & $0(1)$ \\
\hline $\mathrm{O}(2)$ & $80(2)$ & $26(1)$ & $50(1)$ & $6(1)$ & $-1(1)$ & $0(1)$ \\
\hline $\mathrm{F}(1)$ & $81(2)$ & $42(1)$ & $103(2)$ & $25(1)$ & $-24(1)$ & $-23(1)$ \\
\hline $\mathrm{O}(3)$ & $62(1)$ & $49(1)$ & $42(1)$ & $4(1)$ & $-2(1)$ & $-5(1)$ \\
\hline $\mathrm{O}(4)$ & $87(2)$ & $32(1)$ & $53(1)$ & $-1(1)$ & $-2(1)$ & $-1(1)$ \\
\hline $\mathrm{F}(2)$ & $82(2)$ & $26(1)$ & $170(3)$ & $-3(1)$ & $-13(2)$ & $6(1)$ \\
\hline $\mathrm{N}(1)$ & $49(1)$ & $38(1)$ & $46(2)$ & $4(1)$ & $2(1)$ & $-4(1)$ \\
\hline$C(5)$ & $42(2)$ & $31(1)$ & $47(2)$ & $7(1)$ & $-1(1)$ & $0(1)$ \\
\hline$C(9)$ & $41(2)$ & $29(1)$ & $47(2)$ & $5(1)$ & $-2(1)$ & $-1(1)$ \\
\hline$C(7)$ & $53(2)$ & $36(2)$ & $41(2)$ & $10(1)$ & $-1(1)$ & $-3(1)$ \\
\hline$C(6)$ & $55(2)$ & $29(1)$ & $50(2)$ & $7(1)$ & $-3(2)$ & $-2(1)$ \\
\hline$C(8)$ & $40(2)$ & $35(1)$ & $45(2)$ & $2(1)$ & $-1(1)$ & $-1(1)$ \\
\hline$C(14)$ & $59(2)$ & $28(1)$ & $37(2)$ & $-4(1)$ & $-7(1)$ & $-1(1)$ \\
\hline$C(11)$ & $48(2)$ & $32(1)$ & $45(2)$ & $6(1)$ & $-1(1)$ & $-1(1)$ \\
\hline$C(10)$ & $38(2)$ & $32(1)$ & $42(2)$ & $7(1)$ & $-2(1)$ & $-1(1)$ \\
\hline$C(2)$ & $54(2)$ & $25(1)$ & $38(2)$ & $-1(1)$ & $-1(1)$ & $2(1)$ \\
\hline$C(1)$ & $66(2)$ & $27(1)$ & $42(2)$ & $-1(1)$ & $-2(2)$ & $-1(1)$ \\
\hline$C(3)$ & $54(2)$ & $35(2)$ & $42(2)$ & $3(1)$ & $-4(1)$ & $-4(1)$ \\
\hline$C(19)$ & $78(3)$ & $38(2)$ & $51(2)$ & $0(2)$ & $7(2)$ & $-3(2)$ \\
\hline$C(4)$ & $70(2)$ & $34(2)$ & $68(2)$ & $13(2)$ & $-14(2)$ & $-4(2)$ \\
\hline$C(15)$ & $64(2)$ & $34(2)$ & $60(2)$ & $2(2)$ & $-2(2)$ & $2(2)$ \\
\hline$C(13)$ & $58(2)$ & $30(2)$ & $65(2)$ & $2(2)$ & $-1(2)$ & $-10(1)$ \\
\hline$C(12)$ & $62(2)$ & $37(2)$ & $56(2)$ & $-6(2)$ & $4(2)$ & $8(2)$ \\
\hline$C(17)$ & $116(3)$ & $29(2)$ & $52(2)$ & $-1(2)$ & $-23(2)$ & $0(2)$ \\
\hline$C(16)$ & $78(3)$ & $35(2)$ & $77(3)$ & $1(2)$ & $-19(2)$ & $7(2)$ \\
\hline$C(18)$ & $114(3)$ & $38(2)$ & $49(2)$ & $4(2)$ & $11(2)$ & $-9(2)$ \\
\hline
\end{tabular}


Table S12. Hydrogen coordinates $\left(x_{10}^{4}\right)$ and isotropic displacement parameters $\left(\AA^{2} \times 10^{3}\right)$ for $\mathrm{C}_{19} \mathrm{H}_{19} \mathrm{~F}_{2} \mathrm{NO}_{4} \mathrm{Si}$

\begin{tabular}{lllll}
\hline & $\mathrm{x}$ & $\mathrm{y}$ & $\mathrm{z}$ & $\mathrm{U}(\mathrm{eq})$ \\
\hline $\mathrm{H}(9)$ & 3803 & 9851 & 5043 & 47 \\
$\mathrm{H}(7)$ & 3876 & 5274 & 5639 & 52 \\
$\mathrm{H}(6)$ & 3839 & 3255 & 5195 & 53 \\
$\mathrm{H}(10)$ & 3786 & 7809 & 4600 & 45 \\
$\mathrm{H}(2)$ & 2071 & 6053 & 3805 & 47 \\
$\mathrm{H}(1 \mathrm{~A})$ & 2312 & 2909 & 4023 & 54 \\
$\mathrm{H}(1 \mathrm{~B})$ & 4709 & 3029 & 3978 & 54 \\
$\mathrm{H}(3 \mathrm{~A})$ & 6232 & 5838 & 3646 & 52 \\
$\mathrm{H}(19)$ & 4314 & 6476 & 2845 & 67 \\
$\mathrm{H}(15)$ & -1238 & 6370 & 3235 & 64 \\
$\mathrm{H}(13 \mathrm{~A})$ & -531 & 2280 & 3215 & 77 \\
$\mathrm{H}(13 \mathrm{~B})$ & -779 & 3220 & 3562 & 77 \\
$\mathrm{H}(13 \mathrm{C})$ & 584 & 1366 & 3518 & 77 \\
$\mathrm{H}(12 \mathrm{~A})$ & 4875 & 1685 & 3288 & 77 \\
$\mathrm{H}(12 \mathrm{~B})$ & 5630 & 3592 & 3117 & 77 \\
$\mathrm{H}(12 \mathrm{C})$ & 4038 & 2247 & 2941 & 77 \\
$\mathrm{H}(17)$ & 68 & 10212 & 2552 & 79 \\
$\mathrm{H}(16)$ & -2184 & 8925 & 2916 & 76 \\
$\mathrm{H}(18)$ & 3325 & 9032 & 2520 & 80 \\
\hline
\end{tabular}

Table S13. Torsion angles $\left[{ }^{\circ}\right]$ for $\mathrm{C}_{19} \mathrm{H}_{19} \mathrm{~F}_{2} \mathrm{NO}_{4} \mathrm{Si}$

\begin{tabular}{ll}
\hline $\mathrm{C}(8)-\mathrm{C}(7)-\mathrm{C}(6)-\mathrm{C}(5)$ & $0.3(5)$ \\
$\mathrm{C}(10)-\mathrm{C}(5)-\mathrm{C}(6)-\mathrm{C}(7)$ & $-0.1(5)$ \\
$\mathrm{C}(11)-\mathrm{C}(5)-\mathrm{C}(6)-\mathrm{C}(7)$ & $-179.0(3)$ \\
$\mathrm{C}(6)-\mathrm{C}(7)-\mathrm{C}(8)-\mathrm{C}(9)$ & $-0.3(5)$ \\
$\mathrm{C}(6)-\mathrm{C}(7)-\mathrm{C}(8)-\mathrm{N}(1)$ & $179.9(3)$ \\
$\mathrm{C}(10)-\mathrm{C}(9)-\mathrm{C}(8)-\mathrm{C}(7)$ & $0.1(5)$ \\
$\mathrm{C}(10)-\mathrm{C}(9)-\mathrm{C}(8)-\mathrm{N}(1)$ & $179.9(3)$ \\
$\mathrm{O}(3)-\mathrm{N}(1)-\mathrm{C}(8)-\mathrm{C}(7)$ & $5.9(4)$ \\
$\mathrm{O}(4)-\mathrm{N}(1)-\mathrm{C}(8)-\mathrm{C}(7)$ & $-173.9(3)$ \\
$\mathrm{O}(3)-\mathrm{N}(1)-\mathrm{C}(8)-\mathrm{C}(9)$ & $-173.9(3)$ \\
$\mathrm{O}(4)-\mathrm{N}(1)-\mathrm{C}(8)-\mathrm{C}(9)$ & $6.3(4)$ \\
$\mathrm{C}(13)-\mathrm{Si}(01)-\mathrm{C}(14)-\mathrm{C}(19)$ & $-149.0(3)$ \\
$\mathrm{C}(12)-\mathrm{Si}(01)-\mathrm{C}(14)-\mathrm{C}(19)$ & $-25.5(3)$ \\
$\mathrm{C}(2)-\mathrm{Si}(01)-\mathrm{C}(14)-\mathrm{C}(19)$ & $94.6(3)$ \\
$\mathrm{C}(13)-\mathrm{Si}(01)-\mathrm{C}(14)-\mathrm{C}(15)$ & $31.4(3)$ \\
\hline
\end{tabular}




\begin{tabular}{ll}
\hline $\mathrm{C}(12)-\mathrm{Si}(01)-\mathrm{C}(14)-\mathrm{C}(15)$ & $154.9(3)$ \\
$\mathrm{C}(2)-\mathrm{Si}(01)-\mathrm{C}(14)-\mathrm{C}(15)$ & $-85.0(3)$ \\
$\mathrm{C}(1)-\mathrm{O}(1)-\mathrm{C}(11)-\mathrm{O}(2)$ & $1.4(5)$ \\
$\mathrm{C}(1)-\mathrm{O}(1)-\mathrm{C}(11)-\mathrm{C}(5)$ & $-177.5(3)$ \\
$\mathrm{C}(10)-\mathrm{C}(5)-\mathrm{C}(11)-\mathrm{O}(2)$ & $178.9(3)$ \\
$\mathrm{C}(6)-\mathrm{C}(5)-\mathrm{C}(11)-\mathrm{O}(2)$ & $-2.2(5)$ \\
$\mathrm{C}(10)-\mathrm{C}(5)-\mathrm{C}(11)-\mathrm{O}(1)$ & $-2.2(4)$ \\
$\mathrm{C}(6)-\mathrm{C}(5)-\mathrm{C}(11)-\mathrm{O}(1)$ & $176.6(3)$ \\
$\mathrm{C}(8)-\mathrm{C}(9)-\mathrm{C}(10)-\mathrm{C}(5)$ & $0.1(5)$ \\
$\mathrm{C}(6)-\mathrm{C}(5)-\mathrm{C}(10)-\mathrm{C}(9)$ & $-0.1(5)$ \\
$\mathrm{C}(11)-\mathrm{C}(5)-\mathrm{C}(10)-\mathrm{C}(9)$ & $178.7(3)$ \\
$\mathrm{C}(11)-\mathrm{O}(1)-\mathrm{C}(1)-\mathrm{C}(2)$ & $175.9(3)$ \\
$\mathrm{C}(3)-\mathrm{C}(2)-\mathrm{C}(1)-\mathrm{O}(1)$ & $64.5(3)$ \\
$\mathrm{Si}(01)-\mathrm{C}(2)-\mathrm{C}(1)-\mathrm{O}(1)$ & $-167.3(2)$ \\
$\mathrm{C}(1)-\mathrm{C}(2)-\mathrm{C}(3)-\mathrm{C}(4)$ & $-118.3(4)$ \\
$\mathrm{Si}(01)-\mathrm{C}(2)-\mathrm{C}(3)-\mathrm{C}(4)$ & $112.0(4)$ \\
$\mathrm{C}(15)-\mathrm{C}(14)-\mathrm{C}(19)-\mathrm{C}(18)$ & $-0.3(5)$ \\
$\mathrm{Si}(01)-\mathrm{C}(14)-\mathrm{C}(19)-\mathrm{C}(18)$ & $-179.9(3)$ \\
$\mathrm{C}(2)-\mathrm{C}(3)-\mathrm{C}(4)-\mathrm{F}(2)$ & $-0.9(7)$ \\
$\mathrm{C}(2)-\mathrm{C}(3)-\mathrm{C}(4)-\mathrm{F}(1)$ & $-179.9(3)$ \\
$\mathrm{C}(19)-\mathrm{C}(14)-\mathrm{C}(15)-\mathrm{C}(16)$ & $0.0(5)$ \\
$\mathrm{Si}(01)-\mathrm{C}(14)-\mathrm{C}(15)-\mathrm{C}(16)$ & $179.6(3)$ \\
$\mathrm{C}(18)-\mathrm{C}(17)-\mathrm{C}(16)-\mathrm{C}(15)$ & $-1.3(6)$ \\
$\mathrm{C}(14)-\mathrm{C}(15)-\mathrm{C}(16)-\mathrm{C}(17)$ & $0.9(6)$ \\
$\mathrm{C}(16)-\mathrm{C}(17)-\mathrm{C}(18)-\mathrm{C}(19)$ & $0.9(6)$ \\
$\mathrm{C}(14)-\mathrm{C}(19)-\mathrm{C}(18)-\mathrm{C}(17)$ & $-0.1(6)$ \\
& \\
\hline & \\
& \\
&
\end{tabular}

\subsection{Cu-alkyl complex 18}

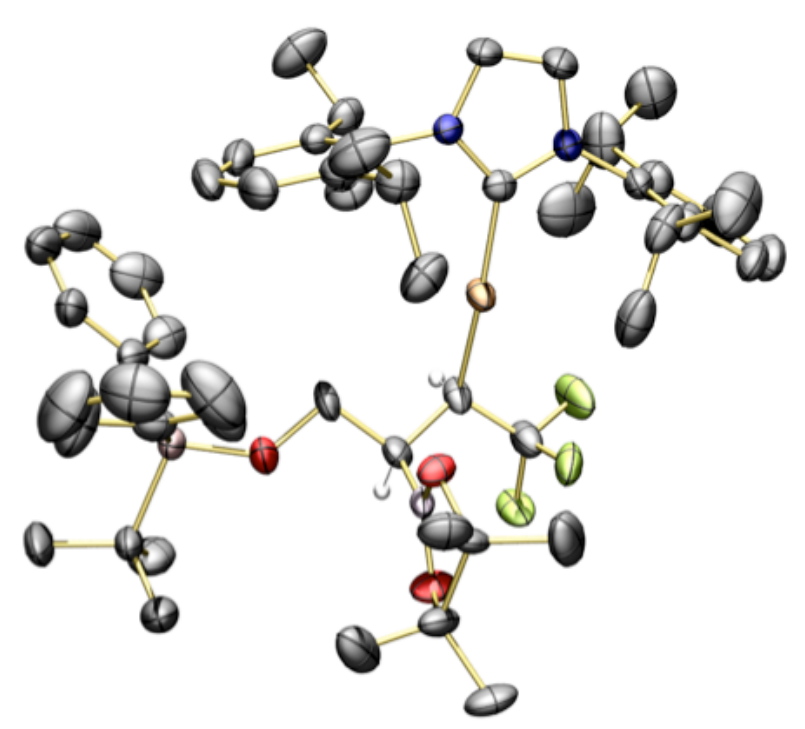


Table S14. Crystal data and structure refinement for $\mathrm{Cu}$-alkyl complex $\mathrm{C}_{53} \mathrm{H}_{71} \mathrm{BCuF}_{3} \mathrm{~N}_{2} \mathrm{O}_{3} \mathrm{Si}$.

\begin{tabular}{|c|c|c|}
\hline Identification code & \multicolumn{2}{|c|}{$\mathrm{C}_{53} \mathrm{H}_{71} \mathrm{BCuF}_{3} \mathrm{~N}_{2} \mathrm{O}_{3} \mathrm{Si}$} \\
\hline Empirical formula & \multicolumn{2}{|c|}{$\mathrm{C}_{54.50} \mathrm{H}_{74.50} \mathrm{BCuF}_{3} \mathrm{~N}_{2} \mathrm{O}_{3} \mathrm{Si}$} \\
\hline Formula weight & \multicolumn{2}{|l|}{965.10} \\
\hline Temperature & \multicolumn{2}{|l|}{$100(2) \mathrm{K}$} \\
\hline Wavelength & \multicolumn{2}{|l|}{$1.54178 \AA$} \\
\hline Crystal system & \multicolumn{2}{|l|}{ Monoclinic } \\
\hline Space group & \multicolumn{2}{|l|}{$\mathrm{Pc}$} \\
\hline \multirow[t]{3}{*}{ Unit cell dimensions } & $\mathrm{a}=24.1829(8) \AA$ & $\alpha=90^{\circ}$ \\
\hline & $\mathrm{b}=11.0610(3) \AA$ & $\beta=112.408$ \\
\hline & $\mathrm{c}=24.7085(8) \AA$ & $\gamma=90^{\circ}$ \\
\hline Volume & $6110.2(3) \AA^{3}$ & \\
\hline Z & 4 & \\
\hline Density (calculated) & $1.049 \mathrm{Mg} / \mathrm{m}^{3}$ & \\
\hline Absorption coefficient & $1.059 \mathrm{~mm}^{-1}$ & \\
\hline $\mathrm{F}(000)$ & 2058 & \\
\hline Crystal size & $0.250 \times 0.180 \times 0$. & \\
\hline Theta range for data collection & 1.976 to $69.963^{\circ}$ & \\
\hline Index ranges & $\begin{array}{l}-29<=\mathrm{h}<=29,- \\
<=1<=30\end{array}$ & $<=13,-29$ \\
\hline Reflections collected & 53024 & \\
\hline Independent reflections & $21653[\mathrm{R}($ int $)=0$. & \\
\hline Completeness to theta $=67.679^{\circ}$ & $99.5 \%$ & \\
\hline Absorption correction & Semi-empirical frc & divalents \\
\hline Max. and min. transmission & 0.7533 and 0.6466 & \\
\hline Refinement method & Full-matrix least-s & on $\mathrm{F} 2$ \\
\hline Data / restraints / parameters & $21653 / 1557 / 15$ & \\
\hline Goodness-of-fit on F2 & 1.067 & \\
\hline Final $R$ indices $[\mathrm{I}>2 \sigma(\mathrm{I})]$ & $\mathrm{R} 1=0.0643, \omega \mathrm{R} 2$ & 762 \\
\hline $\mathrm{R}$ indices (all data) & $\mathrm{R} 1=0.0704, \omega \mathrm{R} 2$ & 825 \\
\hline Absolute structure parameter & $0.03(3)$ & \\
\hline Extinction coefficient & $\mathrm{n} / \mathrm{a}$ & \\
\hline Largest diff. peak and hole & 1.185 and $-0.421 \epsilon$ & \\
\hline
\end{tabular}

Table S15. Atomic coordinates $\left(\mathrm{x10}^{4}\right)$ and equivalent isotropic displacement parameters $\left(\AA^{2} \times 10^{3}\right)$ for $\mathrm{C}_{53} \mathrm{H}_{71} \mathrm{BCuF}_{3} \mathrm{~N}_{2} \mathrm{O}_{3} \mathrm{Si}$. $\mathrm{U}(\mathrm{eq})$ is defined as one third of the trace of the orthogonalized Uij tensor

\begin{tabular}{lllll}
\hline & $\mathrm{x}$ & $\mathrm{y}$ & $\mathrm{z}$ & $\mathrm{U}(\mathrm{eq})$ \\
\hline $\mathrm{Cu}(1)$ & $2645(1)$ & $8267(1)$ & $4991(1)$ & $27(1)$ \\
$\mathrm{Si}(1)$ & $2070(1)$ & $5345(1)$ & $6686(1)$ & $27(1)$ \\
\hline
\end{tabular}




\begin{tabular}{|c|c|c|c|c|}
\hline$C(28)$ & $2888(7)$ & $6096(10)$ & $4490(5)$ & $46(3)$ \\
\hline$C(29)$ & $2840(4)$ & $6539(6)$ & $5036(3)$ & $29(1)$ \\
\hline $\mathrm{F}(1)$ & $3063(3)$ & $4925(5)$ & $4502(3)$ & $58(2)$ \\
\hline $\mathrm{F}(2)$ & $3283(4)$ & $6762(7)$ & $4343(4)$ & $63(2)$ \\
\hline$F(3)$ & $2369(3)$ & $6172(6)$ & $4014(3)$ & $53(2)$ \\
\hline $\mathrm{B}(1)$ & $1808(4)$ & $5400(7)$ & $4770(3)$ & $29(2)$ \\
\hline $\mathrm{O}(2)$ & $1663(3)$ & $4345(6)$ & $4461(3)$ & $51(2)$ \\
\hline $\mathrm{O}(3)$ & $1328(2)$ & $6167(5)$ & $4640(2)$ & $40(1)$ \\
\hline$C(38)$ & $976(7)$ & $4400(13)$ & $4106(6)$ & $40(3)$ \\
\hline$C(39)$ & $811(7)$ & $5715(13)$ & $4149(5)$ & $34(3)$ \\
\hline $\mathrm{C}(40)$ & $840(8)$ & $4023(16)$ & $3476(6)$ & $53(4)$ \\
\hline $\mathrm{C}(41)$ & $735(7)$ & $3521(19)$ & $4424(8)$ & $60(5)$ \\
\hline$C(42)$ & $224(7)$ & $5918(18)$ & $4241(8)$ & $60(4)$ \\
\hline$C(43)$ & $797(10)$ & $6522(18)$ & $3643(7)$ & $59(4)$ \\
\hline $\mathrm{C}(28 \mathrm{X})$ & $2711(13)$ & $6130(20)$ & $4374(12)$ & $35(6)$ \\
\hline$C(29 X)$ & $2454(11)$ & $6586(19)$ & 4792(9) & $31(4)$ \\
\hline$F(1 X)$ & $2617(11)$ & $4942(13)$ & $4236(8)$ & $60(4)$ \\
\hline$F(2 X)$ & $3320(8)$ & $6270(20)$ & $4574(8)$ & $57(4)$ \\
\hline$F(3 X)$ & $2490(9)$ & $6696(19)$ & $3863(6)$ & $55(5)$ \\
\hline$B(1 X)$ & $3248(8)$ & $5368(19)$ & $5647(9)$ & $36(4)$ \\
\hline $\mathrm{O}(2 \mathrm{X})$ & $3673(7)$ & $6040(14)$ & $6091(7)$ & $41(3)$ \\
\hline $\mathrm{O}(3 \mathrm{X})$ & $3513(7)$ & $4362(17)$ & $5515(8)$ & $50(4)$ \\
\hline $\mathrm{C}(38 \mathrm{X})$ & $4296(8)$ & $5540(20)$ & $6203(8)$ & $46(4)$ \\
\hline$C(39 X)$ & $4139(9)$ & $4300(20)$ & $5951(10)$ & $53(4)$ \\
\hline$C(40 X)$ & $4619(14)$ & $6240(30)$ & $5867(11)$ & $61(5)$ \\
\hline$C(41 X)$ & $4681(14)$ & $5630(40)$ & $6835(10)$ & $73(6)$ \\
\hline$C(42 X)$ & $4502(16)$ & $3830(30)$ & $5601(18)$ & $79(10)$ \\
\hline$C(43 X)$ & $4046(10)$ & $3390(20)$ & $6337(13)$ & $56(6)$ \\
\hline $\mathrm{C}(38 \mathrm{Y})$ & $1123(12)$ & $4270(20)$ & $4082(11)$ & $46(4)$ \\
\hline $\mathrm{C}(39 \mathrm{Y})$ & $857(14)$ & $5440(30)$ & $4200(14)$ & $53(4)$ \\
\hline $\mathrm{C}(40 \mathrm{Y})$ & $1216(14)$ & $4350(30)$ & $3510(10)$ & $61(5)$ \\
\hline$C(41 Y)$ & $819(18)$ & $3120(30)$ & $4112(16)$ & $78(9)$ \\
\hline $\mathrm{C}(42 \mathrm{Y})$ & $501(11)$ & $5250(30)$ & $4589(10)$ & $62(7)$ \\
\hline $\mathrm{C}(43 \mathrm{Y})$ & $524(16)$ & $6240(30)$ & $3687(12)$ & $73(6)$ \\
\hline $\mathrm{O}(1)$ & 2193(2) & $5264(4)$ & $6073(2)$ & $33(1)$ \\
\hline $\mathrm{N}(1)$ & $2414(2)$ & $10684(4)$ & $5363(2)$ & $27(1)$ \\
\hline $\mathrm{N}(2)$ & $2700(2)$ & $10772(4)$ & $4650(2)$ & $30(1)$ \\
\hline$C(1)$ & $2581(2)$ & $9985(4)$ & $5009(2)$ & $25(1)$ \\
\hline$C(2)$ & $2420(3)$ & 11894(5) & $5233(3)$ & $39(1)$ \\
\hline$C(3)$ & $2597(3)$ & $11962(5)$ & $4779(3)$ & $40(1)$ \\
\hline
\end{tabular}




\begin{tabular}{|c|c|c|c|c|}
\hline$C(4)$ & $2279(2)$ & $10191(5)$ & $5836(2)$ & $29(1)$ \\
\hline$C(5)$ & $2758(2)$ & $9864(5)$ & $6355(2)$ & $31(1)$ \\
\hline$C(6)$ & $2624(3)$ & $9345(6)$ & $6801(2)$ & $40(1)$ \\
\hline$C(7)$ & $2037(3)$ & $9187(6)$ & $6737(3)$ & $47(2)$ \\
\hline$C(8)$ & 1571(3) & $9520(6)$ & $6225(3)$ & $44(1)$ \\
\hline$C(9)$ & $1680(3)$ & $10020(6)$ & $5765(3)$ & $36(1)$ \\
\hline$C(10)$ & $3409(3)$ & $10047(6)$ & $6437(2)$ & $36(1)$ \\
\hline$C(11)$ & $3730(3)$ & $8836(7)$ & $6503(3)$ & $51(2)$ \\
\hline$C(12)$ & $3729(3)$ & $10871(7)$ & $6957(3)$ & $48(2)$ \\
\hline$C(13)$ & $1176(3)$ & $10293(6)$ & $5175(3)$ & $44(1)$ \\
\hline$C(14)$ & $604(3)$ & $10762(9)$ & $5244(4)$ & $71(3)$ \\
\hline$C(15)$ & $1044(3)$ & $9168(8)$ & $4789(3)$ & $53(2)$ \\
\hline$C(16)$ & $2897(2)$ & $10379(5)$ & $4198(2)$ & $30(1)$ \\
\hline$C(17)$ & $2454(3)$ & $10022(5)$ & $3656(2)$ & $35(1)$ \\
\hline$C(18)$ & $2649(3)$ & $9565(6)$ & $3242(3)$ & $41(1)$ \\
\hline$C(19)$ & $3250(3)$ & $9443(6)$ & $3353(3)$ & $48(1)$ \\
\hline$C(20)$ & $3672(3)$ & $9803(6)$ & $3879(3)$ & $45(1)$ \\
\hline$C(21)$ & $3504(3)$ & $10303(6)$ & $4323(3)$ & $41(1)$ \\
\hline$C(22)$ & $1792(3)$ & $10128(6)$ & $3541(2)$ & $40(1)$ \\
\hline$C(23)$ & $1499(5)$ & $8864(11)$ & $3500(5)$ & $48(3)$ \\
\hline$C(24)$ & $1430(5)$ & $10836(16)$ & $2976(6)$ & $62(5)$ \\
\hline$C(26)$ & $4330(10)$ & $11820(20)$ & 4853(9) & $81(5)$ \\
\hline$C(27)$ & $4327(13)$ & $9670(30)$ & $5239(14)$ & $79(7)$ \\
\hline$C(22 X)$ & $1792(3)$ & $10128(6)$ & $3541(2)$ & $40(1)$ \\
\hline$C(23 X)$ & $1474(12)$ & $9169(18)$ & $3085(10)$ & $68(7)$ \\
\hline$C(24 X)$ & 1591(8) & $11390(14)$ & $3295(9)$ & $44(4)$ \\
\hline$C(26 X)$ & $4530(14)$ & $11110(40)$ & $4807(11)$ & $80(10)$ \\
\hline$C(27 X)$ & $4201(15)$ & $9360(30)$ & $5274(18)$ & $47(6)$ \\
\hline$C(25)$ & $3962(3)$ & $10683(8)$ & $4918(3)$ & $52(2)$ \\
\hline$C(30)$ & 2481(3) & $5671(5)$ & $5266(2)$ & $34(1)$ \\
\hline$C(31)$ & 2391(2) & $6198(5)$ & $5790(2)$ & $27(1)$ \\
\hline$C(32)$ & $1359(2)$ & $6223(5)$ & $6542(2)$ & $33(1)$ \\
\hline$C(33)$ & $999(3)$ & $6541(6)$ & $5965(3)$ & $44(1)$ \\
\hline$C(34)$ & $463(3)$ & $7169(7)$ & $5837(3)$ & $53(2)$ \\
\hline$C(35)$ & $267(3)$ & $7471(7)$ & $6270(4)$ & $58(2)$ \\
\hline$C(36)$ & $604(3)$ & $7154(7)$ & $6839(4)$ & $54(2)$ \\
\hline$C(37)$ & $1144(3)$ & $6537(6)$ & $6969(3)$ & $42(1)$ \\
\hline$C(44)$ & $2734(3)$ & $6031(5)$ & $7288(2)$ & $34(1)$ \\
\hline$C(45)$ & 2704(3) & $6710(7)$ & $7739(3)$ & $54(2)$ \\
\hline $\mathrm{C}(46)$ & $3205(4)$ & $7162(8)$ & $8174(4)$ & $66(2)$ \\
\hline
\end{tabular}




\begin{tabular}{|c|c|c|c|c|}
\hline$C(47)$ & $3752(3)$ & $6946(7)$ & $8180(3)$ & $57(2)$ \\
\hline$C(48)$ & $3805(3)$ & $6318(9)$ & $7720(3)$ & $61(2)$ \\
\hline $\mathrm{C}(49)$ & $3300(3)$ & $5845(8)$ & $7278(3)$ & $52(2)$ \\
\hline $\mathrm{C}(50)$ & $1965(3)$ & $3730(5)$ & $6861(2)$ & $34(1)$ \\
\hline $\mathrm{C}(51)$ & 2527(3) & $2999(6)$ & $6952(3)$ & $45(1)$ \\
\hline$C(52)$ & $1448(3)$ & $3175(6)$ & $6345(3)$ & $52(2)$ \\
\hline$C(53)$ & $1824(4)$ & $3647(7)$ & $7420(3)$ & $59(2)$ \\
\hline $\mathrm{Cu}(2)$ & $7702(1)$ & $5999(1)$ & $5301(1)$ & $34(1)$ \\
\hline $\operatorname{Si}(2)$ & $5866(1)$ & $8907(1)$ & $3498(1)$ & $37(1)$ \\
\hline $\mathrm{C}(81)$ & $8193(5)$ & $8167(8)$ & $5888(5)$ & $43(2)$ \\
\hline $\mathrm{C}(82)$ & $7628(3)$ & $7700(7)$ & $5459(3)$ & $33(2)$ \\
\hline $\mathrm{F}(4)$ & $8660(3)$ & $8121(5)$ & $5708(3)$ & $51(1)$ \\
\hline$F(5)$ & $8186(3)$ & $9365(4)$ & $6034(2)$ & $53(1)$ \\
\hline$F(6)$ & $8396(4)$ & $7559(7)$ & $6402(3)$ & $65(2)$ \\
\hline $\mathrm{B}(2)$ & $7802(3)$ & $8856(6)$ & $4596(3)$ & $28(1)$ \\
\hline $\mathrm{O}(5)$ & $7974(2)$ & $8059(5)$ & $4269(2)$ & $36(1)$ \\
\hline $\mathrm{O}(6)$ & $8039(3)$ & $9980(5)$ & $4616(3)$ & $46(1)$ \\
\hline $\mathrm{C}(91)$ & $8443(8)$ & $8659(16)$ & $4100(8)$ & $36(4)$ \\
\hline $\mathrm{C}(92)$ & $8302(8)$ & $10024(15)$ & $4143(9)$ & $44(4)$ \\
\hline $\mathrm{C}(93)$ & $9081(7)$ & $8360(20)$ & $4569(9)$ & $64(5)$ \\
\hline $\mathrm{C}(94)$ & $8393(9)$ & $8258(15)$ & $3533(8)$ & $55(4)$ \\
\hline $\mathrm{C}(95)$ & $7854(7)$ & $10502(18)$ & $3596(9)$ & $64(4)$ \\
\hline $\mathrm{C}(96)$ & $8813(8)$ & $10903(14)$ & $4349(9)$ & $53(4)$ \\
\hline $\mathrm{C}(81 \mathrm{X})$ & $8379(13)$ & $8210(30)$ & $5783(14)$ & $50(7)$ \\
\hline$C(82 X)$ & $7915(10)$ & $7830(20)$ & $5222(12)$ & $46(6)$ \\
\hline$F(4 X)$ & $8547(9)$ & $9399(16)$ & $5805(11)$ & $66(5)$ \\
\hline$F(5 X)$ & $8234(11)$ & $8010(30)$ & $6265(13)$ & $62(6)$ \\
\hline$F(6 X)$ & $8891(9)$ & $7580(30)$ & $5909(13)$ & $85(8)$ \\
\hline $\mathrm{B}(2 \mathrm{X})$ & $7099(11)$ & $8950(20)$ & $5493(12)$ & $40(5)$ \\
\hline $\mathrm{O}(5 \mathrm{X})$ & $7221(9)$ & 9991(17) & $5840(9)$ & $50(5)$ \\
\hline$O(6 X)$ & $6726(11)$ & $8210(20)$ & $5627(10)$ & $60(6)$ \\
\hline $\mathrm{C}(91 \mathrm{X})$ & $6812(9)$ & $10100(20)$ & $6147(9)$ & $39(4)$ \\
\hline $\mathrm{C}(92 \mathrm{X})$ & $6621(12)$ & $8700(20)$ & $6147(11)$ & $58(5)$ \\
\hline$C(93 X)$ & $6258(15)$ & $10730(40)$ & $5716(14)$ & $75(12)$ \\
\hline $\mathrm{C}(94 \mathrm{X})$ & $7132(18)$ & $10430(30)$ & $6733(12)$ & $70(4)$ \\
\hline$C(95 X)$ & $5997(12)$ & $8530(30)$ & $6017(15)$ & $61(8)$ \\
\hline$C(96 X)$ & $6944(18)$ & $7940(30)$ & $6655(13)$ & $70(4)$ \\
\hline $\mathrm{C}(91 \mathrm{Y})$ & $8249(12)$ & $8810(30)$ & $3960(11)$ & $40(5)$ \\
\hline $\mathrm{C}(92 \mathrm{Y})$ & $8476(13)$ & $9880(30)$ & $4374(11)$ & $47(5)$ \\
\hline C(93Y) & $8771(11)$ & $8030(20)$ & $3920(11)$ & $50(5)$ \\
\hline
\end{tabular}




\begin{tabular}{|c|c|c|c|c|}
\hline $\mathrm{C}(94 \mathrm{Y})$ & $7821(10)$ & $9190(40)$ & $3359(10)$ & $77(9)$ \\
\hline $\mathrm{C}(95 \mathrm{Y})$ & $9090(10)$ & $9630(30)$ & $4869(12)$ & $72(7)$ \\
\hline $\mathrm{C}(96 \mathrm{Y})$ & $8413(17)$ & $11080(30)$ & $4076(13)$ & $70(4)$ \\
\hline $\mathrm{O}(4)$ & $6498(2)$ & $8876(4)$ & $4059(2)$ & $48(1)$ \\
\hline $\mathrm{N}(3)$ & $7275(2)$ & $3596(4)$ & $4823(2)$ & $32(1)$ \\
\hline $\mathrm{N}(4)$ & $8102(2)$ & $3502(4)$ & $5560(2)$ & $33(1)$ \\
\hline$C(54)$ & $7693(3)$ & $4296(5)$ & $5219(2)$ & $32(1)$ \\
\hline$C(55)$ & $7428(3)$ & $2370(5)$ & $4911(3)$ & $43(1)$ \\
\hline$C(56)$ & $7945(3)$ & $2326(6)$ & $5373(3)$ & $44(1)$ \\
\hline$C(57)$ & $6754(2)$ & $4070(5)$ & $4361(3)$ & $33(1)$ \\
\hline$C(58)$ & $6781(3)$ & $4254(6)$ & $3806(3)$ & $40(1)$ \\
\hline$C(59)$ & $6276(3)$ & $4716(7)$ & $3370(3)$ & $52(2)$ \\
\hline$C(60)$ & $5756(3)$ & $4953(6)$ & $3476(3)$ & $54(2)$ \\
\hline$C(61)$ & $5749(3)$ & $4773(6)$ & $4014(3)$ & $45(1)$ \\
\hline$C(62)$ & $6240(3)$ & $4301(5)$ & $4476(3)$ & $36(1)$ \\
\hline$C(63)$ & $7348(3)$ & $4022(7)$ & $3695(3)$ & $49(2)$ \\
\hline$C(64)$ & $7705(3)$ & $5191(8)$ & $3776(4)$ & $58(2)$ \\
\hline$C(65)$ & $7217(5)$ & $3516(9)$ & $3082(4)$ & $69(2)$ \\
\hline$C(66)$ & $6219(3)$ & $4114(6)$ & $5077(3)$ & $44(1)$ \\
\hline$C(67)$ & $5666(5)$ & $3444(11)$ & $5057(5)$ & $80(3)$ \\
\hline$C(68)$ & $6260(4)$ & $5329(8)$ & $5386(4)$ & $60(2)$ \\
\hline$C(69)$ & $8643(2)$ & $3881(5)$ & $6038(3)$ & $35(1)$ \\
\hline$C(70)$ & $8631(3)$ & $4005(7)$ & $6592(3)$ & $49(1)$ \\
\hline $\mathrm{C}(71)$ & $9164(4)$ & $4410(9)$ & $7032(3)$ & $63(2)$ \\
\hline$C(72)$ & $9662(3)$ & $4634(8)$ & $6920(3)$ & $58(2)$ \\
\hline$C(73)$ & $9656(3)$ & $4494(6)$ & $6364(3)$ & $47(2)$ \\
\hline$C(74)$ & $9147(3)$ & $4101(6)$ & $5910(3)$ & $40(1)$ \\
\hline$C(75)$ & $8069(4)$ & $3756(10)$ & $6710(3)$ & $67(2)$ \\
\hline$C(76)$ & $7820(20)$ & $4790(20)$ & $6940(20)$ & $94(7)$ \\
\hline$C(77)$ & $8090(10)$ & $2515(18)$ & $6978(10)$ & $83(4)$ \\
\hline$C(76 X)$ & $7850(30)$ & $5030(30)$ & $6780(30)$ & $94(7)$ \\
\hline$C(77 X)$ & $8244(12)$ & $3020(30)$ & $7280(11)$ & $83(4)$ \\
\hline $\mathrm{C}(78)$ & $9133(3)$ & $4016(7)$ & $5290(3)$ & $50(2)$ \\
\hline$C(79)$ & $9669(4)$ & $3310(11)$ & $5269(5)$ & $83(3)$ \\
\hline $\mathrm{C}(80)$ & $9125(3)$ & $5255(9)$ & $5028(3)$ & $64(2)$ \\
\hline$C(83)$ & $7372(3)$ & $8562(5)$ & $4932(3)$ & $36(1)$ \\
\hline $\mathrm{C}(84)$ & $6810(3)$ & $7976(6)$ & $4479(2)$ & $37(1)$ \\
\hline$C(85)$ & $5267(3)$ & $8056(6)$ & $3641(3)$ & $41(1)$ \\
\hline$C(86)$ & $4809(3)$ & $7454(6)$ & $3197(3)$ & $50(2)$ \\
\hline $\mathrm{C}(87)$ & $4363(3)$ & $6825(7)$ & $3299(4)$ & $63(2)$ \\
\hline
\end{tabular}




\begin{tabular}{lllll}
\hline $\mathrm{C}(88)$ & $4367(4)$ & $6769(8)$ & $3858(5)$ & $70(2)$ \\
$\mathrm{C}(89)$ & $4818(4)$ & $7337(9)$ & $4304(5)$ & $71(2)$ \\
$\mathrm{C}(90)$ & $5263(3)$ & $7979(7)$ & $4203(4)$ & $57(2)$ \\
$\mathrm{C}(97)$ & $5981(3)$ & $8233(6)$ & $2851(3)$ & $48(1)$ \\
$\mathrm{C}(98)$ & $6526(5)$ & $7655(10)$ & $2921(4)$ & $74(3)$ \\
$\mathrm{C}(99)$ & $6641(6)$ & $7140(12)$ & $2466(5)$ & $93(3)$ \\
$\mathrm{C}(100)$ & $6222(6)$ & $7174(11)$ & $1906(5)$ & $87(3)$ \\
$\mathrm{C}(101)$ & $5681(5)$ & $7723(14)$ & $1799(5)$ & $94(3)$ \\
$\mathrm{C}(102)$ & $5563(4)$ & $8239(13)$ & $2261(4)$ & $85(3)$ \\
$\mathrm{C}(103)$ & $5687(3)$ & $10572(6)$ & $3390(3)$ & $47(2)$ \\
$\mathrm{C}(104)$ & $6171(3)$ & $11208(7)$ & $3247(4)$ & $61(2)$ \\
$\mathrm{C}(105)$ & $5078(4)$ & $10808(8)$ & $2880(5)$ & $80(3)$ \\
$\mathrm{C}(106)$ & $5661(4)$ & $11099(7)$ & $3943(4)$ & $65(2)$ \\
$\mathrm{C}(1 \mathrm{~S})$ & $9024(17)$ & $13070(30)$ & $3246(16)$ & $140(12)$ \\
$\mathrm{C}(2 S)$ & $9237(12)$ & $12520(20)$ & $2855(11)$ & $96(7)$ \\
$\mathrm{C}(3 S)$ & $9327(19)$ & $11280(30)$ & $2851(16)$ & $141(12)$ \\
$\mathrm{C}(4 S)$ & $9513(11)$ & $10660(20)$ & $2420(10)$ & $91(6)$ \\
$\mathrm{C}(5 \mathrm{~S})$ & $9650(30)$ & $9500(40)$ & $2390(20)$ & $210(20)$ \\
$\mathrm{C}(6 \mathrm{~S})$ & $9691(12)$ & $8960(20)$ & $1911(12)$ & $96(7)$ \\
\hline
\end{tabular}

Table S16. Bond lengths $[\AA \AA]$ and angles $\left[{ }^{\circ}\right]$ for $\mathrm{C}_{53} \mathrm{H}_{71} \mathrm{BCuF}_{3} \mathrm{~N}_{2} \mathrm{O}_{3} \mathrm{Si}$

\begin{tabular}{ll}
\hline $\mathrm{Cu}(1)-\mathrm{C}(1)$ & $1.908(5)$ \\
$\mathrm{Cu}(1)-\mathrm{C}(29)$ & $1.962(7)$ \\
$\mathrm{Si}(1)-\mathrm{O}(1)$ & $1.652(4)$ \\
$\mathrm{Si}(1)-\mathrm{C}(50)$ & $1.878(6)$ \\
$\mathrm{Si}(1)-\mathrm{C}(44)$ & $1.885(6)$ \\
$\mathrm{Si}(1)-\mathrm{C}(32)$ & $1.886(6)$ \\
$\mathrm{C}(28)-\mathrm{F}(3)$ & $1.356(15)$ \\
$\mathrm{C}(28)-\mathrm{F}(1)$ & $1.360(12)$ \\
$\mathrm{C}(28)-\mathrm{F}(2)$ & $1.363(13)$ \\
$\mathrm{C}(28)-\mathrm{C}(29)$ & $1.480(11)$ \\
$\mathrm{C}(29)-\mathrm{C}(30)$ & $1.540(8)$ \\
$\mathrm{C}(29)-\mathrm{H}(29)$ & 1.0000 \\
$\mathrm{~B}(1)-\mathrm{O}(2)$ & $1.365(10)$ \\
$\mathrm{B}(1)-\mathrm{O}(3)$ & $1.373(10)$ \\
$\mathrm{B}(1)-\mathrm{C}(30)$ & $1.649(10)$ \\
$\mathrm{O}(2)-\mathrm{C}(38)$ & $1.556(17)$ \\
$\mathrm{O}(3)-\mathrm{C}(39)$ & $1.458(14)$ \\
$\mathrm{C}(38)-\mathrm{C}(41)$ & $1.503(17)$ \\
$\mathrm{C}(38)-\mathrm{C}(40)$ & $1.522(16)$ \\
\hline
\end{tabular}




\begin{tabular}{|c|c|}
\hline $\mathrm{C}(38)-\mathrm{C}(39)$ & $1.523(18)$ \\
\hline$C(39)-C(43)$ & $1.526(18)$ \\
\hline$C(39)-C(42)$ & $1.538(18)$ \\
\hline $\mathrm{C}(40)-\mathrm{H}(40 \mathrm{~A})$ & 0.9800 \\
\hline $\mathrm{C}(40)-\mathrm{H}(40 \mathrm{~B})$ & 0.9800 \\
\hline $\mathrm{C}(40)-\mathrm{H}(40 \mathrm{C})$ & 0.9800 \\
\hline $\mathrm{C}(41)-\mathrm{H}(41 \mathrm{~A})$ & 0.9800 \\
\hline $\mathrm{C}(41)-\mathrm{H}(41 \mathrm{~B})$ & 0.9800 \\
\hline $\mathrm{C}(41)-\mathrm{H}(41 \mathrm{C})$ & 0.9800 \\
\hline $\mathrm{C}(42)-\mathrm{H}(42 \mathrm{~A})$ & 0.9800 \\
\hline $\mathrm{C}(42)-\mathrm{H}(42 \mathrm{~B})$ & 0.9800 \\
\hline $\mathrm{C}(42)-\mathrm{H}(42 \mathrm{C})$ & 0.9800 \\
\hline $\mathrm{C}(43)-\mathrm{H}(43 \mathrm{~A})$ & 0.9800 \\
\hline $\mathrm{C}(43)-\mathrm{H}(43 \mathrm{~B})$ & 0.9800 \\
\hline $\mathrm{C}(43)-\mathrm{H}(43 \mathrm{C})$ & 0.9800 \\
\hline $\mathrm{O}(1)-\mathrm{C}(31)$ & $1.429(6)$ \\
\hline $\mathrm{N}(1)-\mathrm{C}(1)$ & $1.341(7)$ \\
\hline $\mathrm{N}(1)-\mathrm{C}(2)$ & $1.378(8)$ \\
\hline $\mathrm{N}(1)-\mathrm{C}(4)$ & $1.435(6)$ \\
\hline $\mathrm{N}(2)-\mathrm{C}(1)$ & $1.349(7)$ \\
\hline $\mathrm{N}(2)-\mathrm{C}(3)$ & $1.399(8)$ \\
\hline $\mathrm{N}(2)-\mathrm{C}(16)$ & $1.438(7)$ \\
\hline$C(2)-C(3)$ & $1.346(9)$ \\
\hline $\mathrm{C}(2)-\mathrm{H}(2)$ & 0.9500 \\
\hline $\mathrm{C}(3)-\mathrm{H}(3)$ & 0.9500 \\
\hline$C(4)-C(9)$ & $1.405(8)$ \\
\hline$C(4)-C(5)$ & $1.408(8)$ \\
\hline$C(5)-C(6)$ & $1.386(8)$ \\
\hline$C(5)-C(10)$ & $1.522(8)$ \\
\hline$C(6)-C(7)$ & $1.379(10)$ \\
\hline $\mathrm{C}(6)-\mathrm{H}(6)$ & 0.9500 \\
\hline$C(7)-C(8)$ & $1.385(11)$ \\
\hline $\mathrm{C}(7)-\mathrm{H}(7)$ & 0.9500 \\
\hline $\mathrm{C}(8)-\mathrm{C}(9)$ & $1.376(9)$ \\
\hline $\mathrm{C}(8)-\mathrm{H}(8)$ & 0.9500 \\
\hline$C(9)-C(13)$ & $1.532(9)$ \\
\hline$C(10)-C(12)$ & $1.524(8)$ \\
\hline$C(10)-C(11)$ & $1.525(9)$ \\
\hline $\mathrm{C}(10)-\mathrm{H}(10)$ & 1.0000 \\
\hline $\mathrm{C}(11)-\mathrm{H}(11 \mathrm{~A})$ & 0.9800 \\
\hline
\end{tabular}




\begin{tabular}{|c|c|}
\hline $\mathrm{C}(11)-\mathrm{H}(11 \mathrm{~B})$ & 0.9800 \\
\hline $\mathrm{C}(11)-\mathrm{H}(11 \mathrm{C})$ & 0.9800 \\
\hline $\mathrm{C}(12)-\mathrm{H}(12 \mathrm{~A})$ & 0.9800 \\
\hline $\mathrm{C}(12)-\mathrm{H}(12 \mathrm{~B})$ & 0.9800 \\
\hline $\mathrm{C}(12)-\mathrm{H}(12 \mathrm{C})$ & 0.9800 \\
\hline$C(13)-C(15)$ & $1.525(9)$ \\
\hline$C(13)-C(14)$ & $1.548(10)$ \\
\hline $\mathrm{C}(13)-\mathrm{H}(13)$ & 1.0000 \\
\hline $\mathrm{C}(14)-\mathrm{H}(14 \mathrm{~A})$ & 0.9800 \\
\hline $\mathrm{C}(14)-\mathrm{H}(14 \mathrm{~B})$ & 0.9800 \\
\hline $\mathrm{C}(14)-\mathrm{H}(14 \mathrm{C})$ & 0.9800 \\
\hline $\mathrm{C}(15)-\mathrm{H}(15 \mathrm{~A})$ & 0.9800 \\
\hline $\mathrm{C}(15)-\mathrm{H}(15 \mathrm{~B})$ & 0.9800 \\
\hline $\mathrm{C}(15)-\mathrm{H}(15 \mathrm{C})$ & 0.9800 \\
\hline$C(16)-C(21)$ & $1.381(8)$ \\
\hline$C(16)-C(17)$ & $1.417(8)$ \\
\hline$C(17)-C(18)$ & $1.375(8)$ \\
\hline$C(17)-C(22)$ & $1.520(9)$ \\
\hline$C(18)-C(19)$ & $1.379(10)$ \\
\hline $\mathrm{C}(18)-\mathrm{H}(18)$ & 0.9500 \\
\hline$C(19)-C(20)$ & $1.371(11)$ \\
\hline $\mathrm{C}(19)-\mathrm{H}(19)$ & 0.9500 \\
\hline$C(20)-C(21)$ & $1.419(9)$ \\
\hline $\mathrm{C}(20)-\mathrm{H}(20)$ & 0.9500 \\
\hline$C(21)-C(25)$ & $1.525(9)$ \\
\hline$C(22)-C(24)$ & $1.549(11)$ \\
\hline$C(22)-C(23)$ & $1.554(12)$ \\
\hline $\mathrm{C}(22)-\mathrm{H}(22)$ & 1.0000 \\
\hline $\mathrm{C}(23)-\mathrm{H}(23 \mathrm{~A})$ & 0.9800 \\
\hline $\mathrm{C}(23)-\mathrm{H}(23 \mathrm{~B})$ & 0.9800 \\
\hline $\mathrm{C}(23)-\mathrm{H}(23 \mathrm{C})$ & 0.9800 \\
\hline $\mathrm{C}(24)-\mathrm{H}(24 \mathrm{~A})$ & 0.9800 \\
\hline $\mathrm{C}(24)-\mathrm{H}(24 \mathrm{~B})$ & 0.9800 \\
\hline $\mathrm{C}(24)-\mathrm{H}(24 \mathrm{C})$ & 0.9800 \\
\hline $\mathrm{C}(26)-\mathrm{C}(25)$ & $1.580(18)$ \\
\hline $\mathrm{C}(26)-\mathrm{H}(26 \mathrm{~A})$ & 0.9800 \\
\hline $\mathrm{C}(26)-\mathrm{H}(26 \mathrm{~B})$ & 0.9800 \\
\hline $\mathrm{C}(26)-\mathrm{H}(26 \mathrm{C})$ & 0.9800 \\
\hline$C(27)-C(25)$ & $1.46(2)$ \\
\hline $\mathrm{C}(27)-\mathrm{H}(27 \mathrm{~A})$ & 0.9800 \\
\hline
\end{tabular}




\begin{tabular}{|c|c|}
\hline $\mathrm{C}(27)-\mathrm{H}(27 \mathrm{~B})$ & 0.9800 \\
\hline $\mathrm{C}(27)-\mathrm{H}(27 \mathrm{C})$ & 0.9800 \\
\hline $\mathrm{C}(25)-\mathrm{H}(25)$ & 1.0000 \\
\hline$C(30)-C(31)$ & $1.510(7)$ \\
\hline $\mathrm{C}(30)-\mathrm{H}(30)$ & 1.0000 \\
\hline $\mathrm{C}(31)-\mathrm{H}(31 \mathrm{~A})$ & 0.9900 \\
\hline $\mathrm{C}(31)-\mathrm{H}(31 \mathrm{~B})$ & 0.9900 \\
\hline $\mathrm{C}(32)-\mathrm{C}(37)$ & $1.388(8)$ \\
\hline$C(32)-C(33)$ & $1.403(9)$ \\
\hline $\mathrm{C}(33)-\mathrm{C}(34)$ & $1.396(10)$ \\
\hline $\mathrm{C}(33)-\mathrm{H}(33)$ & 0.9500 \\
\hline$C(34)-C(35)$ & $1.366(12)$ \\
\hline $\mathrm{C}(34)-\mathrm{H}(34)$ & 0.9500 \\
\hline$C(35)-C(36)$ & $1.373(12)$ \\
\hline $\mathrm{C}(35)-\mathrm{H}(35)$ & 0.9500 \\
\hline$C(36)-C(37)$ & $1.397(10)$ \\
\hline $\mathrm{C}(36)-\mathrm{H}(36)$ & 0.9500 \\
\hline $\mathrm{C}(37)-\mathrm{H}(37)$ & 0.9500 \\
\hline$C(44)-C(45)$ & $1.367(9)$ \\
\hline$C(44)-C(49)$ & $1.393(9)$ \\
\hline$C(45)-C(46)$ & $1.371(11)$ \\
\hline $\mathrm{C}(45)-\mathrm{H}(45)$ & 0.9500 \\
\hline$C(46)-C(47)$ & $1.340(12)$ \\
\hline $\mathrm{C}(46)-\mathrm{H}(46)$ & 0.9500 \\
\hline$C(47)-C(48)$ & $1.378(12)$ \\
\hline $\mathrm{C}(47)-\mathrm{H}(47)$ & 0.9500 \\
\hline$C(48)-C(49)$ & $1.394(10)$ \\
\hline $\mathrm{C}(48)-\mathrm{H}(48)$ & 0.9500 \\
\hline $\mathrm{C}(49)-\mathrm{H}(49)$ & 0.9500 \\
\hline$C(50)-C(51)$ & $1.524(9)$ \\
\hline$C(50)-C(52)$ & $1.532(9)$ \\
\hline$C(50)-C(53)$ & $1.547(8)$ \\
\hline $\mathrm{C}(51)-\mathrm{H}(51 \mathrm{~A})$ & 0.9800 \\
\hline $\mathrm{C}(51)-\mathrm{H}(51 \mathrm{~B})$ & 0.9800 \\
\hline $\mathrm{C}(51)-\mathrm{H}(51 \mathrm{C})$ & 0.9800 \\
\hline $\mathrm{C}(52)-\mathrm{H}(52 \mathrm{~A})$ & 0.9800 \\
\hline $\mathrm{C}(52)-\mathrm{H}(52 \mathrm{~B})$ & 0.9800 \\
\hline $\mathrm{C}(52)-\mathrm{H}(52 \mathrm{C})$ & 0.9800 \\
\hline $\mathrm{C}(53)-\mathrm{H}(53 \mathrm{~A})$ & 0.9800 \\
\hline $\mathrm{C}(53)-\mathrm{H}(53 \mathrm{~B})$ & 0.9800 \\
\hline
\end{tabular}




\begin{tabular}{|c|c|}
\hline $\mathrm{C}(53)-\mathrm{H}(53 \mathrm{C})$ & 0.9800 \\
\hline $\mathrm{Cu}(2)-\mathrm{C}(54)$ & $1.894(6)$ \\
\hline $\mathrm{Cu}(2)-\mathrm{C}(82)$ & $1.944(7)$ \\
\hline $\mathrm{Si}(2)-\mathrm{O}(4)$ & $1.626(4)$ \\
\hline $\operatorname{Si}(2)-C(85)$ & $1.869(6)$ \\
\hline $\mathrm{Si}(2)-\mathrm{C}(97)$ & $1.878(8)$ \\
\hline $\operatorname{Si}(2)-C(103)$ & $1.888(7)$ \\
\hline $\mathrm{C}(81)-\mathrm{F}(6)$ & $1.353(11)$ \\
\hline$C(81)-F(4)$ & $1.364(14)$ \\
\hline $\mathrm{C}(81)-\mathrm{F}(5)$ & $1.375(10)$ \\
\hline $\mathrm{C}(81)-\mathrm{C}(82)$ & $1.467(11)$ \\
\hline $\mathrm{C}(82)-\mathrm{C}(83)$ & $1.541(9)$ \\
\hline $\mathrm{C}(82)-\mathrm{H}(82)$ & 1.0000 \\
\hline $\mathrm{B}(2)-\mathrm{O}(6)$ & $1.362(9)$ \\
\hline $\mathrm{B}(2)-\mathrm{O}(5)$ & $1.363(9)$ \\
\hline $\mathrm{B}(2)-\mathrm{C}(83)$ & $1.593(10)$ \\
\hline $\mathrm{O}(5)-\mathrm{C}(91)$ & $1.503(19)$ \\
\hline $\mathrm{O}(6)-\mathrm{C}(92)$ & $1.53(2)$ \\
\hline $\mathrm{C}(91)-\mathrm{C}(94)$ & $1.43(2)$ \\
\hline $\mathrm{C}(91)-\mathrm{C}(92)$ & $1.56(2)$ \\
\hline $\mathrm{C}(91)-\mathrm{C}(93)$ & $1.57(2)$ \\
\hline$C(92)-C(95)$ & $1.47(2)$ \\
\hline $\mathrm{C}(92)-\mathrm{C}(96)$ & $1.50(2)$ \\
\hline $\mathrm{C}(93)-\mathrm{H}(93 \mathrm{~A})$ & 0.9800 \\
\hline $\mathrm{C}(93)-\mathrm{H}(93 \mathrm{~B})$ & 0.9800 \\
\hline $\mathrm{C}(93)-\mathrm{H}(93 \mathrm{C})$ & 0.9800 \\
\hline $\mathrm{C}(94)-\mathrm{H}(94 \mathrm{~A})$ & 0.9800 \\
\hline $\mathrm{C}(94)-\mathrm{H}(94 \mathrm{~B})$ & 0.9800 \\
\hline $\mathrm{C}(94)-\mathrm{H}(94 \mathrm{C})$ & 0.9800 \\
\hline $\mathrm{C}(95)-\mathrm{H}(95 \mathrm{~A})$ & 0.9800 \\
\hline $\mathrm{C}(95)-\mathrm{H}(95 \mathrm{~B})$ & 0.9800 \\
\hline $\mathrm{C}(95)-\mathrm{H}(95 \mathrm{C})$ & 0.9800 \\
\hline $\mathrm{C}(96)-\mathrm{H}(96 \mathrm{~A})$ & 0.9800 \\
\hline $\mathrm{C}(96)-\mathrm{H}(96 \mathrm{~B})$ & 0.9800 \\
\hline $\mathrm{C}(96)-\mathrm{H}(96 \mathrm{C})$ & 0.9800 \\
\hline $\mathrm{O}(4)-\mathrm{C}(84)$ & $1.428(7)$ \\
\hline $\mathrm{N}(3)-\mathrm{C}(54)$ & $1.351(7)$ \\
\hline $\mathrm{N}(3)-\mathrm{C}(55)$ & $1.401(8)$ \\
\hline $\mathrm{N}(3)-\mathrm{C}(57)$ & $1.438(7)$ \\
\hline $\mathrm{N}(4)-\mathrm{C}(54)$ & $1.351(8)$ \\
\hline
\end{tabular}




\begin{tabular}{|c|c|}
\hline $\mathrm{N}(4)-\mathrm{C}(56)$ & $1.385(8)$ \\
\hline $\mathrm{N}(4)-\mathrm{C}(69)$ & $1.450(7)$ \\
\hline$C(55)-C(56)$ & $1.333(9)$ \\
\hline $\mathrm{C}(55)-\mathrm{H}(55)$ & 0.9500 \\
\hline $\mathrm{C}(56)-\mathrm{H}(56)$ & 0.9500 \\
\hline$C(57)-C(62)$ & $1.402(8)$ \\
\hline$C(57)-C(58)$ & $1.410(9)$ \\
\hline$C(58)-C(59)$ & $1.381(10)$ \\
\hline$C(58)-C(63)$ & $1.519(9)$ \\
\hline$C(59)-C(60)$ & $1.405(12)$ \\
\hline $\mathrm{C}(59)-\mathrm{H}(59)$ & 0.9500 \\
\hline$C(60)-C(61)$ & $1.350(11)$ \\
\hline $\mathrm{C}(60)-\mathrm{H}(60)$ & 0.9500 \\
\hline$C(61)-C(62)$ & $1.397(9)$ \\
\hline $\mathrm{C}(61)-\mathrm{H}(61)$ & 0.9500 \\
\hline$C(62)-C(66)$ & $1.519(9)$ \\
\hline$C(63)-C(64)$ & $1.525(10)$ \\
\hline$C(63)-C(65)$ & $1.530(10)$ \\
\hline $\mathrm{C}(63)-\mathrm{H}(63)$ & 1.0000 \\
\hline $\mathrm{C}(64)-\mathrm{H}(64 \mathrm{~A})$ & 0.9800 \\
\hline $\mathrm{C}(64)-\mathrm{H}(64 \mathrm{~B})$ & 0.9800 \\
\hline $\mathrm{C}(64)-\mathrm{H}(64 \mathrm{C})$ & 0.9800 \\
\hline $\mathrm{C}(65)-\mathrm{H}(65 \mathrm{~A})$ & 0.9800 \\
\hline $\mathrm{C}(65)-\mathrm{H}(65 \mathrm{~B})$ & 0.9800 \\
\hline $\mathrm{C}(65)-\mathrm{H}(65 \mathrm{C})$ & 0.9800 \\
\hline $\mathrm{C}(66)-\mathrm{C}(67)$ & $1.513(10)$ \\
\hline$C(66)-C(68)$ & $1.530(10)$ \\
\hline $\mathrm{C}(66)-\mathrm{H}(66)$ & 1.0000 \\
\hline $\mathrm{C}(67)-\mathrm{H}(67 \mathrm{~A})$ & 0.9800 \\
\hline $\mathrm{C}(67)-\mathrm{H}(67 \mathrm{~B})$ & 0.9800 \\
\hline $\mathrm{C}(67)-\mathrm{H}(67 \mathrm{C})$ & 0.9800 \\
\hline $\mathrm{C}(68)-\mathrm{H}(68 \mathrm{~A})$ & 0.9800 \\
\hline $\mathrm{C}(68)-\mathrm{H}(68 \mathrm{~B})$ & 0.9800 \\
\hline $\mathrm{C}(68)-\mathrm{H}(68 \mathrm{C})$ & 0.9800 \\
\hline$C(69)-C(70)$ & $1.387(9)$ \\
\hline$C(69)-C(74)$ & $1.393(9)$ \\
\hline$C(70)-C(71)$ & $1.407(11)$ \\
\hline$C(70)-C(75)$ & $1.520(11)$ \\
\hline$C(71)-C(72)$ & $1.357(13)$ \\
\hline $\mathrm{C}(71)-\mathrm{H}(71)$ & 0.9500 \\
\hline
\end{tabular}




\begin{tabular}{|c|c|}
\hline$C(72)-C(73)$ & $1.378(11)$ \\
\hline $\mathrm{C}(72)-\mathrm{H}(72)$ & 0.9500 \\
\hline$C(73)-C(74)$ & $1.383(8)$ \\
\hline $\mathrm{C}(73)-\mathrm{H}(73)$ & 0.9500 \\
\hline$C(74)-C(78)$ & $1.523(9)$ \\
\hline$C(75)-C(76)$ & $1.50(2)$ \\
\hline$C(75)-C(77)$ & $1.517(19)$ \\
\hline $\mathrm{C}(75)-\mathrm{H}(75)$ & 1.0000 \\
\hline $\mathrm{C}(76)-\mathrm{H}(76 \mathrm{~A})$ & 0.9800 \\
\hline $\mathrm{C}(76)-\mathrm{H}(76 \mathrm{~B})$ & 0.9800 \\
\hline $\mathrm{C}(76)-\mathrm{H}(76 \mathrm{C})$ & 0.9800 \\
\hline $\mathrm{C}(77)-\mathrm{H}(77 \mathrm{~A})$ & 0.9800 \\
\hline $\mathrm{C}(77)-\mathrm{H}(77 \mathrm{~B})$ & 0.9800 \\
\hline $\mathrm{C}(77)-\mathrm{H}(77 \mathrm{C})$ & 0.9800 \\
\hline$C(78)-C(80)$ & $1.513(13)$ \\
\hline$C(78)-C(79)$ & $1.530(11)$ \\
\hline $\mathrm{C}(78)-\mathrm{H}(78)$ & 1.0000 \\
\hline $\mathrm{C}(79)-\mathrm{H}(79 \mathrm{~A})$ & 0.9800 \\
\hline $\mathrm{C}(79)-\mathrm{H}(79 \mathrm{~B})$ & 0.9800 \\
\hline $\mathrm{C}(79)-\mathrm{H}(79 \mathrm{C})$ & 0.9800 \\
\hline $\mathrm{C}(80)-\mathrm{H}(80 \mathrm{~A})$ & 0.9800 \\
\hline $\mathrm{C}(80)-\mathrm{H}(80 \mathrm{~B})$ & 0.9800 \\
\hline $\mathrm{C}(80)-\mathrm{H}(80 \mathrm{C})$ & 0.9800 \\
\hline$C(83)-C(84)$ & $1.537(8)$ \\
\hline $\mathrm{C}(83)-\mathrm{H}(83)$ & 1.0000 \\
\hline $\mathrm{C}(84)-\mathrm{H}(84 \mathrm{~A})$ & 0.9900 \\
\hline $\mathrm{C}(84)-\mathrm{H}(84 \mathrm{~B})$ & 0.9900 \\
\hline$C(85)-C(86)$ & $1.395(10)$ \\
\hline$C(85)-C(90)$ & $1.396(11)$ \\
\hline$C(86)-C(87)$ & $1.386(10)$ \\
\hline $\mathrm{C}(86)-\mathrm{H}(86)$ & 0.9500 \\
\hline$C(87)-C(88)$ & $1.379(15)$ \\
\hline $\mathrm{C}(87)-\mathrm{H}(87)$ & 0.9500 \\
\hline $\mathrm{C}(88)-\mathrm{C}(89)$ & $1.373(15)$ \\
\hline $\mathrm{C}(88)-\mathrm{H}(88)$ & 0.9500 \\
\hline $\mathrm{C}(89)-\mathrm{C}(90)$ & $1.388(12)$ \\
\hline C(89)-H(89) & 0.9500 \\
\hline $\mathrm{C}(90)-\mathrm{H}(90)$ & 0.9500 \\
\hline $\mathrm{C}(97)-\mathrm{C}(98)$ & $1.416(12)$ \\
\hline$C(97)-C(102)$ & $1.423(12)$ \\
\hline
\end{tabular}




\begin{tabular}{|c|c|}
\hline C(98)-C(99) & $1.379(14)$ \\
\hline $\mathrm{C}(98)-\mathrm{H}(98)$ & 0.9500 \\
\hline$C(99)-C(100)$ & $1.370(17)$ \\
\hline C(99)-H(99) & 0.9500 \\
\hline$C(100)-C(101)$ & $1.372(17)$ \\
\hline $\mathrm{C}(100)-\mathrm{H}(100)$ & 0.9500 \\
\hline$C(101)-C(102)$ & $1.400(15)$ \\
\hline $\mathrm{C}(101)-\mathrm{H}(101)$ & 0.9500 \\
\hline $\mathrm{C}(102)-\mathrm{H}(102)$ & 0.9500 \\
\hline$C(103)-C(106)$ & $1.507(12)$ \\
\hline$C(103)-C(104)$ & $1.520(11)$ \\
\hline$C(103)-C(105)$ & $1.552(9)$ \\
\hline $\mathrm{C}(104)-\mathrm{H}(10 \mathrm{~A})$ & 0.9800 \\
\hline $\mathrm{C}(104)-\mathrm{H}(10 \mathrm{~B})$ & 0.9800 \\
\hline $\mathrm{C}(104)-\mathrm{H}(10 \mathrm{C})$ & 0.9800 \\
\hline $\mathrm{C}(105)-\mathrm{H}(10 \mathrm{D})$ & 0.9800 \\
\hline $\mathrm{C}(105)-\mathrm{H}(10 \mathrm{E})$ & 0.9800 \\
\hline $\mathrm{C}(105)-\mathrm{H}(10 \mathrm{~F})$ & 0.9800 \\
\hline $\mathrm{C}(106)-\mathrm{H}(10 \mathrm{G})$ & 0.9800 \\
\hline $\mathrm{C}(106)-\mathrm{H}(10 \mathrm{H})$ & 0.9800 \\
\hline $\mathrm{C}(106)-\mathrm{H}(10 \mathrm{I})$ & 0.9800 \\
\hline$C(1 S)-C(2 S)$ & $1.40(2)$ \\
\hline $\mathrm{C}(1 \mathrm{~S})-\mathrm{H}(1 \mathrm{~S} 1)$ & 0.9800 \\
\hline $\mathrm{C}(1 \mathrm{~S})-\mathrm{H}(1 \mathrm{~S} 2)$ & 0.9800 \\
\hline $\mathrm{C}(1 \mathrm{~S})-\mathrm{H}(1 \mathrm{~S} 3)$ & 0.9800 \\
\hline$C(2 S)-C(3 S)$ & $1.39(2)$ \\
\hline $\mathrm{C}(2 \mathrm{~S})-\mathrm{H}(2 \mathrm{~S} 1)$ & 0.9900 \\
\hline $\mathrm{C}(2 \mathrm{~S})-\mathrm{H}(2 \mathrm{~S} 2)$ & 0.9900 \\
\hline$C(3 S)-C(4 S)$ & $1.47(2)$ \\
\hline $\mathrm{C}(3 \mathrm{~S})-\mathrm{H}(3 \mathrm{~S} 1)$ & 0.9900 \\
\hline $\mathrm{C}(3 \mathrm{~S})-\mathrm{H}(3 \mathrm{~S} 2)$ & 0.9900 \\
\hline$C(4 S)-C(5 S)$ & $1.33(3)$ \\
\hline $\mathrm{C}(4 \mathrm{~S})-\mathrm{H}(4 \mathrm{~S} 1)$ & 0.9900 \\
\hline $\mathrm{C}(4 \mathrm{~S})-\mathrm{H}(4 \mathrm{~S} 2)$ & 0.9900 \\
\hline$C(5 S)-C(6 S)$ & $1.37(3)$ \\
\hline $\mathrm{C}(5 \mathrm{~S})-\mathrm{H}(5 \mathrm{~S} 1)$ & 0.9900 \\
\hline $\mathrm{C}(5 \mathrm{~S})-\mathrm{H}(5 \mathrm{~S} 2)$ & 0.9900 \\
\hline $\mathrm{C}(6 \mathrm{~S})-\mathrm{H}(6 \mathrm{~S} 1)$ & 0.9800 \\
\hline $\mathrm{C}(6 \mathrm{~S})-\mathrm{H}(6 \mathrm{~S} 2)$ & 0.9800 \\
\hline $\mathrm{C}(6 \mathrm{~S})-\mathrm{H}(6 \mathrm{~S} 3)$ & 0.9800 \\
\hline
\end{tabular}




\begin{tabular}{|c|c|}
\hline $\mathrm{C}(1)-\mathrm{Cu}(1)-\mathrm{C}(29)$ & $171.4(3)$ \\
\hline $\mathrm{O}(1)-\mathrm{Si}(1)-\mathrm{C}(50)$ & $104.3(2)$ \\
\hline $\mathrm{O}(1)-\mathrm{Si}(1)-\mathrm{C}(44)$ & $110.4(2)$ \\
\hline$C(50)-\operatorname{Si}(1)-C(44)$ & $110.5(3)$ \\
\hline $\mathrm{O}(1)-\mathrm{Si}(1)-\mathrm{C}(32)$ & $108.9(2)$ \\
\hline$C(50)-\operatorname{Si}(1)-C(32)$ & $109.9(3)$ \\
\hline$C(44)-\operatorname{Si}(1)-C(32)$ & $112.5(3)$ \\
\hline $\mathrm{F}(3)-\mathrm{C}(28)-\mathrm{F}(1)$ & $104.7(10)$ \\
\hline $\mathrm{F}(3)-\mathrm{C}(28)-\mathrm{F}(2)$ & $104.2(9)$ \\
\hline $\mathrm{F}(1)-\mathrm{C}(28)-\mathrm{F}(2)$ & $105.9(10)$ \\
\hline $\mathrm{F}(3)-\mathrm{C}(28)-\mathrm{C}(29)$ & $113.7(10)$ \\
\hline $\mathrm{F}(1)-\mathrm{C}(28)-\mathrm{C}(29)$ & $115.4(9)$ \\
\hline $\mathrm{F}(2)-\mathrm{C}(28)-\mathrm{C}(29)$ & $111.9(10)$ \\
\hline$C(28)-C(29)-C(30)$ & $112.4(7)$ \\
\hline $\mathrm{C}(28)-\mathrm{C}(29)-\mathrm{Cu}(1)$ & $111.8(6)$ \\
\hline$C(30)-C(29)-C u(1)$ & $118.1(4)$ \\
\hline $\mathrm{C}(28)-\mathrm{C}(29)-\mathrm{H}(29)$ & 104.3 \\
\hline $\mathrm{C}(30)-\mathrm{C}(29)-\mathrm{H}(29)$ & 104.3 \\
\hline $\mathrm{Cu}(1)-\mathrm{C}(29)-\mathrm{H}(29)$ & 104.3 \\
\hline $\mathrm{O}(2)-\mathrm{B}(1)-\mathrm{O}(3)$ & $112.6(7)$ \\
\hline $\mathrm{O}(2)-\mathrm{B}(1)-\mathrm{C}(30)$ & $122.7(7)$ \\
\hline $\mathrm{O}(3)-\mathrm{B}(1)-\mathrm{C}(30)$ & $124.6(6)$ \\
\hline $\mathrm{B}(1)-\mathrm{O}(2)-\mathrm{C}(38)$ & $105.8(8)$ \\
\hline $\mathrm{B}(1)-\mathrm{O}(3)-\mathrm{C}(39)$ & $111.4(7)$ \\
\hline$C(41)-C(38)-C(40)$ & $112.5(14)$ \\
\hline$C(41)-C(38)-C(39)$ & $114.6(14)$ \\
\hline$C(40)-C(38)-C(39)$ & $111.9(12)$ \\
\hline $\mathrm{C}(41)-\mathrm{C}(38)-\mathrm{O}(2)$ & $102.9(11)$ \\
\hline $\mathrm{C}(40)-\mathrm{C}(38)-\mathrm{O}(2)$ & $109.6(12)$ \\
\hline $\mathrm{C}(39)-\mathrm{C}(38)-\mathrm{O}(2)$ & $104.6(10)$ \\
\hline $\mathrm{O}(3)-\mathrm{C}(39)-\mathrm{C}(38)$ & $102.7(10)$ \\
\hline $\mathrm{O}(3)-\mathrm{C}(39)-\mathrm{C}(43)$ & $103.0(12)$ \\
\hline$C(38)-C(39)-C(43)$ & $115.2(11)$ \\
\hline $\mathrm{O}(3)-\mathrm{C}(39)-\mathrm{C}(42)$ & $112.0(10)$ \\
\hline$C(38)-C(39)-C(42)$ & $115.6(13)$ \\
\hline$C(43)-C(39)-C(42)$ & $107.6(14)$ \\
\hline $\mathrm{C}(38)-\mathrm{C}(40)-\mathrm{H}(40 \mathrm{~A})$ & 109.5 \\
\hline $\mathrm{C}(38)-\mathrm{C}(40)-\mathrm{H}(40 \mathrm{~B})$ & 109.5 \\
\hline $\mathrm{H}(40 \mathrm{~A})-\mathrm{C}(40)-\mathrm{H}(40 \mathrm{~B})$ & 109.5 \\
\hline
\end{tabular}




\begin{tabular}{|c|c|}
\hline $\mathrm{C}(38)-\mathrm{C}(40)-\mathrm{H}(40 \mathrm{C})$ & 109.5 \\
\hline $\mathrm{H}(40 \mathrm{~A})-\mathrm{C}(40)-\mathrm{H}(40 \mathrm{C})$ & 109.5 \\
\hline $\mathrm{H}(40 \mathrm{~B})-\mathrm{C}(40)-\mathrm{H}(40 \mathrm{C})$ & 109.5 \\
\hline $\mathrm{C}(38)-\mathrm{C}(41)-\mathrm{H}(41 \mathrm{~A})$ & 109.5 \\
\hline $\mathrm{C}(38)-\mathrm{C}(41)-\mathrm{H}(41 \mathrm{~B})$ & 109.5 \\
\hline $\mathrm{H}(41 \mathrm{~A})-\mathrm{C}(41)-\mathrm{H}(41 \mathrm{~B})$ & 109.5 \\
\hline $\mathrm{C}(38)-\mathrm{C}(41)-\mathrm{H}(41 \mathrm{C})$ & 109.5 \\
\hline $\mathrm{H}(41 \mathrm{~A})-\mathrm{C}(41)-\mathrm{H}(41 \mathrm{C})$ & 109.5 \\
\hline $\mathrm{H}(41 \mathrm{~B})-\mathrm{C}(41)-\mathrm{H}(41 \mathrm{C})$ & 109.5 \\
\hline $\mathrm{C}(39)-\mathrm{C}(42)-\mathrm{H}(42 \mathrm{~A})$ & 109.5 \\
\hline $\mathrm{C}(39)-\mathrm{C}(42)-\mathrm{H}(42 \mathrm{~B})$ & 109.5 \\
\hline $\mathrm{H}(42 \mathrm{~A})-\mathrm{C}(42)-\mathrm{H}(42 \mathrm{~B})$ & 109.5 \\
\hline $\mathrm{C}(39)-\mathrm{C}(42)-\mathrm{H}(42 \mathrm{C})$ & 109.5 \\
\hline $\mathrm{H}(42 \mathrm{~A})-\mathrm{C}(42)-\mathrm{H}(42 \mathrm{C})$ & 109.5 \\
\hline $\mathrm{H}(42 \mathrm{~B})-\mathrm{C}(42)-\mathrm{H}(42 \mathrm{C})$ & 109.5 \\
\hline $\mathrm{C}(39)-\mathrm{C}(43)-\mathrm{H}(43 \mathrm{~A})$ & 109.5 \\
\hline $\mathrm{C}(39)-\mathrm{C}(43)-\mathrm{H}(43 \mathrm{~B})$ & 109.5 \\
\hline $\mathrm{H}(43 \mathrm{~A})-\mathrm{C}(43)-\mathrm{H}(43 \mathrm{~B})$ & 109.5 \\
\hline $\mathrm{C}(39)-\mathrm{C}(43)-\mathrm{H}(43 \mathrm{C})$ & 109.5 \\
\hline $\mathrm{H}(43 \mathrm{~A})-\mathrm{C}(43)-\mathrm{H}(43 \mathrm{C})$ & 109.5 \\
\hline $\mathrm{H}(43 \mathrm{~B})-\mathrm{C}(43)-\mathrm{H}(43 \mathrm{C})$ & 109.5 \\
\hline $\mathrm{C}(31)-\mathrm{O}(1)-\mathrm{Si}(1)$ & $128.3(3)$ \\
\hline $\mathrm{C}(1)-\mathrm{N}(1)-\mathrm{C}(2)$ & $112.0(4)$ \\
\hline $\mathrm{C}(1)-\mathrm{N}(1)-\mathrm{C}(4)$ & $122.1(4)$ \\
\hline $\mathrm{C}(2)-\mathrm{N}(1)-\mathrm{C}(4)$ & $125.8(4)$ \\
\hline $\mathrm{C}(1)-\mathrm{N}(2)-\mathrm{C}(3)$ & $110.9(4)$ \\
\hline$C(1)-N(2)-C(16)$ & $122.1(4)$ \\
\hline $\mathrm{C}(3)-\mathrm{N}(2)-\mathrm{C}(16)$ & $127.0(5)$ \\
\hline $\mathrm{N}(1)-\mathrm{C}(1)-\mathrm{N}(2)$ & $104.5(4)$ \\
\hline $\mathrm{N}(1)-\mathrm{C}(1)-\mathrm{Cu}(1)$ & $129.5(4)$ \\
\hline $\mathrm{N}(2)-\mathrm{C}(1)-\mathrm{Cu}(1)$ & $126.0(4)$ \\
\hline $\mathrm{C}(3)-\mathrm{C}(2)-\mathrm{N}(1)$ & $106.5(5)$ \\
\hline $\mathrm{C}(3)-\mathrm{C}(2)-\mathrm{H}(2)$ & 126.8 \\
\hline $\mathrm{N}(1)-\mathrm{C}(2)-\mathrm{H}(2)$ & 126.8 \\
\hline $\mathrm{C}(2)-\mathrm{C}(3)-\mathrm{N}(2)$ & $106.2(5)$ \\
\hline $\mathrm{C}(2)-\mathrm{C}(3)-\mathrm{H}(3)$ & 126.9 \\
\hline $\mathrm{N}(2)-\mathrm{C}(3)-\mathrm{H}(3)$ & 126.9 \\
\hline$C(9)-C(4)-C(5)$ & $122.0(5)$ \\
\hline $\mathrm{C}(9)-\mathrm{C}(4)-\mathrm{N}(1)$ & $119.5(5)$ \\
\hline$C(5)-C(4)-N(1)$ & $118.4(5)$ \\
\hline
\end{tabular}




\begin{tabular}{|c|c|}
\hline$C(6)-C(5)-C(4)$ & $118.1(5)$ \\
\hline$C(6)-C(5)-C(10)$ & $119.5(5)$ \\
\hline$C(4)-C(5)-C(10)$ & $122.4(5)$ \\
\hline$C(7)-C(6)-C(5)$ & $120.3(6)$ \\
\hline $\mathrm{C}(7)-\mathrm{C}(6)-\mathrm{H}(6)$ & 119.9 \\
\hline $\mathrm{C}(5)-\mathrm{C}(6)-\mathrm{H}(6)$ & 119.9 \\
\hline$C(6)-C(7)-C(8)$ & $120.9(5)$ \\
\hline $\mathrm{C}(6)-\mathrm{C}(7)-\mathrm{H}(7)$ & 119.5 \\
\hline $\mathrm{C}(8)-\mathrm{C}(7)-\mathrm{H}(7)$ & 119.5 \\
\hline$C(9)-C(8)-C(7)$ & $121.1(5)$ \\
\hline $\mathrm{C}(9)-\mathrm{C}(8)-\mathrm{H}(8)$ & 119.4 \\
\hline $\mathrm{C}(7)-\mathrm{C}(8)-\mathrm{H}(8)$ & 119.4 \\
\hline$C(8)-C(9)-C(4)$ & $117.6(6)$ \\
\hline $\mathrm{C}(8)-\mathrm{C}(9)-\mathrm{C}(13)$ & $122.2(5)$ \\
\hline$C(4)-C(9)-C(13)$ & $120.0(5)$ \\
\hline$C(5)-C(10)-C(12)$ & $111.0(5)$ \\
\hline$C(5)-C(10)-C(11)$ & $110.8(5)$ \\
\hline$C(12)-C(10)-C(11)$ & $111.1(5)$ \\
\hline $\mathrm{C}(5)-\mathrm{C}(10)-\mathrm{H}(10)$ & 107.9 \\
\hline$C(12)-C(10)-H(10)$ & 107.9 \\
\hline $\mathrm{C}(11)-\mathrm{C}(10)-\mathrm{H}(10)$ & 107.9 \\
\hline $\mathrm{C}(10)-\mathrm{C}(11)-\mathrm{H}(11 \mathrm{~A})$ & 109.5 \\
\hline $\mathrm{C}(10)-\mathrm{C}(11)-\mathrm{H}(11 \mathrm{~B})$ & 109.5 \\
\hline $\mathrm{H}(11 \mathrm{~A})-\mathrm{C}(11)-\mathrm{H}(11 \mathrm{~B})$ & 109.5 \\
\hline $\mathrm{C}(10)-\mathrm{C}(11)-\mathrm{H}(11 \mathrm{C})$ & 109.5 \\
\hline $\mathrm{H}(11 \mathrm{~A})-\mathrm{C}(11)-\mathrm{H}(11 \mathrm{C})$ & 109.5 \\
\hline $\mathrm{H}(11 \mathrm{~B})-\mathrm{C}(11)-\mathrm{H}(11 \mathrm{C})$ & 109.5 \\
\hline $\mathrm{C}(10)-\mathrm{C}(12)-\mathrm{H}(12 \mathrm{~A})$ & 109.5 \\
\hline $\mathrm{C}(10)-\mathrm{C}(12)-\mathrm{H}(12 \mathrm{~B})$ & 109.5 \\
\hline $\mathrm{H}(12 \mathrm{~A})-\mathrm{C}(12)-\mathrm{H}(12 \mathrm{~B})$ & 109.5 \\
\hline $\mathrm{C}(10)-\mathrm{C}(12)-\mathrm{H}(12 \mathrm{C})$ & 109.5 \\
\hline $\mathrm{H}(12 \mathrm{~A})-\mathrm{C}(12)-\mathrm{H}(12 \mathrm{C})$ & 109.5 \\
\hline $\mathrm{H}(12 \mathrm{~B})-\mathrm{C}(12)-\mathrm{H}(12 \mathrm{C})$ & 109.5 \\
\hline$C(15)-C(13)-C(9)$ & $109.6(6)$ \\
\hline$C(15)-C(13)-C(14)$ & $111.0(6)$ \\
\hline$C(9)-C(13)-C(14)$ & $112.4(6)$ \\
\hline $\mathrm{C}(15)-\mathrm{C}(13)-\mathrm{H}(13)$ & 107.9 \\
\hline $\mathrm{C}(9)-\mathrm{C}(13)-\mathrm{H}(13)$ & 107.9 \\
\hline $\mathrm{C}(14)-\mathrm{C}(13)-\mathrm{H}(13)$ & 107.9 \\
\hline $\mathrm{C}(13)-\mathrm{C}(14)-\mathrm{H}(14 \mathrm{~A})$ & 109.5 \\
\hline
\end{tabular}




\begin{tabular}{|c|c|}
\hline $\mathrm{C}(13)-\mathrm{C}(14)-\mathrm{H}(14 \mathrm{~B})$ & 109.5 \\
\hline $\mathrm{H}(14 \mathrm{~A})-\mathrm{C}(14)-\mathrm{H}(14 \mathrm{~B})$ & 109.5 \\
\hline $\mathrm{C}(13)-\mathrm{C}(14)-\mathrm{H}(14 \mathrm{C})$ & 109.5 \\
\hline $\mathrm{H}(14 \mathrm{~A})-\mathrm{C}(14)-\mathrm{H}(14 \mathrm{C})$ & 109.5 \\
\hline $\mathrm{H}(14 \mathrm{~B})-\mathrm{C}(14)-\mathrm{H}(14 \mathrm{C})$ & 109.5 \\
\hline $\mathrm{C}(13)-\mathrm{C}(15)-\mathrm{H}(15 \mathrm{~A})$ & 109.5 \\
\hline $\mathrm{C}(13)-\mathrm{C}(15)-\mathrm{H}(15 \mathrm{~B})$ & 109.5 \\
\hline $\mathrm{H}(15 \mathrm{~A})-\mathrm{C}(15)-\mathrm{H}(15 \mathrm{~B})$ & 109.5 \\
\hline $\mathrm{C}(13)-\mathrm{C}(15)-\mathrm{H}(15 \mathrm{C})$ & 109.5 \\
\hline $\mathrm{H}(15 \mathrm{~A})-\mathrm{C}(15)-\mathrm{H}(15 \mathrm{C})$ & 109.5 \\
\hline $\mathrm{H}(15 \mathrm{~B})-\mathrm{C}(15)-\mathrm{H}(15 \mathrm{C})$ & 109.5 \\
\hline$C(21)-C(16)-C(17)$ & $123.4(5)$ \\
\hline $\mathrm{C}(21)-\mathrm{C}(16)-\mathrm{N}(2)$ & $118.9(5)$ \\
\hline$C(17)-C(16)-N(2)$ & $117.6(5)$ \\
\hline$C(18)-C(17)-C(16)$ & $117.1(6)$ \\
\hline$C(18)-C(17)-C(22)$ & $121.7(5)$ \\
\hline$C(16)-C(17)-C(22)$ & $121.2(5)$ \\
\hline$C(17)-C(18)-C(19)$ & $121.5(6)$ \\
\hline $\mathrm{C}(17)-\mathrm{C}(18)-\mathrm{H}(18)$ & 119.2 \\
\hline $\mathrm{C}(19)-\mathrm{C}(18)-\mathrm{H}(18)$ & 119.2 \\
\hline$C(20)-C(19)-C(18)$ & $120.4(6)$ \\
\hline $\mathrm{C}(20)-\mathrm{C}(19)-\mathrm{H}(19)$ & 119.8 \\
\hline $\mathrm{C}(18)-\mathrm{C}(19)-\mathrm{H}(19)$ & 119.8 \\
\hline$C(19)-C(20)-C(21)$ & $121.2(6)$ \\
\hline$C(19)-C(20)-H(20)$ & 119.4 \\
\hline $\mathrm{C}(21)-\mathrm{C}(20)-\mathrm{H}(20)$ & 119.4 \\
\hline$C(16)-C(21)-C(20)$ & $116.3(6)$ \\
\hline$C(16)-C(21)-C(25)$ & $121.2(6)$ \\
\hline$C(20)-C(21)-C(25)$ & $122.4(6)$ \\
\hline$C(17)-C(22)-C(24)$ & $113.6(6)$ \\
\hline$C(17)-C(22)-C(23)$ & $111.4(6)$ \\
\hline$C(24)-C(22)-C(23)$ & $108.0(9)$ \\
\hline $\mathrm{C}(17)-\mathrm{C}(22)-\mathrm{H}(22)$ & 107.9 \\
\hline $\mathrm{C}(24)-\mathrm{C}(22)-\mathrm{H}(22)$ & 107.9 \\
\hline $\mathrm{C}(23)-\mathrm{C}(22)-\mathrm{H}(22)$ & 107.9 \\
\hline $\mathrm{C}(22)-\mathrm{C}(23)-\mathrm{H}(23 \mathrm{~A})$ & 109.5 \\
\hline $\mathrm{C}(22)-\mathrm{C}(23)-\mathrm{H}(23 \mathrm{~B})$ & 109.5 \\
\hline $\mathrm{H}(23 \mathrm{~A})-\mathrm{C}(23)-\mathrm{H}(23 \mathrm{~B})$ & 109.5 \\
\hline $\mathrm{C}(22)-\mathrm{C}(23)-\mathrm{H}(23 \mathrm{C})$ & 109.5 \\
\hline $\mathrm{H}(23 \mathrm{~A})-\mathrm{C}(23)-\mathrm{H}(23 \mathrm{C})$ & 109.5 \\
\hline
\end{tabular}




\begin{tabular}{|c|c|}
\hline $\mathrm{H}(23 \mathrm{~B})-\mathrm{C}(23)-\mathrm{H}(23 \mathrm{C})$ & 109.5 \\
\hline $\mathrm{C}(22)-\mathrm{C}(24)-\mathrm{H}(24 \mathrm{~A})$ & 109.5 \\
\hline $\mathrm{C}(22)-\mathrm{C}(24)-\mathrm{H}(24 \mathrm{~B})$ & 109.5 \\
\hline $\mathrm{H}(24 \mathrm{~A})-\mathrm{C}(24)-\mathrm{H}(24 \mathrm{~B})$ & 109.5 \\
\hline $\mathrm{C}(22)-\mathrm{C}(24)-\mathrm{H}(24 \mathrm{C})$ & 109.5 \\
\hline $\mathrm{H}(24 \mathrm{~A})-\mathrm{C}(24)-\mathrm{H}(24 \mathrm{C})$ & 109.5 \\
\hline $\mathrm{H}(24 \mathrm{~B})-\mathrm{C}(24)-\mathrm{H}(24 \mathrm{C})$ & 109.5 \\
\hline $\mathrm{C}(25)-\mathrm{C}(26)-\mathrm{H}(26 \mathrm{~A})$ & 109.5 \\
\hline $\mathrm{C}(25)-\mathrm{C}(26)-\mathrm{H}(26 \mathrm{~B})$ & 109.5 \\
\hline $\mathrm{H}(26 \mathrm{~A})-\mathrm{C}(26)-\mathrm{H}(26 \mathrm{~B})$ & 109.5 \\
\hline $\mathrm{C}(25)-\mathrm{C}(26)-\mathrm{H}(26 \mathrm{C})$ & 109.5 \\
\hline $\mathrm{H}(26 \mathrm{~A})-\mathrm{C}(26)-\mathrm{H}(26 \mathrm{C})$ & 109.5 \\
\hline $\mathrm{H}(26 \mathrm{~B})-\mathrm{C}(26)-\mathrm{H}(26 \mathrm{C})$ & 109.5 \\
\hline $\mathrm{C}(25)-\mathrm{C}(27)-\mathrm{H}(27 \mathrm{~A})$ & 109.5 \\
\hline $\mathrm{C}(25)-\mathrm{C}(27)-\mathrm{H}(27 \mathrm{~B})$ & 109.5 \\
\hline $\mathrm{H}(27 \mathrm{~A})-\mathrm{C}(27)-\mathrm{H}(27 \mathrm{~B})$ & 109.5 \\
\hline $\mathrm{C}(25)-\mathrm{C}(27)-\mathrm{H}(27 \mathrm{C})$ & 109.5 \\
\hline $\mathrm{H}(27 \mathrm{~A})-\mathrm{C}(27)-\mathrm{H}(27 \mathrm{C})$ & 109.5 \\
\hline $\mathrm{H}(27 \mathrm{~B})-\mathrm{C}(27)-\mathrm{H}(27 \mathrm{C})$ & 109.5 \\
\hline$C(27)-C(25)-C(21)$ & $112.3(15)$ \\
\hline$C(27)-C(25)-C(26)$ & $114.6(15)$ \\
\hline$C(21)-C(25)-C(26)$ & $110.5(9)$ \\
\hline $\mathrm{C}(27)-\mathrm{C}(25)-\mathrm{H}(25)$ & 106.3 \\
\hline $\mathrm{C}(21)-\mathrm{C}(25)-\mathrm{H}(25)$ & 106.3 \\
\hline $\mathrm{C}(26)-\mathrm{C}(25)-\mathrm{H}(25)$ & 106.3 \\
\hline$C(31)-C(30)-C(29)$ & $111.2(5)$ \\
\hline $\mathrm{C}(31)-\mathrm{C}(30)-\mathrm{B}(1)$ & $106.6(4)$ \\
\hline $\mathrm{C}(29)-\mathrm{C}(30)-\mathrm{B}(1)$ & $112.0(5)$ \\
\hline $\mathrm{C}(31)-\mathrm{C}(30)-\mathrm{H}(30)$ & 109.0 \\
\hline $\mathrm{C}(29)-\mathrm{C}(30)-\mathrm{H}(30)$ & 109.0 \\
\hline $\mathrm{B}(1)-\mathrm{C}(30)-\mathrm{H}(30)$ & 109.0 \\
\hline $\mathrm{O}(1)-\mathrm{C}(31)-\mathrm{C}(30)$ & $109.0(4)$ \\
\hline $\mathrm{O}(1)-\mathrm{C}(31)-\mathrm{H}(31 \mathrm{~A})$ & 109.9 \\
\hline $\mathrm{C}(30)-\mathrm{C}(31)-\mathrm{H}(31 \mathrm{~A})$ & 109.9 \\
\hline $\mathrm{O}(1)-\mathrm{C}(31)-\mathrm{H}(31 \mathrm{~B})$ & 109.9 \\
\hline $\mathrm{C}(30)-\mathrm{C}(31)-\mathrm{H}(31 \mathrm{~B})$ & 109.9 \\
\hline $\mathrm{H}(31 \mathrm{~A})-\mathrm{C}(31)-\mathrm{H}(31 \mathrm{~B})$ & 108.3 \\
\hline$C(37)-C(32)-C(33)$ & $116.3(6)$ \\
\hline$C(37)-C(32)-\operatorname{Si}(1)$ & $124.3(5)$ \\
\hline $\mathrm{C}(33)-\mathrm{C}(32)-\mathrm{Si}(1)$ & $119.3(4)$ \\
\hline
\end{tabular}




\begin{tabular}{|c|c|}
\hline $\mathrm{C}(34)-\mathrm{C}(33)-\mathrm{C}(32)$ & $121.2(6)$ \\
\hline $\mathrm{C}(34)-\mathrm{C}(33)-\mathrm{H}(33)$ & 119.4 \\
\hline $\mathrm{C}(32)-\mathrm{C}(33)-\mathrm{H}(33)$ & 119.4 \\
\hline$C(35)-C(34)-C(33)$ & $120.9(7)$ \\
\hline $\mathrm{C}(35)-\mathrm{C}(34)-\mathrm{H}(34)$ & 119.6 \\
\hline $\mathrm{C}(33)-\mathrm{C}(34)-\mathrm{H}(34)$ & 119.6 \\
\hline$C(34)-C(35)-C(36)$ & $119.4(7)$ \\
\hline $\mathrm{C}(34)-\mathrm{C}(35)-\mathrm{H}(35)$ & 120.3 \\
\hline $\mathrm{C}(36)-\mathrm{C}(35)-\mathrm{H}(35)$ & 120.3 \\
\hline$C(35)-C(36)-C(37)$ & $119.9(7)$ \\
\hline $\mathrm{C}(35)-\mathrm{C}(36)-\mathrm{H}(36)$ & 120.0 \\
\hline $\mathrm{C}(37)-\mathrm{C}(36)-\mathrm{H}(36)$ & 120.0 \\
\hline$C(32)-C(37)-C(36)$ & $122.3(6)$ \\
\hline $\mathrm{C}(32)-\mathrm{C}(37)-\mathrm{H}(37)$ & 118.8 \\
\hline $\mathrm{C}(36)-\mathrm{C}(37)-\mathrm{H}(37)$ & 118.8 \\
\hline$C(45)-C(44)-C(49)$ & $117.0(6)$ \\
\hline $\mathrm{C}(45)-\mathrm{C}(44)-\mathrm{Si}(1)$ & $124.7(5)$ \\
\hline $\mathrm{C}(49)-\mathrm{C}(44)-\mathrm{Si}(1)$ & $118.2(5)$ \\
\hline$C(44)-C(45)-C(46)$ & $122.2(7)$ \\
\hline $\mathrm{C}(44)-\mathrm{C}(45)-\mathrm{H}(45)$ & 118.9 \\
\hline $\mathrm{C}(46)-\mathrm{C}(45)-\mathrm{H}(45)$ & 118.9 \\
\hline$C(47)-C(46)-C(45)$ & $121.1(7)$ \\
\hline $\mathrm{C}(47)-\mathrm{C}(46)-\mathrm{H}(46)$ & 119.4 \\
\hline $\mathrm{C}(45)-\mathrm{C}(46)-\mathrm{H}(46)$ & 119.4 \\
\hline$C(46)-C(47)-C(48)$ & $118.9(7)$ \\
\hline $\mathrm{C}(46)-\mathrm{C}(47)-\mathrm{H}(47)$ & 120.6 \\
\hline $\mathrm{C}(48)-\mathrm{C}(47)-\mathrm{H}(47)$ & 120.6 \\
\hline $\mathrm{C}(47)-\mathrm{C}(48)-\mathrm{C}(49)$ & $120.5(7)$ \\
\hline $\mathrm{C}(47)-\mathrm{C}(48)-\mathrm{H}(48)$ & 119.8 \\
\hline $\mathrm{C}(49)-\mathrm{C}(48)-\mathrm{H}(48)$ & 119.8 \\
\hline $\mathrm{C}(44)-\mathrm{C}(49)-\mathrm{C}(48)$ & $120.1(7)$ \\
\hline $\mathrm{C}(44)-\mathrm{C}(49)-\mathrm{H}(49)$ & 119.9 \\
\hline $\mathrm{C}(48)-\mathrm{C}(49)-\mathrm{H}(49)$ & 119.9 \\
\hline$C(51)-C(50)-C(52)$ & $107.9(5)$ \\
\hline$C(51)-C(50)-C(53)$ & $109.0(6)$ \\
\hline$C(52)-C(50)-C(53)$ & $109.5(6)$ \\
\hline $\mathrm{C}(51)-\mathrm{C}(50)-\mathrm{Si}(1)$ & $110.3(4)$ \\
\hline $\mathrm{C}(52)-\mathrm{C}(50)-\mathrm{Si}(1)$ & $109.1(4)$ \\
\hline $\mathrm{C}(53)-\mathrm{C}(50)-\mathrm{Si}(1)$ & $111.0(4)$ \\
\hline $\mathrm{C}(50)-\mathrm{C}(51)-\mathrm{H}(51 \mathrm{~A})$ & 109.5 \\
\hline
\end{tabular}




\begin{tabular}{|c|c|}
\hline $\mathrm{C}(50)-\mathrm{C}(51)-\mathrm{H}(51 \mathrm{~B})$ & 109.5 \\
\hline $\mathrm{H}(51 \mathrm{~A})-\mathrm{C}(51)-\mathrm{H}(51 \mathrm{~B})$ & 109.5 \\
\hline $\mathrm{C}(50)-\mathrm{C}(51)-\mathrm{H}(51 \mathrm{C})$ & 109.5 \\
\hline $\mathrm{H}(51 \mathrm{~A})-\mathrm{C}(51)-\mathrm{H}(51 \mathrm{C})$ & 109.5 \\
\hline $\mathrm{H}(51 \mathrm{~B})-\mathrm{C}(51)-\mathrm{H}(51 \mathrm{C})$ & 109.5 \\
\hline $\mathrm{C}(50)-\mathrm{C}(52)-\mathrm{H}(52 \mathrm{~A})$ & 109.5 \\
\hline $\mathrm{C}(50)-\mathrm{C}(52)-\mathrm{H}(52 \mathrm{~B})$ & 109.5 \\
\hline $\mathrm{H}(52 \mathrm{~A})-\mathrm{C}(52)-\mathrm{H}(52 \mathrm{~B})$ & 109.5 \\
\hline $\mathrm{C}(50)-\mathrm{C}(52)-\mathrm{H}(52 \mathrm{C})$ & 109.5 \\
\hline $\mathrm{H}(52 \mathrm{~A})-\mathrm{C}(52)-\mathrm{H}(52 \mathrm{C})$ & 109.5 \\
\hline $\mathrm{H}(52 \mathrm{~B})-\mathrm{C}(52)-\mathrm{H}(52 \mathrm{C})$ & 109.5 \\
\hline $\mathrm{C}(50)-\mathrm{C}(53)-\mathrm{H}(53 \mathrm{~A})$ & 109.5 \\
\hline $\mathrm{C}(50)-\mathrm{C}(53)-\mathrm{H}(53 \mathrm{~B})$ & 109.5 \\
\hline $\mathrm{H}(53 \mathrm{~A})-\mathrm{C}(53)-\mathrm{H}(53 \mathrm{~B})$ & 109.5 \\
\hline $\mathrm{C}(50)-\mathrm{C}(53)-\mathrm{H}(53 \mathrm{C})$ & 109.5 \\
\hline $\mathrm{H}(53 \mathrm{~A})-\mathrm{C}(53)-\mathrm{H}(53 \mathrm{C})$ & 109.5 \\
\hline $\mathrm{H}(53 \mathrm{~B})-\mathrm{C}(53)-\mathrm{H}(53 \mathrm{C})$ & 109.5 \\
\hline $\mathrm{C}(54)-\mathrm{Cu}(2)-\mathrm{C}(82)$ & $170.5(3)$ \\
\hline $\mathrm{O}(4)-\mathrm{Si}(2)-\mathrm{C}(85)$ & $111.9(3)$ \\
\hline $\mathrm{O}(4)-\mathrm{Si}(2)-\mathrm{C}(97)$ & $108.7(3)$ \\
\hline$C(85)-\operatorname{Si}(2)-C(97)$ & $109.7(3)$ \\
\hline $\mathrm{O}(4)-\mathrm{Si}(2)-\mathrm{C}(103)$ & $103.4(3)$ \\
\hline$C(85)-\operatorname{Si}(2)-C(103)$ & $111.4(3)$ \\
\hline$C(97)-\operatorname{Si}(2)-C(103)$ & $111.6(3)$ \\
\hline $\mathrm{F}(6)-\mathrm{C}(81)-\mathrm{F}(4)$ & $103.8(9)$ \\
\hline $\mathrm{F}(6)-\mathrm{C}(81)-\mathrm{F}(5)$ & $105.6(8)$ \\
\hline $\mathrm{F}(4)-\mathrm{C}(81)-\mathrm{F}(5)$ & $102.4(8)$ \\
\hline $\mathrm{F}(6)-\mathrm{C}(81)-\mathrm{C}(82)$ & $114.0(9)$ \\
\hline$F(4)-C(81)-C(82)$ & $114.3(9)$ \\
\hline$F(5)-C(81)-C(82)$ & $115.3(7)$ \\
\hline $\mathrm{C}(81)-\mathrm{C}(82)-\mathrm{C}(83)$ & $110.9(7)$ \\
\hline $\mathrm{C}(81)-\mathrm{C}(82)-\mathrm{Cu}(2)$ & $110.7(5)$ \\
\hline $\mathrm{C}(83)-\mathrm{C}(82)-\mathrm{Cu}(2)$ & $117.8(4)$ \\
\hline $\mathrm{C}(81)-\mathrm{C}(82)-\mathrm{H}(82)$ & 105.5 \\
\hline $\mathrm{C}(83)-\mathrm{C}(82)-\mathrm{H}(82)$ & 105.5 \\
\hline $\mathrm{Cu}(2)-\mathrm{C}(82)-\mathrm{H}(82)$ & 105.5 \\
\hline $\mathrm{O}(6)-\mathrm{B}(2)-\mathrm{O}(5)$ & $113.2(7)$ \\
\hline $\mathrm{O}(6)-\mathrm{B}(2)-\mathrm{C}(83)$ & $121.1(6)$ \\
\hline $\mathrm{O}(5)-\mathrm{B}(2)-\mathrm{C}(83)$ & $125.8(6)$ \\
\hline $\mathrm{B}(2)-\mathrm{O}(5)-\mathrm{C}(91)$ & $108.2(8)$ \\
\hline
\end{tabular}




\begin{tabular}{|c|c|}
\hline $\mathrm{B}(2)-\mathrm{O}(6)-\mathrm{C}(92)$ & $107.0(8)$ \\
\hline $\mathrm{C}(94)-\mathrm{C}(91)-\mathrm{O}(5)$ & $110.2(13)$ \\
\hline $\mathrm{C}(94)-\mathrm{C}(91)-\mathrm{C}(92)$ & $115.3(16)$ \\
\hline $\mathrm{O}(5)-\mathrm{C}(91)-\mathrm{C}(92)$ & $101.6(12)$ \\
\hline $\mathrm{C}(94)-\mathrm{C}(91)-\mathrm{C}(93)$ & $110.6(15)$ \\
\hline $\mathrm{O}(5)-\mathrm{C}(91)-\mathrm{C}(93)$ & $109.6(13)$ \\
\hline $\mathrm{C}(92)-\mathrm{C}(91)-\mathrm{C}(93)$ & $109.2(15)$ \\
\hline $\mathrm{C}(95)-\mathrm{C}(92)-\mathrm{C}(96)$ & $107.5(16)$ \\
\hline $\mathrm{C}(95)-\mathrm{C}(92)-\mathrm{O}(6)$ & $109.8(13)$ \\
\hline $\mathrm{C}(96)-\mathrm{C}(92)-\mathrm{O}(6)$ & $106.8(14)$ \\
\hline$C(95)-C(92)-C(91)$ & $112.9(17)$ \\
\hline $\mathrm{C}(96)-\mathrm{C}(92)-\mathrm{C}(91)$ & $118.6(15)$ \\
\hline $\mathrm{O}(6)-\mathrm{C}(92)-\mathrm{C}(91)$ & $100.7(12)$ \\
\hline $\mathrm{C}(91)-\mathrm{C}(93)-\mathrm{H}(93 \mathrm{~A})$ & 109.5 \\
\hline $\mathrm{C}(91)-\mathrm{C}(93)-\mathrm{H}(93 \mathrm{~B})$ & 109.5 \\
\hline $\mathrm{H}(93 \mathrm{~A})-\mathrm{C}(93)-\mathrm{H}(93 \mathrm{~B})$ & 109.5 \\
\hline $\mathrm{C}(91)-\mathrm{C}(93)-\mathrm{H}(93 \mathrm{C})$ & 109.5 \\
\hline $\mathrm{H}(93 \mathrm{~A})-\mathrm{C}(93)-\mathrm{H}(93 \mathrm{C})$ & 109.5 \\
\hline $\mathrm{H}(93 \mathrm{~B})-\mathrm{C}(93)-\mathrm{H}(93 \mathrm{C})$ & 109.5 \\
\hline $\mathrm{C}(91)-\mathrm{C}(94)-\mathrm{H}(94 \mathrm{~A})$ & 109.5 \\
\hline $\mathrm{C}(91)-\mathrm{C}(94)-\mathrm{H}(94 \mathrm{~B})$ & 109.5 \\
\hline $\mathrm{H}(94 \mathrm{~A})-\mathrm{C}(94)-\mathrm{H}(94 \mathrm{~B})$ & 109.5 \\
\hline $\mathrm{C}(91)-\mathrm{C}(94)-\mathrm{H}(94 \mathrm{C})$ & 109.5 \\
\hline $\mathrm{H}(94 \mathrm{~A})-\mathrm{C}(94)-\mathrm{H}(94 \mathrm{C})$ & 109.5 \\
\hline $\mathrm{H}(94 \mathrm{~B})-\mathrm{C}(94)-\mathrm{H}(94 \mathrm{C})$ & 109.5 \\
\hline $\mathrm{C}(92)-\mathrm{C}(95)-\mathrm{H}(95 \mathrm{~A})$ & 109.5 \\
\hline $\mathrm{C}(92)-\mathrm{C}(95)-\mathrm{H}(95 \mathrm{~B})$ & 109.5 \\
\hline $\mathrm{H}(95 \mathrm{~A})-\mathrm{C}(95)-\mathrm{H}(95 \mathrm{~B})$ & 109.5 \\
\hline $\mathrm{C}(92)-\mathrm{C}(95)-\mathrm{H}(95 \mathrm{C})$ & 109.5 \\
\hline $\mathrm{H}(95 \mathrm{~A})-\mathrm{C}(95)-\mathrm{H}(95 \mathrm{C})$ & 109.5 \\
\hline $\mathrm{H}(95 \mathrm{~B})-\mathrm{C}(95)-\mathrm{H}(95 \mathrm{C})$ & 109.5 \\
\hline $\mathrm{C}(92)-\mathrm{C}(96)-\mathrm{H}(96 \mathrm{~A})$ & 109.5 \\
\hline $\mathrm{C}(92)-\mathrm{C}(96)-\mathrm{H}(96 \mathrm{~B})$ & 109.5 \\
\hline $\mathrm{H}(96 \mathrm{~A})-\mathrm{C}(96)-\mathrm{H}(96 \mathrm{~B})$ & 109.5 \\
\hline $\mathrm{C}(92)-\mathrm{C}(96)-\mathrm{H}(96 \mathrm{C})$ & 109.5 \\
\hline $\mathrm{H}(96 \mathrm{~A})-\mathrm{C}(96)-\mathrm{H}(96 \mathrm{C})$ & 109.5 \\
\hline $\mathrm{H}(96 \mathrm{~B})-\mathrm{C}(96)-\mathrm{H}(96 \mathrm{C})$ & 109.5 \\
\hline $\mathrm{C}(84)-\mathrm{O}(4)-\mathrm{Si}(2)$ & $134.3(4)$ \\
\hline $\mathrm{C}(54)-\mathrm{N}(3)-\mathrm{C}(55)$ & $111.2(5)$ \\
\hline $\mathrm{C}(54)-\mathrm{N}(3)-\mathrm{C}(57)$ & $123.6(5)$ \\
\hline
\end{tabular}




\begin{tabular}{|c|c|}
\hline $\mathrm{C}(55)-\mathrm{N}(3)-\mathrm{C}(57)$ & $125.2(5)$ \\
\hline$C(54)-N(4)-C(56)$ & $111.1(5)$ \\
\hline$C(54)-N(4)-C(69)$ & $122.6(5)$ \\
\hline$C(56)-N(4)-C(69)$ & $126.2(5)$ \\
\hline $\mathrm{N}(4)-\mathrm{C}(54)-\mathrm{N}(3)$ & $104.3(5)$ \\
\hline $\mathrm{N}(4)-\mathrm{C}(54)-\mathrm{Cu}(2)$ & $127.2(4)$ \\
\hline $\mathrm{N}(3)-\mathrm{C}(54)-\mathrm{Cu}(2)$ & $128.5(4)$ \\
\hline $\mathrm{C}(56)-\mathrm{C}(55)-\mathrm{N}(3)$ & $106.0(5)$ \\
\hline $\mathrm{C}(56)-\mathrm{C}(55)-\mathrm{H}(55)$ & 127.0 \\
\hline $\mathrm{N}(3)-\mathrm{C}(55)-\mathrm{H}(55)$ & 127.0 \\
\hline $\mathrm{C}(55)-\mathrm{C}(56)-\mathrm{N}(4)$ & $107.4(5)$ \\
\hline $\mathrm{C}(55)-\mathrm{C}(56)-\mathrm{H}(56)$ & 126.3 \\
\hline $\mathrm{N}(4)-\mathrm{C}(56)-\mathrm{H}(56)$ & 126.3 \\
\hline $\mathrm{C}(62)-\mathrm{C}(57)-\mathrm{C}(58)$ & $122.9(5)$ \\
\hline $\mathrm{C}(62)-\mathrm{C}(57)-\mathrm{N}(3)$ & $118.7(5)$ \\
\hline $\mathrm{C}(58)-\mathrm{C}(57)-\mathrm{N}(3)$ & $118.3(5)$ \\
\hline $\mathrm{C}(59)-\mathrm{C}(58)-\mathrm{C}(57)$ & $117.3(6)$ \\
\hline $\mathrm{C}(59)-\mathrm{C}(58)-\mathrm{C}(63)$ & $120.7(6)$ \\
\hline$C(57)-C(58)-C(63)$ & $122.0(6)$ \\
\hline $\mathrm{C}(58)-\mathrm{C}(59)-\mathrm{C}(60)$ & $120.6(7)$ \\
\hline $\mathrm{C}(58)-\mathrm{C}(59)-\mathrm{H}(59)$ & 119.7 \\
\hline $\mathrm{C}(60)-\mathrm{C}(59)-\mathrm{H}(59)$ & 119.7 \\
\hline$C(61)-C(60)-C(59)$ & $120.4(6)$ \\
\hline $\mathrm{C}(61)-\mathrm{C}(60)-\mathrm{H}(60)$ & 119.8 \\
\hline $\mathrm{C}(59)-\mathrm{C}(60)-\mathrm{H}(60)$ & 119.8 \\
\hline $\mathrm{C}(60)-\mathrm{C}(61)-\mathrm{C}(62)$ & $122.2(6)$ \\
\hline $\mathrm{C}(60)-\mathrm{C}(61)-\mathrm{H}(61)$ & 118.9 \\
\hline $\mathrm{C}(62)-\mathrm{C}(61)-\mathrm{H}(61)$ & 118.9 \\
\hline $\mathrm{C}(61)-\mathrm{C}(62)-\mathrm{C}(57)$ & $116.4(6)$ \\
\hline$C(61)-C(62)-C(66)$ & $121.0(6)$ \\
\hline$C(57)-C(62)-C(66)$ & $122.5(5)$ \\
\hline $\mathrm{C}(58)-\mathrm{C}(63)-\mathrm{C}(64)$ & $109.8(6)$ \\
\hline$C(58)-C(63)-C(65)$ & $112.4(6)$ \\
\hline$C(64)-C(63)-C(65)$ & $109.4(6)$ \\
\hline $\mathrm{C}(58)-\mathrm{C}(63)-\mathrm{H}(63)$ & 108.4 \\
\hline $\mathrm{C}(64)-\mathrm{C}(63)-\mathrm{H}(63)$ & 108.4 \\
\hline $\mathrm{C}(65)-\mathrm{C}(63)-\mathrm{H}(63)$ & 108.4 \\
\hline $\mathrm{C}(63)-\mathrm{C}(64)-\mathrm{H}(64 \mathrm{~A})$ & 109.5 \\
\hline $\mathrm{C}(63)-\mathrm{C}(64)-\mathrm{H}(64 \mathrm{~B})$ & 109.5 \\
\hline $\mathrm{H}(64 \mathrm{~A})-\mathrm{C}(64)-\mathrm{H}(64 \mathrm{~B})$ & 109.5 \\
\hline
\end{tabular}




\begin{tabular}{|c|c|}
\hline $\mathrm{C}(63)-\mathrm{C}(64)-\mathrm{H}(64 \mathrm{C})$ & 109.5 \\
\hline $\mathrm{H}(64 \mathrm{~A})-\mathrm{C}(64)-\mathrm{H}(64 \mathrm{C})$ & 109.5 \\
\hline $\mathrm{H}(64 \mathrm{~B})-\mathrm{C}(64)-\mathrm{H}(64 \mathrm{C})$ & 109.5 \\
\hline $\mathrm{C}(63)-\mathrm{C}(65)-\mathrm{H}(65 \mathrm{~A})$ & 109.5 \\
\hline $\mathrm{C}(63)-\mathrm{C}(65)-\mathrm{H}(65 \mathrm{~B})$ & 109.5 \\
\hline $\mathrm{H}(65 \mathrm{~A})-\mathrm{C}(65)-\mathrm{H}(65 \mathrm{~B})$ & 109.5 \\
\hline $\mathrm{C}(63)-\mathrm{C}(65)-\mathrm{H}(65 \mathrm{C})$ & 109.5 \\
\hline $\mathrm{H}(65 \mathrm{~A})-\mathrm{C}(65)-\mathrm{H}(65 \mathrm{C})$ & 109.5 \\
\hline $\mathrm{H}(65 \mathrm{~B})-\mathrm{C}(65)-\mathrm{H}(65 \mathrm{C})$ & 109.5 \\
\hline$C(67)-C(66)-C(62)$ & $113.2(6)$ \\
\hline$C(67)-C(66)-C(68)$ & $109.6(7)$ \\
\hline$C(62)-C(66)-C(68)$ & $110.3(6)$ \\
\hline $\mathrm{C}(67)-\mathrm{C}(66)-\mathrm{H}(66)$ & 107.8 \\
\hline $\mathrm{C}(62)-\mathrm{C}(66)-\mathrm{H}(66)$ & 107.8 \\
\hline $\mathrm{C}(68)-\mathrm{C}(66)-\mathrm{H}(66)$ & 107.8 \\
\hline $\mathrm{C}(66)-\mathrm{C}(67)-\mathrm{H}(67 \mathrm{~A})$ & 109.5 \\
\hline $\mathrm{C}(66)-\mathrm{C}(67)-\mathrm{H}(67 \mathrm{~B})$ & 109.5 \\
\hline $\mathrm{H}(67 \mathrm{~A})-\mathrm{C}(67)-\mathrm{H}(67 \mathrm{~B})$ & 109.5 \\
\hline $\mathrm{C}(66)-\mathrm{C}(67)-\mathrm{H}(67 \mathrm{C})$ & 109.5 \\
\hline $\mathrm{H}(67 \mathrm{~A})-\mathrm{C}(67)-\mathrm{H}(67 \mathrm{C})$ & 109.5 \\
\hline $\mathrm{H}(67 \mathrm{~B})-\mathrm{C}(67)-\mathrm{H}(67 \mathrm{C})$ & 109.5 \\
\hline $\mathrm{C}(66)-\mathrm{C}(68)-\mathrm{H}(68 \mathrm{~A})$ & 109.5 \\
\hline $\mathrm{C}(66)-\mathrm{C}(68)-\mathrm{H}(68 \mathrm{~B})$ & 109.5 \\
\hline $\mathrm{H}(68 \mathrm{~A})-\mathrm{C}(68)-\mathrm{H}(68 \mathrm{~B})$ & 109.5 \\
\hline $\mathrm{C}(66)-\mathrm{C}(68)-\mathrm{H}(68 \mathrm{C})$ & 109.5 \\
\hline $\mathrm{H}(68 \mathrm{~A})-\mathrm{C}(68)-\mathrm{H}(68 \mathrm{C})$ & 109.5 \\
\hline $\mathrm{H}(68 \mathrm{~B})-\mathrm{C}(68)-\mathrm{H}(68 \mathrm{C})$ & 109.5 \\
\hline$C(70)-C(69)-C(74)$ & $123.8(6)$ \\
\hline$C(70)-C(69)-N(4)$ & $118.7(5)$ \\
\hline$C(74)-C(69)-N(4)$ & $117.5(5)$ \\
\hline$C(69)-C(70)-C(71)$ & $115.9(6)$ \\
\hline$C(69)-C(70)-C(75)$ & $121.8(6)$ \\
\hline $\mathrm{C}(71)-\mathrm{C}(70)-\mathrm{C}(75)$ & $122.2(7)$ \\
\hline $\mathrm{C}(72)-\mathrm{C}(71)-\mathrm{C}(70)$ & $121.6(7)$ \\
\hline $\mathrm{C}(72)-\mathrm{C}(71)-\mathrm{H}(71)$ & 119.2 \\
\hline $\mathrm{C}(70)-\mathrm{C}(71)-\mathrm{H}(71)$ & 119.2 \\
\hline$C(71)-C(72)-C(73)$ & $120.7(6)$ \\
\hline $\mathrm{C}(71)-\mathrm{C}(72)-\mathrm{H}(72)$ & 119.7 \\
\hline $\mathrm{C}(73)-\mathrm{C}(72)-\mathrm{H}(72)$ & 119.7 \\
\hline $\mathrm{C}(72)-\mathrm{C}(73)-\mathrm{C}(74)$ & $120.8(7)$ \\
\hline
\end{tabular}




\begin{tabular}{|c|c|}
\hline $\mathrm{C}(72)-\mathrm{C}(73)-\mathrm{H}(73)$ & 119.6 \\
\hline $\mathrm{C}(74)-\mathrm{C}(73)-\mathrm{H}(73)$ & 119.6 \\
\hline$C(73)-C(74)-C(69)$ & $117.2(6)$ \\
\hline $\mathrm{C}(73)-\mathrm{C}(74)-\mathrm{C}(78)$ & $120.5(6)$ \\
\hline $\mathrm{C}(69)-\mathrm{C}(74)-\mathrm{C}(78)$ & $122.2(5)$ \\
\hline$C(76)-C(75)-C(77)$ & $118.6(13)$ \\
\hline$C(76)-C(75)-C(70)$ & $116.7(16)$ \\
\hline$C(77)-C(75)-C(70)$ & $111.3(10)$ \\
\hline $\mathrm{C}(76)-\mathrm{C}(75)-\mathrm{H}(75)$ & 102.4 \\
\hline $\mathrm{C}(77)-\mathrm{C}(75)-\mathrm{H}(75)$ & 102.4 \\
\hline $\mathrm{C}(70)-\mathrm{C}(75)-\mathrm{H}(75)$ & 102.4 \\
\hline $\mathrm{C}(75)-\mathrm{C}(76)-\mathrm{H}(76 \mathrm{~A})$ & 109.5 \\
\hline $\mathrm{C}(75)-\mathrm{C}(76)-\mathrm{H}(76 \mathrm{~B})$ & 109.5 \\
\hline $\mathrm{H}(76 \mathrm{~A})-\mathrm{C}(76)-\mathrm{H}(76 \mathrm{~B})$ & 109.5 \\
\hline $\mathrm{C}(75)-\mathrm{C}(76)-\mathrm{H}(76 \mathrm{C})$ & 109.5 \\
\hline $\mathrm{H}(76 \mathrm{~A})-\mathrm{C}(76)-\mathrm{H}(76 \mathrm{C})$ & 109.5 \\
\hline $\mathrm{H}(76 \mathrm{~B})-\mathrm{C}(76)-\mathrm{H}(76 \mathrm{C})$ & 109.5 \\
\hline $\mathrm{C}(75)-\mathrm{C}(77)-\mathrm{H}(77 \mathrm{~A})$ & 109.5 \\
\hline $\mathrm{C}(75)-\mathrm{C}(77)-\mathrm{H}(77 \mathrm{~B})$ & 109.5 \\
\hline $\mathrm{H}(77 \mathrm{~A})-\mathrm{C}(77)-\mathrm{H}(77 \mathrm{~B})$ & 109.5 \\
\hline $\mathrm{C}(75)-\mathrm{C}(77)-\mathrm{H}(77 \mathrm{C})$ & 109.5 \\
\hline $\mathrm{H}(77 \mathrm{~A})-\mathrm{C}(77)-\mathrm{H}(77 \mathrm{C})$ & 109.5 \\
\hline $\mathrm{H}(77 \mathrm{~B})-\mathrm{C}(77)-\mathrm{H}(77 \mathrm{C})$ & 109.5 \\
\hline $\mathrm{C}(80)-\mathrm{C}(78)-\mathrm{C}(74)$ & $111.4(6)$ \\
\hline $\mathrm{C}(80)-\mathrm{C}(78)-\mathrm{C}(79)$ & $108.8(7)$ \\
\hline $\mathrm{C}(74)-\mathrm{C}(78)-\mathrm{C}(79)$ & $111.8(7)$ \\
\hline $\mathrm{C}(80)-\mathrm{C}(78)-\mathrm{H}(78)$ & 108.2 \\
\hline $\mathrm{C}(74)-\mathrm{C}(78)-\mathrm{H}(78)$ & 108.2 \\
\hline $\mathrm{C}(79)-\mathrm{C}(78)-\mathrm{H}(78)$ & 108.2 \\
\hline $\mathrm{C}(78)-\mathrm{C}(79)-\mathrm{H}(79 \mathrm{~A})$ & 109.5 \\
\hline $\mathrm{C}(78)-\mathrm{C}(79)-\mathrm{H}(79 \mathrm{~B})$ & 109.5 \\
\hline $\mathrm{H}(79 \mathrm{~A})-\mathrm{C}(79)-\mathrm{H}(79 \mathrm{~B})$ & 109.5 \\
\hline $\mathrm{C}(78)-\mathrm{C}(79)-\mathrm{H}(79 \mathrm{C})$ & 109.5 \\
\hline $\mathrm{H}(79 \mathrm{~A})-\mathrm{C}(79)-\mathrm{H}(79 \mathrm{C})$ & 109.5 \\
\hline $\mathrm{H}(79 \mathrm{~B})-\mathrm{C}(79)-\mathrm{H}(79 \mathrm{C})$ & 109.5 \\
\hline $\mathrm{C}(78)-\mathrm{C}(80)-\mathrm{H}(80 \mathrm{~A})$ & 109.5 \\
\hline $\mathrm{C}(78)-\mathrm{C}(80)-\mathrm{H}(80 \mathrm{~B})$ & 109.5 \\
\hline $\mathrm{H}(80 \mathrm{~A})-\mathrm{C}(80)-\mathrm{H}(80 \mathrm{~B})$ & 109.5 \\
\hline $\mathrm{C}(78)-\mathrm{C}(80)-\mathrm{H}(80 \mathrm{C})$ & 109.5 \\
\hline $\mathrm{H}(80 \mathrm{~A})-\mathrm{C}(80)-\mathrm{H}(80 \mathrm{C})$ & 109.5 \\
\hline
\end{tabular}




\begin{tabular}{|c|c|}
\hline $\mathrm{H}(80 \mathrm{~B})-\mathrm{C}(80)-\mathrm{H}(80 \mathrm{C})$ & 109.5 \\
\hline $\mathrm{C}(84)-\mathrm{C}(83)-\mathrm{C}(82)$ & $108.3(5)$ \\
\hline $\mathrm{C}(84)-\mathrm{C}(83)-\mathrm{B}(2)$ & $106.2(5)$ \\
\hline $\mathrm{C}(82)-\mathrm{C}(83)-\mathrm{B}(2)$ & $115.8(5)$ \\
\hline $\mathrm{C}(84)-\mathrm{C}(83)-\mathrm{H}(83)$ & 108.8 \\
\hline $\mathrm{C}(82)-\mathrm{C}(83)-\mathrm{H}(83)$ & 108.8 \\
\hline $\mathrm{B}(2)-\mathrm{C}(83)-\mathrm{H}(83)$ & 108.8 \\
\hline $\mathrm{O}(4)-\mathrm{C}(84)-\mathrm{C}(83)$ & $108.1(5)$ \\
\hline $\mathrm{O}(4)-\mathrm{C}(84)-\mathrm{H}(84 \mathrm{~A})$ & 110.1 \\
\hline $\mathrm{C}(83)-\mathrm{C}(84)-\mathrm{H}(84 \mathrm{~A})$ & 110.1 \\
\hline $\mathrm{O}(4)-\mathrm{C}(84)-\mathrm{H}(84 \mathrm{~B})$ & 110.1 \\
\hline $\mathrm{C}(83)-\mathrm{C}(84)-\mathrm{H}(84 \mathrm{~B})$ & 110.1 \\
\hline $\mathrm{H}(84 \mathrm{~A})-\mathrm{C}(84)-\mathrm{H}(84 \mathrm{~B})$ & 108.4 \\
\hline$C(86)-C(85)-C(90)$ & $116.7(6)$ \\
\hline$C(86)-C(85)-\operatorname{Si}(2)$ & $122.1(5)$ \\
\hline$C(90)-C(85)-S i(2)$ & $121.2(5)$ \\
\hline$C(87)-C(86)-C(85)$ & $122.4(8)$ \\
\hline $\mathrm{C}(87)-\mathrm{C}(86)-\mathrm{H}(86)$ & 118.8 \\
\hline $\mathrm{C}(85)-\mathrm{C}(86)-\mathrm{H}(86)$ & 118.8 \\
\hline $\mathrm{C}(88)-\mathrm{C}(87)-\mathrm{C}(86)$ & $119.7(8)$ \\
\hline $\mathrm{C}(88)-\mathrm{C}(87)-\mathrm{H}(87)$ & 120.1 \\
\hline $\mathrm{C}(86)-\mathrm{C}(87)-\mathrm{H}(87)$ & 120.1 \\
\hline $\mathrm{C}(89)-\mathrm{C}(88)-\mathrm{C}(87)$ & $119.0(7)$ \\
\hline $\mathrm{C}(89)-\mathrm{C}(88)-\mathrm{H}(88)$ & 120.5 \\
\hline $\mathrm{C}(87)-\mathrm{C}(88)-\mathrm{H}(88)$ & 120.5 \\
\hline $\mathrm{C}(88)-\mathrm{C}(89)-\mathrm{C}(90)$ & $121.5(9)$ \\
\hline $\mathrm{C}(88)-\mathrm{C}(89)-\mathrm{H}(89)$ & 119.2 \\
\hline $\mathrm{C}(90)-\mathrm{C}(89)-\mathrm{H}(89)$ & 119.2 \\
\hline$C(89)-C(90)-C(85)$ & $120.6(8)$ \\
\hline $\mathrm{C}(89)-\mathrm{C}(90)-\mathrm{H}(90)$ & 119.7 \\
\hline $\mathrm{C}(85)-\mathrm{C}(90)-\mathrm{H}(90)$ & 119.7 \\
\hline$C(98)-C(97)-C(102)$ & $113.1(8)$ \\
\hline $\mathrm{C}(98)-\mathrm{C}(97)-\mathrm{Si}(2)$ & $120.6(6)$ \\
\hline$C(102)-C(97)-S i(2)$ & $126.3(6)$ \\
\hline $\mathrm{C}(99)-\mathrm{C}(98)-\mathrm{C}(97)$ & $123.7(9)$ \\
\hline $\mathrm{C}(99)-\mathrm{C}(98)-\mathrm{H}(98)$ & 118.1 \\
\hline $\mathrm{C}(97)-\mathrm{C}(98)-\mathrm{H}(98)$ & 118.1 \\
\hline$C(100)-C(99)-C(98)$ & $120.6(11)$ \\
\hline $\mathrm{C}(100)-\mathrm{C}(99)-\mathrm{H}(99)$ & 119.7 \\
\hline $\mathrm{C}(98)-\mathrm{C}(99)-\mathrm{H}(99)$ & 119.7 \\
\hline
\end{tabular}




\begin{tabular}{|c|c|}
\hline$C(99)-C(100)-C(101)$ & $119.5(10)$ \\
\hline $\mathrm{C}(99)-\mathrm{C}(100)-\mathrm{H}(100)$ & 120.3 \\
\hline $\mathrm{C}(101)-\mathrm{C}(100)-\mathrm{H}(100)$ & 120.3 \\
\hline$C(100)-C(101)-C(102)$ & $119.9(10)$ \\
\hline $\mathrm{C}(100)-\mathrm{C}(101)-\mathrm{H}(101)$ & 120.0 \\
\hline $\mathrm{C}(102)-\mathrm{C}(101)-\mathrm{H}(101)$ & 120.0 \\
\hline $\mathrm{C}(101)-\mathrm{C}(102)-\mathrm{C}(97)$ & $123.2(10)$ \\
\hline $\mathrm{C}(101)-\mathrm{C}(102)-\mathrm{H}(102)$ & 118.4 \\
\hline $\mathrm{C}(97)-\mathrm{C}(102)-\mathrm{H}(102)$ & 118.4 \\
\hline$C(106)-C(103)-C(104)$ & $109.5(6)$ \\
\hline$C(106)-C(103)-C(105)$ & $108.5(7)$ \\
\hline $\mathrm{C}(104)-\mathrm{C}(103)-\mathrm{C}(105)$ & $108.0(7)$ \\
\hline$C(106)-C(103)-\operatorname{Si}(2)$ & $109.6(5)$ \\
\hline$C(104)-C(103)-\operatorname{Si}(2)$ & $109.2(5)$ \\
\hline$C(105)-C(103)-\operatorname{Si}(2)$ & $112.0(5)$ \\
\hline $\mathrm{C}(103)-\mathrm{C}(104)-\mathrm{H}(10 \mathrm{~A})$ & 109.5 \\
\hline $\mathrm{C}(103)-\mathrm{C}(104)-\mathrm{H}(10 \mathrm{~B})$ & 109.5 \\
\hline $\mathrm{H}(10 \mathrm{~A})-\mathrm{C}(104)-\mathrm{H}(10 \mathrm{~B})$ & 109.5 \\
\hline $\mathrm{C}(103)-\mathrm{C}(104)-\mathrm{H}(10 \mathrm{C})$ & 109.5 \\
\hline $\mathrm{H}(10 \mathrm{~A})-\mathrm{C}(104)-\mathrm{H}(10 \mathrm{C})$ & 109.5 \\
\hline $\mathrm{H}(10 \mathrm{~B})-\mathrm{C}(104)-\mathrm{H}(10 \mathrm{C})$ & 109.5 \\
\hline$C(103)-C(105)-H(10 D)$ & 109.5 \\
\hline$C(103)-C(105)-H(10 E)$ & 109.5 \\
\hline $\mathrm{H}(10 \mathrm{D})-\mathrm{C}(105)-\mathrm{H}(10 \mathrm{E})$ & 109.5 \\
\hline $\mathrm{C}(103)-\mathrm{C}(105)-\mathrm{H}(10 \mathrm{~F})$ & 109.5 \\
\hline $\mathrm{H}(10 \mathrm{D})-\mathrm{C}(105)-\mathrm{H}(10 \mathrm{~F})$ & 109.5 \\
\hline $\mathrm{H}(10 \mathrm{E})-\mathrm{C}(105)-\mathrm{H}(10 \mathrm{~F})$ & 109.5 \\
\hline $\mathrm{C}(103)-\mathrm{C}(106)-\mathrm{H}(10 \mathrm{G})$ & 109.5 \\
\hline $\mathrm{C}(103)-\mathrm{C}(106)-\mathrm{H}(10 \mathrm{H})$ & 109.5 \\
\hline $\mathrm{H}(10 \mathrm{G})-\mathrm{C}(106)-\mathrm{H}(10 \mathrm{H})$ & 109.5 \\
\hline $\mathrm{C}(103)-\mathrm{C}(106)-\mathrm{H}(10 \mathrm{I})$ & 109.5 \\
\hline $\mathrm{H}(10 \mathrm{G})-\mathrm{C}(106)-\mathrm{H}(10 \mathrm{I})$ & 109.5 \\
\hline $\mathrm{H}(10 \mathrm{H})-\mathrm{C}(106)-\mathrm{H}(10 \mathrm{I})$ & 109.5 \\
\hline $\mathrm{C}(2 \mathrm{~S})-\mathrm{C}(1 \mathrm{~S})-\mathrm{H}(1 \mathrm{~S} 1)$ & 109.5 \\
\hline $\mathrm{C}(2 \mathrm{~S})-\mathrm{C}(1 \mathrm{~S})-\mathrm{H}(1 \mathrm{~S} 2)$ & 109.5 \\
\hline $\mathrm{H}(1 \mathrm{~S} 1)-\mathrm{C}(1 \mathrm{~S})-\mathrm{H}(1 \mathrm{~S} 2)$ & 109.5 \\
\hline $\mathrm{C}(2 \mathrm{~S})-\mathrm{C}(1 \mathrm{~S})-\mathrm{H}(1 \mathrm{~S} 3)$ & 109.5 \\
\hline $\mathrm{H}(1 \mathrm{~S} 1)-\mathrm{C}(1 \mathrm{~S})-\mathrm{H}(1 \mathrm{~S} 3)$ & 109.5 \\
\hline $\mathrm{H}(1 \mathrm{~S} 2)-\mathrm{C}(1 \mathrm{~S})-\mathrm{H}(1 \mathrm{~S} 3)$ & 109.5 \\
\hline$C(3 S)-C(2 S)-C(1 S)$ & $122(3)$ \\
\hline
\end{tabular}




\begin{tabular}{ll}
\hline $\mathrm{C}(3 \mathrm{~S})-\mathrm{C}(2 \mathrm{~S})-\mathrm{H}(2 \mathrm{~S} 1)$ & 106.7 \\
$\mathrm{C}(1 \mathrm{~S})-\mathrm{C}(2 \mathrm{~S})-\mathrm{H}(2 \mathrm{~S} 1)$ & 106.7 \\
$\mathrm{C}(3 \mathrm{~S})-\mathrm{C}(2 \mathrm{~S})-\mathrm{H}(2 \mathrm{~S} 2)$ & 106.7 \\
$\mathrm{C}(1 \mathrm{~S})-\mathrm{C}(2 \mathrm{~S})-\mathrm{H}(2 \mathrm{~S} 2)$ & 106.7 \\
$\mathrm{H}(2 \mathrm{~S} 1)-\mathrm{C}(2 \mathrm{~S})-\mathrm{H}(2 \mathrm{~S} 2)$ & 106.6 \\
$\mathrm{C}(2 \mathrm{~S})-\mathrm{C}(3 \mathrm{~S})-\mathrm{C}(4 \mathrm{~S})$ & $124(3)$ \\
$\mathrm{C}(2 \mathrm{~S})-\mathrm{C}(3 \mathrm{~S})-\mathrm{H}(3 \mathrm{~S} 1)$ & 106.3 \\
$\mathrm{C}(4 \mathrm{~S})-\mathrm{C}(3 \mathrm{~S})-\mathrm{H}(3 \mathrm{~S} 1)$ & 106.3 \\
$\mathrm{C}(2 \mathrm{~S})-\mathrm{C}(3 \mathrm{~S})-\mathrm{H}(3 \mathrm{~S} 2)$ & 106.3 \\
$\mathrm{C}(4 \mathrm{~S})-\mathrm{C}(3 \mathrm{~S})-\mathrm{H}(3 \mathrm{~S} 2)$ & 106.3 \\
$\mathrm{H}(3 \mathrm{~S} 1)-\mathrm{C}(3 \mathrm{~S})-\mathrm{H}(3 \mathrm{~S} 2)$ & 106.4 \\
$\mathrm{C}(5 \mathrm{~S})-\mathrm{C}(4 \mathrm{~S})-\mathrm{C}(3 \mathrm{~S})$ & $130(3)$ \\
$\mathrm{C}(5 \mathrm{~S})-\mathrm{C}(4 \mathrm{~S})-\mathrm{H}(4 \mathrm{~S} 1)$ & 104.8 \\
$\mathrm{C}(3 \mathrm{~S})-\mathrm{C}(4 \mathrm{~S})-\mathrm{H}(4 \mathrm{~S} 1)$ & 104.8 \\
$\mathrm{C}(5 \mathrm{~S})-\mathrm{C}(4 \mathrm{~S})-\mathrm{H}(4 \mathrm{~S} 2)$ & 104.8 \\
$\mathrm{C}(3 \mathrm{~S})-\mathrm{C}(4 \mathrm{~S})-\mathrm{H}(4 \mathrm{~S} 2)$ & 104.8 \\
$\mathrm{H}(4 \mathrm{~S} 1)-\mathrm{C}(4 \mathrm{~S})-\mathrm{H}(4 \mathrm{~S} 2)$ & 105.8 \\
$\mathrm{C}(4 \mathrm{~S})-\mathrm{C}(5 \mathrm{~S})-\mathrm{C}(6 \mathrm{~S})$ & $124(4)$ \\
$\mathrm{C}(4 \mathrm{~S})-\mathrm{C}(5 \mathrm{~S})-\mathrm{H}(5 \mathrm{~S} 1)$ & 106.2 \\
$\mathrm{C}(6 \mathrm{~S})-\mathrm{C}(5 \mathrm{~S})-\mathrm{H}(5 \mathrm{~S} 1)$ & 106.2 \\
$\mathrm{C}(4 \mathrm{~S})-\mathrm{C}(5 \mathrm{~S})-\mathrm{H}(5 \mathrm{~S} 2)$ & 106.2 \\
$\mathrm{C}(6 \mathrm{~S})-\mathrm{C}(5 \mathrm{~S})-\mathrm{H}(5 \mathrm{~S} 2)$ & 106.2 \\
$\mathrm{H}(5 \mathrm{~S} 1)-\mathrm{C}(5 \mathrm{~S})-\mathrm{H}(5 \mathrm{~S} 2)$ & 106.4 \\
$\mathrm{C}(5 \mathrm{~S})-\mathrm{C}(6 \mathrm{~S})-\mathrm{H}(6 \mathrm{~S} 1)$ & 109.5 \\
$\mathrm{C}(5 \mathrm{~S})-\mathrm{C}(6 \mathrm{~S})-\mathrm{H}(6 \mathrm{~S} 2)$ & 109.5 \\
$\mathrm{H}(6 \mathrm{~S} 1)-\mathrm{C}(6 \mathrm{~S})-\mathrm{H}(6 \mathrm{~S} 2)$ & 109.5 \\
$\mathrm{C}(5 \mathrm{~S})-\mathrm{C}(6 \mathrm{~S})-\mathrm{H}(6 \mathrm{~S} 3)$ & 109.5 \\
$\mathrm{H}(6 \mathrm{~S} 1)-\mathrm{C}(6 \mathrm{~S})-\mathrm{H}(6 \mathrm{~S} 3)$ & 109.5 \\
$\mathrm{H}(6 \mathrm{~S} 2)-\mathrm{C}(6 \mathrm{~S})-\mathrm{H}(6 \mathrm{~S} 3)$ & 109.5 \\
\hline
\end{tabular}

Table S17. Anisotropic displacement parameters $\left(\AA^{2} \times 10^{3}\right)$ for $\mathrm{C}_{53} \mathrm{H}_{71} \mathrm{BCuF}_{3} \mathrm{~N}_{2} \mathrm{O}_{3} \mathrm{Si}$. The anisotropic displacement factor exponent takes the form: $-2 \pi^{2}\left[\mathrm{~h} 2 \mathrm{a} * 2 \mathrm{U}^{11}+\ldots+2 \mathrm{~h} k \mathrm{k} *\right.$ $\left.\mathbf{b}^{*} \mathbf{U}^{12}\right]$

\begin{tabular}{lllllll}
\hline & $\mathrm{U}^{11}$ & $\mathrm{U}^{22}$ & $\mathrm{U}^{33}$ & $\mathrm{U}^{23}$ & $\mathrm{U}^{13}$ & $\mathrm{U}^{12}$ \\
\hline $\mathrm{Cu}(1)$ & $36(1)$ & $24(1)$ & $26(1)$ & $1(1)$ & $19(1)$ & $0(1)$ \\
$\mathrm{Si}(1)$ & $33(1)$ & $27(1)$ & $23(1)$ & $-2(1)$ & $15(1)$ & $-3(1)$ \\
$\mathrm{C}(28)$ & $64(7)$ & $34(5)$ & $60(6)$ & $1(4)$ & $47(5)$ & $5(5)$ \\
$\mathrm{C}(29)$ & $36(4)$ & $24(3)$ & $38(4)$ & $2(3)$ & $25(3)$ & $6(3)$ \\
$\mathrm{F}(1)$ & $83(4)$ & $35(3)$ & $82(4)$ & $-12(3)$ & $62(4)$ & $5(3)$ \\
$\mathrm{F}(2)$ & $92(5)$ & $55(4)$ & $80(5)$ & $-10(3)$ & $75(4)$ & $-10(3)$ \\
$\mathrm{F}(3)$ & $89(4)$ & $52(3)$ & $33(3)$ & $-5(3)$ & $39(3)$ & $-8(3)$ \\
\hline
\end{tabular}




\begin{tabular}{|c|c|c|c|c|c|c|}
\hline $\mathrm{B}(1)$ & $43(4)$ & $31(4)$ & $22(3)$ & $-1(3)$ & $21(3)$ & $-3(3)$ \\
\hline $\mathrm{O}(2)$ & $52(3)$ & $43(3)$ & $65(4)$ & $-26(3)$ & $31(3)$ & $-12(3)$ \\
\hline $\mathrm{O}(3)$ & $38(3)$ & $38(3)$ & $28(2)$ & $-5(2)$ & $-4(2)$ & $-1(2)$ \\
\hline$C(38)$ & $48(8)$ & $45(7)$ & $26(6)$ & $-5(5)$ & $12(5)$ & $-16(6)$ \\
\hline C(39) & $33(6)$ & $48(7)$ & $15(5)$ & $-20(5)$ & $2(4)$ & $-6(5)$ \\
\hline$C(40)$ & $59(9)$ & $66(10)$ & $30(6)$ & $-20(6)$ & $12(6)$ & $-13(8)$ \\
\hline$C(41)$ & $49(8)$ & $80(11)$ & $47(8)$ & $15(8)$ & $13(7)$ & $-29(8)$ \\
\hline $\mathrm{C}(42)$ & $38(7)$ & $78(12)$ & $61(10)$ & $-16(9)$ & $15(7)$ & $-5(7)$ \\
\hline$C(43)$ & $73(12)$ & $66(10)$ & $28(6)$ & $15(6)$ & $7(7)$ & $20(9)$ \\
\hline $\mathrm{C}(28 \mathrm{X})$ & $53(12)$ & $25(9)$ & $32(11)$ & $9(8)$ & $23(10)$ & $22(9)$ \\
\hline$C(29 X)$ & $36(11)$ & $31(8)$ & $26(8)$ & $-6(6)$ & $13(8)$ & $-1(8)$ \\
\hline$F(1 X)$ & $112(15)$ & $32(7)$ & $51(9)$ & $-9(6)$ & $48(10)$ & $5(8)$ \\
\hline$F(2 X)$ & $45(9)$ & $85(14)$ & $47(9)$ & $-5(9)$ & $23(7)$ & $25(8)$ \\
\hline$F(3 X)$ & $82(11)$ & $64(10)$ & $23(7)$ & $10(7)$ & $25(7)$ & $36(10)$ \\
\hline $\mathrm{B}(1 \mathrm{X})$ & $42(8)$ & $37(11)$ & $32(9)$ & $1(7)$ & $18(7)$ & $-5(7)$ \\
\hline $\mathrm{O}(2 \mathrm{X})$ & $44(7)$ & $34(8)$ & $46(8)$ & $1(6)$ & $19(6)$ & $-1(6)$ \\
\hline $\mathrm{O}(3 \mathrm{X})$ & $45(8)$ & $53(9)$ & $48(8)$ & $-11(7)$ & $16(7)$ & $-1(7)$ \\
\hline$C(38 X)$ & $34(7)$ & $76(9)$ & $26(6)$ & $-3(6)$ & $10(5)$ & $-5(6)$ \\
\hline$C(39 X)$ & $28(7)$ & $68(9)$ & $63(9)$ & $9(7)$ & $16(6)$ & $5(6)$ \\
\hline$C(40 X)$ & $73(12)$ & $88(13)$ & $32(7)$ & $-2(8)$ & $29(8)$ & $-18(10)$ \\
\hline$C(41 X)$ & $64(13)$ & $104(16)$ & $30(7)$ & $3(8)$ & $-6(8)$ & $-4(11)$ \\
\hline$C(42 X)$ & $72(19)$ & $80(20)$ & $110(30)$ & $6(18)$ & $60(20)$ & $17(17)$ \\
\hline$C(43 X)$ & $22(10)$ & $61(13)$ & $97(17)$ & $-4(11)$ & $38(11)$ & $-6(9)$ \\
\hline $\mathrm{C}(38 \mathrm{Y})$ & $34(7)$ & $76(9)$ & $26(6)$ & $-3(6)$ & $10(5)$ & $-5(6)$ \\
\hline $\mathrm{C}(39 \mathrm{Y})$ & $28(7)$ & $68(9)$ & $63(9)$ & $9(7)$ & $16(6)$ & $5(6)$ \\
\hline $\mathrm{C}(40 \mathrm{Y})$ & $73(12)$ & $88(13)$ & $32(7)$ & $-2(8)$ & $29(8)$ & $-18(10)$ \\
\hline $\mathrm{C}(41 \mathrm{Y})$ & $100(30)$ & $69(13)$ & $70(19)$ & $7(14)$ & $44(19)$ & $-12(15)$ \\
\hline $\mathrm{C}(42 \mathrm{Y})$ & $49(13)$ & $100(20)$ & $37(10)$ & $-23(12)$ & $16(10)$ & $-24(13)$ \\
\hline $\mathrm{C}(43 \mathrm{Y})$ & $64(13)$ & $104(16)$ & $30(7)$ & $3(8)$ & $-6(8)$ & $-4(11)$ \\
\hline $\mathrm{O}(1)$ & $43(2)$ & $32(2)$ & $29(2)$ & $3(1)$ & $21(2)$ & $-2(2)$ \\
\hline $\mathrm{N}(1)$ & $34(2)$ & $26(2)$ & $22(2)$ & $-1(2)$ & $12(2)$ & $-2(2)$ \\
\hline $\mathrm{N}(2)$ & $40(2)$ & $28(2)$ & $21(2)$ & $1(2)$ & $12(2)$ & $-1(2)$ \\
\hline$C(1)$ & $25(2)$ & $26(2)$ & $25(2)$ & $-2(2)$ & $9(2)$ & $-1(2)$ \\
\hline$C(2)$ & $61(4)$ & $27(3)$ & $32(3)$ & $-4(2)$ & $21(3)$ & $1(2)$ \\
\hline$C(3)$ & $66(4)$ & $25(3)$ & $36(3)$ & $2(2)$ & $29(3)$ & $-1(2)$ \\
\hline$C(4)$ & $36(2)$ & $31(3)$ & $24(2)$ & $-5(2)$ & $17(2)$ & $-5(2)$ \\
\hline$C(5)$ & $38(3)$ & $31(3)$ & $25(2)$ & $-4(2)$ & $13(2)$ & $-4(2)$ \\
\hline$C(6)$ & $57(3)$ & $38(3)$ & $26(2)$ & $2(2)$ & $16(2)$ & $-10(3)$ \\
\hline$C(7)$ & $74(4)$ & $41(3)$ & $36(3)$ & $-11(2)$ & $34(3)$ & $-26(3)$ \\
\hline$C(8)$ & $44(3)$ & $47(3)$ & $52(3)$ & $-15(3)$ & $33(3)$ & $-19(3)$ \\
\hline
\end{tabular}


Paioti, et al.; Supporting Information, Part I; Page S92

\begin{tabular}{|c|c|c|c|c|c|c|}
\hline$C(9)$ & $33(3)$ & $39(3)$ & $40(3)$ & $-14(2)$ & $18(2)$ & $-8(2)$ \\
\hline$C(10)$ & $35(3)$ & $45(3)$ & $27(2)$ & $0(2)$ & $8(2)$ & $0(2)$ \\
\hline$C(11)$ & $46(3)$ & $58(4)$ & $46(3)$ & $-11(3)$ & $14(3)$ & $6(3)$ \\
\hline$C(12)$ & $33(3)$ & $50(4)$ & $56(4)$ & $-15(3)$ & $10(3)$ & $-4(3)$ \\
\hline$C(13)$ & $34(3)$ & $45(3)$ & $50(3)$ & $-12(3)$ & $12(2)$ & $-1(2)$ \\
\hline$C(14)$ & $37(3)$ & $77(6)$ & $88(6)$ & $-37(5)$ & $10(4)$ & $7(3)$ \\
\hline$C(15)$ & $45(3)$ & $67(5)$ & $44(3)$ & $-20(3)$ & $12(3)$ & $1(3)$ \\
\hline$C(16)$ & $42(3)$ & $26(3)$ & $28(2)$ & $6(2)$ & $19(2)$ & $1(2)$ \\
\hline$C(17)$ & $47(3)$ & $33(3)$ & $27(2)$ & $1(2)$ & $18(2)$ & $4(2)$ \\
\hline$C(18)$ & $61(3)$ & $38(3)$ & $30(2)$ & $5(2)$ & $24(3)$ & $5(3)$ \\
\hline C(19) & $68(4)$ & $47(4)$ & $44(3)$ & $11(3)$ & $38(3)$ & $11(3)$ \\
\hline$C(20)$ & $47(3)$ & $48(4)$ & $52(3)$ & $17(3)$ & $31(3)$ & $9(3)$ \\
\hline $\mathrm{C}(21)$ & $43(3)$ & $48(3)$ & $38(3)$ & $14(2)$ & $22(2)$ & $0(2)$ \\
\hline$C(22)$ & $46(3)$ & $50(3)$ & $25(2)$ & $8(2)$ & $14(2)$ & $5(3)$ \\
\hline$C(23)$ & $39(5)$ & $65(7)$ & $49(7)$ & $-11(5)$ & $26(5)$ & $-15(5)$ \\
\hline$C(24)$ & $35(5)$ & $105(12)$ & $46(7)$ & $31(8)$ & $17(5)$ & $20(6)$ \\
\hline$C(26)$ & $90(12)$ & $96(12)$ & $70(9)$ & $-13(9)$ & $43(9)$ & $-42(10)$ \\
\hline$C(27)$ & $62(14)$ & $108(16)$ & $59(10)$ & $29(11)$ & $15(10)$ & $23(12)$ \\
\hline$C(22 X)$ & $46(3)$ & $50(3)$ & $25(2)$ & $8(2)$ & $14(2)$ & $5(3)$ \\
\hline$C(23 X)$ & $75(13)$ & $40(10)$ & $68(14)$ & $4(8)$ & $6(11)$ & $-7(9)$ \\
\hline$C(24 X)$ & $43(9)$ & $38(8)$ & $42(10)$ & $-12(7)$ & $5(7)$ & $3(6)$ \\
\hline$C(26 X)$ & $67(14)$ & $110(20)$ & $50(12)$ & $6(14)$ & $12(11)$ & $-63(17)$ \\
\hline $\mathrm{C}(27 \mathrm{X})$ & $30(11)$ & $81(15)$ & $35(10)$ & $19(10)$ & $17(8)$ & $-2(10)$ \\
\hline$C(25)$ & $36(3)$ & $76(5)$ & $42(3)$ & $13(3)$ & $13(3)$ & $-10(3)$ \\
\hline$C(30)$ & $48(3)$ & $24(2)$ & $39(3)$ & $3(2)$ & $27(2)$ & $2(2)$ \\
\hline$C(31)$ & $35(2)$ & $24(2)$ & $27(2)$ & $0(2)$ & $17(2)$ & $-6(2)$ \\
\hline$C(32)$ & $32(2)$ & $29(3)$ & $38(3)$ & $-4(2)$ & $15(2)$ & $-6(2)$ \\
\hline$C(33)$ & $32(3)$ & $54(4)$ & $45(3)$ & $3(3)$ & $14(2)$ & $-2(3)$ \\
\hline$C(34)$ & $31(3)$ & $57(4)$ & $61(4)$ & $7(3)$ & $7(3)$ & $-5(3)$ \\
\hline$C(35)$ & $30(3)$ & $54(4)$ & $86(5)$ & $-7(4)$ & $18(3)$ & $-5(3)$ \\
\hline$C(36)$ & $39(3)$ & $55(4)$ & $69(4)$ & $-24(3)$ & $22(3)$ & $-9(3)$ \\
\hline$C(37)$ & $38(3)$ & $40(3)$ & $48(3)$ & $-15(3)$ & $16(2)$ & $-3(2)$ \\
\hline $\mathrm{C}(44)$ & $33(3)$ & $32(3)$ & $33(2)$ & $1(2)$ & $7(2)$ & $0(2)$ \\
\hline$C(45)$ & $49(3)$ & $60(4)$ & $51(4)$ & $-19(3)$ & $15(3)$ & $1(3)$ \\
\hline $\mathrm{C}(46)$ & $61(4)$ & $65(5)$ & $62(4)$ & $-29(4)$ & $12(3)$ & $2(4)$ \\
\hline$C(47)$ & $48(3)$ & $51(4)$ & $54(4)$ & $-6(3)$ & $-3(3)$ & $-5(3)$ \\
\hline$C(48)$ & $39(3)$ & $97(6)$ & $40(3)$ & $9(3)$ & $7(3)$ & $-8(4)$ \\
\hline$C(49)$ & $38(3)$ & $87(5)$ & $30(3)$ & $0(3)$ & $11(2)$ & $-5(3)$ \\
\hline$C(50)$ & $49(3)$ & $27(3)$ & $33(2)$ & $-2(2)$ & $24(2)$ & $-6(2)$ \\
\hline $\mathrm{C}(51)$ & $60(4)$ & $29(3)$ & $45(3)$ & $3(2)$ & $19(3)$ & $5(3)$ \\
\hline
\end{tabular}




\begin{tabular}{|c|c|c|c|c|c|c|}
\hline$C(52)$ & $54(4)$ & $35(3)$ & $63(4)$ & $-9(3)$ & $17(3)$ & $-12(3)$ \\
\hline$C(53)$ & $105(6)$ & $41(4)$ & $59(4)$ & $6(3)$ & $60(4)$ & $-4(4)$ \\
\hline $\mathrm{Cu}(2)$ & $35(1)$ & $26(1)$ & $32(1)$ & $-4(1)$ & $5(1)$ & $6(1)$ \\
\hline $\operatorname{Si}(2)$ & $25(1)$ & $31(1)$ & $47(1)$ & $4(1)$ & $5(1)$ & $0(1)$ \\
\hline $\mathrm{C}(81)$ & $52(5)$ & $32(4)$ & $31(4)$ & $-3(3)$ & $2(4)$ & $7(4)$ \\
\hline$C(82)$ & $36(3)$ & $30(3)$ & $26(3)$ & $-8(2)$ & $5(3)$ & $11(3)$ \\
\hline $\mathrm{F}(4)$ & $30(3)$ & $47(3)$ & $55(3)$ & $-12(2)$ & $-5(2)$ & $4(2)$ \\
\hline $\mathrm{F}(5)$ & $70(3)$ & $28(2)$ & $40(2)$ & $-15(2)$ & $-2(2)$ & $2(2)$ \\
\hline $\mathrm{F}(6)$ & $87(5)$ & $49(4)$ & $29(3)$ & $1(2)$ & $-12(3)$ & $6(3)$ \\
\hline $\mathrm{B}(2)$ & $24(3)$ & $22(3)$ & $30(3)$ & $-3(3)$ & $-1(3)$ & $3(2)$ \\
\hline $\mathrm{O}(5)$ & $36(3)$ & $30(3)$ & $49(3)$ & $-9(2)$ & $22(2)$ & $-5(2)$ \\
\hline $\mathrm{O}(6)$ & $56(3)$ & $25(3)$ & $66(3)$ & $-15(2)$ & $31(3)$ & $-7(2)$ \\
\hline $\mathrm{C}(91)$ & $37(9)$ & $17(6)$ & $57(9)$ & $4(6)$ & $23(7)$ & $-1(6)$ \\
\hline $\mathrm{C}(92)$ & $39(8)$ & $27(7)$ & $74(10)$ & $0(7)$ & $29(7)$ & $-5(6)$ \\
\hline $\mathrm{C}(93)$ & $36(7)$ & $83(13)$ & $79(10)$ & $24(9)$ & $28(7)$ & $15(7)$ \\
\hline $\mathrm{C}(94)$ & $70(10)$ & $44(8)$ & $69(9)$ & $3(7)$ & $47(8)$ & $-11(7)$ \\
\hline$C(95)$ & $49(8)$ & $64(11)$ & $93(10)$ & $31(9)$ & $42(7)$ & $17(7)$ \\
\hline$C(96)$ & $66(9)$ & $33(7)$ & $73(10)$ & $-18(7)$ & $41(8)$ & $-23(7)$ \\
\hline $\mathrm{C}(81 \mathrm{X})$ & $27(13)$ & $41(12)$ & $75(15)$ & $-7(11)$ & $11(9)$ & $0(10)$ \\
\hline$C(82 X)$ & $29(9)$ & $34(10)$ & $65(13)$ & $7(10)$ & $8(9)$ & $0(7)$ \\
\hline$F(4 X)$ & $48(10)$ & $50(9)$ & $95(15)$ & $-9(9)$ & $23(10)$ & $-12(7)$ \\
\hline$F(5 X)$ & $45(12)$ & $66(17)$ & $61(15)$ & $-13(11)$ & $3(11)$ & $-14(11)$ \\
\hline$F(6 X)$ & $26(9)$ & $90(15)$ & $110(18)$ & $-27(14)$ & $-6(9)$ & $15(10)$ \\
\hline $\mathrm{B}(2 \mathrm{X})$ & $29(12)$ & $45(12)$ & $41(11)$ & $-5(9)$ & $7(9)$ & $-3(9)$ \\
\hline $\mathrm{O}(5 \mathrm{X})$ & $51(10)$ & $46(10)$ & $65(11)$ & $-9(8)$ & $38(10)$ & $-7(8)$ \\
\hline $\mathrm{O}(6 \mathrm{X})$ & $69(13)$ & $62(12)$ & $60(11)$ & $-21(10)$ & $38(11)$ & $-25(10)$ \\
\hline$C(91 X)$ & $38(10)$ & $59(11)$ & $35(9)$ & $-4(8)$ & $31(8)$ & $12(9)$ \\
\hline$C(92 X)$ & $61(13)$ & $64(12)$ & $57(12)$ & $0(9)$ & $31(11)$ & $1(10)$ \\
\hline$C(93 X)$ & $74(18)$ & $120(30)$ & $48(14)$ & $36(18)$ & $40(13)$ & $40(20)$ \\
\hline $\mathrm{C}(94 \mathrm{X})$ & 101(13) & $64(9)$ & $57(7)$ & $3(7)$ & $42(8)$ & $7(9)$ \\
\hline$C(95 X)$ & $52(12)$ & $51(17)$ & $68(18)$ & $-46(15)$ & 11(10) & $-6(10)$ \\
\hline$C(96 X)$ & 101(13) & $64(9)$ & $57(7)$ & $3(7)$ & $42(8)$ & $7(9)$ \\
\hline $\mathrm{C}(91 \mathrm{Y})$ & $38(12)$ & $47(12)$ & $42(10)$ & $3(8)$ & $22(8)$ & $2(9)$ \\
\hline $\mathrm{C}(92 \mathrm{Y})$ & $55(12)$ & $47(11)$ & $49(11)$ & $-9(8)$ & $31(9)$ & $-12(9)$ \\
\hline $\mathrm{C}(93 \mathrm{Y})$ & $60(12)$ & $43(11)$ & $60(12)$ & $-1(9)$ & $36(11)$ & $2(8)$ \\
\hline $\mathrm{C}(94 \mathrm{Y})$ & $39(11)$ & $140(30)$ & $42(10)$ & $-5(12)$ & $8(8)$ & $14(13)$ \\
\hline $\mathrm{C}(95 \mathrm{Y})$ & $42(10)$ & $110(20)$ & $62(12)$ & $-14(11)$ & $13(8)$ & $-40(11)$ \\
\hline $\mathrm{C}(96 \mathrm{Y})$ & 101(13) & $64(9)$ & $57(7)$ & $3(7)$ & $42(8)$ & $7(9)$ \\
\hline $\mathrm{O}(4)$ & $30(2)$ & $47(3)$ & $58(3)$ & $20(2)$ & $5(2)$ & $1(2)$ \\
\hline $\mathrm{N}(3)$ & $27(2)$ & $26(2)$ & $40(2)$ & $-1(2)$ & $11(2)$ & $-1(2)$ \\
\hline
\end{tabular}


Paioti, et al.; Supporting Information, Part I; Page S94

\begin{tabular}{|c|c|c|c|c|c|c|}
\hline $\mathrm{N}(4)$ & $28(2)$ & $30(2)$ & $39(2)$ & $1(2)$ & $9(2)$ & $2(2)$ \\
\hline$C(54)$ & $34(2)$ & $29(2)$ & $37(3)$ & $-3(2)$ & $19(2)$ & $-1(2)$ \\
\hline$C(55)$ & $40(3)$ & $21(3)$ & $63(4)$ & $-2(2)$ & $13(3)$ & $-1(2)$ \\
\hline$C(56)$ & $42(3)$ & $26(3)$ & $59(4)$ & $-1(2)$ & $13(3)$ & $3(2)$ \\
\hline$C(57)$ & $27(2)$ & $27(3)$ & $40(3)$ & $-1(2)$ & $8(2)$ & $-1(2)$ \\
\hline$C(58)$ & $45(3)$ & $33(3)$ & $44(3)$ & $-4(2)$ & $19(2)$ & $-2(2)$ \\
\hline$C(59)$ & $62(4)$ & $47(4)$ & $39(3)$ & $2(3)$ & $9(3)$ & $0(3)$ \\
\hline$C(60)$ & $50(4)$ & $37(3)$ & $54(3)$ & $-4(3)$ & $-3(3)$ & $14(3)$ \\
\hline$C(61)$ & $31(3)$ & $36(3)$ & $59(3)$ & $-8(3)$ & $6(3)$ & $2(2)$ \\
\hline$C(62)$ & $32(3)$ & $26(3)$ & $50(3)$ & $-3(2)$ & $14(2)$ & $-2(2)$ \\
\hline$C(63)$ & $52(4)$ & $50(4)$ & $52(3)$ & $0(3)$ & $28(3)$ & $-1(3)$ \\
\hline$C(64)$ & $48(4)$ & $70(5)$ & $60(4)$ & $-18(4)$ & $26(3)$ & $-15(3)$ \\
\hline$C(65)$ & $85(6)$ & $69(5)$ & $67(5)$ & $-23(4)$ & $46(4)$ & $-28(5)$ \\
\hline$C(66)$ & $35(3)$ & $47(4)$ & $53(3)$ & $-4(3)$ & $21(3)$ & $-4(2)$ \\
\hline$C(67)$ & $71(5)$ & $98(7)$ & $89(6)$ & $-23(6)$ & $50(5)$ & $-40(5)$ \\
\hline$C(68)$ & $72(5)$ & $58(4)$ & $61(4)$ & $-18(4)$ & $37(4)$ & $-9(4)$ \\
\hline$C(69)$ & $30(2)$ & $29(3)$ & $40(3)$ & $1(2)$ & $7(2)$ & $2(2)$ \\
\hline$C(70)$ & $50(3)$ & $52(4)$ & $43(3)$ & $5(3)$ & $17(3)$ & $1(3)$ \\
\hline$C(71)$ & $71(4)$ & $80(6)$ & $30(3)$ & $3(3)$ & $10(3)$ & $4(4)$ \\
\hline$C(72)$ & $48(4)$ & $61(4)$ & $47(3)$ & $-8(3)$ & $-3(3)$ & $-1(3)$ \\
\hline$C(73)$ & $31(3)$ & $47(4)$ & $54(3)$ & $-13(3)$ & $5(3)$ & $-3(2)$ \\
\hline$C(74)$ & $30(3)$ & $40(3)$ & $47(3)$ & $-11(2)$ & $11(2)$ & $1(2)$ \\
\hline$C(75)$ & $63(4)$ & $100(6)$ & $44(4)$ & $13(4)$ & $29(3)$ & $9(4)$ \\
\hline$C(76)$ & $87(9)$ & $104(11)$ & $130(20)$ & $-6(10)$ & $84(14)$ & $-8(11)$ \\
\hline$C(77)$ & $85(10)$ & $98(11)$ & $83(10)$ & $16(8)$ & $51(10)$ & $-4(8)$ \\
\hline$C(76 X)$ & $87(9)$ & $104(11)$ & $130(20)$ & $-6(10)$ & $84(14)$ & $-8(11)$ \\
\hline$C(77 X)$ & $85(10)$ & $98(11)$ & $83(10)$ & $16(8)$ & $51(10)$ & $-4(8)$ \\
\hline$C(78)$ & $33(3)$ & $69(4)$ & $51(3)$ & $-22(3)$ & $18(3)$ & $-10(3)$ \\
\hline$C(79)$ & $59(5)$ & $99(7)$ & $96(7)$ & $-37(6)$ & $37(5)$ & $5(5)$ \\
\hline$C(80)$ & $42(4)$ & $100(6)$ & $49(4)$ & $2(4)$ & $16(3)$ & $-12(4)$ \\
\hline$C(83)$ & $34(3)$ & $26(3)$ & $44(3)$ & $3(2)$ & $9(2)$ & $7(2)$ \\
\hline$C(84)$ & $33(3)$ & $37(3)$ & $33(3)$ & $4(2)$ & $5(2)$ & $16(2)$ \\
\hline$C(85)$ & $29(3)$ & $33(3)$ & $58(3)$ & $3(2)$ & $14(2)$ & $5(2)$ \\
\hline$C(86)$ & $33(3)$ & $47(4)$ & $61(4)$ & $10(3)$ & $8(3)$ & $0(3)$ \\
\hline$C(87)$ & $32(3)$ & $50(4)$ & $97(5)$ & $14(4)$ & $13(3)$ & $-3(3)$ \\
\hline $\mathrm{C}(88)$ & $47(4)$ & $54(4)$ & $126(7)$ & $14(4)$ & $51(4)$ & $7(3)$ \\
\hline $\mathrm{C}(89)$ & $75(5)$ & $64(5)$ & $102(6)$ & $3(4)$ & $66(5)$ & $9(4)$ \\
\hline$C(90)$ & $52(4)$ & $53(4)$ & $75(4)$ & $-10(3)$ & $35(3)$ & $5(3)$ \\
\hline$C(97)$ & $53(4)$ & $35(3)$ & $61(4)$ & $4(3)$ & $27(3)$ & $-7(3)$ \\
\hline $\mathrm{C}(98)$ & $91(6)$ & $84(6)$ & $56(4)$ & $24(4)$ & $39(4)$ & $31(5)$ \\
\hline
\end{tabular}




\begin{tabular}{lllllll}
\hline $\mathrm{C}(99)$ & $123(8)$ & $99(8)$ & $81(5)$ & $28(6)$ & $65(6)$ & $41(7)$ \\
$\mathrm{C}(100)$ & $126(8)$ & $84(7)$ & $74(5)$ & $-2(5)$ & $65(6)$ & $-2(6)$ \\
$\mathrm{C}(101)$ & $78(6)$ & $136(10)$ & $65(5)$ & $-33(6)$ & $25(5)$ & $-29(6)$ \\
$\mathrm{C}(102)$ & $55(5)$ & $132(10)$ & $63(5)$ & $-26(5)$ & $17(4)$ & $-11(5)$ \\
$\mathrm{C}(103)$ & $32(3)$ & $32(3)$ & $59(4)$ & $4(3)$ & $-3(3)$ & $1(2)$ \\
$\mathrm{C}(104)$ & $48(4)$ & $41(4)$ & $75(5)$ & $8(3)$ & $3(3)$ & $-8(3)$ \\
$\mathrm{C}(105)$ & $49(4)$ & $44(4)$ & $101(6)$ & $12(4)$ & $-22(4)$ & $10(3)$ \\
$\mathrm{C}(106)$ & $68(5)$ & $38(4)$ & $91(5)$ & $-14(4)$ & $31(4)$ & $-3(3)$ \\
\hline
\end{tabular}

Table S18. Hydrogen coordinates $\left(\mathrm{x}^{4} 0^{4}\right)$ and isotropic displacement parameters $\left(\AA^{2} \times 10^{3}\right)$ for $\mathrm{C}_{53} \mathrm{H}_{71} \mathrm{BCuF}_{3} \mathrm{~N}_{2} \mathrm{O}_{3} \mathrm{Si}$

\begin{tabular}{|c|c|c|c|c|}
\hline & $\mathrm{x}$ & $\mathrm{y}$ & $\mathrm{z}$ & $\mathrm{U}(\mathrm{eq})$ \\
\hline H(29) & 3257 & 6490 & 5335 & 35 \\
\hline $\mathrm{H}(40 \mathrm{~A})$ & 1006 & 4622 & 3287 & 80 \\
\hline $\mathrm{H}(40 \mathrm{~B})$ & 1020 & 3232 & 3471 & 80 \\
\hline $\mathrm{H}(40 \mathrm{C})$ & 406 & 3973 & 3263 & 80 \\
\hline $\mathrm{H}(41 \mathrm{~A})$ & 833 & 3802 & 4827 & 91 \\
\hline $\mathrm{H}(41 \mathrm{~B})$ & 299 & 3465 & 4223 & 91 \\
\hline $\mathrm{H}(41 \mathrm{C})$ & 913 & 2724 & 4431 & 91 \\
\hline $\mathrm{H}(42 \mathrm{~A})$ & -112 & 5604 & 3903 & 90 \\
\hline $\mathrm{H}(42 \mathrm{~B})$ & 242 & 5495 & 4596 & 90 \\
\hline $\mathrm{H}(42 \mathrm{C})$ & 167 & 6785 & 4283 & 90 \\
\hline $\mathrm{H}(43 \mathrm{~A})$ & 459 & 6289 & 3286 & 89 \\
\hline $\mathrm{H}(43 \mathrm{~B})$ & 751 & 7368 & 3737 & 89 \\
\hline $\mathrm{H}(43 \mathrm{C})$ & 1171 & 6428 & 3581 & 89 \\
\hline $\mathrm{H}(29 \mathrm{X})$ & 2016 & 6619 & 4545 & 37 \\
\hline $\mathrm{H}(40 \mathrm{D})$ & 4378 & 6198 & 5446 & 92 \\
\hline $\mathrm{H}(40 \mathrm{E})$ & 4673 & 7081 & 5994 & 92 \\
\hline $\mathrm{H}(40 \mathrm{~F})$ & 5010 & 5866 & 5946 & 92 \\
\hline $\mathrm{H}(41 \mathrm{D})$ & 4752 & 6484 & 6948 & 110 \\
\hline $\mathrm{H}(41 \mathrm{E})$ & 4482 & 5237 & 7067 & 110 \\
\hline $\mathrm{H}(41 \mathrm{~F})$ & 5064 & 5230 & 6908 & 110 \\
\hline $\mathrm{H}(42 \mathrm{D})$ & 4548 & 4480 & 5351 & 119 \\
\hline $\mathrm{H}(42 \mathrm{E})$ & 4898 & 3568 & 5872 & 119 \\
\hline $\mathrm{H}(42 \mathrm{~F})$ & 4293 & 3147 & 5356 & 119 \\
\hline $\mathrm{H}(43 \mathrm{D})$ & 4426 & 3231 & 6663 & 83 \\
\hline $\mathrm{H}(43 \mathrm{E})$ & 3754 & 3698 & 6491 & 83 \\
\hline $\mathrm{H}(43 \mathrm{~F})$ & 3895 & 2646 & 6118 & 83 \\
\hline $\mathrm{H}(40 \mathrm{G})$ & 1416 & 5111 & 3495 & 92 \\
\hline $\mathrm{H}(40 \mathrm{H})$ & 1464 & 3669 & 3483 & 92 \\
\hline
\end{tabular}




\begin{tabular}{|c|c|c|c|c|}
\hline $\mathrm{H}(40 \mathrm{I})$ & 828 & 4315 & 3182 & 92 \\
\hline $\mathrm{H}(41 \mathrm{G})$ & 762 & 3080 & 4483 & 117 \\
\hline $\mathrm{H}(41 \mathrm{H})$ & 430 & 3083 & 3785 & 117 \\
\hline $\mathrm{H}(41 \mathrm{I})$ & 1066 & 2436 & 4086 & 117 \\
\hline $\mathrm{H}(42 \mathrm{G})$ & 728 & 4720 & 4918 & 93 \\
\hline $\mathrm{H}(42 \mathrm{H})$ & 432 & 6028 & 4738 & 93 \\
\hline $\mathrm{H}(42 \mathrm{I})$ & 117 & 4866 & 4360 & 93 \\
\hline $\mathrm{H}(43 \mathrm{G})$ & 377 & 6956 & 3824 & 110 \\
\hline $\mathrm{H}(43 \mathrm{H})$ & 794 & 6493 & 3496 & 110 \\
\hline $\mathrm{H}(43 \mathrm{I})$ & 185 & 5796 & 3406 & 110 \\
\hline $\mathrm{H}(2)$ & 2319 & 12551 & 5425 & 47 \\
\hline $\mathrm{H}(3)$ & 2643 & 12674 & 4586 & 47 \\
\hline $\mathrm{H}(6)$ & 2938 & 9096 & 7152 & 48 \\
\hline $\mathrm{H}(7)$ & 1950 & 8845 & 7049 & 56 \\
\hline $\mathrm{H}(8)$ & 1170 & 9401 & 6190 & 52 \\
\hline $\mathrm{H}(10)$ & 3415 & 10450 & 6077 & 44 \\
\hline $\mathrm{H}(11 \mathrm{~A})$ & 4147 & 8975 & 6555 & 76 \\
\hline $\mathrm{H}(11 \mathrm{~B})$ & 3717 & 8410 & 6846 & 76 \\
\hline $\mathrm{H}(11 \mathrm{C})$ & 3532 & 8346 & 6152 & 76 \\
\hline $\mathrm{H}(12 \mathrm{~A})$ & 4146 & 10975 & 7000 & 72 \\
\hline $\mathrm{H}(12 \mathrm{~B})$ & 3530 & 11661 & 6891 & 72 \\
\hline $\mathrm{H}(12 \mathrm{C})$ & 3716 & 10508 & 7314 & 72 \\
\hline $\mathrm{H}(13)$ & 1320 & 10939 & 4977 & 53 \\
\hline $\mathrm{H}(14 \mathrm{~A})$ & 700 & 11484 & 5493 & 107 \\
\hline $\mathrm{H}(14 \mathrm{~B})$ & 303 & 10966 & 4858 & 107 \\
\hline $\mathrm{H}(14 \mathrm{C})$ & 445 & 10133 & 5425 & 107 \\
\hline $\mathrm{H}(15 \mathrm{~A})$ & 722 & 9344 & 4412 & 80 \\
\hline $\mathrm{H}(15 \mathrm{~B})$ & 1404 & 8928 & 4725 & 80 \\
\hline $\mathrm{H}(15 \mathrm{C})$ & 920 & 8508 & 4983 & 80 \\
\hline $\mathrm{H}(18)$ & 2363 & 9328 & 2871 & 49 \\
\hline $\mathrm{H}(19)$ & 3372 & 9107 & 3062 & 57 \\
\hline $\mathrm{H}(20)$ & 4084 & 9716 & 3948 & 54 \\
\hline $\mathrm{H}(22)$ & 1755 & 10567 & 3879 & 48 \\
\hline $\mathrm{H}(23 \mathrm{~A})$ & 1073 & 8963 & 3426 & 73 \\
\hline $\mathrm{H}(23 \mathrm{~B})$ & 1541 & 8405 & 3179 & 73 \\
\hline $\mathrm{H}(23 \mathrm{C})$ & 1697 & 8428 & 3869 & 73 \\
\hline $\mathrm{H}(24 \mathrm{~A})$ & 1009 & 10871 & 2928 & 92 \\
\hline $\mathrm{H}(24 \mathrm{~B})$ & 1589 & 11659 & 3004 & 92 \\
\hline $\mathrm{H}(24 \mathrm{C})$ & 1462 & 10426 & 2638 & 92 \\
\hline $\mathrm{H}(26 \mathrm{~A})$ & 4053 & 12452 & 4633 & 122 \\
\hline
\end{tabular}




\begin{tabular}{|c|c|c|c|c|}
\hline $\mathrm{H}(26 \mathrm{~B})$ & 4581 & 12120 & 5242 & 122 \\
\hline $\mathrm{H}(26 \mathrm{C})$ & 4584 & 11578 & 4643 & 122 \\
\hline $\mathrm{H}(27 \mathrm{~A})$ & 4614 & 9957 & 5617 & 118 \\
\hline $\mathrm{H}(27 \mathrm{~B})$ & 4068 & 9054 & 5303 & 118 \\
\hline $\mathrm{H}(27 \mathrm{C})$ & 4543 & 9326 & 5012 & 118 \\
\hline $\mathrm{H}(22 \mathrm{X})$ & 1720 & 9996 & 3909 & 48 \\
\hline $\mathrm{H}(23 \mathrm{D})$ & 1043 & 9202 & 2996 & 102 \\
\hline $\mathrm{H}(23 \mathrm{E})$ & 1547 & 9322 & 2727 & 102 \\
\hline $\mathrm{H}(23 \mathrm{~F})$ & 1627 & 8367 & 3238 & 102 \\
\hline $\mathrm{H}(24 \mathrm{D})$ & 1165 & 11489 & 3216 & 66 \\
\hline $\mathrm{H}(24 \mathrm{E})$ & 1822 & 11998 & 3580 & 66 \\
\hline $\mathrm{H}(24 \mathrm{~F})$ & 1658 & 11492 & 2931 & 66 \\
\hline $\mathrm{H}(26 \mathrm{D})$ & 4841 & 11363 & 5178 & 120 \\
\hline $\mathrm{H}(26 \mathrm{E})$ & 4680 & 10436 & 4642 & 120 \\
\hline $\mathrm{H}(26 \mathrm{~F})$ & 4423 & 11786 & 4531 & 120 \\
\hline $\mathrm{H}(27 \mathrm{D})$ & 4500 & 9524 & 5666 & 71 \\
\hline $\mathrm{H}(27 \mathrm{E})$ & 3861 & 8931 & 5307 & 71 \\
\hline $\mathrm{H}(27 \mathrm{~F})$ & 4379 & 8864 & 5055 & 71 \\
\hline $\mathrm{H}(25)$ & 3728 & 10962 & 5153 & 62 \\
\hline $\mathrm{H}(30)$ & 2703 & 4890 & 5381 & 40 \\
\hline $\mathrm{H}(31 \mathrm{~A})$ & 2772 & 6543 & 6066 & 33 \\
\hline $\mathrm{H}(31 \mathrm{~B})$ & 2090 & 6853 & 5664 & 33 \\
\hline $\mathrm{H}(33)$ & 1122 & 6326 & 5655 & 53 \\
\hline $\mathrm{H}(34)$ & 231 & 7388 & 5444 & 63 \\
\hline $\mathrm{H}(35)$ & -98 & 7896 & 6179 & 69 \\
\hline $\mathrm{H}(36)$ & 471 & 7355 & 7142 & 65 \\
\hline $\mathrm{H}(37)$ & 1371 & 6324 & 7365 & 51 \\
\hline $\mathrm{H}(45)$ & 2323 & 6874 & 7751 & 65 \\
\hline $\mathrm{H}(46)$ & 3163 & 7637 & 8477 & 79 \\
\hline $\mathrm{H}(47)$ & 4098 & 7221 & 8495 & 69 \\
\hline $\mathrm{H}(48)$ & 4188 & 6207 & 7705 & 73 \\
\hline $\mathrm{H}(49)$ & 3341 & 5394 & 6968 & 63 \\
\hline $\mathrm{H}(51 \mathrm{~A})$ & 2864 & 3337 & 7281 & 67 \\
\hline $\mathrm{H}(51 \mathrm{~B})$ & 2464 & 2156 & 7037 & 67 \\
\hline $\mathrm{H}(51 \mathrm{C})$ & 2614 & 3032 & 6596 & 67 \\
\hline $\mathrm{H}(52 \mathrm{~A})$ & 1081 & 3631 & 6278 & 78 \\
\hline $\mathrm{H}(52 \mathrm{~B})$ & 1542 & 3207 & 5993 & 78 \\
\hline $\mathrm{H}(52 \mathrm{C})$ & 1392 & 2331 & 6434 & 78 \\
\hline $\mathrm{H}(53 \mathrm{~A})$ & 1462 & 4116 & 7365 & 89 \\
\hline $\mathrm{H}(53 \mathrm{~B})$ & 1759 & 2800 & 7496 & 89 \\
\hline
\end{tabular}




\begin{tabular}{|c|c|c|c|c|}
\hline $\mathrm{H}(53 \mathrm{C})$ & 2161 & 3974 & 7753 & 89 \\
\hline $\mathrm{H}(82)$ & 7338 & 7730 & 5659 & 39 \\
\hline H(93A) & 9107 & 8645 & 4955 & 96 \\
\hline H(93B) & 9149 & 7489 & 4582 & 96 \\
\hline $\mathrm{H}(93 \mathrm{C})$ & 9385 & 8775 & 4464 & 96 \\
\hline $\mathrm{H}(94 \mathrm{~A})$ & 8700 & 8654 & 3427 & 82 \\
\hline H(94B) & 8448 & 7380 & 3538 & 82 \\
\hline $\mathrm{H}(94 \mathrm{C})$ & 7996 & 8465 & 3244 & 82 \\
\hline $\mathrm{H}(95 \mathrm{~A})$ & 7514 & 9946 & 3449 & 96 \\
\hline H(95B) & 7717 & 11295 & 3670 & 96 \\
\hline $\mathrm{H}(95 \mathrm{C})$ & 8034 & 10585 & 3303 & 96 \\
\hline $\mathrm{H}(96 \mathrm{~A})$ & 9120 & 10609 & 4714 & 79 \\
\hline H(96B) & 8985 & 10982 & 4050 & 79 \\
\hline $\mathrm{H}(96 \mathrm{C})$ & 8667 & 11693 & 4417 & 79 \\
\hline $\mathrm{H}(82 \mathrm{X})$ & 8121 & 7820 & 4940 & 55 \\
\hline H(93D) & 6123 & 10318 & 5337 & 112 \\
\hline $\mathrm{H}(93 \mathrm{E})$ & 5938 & 10715 & 5868 & 112 \\
\hline $\mathrm{H}(93 \mathrm{~F})$ & 6357 & 11574 & 5666 & 112 \\
\hline H(94D) & 6856 & 10498 & 6937 & 105 \\
\hline $\mathrm{H}(94 \mathrm{E})$ & 7434 & 9812 & 6926 & 105 \\
\hline $\mathrm{H}(94 \mathrm{~F})$ & 7329 & 11208 & 6746 & 105 \\
\hline $\mathrm{H}(95 \mathrm{D})$ & 5763 & 9029 & 5679 & 91 \\
\hline $\mathrm{H}(95 \mathrm{E})$ & 5894 & 7678 & 5927 & 91 \\
\hline $\mathrm{H}(95 \mathrm{~F})$ & 5906 & 8769 & 6356 & 91 \\
\hline $\mathrm{H}(96 \mathrm{D})$ & 7376 & 8028 & 6761 & 105 \\
\hline $\mathrm{H}(96 \mathrm{E})$ & 6841 & 8183 & 6987 & 105 \\
\hline $\mathrm{H}(96 \mathrm{~F})$ & 6830 & 7091 & 6558 & 105 \\
\hline $\mathrm{H}(93 \mathrm{G})$ & 9041 & 7789 & 4314 & 75 \\
\hline $\mathrm{H}(93 \mathrm{H})$ & 8606 & 7301 & 3686 & 75 \\
\hline $\mathrm{H}(93 \mathrm{I})$ & 8992 & 8500 & 3733 & 75 \\
\hline $\mathrm{H}(94 \mathrm{G})$ & 7686 & 8480 & 3108 & 116 \\
\hline $\mathrm{H}(94 \mathrm{H})$ & 7475 & 9598 & 3393 & 116 \\
\hline $\mathrm{H}(94 \mathrm{I})$ & 8024 & 9751 & 3188 & 116 \\
\hline $\mathrm{H}(95 \mathrm{G})$ & 9084 & 8828 & 5035 & 108 \\
\hline $\mathrm{H}(95 \mathrm{H})$ & 9404 & 9659 & 4710 & 108 \\
\hline $\mathrm{H}(95 \mathrm{I})$ & 9169 & 10244 & 5176 & 108 \\
\hline $\mathrm{H}(96 \mathrm{G})$ & 8568 & 11715 & 4370 & 105 \\
\hline $\mathrm{H}(96 \mathrm{H})$ & 8639 & 11069 & 3821 & 105 \\
\hline $\mathrm{H}(96 \mathrm{I})$ & 7989 & 11229 & 3841 & 105 \\
\hline $\mathrm{H}(55)$ & 7208 & 1706 & 4689 & 52 \\
\hline
\end{tabular}




\begin{tabular}{|c|c|c|c|c|}
\hline $\mathrm{H}(56)$ & 8165 & 1617 & 5542 & 53 \\
\hline $\mathrm{H}(59)$ & 6282 & 4875 & 2994 & 63 \\
\hline $\mathrm{H}(60)$ & 5408 & 5242 & 3169 & 65 \\
\hline $\mathrm{H}(61)$ & 5398 & 4974 & 4080 & 54 \\
\hline $\mathrm{H}(63)$ & 7596 & 3420 & 3989 & 59 \\
\hline $\mathrm{H}(64 \mathrm{~A})$ & 8070 & 5037 & 3703 & 87 \\
\hline $\mathrm{H}(64 \mathrm{~B})$ & 7462 & 5800 & 3499 & 87 \\
\hline $\mathrm{H}(64 \mathrm{C})$ & 7811 & 5487 & 4177 & 87 \\
\hline $\mathrm{H}(65 \mathrm{~A})$ & 7594 & 3381 & 3030 & 103 \\
\hline $\mathrm{H}(65 \mathrm{~B})$ & 7001 & 2748 & 3035 & 103 \\
\hline $\mathrm{H}(65 \mathrm{C})$ & 6972 & 4094 & 2788 & 103 \\
\hline $\mathrm{H}(66)$ & 6576 & 3622 & 5315 & 53 \\
\hline $\mathrm{H}(67 \mathrm{~A})$ & 5677 & 3351 & 5456 & 121 \\
\hline $\mathrm{H}(67 \mathrm{~B})$ & 5309 & 3903 & 4821 & 121 \\
\hline $\mathrm{H}(67 \mathrm{C})$ & 5654 & 2645 & 4882 & 121 \\
\hline $\mathrm{H}(68 \mathrm{~A})$ & 6619 & 5762 & 5399 & 90 \\
\hline $\mathrm{H}(68 \mathrm{~B})$ & 5905 & 5814 & 5172 & 90 \\
\hline $\mathrm{H}(68 \mathrm{C})$ & 6284 & 5191 & 5786 & 90 \\
\hline $\mathrm{H}(71)$ & 9177 & 4530 & 7417 & 76 \\
\hline $\mathrm{H}(72)$ & 10019 & 4889 & 7229 & 70 \\
\hline $\mathrm{H}(73)$ & 10007 & 4670 & 6292 & 57 \\
\hline $\mathrm{H}(75)$ & 7759 & 3646 & 6306 & 80 \\
\hline $\mathrm{H}(76 \mathrm{~A})$ & 7835 & 5530 & 6725 & 141 \\
\hline $\mathrm{H}(76 \mathrm{~B})$ & 7405 & 4617 & 6883 & 141 \\
\hline $\mathrm{H}(76 \mathrm{C})$ & 8060 & 4903 & 7356 & 141 \\
\hline $\mathrm{H}(77 \mathrm{~A})$ & 8261 & 1933 & 6786 & 124 \\
\hline $\mathrm{H}(77 \mathrm{~B})$ & 8338 & 2548 & 7397 & 124 \\
\hline $\mathrm{H}(77 \mathrm{C})$ & 7684 & 2262 & 6924 & 124 \\
\hline $\mathrm{H}(76 \mathrm{D})$ & 7479 & 4954 & 6862 & 141 \\
\hline $\mathrm{H}(76 \mathrm{E})$ & 8153 & 5439 & 7111 & 141 \\
\hline$H(76 F)$ & 7762 & 5492 & 6423 & 141 \\
\hline H(77D) & 7886 & 2853 & 7363 & 124 \\
\hline $\mathrm{H}(77 \mathrm{E})$ & 8429 & 2258 & 7237 & 124 \\
\hline $\mathrm{H}(77 \mathrm{~F})$ & 8530 & 3487 & 7604 & 124 \\
\hline $\mathrm{H}(78)$ & 8760 & 3580 & 5042 & 61 \\
\hline $\mathrm{H}(79 \mathrm{~A})$ & 9679 & 2504 & 5438 & 124 \\
\hline H(79B) & 9633 & 3230 & 4862 & 124 \\
\hline $\mathrm{H}(79 \mathrm{C})$ & 10039 & 3743 & 5495 & 124 \\
\hline $\mathrm{H}(80 \mathrm{~A})$ & 9116 & 5171 & 4630 & 96 \\
\hline $\mathrm{H}(80 \mathrm{~B})$ & 8768 & 5696 & 5015 & 96 \\
\hline
\end{tabular}




\begin{tabular}{|c|c|c|c|c|}
\hline $\mathrm{H}(80 \mathrm{C})$ & 9484 & 5703 & 5269 & 96 \\
\hline $\mathrm{H}(83)$ & 7256 & 9339 & 5067 & 43 \\
\hline $\mathrm{H}(84 \mathrm{~A})$ & 6924 & 7295 & 4283 & 44 \\
\hline $\mathrm{H}(84 \mathrm{~B})$ & 6550 & 7660 & 4674 & 44 \\
\hline $\mathrm{H}(86)$ & 4803 & 7477 & 2810 & 60 \\
\hline $\mathrm{H}(87)$ & 4055 & 6433 & 2985 & 75 \\
\hline $\mathrm{H}(88)$ & 4062 & 6344 & 3933 & 84 \\
\hline H(89) & 4827 & 7290 & 4691 & 85 \\
\hline $\mathrm{H}(90)$ & 5568 & 8370 & 4520 & 68 \\
\hline $\mathrm{H}(98)$ & 6830 & 7621 & 3302 & 89 \\
\hline $\mathrm{H}(99)$ & 7015 & 6756 & 2542 & 112 \\
\hline $\mathrm{H}(100)$ & 6304 & 6822 & 1594 & 104 \\
\hline $\mathrm{H}(101)$ & 5388 & 7753 & 1412 & 112 \\
\hline $\mathrm{H}(102)$ & 5185 & 8610 & 2176 & 102 \\
\hline $\mathrm{H}(10 \mathrm{~A})$ & 6188 & 10865 & 2887 & 91 \\
\hline $\mathrm{H}(10 \mathrm{~B})$ & 6080 & 12073 & 3190 & 91 \\
\hline $\mathrm{H}(10 \mathrm{C})$ & 6559 & 11095 & 3570 & 91 \\
\hline $\mathrm{H}(10 \mathrm{D})$ & 5088 & 10470 & 2517 & 120 \\
\hline $\mathrm{H}(10 \mathrm{E})$ & 4757 & 10423 & 2967 & 120 \\
\hline $\mathrm{H}(10 \mathrm{~F})$ & 5005 & 11681 & 2833 & 120 \\
\hline $\mathrm{H}(10 \mathrm{G})$ & 5349 & 10689 & 4035 & 98 \\
\hline $\mathrm{H}(10 \mathrm{H})$ & 6048 & 10987 & 4267 & 98 \\
\hline $\mathrm{H}(10 \mathrm{I})$ & 5570 & 11964 & 3887 & 98 \\
\hline $\mathrm{H}(1 \mathrm{~S} 1)$ & 8993 & 13947 & 3176 & 209 \\
\hline $\mathrm{H}(1 \mathrm{~S} 2)$ & 8628 & 12746 & 3188 & 209 \\
\hline $\mathrm{H}(1 \mathrm{~S} 3)$ & 9301 & 12914 & 3648 & 209 \\
\hline $\mathrm{H}(2 \mathrm{~S} 1)$ & 8958 & 12743 & 2456 & 115 \\
\hline $\mathrm{H}(2 \mathrm{~S} 2)$ & 9625 & 12909 & 2913 & 115 \\
\hline $\mathrm{H}(3 \mathrm{~S} 1)$ & 8949 & 10899 & 2825 & 170 \\
\hline $\mathrm{H}(3 \mathrm{~S} 2)$ & 9629 & 11076 & 3241 & 170 \\
\hline $\mathrm{H}(4 \mathrm{~S} 1)$ & 9190 & 10828 & 2036 & 109 \\
\hline $\mathrm{H}(4 \mathrm{~S} 2)$ & 9866 & 11113 & 2423 & 109 \\
\hline $\mathrm{H}(5 \mathrm{~S} 1)$ & 9355 & 9027 & 2491 & 246 \\
\hline $\mathrm{H}(5 \mathrm{~S} 2)$ & 10042 & 9373 & 2718 & 246 \\
\hline $\mathrm{H}(6 \mathrm{~S} 1)$ & 9799 & 8110 & 1997 & 143 \\
\hline $\mathrm{H}(6 \mathrm{~S} 2)$ & 9305 & 9021 & 1582 & 143 \\
\hline $\mathrm{H}(6 \mathrm{~S} 3)$ & 9999 & 9371 & 1810 & 143 \\
\hline
\end{tabular}

Table S19. Torsion angles $\left[{ }^{\circ}\right]$ for $\mathrm{C}_{53} \mathrm{H}_{71} \mathrm{BCuF}_{3} \mathrm{~N}_{2} \mathrm{O}_{3} \mathrm{Si}$ 


\begin{tabular}{|c|c|}
\hline $\mathrm{F}(3)-\mathrm{C}(28)-\mathrm{C}(29)-\mathrm{C}(30)$ & $72.1(10)$ \\
\hline $\mathrm{F}(1)-\mathrm{C}(28)-\mathrm{C}(29)-\mathrm{C}(30)$ & $-48.9(14)$ \\
\hline $\mathrm{F}(2)-\mathrm{C}(28)-\mathrm{C}(29)-\mathrm{C}(30)$ & $-170.2(9)$ \\
\hline $\mathrm{F}(3)-\mathrm{C}(28)-\mathrm{C}(29)-\mathrm{Cu}(1)$ & $-63.4(11)$ \\
\hline $\mathrm{F}(1)-\mathrm{C}(28)-\mathrm{C}(29)-\mathrm{Cu}(1)$ & $175.6(9)$ \\
\hline $\mathrm{F}(2)-\mathrm{C}(28)-\mathrm{C}(29)-\mathrm{Cu}(1)$ & $54.4(13)$ \\
\hline $\mathrm{O}(3)-\mathrm{B}(1)-\mathrm{O}(2)-\mathrm{C}(38)$ & $-4.1(9)$ \\
\hline $\mathrm{C}(30)-\mathrm{B}(1)-\mathrm{O}(2)-\mathrm{C}(38)$ & $173.0(7)$ \\
\hline $\mathrm{O}(2)-\mathrm{B}(1)-\mathrm{O}(3)-\mathrm{C}(39)$ & $-7.6(10)$ \\
\hline $\mathrm{C}(30)-\mathrm{B}(1)-\mathrm{O}(3)-\mathrm{C}(39)$ & $175.3(8)$ \\
\hline $\mathrm{B}(1)-\mathrm{O}(2)-\mathrm{C}(38)-\mathrm{C}(41)$ & $-106.6(12)$ \\
\hline $\mathrm{B}(1)-\mathrm{O}(2)-\mathrm{C}(38)-\mathrm{C}(40)$ & $133.5(11)$ \\
\hline $\mathrm{B}(1)-\mathrm{O}(2)-\mathrm{C}(38)-\mathrm{C}(39)$ & $13.4(11)$ \\
\hline $\mathrm{B}(1)-\mathrm{O}(3)-\mathrm{C}(39)-\mathrm{C}(38)$ & $15.7(11)$ \\
\hline $\mathrm{B}(1)-\mathrm{O}(3)-\mathrm{C}(39)-\mathrm{C}(43)$ & $-104.3(11)$ \\
\hline $\mathrm{B}(1)-\mathrm{O}(3)-\mathrm{C}(39)-\mathrm{C}(42)$ & $140.4(12)$ \\
\hline $\mathrm{C}(41)-\mathrm{C}(38)-\mathrm{C}(39)-\mathrm{O}(3)$ & $95.0(13)$ \\
\hline $\mathrm{C}(40)-\mathrm{C}(38)-\mathrm{C}(39)-\mathrm{O}(3)$ & $-135.5(12)$ \\
\hline $\mathrm{O}(2)-\mathrm{C}(38)-\mathrm{C}(39)-\mathrm{O}(3)$ & $-16.9(11)$ \\
\hline$C(41)-C(38)-C(39)-C(43)$ & $-153.9(15)$ \\
\hline$C(40)-C(38)-C(39)-C(43)$ & $-24.3(19)$ \\
\hline $\mathrm{O}(2)-\mathrm{C}(38)-\mathrm{C}(39)-\mathrm{C}(43)$ & $94.2(14)$ \\
\hline$C(41)-C(38)-C(39)-C(42)$ & $-27.3(18)$ \\
\hline$C(40)-C(38)-C(39)-C(42)$ & $102.3(15)$ \\
\hline $\mathrm{O}(2)-\mathrm{C}(38)-\mathrm{C}(39)-\mathrm{C}(42)$ & $-139.2(12)$ \\
\hline $\mathrm{C}(50)-\mathrm{Si}(1)-\mathrm{O}(1)-\mathrm{C}(31)$ & $-169.5(4)$ \\
\hline $\mathrm{C}(44)-\mathrm{Si}(1)-\mathrm{O}(1)-\mathrm{C}(31)$ & $-50.8(5)$ \\
\hline $\mathrm{C}(32)-\mathrm{Si}(1)-\mathrm{O}(1)-\mathrm{C}(31)$ & $73.2(5)$ \\
\hline $\mathrm{C}(2)-\mathrm{N}(1)-\mathrm{C}(1)-\mathrm{N}(2)$ & $0.5(6)$ \\
\hline $\mathrm{C}(4)-\mathrm{N}(1)-\mathrm{C}(1)-\mathrm{N}(2)$ & $-176.5(4)$ \\
\hline $\mathrm{C}(2)-\mathrm{N}(1)-\mathrm{C}(1)-\mathrm{Cu}(1)$ & $-179.4(4)$ \\
\hline $\mathrm{C}(4)-\mathrm{N}(1)-\mathrm{C}(1)-\mathrm{Cu}(1)$ & $3.6(7)$ \\
\hline $\mathrm{C}(3)-\mathrm{N}(2)-\mathrm{C}(1)-\mathrm{N}(1)$ & $-0.9(6)$ \\
\hline $\mathrm{C}(16)-\mathrm{N}(2)-\mathrm{C}(1)-\mathrm{N}(1)$ & $179.9(4)$ \\
\hline $\mathrm{C}(3)-\mathrm{N}(2)-\mathrm{C}(1)-\mathrm{Cu}(1)$ & $179.1(4)$ \\
\hline $\mathrm{C}(16)-\mathrm{N}(2)-\mathrm{C}(1)-\mathrm{Cu}(1)$ & $-0.2(7)$ \\
\hline $\mathrm{C}(1)-\mathrm{N}(1)-\mathrm{C}(2)-\mathrm{C}(3)$ & $0.0(7)$ \\
\hline $\mathrm{C}(4)-\mathrm{N}(1)-\mathrm{C}(2)-\mathrm{C}(3)$ & $176.9(5)$ \\
\hline $\mathrm{N}(1)-\mathrm{C}(2)-\mathrm{C}(3)-\mathrm{N}(2)$ & $-0.5(7)$ \\
\hline $\mathrm{C}(1)-\mathrm{N}(2)-\mathrm{C}(3)-\mathrm{C}(2)$ & $0.9(7)$ \\
\hline
\end{tabular}




\begin{tabular}{|c|c|}
\hline $\mathrm{C}(16)-\mathrm{N}(2)-\mathrm{C}(3)-\mathrm{C}(2)$ & $-179.9(5)$ \\
\hline $\mathrm{C}(1)-\mathrm{N}(1)-\mathrm{C}(4)-\mathrm{C}(9)$ & $-100.3(6)$ \\
\hline $\mathrm{C}(2)-\mathrm{N}(1)-\mathrm{C}(4)-\mathrm{C}(9)$ & $83.1(7)$ \\
\hline $\mathrm{C}(1)-\mathrm{N}(1)-\mathrm{C}(4)-\mathrm{C}(5)$ & $78.1(6)$ \\
\hline$C(2)-N(1)-C(4)-C(5)$ & $-98.5(7)$ \\
\hline$C(9)-C(4)-C(5)-C(6)$ & $0.9(8)$ \\
\hline $\mathrm{N}(1)-\mathrm{C}(4)-\mathrm{C}(5)-\mathrm{C}(6)$ & $-177.5(5)$ \\
\hline$C(9)-C(4)-C(5)-C(10)$ & $-179.9(5)$ \\
\hline $\mathrm{N}(1)-\mathrm{C}(4)-\mathrm{C}(5)-\mathrm{C}(10)$ & $1.7(8)$ \\
\hline$C(4)-C(5)-C(6)-C(7)$ & $-1.6(9)$ \\
\hline$C(10)-C(5)-C(6)-C(7)$ & $179.2(6)$ \\
\hline$C(5)-C(6)-C(7)-C(8)$ & $1.3(10)$ \\
\hline$C(6)-C(7)-C(8)-C(9)$ & $-0.2(10)$ \\
\hline$C(7)-C(8)-C(9)-C(4)$ & $-0.6(9)$ \\
\hline$C(7)-C(8)-C(9)-C(13)$ & $174.5(6)$ \\
\hline$C(5)-C(4)-C(9)-C(8)$ & $0.2(8)$ \\
\hline $\mathrm{N}(1)-\mathrm{C}(4)-\mathrm{C}(9)-\mathrm{C}(8)$ & $178.6(5)$ \\
\hline$C(5)-C(4)-C(9)-C(13)$ & $-175.0(5)$ \\
\hline $\mathrm{N}(1)-\mathrm{C}(4)-\mathrm{C}(9)-\mathrm{C}(13)$ & $3.4(8)$ \\
\hline$C(6)-C(5)-C(10)-C(12)$ & $-60.4(8)$ \\
\hline$C(4)-C(5)-C(10)-C(12)$ & $120.4(6)$ \\
\hline$C(6)-C(5)-C(10)-C(11)$ & $63.6(7)$ \\
\hline$C(4)-C(5)-C(10)-C(11)$ & $-115.6(6)$ \\
\hline$C(8)-C(9)-C(13)-C(15)$ & $-86.3(7)$ \\
\hline$C(4)-C(9)-C(13)-C(15)$ & $88.7(7)$ \\
\hline$C(8)-C(9)-C(13)-C(14)$ & $37.7(9)$ \\
\hline$C(4)-C(9)-C(13)-C(14)$ & $-147.4(6)$ \\
\hline$C(1)-N(2)-C(16)-C(21)$ & $-92.4(7)$ \\
\hline$C(3)-N(2)-C(16)-C(21)$ & $88.5(7)$ \\
\hline$C(1)-N(2)-C(16)-C(17)$ & $84.0(6)$ \\
\hline$C(3)-N(2)-C(16)-C(17)$ & $-95.1(7)$ \\
\hline $\mathrm{C}(21)-\mathrm{C}(16)-\mathrm{C}(17)-\mathrm{C}(18)$ & $0.9(8)$ \\
\hline $\mathrm{N}(2)-\mathrm{C}(16)-\mathrm{C}(17)-\mathrm{C}(18)$ & $-175.4(5)$ \\
\hline$C(21)-C(16)-C(17)-C(22)$ & $-179.8(5)$ \\
\hline $\mathrm{N}(2)-\mathrm{C}(16)-\mathrm{C}(17)-\mathrm{C}(22)$ & $3.9(8)$ \\
\hline$C(16)-C(17)-C(18)-C(19)$ & $0.9(9)$ \\
\hline$C(22)-C(17)-C(18)-C(19)$ & $-178.4(6)$ \\
\hline$C(17)-C(18)-C(19)-C(20)$ & $-1.5(10)$ \\
\hline$C(18)-C(19)-C(20)-C(21)$ & $0.3(10)$ \\
\hline$C(17)-C(16)-C(21)-C(20)$ & $-2.0(9)$ \\
\hline
\end{tabular}




\begin{tabular}{|c|c|}
\hline $\mathrm{N}(2)-\mathrm{C}(16)-\mathrm{C}(21)-\mathrm{C}(20)$ & $174.3(5)$ \\
\hline$C(17)-C(16)-C(21)-C(25)$ & $-179.1(6)$ \\
\hline $\mathrm{N}(2)-\mathrm{C}(16)-\mathrm{C}(21)-\mathrm{C}(25)$ & $-2.9(9)$ \\
\hline$C(19)-C(20)-C(21)-C(16)$ & $1.4(9)$ \\
\hline$C(19)-C(20)-C(21)-C(25)$ & $178.5(6)$ \\
\hline$C(18)-C(17)-C(22)-C(24)$ & $-54.0(11)$ \\
\hline $\mathrm{C}(16)-\mathrm{C}(17)-\mathrm{C}(22)-\mathrm{C}(24)$ & $126.8(10)$ \\
\hline $\mathrm{C}(18)-\mathrm{C}(17)-\mathrm{C}(22)-\mathrm{C}(23)$ & $68.2(8)$ \\
\hline$C(16)-C(17)-C(22)-C(23)$ & $-111.0(7)$ \\
\hline$C(16)-C(21)-C(25)-C(27)$ & $115.6(14)$ \\
\hline$C(20)-C(21)-C(25)-C(27)$ & $-61.3(14)$ \\
\hline$C(16)-C(21)-C(25)-C(26)$ & $-115.0(12)$ \\
\hline$C(20)-C(21)-C(25)-C(26)$ & $68.0(13)$ \\
\hline $\mathrm{C}(28)-\mathrm{C}(29)-\mathrm{C}(30)-\mathrm{C}(31)$ & $-174.9(8)$ \\
\hline $\mathrm{Cu}(1)-\mathrm{C}(29)-\mathrm{C}(30)-\mathrm{C}(31)$ & $-42.5(7)$ \\
\hline $\mathrm{C}(28)-\mathrm{C}(29)-\mathrm{C}(30)-\mathrm{B}(1)$ & $-55.8(9)$ \\
\hline $\mathrm{Cu}(1)-\mathrm{C}(29)-\mathrm{C}(30)-\mathrm{B}(1)$ & $76.6(6)$ \\
\hline $\mathrm{O}(2)-\mathrm{B}(1)-\mathrm{C}(30)-\mathrm{C}(31)$ & $-134.5(6)$ \\
\hline $\mathrm{O}(3)-\mathrm{B}(1)-\mathrm{C}(30)-\mathrm{C}(31)$ & $42.2(8)$ \\
\hline $\mathrm{O}(2)-\mathrm{B}(1)-\mathrm{C}(30)-\mathrm{C}(29)$ & $103.7(7)$ \\
\hline $\mathrm{O}(3)-\mathrm{B}(1)-\mathrm{C}(30)-\mathrm{C}(29)$ & $-79.6(7)$ \\
\hline $\mathrm{Si}(1)-\mathrm{O}(1)-\mathrm{C}(31)-\mathrm{C}(30)$ & $176.1(4)$ \\
\hline $\mathrm{C}(29)-\mathrm{C}(30)-\mathrm{C}(31)-\mathrm{O}(1)$ & $-165.8(5)$ \\
\hline $\mathrm{B}(1)-\mathrm{C}(30)-\mathrm{C}(31)-\mathrm{O}(1)$ & $71.9(5)$ \\
\hline $\mathrm{O}(1)-\mathrm{Si}(1)-\mathrm{C}(32)-\mathrm{C}(37)$ & $-175.2(5)$ \\
\hline $\mathrm{C}(50)-\mathrm{Si}(1)-\mathrm{C}(32)-\mathrm{C}(37)$ & $71.0(5)$ \\
\hline $\mathrm{C}(44)-\mathrm{Si}(1)-\mathrm{C}(32)-\mathrm{C}(37)$ & $-52.5(6)$ \\
\hline $\mathrm{O}(1)-\mathrm{Si}(1)-\mathrm{C}(32)-\mathrm{C}(33)$ & $8.1(5)$ \\
\hline $\mathrm{C}(50)-\mathrm{Si}(1)-\mathrm{C}(32)-\mathrm{C}(33)$ & $-105.6(5)$ \\
\hline $\mathrm{C}(44)-\mathrm{Si}(1)-\mathrm{C}(32)-\mathrm{C}(33)$ & $130.8(5)$ \\
\hline $\mathrm{C}(37)-\mathrm{C}(32)-\mathrm{C}(33)-\mathrm{C}(34)$ & $1.7(9)$ \\
\hline Si(1)-C(32)-C(33)-C(34) & $178.6(5)$ \\
\hline $\mathrm{C}(32)-\mathrm{C}(33)-\mathrm{C}(34)-\mathrm{C}(35)$ & $-1.3(11)$ \\
\hline$C(33)-C(34)-C(35)-C(36)$ & $0.1(11)$ \\
\hline$C(34)-C(35)-C(36)-C(37)$ & $0.5(11)$ \\
\hline $\mathrm{C}(33)-\mathrm{C}(32)-\mathrm{C}(37)-\mathrm{C}(36)$ & $-1.1(9)$ \\
\hline $\mathrm{Si}(1)-\mathrm{C}(32)-\mathrm{C}(37)-\mathrm{C}(36)$ & $-177.9(5)$ \\
\hline$C(35)-C(36)-C(37)-C(32)$ & $0.0(11)$ \\
\hline $\mathrm{O}(1)-\mathrm{Si}(1)-\mathrm{C}(44)-\mathrm{C}(45)$ & $149.1(6)$ \\
\hline $\mathrm{C}(50)-\mathrm{Si}(1)-\mathrm{C}(44)-\mathrm{C}(45)$ & $-96.0(6)$ \\
\hline
\end{tabular}




\begin{tabular}{|c|c|}
\hline $\mathrm{C}(32)-\mathrm{Si}(1)-\mathrm{C}(44)-\mathrm{C}(45)$ & $27.2(7)$ \\
\hline $\mathrm{O}(1)-\mathrm{Si}(1)-\mathrm{C}(44)-\mathrm{C}(49)$ & $-30.6(6)$ \\
\hline $\mathrm{C}(50)-\mathrm{Si}(1)-\mathrm{C}(44)-\mathrm{C}(49)$ & $84.3(6)$ \\
\hline $\mathrm{C}(32)-\mathrm{Si}(1)-\mathrm{C}(44)-\mathrm{C}(49)$ & $-152.5(5)$ \\
\hline$C(49)-C(44)-C(45)-C(46)$ & $-2.0(12)$ \\
\hline $\mathrm{Si}(1)-\mathrm{C}(44)-\mathrm{C}(45)-\mathrm{C}(46)$ & $178.3(7)$ \\
\hline $\mathrm{C}(44)-\mathrm{C}(45)-\mathrm{C}(46)-\mathrm{C}(47)$ & $-0.6(15)$ \\
\hline$C(45)-C(46)-C(47)-C(48)$ & $3.8(15)$ \\
\hline$C(46)-C(47)-C(48)-C(49)$ & $-4.3(14)$ \\
\hline $\mathrm{C}(45)-\mathrm{C}(44)-\mathrm{C}(49)-\mathrm{C}(48)$ & $1.4(11)$ \\
\hline $\mathrm{Si}(1)-\mathrm{C}(44)-\mathrm{C}(49)-\mathrm{C}(48)$ & $-178.9(6)$ \\
\hline $\mathrm{C}(47)-\mathrm{C}(48)-\mathrm{C}(49)-\mathrm{C}(44)$ & $1.7(13)$ \\
\hline $\mathrm{O}(1)-\mathrm{Si}(1)-\mathrm{C}(50)-\mathrm{C}(51)$ & $60.9(4)$ \\
\hline $\mathrm{C}(44)-\mathrm{Si}(1)-\mathrm{C}(50)-\mathrm{C}(51)$ & $-57.7(5)$ \\
\hline $\mathrm{C}(32)-\mathrm{Si}(1)-\mathrm{C}(50)-\mathrm{C}(51)$ & $177.5(4)$ \\
\hline $\mathrm{O}(1)-\mathrm{Si}(1)-\mathrm{C}(50)-\mathrm{C}(52)$ & $-57.6(5)$ \\
\hline $\mathrm{C}(44)-\mathrm{Si}(1)-\mathrm{C}(50)-\mathrm{C}(52)$ & $-176.2(4)$ \\
\hline $\mathrm{C}(32)-\mathrm{Si}(1)-\mathrm{C}(50)-\mathrm{C}(52)$ & $59.1(5)$ \\
\hline $\mathrm{O}(1)-\mathrm{Si}(1)-\mathrm{C}(50)-\mathrm{C}(53)$ & $-178.3(5)$ \\
\hline $\mathrm{C}(44)-\mathrm{Si}(1)-\mathrm{C}(50)-\mathrm{C}(53)$ & $63.1(6)$ \\
\hline $\mathrm{C}(32)-\mathrm{Si}(1)-\mathrm{C}(50)-\mathrm{C}(53)$ & $-61.6(6)$ \\
\hline $\mathrm{F}(6)-\mathrm{C}(81)-\mathrm{C}(82)-\mathrm{C}(83)$ & $170.2(8)$ \\
\hline $\mathrm{F}(4)-\mathrm{C}(81)-\mathrm{C}(82)-\mathrm{C}(83)$ & $-70.6(9)$ \\
\hline $\mathrm{F}(5)-\mathrm{C}(81)-\mathrm{C}(82)-\mathrm{C}(83)$ & $47.8(11)$ \\
\hline $\mathrm{F}(6)-\mathrm{C}(81)-\mathrm{C}(82)-\mathrm{Cu}(2)$ & $-57.0(11)$ \\
\hline $\mathrm{F}(4)-\mathrm{C}(81)-\mathrm{C}(82)-\mathrm{Cu}(2)$ & $62.2(9)$ \\
\hline $\mathrm{F}(5)-\mathrm{C}(81)-\mathrm{C}(82)-\mathrm{Cu}(2)$ & $-179.5(7)$ \\
\hline $\mathrm{O}(6)-\mathrm{B}(2)-\mathrm{O}(5)-\mathrm{C}(91)$ & $7.4(10)$ \\
\hline $\mathrm{C}(83)-\mathrm{B}(2)-\mathrm{O}(5)-\mathrm{C}(91)$ & $-172.4(9)$ \\
\hline $\mathrm{O}(5)-\mathrm{B}(2)-\mathrm{O}(6)-\mathrm{C}(92)$ & $13.0(10)$ \\
\hline $\mathrm{C}(83)-\mathrm{B}(2)-\mathrm{O}(6)-\mathrm{C}(92)$ & $-167.2(9)$ \\
\hline $\mathrm{B}(2)-\mathrm{O}(5)-\mathrm{C}(91)-\mathrm{C}(94)$ & $-146.3(12)$ \\
\hline $\mathrm{B}(2)-\mathrm{O}(5)-\mathrm{C}(91)-\mathrm{C}(92)$ & $-23.6(14)$ \\
\hline $\mathrm{B}(2)-\mathrm{O}(5)-\mathrm{C}(91)-\mathrm{C}(93)$ & $91.8(14)$ \\
\hline $\mathrm{B}(2)-\mathrm{O}(6)-\mathrm{C}(92)-\mathrm{C}(95)$ & $92.8(14)$ \\
\hline $\mathrm{B}(2)-\mathrm{O}(6)-\mathrm{C}(92)-\mathrm{C}(96)$ & $-150.9(12)$ \\
\hline $\mathrm{B}(2)-\mathrm{O}(6)-\mathrm{C}(92)-\mathrm{C}(91)$ & $-26.4(13)$ \\
\hline $\mathrm{C}(94)-\mathrm{C}(91)-\mathrm{C}(92)-\mathrm{C}(95)$ & $31(2)$ \\
\hline $\mathrm{O}(5)-\mathrm{C}(91)-\mathrm{C}(92)-\mathrm{C}(95)$ & $-87.9(16)$ \\
\hline $\mathrm{C}(93)-\mathrm{C}(91)-\mathrm{C}(92)-\mathrm{C}(95)$ & $156.3(14)$ \\
\hline
\end{tabular}




\begin{tabular}{|c|c|}
\hline $\mathrm{C}(94)-\mathrm{C}(91)-\mathrm{C}(92)-\mathrm{C}(96)$ & $-96(2)$ \\
\hline $\mathrm{O}(5)-\mathrm{C}(91)-\mathrm{C}(92)-\mathrm{C}(96)$ & $145.1(16)$ \\
\hline $\mathrm{C}(93)-\mathrm{C}(91)-\mathrm{C}(92)-\mathrm{C}(96)$ & $29(2)$ \\
\hline $\mathrm{C}(94)-\mathrm{C}(91)-\mathrm{C}(92)-\mathrm{O}(6)$ & $148.1(14)$ \\
\hline $\mathrm{O}(5)-\mathrm{C}(91)-\mathrm{C}(92)-\mathrm{O}(6)$ & $29.0(14)$ \\
\hline $\mathrm{C}(93)-\mathrm{C}(91)-\mathrm{C}(92)-\mathrm{O}(6)$ & $-86.7(15)$ \\
\hline $\mathrm{C}(85)-\mathrm{Si}(2)-\mathrm{O}(4)-\mathrm{C}(84)$ & $39.0(7)$ \\
\hline $\mathrm{C}(97)-\mathrm{Si}(2)-\mathrm{O}(4)-\mathrm{C}(84)$ & $-82.4(6)$ \\
\hline $\mathrm{C}(103)-\mathrm{Si}(2)-\mathrm{O}(4)-\mathrm{C}(84)$ & $159.0(6)$ \\
\hline $\mathrm{C}(56)-\mathrm{N}(4)-\mathrm{C}(54)-\mathrm{N}(3)$ & $0.9(7)$ \\
\hline $\mathrm{C}(69)-\mathrm{N}(4)-\mathrm{C}(54)-\mathrm{N}(3)$ & $178.2(5)$ \\
\hline $\mathrm{C}(56)-\mathrm{N}(4)-\mathrm{C}(54)-\mathrm{Cu}(2)$ & $179.2(5)$ \\
\hline $\mathrm{C}(69)-\mathrm{N}(4)-\mathrm{C}(54)-\mathrm{Cu}(2)$ & $-3.5(8)$ \\
\hline $\mathrm{C}(55)-\mathrm{N}(3)-\mathrm{C}(54)-\mathrm{N}(4)$ & $-0.9(6)$ \\
\hline $\mathrm{C}(57)-\mathrm{N}(3)-\mathrm{C}(54)-\mathrm{N}(4)$ & $-178.8(5)$ \\
\hline $\mathrm{C}(55)-\mathrm{N}(3)-\mathrm{C}(54)-\mathrm{Cu}(2)$ & $-179.2(5)$ \\
\hline $\mathrm{C}(57)-\mathrm{N}(3)-\mathrm{C}(54)-\mathrm{Cu}(2)$ & $2.9(8)$ \\
\hline$C(54)-N(3)-C(55)-C(56)$ & $0.6(7)$ \\
\hline$C(57)-N(3)-C(55)-C(56)$ & $178.4(6)$ \\
\hline $\mathrm{N}(3)-\mathrm{C}(55)-\mathrm{C}(56)-\mathrm{N}(4)$ & $0.0(8)$ \\
\hline$C(54)-N(4)-C(56)-C(55)$ & $-0.6(8)$ \\
\hline$C(69)-N(4)-C(56)-C(55)$ & $-177.8(6)$ \\
\hline $\mathrm{C}(54)-\mathrm{N}(3)-\mathrm{C}(57)-\mathrm{C}(62)$ & $-86.8(7)$ \\
\hline $\mathrm{C}(55)-\mathrm{N}(3)-\mathrm{C}(57)-\mathrm{C}(62)$ & $95.6(7)$ \\
\hline $\mathrm{C}(54)-\mathrm{N}(3)-\mathrm{C}(57)-\mathrm{C}(58)$ & $94.7(7)$ \\
\hline $\mathrm{C}(55)-\mathrm{N}(3)-\mathrm{C}(57)-\mathrm{C}(58)$ & $-82.9(7)$ \\
\hline $\mathrm{C}(62)-\mathrm{C}(57)-\mathrm{C}(58)-\mathrm{C}(59)$ & $1.9(9)$ \\
\hline $\mathrm{N}(3)-\mathrm{C}(57)-\mathrm{C}(58)-\mathrm{C}(59)$ & $-179.7(6)$ \\
\hline$C(62)-C(57)-C(58)-C(63)$ & $178.7(6)$ \\
\hline $\mathrm{N}(3)-\mathrm{C}(57)-\mathrm{C}(58)-\mathrm{C}(63)$ & $-2.9(9)$ \\
\hline $\mathrm{C}(57)-\mathrm{C}(58)-\mathrm{C}(59)-\mathrm{C}(60)$ & $-1.9(10)$ \\
\hline$C(63)-C(58)-C(59)-C(60)$ & $-178.7(6)$ \\
\hline$C(58)-C(59)-C(60)-C(61)$ & $2.4(11)$ \\
\hline$C(59)-C(60)-C(61)-C(62)$ & $-2.8(11)$ \\
\hline$C(60)-C(61)-C(62)-C(57)$ & $2.7(9)$ \\
\hline$C(60)-C(61)-C(62)-C(66)$ & $179.7(6)$ \\
\hline$C(58)-C(57)-C(62)-C(61)$ & $-2.2(8)$ \\
\hline $\mathrm{N}(3)-\mathrm{C}(57)-\mathrm{C}(62)-\mathrm{C}(61)$ & $179.4(5)$ \\
\hline $\mathrm{C}(58)-\mathrm{C}(57)-\mathrm{C}(62)-\mathrm{C}(66)$ & $-179.3(5)$ \\
\hline $\mathrm{N}(3)-\mathrm{C}(57)-\mathrm{C}(62)-\mathrm{C}(66)$ & $2.3(8)$ \\
\hline
\end{tabular}




\begin{tabular}{|c|c|}
\hline$C(59)-C(58)-C(63)-C(64)$ & $83.2(8)$ \\
\hline$C(57)-C(58)-C(63)-C(64)$ & $-93.5(8)$ \\
\hline$C(59)-C(58)-C(63)-C(65)$ & $-38.9(9)$ \\
\hline$C(57)-C(58)-C(63)-C(65)$ & $144.5(7)$ \\
\hline$C(61)-C(62)-C(66)-C(67)$ & $49.5(9)$ \\
\hline$C(57)-C(62)-C(66)-C(67)$ & $-133.6(8)$ \\
\hline $\mathrm{C}(61)-\mathrm{C}(62)-\mathrm{C}(66)-\mathrm{C}(68)$ & $-73.7(8)$ \\
\hline$C(57)-C(62)-C(66)-C(68)$ & $103.2(7)$ \\
\hline $\mathrm{C}(54)-\mathrm{N}(4)-\mathrm{C}(69)-\mathrm{C}(70)$ & $90.5(7)$ \\
\hline$C(56)-N(4)-C(69)-C(70)$ & $-92.6(8)$ \\
\hline $\mathrm{C}(54)-\mathrm{N}(4)-\mathrm{C}(69)-\mathrm{C}(74)$ & $-89.4(7)$ \\
\hline $\mathrm{C}(56)-\mathrm{N}(4)-\mathrm{C}(69)-\mathrm{C}(74)$ & $87.4(8)$ \\
\hline$C(74)-C(69)-C(70)-C(71)$ & $1.8(10)$ \\
\hline $\mathrm{N}(4)-\mathrm{C}(69)-\mathrm{C}(70)-\mathrm{C}(71)$ & $-178.1(6)$ \\
\hline $\mathrm{C}(74)-\mathrm{C}(69)-\mathrm{C}(70)-\mathrm{C}(75)$ & 179.9(7) \\
\hline $\mathrm{N}(4)-\mathrm{C}(69)-\mathrm{C}(70)-\mathrm{C}(75)$ & $0.0(10)$ \\
\hline$C(69)-C(70)-C(71)-C(72)$ & $-1.6(12)$ \\
\hline$C(75)-C(70)-C(71)-C(72)$ & $-179.7(8)$ \\
\hline$C(70)-C(71)-C(72)-C(73)$ & $1.4(14)$ \\
\hline$C(71)-C(72)-C(73)-C(74)$ & $-1.3(12)$ \\
\hline$C(72)-C(73)-C(74)-C(69)$ & $1.4(10)$ \\
\hline$C(72)-C(73)-C(74)-C(78)$ & $176.6(7)$ \\
\hline$C(70)-C(69)-C(74)-C(73)$ & $-1.7(10)$ \\
\hline $\mathrm{N}(4)-\mathrm{C}(69)-\mathrm{C}(74)-\mathrm{C}(73)$ & $178.2(6)$ \\
\hline$C(70)-C(69)-C(74)-C(78)$ & $-176.9(6)$ \\
\hline $\mathrm{N}(4)-\mathrm{C}(69)-\mathrm{C}(74)-\mathrm{C}(78)$ & $3.1(9)$ \\
\hline$C(69)-C(70)-C(75)-C(76)$ & $-119(2)$ \\
\hline$C(71)-C(70)-C(75)-C(76)$ & $59(2)$ \\
\hline$C(69)-C(70)-C(75)-C(77)$ & $100.2(13)$ \\
\hline $\mathrm{C}(71)-\mathrm{C}(70)-\mathrm{C}(75)-\mathrm{C}(77)$ & $-81.8(14)$ \\
\hline $\mathrm{C}(73)-\mathrm{C}(74)-\mathrm{C}(78)-\mathrm{C}(80)$ & $-71.1(8)$ \\
\hline $\mathrm{C}(69)-\mathrm{C}(74)-\mathrm{C}(78)-\mathrm{C}(80)$ & $103.9(7)$ \\
\hline $\mathrm{C}(73)-\mathrm{C}(74)-\mathrm{C}(78)-\mathrm{C}(79)$ & $51.0(10)$ \\
\hline $\mathrm{C}(69)-\mathrm{C}(74)-\mathrm{C}(78)-\mathrm{C}(79)$ & $-134.1(7)$ \\
\hline $\mathrm{C}(81)-\mathrm{C}(82)-\mathrm{C}(83)-\mathrm{C}(84)$ & $175.5(7)$ \\
\hline $\mathrm{Cu}(2)-\mathrm{C}(82)-\mathrm{C}(83)-\mathrm{C}(84)$ & $46.5(7)$ \\
\hline $\mathrm{C}(81)-\mathrm{C}(82)-\mathrm{C}(83)-\mathrm{B}(2)$ & $56.5(8)$ \\
\hline $\mathrm{Cu}(2)-\mathrm{C}(82)-\mathrm{C}(83)-\mathrm{B}(2)$ & $-72.5(7)$ \\
\hline $\mathrm{O}(6)-\mathrm{B}(2)-\mathrm{C}(83)-\mathrm{C}(84)$ & $128.4(6)$ \\
\hline $\mathrm{O}(5)-\mathrm{B}(2)-\mathrm{C}(83)-\mathrm{C}(84)$ & $-51.8(8)$ \\
\hline
\end{tabular}




\begin{tabular}{|c|c|}
\hline $\mathrm{O}(6)-\mathrm{B}(2)-\mathrm{C}(83)-\mathrm{C}(82)$ & $-111.4(7)$ \\
\hline $\mathrm{O}(5)-\mathrm{B}(2)-\mathrm{C}(83)-\mathrm{C}(82)$ & $68.4(8)$ \\
\hline $\mathrm{Si}(2)-\mathrm{O}(4)-\mathrm{C}(84)-\mathrm{C}(83)$ & $-175.6(5)$ \\
\hline $\mathrm{C}(82)-\mathrm{C}(83)-\mathrm{C}(84)-\mathrm{O}(4)$ & $166.8(5)$ \\
\hline $\mathrm{B}(2)-\mathrm{C}(83)-\mathrm{C}(84)-\mathrm{O}(4)$ & $-68.2(6)$ \\
\hline $\mathrm{O}(4)-\mathrm{Si}(2)-\mathrm{C}(85)-\mathrm{C}(86)$ & $-148.3(5)$ \\
\hline $\mathrm{C}(97)-\mathrm{Si}(2)-\mathrm{C}(85)-\mathrm{C}(86)$ & $-27.6(6)$ \\
\hline$C(103)-\operatorname{Si}(2)-C(85)-C(86)$ & $96.5(6)$ \\
\hline $\mathrm{O}(4)-\mathrm{Si}(2)-\mathrm{C}(85)-\mathrm{C}(90)$ & $30.8(6)$ \\
\hline $\mathrm{C}(97)-\mathrm{Si}(2)-\mathrm{C}(85)-\mathrm{C}(90)$ & $151.5(5)$ \\
\hline$C(103)-\operatorname{Si}(2)-C(85)-C(90)$ & $-84.4(6)$ \\
\hline $\mathrm{C}(90)-\mathrm{C}(85)-\mathrm{C}(86)-\mathrm{C}(87)$ & $1.1(10)$ \\
\hline $\mathrm{Si}(2)-\mathrm{C}(85)-\mathrm{C}(86)-\mathrm{C}(87)$ & $-179.8(5)$ \\
\hline $\mathrm{C}(85)-\mathrm{C}(86)-\mathrm{C}(87)-\mathrm{C}(88)$ & $-0.7(11)$ \\
\hline $\mathrm{C}(86)-\mathrm{C}(87)-\mathrm{C}(88)-\mathrm{C}(89)$ & $-0.4(12)$ \\
\hline$C(87)-C(88)-C(89)-C(90)$ & $1.0(13)$ \\
\hline $\mathrm{C}(88)-\mathrm{C}(89)-\mathrm{C}(90)-\mathrm{C}(85)$ & $-0.6(12)$ \\
\hline $\mathrm{C}(86)-\mathrm{C}(85)-\mathrm{C}(90)-\mathrm{C}(89)$ & $-0.4(10)$ \\
\hline $\mathrm{Si}(2)-\mathrm{C}(85)-\mathrm{C}(90)-\mathrm{C}(89)$ & $-179.5(6)$ \\
\hline $\mathrm{O}(4)-\mathrm{Si}(2)-\mathrm{C}(97)-\mathrm{C}(98)$ & $8.6(7)$ \\
\hline$C(85)-\operatorname{Si}(2)-C(97)-C(98)$ & $-114.1(7)$ \\
\hline$C(103)-\operatorname{Si}(2)-C(97)-C(98)$ & $121.9(7)$ \\
\hline $\mathrm{O}(4)-\mathrm{Si}(2)-\mathrm{C}(97)-\mathrm{C}(102)$ & $-170.9(8)$ \\
\hline$C(85)-\operatorname{Si}(2)-C(97)-C(102)$ & $66.4(9)$ \\
\hline$C(103)-\operatorname{Si}(2)-C(97)-C(102)$ & $-57.6(9)$ \\
\hline $\mathrm{C}(102)-\mathrm{C}(97)-\mathrm{C}(98)-\mathrm{C}(99)$ & $-0.6(15)$ \\
\hline $\mathrm{Si}(2)-\mathrm{C}(97)-\mathrm{C}(98)-\mathrm{C}(99)$ & $179.9(9)$ \\
\hline $\mathrm{C}(97)-\mathrm{C}(98)-\mathrm{C}(99)-\mathrm{C}(100)$ & $0.7(19)$ \\
\hline $\mathrm{C}(98)-\mathrm{C}(99)-\mathrm{C}(100)-\mathrm{C}(101)$ & $-0.3(19)$ \\
\hline$C(99)-C(100)-C(101)-C(102)$ & $0(2)$ \\
\hline$C(100)-C(101)-C(102)-C(97)$ & $0(2)$ \\
\hline $\mathrm{C}(98)-\mathrm{C}(97)-\mathrm{C}(102)-\mathrm{C}(101)$ & $0.1(16)$ \\
\hline $\mathrm{Si}(2)-\mathrm{C}(97)-\mathrm{C}(102)-\mathrm{C}(101)$ & $179.6(10)$ \\
\hline $\mathrm{O}(4)-\mathrm{Si}(2)-\mathrm{C}(103)-\mathrm{C}(106)$ & $-57.6(6)$ \\
\hline$C(85)-\operatorname{Si}(2)-C(103)-C(106)$ & $62.8(6)$ \\
\hline$C(97)-S i(2)-C(103)-C(106)$ & $-174.2(5)$ \\
\hline $\mathrm{O}(4)-\mathrm{Si}(2)-\mathrm{C}(103)-\mathrm{C}(104)$ & $62.4(6)$ \\
\hline$C(85)-\operatorname{Si}(2)-C(103)-C(104)$ & $-177.2(5)$ \\
\hline$C(97)-S i(2)-C(103)-C(104)$ & $-54.2(6)$ \\
\hline $\mathrm{O}(4)-\mathrm{Si}(2)-\mathrm{C}(103)-\mathrm{C}(105)$ & $-178.1(7)$ \\
\hline
\end{tabular}




\begin{tabular}{ll}
\hline $\mathrm{C}(85)-\mathrm{Si}(2)-\mathrm{C}(103)-\mathrm{C}(105)$ & $-57.7(8)$ \\
$\mathrm{C}(97)-\mathrm{Si}(2)-\mathrm{C}(103)-\mathrm{C}(105)$ & $65.3(7)$ \\
$\mathrm{C}(1 \mathrm{~S})-\mathrm{C}(2 \mathrm{~S})-\mathrm{C}(3 \mathrm{~S})-\mathrm{C}(4 \mathrm{~S})$ & $176(3)$ \\
$\mathrm{C}(2 \mathrm{~S})-\mathrm{C}(3 \mathrm{~S})-\mathrm{C}(4 \mathrm{~S})-\mathrm{C}(5 \mathrm{~S})$ & $175(4)$ \\
$\mathrm{C}(3 \mathrm{~S})-\mathrm{C}(4 \mathrm{~S})-\mathrm{C}(5 \mathrm{~S})-\mathrm{C}(6 \mathrm{~S})$ & $165(4)$ \\
\hline
\end{tabular}

\section{4. $\mathrm{Cu}$-alkyl complex 19a}

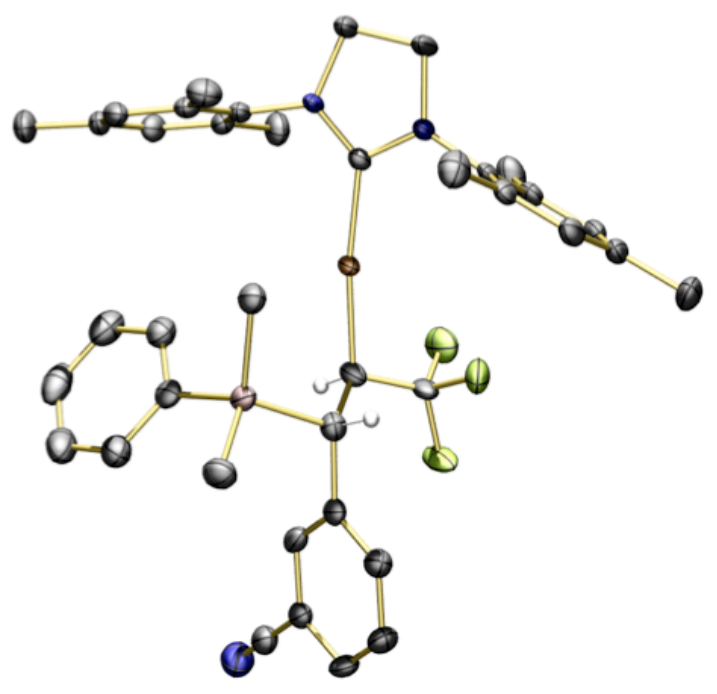

Table S20. Crystal data and structure refinement for $\mathrm{C}_{39} \mathrm{H}_{43} \mathrm{CuF}_{3} \mathrm{~N}_{3} \mathrm{Si}$

\begin{tabular}{lll}
\hline Identification code & $\mathrm{C}_{39} \mathrm{H}_{43} \mathrm{CuF}_{3} \mathrm{~N}_{3} \mathrm{Si}$ & \\
Empirical formula & $\mathrm{C}_{39} \mathrm{H}_{43} \mathrm{Cu} \mathrm{F}_{3} \mathrm{~N}_{3} \mathrm{Si}$ & \\
Formula weight & 702.39 & \\
Temperature & $100(2) \mathrm{K}$ & \\
Wavelength & $1.54178 \AA$ & \\
Crystal system & Monoclinic & $\alpha=90^{\circ}$ \\
Space group & $\mathrm{P} 2{ }_{1} / \mathrm{c}$ & $\beta=110.253(2)^{\circ}$ \\
Unit cell dimensions & $\mathrm{a}=16.6030(6) \AA$ & $\gamma=90^{\circ}$ \\
& $\mathrm{b}=13.7487(4) \AA$ & \\
& $\mathrm{c}=16.9259(6) \AA$ & \\
Volume & $3624.8(2) \AA^{3}$ & \\
Z & 4 & \\
Density (calculated) & $1.287 \mathrm{Mg} / \mathrm{m}^{3}$ & \\
Absorption coefficient & $1.544 \mathrm{~mm}^{-1}$ & \\
F(000) & 1472 \\
Crystal size & $0.420 \times 0.180 \times 0.160 \mathrm{~mm}^{3}$ & \\
Theta range for data collection & 2.837 to $66.659^{\circ}$ & \\
Index ranges & $-16<=\mathrm{h}<=19,-16<=\mathrm{k}<=$ & \\
Reflections collected & $16,-20<=1<=19$ & \\
Independent reflections & 30093 & $6380[\mathrm{R}(\mathrm{int})=0.0351]$ \\
\hline
\end{tabular}




\begin{tabular}{ll}
\hline Completeness to theta $=66.659^{\circ}$ & $\begin{array}{l}99.5 \% \\
\text { Absorption correction }\end{array}$ \\
& $\begin{array}{l}\text { Semi-empirical from } \\
\text { equivalents }\end{array}$ \\
Max. and min. transmission & 0.7528 and 0.6761 \\
Refinement method & Full-matrix least-squares on F2 \\
Data / restraints / parameters & $6380 / 387 / 443$ \\
Goodness-of-fit on F2 & 1.231 \\
Final R indices [I $>2 \sigma(\mathrm{I})]$ & $\mathrm{R} 1=0.0555, \omega \mathrm{R} 2=0.1252$ \\
R indices (all data) & $\mathrm{R} 1=0.0574, \omega \mathrm{R} 2=0.1261$ \\
Extinction coefficient & $\mathrm{n} / \mathrm{a}$ \\
Largest diff. peak and hole & 0.707 and -0.629 e $\AA^{-3}$ \\
\hline
\end{tabular}

Table S21. Atomic coordinates $\left(\mathrm{x10}^{4}\right)$ and equivalent isotropic displacement parameters $\left(\AA^{2} \times 10^{3}\right)$ for $\mathrm{C}_{39} \mathrm{H}_{43} \mathrm{CuF}_{3} \mathrm{~N}_{3} \mathrm{Si}$. U(eq) is defined as one third of the trace of the orthogonalized $\mathrm{U}^{\mathrm{ij}}$ tensor

\begin{tabular}{|c|c|c|c|c|}
\hline & $\mathrm{x}$ & $\mathrm{y}$ & z & $\mathrm{U}(\mathrm{eq})$ \\
\hline $\mathrm{Cu}(1)$ & $3157(1)$ & $8006(1)$ & $7388(1)$ & $22(1)$ \\
\hline $\operatorname{Si}(1)$ & $1232(1)$ & $6749(1)$ & $6705(1)$ & $27(1)$ \\
\hline $\mathrm{F}(1)$ & $4045(1)$ & $6173(2)$ & $8380(1)$ & $37(1)$ \\
\hline $\mathrm{F}(2)$ & $4005(2)$ & $5250(2)$ & $7358(3)$ & $46(1)$ \\
\hline $\mathrm{F}(3)$ & $4556(1)$ & $6676(2)$ & $7439(2)$ & $41(1)$ \\
\hline$F(1 X)$ & $3890(30)$ & $5140(20)$ & $7580(20)$ & $33(10)$ \\
\hline $\mathrm{F}(2 \mathrm{X})$ & $4115(12)$ & $6259(14)$ & $6843(11)$ & $22(6)$ \\
\hline $\mathrm{F}(3 \mathrm{X})$ & $4513(16)$ & $6479(17)$ & $8178(13)$ & $35(7)$ \\
\hline $\mathrm{N}(1)$ & $3180(2)$ & $10150(2)$ & $7484(2)$ & $27(1)$ \\
\hline $\mathrm{N}(2)$ & $4001(2)$ & $9408(2)$ & $8595(2)$ & $25(1)$ \\
\hline $\mathrm{C}(1)$ & $3437(2)$ & $9280(2)$ & $7821(2)$ & $20(1)$ \\
\hline$C(2)$ & $3588(2)$ & $10966(2)$ & $8052(2)$ & $35(1)$ \\
\hline$C(3)$ & $4185(3)$ & $10436(2)$ & $8825(3)$ & $58(1)$ \\
\hline$C(4)$ & $2576(2)$ & $10321(2)$ & $6652(2)$ & $24(1)$ \\
\hline$C(5)$ & $1718(2)$ & $10511(2)$ & $6548(2)$ & $26(1)$ \\
\hline$C(6)$ & $1153(2)$ & $10705(2)$ & $5736(2)$ & $27(1)$ \\
\hline$C(7)$ & $1426(2)$ & $10736(2)$ & $5049(2)$ & $27(1)$ \\
\hline$C(8)$ & $2283(2)$ & $10540(2)$ & $5178(2)$ & $29(1)$ \\
\hline$C(9)$ & $2869(2)$ & $10328(2)$ & $5974(2)$ & $26(1)$ \\
\hline$C(10)$ & 1401(2) & $10531(3)$ & $7277(2)$ & $35(1)$ \\
\hline$C(11)$ & $809(2)$ & $10992(3)$ & $4184(2)$ & $39(1)$ \\
\hline$C(12)$ & $3793(2)$ & $10109(3)$ & $6088(2)$ & $37(1)$ \\
\hline$C(13)$ & $4383(2)$ & $8635(2)$ & $9175(2)$ & $22(1)$ \\
\hline$C(14)$ & $5168(2)$ & $8244(2)$ & $9198(2)$ & $26(1)$ \\
\hline$C(15)$ & $5543(2)$ & $7538(2)$ & $9803(2)$ & $29(1)$ \\
\hline$C(16)$ & $5160(2)$ & $7217(2)$ & $10359(2)$ & $30(1)$ \\
\hline
\end{tabular}




\begin{tabular}{lllll}
\hline $\mathrm{C}(17)$ & $4374(2)$ & $7600(2)$ & $10306(2)$ & $30(1)$ \\
$\mathrm{C}(18)$ & $3970(2)$ & $8312(2)$ & $9716(2)$ & $25(1)$ \\
$\mathrm{C}(19)$ & $5594(2)$ & $8570(3)$ & $8596(2)$ & $43(1)$ \\
$\mathrm{C}(20)$ & $5592(3)$ & $6450(3)$ & $11010(3)$ & $46(1)$ \\
$\mathrm{C}(21)$ & $3116(2)$ & $8726(3)$ & $9673(2)$ & $39(1)$ \\
$\mathrm{C}(22)$ & $3042(2)$ & $6638(2)$ & $7059(2)$ & $28(1)$ \\
$\mathrm{C}(23)$ & $3879(2)$ & $6185(2)$ & $7539(2)$ & $28(1)$ \\
$\mathrm{C}(24)$ & $2289(2)$ & $6078(2)$ & $7175(2)$ & $30(1)$ \\
$\mathrm{C}(25)$ & $2202(2)$ & $5023(2)$ & $6876(2)$ & $29(1)$ \\
$\mathrm{C}(26)$ & $2211(2)$ & $4277(2)$ & $7427(2)$ & $35(1)$ \\
$\mathrm{C}(27)$ & $2176(2)$ & $3310(2)$ & $7180(2)$ & $38(1)$ \\
$\mathrm{C}(28)$ & $2129(2)$ & $3056(2)$ & $6373(2)$ & $35(1)$ \\
$\mathrm{C}(29)$ & $2098(2)$ & $3797(2)$ & $5807(2)$ & $31(1)$ \\
$\mathrm{C}(30)$ & $2131(2)$ & $4778(2)$ & $6063(2)$ & $31(1)$ \\
$\mathrm{C}(31)$ & $2071(2)$ & $3552(3)$ & $4980(3)$ & $37(1)$ \\
$\mathrm{N}(3)$ & $2066(2)$ & $3343(3)$ & $4321(2)$ & $50(1)$ \\
$\mathrm{C}(33)$ & $1287(2)$ & $7903(2)$ & $7298(2)$ & $31(1)$ \\
$\mathrm{C}(34)$ & $376(2)$ & $5946(3)$ & $6830(3)$ & $38(1)$ \\
$\mathrm{C}(35)$ & $955(2)$ & $7065(2)$ & $5566(2)$ & $30(1)$ \\
$\mathrm{C}(36)$ & $334(2)$ & $6540(3)$ & $4932(2)$ & $40(1)$ \\
$\mathrm{C}(37)$ & $92(3)$ & $6807(3)$ & $4096(3)$ & $48(1)$ \\
$\mathrm{C}(38)$ & $468(3)$ & $7605(3)$ & $3873(3)$ & $49(1)$ \\
$\mathrm{C}(39)$ & $1095(3)$ & $8128(3)$ & $4479(3)$ & $45(1)$ \\
$\mathrm{C}(40)$ & $1330(2)$ & $7862(3)$ & $5315(2)$ & $36(1)$ \\
\hline
\end{tabular}

Table S22. Bond lengths $[\AA]$ and angles $\left[{ }^{\circ}\right.$ ] for $\mathrm{C}_{39} \mathrm{H}_{43} \mathrm{CuF}_{3} \mathrm{~N}_{3} \mathrm{Si}$

\begin{tabular}{ll}
\hline $\mathrm{Cu}(1)-\mathrm{C}(1)$ & $1.893(3)$ \\
$\mathrm{Cu}(1)-\mathrm{C}(22)$ & $1.952(3)$ \\
$\mathrm{Si}(1)-\mathrm{C}(33)$ & $1.863(3)$ \\
$\mathrm{Si}(1)-\mathrm{C}(34)$ & $1.867(3)$ \\
$\mathrm{Si}(1)-\mathrm{C}(35)$ & $1.872(4)$ \\
$\mathrm{Si}(1)-\mathrm{C}(24)$ & $1.898(3)$ \\
$\mathrm{F}(1)-\mathrm{C}(23)$ & $1.354(4)$ \\
$\mathrm{F}(2)-\mathrm{C}(23)$ & $1.355(4)$ \\
$\mathrm{F}(3)-\mathrm{C}(23)$ & $1.370(4)$ \\
$\mathrm{N}(1)-\mathrm{C}(1)$ & $1.330(4)$ \\
$\mathrm{N}(1)-\mathrm{C}(4)$ & $1.438(4)$ \\
$\mathrm{N}(1)-\mathrm{C}(2)$ & $1.480(4)$ \\
$\mathrm{N}(2)-\mathrm{C}(1)$ & $1.332(4)$ \\
$\mathrm{N}(2)-\mathrm{C}(13)$ & $1.438(4)$ \\
$\mathrm{N}(2)-\mathrm{C}(3)$ & $1.470(4)$ \\
$\mathrm{C}(2)-\mathrm{C}(3)$ & $1.525(5)$ \\
$\mathrm{C}(2)-\mathrm{H}(2 \mathrm{~A})$ & 0.9900 \\
\hline
\end{tabular}




\begin{tabular}{|c|c|}
\hline $\mathrm{C}(2)-\mathrm{H}(2 \mathrm{~B})$ & 0.9900 \\
\hline $\mathrm{C}(3)-\mathrm{H}(3 \mathrm{~A})$ & 0.9900 \\
\hline $\mathrm{C}(3)-\mathrm{H}(3 \mathrm{~B})$ & 0.9900 \\
\hline$C(4)-C(9)$ & $1.393(5)$ \\
\hline$C(4)-C(5)$ & $1.398(4)$ \\
\hline$C(5)-C(6)$ & $1.396(4)$ \\
\hline$C(5)-C(10)$ & $1.500(5)$ \\
\hline$C(6)-C(7)$ & $1.386(5)$ \\
\hline $\mathrm{C}(6)-\mathrm{H}(6 \mathrm{~A})$ & 0.9500 \\
\hline$C(7)-C(8)$ & $1.389(5)$ \\
\hline$C(7)-C(11)$ & $1.509(4)$ \\
\hline$C(8)-C(9)$ & $1.392(4)$ \\
\hline $\mathrm{C}(8)-\mathrm{H}(8 \mathrm{~A})$ & 0.9500 \\
\hline$C(9)-C(12)$ & $1.510(4)$ \\
\hline $\mathrm{C}(10)-\mathrm{H}(10 \mathrm{~A})$ & 0.9800 \\
\hline $\mathrm{C}(10)-\mathrm{H}(10 \mathrm{~B})$ & 0.9800 \\
\hline $\mathrm{C}(10)-\mathrm{H}(10 \mathrm{C})$ & 0.9800 \\
\hline $\mathrm{C}(11)-\mathrm{H}(11 \mathrm{~A})$ & 0.9800 \\
\hline $\mathrm{C}(11)-\mathrm{H}(11 \mathrm{~B})$ & 0.9800 \\
\hline $\mathrm{C}(11)-\mathrm{H}(11 \mathrm{C})$ & 0.9800 \\
\hline $\mathrm{C}(12)-\mathrm{H}(12 \mathrm{~A})$ & 0.9800 \\
\hline $\mathrm{C}(12)-\mathrm{H}(12 \mathrm{~B})$ & 0.9800 \\
\hline $\mathrm{C}(12)-\mathrm{H}(12 \mathrm{C})$ & 0.9800 \\
\hline$C(13)-C(18)$ & $1.393(4)$ \\
\hline$C(13)-C(14)$ & $1.398(5)$ \\
\hline$C(14)-C(15)$ & $1.392(4)$ \\
\hline$C(14)-C(19)$ & $1.497(5)$ \\
\hline$C(15)-C(16)$ & $1.378(5)$ \\
\hline $\mathrm{C}(15)-\mathrm{H}(15 \mathrm{~A})$ & 0.9500 \\
\hline$C(16)-C(17)$ & $1.382(5)$ \\
\hline$C(16)-C(20)$ & $1.514(4)$ \\
\hline$C(17)-C(18)$ & $1.394(4)$ \\
\hline $\mathrm{C}(17)-\mathrm{H}(17 \mathrm{~A})$ & 0.9500 \\
\hline$C(18)-C(21)$ & $1.505(5)$ \\
\hline $\mathrm{C}(19)-\mathrm{H}(19 \mathrm{~A})$ & 0.9800 \\
\hline $\mathrm{C}(19)-\mathrm{H}(19 \mathrm{~B})$ & 0.9800 \\
\hline C(19)-H(19C) & 0.9800 \\
\hline $\mathrm{C}(20)-\mathrm{H}(20 \mathrm{~A})$ & 0.9800 \\
\hline $\mathrm{C}(20)-\mathrm{H}(20 \mathrm{~B})$ & 0.9800 \\
\hline $\mathrm{C}(20)-\mathrm{H}(20 \mathrm{C})$ & 0.9800 \\
\hline $\mathrm{C}(21)-\mathrm{H}(21 \mathrm{~A})$ & 0.9800 \\
\hline $\mathrm{C}(21)-\mathrm{H}(21 \mathrm{~B})$ & 0.9800 \\
\hline $\mathrm{C}(21)-\mathrm{H}(21 \mathrm{C})$ & 0.9800 \\
\hline
\end{tabular}




\begin{tabular}{|c|c|}
\hline$C(22)-C(23)$ & $1.484(4)$ \\
\hline$C(22)-C(24)$ & $1.537(4)$ \\
\hline $\mathrm{C}(22)-\mathrm{H}(22 \mathrm{~A})$ & 1.0000 \\
\hline$C(24)-C(25)$ & $1.525(4)$ \\
\hline $\mathrm{C}(24)-\mathrm{H}(24 \mathrm{~A})$ & 1.0000 \\
\hline$C(25)-C(30)$ & $1.382(5)$ \\
\hline$C(25)-C(26)$ & $1.383(5)$ \\
\hline$C(26)-C(27)$ & $1.388(5)$ \\
\hline $\mathrm{C}(26)-\mathrm{H}(26 \mathrm{~A})$ & 0.9500 \\
\hline $\mathrm{C}(27)-\mathrm{C}(28)$ & $1.386(5)$ \\
\hline $\mathrm{C}(27)-\mathrm{H}(27 \mathrm{~A})$ & 0.9500 \\
\hline$C(28)-C(29)$ & $1.388(5)$ \\
\hline $\mathrm{C}(28)-\mathrm{H}(28 \mathrm{~A})$ & 0.9500 \\
\hline$C(29)-C(30)$ & $1.412(5)$ \\
\hline$C(29)-C(31)$ & $1.425(5)$ \\
\hline $\mathrm{C}(30)-\mathrm{H}(30 \mathrm{~A})$ & 0.9500 \\
\hline $\mathrm{C}(31)-\mathrm{N}(3)$ & $1.148(5)$ \\
\hline $\mathrm{C}(33)-\mathrm{H}(33 \mathrm{~A})$ & 0.9800 \\
\hline $\mathrm{C}(33)-\mathrm{H}(33 \mathrm{~B})$ & 0.9800 \\
\hline $\mathrm{C}(33)-\mathrm{H}(33 \mathrm{C})$ & 0.9800 \\
\hline $\mathrm{C}(34)-\mathrm{H}(34 \mathrm{~A})$ & 0.9800 \\
\hline $\mathrm{C}(34)-\mathrm{H}(34 \mathrm{~B})$ & 0.9800 \\
\hline $\mathrm{C}(34)-\mathrm{H}(34 \mathrm{C})$ & 0.9800 \\
\hline$C(35)-C(40)$ & $1.397(5)$ \\
\hline$C(35)-C(36)$ & $1.404(5)$ \\
\hline$C(36)-C(37)$ & $1.382(6)$ \\
\hline $\mathrm{C}(36)-\mathrm{H}(36 \mathrm{~A})$ & 0.9500 \\
\hline$C(37)-C(38)$ & $1.378(6)$ \\
\hline $\mathrm{C}(37)-\mathrm{H}(37 \mathrm{~A})$ & 0.9500 \\
\hline$C(38)-C(39)$ & $1.384(6)$ \\
\hline $\mathrm{C}(38)-\mathrm{H}(38 \mathrm{~A})$ & 0.9500 \\
\hline$C(39)-C(40)$ & $1.381(5)$ \\
\hline $\mathrm{C}(39)-\mathrm{H}(39 \mathrm{~A})$ & 0.9500 \\
\hline $\mathrm{C}(40)-\mathrm{H}(40 \mathrm{~A})$ & 0.9500 \\
\hline $\mathrm{C}(1)-\mathrm{Cu}(1)-\mathrm{C}(22)$ & $171.31(13)$ \\
\hline $\mathrm{C}(33)-\mathrm{Si}(1)-\mathrm{C}(34)$ & $109.89(17)$ \\
\hline $\mathrm{C}(33)-\mathrm{Si}(1)-\mathrm{C}(35)$ & $107.77(15)$ \\
\hline $\mathrm{C}(34)-\mathrm{Si}(1)-\mathrm{C}(35)$ & $109.17(16)$ \\
\hline $\mathrm{C}(33)-\mathrm{Si}(1)-\mathrm{C}(24)$ & $108.86(15)$ \\
\hline $\mathrm{C}(34)-\mathrm{Si}(1)-\mathrm{C}(24)$ & $107.17(16)$ \\
\hline $\mathrm{C}(35)-\mathrm{Si}(1)-\mathrm{C}(24)$ & $113.95(15)$ \\
\hline $\mathrm{C}(1)-\mathrm{N}(1)-\mathrm{C}(4)$ & $125.3(2)$ \\
\hline
\end{tabular}




\begin{tabular}{|c|c|}
\hline $\mathrm{C}(1)-\mathrm{N}(1)-\mathrm{C}(2)$ & $113.3(2)$ \\
\hline $\mathrm{C}(4)-\mathrm{N}(1)-\mathrm{C}(2)$ & $121.4(2)$ \\
\hline $\mathrm{C}(1)-\mathrm{N}(2)-\mathrm{C}(13)$ & $124.6(2)$ \\
\hline$C(1)-N(2)-C(3)$ & $113.5(3)$ \\
\hline $\mathrm{C}(13)-\mathrm{N}(2)-\mathrm{C}(3)$ & $121.9(2)$ \\
\hline $\mathrm{N}(1)-\mathrm{C}(1)-\mathrm{N}(2)$ & $108.4(2)$ \\
\hline $\mathrm{N}(1)-\mathrm{C}(1)-\mathrm{Cu}(1)$ & $131.8(2)$ \\
\hline $\mathrm{N}(2)-\mathrm{C}(1)-\mathrm{Cu}(1)$ & $119.8(2)$ \\
\hline $\mathrm{N}(1)-\mathrm{C}(2)-\mathrm{C}(3)$ & $102.2(3)$ \\
\hline $\mathrm{N}(1)-\mathrm{C}(2)-\mathrm{H}(2 \mathrm{~A})$ & 111.3 \\
\hline $\mathrm{C}(3)-\mathrm{C}(2)-\mathrm{H}(2 \mathrm{~A})$ & 111.3 \\
\hline $\mathrm{N}(1)-\mathrm{C}(2)-\mathrm{H}(2 \mathrm{~B})$ & 111.3 \\
\hline $\mathrm{C}(3)-\mathrm{C}(2)-\mathrm{H}(2 \mathrm{~B})$ & 111.3 \\
\hline $\mathrm{H}(2 \mathrm{~A})-\mathrm{C}(2)-\mathrm{H}(2 \mathrm{~B})$ & 109.2 \\
\hline $\mathrm{N}(2)-\mathrm{C}(3)-\mathrm{C}(2)$ & $102.6(3)$ \\
\hline $\mathrm{N}(2)-\mathrm{C}(3)-\mathrm{H}(3 \mathrm{~A})$ & 111.2 \\
\hline $\mathrm{C}(2)-\mathrm{C}(3)-\mathrm{H}(3 \mathrm{~A})$ & 111.2 \\
\hline $\mathrm{N}(2)-\mathrm{C}(3)-\mathrm{H}(3 \mathrm{~B})$ & 111.2 \\
\hline $\mathrm{C}(2)-\mathrm{C}(3)-\mathrm{H}(3 \mathrm{~B})$ & 111.2 \\
\hline $\mathrm{H}(3 \mathrm{~A})-\mathrm{C}(3)-\mathrm{H}(3 \mathrm{~B})$ & 109.2 \\
\hline$C(9)-C(4)-C(5)$ & $121.7(3)$ \\
\hline $\mathrm{C}(9)-\mathrm{C}(4)-\mathrm{N}(1)$ & $119.0(3)$ \\
\hline $\mathrm{C}(5)-\mathrm{C}(4)-\mathrm{N}(1)$ & $119.3(3)$ \\
\hline$C(6)-C(5)-C(4)$ & $117.9(3)$ \\
\hline$C(6)-C(5)-C(10)$ & $120.0(3)$ \\
\hline$C(4)-C(5)-C(10)$ & $122.1(3)$ \\
\hline$C(7)-C(6)-C(5)$ & $121.9(3)$ \\
\hline$C(7)-C(6)-H(6 A)$ & 119.1 \\
\hline $\mathrm{C}(5)-\mathrm{C}(6)-\mathrm{H}(6 \mathrm{~A})$ & 119.1 \\
\hline$C(6)-C(7)-C(8)$ & $118.5(3)$ \\
\hline$C(6)-C(7)-C(11)$ & $120.7(3)$ \\
\hline $\mathrm{C}(8)-\mathrm{C}(7)-\mathrm{C}(11)$ & $120.8(3)$ \\
\hline$C(7)-C(8)-C(9)$ & $121.8(3)$ \\
\hline $\mathrm{C}(7)-\mathrm{C}(8)-\mathrm{H}(8 \mathrm{~A})$ & 119.1 \\
\hline $\mathrm{C}(9)-\mathrm{C}(8)-\mathrm{H}(8 \mathrm{~A})$ & 119.1 \\
\hline$C(8)-C(9)-C(4)$ & $118.2(3)$ \\
\hline $\mathrm{C}(8)-\mathrm{C}(9)-\mathrm{C}(12)$ & $120.3(3)$ \\
\hline$C(4)-C(9)-C(12)$ & $121.5(3)$ \\
\hline $\mathrm{C}(5)-\mathrm{C}(10)-\mathrm{H}(10 \mathrm{~A})$ & 109.5 \\
\hline $\mathrm{C}(5)-\mathrm{C}(10)-\mathrm{H}(10 \mathrm{~B})$ & 109.5 \\
\hline $\mathrm{H}(10 \mathrm{~A})-\mathrm{C}(10)-\mathrm{H}(10 \mathrm{~B})$ & 109.5 \\
\hline $\mathrm{C}(5)-\mathrm{C}(10)-\mathrm{H}(10 \mathrm{C})$ & 109.5 \\
\hline $\mathrm{H}(10 \mathrm{~A})-\mathrm{C}(10)-\mathrm{H}(10 \mathrm{C})$ & 109.5 \\
\hline
\end{tabular}




\begin{tabular}{|c|c|}
\hline $\mathrm{H}(10 \mathrm{~B})-\mathrm{C}(10)-\mathrm{H}(10 \mathrm{C})$ & 109.5 \\
\hline$C(7)-C(11)-H(11 A)$ & 109.5 \\
\hline $\mathrm{C}(7)-\mathrm{C}(11)-\mathrm{H}(11 \mathrm{~B})$ & 109.5 \\
\hline $\mathrm{H}(11 \mathrm{~A})-\mathrm{C}(11)-\mathrm{H}(11 \mathrm{~B})$ & 109.5 \\
\hline $\mathrm{C}(7)-\mathrm{C}(11)-\mathrm{H}(11 \mathrm{C})$ & 109.5 \\
\hline $\mathrm{H}(11 \mathrm{~A})-\mathrm{C}(11)-\mathrm{H}(11 \mathrm{C})$ & 109.5 \\
\hline $\mathrm{H}(11 \mathrm{~B})-\mathrm{C}(11)-\mathrm{H}(11 \mathrm{C})$ & 109.5 \\
\hline $\mathrm{C}(9)-\mathrm{C}(12)-\mathrm{H}(12 \mathrm{~A})$ & 109.5 \\
\hline $\mathrm{C}(9)-\mathrm{C}(12)-\mathrm{H}(12 \mathrm{~B})$ & 109.5 \\
\hline $\mathrm{H}(12 \mathrm{~A})-\mathrm{C}(12)-\mathrm{H}(12 \mathrm{~B})$ & 109.5 \\
\hline $\mathrm{C}(9)-\mathrm{C}(12)-\mathrm{H}(12 \mathrm{C})$ & 109.5 \\
\hline $\mathrm{H}(12 \mathrm{~A})-\mathrm{C}(12)-\mathrm{H}(12 \mathrm{C})$ & 109.5 \\
\hline $\mathrm{H}(12 \mathrm{~B})-\mathrm{C}(12)-\mathrm{H}(12 \mathrm{C})$ & 109.5 \\
\hline$C(18)-C(13)-C(14)$ & $121.8(3)$ \\
\hline $\mathrm{C}(18)-\mathrm{C}(13)-\mathrm{N}(2)$ & $118.9(3)$ \\
\hline $\mathrm{C}(14)-\mathrm{C}(13)-\mathrm{N}(2)$ & $119.3(3)$ \\
\hline$C(15)-C(14)-C(13)$ & $117.6(3)$ \\
\hline$C(15)-C(14)-C(19)$ & $120.9(3)$ \\
\hline$C(13)-C(14)-C(19)$ & $121.5(3)$ \\
\hline$C(16)-C(15)-C(14)$ & $122.1(3)$ \\
\hline $\mathrm{C}(16)-\mathrm{C}(15)-\mathrm{H}(15 \mathrm{~A})$ & 119.0 \\
\hline $\mathrm{C}(14)-\mathrm{C}(15)-\mathrm{H}(15 \mathrm{~A})$ & 119.0 \\
\hline$C(15)-C(16)-C(17)$ & $118.9(3)$ \\
\hline$C(15)-C(16)-C(20)$ & $120.3(3)$ \\
\hline$C(17)-C(16)-C(20)$ & $120.8(3)$ \\
\hline$C(16)-C(17)-C(18)$ & $121.6(3)$ \\
\hline $\mathrm{C}(16)-\mathrm{C}(17)-\mathrm{H}(17 \mathrm{~A})$ & 119.2 \\
\hline $\mathrm{C}(18)-\mathrm{C}(17)-\mathrm{H}(17 \mathrm{~A})$ & 119.2 \\
\hline$C(13)-C(18)-C(17)$ & $118.0(3)$ \\
\hline$C(13)-C(18)-C(21)$ & $121.1(3)$ \\
\hline $\mathrm{C}(17)-\mathrm{C}(18)-\mathrm{C}(21)$ & $120.9(3)$ \\
\hline $\mathrm{C}(14)-\mathrm{C}(19)-\mathrm{H}(19 \mathrm{~A})$ & 109.5 \\
\hline $\mathrm{C}(14)-\mathrm{C}(19)-\mathrm{H}(19 \mathrm{~B})$ & 109.5 \\
\hline $\mathrm{H}(19 \mathrm{~A})-\mathrm{C}(19)-\mathrm{H}(19 \mathrm{~B})$ & 109.5 \\
\hline $\mathrm{C}(14)-\mathrm{C}(19)-\mathrm{H}(19 \mathrm{C})$ & 109.5 \\
\hline $\mathrm{H}(19 \mathrm{~A})-\mathrm{C}(19)-\mathrm{H}(19 \mathrm{C})$ & 109.5 \\
\hline $\mathrm{H}(19 \mathrm{~B})-\mathrm{C}(19)-\mathrm{H}(19 \mathrm{C})$ & 109.5 \\
\hline $\mathrm{C}(16)-\mathrm{C}(20)-\mathrm{H}(20 \mathrm{~A})$ & 109.5 \\
\hline $\mathrm{C}(16)-\mathrm{C}(20)-\mathrm{H}(20 \mathrm{~B})$ & 109.5 \\
\hline $\mathrm{H}(20 \mathrm{~A})-\mathrm{C}(20)-\mathrm{H}(20 \mathrm{~B})$ & 109.5 \\
\hline $\mathrm{C}(16)-\mathrm{C}(20)-\mathrm{H}(20 \mathrm{C})$ & 109.5 \\
\hline $\mathrm{H}(20 \mathrm{~A})-\mathrm{C}(20)-\mathrm{H}(20 \mathrm{C})$ & 109.5 \\
\hline $\mathrm{H}(20 \mathrm{~B})-\mathrm{C}(20)-\mathrm{H}(20 \mathrm{C})$ & 109.5 \\
\hline
\end{tabular}




\begin{tabular}{|c|c|}
\hline $\mathrm{C}(18)-\mathrm{C}(21)-\mathrm{H}(21 \mathrm{~A})$ & 109.5 \\
\hline $\mathrm{C}(18)-\mathrm{C}(21)-\mathrm{H}(21 \mathrm{~B})$ & 109.5 \\
\hline $\mathrm{H}(21 \mathrm{~A})-\mathrm{C}(21)-\mathrm{H}(21 \mathrm{~B})$ & 109.5 \\
\hline $\mathrm{C}(18)-\mathrm{C}(21)-\mathrm{H}(21 \mathrm{C})$ & 109.5 \\
\hline $\mathrm{H}(21 \mathrm{~A})-\mathrm{C}(21)-\mathrm{H}(21 \mathrm{C})$ & 109.5 \\
\hline $\mathrm{H}(21 \mathrm{~B})-\mathrm{C}(21)-\mathrm{H}(21 \mathrm{C})$ & 109.5 \\
\hline$C(23)-C(22)-C(24)$ & $111.6(3)$ \\
\hline $\mathrm{C}(23)-\mathrm{C}(22)-\mathrm{Cu}(1)$ & $105.5(2)$ \\
\hline $\mathrm{C}(24)-\mathrm{C}(22)-\mathrm{Cu}(1)$ & $116.8(2)$ \\
\hline $\mathrm{C}(23)-\mathrm{C}(22)-\mathrm{H}(22 \mathrm{~A})$ & 107.5 \\
\hline $\mathrm{C}(24)-\mathrm{C}(22)-\mathrm{H}(22 \mathrm{~A})$ & 107.5 \\
\hline $\mathrm{Cu}(1)-\mathrm{C}(22)-\mathrm{H}(22 \mathrm{~A})$ & 107.5 \\
\hline $\mathrm{F}(1)-\mathrm{C}(23)-\mathrm{F}(2)$ & $103.6(3)$ \\
\hline $\mathrm{F}(1)-\mathrm{C}(23)-\mathrm{F}(3)$ & $105.0(2)$ \\
\hline $\mathrm{F}(2)-\mathrm{C}(23)-\mathrm{F}(3)$ & $104.0(3)$ \\
\hline $\mathrm{F}(3 \mathrm{X})-\mathrm{C}(23)-\mathrm{C}(22)$ & $131.9(11)$ \\
\hline $\mathrm{F}(1)-\mathrm{C}(23)-\mathrm{C}(22)$ & $113.1(3)$ \\
\hline $\mathrm{F}(2)-\mathrm{C}(23)-\mathrm{C}(22)$ & $117.6(3)$ \\
\hline $\mathrm{F}(2 \mathrm{X})-\mathrm{C}(23)-\mathrm{C}(22)$ & $89.4(8)$ \\
\hline $\mathrm{F}(3)-\mathrm{C}(23)-\mathrm{C}(22)$ & $112.3(3)$ \\
\hline $\mathrm{F}(1 \mathrm{X})-\mathrm{C}(23)-\mathrm{C}(22)$ & $116.2(17)$ \\
\hline$C(25)-C(24)-C(22)$ & $115.0(3)$ \\
\hline$C(25)-C(24)-S i(1)$ & $110.8(2)$ \\
\hline$C(22)-C(24)-S i(1)$ & $112.2(2)$ \\
\hline $\mathrm{C}(25)-\mathrm{C}(24)-\mathrm{H}(24 \mathrm{~A})$ & 106.0 \\
\hline $\mathrm{C}(22)-\mathrm{C}(24)-\mathrm{H}(24 \mathrm{~A})$ & 106.0 \\
\hline $\mathrm{Si}(1)-\mathrm{C}(24)-\mathrm{H}(24 \mathrm{~A})$ & 106.0 \\
\hline$C(30)-C(25)-C(26)$ & $117.8(3)$ \\
\hline$C(30)-C(25)-C(24)$ & $121.8(3)$ \\
\hline$C(26)-C(25)-C(24)$ & $120.3(3)$ \\
\hline$C(25)-C(26)-C(27)$ & $121.2(4)$ \\
\hline $\mathrm{C}(25)-\mathrm{C}(26)-\mathrm{H}(26 \mathrm{~A})$ & 119.4 \\
\hline $\mathrm{C}(27)-\mathrm{C}(26)-\mathrm{H}(26 \mathrm{~A})$ & 119.4 \\
\hline$C(28)-C(27)-C(26)$ & $121.4(3)$ \\
\hline $\mathrm{C}(28)-\mathrm{C}(27)-\mathrm{H}(27 \mathrm{~A})$ & 119.3 \\
\hline $\mathrm{C}(26)-\mathrm{C}(27)-\mathrm{H}(27 \mathrm{~A})$ & 119.3 \\
\hline$C(27)-C(28)-C(29)$ & 118.1(3) \\
\hline $\mathrm{C}(27)-\mathrm{C}(28)-\mathrm{H}(28 \mathrm{~A})$ & 120.9 \\
\hline $\mathrm{C}(29)-\mathrm{C}(28)-\mathrm{H}(28 \mathrm{~A})$ & 120.9 \\
\hline$C(28)-C(29)-C(30)$ & $120.0(3)$ \\
\hline $\mathrm{C}(28)-\mathrm{C}(29)-\mathrm{C}(31)$ & 119.1(3) \\
\hline $\mathrm{C}(30)-\mathrm{C}(29)-\mathrm{C}(31)$ & $120.9(3)$ \\
\hline $\mathrm{C}(25)-\mathrm{C}(30)-\mathrm{C}(29)$ & $121.4(3)$ \\
\hline
\end{tabular}




\begin{tabular}{ll}
\hline $\mathrm{C}(25)-\mathrm{C}(30)-\mathrm{H}(30 \mathrm{~A})$ & 119.3 \\
$\mathrm{C}(29)-\mathrm{C}(30)-\mathrm{H}(30 \mathrm{~A})$ & 119.3 \\
$\mathrm{~N}(3)-\mathrm{C}(31)-\mathrm{C}(29)$ & $178.5(4)$ \\
$\mathrm{Si}(1)-\mathrm{C}(33)-\mathrm{H}(33 \mathrm{~A})$ & 109.5 \\
$\mathrm{Si}(1)-\mathrm{C}(33)-\mathrm{H}(33 \mathrm{~B})$ & 109.5 \\
$\mathrm{H}(33 \mathrm{~A})-\mathrm{C}(33)-\mathrm{H}(33 \mathrm{~B})$ & 109.5 \\
$\mathrm{Si}(1)-\mathrm{C}(33)-\mathrm{H}(33 \mathrm{C})$ & 109.5 \\
$\mathrm{H}(33 \mathrm{~A})-\mathrm{C}(33)-\mathrm{H}(33 \mathrm{C})$ & 109.5 \\
$\mathrm{H}(33 \mathrm{~B})-\mathrm{C}(33)-\mathrm{H}(33 \mathrm{C})$ & 109.5 \\
$\mathrm{Si}(1)-\mathrm{C}(34)-\mathrm{H}(34 \mathrm{~A})$ & 109.5 \\
$\mathrm{Si}(1)-\mathrm{C}(34)-\mathrm{H}(34 \mathrm{~B})$ & 109.5 \\
$\mathrm{H}(34 \mathrm{~A})-\mathrm{C}(34)-\mathrm{H}(34 \mathrm{~B})$ & 109.5 \\
$\mathrm{Si}(1)-\mathrm{C}(34)-\mathrm{H}(34 \mathrm{C})$ & 109.5 \\
$\mathrm{H}(34 \mathrm{~A})-\mathrm{C}(34)-\mathrm{H}(34 \mathrm{C})$ & 109.5 \\
$\mathrm{H}(34 \mathrm{~B})-\mathrm{C}(34)-\mathrm{H}(34 \mathrm{C})$ & 109.5 \\
$\mathrm{C}(40)-\mathrm{C}(35)-\mathrm{C}(36)$ & $117.3(3)$ \\
$\mathrm{C}(40)-\mathrm{C}(35)-\mathrm{Si}(1)$ & $121.3(3)$ \\
$\mathrm{C}(36)-\mathrm{C}(35)-\mathrm{Si}(1)$ & $121.4(3)$ \\
$\mathrm{C}(37)-\mathrm{C}(36)-\mathrm{C}(35)$ & $121.5(4)$ \\
$\mathrm{C}(37)-\mathrm{C}(36)-\mathrm{H}(36 \mathrm{~A})$ & 119.3 \\
$\mathrm{C}(35)-\mathrm{C}(36)-\mathrm{H}(36 \mathrm{~A})$ & 119.3 \\
$\mathrm{C}(38)-\mathrm{C}(37)-\mathrm{C}(36)$ & $119.6(4)$ \\
$\mathrm{C}(38)-\mathrm{C}(37)-\mathrm{H}(37 \mathrm{~A})$ & 120.2 \\
$\mathrm{C}(36)-\mathrm{C}(37)-\mathrm{H}(37 \mathrm{~A})$ & 120.2 \\
$\mathrm{C}(37)-\mathrm{C}(38)-\mathrm{C}(39)$ & $120.5(4)$ \\
$\mathrm{C}(37)-\mathrm{C}(38)-\mathrm{H}(38 \mathrm{~A})$ & \\
$\mathrm{C}(39)-\mathrm{C}(38)-\mathrm{H}(38 \mathrm{~A})$ & 119.3 \\
$\mathrm{C}(40)-\mathrm{C}(39)-\mathrm{C}(38)$ & \\
$\mathrm{C}(40)-\mathrm{C}(39)-\mathrm{H}(39 \mathrm{~A})$ & 119.8 \\
$\mathrm{C}(38)-\mathrm{C}(39)-\mathrm{H}(39 \mathrm{~A})$ & 119.8 \\
$\mathrm{C}(39)-\mathrm{C}(40)-\mathrm{C}(35)$ & 120.2 \\
$\mathrm{C}(39)-\mathrm{C}(40)-\mathrm{H}(40 \mathrm{~A})$ & $121.4(4)$ \\
$\mathrm{C}(35)-\mathrm{C}(40)-\mathrm{H}(40 \mathrm{~A})$ & \\
\hline
\end{tabular}

Table S23. Anisotropic displacement parameters $\left(\AA^{2} \times 10^{3}\right)$ for $\mathrm{C}_{39} \mathrm{H}_{43} \mathrm{CuF}_{3} \mathrm{~N}_{3} \mathrm{Si}$. The anisotropic displacement factor exponent takes the form: $-2 \pi^{2}\left[h^{2} a^{2} U^{11}+\ldots+2 h k\right.$ a b $\left.\mathbf{U}^{12}\right]$

\begin{tabular}{lllllll}
\hline & $\mathrm{U}^{11}$ & $\mathrm{U}^{22}$ & $\mathrm{U}^{33}$ & $\mathrm{U}^{23}$ & $\mathrm{U}^{13}$ & $\mathrm{U}^{12}$ \\
\hline $\mathrm{Cu}(1)$ & $21(1)$ & $16(1)$ & $25(1)$ & $-5(1)$ & $2(1)$ & $-1(1)$ \\
$\mathrm{Si}(1)$ & $19(1)$ & $21(1)$ & $39(1)$ & $1(1)$ & $8(1)$ & $0(1)$ \\
$\mathrm{F}(1)$ & $36(1)$ & $34(1)$ & $29(1)$ & $2(1)$ & $-4(1)$ & $7(1)$ \\
$\mathrm{F}(2)$ & $28(2)$ & $26(1)$ & $74(3)$ & $-23(2)$ & $6(2)$ & $6(1)$ \\
$\mathrm{F}(3)$ & $22(1)$ & $41(1)$ & $58(2)$ & $-4(1)$ & $11(1)$ & $-2(1)$ \\
\hline
\end{tabular}




\begin{tabular}{|c|c|c|c|c|c|c|}
\hline $\mathrm{N}(1)$ & $34(1)$ & $14(1)$ & $22(1)$ & $-1(1)$ & $-5(1)$ & $-5(1)$ \\
\hline $\mathrm{N}(2)$ & $32(1)$ & $16(1)$ & $20(1)$ & $1(1)$ & $-1(1)$ & $-5(1)$ \\
\hline$C(1)$ & $22(1)$ & $18(1)$ & $20(1)$ & $-1(1)$ & $5(1)$ & $-4(1)$ \\
\hline$C(2)$ & $46(2)$ & $16(2)$ & $29(2)$ & $0(1)$ & $-6(2)$ & $-6(1)$ \\
\hline$C(3)$ & $86(3)$ & $15(2)$ & $37(2)$ & $2(2)$ & $-26(2)$ & $-11(2)$ \\
\hline$C(4)$ & $27(2)$ & $15(1)$ & $24(2)$ & $0(1)$ & $0(1)$ & $-4(1)$ \\
\hline$C(5)$ & $31(2)$ & $15(1)$ & $28(2)$ & $-2(1)$ & $6(1)$ & $-2(1)$ \\
\hline$C(6)$ & $22(2)$ & $19(2)$ & $35(2)$ & $-4(1)$ & $3(1)$ & $-1(1)$ \\
\hline$C(7)$ & $29(2)$ & $19(2)$ & $25(2)$ & $1(1)$ & $-1(1)$ & $-1(1)$ \\
\hline$C(8)$ & $32(2)$ & $29(2)$ & $22(2)$ & $2(1)$ & $6(1)$ & $0(1)$ \\
\hline$C(9)$ & $26(2)$ & $19(1)$ & $30(2)$ & $1(1)$ & $4(1)$ & $1(1)$ \\
\hline$C(10)$ & $41(2)$ & $29(2)$ & $36(2)$ & $-6(1)$ & $16(2)$ & $-6(2)$ \\
\hline$C(11)$ & $37(2)$ & $38(2)$ & $31(2)$ & $2(2)$ & $-3(2)$ & $4(2)$ \\
\hline$C(12)$ & $25(2)$ & $43(2)$ & $37(2)$ & $2(2)$ & $5(1)$ & $2(2)$ \\
\hline$C(13)$ & $26(2)$ & $16(1)$ & $17(1)$ & $-2(1)$ & $-2(1)$ & $-6(1)$ \\
\hline$C(14)$ & $25(2)$ & $23(2)$ & $24(2)$ & $-2(1)$ & $1(1)$ & $-9(1)$ \\
\hline$C(15)$ & $24(2)$ & $22(2)$ & $32(2)$ & $-3(1)$ & $-2(1)$ & $-2(1)$ \\
\hline$C(16)$ & $34(2)$ & $21(2)$ & $24(2)$ & $2(1)$ & $-3(1)$ & $-6(1)$ \\
\hline$C(17)$ & $36(2)$ & $27(2)$ & $22(2)$ & $2(1)$ & $5(1)$ & $-8(1)$ \\
\hline$C(18)$ & $30(2)$ & $23(2)$ & $19(1)$ & $-3(1)$ & $3(1)$ & $-3(1)$ \\
\hline$C(19)$ & $34(2)$ & $58(2)$ & $36(2)$ & $6(2)$ & $12(2)$ & $-10(2)$ \\
\hline$C(20)$ & $45(2)$ & $34(2)$ & $44(2)$ & $16(2)$ & $-5(2)$ & $-3(2)$ \\
\hline $\mathrm{C}(21)$ & $42(2)$ & $44(2)$ & $34(2)$ & $1(2)$ & $15(2)$ & $7(2)$ \\
\hline$C(22)$ & $23(2)$ & $24(2)$ & $35(2)$ & $-10(1)$ & $5(1)$ & $-1(1)$ \\
\hline$C(23)$ & $28(2)$ & $20(2)$ & $33(2)$ & $-10(1)$ & $5(1)$ & $-2(1)$ \\
\hline$C(24)$ & $27(2)$ & $28(2)$ & $31(2)$ & $0(1)$ & $6(1)$ & $0(1)$ \\
\hline$C(25)$ & $18(2)$ & $25(2)$ & $39(2)$ & $0(1)$ & $3(1)$ & $1(1)$ \\
\hline$C(26)$ & $32(2)$ & $26(2)$ & $40(2)$ & $1(1)$ & $4(2)$ & $0(1)$ \\
\hline$C(27)$ & $41(2)$ & $23(2)$ & $45(2)$ & $6(2)$ & $7(2)$ & $-2(2)$ \\
\hline $\mathrm{C}(28)$ & $33(2)$ & $15(2)$ & $52(2)$ & $0(1)$ & $8(2)$ & $0(1)$ \\
\hline$C(29)$ & $18(2)$ & $25(2)$ & $42(2)$ & $2(1)$ & $3(1)$ & $-1(1)$ \\
\hline$C(30)$ & $18(2)$ & $21(2)$ & $49(2)$ & $10(1)$ & $6(1)$ & $-1(1)$ \\
\hline$C(31)$ & $29(2)$ & $31(2)$ & $47(2)$ & $4(2)$ & $7(2)$ & $0(1)$ \\
\hline $\mathrm{N}(3)$ & $51(2)$ & $47(2)$ & $48(2)$ & $-2(2)$ & $13(2)$ & $2(2)$ \\
\hline$C(33)$ & $26(2)$ & $27(2)$ & $39(2)$ & $1(1)$ & $9(1)$ & $1(1)$ \\
\hline$C(34)$ & $30(2)$ & $31(2)$ & $52(2)$ & $0(2)$ & $14(2)$ & $-7(1)$ \\
\hline$C(35)$ & $26(2)$ & $25(2)$ & $39(2)$ & $-1(1)$ & $12(1)$ & $6(1)$ \\
\hline$C(36)$ & $39(2)$ & $35(2)$ & $42(2)$ & $-1(2)$ & $9(2)$ & $3(2)$ \\
\hline$C(37)$ & $51(2)$ & $45(2)$ & $42(2)$ & $-7(2)$ & $8(2)$ & $9(2)$ \\
\hline$C(38)$ & $59(3)$ & $51(2)$ & $37(2)$ & $4(2)$ & $19(2)$ & $23(2)$ \\
\hline$C(39)$ & $56(2)$ & $38(2)$ & $48(2)$ & $7(2)$ & $24(2)$ & $10(2)$ \\
\hline$C(40)$ & $38(2)$ & $32(2)$ & $40(2)$ & $1(2)$ & $15(2)$ & $2(2)$ \\
\hline
\end{tabular}


Table S24. Hydrogen coordinates $\left(\mathrm{x}^{4} 0^{4}\right)$ and isotropic displacement parameters $\left(\AA^{2} \times 10^{3}\right)$ for $\mathrm{C}_{39} \mathrm{H}_{43} \mathrm{CuF}_{3} \mathrm{~N}_{3} \mathrm{Si}$

\begin{tabular}{|c|c|c|c|c|}
\hline & $\mathrm{x}$ & $\mathrm{y}$ & $\mathrm{z}$ & $\mathrm{U}(\mathrm{eq})$ \\
\hline $\mathrm{H}(2 \mathrm{~A})$ & 3157 & 11359 & 8193 & 42 \\
\hline $\mathrm{H}(2 \mathrm{~B})$ & 3914 & 11393 & 7800 & 42 \\
\hline $\mathrm{H}(3 \mathrm{~A})$ & 4794 & 10594 & 8924 & 70 \\
\hline $\mathrm{H}(3 \mathrm{~B})$ & 4050 & 10601 & 9335 & 70 \\
\hline $\mathrm{H}(6 \mathrm{~A})$ & 565 & 10818 & 5651 & 33 \\
\hline $\mathrm{H}(8 \mathrm{~A})$ & 2475 & 10552 & 4711 & 34 \\
\hline $\mathrm{H}(10 \mathrm{~A})$ & 1476 & 11186 & 7521 & 52 \\
\hline $\mathrm{H}(10 \mathrm{~B})$ & 1729 & 10064 & 7705 & 52 \\
\hline $\mathrm{H}(10 \mathrm{C})$ & 791 & 10357 & 7082 & 52 \\
\hline $\mathrm{H}(11 \mathrm{~A})$ & 221 & 10994 & 4191 & 59 \\
\hline $\mathrm{H}(11 \mathrm{~B})$ & 856 & 10510 & 3776 & 59 \\
\hline $\mathrm{H}(11 \mathrm{C})$ & 949 & 11638 & 4024 & 59 \\
\hline $\mathrm{H}(12 \mathrm{~A})$ & 4167 & 10586 & 6474 & 55 \\
\hline $\mathrm{H}(12 \mathrm{~B})$ & 3874 & 10145 & 5542 & 55 \\
\hline $\mathrm{H}(12 \mathrm{C})$ & 3940 & 9454 & 6323 & 55 \\
\hline $\mathrm{H}(15 \mathrm{~A})$ & 6080 & 7269 & 9833 & 35 \\
\hline $\mathrm{H}(17 \mathrm{~A})$ & 4102 & 7372 & 10681 & 36 \\
\hline H(19A) & 5167 & 8605 & 8026 & 64 \\
\hline H(19B) & 6044 & 8105 & 8604 & 64 \\
\hline $\mathrm{H}(19 \mathrm{C})$ & 5850 & 9214 & 8764 & 64 \\
\hline $\mathrm{H}(20 \mathrm{~A})$ & 5376 & 5806 & 10789 & 70 \\
\hline $\mathrm{H}(20 \mathrm{~B})$ & 5467 & 6573 & 11525 & 70 \\
\hline $\mathrm{H}(20 \mathrm{C})$ & 6214 & 6474 & 11136 & 70 \\
\hline $\mathrm{H}(21 \mathrm{~A})$ & 3202 & 9374 & 9930 & 59 \\
\hline $\mathrm{H}(21 \mathrm{~B})$ & 2851 & 8299 & 9977 & 59 \\
\hline $\mathrm{H}(21 \mathrm{C})$ & 2740 & 8776 & 9082 & 59 \\
\hline $\mathrm{H}(22 \mathrm{~A})$ & 2971 & 6608 & 6448 & 34 \\
\hline $\mathrm{H}(24 \mathrm{~A})$ & 2410 & 6052 & 7796 & 35 \\
\hline $\mathrm{H}(26 \mathrm{~A})$ & 2242 & 4428 & 7984 & 42 \\
\hline $\mathrm{H}(27 \mathrm{~A})$ & 2185 & 2813 & 7573 & 46 \\
\hline $\mathrm{H}(28 \mathrm{~A})$ & 2117 & 2392 & 6212 & 42 \\
\hline $\mathrm{H}(30 \mathrm{~A})$ & 2104 & 5279 & 5669 & 37 \\
\hline $\mathrm{H}(33 \mathrm{~A})$ & 1736 & 8321 & 7230 & 47 \\
\hline H(33B) & 733 & 8239 & 7079 & 47 \\
\hline $\mathrm{H}(33 \mathrm{C})$ & 1420 & 7757 & 7896 & 47 \\
\hline $\mathrm{H}(34 \mathrm{~A})$ & 351 & 5341 & 6517 & 57 \\
\hline $\mathrm{H}(34 \mathrm{~B})$ & 508 & 5798 & 7428 & 57 \\
\hline $\mathrm{H}(34 \mathrm{C})$ & -179 & 6279 & 6611 & 57 \\
\hline $\mathrm{H}(36 \mathrm{~A})$ & 74 & 5988 & 5082 & 48 \\
\hline
\end{tabular}




\begin{tabular}{lllll}
\hline $\mathrm{H}(37 \mathrm{~A})$ & -330 & 6442 & 3676 & 58 \\
$\mathrm{H}(38 \mathrm{~A})$ & 294 & 7798 & 3299 & 58 \\
$\mathrm{H}(39 \mathrm{~A})$ & 1363 & 8667 & 4320 & 54 \\
$\mathrm{H}(40 \mathrm{~A})$ & 1756 & 8229 & 5729 & 43 \\
\hline
\end{tabular}

Table S25. Torsion angles $\left[{ }^{\circ}\right]$ for $\mathrm{C}_{\mathbf{3 9}} \mathrm{H}_{43} \mathrm{CuF}_{3} \mathrm{~N}_{\mathbf{3}} \mathrm{Si}$

\begin{tabular}{ll}
\hline $\mathrm{C}(4)-\mathrm{N}(1)-\mathrm{C}(1)-\mathrm{N}(2)$ & $179.5(3)$ \\
$\mathrm{C}(2)-\mathrm{N}(1)-\mathrm{C}(1)-\mathrm{N}(2)$ & $0.1(4)$ \\
$\mathrm{C}(4)-\mathrm{N}(1)-\mathrm{C}(1)-\mathrm{Cu}(1)$ & $1.0(5)$ \\
$\mathrm{C}(2)-\mathrm{N}(1)-\mathrm{C}(1)-\mathrm{Cu}(1)$ & $-178.5(3)$ \\
$\mathrm{C}(13)-\mathrm{N}(2)-\mathrm{C}(1)-\mathrm{N}(1)$ & $176.1(3)$ \\
$\mathrm{C}(3)-\mathrm{N}(2)-\mathrm{C}(1)-\mathrm{N}(1)$ & $-1.8(4)$ \\
$\mathrm{C}(13)-\mathrm{N}(2)-\mathrm{C}(1)-\mathrm{Cu}(1)$ & $-5.1(4)$ \\
$\mathrm{C}(3)-\mathrm{N}(2)-\mathrm{C}(1)-\mathrm{Cu}(1)$ & $177.0(3)$ \\
$\mathrm{C}(1)-\mathrm{N}(1)-\mathrm{C}(2)-\mathrm{C}(3)$ & $1.5(4)$ \\
$\mathrm{C}(4)-\mathrm{N}(1)-\mathrm{C}(2)-\mathrm{C}(3)$ & $-178.0(3)$ \\
$\mathrm{C}(1)-\mathrm{N}(2)-\mathrm{C}(3)-\mathrm{C}(2)$ & $2.6(5)$ \\
$\mathrm{C}(13)-\mathrm{N}(2)-\mathrm{C}(3)-\mathrm{C}(2)$ & $-175.4(3)$ \\
$\mathrm{N}(1)-\mathrm{C}(2)-\mathrm{C}(3)-\mathrm{N}(2)$ & $-2.2(5)$ \\
$\mathrm{C}(1)-\mathrm{N}(1)-\mathrm{C}(4)-\mathrm{C}(9)$ & $-84.2(4)$ \\
$\mathrm{C}(2)-\mathrm{N}(1)-\mathrm{C}(4)-\mathrm{C}(9)$ & $95.2(4)$ \\
$\mathrm{C}(1)-\mathrm{N}(1)-\mathrm{C}(4)-\mathrm{C}(5)$ & $98.1(4)$ \\
$\mathrm{C}(2)-\mathrm{N}(1)-\mathrm{C}(4)-\mathrm{C}(5)$ & $-82.5(4)$ \\
$\mathrm{C}(9)-\mathrm{C}(4)-\mathrm{C}(5)-\mathrm{C}(6)$ & $0.4(4)$ \\
$\mathrm{N}(1)-\mathrm{C}(4)-\mathrm{C}(5)-\mathrm{C}(6)$ & $178.0(3)$ \\
$\mathrm{C}(9)-\mathrm{C}(4)-\mathrm{C}(5)-\mathrm{C}(10)$ & $-178.4(3)$ \\
$\mathrm{N}(1)-\mathrm{C}(4)-\mathrm{C}(5)-\mathrm{C}(10)$ & $-0.8(4)$ \\
$\mathrm{C}(4)-\mathrm{C}(5)-\mathrm{C}(6)-\mathrm{C}(7)$ & $-1.7(4)$ \\
$\mathrm{C}(10)-\mathrm{C}(5)-\mathrm{C}(6)-\mathrm{C}(7)$ & $177.1(3)$ \\
$\mathrm{C}(5)-\mathrm{C}(6)-\mathrm{C}(7)-\mathrm{C}(8)$ & $1.9(5)$ \\
$\mathrm{C}(5)-\mathrm{C}(6)-\mathrm{C}(7)-\mathrm{C}(11)$ & $-177.2(3)$ \\
$\mathrm{C}(6)-\mathrm{C}(7)-\mathrm{C}(8)-\mathrm{C}(9)$ & $-0.8(5)$ \\
$\mathrm{C}(11)-\mathrm{C}(7)-\mathrm{C}(8)-\mathrm{C}(9)$ & $178.3(3)$ \\
$\mathrm{C}(7)-\mathrm{C}(8)-\mathrm{C}(9)-\mathrm{C}(4)$ & $-0.5(5)$ \\
$\mathrm{C}(7)-\mathrm{C}(8)-\mathrm{C}(9)-\mathrm{C}(12)$ & $179.4(3)$ \\
$\mathrm{C}(5)-\mathrm{C}(4)-\mathrm{C}(9)-\mathrm{C}(8)$ & $0.7(4)$ \\
$\mathrm{N}(1)-\mathrm{C}(4)-\mathrm{C}(9)-\mathrm{C}(8)$ & $-177.0(3)$ \\
$\mathrm{C}(5)-\mathrm{C}(4)-\mathrm{C}(9)-\mathrm{C}(12)$ & $-179.2(3)$ \\
$\mathrm{N}(1)-\mathrm{C}(4)-\mathrm{C}(9)-\mathrm{C}(12)$ & $3.2(4)$ \\
$\mathrm{C}(1)-\mathrm{N}(2)-\mathrm{C}(13)-\mathrm{C}(18)$ & $-89.2(4)$ \\
$\mathrm{C}(3)-\mathrm{N}(2)-\mathrm{C}(13)-\mathrm{C}(18)$ & $88.5(4)$ \\
$\mathrm{C}(1)-\mathrm{N}(2)-\mathrm{C}(13)-\mathrm{C}(14)$ & $92.4(4)$ \\
$\mathrm{C}(3)-\mathrm{N}(2)-\mathrm{C}(13)-\mathrm{C}(14)$ & $-89.9(4)$ \\
\hline & \\
& \\
& \\
&
\end{tabular}




\begin{tabular}{|c|c|}
\hline$C(18)-C(13)-C(14)-C(15)$ & $-2.1(4)$ \\
\hline $\mathrm{N}(2)-\mathrm{C}(13)-\mathrm{C}(14)-\mathrm{C}(15)$ & $176.2(3)$ \\
\hline $\mathrm{C}(18)-\mathrm{C}(13)-\mathrm{C}(14)-\mathrm{C}(19)$ & $177.9(3)$ \\
\hline $\mathrm{N}(2)-\mathrm{C}(13)-\mathrm{C}(14)-\mathrm{C}(19)$ & $-3.8(4)$ \\
\hline$C(13)-C(14)-C(15)-C(16)$ & $0.7(5)$ \\
\hline$C(19)-C(14)-C(15)-C(16)$ & $-179.3(3)$ \\
\hline$C(14)-C(15)-C(16)-C(17)$ & $0.9(5)$ \\
\hline$C(14)-C(15)-C(16)-C(20)$ & $-179.8(3)$ \\
\hline $\mathrm{C}(15)-\mathrm{C}(16)-\mathrm{C}(17)-\mathrm{C}(18)$ & $-1.2(5)$ \\
\hline $\mathrm{C}(20)-\mathrm{C}(16)-\mathrm{C}(17)-\mathrm{C}(18)$ & $179.5(3)$ \\
\hline $\mathrm{C}(14)-\mathrm{C}(13)-\mathrm{C}(18)-\mathrm{C}(17)$ & $1.8(4)$ \\
\hline $\mathrm{N}(2)-\mathrm{C}(13)-\mathrm{C}(18)-\mathrm{C}(17)$ & $-176.5(3)$ \\
\hline $\mathrm{C}(14)-\mathrm{C}(13)-\mathrm{C}(18)-\mathrm{C}(21)$ & $-178.8(3)$ \\
\hline $\mathrm{N}(2)-\mathrm{C}(13)-\mathrm{C}(18)-\mathrm{C}(21)$ & $2.9(4)$ \\
\hline$C(16)-C(17)-C(18)-C(13)$ & $-0.1(5)$ \\
\hline$C(16)-C(17)-C(18)-C(21)$ & $-179.5(3)$ \\
\hline $\mathrm{C}(24)-\mathrm{C}(22)-\mathrm{C}(23)-\mathrm{F}(1)$ & $-61.6(3)$ \\
\hline $\mathrm{Cu}(1)-\mathrm{C}(22)-\mathrm{C}(23)-\mathrm{F}(1)$ & $66.2(3)$ \\
\hline $\mathrm{C}(24)-\mathrm{C}(22)-\mathrm{C}(23)-\mathrm{F}(2)$ & $59.1(5)$ \\
\hline $\mathrm{Cu}(1)-\mathrm{C}(22)-\mathrm{C}(23)-\mathrm{F}(2)$ & $-173.1(3)$ \\
\hline $\mathrm{C}(24)-\mathrm{C}(22)-\mathrm{C}(23)-\mathrm{F}(3)$ & $179.8(3)$ \\
\hline $\mathrm{Cu}(1)-\mathrm{C}(22)-\mathrm{C}(23)-\mathrm{F}(3)$ & $-52.4(3)$ \\
\hline $\mathrm{C}(23)-\mathrm{C}(22)-\mathrm{C}(24)-\mathrm{C}(25)$ & $-60.9(4)$ \\
\hline $\mathrm{Cu}(1)-\mathrm{C}(22)-\mathrm{C}(24)-\mathrm{C}(25)$ & $177.6(2)$ \\
\hline $\mathrm{C}(23)-\mathrm{C}(22)-\mathrm{C}(24)-\mathrm{Si}(1)$ & $171.2(2)$ \\
\hline $\mathrm{Cu}(1)-\mathrm{C}(22)-\mathrm{C}(24)-\mathrm{Si}(1)$ & $49.8(3)$ \\
\hline $\mathrm{C}(33)-\mathrm{Si}(1)-\mathrm{C}(24)-\mathrm{C}(25)$ & $165.0(2)$ \\
\hline $\mathrm{C}(34)-\mathrm{Si}(1)-\mathrm{C}(24)-\mathrm{C}(25)$ & $46.2(3)$ \\
\hline $\mathrm{C}(35)-\mathrm{Si}(1)-\mathrm{C}(24)-\mathrm{C}(25)$ & $-74.7(3)$ \\
\hline $\mathrm{C}(33)-\mathrm{Si}(1)-\mathrm{C}(24)-\mathrm{C}(22)$ & $-64.9(3)$ \\
\hline $\mathrm{C}(34)-\mathrm{Si}(1)-\mathrm{C}(24)-\mathrm{C}(22)$ & $176.3(2)$ \\
\hline $\mathrm{C}(35)-\mathrm{Si}(1)-\mathrm{C}(24)-\mathrm{C}(22)$ & $55.4(3)$ \\
\hline $\mathrm{C}(22)-\mathrm{C}(24)-\mathrm{C}(25)-\mathrm{C}(30)$ & $-55.6(4)$ \\
\hline $\mathrm{Si}(1)-\mathrm{C}(24)-\mathrm{C}(25)-\mathrm{C}(30)$ & $73.0(3)$ \\
\hline$C(22)-C(24)-C(25)-C(26)$ & $122.9(3)$ \\
\hline $\mathrm{Si}(1)-\mathrm{C}(24)-\mathrm{C}(25)-\mathrm{C}(26)$ & $-108.6(3)$ \\
\hline$C(30)-C(25)-C(26)-C(27)$ & $1.8(5)$ \\
\hline$C(24)-C(25)-C(26)-C(27)$ & $-176.7(3)$ \\
\hline $\mathrm{C}(25)-\mathrm{C}(26)-\mathrm{C}(27)-\mathrm{C}(28)$ & $-0.1(6)$ \\
\hline$C(26)-C(27)-C(28)-C(29)$ & $-1.4(5)$ \\
\hline $\mathrm{C}(27)-\mathrm{C}(28)-\mathrm{C}(29)-\mathrm{C}(30)$ & $1.2(5)$ \\
\hline $\mathrm{C}(27)-\mathrm{C}(28)-\mathrm{C}(29)-\mathrm{C}(31)$ & $178.4(3)$ \\
\hline$C(26)-C(25)-C(30)-C(29)$ & $-2.0(5)$ \\
\hline
\end{tabular}




\begin{tabular}{ll}
\hline $\mathrm{C}(24)-\mathrm{C}(25)-\mathrm{C}(30)-\mathrm{C}(29)$ & $176.4(3)$ \\
$\mathrm{C}(28)-\mathrm{C}(29)-\mathrm{C}(30)-\mathrm{C}(25)$ & $0.6(5)$ \\
$\mathrm{C}(31)-\mathrm{C}(29)-\mathrm{C}(30)-\mathrm{C}(25)$ & $-176.6(3)$ \\
$\mathrm{C}(33)-\mathrm{Si}(1)-\mathrm{C}(35)-\mathrm{C}(40)$ & $41.8(3)$ \\
$\mathrm{C}(34)-\mathrm{Si}(1)-\mathrm{C}(35)-\mathrm{C}(40)$ & $161.1(3)$ \\
$\mathrm{C}(24)-\mathrm{Si}(1)-\mathrm{C}(35)-\mathrm{C}(40)$ & $-79.1(3)$ \\
$\mathrm{C}(33)-\mathrm{Si}(1)-\mathrm{C}(35)-\mathrm{C}(36)$ & $-135.3(3)$ \\
$\mathrm{C}(34)-\mathrm{Si}(1)-\mathrm{C}(35)-\mathrm{C}(36)$ & $-15.9(3)$ \\
$\mathrm{C}(24)-\mathrm{Si}(1)-\mathrm{C}(35)-\mathrm{C}(36)$ & $103.8(3)$ \\
$\mathrm{C}(40)-\mathrm{C}(35)-\mathrm{C}(36)-\mathrm{C}(37)$ & $-1.0(5)$ \\
$\mathrm{Si}(1)-\mathrm{C}(35)-\mathrm{C}(36)-\mathrm{C}(37)$ & $176.2(3)$ \\
$\mathrm{C}(35)-\mathrm{C}(36)-\mathrm{C}(37)-\mathrm{C}(38)$ & $0.1(6)$ \\
$\mathrm{C}(36)-\mathrm{C}(37)-\mathrm{C}(38)-\mathrm{C}(39)$ & $1.3(6)$ \\
$\mathrm{C}(37)-\mathrm{C}(38)-\mathrm{C}(39)-\mathrm{C}(40)$ & $-1.7(6)$ \\
$\mathrm{C}(38)-\mathrm{C}(39)-\mathrm{C}(40)-\mathrm{C}(35)$ & $0.8(6)$ \\
$\mathrm{C}(36)-\mathrm{C}(35)-\mathrm{C}(40)-\mathrm{C}(39)$ & $0.6(5)$ \\
$\mathrm{Si}(1)-\mathrm{C}(35)-\mathrm{C}(40)-\mathrm{C}(39)$ & $-176.6(3)$ \\
\hline
\end{tabular}

\subsection{Cu-alkyl complex 21}

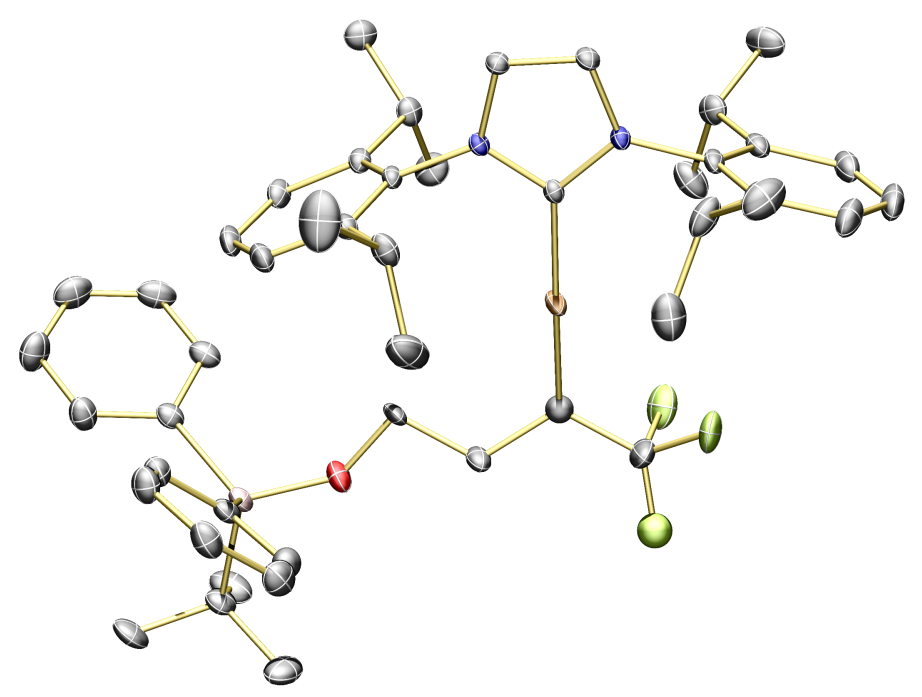

Table S26. Crystal data and structure refinement for $\mathrm{C}_{47} \mathrm{H}_{60} \mathrm{CuF}_{3} \mathrm{~N}_{2} \mathrm{OSi}\left(\mathrm{C}_{6} \mathrm{H}_{14}\right)_{0.5}$

Identification code

Empirical formula

Formula weight

Temperature

Wavelength

Crystal system

Space group
C47H60CuF3N2OSi(C6H14)0.5

C50 H67 Cu F3 N2 O Si

860.68

100(2) K

$1.54178 \AA$

Monoclinic

$\mathrm{P} 21 / \mathrm{c}$ 


\begin{tabular}{|c|c|c|}
\hline \multirow[t]{3}{*}{ Unit cell dimensions } & $a=17.8697(6) \AA$ & $\mathrm{a}=90^{\circ}$ \\
\hline & $\mathrm{b}=16.4289(5) \AA$ & $\mathrm{b}=103.514(2)^{\circ}$ \\
\hline & $c=16.6878(5) \AA$ & $\mathrm{g}=90^{\circ}$ \\
\hline Volume & \multicolumn{2}{|l|}{$4763.6(3) \AA^{3}$} \\
\hline $\mathrm{Z}$ & \multicolumn{2}{|l|}{4} \\
\hline Density (calculated) & \multicolumn{2}{|l|}{$1.200 \mathrm{Mg} / \mathrm{m}^{3}$} \\
\hline Absorption coefficient & \multicolumn{2}{|l|}{$1.270 \mathrm{~mm}^{-1}$} \\
\hline $\mathrm{F}(000)$ & \multicolumn{2}{|l|}{1836} \\
\hline Crystal size & \multicolumn{2}{|c|}{$0.420 \times 0.160 \times 0.100 \mathrm{~mm}^{3}$} \\
\hline Theta range for data collection & \multicolumn{2}{|l|}{2.543 to $66.708^{\circ}$} \\
\hline Index ranges & \multicolumn{2}{|c|}{$-21<=\mathrm{h}<=21,-19<=\mathrm{k}<=13,-19<=\mathrm{l}<=19$} \\
\hline Reflections collected & \multicolumn{2}{|l|}{31931} \\
\hline Independent reflections & \multicolumn{2}{|c|}{$8370[\mathrm{R}(\mathrm{int})=0.0312]$} \\
\hline Completeness to theta $=66.708^{\circ}$ & \multicolumn{2}{|l|}{$99.3 \%$} \\
\hline Absorption correction & \multicolumn{2}{|c|}{ Semi-empirical from equivalents } \\
\hline Max. and min. transmission & \multicolumn{2}{|l|}{0.7528 and 0.6447} \\
\hline Refinement method & \multicolumn{2}{|c|}{ Full-matrix least-squares on $\mathrm{F}^{2}$} \\
\hline Data / restraints / parameters & \multicolumn{2}{|l|}{$8370 / 1053 / 585$} \\
\hline Goodness-of-fit on $\mathrm{F}^{2}$ & \multicolumn{2}{|l|}{1.030} \\
\hline Final $\mathrm{R}$ indices $[\mathrm{I}>2 \operatorname{sigma}(\mathrm{I})]$ & \multicolumn{2}{|c|}{$\mathrm{R} 1=0.0473, \mathrm{wR} 2=0.1262$} \\
\hline $\mathrm{R}$ indices (all data) & \multicolumn{2}{|c|}{$\mathrm{R} 1=0.0519, \mathrm{wR} 2=0.1303$} \\
\hline Extinction coefficient & \multicolumn{2}{|l|}{$\mathrm{n} / \mathrm{a}$} \\
\hline Largest diff. peak and hole & \multicolumn{2}{|c|}{0.973 and -0.907 e..$\AA^{-3}$} \\
\hline
\end{tabular}

Table S27. Atomic coordinates $\left(\times_{10}^{4}\right)$ and equivalent isotropic displacement parameters $\left(\AA^{2} \times 10^{3}\right)$ for $\mathrm{C}_{47} \mathrm{H}_{60} \mathrm{CuF}_{3} \mathrm{~N}_{2} \mathrm{OSi}\left(\mathrm{C}_{6} \mathrm{H}_{14}\right)_{0.5} \mathrm{U}(\mathrm{eq})$ is defined as one third of the trace of the orthogonalized $\mathrm{U}^{\mathrm{ij}}$ tensor

\begin{tabular}{lcccc}
\hline & $\mathrm{x}$ & $\mathrm{y}$ & $\mathrm{z}$ & $\mathrm{U}(\mathrm{eq})$ \\
\hline $\mathrm{Cu}(1)$ & $6850(1)$ & $6282(1)$ & $6175(1)$ & $32(1)$ \\
$\mathrm{Si}(1)$ & $8210(1)$ & $2959(1)$ & $6859(1)$ & $26(1)$ \\
$\mathrm{O}(1)$ & $7711(1)$ & $3556(1)$ & $6148(1)$ & $37(1)$ \\
$\mathrm{N}(1)$ & $6410(1)$ & $6600(1)$ & $7705(1)$ & $19(1)$ \\
$\mathrm{N}(2)$ & $6207(1)$ & $7660(1)$ & $6945(1)$ & $20(1)$
\end{tabular}




\begin{tabular}{|c|c|c|c|c|}
\hline$C(1)$ & $6463(1)$ & $6881(1)$ & $6955(1)$ & $20(1)$ \\
\hline$C(2)$ & $6136(1)$ & $7187(1)$ & $8154(1)$ & $22(1)$ \\
\hline$C(3)$ & $6006(1)$ & $7856(1)$ & $7676(1)$ & $23(1)$ \\
\hline$C(4)$ & $6644(1)$ & 5791(1) & 7993(1) & $21(1)$ \\
\hline$C(5)$ & $7405(1)$ & $5674(1)$ & $8424(1)$ & $26(1)$ \\
\hline$C(6)$ & $7617(1)$ & $4883(1)$ & $8691(1)$ & $33(1)$ \\
\hline$C(7)$ & $7098(2)$ & $4251(1)$ & $8521(2)$ & $35(1)$ \\
\hline$C(8)$ & $6352(1)$ & $4388(1)$ & $8086(1)$ & $30(1)$ \\
\hline $\mathrm{C}(9)$ & $6104(1)$ & $5166(1)$ & $7813(1)$ & $24(1)$ \\
\hline$C(10)$ & $7995(1)$ & $6355(2)$ & $8582(2)$ & $35(1)$ \\
\hline $\mathrm{C}(11)$ & $8371(2)$ & $6432(2)$ & $9490(2)$ & $77(1)$ \\
\hline$C(12)$ & $8584(2)$ & $6225(2)$ & $8068(3)$ & $64(1)$ \\
\hline$C(13)$ & $5281(1)$ & $5298(1)$ & $7327(1)$ & $30(1)$ \\
\hline$C(14)$ & $4700(2)$ & $5037(2)$ & $7819(2)$ & $39(1)$ \\
\hline$C(15)$ & $5139(2)$ & $4855(2)$ & $6497(2)$ & $46(1)$ \\
\hline$C(16)$ & $6179(1)$ & $8225(1)$ & $6273(1)$ & $24(1)$ \\
\hline$C(17)$ & $5536(1)$ & $8214(1)$ & $5610(1)$ & $29(1)$ \\
\hline$C(18)$ & $5520(2)$ & $8778(2)$ & $4980(2)$ & $40(1)$ \\
\hline$C(19)$ & $6118(2)$ & $9320(2)$ & $5020(2)$ & $46(1)$ \\
\hline $\mathrm{C}(20)$ & $6740(2)$ & $9318(2)$ & $5682(2)$ & $45(1)$ \\
\hline $\mathrm{C}(21)$ & $6788(2)$ & $8771(1)$ & $6334(1)$ & $33(1)$ \\
\hline$C(22)$ & $4880(1)$ & $7616(2)$ & $5550(2)$ & $37(1)$ \\
\hline$C(23)$ & $4955(2)$ & $6908(2)$ & $4981(2)$ & $51(1)$ \\
\hline$C(24)$ & $4085(2)$ & $8010(2)$ & $5251(2)$ & $53(1)$ \\
\hline$C(25)$ & $7486(2)$ & $8758(2)$ & $7054(2)$ & $42(1)$ \\
\hline$C(26)$ & $7805(2)$ & $9603(2)$ & $7309(2)$ & $56(1)$ \\
\hline$C(27)$ & $8117(2)$ & $8220(2)$ & $6860(2)$ & $56(1)$ \\
\hline $\mathrm{C}(31)$ & $7548(3)$ & $4422(3)$ & $6249(5)$ & $33(1)$ \\
\hline$C(30)$ & $7437(7)$ & $4835(6)$ & $5427(6)$ & $33(1)$ \\
\hline$C(29)$ & $7460(3)$ & $5771(2)$ & $5470(2)$ & $30(1)$ \\
\hline$C(28)$ & $7350(5)$ & $6154(5)$ & $4682(4)$ & $46(2)$ \\
\hline $\mathrm{F}(1)$ & $7363(2)$ & $6950(2)$ & $4650(2)$ & $51(1)$ \\
\hline $\mathrm{F}(2)$ & $6542(2)$ & $6018(2)$ & $4242(2)$ & $60(1)$ \\
\hline $\mathrm{F}(3)$ & $7692(3)$ & $5847(3)$ & $4118(2)$ & $71(1)$ \\
\hline$C(31 X)$ & $7326(10)$ & $4290(8)$ & $6184(13)$ & $33(1)$ \\
\hline
\end{tabular}




\begin{tabular}{|c|c|c|c|c|}
\hline$C(30 X)$ & $7542(15)$ & $4827(13)$ & $5544(16)$ & $33(1)$ \\
\hline$C(29 X)$ & $6918(5)$ & $5490(4)$ & $5293(4)$ & $23(2)$ \\
\hline $\mathrm{C}(28 \mathrm{X})$ & $7080(7)$ & $6023(8)$ & $4654(7)$ & $32(3)$ \\
\hline$F(1 X)$ & $7765(5)$ & $6403(5)$ & $4823(6)$ & $68(2)$ \\
\hline$F(2 X)$ & $7137(6)$ & $5565(5)$ & $3921(4)$ & $60(1)$ \\
\hline$F(3 X)$ & $6469(5)$ & $6531(5)$ & $4354(3)$ & $52(2)$ \\
\hline $\mathrm{C}(31 \mathrm{Y})$ & $7330(20)$ & $4312(15)$ & $6030(30)$ & $33(5)$ \\
\hline $\mathrm{C}(30 \mathrm{Y})$ & $7708(17)$ & $4920(20)$ & $5590(30)$ & $29(4)$ \\
\hline C(29Y) & $7130(20)$ & $5621(14)$ & $5304(12)$ & $35(4)$ \\
\hline $\mathrm{C}(28 \mathrm{Y})$ & $7130(15)$ & $5951(13)$ & $4512(13)$ & $34(5)$ \\
\hline $\mathrm{F}(1 \mathrm{Y})$ & $6857(8)$ & $5469(9)$ & $3839(9)$ & $22(4)$ \\
\hline$F(2 Y)$ & $7897(12)$ & $6072(16)$ & $4366(18)$ & $53(6)$ \\
\hline $\mathrm{F}(3 \mathrm{Y})$ & 6901(17) & $6739(12)$ & $4435(14)$ & $56(6)$ \\
\hline$C(32)$ & $8656(1)$ & $2185(1)$ & $6272(2)$ & $35(1)$ \\
\hline$C(33)$ & $8020(2)$ & $1698(2)$ & $5702(2)$ & $58(1)$ \\
\hline$C(34)$ & $9144(2)$ & $2608(2)$ & $5751(2)$ & $57(1)$ \\
\hline$C(35)$ & $9174(2)$ & $1605(2)$ & $6875(2)$ & $49(1)$ \\
\hline$C(36)$ & $8965(1)$ & $3559(1)$ & $7592(2)$ & $28(1)$ \\
\hline $\mathrm{C}(37)$ & $9433(2)$ & $4099(2)$ & $7275(2)$ & $36(1)$ \\
\hline$C(38)$ & $10013(2)$ & $4538(2)$ & $7780(2)$ & $43(1)$ \\
\hline C(39) & $10148(1)$ & $4457(2)$ & $8625(2)$ & $41(1)$ \\
\hline $\mathrm{C}(40)$ & $9694(2)$ & $3942(2)$ & $8959(2)$ & $39(1)$ \\
\hline $\mathrm{C}(41)$ & $9109(1)$ & $3503(1)$ & $8450(2)$ & $33(1)$ \\
\hline $\mathrm{C}(42)$ & $7548(1)$ & $2438(1)$ & $7420(2)$ & $30(1)$ \\
\hline $\mathrm{C}(43)$ & $7804(2)$ & $1936(2)$ & $8100(2)$ & $42(1)$ \\
\hline $\mathrm{C}(44)$ & $7293(2)$ & $1562(2)$ & $8497(2)$ & $54(1)$ \\
\hline$C(45)$ & $6513(2)$ & $1679(2)$ & $8210(2)$ & $54(1)$ \\
\hline$C(46)$ & $6242(2)$ & $2158(2)$ & $7533(2)$ & $47(1)$ \\
\hline $\mathrm{C}(47)$ & $6751(1)$ & $2535(1)$ & $7140(2)$ & $35(1)$ \\
\hline$C(1 S)$ & $9619(4)$ & $6642(5)$ & $5773(5)$ & $154(3)$ \\
\hline $\mathrm{C}(2 \mathrm{~S})$ & $9946(5)$ & $5842(5)$ & $5718(5)$ & $162(3)$ \\
\hline$C(3 S)$ & $9819(4)$ & $5393(4)$ & $4998(5)$ & $136(2)$ \\
\hline
\end{tabular}




\begin{tabular}{|c|c|}
\hline $\mathrm{Cu}(1)-\mathrm{C}(1)$ & $1.887(2)$ \\
\hline $\mathrm{Cu}(1)-\mathrm{C}(29)$ & $1.969(3)$ \\
\hline $\mathrm{Si}(1)-\mathrm{O}(1)$ & $1.6342(17)$ \\
\hline $\mathrm{Si}(1)-\mathrm{C}(36)$ & $1.875(2)$ \\
\hline $\mathrm{Si}(1)-\mathrm{C}(42)$ & $1.877(2)$ \\
\hline $\mathrm{Si}(1)-\mathrm{C}(32)$ & $1.892(2)$ \\
\hline $\mathrm{O}(1)-\mathrm{C}(31)$ & $1.470(6)$ \\
\hline $\mathrm{N}(1)-\mathrm{C}(1)$ & $1.358(3)$ \\
\hline $\mathrm{N}(1)-\mathrm{C}(2)$ & $1.379(3)$ \\
\hline $\mathrm{N}(1)-\mathrm{C}(4)$ & $1.443(2)$ \\
\hline $\mathrm{N}(2)-\mathrm{C}(1)$ & $1.358(3)$ \\
\hline $\mathrm{N}(2)-\mathrm{C}(3)$ & $1.388(3)$ \\
\hline$N(2)-C(16)$ & $1.447(3)$ \\
\hline $\mathrm{C}(2)-\mathrm{C}(3)$ & $1.346(3)$ \\
\hline $\mathrm{C}(2)-\mathrm{H}(2)$ & 0.9500 \\
\hline $\mathrm{C}(3)-\mathrm{H}(3)$ & 0.9500 \\
\hline $\mathrm{C}(4)-\mathrm{C}(9)$ & $1.393(3)$ \\
\hline$C(4)-C(5)$ & $1.394(3)$ \\
\hline$C(5)-C(6)$ & $1.397(3)$ \\
\hline$C(5)-C(10)$ & $1.519(3)$ \\
\hline$C(6)-C(7)$ & $1.377(4)$ \\
\hline $\mathrm{C}(6)-\mathrm{H}(6)$ & 0.9500 \\
\hline$C(7)-C(8)$ & $1.378(4)$ \\
\hline $\mathrm{C}(7)-\mathrm{H}(7)$ & 0.9500 \\
\hline $\mathrm{C}(8)-\mathrm{C}(9)$ & $1.394(3)$ \\
\hline $\mathrm{C}(8)-\mathrm{H}(8)$ & 0.9500 \\
\hline$C(9)-C(13)$ & $1.520(3)$ \\
\hline $\mathrm{C}(10)-\mathrm{C}(11)$ & $1.512(4)$ \\
\hline $\mathrm{C}(10)-\mathrm{C}(12)$ & $1.521(4)$ \\
\hline $\mathrm{C}(10)-\mathrm{H}(10)$ & 1.0000 \\
\hline $\mathrm{C}(11)-\mathrm{H}(11 \mathrm{~A})$ & 0.9800 \\
\hline $\mathrm{C}(11)-\mathrm{H}(11 \mathrm{~B})$ & 0.9800 \\
\hline $\mathrm{C}(11)-\mathrm{H}(11 \mathrm{C})$ & 0.9800 \\
\hline $\mathrm{C}(12)-\mathrm{H}(12 \mathrm{~A})$ & 0.9800 \\
\hline
\end{tabular}




\begin{tabular}{|c|c|}
\hline $\mathrm{C}(12)-\mathrm{H}(12 \mathrm{~B})$ & 0.9800 \\
\hline $\mathrm{C}(12)-\mathrm{H}(12 \mathrm{C})$ & 0.9800 \\
\hline$C(13)-C(14)$ & $1.528(3)$ \\
\hline$C(13)-C(15)$ & $1.533(3)$ \\
\hline $\mathrm{C}(13)-\mathrm{H}(13)$ & 1.0000 \\
\hline $\mathrm{C}(14)-\mathrm{H}(14 \mathrm{~A})$ & 0.9800 \\
\hline $\mathrm{C}(14)-\mathrm{H}(14 \mathrm{~B})$ & 0.9800 \\
\hline $\mathrm{C}(14)-\mathrm{H}(14 \mathrm{C})$ & 0.9800 \\
\hline $\mathrm{C}(15)-\mathrm{H}(15 \mathrm{~A})$ & 0.9800 \\
\hline $\mathrm{C}(15)-\mathrm{H}(15 \mathrm{~B})$ & 0.9800 \\
\hline $\mathrm{C}(15)-\mathrm{H}(15 \mathrm{C})$ & 0.9800 \\
\hline$C(16)-C(17)$ & $1.396(3)$ \\
\hline$C(16)-C(21)$ & $1.397(3)$ \\
\hline$C(17)-C(18)$ & $1.397(3)$ \\
\hline$C(17)-C(22)$ & $1.514(4)$ \\
\hline $\mathrm{C}(18)-\mathrm{C}(19)$ & $1.380(4)$ \\
\hline $\mathrm{C}(18)-\mathrm{H}(18)$ & 0.9500 \\
\hline C(19)-C(20) & $1.372(4)$ \\
\hline $\mathrm{C}(19)-\mathrm{H}(19)$ & 0.9500 \\
\hline $\mathrm{C}(20)-\mathrm{C}(21)$ & $1.398(3)$ \\
\hline $\mathrm{C}(20)-\mathrm{H}(20)$ & 0.9500 \\
\hline$C(21)-C(25)$ & $1.516(4)$ \\
\hline$C(22)-C(23)$ & $1.528(4)$ \\
\hline$C(22)-C(24)$ & $1.534(3)$ \\
\hline $\mathrm{C}(22)-\mathrm{H}(22)$ & 1.0000 \\
\hline $\mathrm{C}(23)-\mathrm{H}(23 \mathrm{~A})$ & 0.9800 \\
\hline $\mathrm{C}(23)-\mathrm{H}(23 \mathrm{~B})$ & 0.9800 \\
\hline $\mathrm{C}(23)-\mathrm{H}(23 \mathrm{C})$ & 0.9800 \\
\hline $\mathrm{C}(24)-\mathrm{H}(24 \mathrm{~A})$ & 0.9800 \\
\hline $\mathrm{C}(24)-\mathrm{H}(24 \mathrm{~B})$ & 0.9800 \\
\hline $\mathrm{C}(24)-\mathrm{H}(24 \mathrm{C})$ & 0.9800 \\
\hline$C(25)-C(26)$ & $1.523(4)$ \\
\hline $\mathrm{C}(25)-\mathrm{C}(27)$ & $1.525(5)$ \\
\hline $\mathrm{C}(25)-\mathrm{H}(25)$ & 1.0000 \\
\hline $\mathrm{C}(26)-\mathrm{H}(26 \mathrm{~A})$ & 0.9800 \\
\hline
\end{tabular}




\begin{tabular}{|c|c|}
\hline $\mathrm{C}(26)-\mathrm{H}(26 \mathrm{~B})$ & 0.9800 \\
\hline $\mathrm{C}(26)-\mathrm{H}(26 \mathrm{C})$ & 0.9800 \\
\hline $\mathrm{C}(27)-\mathrm{H}(27 \mathrm{~A})$ & 0.9800 \\
\hline $\mathrm{C}(27)-\mathrm{H}(27 \mathrm{~B})$ & 0.9800 \\
\hline $\mathrm{C}(27)-\mathrm{H}(27 \mathrm{C})$ & 0.9800 \\
\hline $\mathrm{C}(31)-\mathrm{C}(30)$ & $1.502(8)$ \\
\hline $\mathrm{C}(31)-\mathrm{H}(31 \mathrm{~A})$ & 0.9900 \\
\hline $\mathrm{C}(31)-\mathrm{H}(31 \mathrm{~B})$ & 0.9900 \\
\hline $\mathrm{C}(30)-\mathrm{C}(29)$ & $1.539(10)$ \\
\hline $\mathrm{C}(30)-\mathrm{H}(30 \mathrm{~A})$ & 0.9900 \\
\hline $\mathrm{C}(30)-\mathrm{H}(30 \mathrm{~B})$ & 0.9900 \\
\hline$C(29)-C(28)$ & $1.429(7)$ \\
\hline C(29)-H(29) & 1.0000 \\
\hline$C(28)-F(1)$ & $1.309(8)$ \\
\hline$C(28)-F(3)$ & $1.335(9)$ \\
\hline$C(28)-F(2)$ & $1.474(9)$ \\
\hline $\mathrm{C}(32)-\mathrm{C}(33)$ & $1.527(4)$ \\
\hline$C(32)-C(35)$ & $1.531(4)$ \\
\hline $\mathrm{C}(32)-\mathrm{C}(34)$ & $1.533(4)$ \\
\hline $\mathrm{C}(33)-\mathrm{H}(33 \mathrm{~A})$ & 0.9800 \\
\hline $\mathrm{C}(33)-\mathrm{H}(33 \mathrm{~B})$ & 0.9800 \\
\hline $\mathrm{C}(33)-\mathrm{H}(33 \mathrm{C})$ & 0.9800 \\
\hline $\mathrm{C}(34)-\mathrm{H}(34 \mathrm{~A})$ & 0.9800 \\
\hline $\mathrm{C}(34)-\mathrm{H}(34 \mathrm{~B})$ & 0.9800 \\
\hline $\mathrm{C}(34)-\mathrm{H}(34 \mathrm{C})$ & 0.9800 \\
\hline $\mathrm{C}(35)-\mathrm{H}(35 \mathrm{~A})$ & 0.9800 \\
\hline $\mathrm{C}(35)-\mathrm{H}(35 \mathrm{~B})$ & 0.9800 \\
\hline $\mathrm{C}(35)-\mathrm{H}(35 \mathrm{C})$ & 0.9800 \\
\hline$C(36)-C(41)$ & $1.399(3)$ \\
\hline$C(36)-C(37)$ & $1.405(3)$ \\
\hline $\mathrm{C}(37)-\mathrm{C}(38)$ & $1.377(4)$ \\
\hline $\mathrm{C}(37)-\mathrm{H}(37)$ & 0.9500 \\
\hline $\mathrm{C}(38)-\mathrm{C}(39)$ & $1.380(4)$ \\
\hline $\mathrm{C}(38)-\mathrm{H}(38)$ & 0.9500 \\
\hline $\mathrm{C}(39)-\mathrm{C}(40)$ & $1.377(4)$ \\
\hline
\end{tabular}




\begin{tabular}{|c|c|}
\hline $\mathrm{C}(39)-\mathrm{H}(39)$ & 0.9500 \\
\hline$C(40)-C(41)$ & $1.386(4)$ \\
\hline $\mathrm{C}(40)-\mathrm{H}(40)$ & 0.9500 \\
\hline $\mathrm{C}(41)-\mathrm{H}(41)$ & 0.9500 \\
\hline$C(42)-C(43)$ & $1.391(4)$ \\
\hline$C(42)-C(47)$ & $1.401(3)$ \\
\hline$C(43)-C(44)$ & $1.389(4)$ \\
\hline $\mathrm{C}(43)-\mathrm{H}(43)$ & 0.9500 \\
\hline$C(44)-C(45)$ & $1.378(5)$ \\
\hline $\mathrm{C}(44)-\mathrm{H}(44)$ & 0.9500 \\
\hline$C(45)-C(46)$ & $1.369(5)$ \\
\hline $\mathrm{C}(45)-\mathrm{H}(45)$ & 0.9500 \\
\hline$C(46)-C(47)$ & $1.386(4)$ \\
\hline $\mathrm{C}(46)-\mathrm{H}(46)$ & 0.9500 \\
\hline $\mathrm{C}(47)-\mathrm{H}(47)$ & 0.9500 \\
\hline$C(1 S)-C(2 S)$ & $1.450(10)$ \\
\hline $\mathrm{C}(1 \mathrm{~S})-\mathrm{H}(1 \mathrm{~S} 1)$ & 0.9800 \\
\hline $\mathrm{C}(1 \mathrm{~S})-\mathrm{H}(1 \mathrm{~S} 2)$ & 0.9800 \\
\hline $\mathrm{C}(1 \mathrm{~S})-\mathrm{H}(1 \mathrm{~S} 3)$ & 0.9800 \\
\hline$C(2 S)-C(3 S)$ & $1.382(9)$ \\
\hline $\mathrm{C}(2 \mathrm{~S})-\mathrm{H}(2 \mathrm{~S} 1)$ & 0.9900 \\
\hline $\mathrm{C}(2 \mathrm{~S})-\mathrm{H}(2 \mathrm{~S} 2)$ & 0.9900 \\
\hline$C(3 S)-C(3 S) \# 1$ & $1.445(12)$ \\
\hline $\mathrm{C}(3 \mathrm{~S})-\mathrm{H}(3 \mathrm{~S} 1)$ & 0.9900 \\
\hline $\mathrm{C}(3 \mathrm{~S})-\mathrm{H}(3 \mathrm{~S} 2)$ & 0.9900 \\
\hline $\mathrm{C}(1)-\mathrm{Cu}(1)-\mathrm{C}(29)$ & $167.88(16)$ \\
\hline $\mathrm{O}(1)-\mathrm{Si}(1)-\mathrm{C}(36)$ & $110.22(10)$ \\
\hline $\mathrm{O}(1)-\mathrm{Si}(1)-\mathrm{C}(42)$ & $109.56(10)$ \\
\hline$C(36)-\operatorname{Si}(1)-C(42)$ & $110.88(10)$ \\
\hline $\mathrm{O}(1)-\mathrm{Si}(1)-\mathrm{C}(32)$ & $104.56(10)$ \\
\hline $\mathrm{C}(36)-\mathrm{Si}(1)-\mathrm{C}(32)$ & $111.39(10)$ \\
\hline $\mathrm{C}(42)-\mathrm{Si}(1)-\mathrm{C}(32)$ & $110.04(10)$ \\
\hline $\mathrm{C}(31)-\mathrm{O}(1)-\mathrm{Si}(1)$ & $125.9(3)$ \\
\hline $\mathrm{C}(1)-\mathrm{N}(1)-\mathrm{C}(2)$ & $112.00(16)$ \\
\hline $\mathrm{C}(1)-\mathrm{N}(1)-\mathrm{C}(4)$ & $122.80(16)$ \\
\hline
\end{tabular}




$\begin{array}{ll}\mathrm{C}(2)-\mathrm{N}(1)-\mathrm{C}(4) & 125.15(17) \\ \mathrm{C}(1)-\mathrm{N}(2)-\mathrm{C}(3) & 111.30(16) \\ \mathrm{C}(1)-\mathrm{N}(2)-\mathrm{C}(16) & 124.39(17) \\ \mathrm{C}(3)-\mathrm{N}(2)-\mathrm{C}(16) & 124.26(16) \\ \mathrm{N}(1)-\mathrm{C}(1)-\mathrm{N}(2) & 103.59(16) \\ \mathrm{N}(1)-\mathrm{C}(1)-\mathrm{Cu}(1) & 125.13(14) \\ \mathrm{N}(2)-\mathrm{C}(1)-\mathrm{Cu}(1) & 131.24(15) \\ \mathrm{C}(3)-\mathrm{C}(2)-\mathrm{N}(1) & 106.37(17) \\ \mathrm{C}(3)-\mathrm{C}(2)-\mathrm{H}(2) & 126.8 \\ \mathrm{~N}(1)-\mathrm{C}(2)-\mathrm{H}(2) & 126.8 \\ \mathrm{C}(2)-\mathrm{C}(3)-\mathrm{N}(2) & 106.72(17) \\ \mathrm{C}(2)-\mathrm{C}(3)-\mathrm{H}(3) & 126.6 \\ \mathrm{~N}(2)-\mathrm{C}(3)-\mathrm{H}(3) & 126.6 \\ \mathrm{C}(9)-\mathrm{C}(4)-\mathrm{C}(5) & 123.51(19) \\ \mathrm{C}(9)-\mathrm{C}(4)-\mathrm{N}(1) & 118.34(18) \\ \mathrm{C}(5)-\mathrm{C}(4)-\mathrm{N}(1) & 118.13(18) \\ \mathrm{C}(4)-\mathrm{C}(5)-\mathrm{C}(6) & 116.9(2) \\ \mathrm{C}(4)-\mathrm{C}(5)-\mathrm{C}(10) & 122.80(19) \\ \mathrm{C}(6)-\mathrm{C}(5)-\mathrm{C}(10) & 120.3(2) \\ \mathrm{C}(7)-\mathrm{C}(6)-\mathrm{C}(5) & 121.1(2) \\ \mathrm{C}(7)-\mathrm{C}(6)-\mathrm{H}(6) & 119.5 \\ \mathrm{C}(5)-\mathrm{C}(6)-\mathrm{H}(6) & 119.5 \\ \mathrm{C}(6)-\mathrm{C}(7)-\mathrm{C}(8) & 120.4(2) \\ \mathrm{C}(6)-\mathrm{C}(7)-\mathrm{H}(7) & 119.8 \\ \mathrm{C}(8)-\mathrm{C}(7)-\mathrm{H}(7) & 119.8 \\ \mathrm{C}(7)-\mathrm{C}(8)-\mathrm{C}(9) & 121.1(2) \\ \mathrm{C}(7)-\mathrm{C}(8)-\mathrm{H}(8) & 119.5 \\ \mathrm{C}(9)-\mathrm{C}(8)-\mathrm{H}(8) & 119.5 \\ \mathrm{C}(4)-\mathrm{C}(9)-\mathrm{C}(8) & 117.0(2) \\ \mathrm{C}(4)-\mathrm{C}(9)-\mathrm{C}(13) & 123.02(19) \\ \mathrm{C}(8)-\mathrm{C}(9)-\mathrm{C}(13) & 120.0(2) \\ \mathrm{C}(11)-\mathrm{C}(10)-\mathrm{C}(5) & 111.4(2) \\ \mathrm{C}(5)-\mathrm{C}(10)-\mathrm{C}(12) & 110.0(2) \\ \mathrm{C}(11)-\mathrm{C}(10)-\mathrm{H}(10) & \end{array}$




\begin{tabular}{|c|c|}
\hline $\mathrm{C}(5)-\mathrm{C}(10)-\mathrm{H}(10)$ & 107.8 \\
\hline $\mathrm{C}(12)-\mathrm{C}(10)-\mathrm{H}(10)$ & 107.8 \\
\hline $\mathrm{C}(10)-\mathrm{C}(11)-\mathrm{H}(11 \mathrm{~A})$ & 109.5 \\
\hline $\mathrm{C}(10)-\mathrm{C}(11)-\mathrm{H}(11 \mathrm{~B})$ & 109.5 \\
\hline $\mathrm{H}(11 \mathrm{~A})-\mathrm{C}(11)-\mathrm{H}(11 \mathrm{~B})$ & 109.5 \\
\hline $\mathrm{C}(10)-\mathrm{C}(11)-\mathrm{H}(11 \mathrm{C})$ & 109.5 \\
\hline $\mathrm{H}(11 \mathrm{~A})-\mathrm{C}(11)-\mathrm{H}(11 \mathrm{C})$ & 109.5 \\
\hline $\mathrm{H}(11 \mathrm{~B})-\mathrm{C}(11)-\mathrm{H}(11 \mathrm{C})$ & 109.5 \\
\hline $\mathrm{C}(10)-\mathrm{C}(12)-\mathrm{H}(12 \mathrm{~A})$ & 109.5 \\
\hline $\mathrm{C}(10)-\mathrm{C}(12)-\mathrm{H}(12 \mathrm{~B})$ & 109.5 \\
\hline $\mathrm{H}(12 \mathrm{~A})-\mathrm{C}(12)-\mathrm{H}(12 \mathrm{~B})$ & 109.5 \\
\hline $\mathrm{C}(10)-\mathrm{C}(12)-\mathrm{H}(12 \mathrm{C})$ & 109.5 \\
\hline $\mathrm{H}(12 \mathrm{~A})-\mathrm{C}(12)-\mathrm{H}(12 \mathrm{C})$ & 109.5 \\
\hline $\mathrm{H}(12 \mathrm{~B})-\mathrm{C}(12)-\mathrm{H}(12 \mathrm{C})$ & 109.5 \\
\hline$C(9)-C(13)-C(14)$ & $111.60(19)$ \\
\hline $\mathrm{C}(9)-\mathrm{C}(13)-\mathrm{C}(15)$ & $110.4(2)$ \\
\hline$C(14)-C(13)-C(15)$ & $111.3(2)$ \\
\hline $\mathrm{C}(9)-\mathrm{C}(13)-\mathrm{H}(13)$ & 107.8 \\
\hline $\mathrm{C}(14)-\mathrm{C}(13)-\mathrm{H}(13)$ & 107.8 \\
\hline $\mathrm{C}(15)-\mathrm{C}(13)-\mathrm{H}(13)$ & 107.8 \\
\hline $\mathrm{C}(13)-\mathrm{C}(14)-\mathrm{H}(14 \mathrm{~A})$ & 109.5 \\
\hline $\mathrm{C}(13)-\mathrm{C}(14)-\mathrm{H}(14 \mathrm{~B})$ & 109.5 \\
\hline $\mathrm{H}(14 \mathrm{~A})-\mathrm{C}(14)-\mathrm{H}(14 \mathrm{~B})$ & 109.5 \\
\hline $\mathrm{C}(13)-\mathrm{C}(14)-\mathrm{H}(14 \mathrm{C})$ & 109.5 \\
\hline $\mathrm{H}(14 \mathrm{~A})-\mathrm{C}(14)-\mathrm{H}(14 \mathrm{C})$ & 109.5 \\
\hline $\mathrm{H}(14 \mathrm{~B})-\mathrm{C}(14)-\mathrm{H}(14 \mathrm{C})$ & 109.5 \\
\hline $\mathrm{C}(13)-\mathrm{C}(15)-\mathrm{H}(15 \mathrm{~A})$ & 109.5 \\
\hline $\mathrm{C}(13)-\mathrm{C}(15)-\mathrm{H}(15 \mathrm{~B})$ & 109.5 \\
\hline $\mathrm{H}(15 \mathrm{~A})-\mathrm{C}(15)-\mathrm{H}(15 \mathrm{~B})$ & 109.5 \\
\hline $\mathrm{C}(13)-\mathrm{C}(15)-\mathrm{H}(15 \mathrm{C})$ & 109.5 \\
\hline $\mathrm{H}(15 \mathrm{~A})-\mathrm{C}(15)-\mathrm{H}(15 \mathrm{C})$ & 109.5 \\
\hline $\mathrm{H}(15 \mathrm{~B})-\mathrm{C}(15)-\mathrm{H}(15 \mathrm{C})$ & 109.5 \\
\hline$C(17)-C(16)-C(21)$ & $123.3(2)$ \\
\hline $\mathrm{C}(17)-\mathrm{C}(16)-\mathrm{N}(2)$ & $118.58(19)$ \\
\hline $\mathrm{C}(21)-\mathrm{C}(16)-\mathrm{N}(2)$ & $118.08(19)$ \\
\hline
\end{tabular}




$\begin{array}{ll}\mathrm{C}(16)-\mathrm{C}(17)-\mathrm{C}(18) & 117.1(2) \\ \mathrm{C}(16)-\mathrm{C}(17)-\mathrm{C}(22) & 122.8(2) \\ \mathrm{C}(18)-\mathrm{C}(17)-\mathrm{C}(22) & 120.0(2) \\ \mathrm{C}(19)-\mathrm{C}(18)-\mathrm{C}(17) & 120.8(2) \\ \mathrm{C}(19)-\mathrm{C}(18)-\mathrm{H}(18) & 119.6 \\ \mathrm{C}(17)-\mathrm{C}(18)-\mathrm{H}(18) & 119.6 \\ \mathrm{C}(20)-\mathrm{C}(19)-\mathrm{C}(18) & 120.7(2) \\ \mathrm{C}(20)-\mathrm{C}(19)-\mathrm{H}(19) & 119.7 \\ \mathrm{C}(18)-\mathrm{C}(19)-\mathrm{H}(19) & 119.7 \\ \mathrm{C}(19)-\mathrm{C}(20)-\mathrm{C}(21) & 121.3(3) \\ \mathrm{C}(19)-\mathrm{C}(20)-\mathrm{H}(20) & 119.4 \\ \mathrm{C}(21)-\mathrm{C}(20)-\mathrm{H}(20) & 119.4 \\ \mathrm{C}(16)-\mathrm{C}(21)-\mathrm{C}(20) & 116.8(2) \\ \mathrm{C}(16)-\mathrm{C}(21)-\mathrm{C}(25) & 122.1(2) \\ \mathrm{C}(20)-\mathrm{C}(21)-\mathrm{C}(25) & 121.0(2) \\ \mathrm{C}(17)-\mathrm{C}(22)-\mathrm{C}(23) & 110.9(2) \\ \mathrm{C}(17)-\mathrm{C}(22)-\mathrm{C}(24) & 113.1(2) \\ \mathrm{C}(23)-\mathrm{C}(22)-\mathrm{C}(24) & 109.2(2) \\ \mathrm{C}(17)-\mathrm{C}(22)-\mathrm{H}(22) & 107.8 \\ \mathrm{C}(23)-\mathrm{C}(22)-\mathrm{H}(22) & 107.8 \\ \mathrm{C}(24)-\mathrm{C}(22)-\mathrm{H}(22) & 107.8 \\ \mathrm{C}(22)-\mathrm{C}(23)-\mathrm{H}(23 \mathrm{~A}) & 109.5 \\ \mathrm{C}(22)-\mathrm{C}(23)-\mathrm{H}(23 \mathrm{~B}) & 109.5 \\ \mathrm{H}(23 \mathrm{~A})-\mathrm{C}(23)-\mathrm{H}(23 \mathrm{~B}) & 109.5 \\ \mathrm{C}(22)-\mathrm{C}(23)-\mathrm{H}(23 \mathrm{C}) & 109.5 \\ \mathrm{H}(23 \mathrm{~A})-\mathrm{C}(23)-\mathrm{H}(23 \mathrm{C}) & 109.5 \\ \mathrm{H}(23 \mathrm{~B})-\mathrm{C}(23)-\mathrm{H}(23 \mathrm{C}) & 109.5 \\ \mathrm{C}(22)-\mathrm{C}(24)-\mathrm{H}(24 \mathrm{~A}) & 109.5 \\ \mathrm{C}(22)-\mathrm{C}(24)-\mathrm{H}(24 \mathrm{~B}) & 109.5 \\ \mathrm{H}(24 \mathrm{~A})-\mathrm{C}(24)-\mathrm{H}(24 \mathrm{~B}) & 109.5 \\ \mathrm{C}(22)-\mathrm{C}(24)-\mathrm{H}(24 \mathrm{C}) & 109.5 \\ \mathrm{H}(24 \mathrm{~A})-\mathrm{C}(24)-\mathrm{H}(24 \mathrm{C}) & 109.5 \\ & 109.5 \\ \mathrm{H}(25)-\mathrm{H}(24 \mathrm{C}) & 113.2(2) \\ & 110.6(2)\end{array}$




$$
\begin{array}{ll}
\mathrm{C}(26)-\mathrm{C}(25)-\mathrm{C}(27) & 110.0(2) \\
\mathrm{C}(21)-\mathrm{C}(25)-\mathrm{H}(25) & 107.6 \\
\mathrm{C}(26)-\mathrm{C}(25)-\mathrm{H}(25) & 107.6 \\
\mathrm{C}(27)-\mathrm{C}(25)-\mathrm{H}(25) & 107.6 \\
\mathrm{C}(25)-\mathrm{C}(26)-\mathrm{H}(26 \mathrm{~A}) & 109.5 \\
\mathrm{C}(25)-\mathrm{C}(26)-\mathrm{H}(26 \mathrm{~B}) & 109.5 \\
\mathrm{H}(26 \mathrm{~A})-\mathrm{C}(26)-\mathrm{H}(26 \mathrm{~B}) & 109.5 \\
\mathrm{C}(25)-\mathrm{C}(26)-\mathrm{H}(26 \mathrm{C}) & 109.5 \\
\mathrm{H}(26 \mathrm{~A})-\mathrm{C}(26)-\mathrm{H}(26 \mathrm{C}) & 109.5 \\
\mathrm{H}(26 \mathrm{~B})-\mathrm{C}(26)-\mathrm{H}(26 \mathrm{C}) & 109.5 \\
\mathrm{C}(25)-\mathrm{C}(27)-\mathrm{H}(27 \mathrm{~A}) & 109.5 \\
\mathrm{C}(25)-\mathrm{C}(27)-\mathrm{H}(27 \mathrm{~B}) & 109.5 \\
\mathrm{H}(27 \mathrm{~A})-\mathrm{C}(27)-\mathrm{H}(27 \mathrm{~B}) & 109.5 \\
\mathrm{C}(25)-\mathrm{C}(27)-\mathrm{H}(27 \mathrm{C}) & 109.5 \\
\mathrm{H}(27 \mathrm{~A})-\mathrm{C}(27)-\mathrm{H}(27 \mathrm{C}) & 109.5 \\
\mathrm{H}(27 \mathrm{~B})-\mathrm{C}(27)-\mathrm{H}(27 \mathrm{C}) & 109.5 \\
\mathrm{O}(1)-\mathrm{C}(31)-\mathrm{C}(30) & 108.7(6) \\
\mathrm{O}(1)-\mathrm{C}(31)-\mathrm{H}(31 \mathrm{~A}) & 109.9 \\
\mathrm{C}(30)-\mathrm{C}(31)-\mathrm{H}(31 \mathrm{~A}) & 109.9 \\
\mathrm{O}(1)-\mathrm{C}(31)-\mathrm{H}(31 \mathrm{~B}) & 109.9 \\
\mathrm{C}(30)-\mathrm{C}(31)-\mathrm{H}(31 \mathrm{~B}) & 109.9 \\
\mathrm{H}(31 \mathrm{~A})-\mathrm{C}(31)-\mathrm{H}(31 \mathrm{~B}) & 108.3 \\
\mathrm{C}(31)-\mathrm{C}(30)-\mathrm{C}(29) & 114.4(8) \\
\mathrm{C}(31)-\mathrm{C}(30)-\mathrm{H}(30 \mathrm{~A}) & 108.7 \\
\mathrm{C}(29)-\mathrm{C}(30)-\mathrm{H}(30 \mathrm{~A}) & 108.7 \\
\mathrm{C}(31)-\mathrm{C}(30)-\mathrm{H}(30 \mathrm{~B}) & 108.7 \\
\mathrm{C}(29)-\mathrm{C}(30)-\mathrm{H}(30 \mathrm{~B}) & 108.7 \\
\mathrm{H}(30 \mathrm{~A})-\mathrm{C}(30)-\mathrm{H}(30 \mathrm{~B}) & 107.6 \\
\mathrm{C}(28)-\mathrm{C}(29)-\mathrm{C}(30) & 113.6(5) \\
\mathrm{C}(28)-\mathrm{C}(29)-\mathrm{Cu}(1) & 112.7(4) \\
\mathrm{C}(30)-\mathrm{C}(29)-\mathrm{Cu}(1) & 116.2(4) \\
\mathrm{C}(29)-\mathrm{H}(29) & 104.2 \\
\mathrm{C}(29) & 104.2 \\
\mathrm{C}(29) & 104.2 \\
\mathrm{C}(309.4(6) \\
\end{array}
$$




\begin{tabular}{|c|c|}
\hline $\mathrm{F}(1)-\mathrm{C}(28)-\mathrm{C}(29)$ & $118.5(6)$ \\
\hline $\mathrm{F}(3)-\mathrm{C}(28)-\mathrm{C}(29)$ & $119.7(6)$ \\
\hline $\mathrm{F}(1)-\mathrm{C}(28)-\mathrm{F}(2)$ & $99.0(5)$ \\
\hline $\mathrm{F}(3)-\mathrm{C}(28)-\mathrm{F}(2)$ & $98.5(6)$ \\
\hline $\mathrm{C}(29)-\mathrm{C}(28)-\mathrm{F}(2)$ & $107.4(6)$ \\
\hline$C(33)-C(32)-C(35)$ & $109.3(2)$ \\
\hline $\mathrm{C}(33)-\mathrm{C}(32)-\mathrm{C}(34)$ & $108.9(3)$ \\
\hline$C(35)-C(32)-C(34)$ & $108.6(2)$ \\
\hline$C(33)-C(32)-\operatorname{Si}(1)$ & $109.37(17)$ \\
\hline$C(35)-C(32)-\operatorname{Si}(1)$ & 109.94(18) \\
\hline $\mathrm{C}(34)-\mathrm{C}(32)-\mathrm{Si}(1)$ & $110.75(17)$ \\
\hline $\mathrm{C}(32)-\mathrm{C}(33)-\mathrm{H}(33 \mathrm{~A})$ & 109.5 \\
\hline $\mathrm{C}(32)-\mathrm{C}(33)-\mathrm{H}(33 \mathrm{~B})$ & 109.5 \\
\hline $\mathrm{H}(33 \mathrm{~A})-\mathrm{C}(33)-\mathrm{H}(33 \mathrm{~B})$ & 109.5 \\
\hline $\mathrm{C}(32)-\mathrm{C}(33)-\mathrm{H}(33 \mathrm{C})$ & 109.5 \\
\hline $\mathrm{H}(33 \mathrm{~A})-\mathrm{C}(33)-\mathrm{H}(33 \mathrm{C})$ & 109.5 \\
\hline $\mathrm{H}(33 \mathrm{~B})-\mathrm{C}(33)-\mathrm{H}(33 \mathrm{C})$ & 109.5 \\
\hline $\mathrm{C}(32)-\mathrm{C}(34)-\mathrm{H}(34 \mathrm{~A})$ & 109.5 \\
\hline $\mathrm{C}(32)-\mathrm{C}(34)-\mathrm{H}(34 \mathrm{~B})$ & 109.5 \\
\hline $\mathrm{H}(34 \mathrm{~A})-\mathrm{C}(34)-\mathrm{H}(34 \mathrm{~B})$ & 109.5 \\
\hline $\mathrm{C}(32)-\mathrm{C}(34)-\mathrm{H}(34 \mathrm{C})$ & 109.5 \\
\hline $\mathrm{H}(34 \mathrm{~A})-\mathrm{C}(34)-\mathrm{H}(34 \mathrm{C})$ & 109.5 \\
\hline $\mathrm{H}(34 \mathrm{~B})-\mathrm{C}(34)-\mathrm{H}(34 \mathrm{C})$ & 109.5 \\
\hline $\mathrm{C}(32)-\mathrm{C}(35)-\mathrm{H}(35 \mathrm{~A})$ & 109.5 \\
\hline $\mathrm{C}(32)-\mathrm{C}(35)-\mathrm{H}(35 \mathrm{~B})$ & 109.5 \\
\hline $\mathrm{H}(35 \mathrm{~A})-\mathrm{C}(35)-\mathrm{H}(35 \mathrm{~B})$ & 109.5 \\
\hline $\mathrm{C}(32)-\mathrm{C}(35)-\mathrm{H}(35 \mathrm{C})$ & 109.5 \\
\hline $\mathrm{H}(35 \mathrm{~A})-\mathrm{C}(35)-\mathrm{H}(35 \mathrm{C})$ & 109.5 \\
\hline $\mathrm{H}(35 \mathrm{~B})-\mathrm{C}(35)-\mathrm{H}(35 \mathrm{C})$ & 109.5 \\
\hline$C(41)-C(36)-C(37)$ & $116.4(2)$ \\
\hline $\mathrm{C}(41)-\mathrm{C}(36)-\mathrm{Si}(1)$ & $124.38(17)$ \\
\hline $\mathrm{C}(37)-\mathrm{C}(36)-\mathrm{Si}(1)$ & $119.23(18)$ \\
\hline $\mathrm{C}(38)-\mathrm{C}(37)-\mathrm{C}(36)$ & $122.0(2)$ \\
\hline $\mathrm{C}(38)-\mathrm{C}(37)-\mathrm{H}(37)$ & 119.0 \\
\hline $\mathrm{C}(36)-\mathrm{C}(37)-\mathrm{H}(37)$ & 119.0 \\
\hline
\end{tabular}




\begin{tabular}{|c|c|}
\hline$C(37)-C(38)-C(39)$ & $120.1(2)$ \\
\hline $\mathrm{C}(37)-\mathrm{C}(38)-\mathrm{H}(38)$ & 120.0 \\
\hline $\mathrm{C}(39)-\mathrm{C}(38)-\mathrm{H}(38)$ & 120.0 \\
\hline $\mathrm{C}(40)-\mathrm{C}(39)-\mathrm{C}(38)$ & $119.6(2)$ \\
\hline $\mathrm{C}(40)-\mathrm{C}(39)-\mathrm{H}(39)$ & 120.2 \\
\hline $\mathrm{C}(38)-\mathrm{C}(39)-\mathrm{H}(39)$ & 120.2 \\
\hline $\mathrm{C}(39)-\mathrm{C}(40)-\mathrm{C}(41)$ & $120.3(2)$ \\
\hline $\mathrm{C}(39)-\mathrm{C}(40)-\mathrm{H}(40)$ & 119.9 \\
\hline $\mathrm{C}(41)-\mathrm{C}(40)-\mathrm{H}(40)$ & 119.9 \\
\hline$C(40)-C(41)-C(36)$ & $121.6(2)$ \\
\hline $\mathrm{C}(40)-\mathrm{C}(41)-\mathrm{H}(41)$ & 119.2 \\
\hline $\mathrm{C}(36)-\mathrm{C}(41)-\mathrm{H}(41)$ & 119.2 \\
\hline$C(43)-C(42)-C(47)$ & $117.0(2)$ \\
\hline $\mathrm{C}(43)-\mathrm{C}(42)-\mathrm{Si}(1)$ & $123.51(18)$ \\
\hline $\mathrm{C}(47)-\mathrm{C}(42)-\mathrm{Si}(1)$ & $119.49(19)$ \\
\hline$C(44)-C(43)-C(42)$ & $121.6(3)$ \\
\hline $\mathrm{C}(44)-\mathrm{C}(43)-\mathrm{H}(43)$ & 119.2 \\
\hline $\mathrm{C}(42)-\mathrm{C}(43)-\mathrm{H}(43)$ & 119.2 \\
\hline$C(45)-C(44)-C(43)$ & $119.8(3)$ \\
\hline $\mathrm{C}(45)-\mathrm{C}(44)-\mathrm{H}(44)$ & 120.1 \\
\hline $\mathrm{C}(43)-\mathrm{C}(44)-\mathrm{H}(44)$ & 120.1 \\
\hline$C(46)-C(45)-C(44)$ & 120.1(3) \\
\hline $\mathrm{C}(46)-\mathrm{C}(45)-\mathrm{H}(45)$ & 120.0 \\
\hline $\mathrm{C}(44)-\mathrm{C}(45)-\mathrm{H}(45)$ & 120.0 \\
\hline$C(45)-C(46)-C(47)$ & $120.1(3)$ \\
\hline $\mathrm{C}(45)-\mathrm{C}(46)-\mathrm{H}(46)$ & 119.9 \\
\hline $\mathrm{C}(47)-\mathrm{C}(46)-\mathrm{H}(46)$ & 119.9 \\
\hline$C(46)-C(47)-C(42)$ & $121.4(3)$ \\
\hline $\mathrm{C}(46)-\mathrm{C}(47)-\mathrm{H}(47)$ & 119.3 \\
\hline $\mathrm{C}(42)-\mathrm{C}(47)-\mathrm{H}(47)$ & 119.3 \\
\hline $\mathrm{C}(2 \mathrm{~S})-\mathrm{C}(1 \mathrm{~S})-\mathrm{H}(1 \mathrm{~S} 1)$ & 109.5 \\
\hline $\mathrm{C}(2 \mathrm{~S})-\mathrm{C}(1 \mathrm{~S})-\mathrm{H}(1 \mathrm{~S} 2)$ & 109.5 \\
\hline $\mathrm{H}(1 \mathrm{~S} 1)-\mathrm{C}(1 \mathrm{~S})-\mathrm{H}(1 \mathrm{~S} 2)$ & 109.5 \\
\hline $\mathrm{C}(2 \mathrm{~S})-\mathrm{C}(1 \mathrm{~S})-\mathrm{H}(1 \mathrm{~S} 3)$ & 109.5 \\
\hline H(1S1)-C(1S)-H(1S3) & 109.5 \\
\hline
\end{tabular}




$\begin{array}{ll}\text { H(1S2)-C(1S)-H(1S3) } & 109.5 \\ \text { C(3S)-C(2S)-C(1S) } & 123.5(8) \\ \text { C(3S)-C(2S)-H(2S1) } & 106.4 \\ \text { C(1S)-C(2S)-H(2S1) } & 106.4 \\ \text { C(3S)-C(2S)-H(2S2) } & 106.4 \\ \text { C(1S)-C(2S)-H(2S2) } & 106.4 \\ \text { H(2S1)-C(2S)-H(2S2) } & 106.5 \\ \text { C(2S)-C(3S)-C(3S)\#1 } & 119.4(9) \\ \text { C(2S)-C(3S)-H(3S1) } & 107.5 \\ \text { C(3S)\#1-C(3S)-H(3S1) } & 107.5 \\ \text { C(2S)-C(3S)-H(3S2) } & 107.5 \\ \text { C(3S)\#1-C(3S)-H(3S2) } & 107.5 \\ \text { H(3S1)-C(3S)-H(3S2) } & 107.0\end{array}$

Table S29. Anisotropic displacement parameters $\left(\AA^{2} \times 10^{3}\right)$ for

$\mathrm{C}_{47} \mathrm{H}_{60} \mathrm{CuF}_{3} \mathrm{~N}_{2} \mathrm{OSi}\left(\mathrm{C}_{6} \mathrm{H}_{14}\right)_{0.5}$. The anisotropic displacement factor exponent takes the form: $-2 p^{2}\left[h^{2} a^{* 2} U^{11}+\ldots+2 h k a^{*} b^{*} U^{12}\right]$

\begin{tabular}{lllllll}
\hline & $\mathrm{U}^{11}$ & $\mathrm{U}^{22}$ & $\mathrm{U}^{33}$ & $\mathrm{U}^{23}$ & $\mathrm{U}^{13}$ & $\mathrm{U}^{12}$ \\
\hline $\mathrm{Cu}(1)$ & $50(1)$ & $25(1)$ & $21(1)$ & $3(1)$ & $10(1)$ & $18(1)$ \\
$\mathrm{Si}(1)$ & $25(1)$ & $19(1)$ & $33(1)$ & $0(1)$ & $5(1)$ & $4(1)$ \\
$\mathrm{O}(1)$ & $42(1)$ & $27(1)$ & $38(1)$ & $3(1)$ & $1(1)$ & $8(1)$ \\
$\mathrm{N}(1)$ & $19(1)$ & $15(1)$ & $22(1)$ & $-1(1)$ & $2(1)$ & $0(1)$ \\
$\mathrm{N}(2)$ & $24(1)$ & $15(1)$ & $20(1)$ & $0(1)$ & $3(1)$ & $1(1)$ \\
$\mathrm{C}(1)$ & $19(1)$ & $17(1)$ & $21(1)$ & $0(1)$ & $1(1)$ & $0(1)$ \\
$\mathrm{C}(2)$ & $26(1)$ & $19(1)$ & $22(1)$ & $-3(1)$ & $7(1)$ & $1(1)$ \\
$\mathrm{C}(3)$ & $28(1)$ & $18(1)$ & $23(1)$ & $-4(1)$ & $6(1)$ & $2(1)$ \\
$\mathrm{C}(4)$ & $28(1)$ & $16(1)$ & $19(1)$ & $1(1)$ & $6(1)$ & $2(1)$ \\
$\mathrm{C}(5)$ & $28(1)$ & $23(1)$ & $25(1)$ & $-1(1)$ & $3(1)$ & $4(1)$ \\
$\mathrm{C}(6)$ & $36(1)$ & $30(1)$ & $31(1)$ & $4(1)$ & $3(1)$ & $12(1)$ \\
$\mathrm{C}(7)$ & $53(2)$ & $20(1)$ & $31(1)$ & $5(1)$ & $9(1)$ & $10(1)$ \\
$\mathrm{C}(8)$ & $45(1)$ & $17(1)$ & $30(1)$ & $-1(1)$ & $9(1)$ & $-2(1)$ \\
$\mathrm{C}(9)$ & $34(1)$ & $18(1)$ & $22(1)$ & $-1(1)$ & $7(1)$ & $0(1)$
\end{tabular}




\begin{tabular}{|c|c|c|c|c|c|c|}
\hline$C(10)$ & $25(1)$ & $30(1)$ & $44(1)$ & $3(1)$ & $-3(1)$ & $1(1)$ \\
\hline $\mathrm{C}(11)$ & $85(3)$ & $67(2)$ & $58(2)$ & $-1(2)$ & $-24(2)$ & $-32(2)$ \\
\hline$C(12)$ & $43(2)$ & $50(2)$ & $107(3)$ & $8(2)$ & $33(2)$ & $1(1)$ \\
\hline$C(13)$ & $30(1)$ & $22(1)$ & $35(1)$ & $-2(1)$ & $3(1)$ & $-6(1)$ \\
\hline$C(14)$ & $36(1)$ & $35(1)$ & $45(1)$ & $-8(1)$ & $10(1)$ & $-12(1)$ \\
\hline$C(15)$ & $43(2)$ & $54(2)$ & $36(1)$ & $-9(1)$ & $1(1)$ & $-9(1)$ \\
\hline$C(16)$ & $37(1)$ & $16(1)$ & $21(1)$ & $1(1)$ & $8(1)$ & $6(1)$ \\
\hline$C(17)$ & $37(1)$ & $26(1)$ & $24(1)$ & $0(1)$ & $6(1)$ & $12(1)$ \\
\hline$C(18)$ & $57(2)$ & $36(1)$ & $24(1)$ & $5(1)$ & $6(1)$ & $16(1)$ \\
\hline$C(19)$ & $81(2)$ & $32(1)$ & $29(1)$ & $9(1)$ & $18(1)$ & $7(1)$ \\
\hline$C(20)$ & $72(2)$ & $31(1)$ & $35(1)$ & $3(1)$ & $19(1)$ & $-12(1)$ \\
\hline $\mathrm{C}(21)$ & $50(1)$ & $25(1)$ & $26(1)$ & $0(1)$ & $12(1)$ & $-5(1)$ \\
\hline $\mathrm{C}(22)$ & $32(1)$ & $46(1)$ & $29(1)$ & $5(1)$ & $-2(1)$ & $6(1)$ \\
\hline$C(23)$ & $42(2)$ & $38(2)$ & $64(2)$ & $-7(1)$ & $-7(1)$ & $4(1)$ \\
\hline$C(24)$ & $36(2)$ & $76(2)$ & $42(2)$ & $-5(1)$ & $-2(1)$ & $18(1)$ \\
\hline$C(25)$ & $50(2)$ & $45(2)$ & $32(1)$ & $4(1)$ & $8(1)$ & $-23(1)$ \\
\hline$C(26)$ & $66(2)$ & $55(2)$ & $50(2)$ & $-14(1)$ & $21(2)$ & $-28(2)$ \\
\hline $\mathrm{C}(27)$ & $51(2)$ & $46(2)$ & $62(2)$ & $8(1)$ & $-7(1)$ & $-13(1)$ \\
\hline$C(31)$ & $34(3)$ & $33(2)$ & $31(2)$ & $6(2)$ & $9(2)$ & $21(2)$ \\
\hline$C(30)$ & $45(3)$ & $28(2)$ & $27(3)$ & $-1(2)$ & $11(2)$ & $13(2)$ \\
\hline C(29) & $39(2)$ & $24(2)$ & $29(2)$ & $2(1)$ & $14(2)$ & $3(2)$ \\
\hline$C(28)$ & $64(5)$ & $47(4)$ & $33(3)$ & $13(3)$ & $24(3)$ & $14(4)$ \\
\hline $\mathrm{F}(1)$ & $66(2)$ & $40(2)$ & $45(2)$ & $21(1)$ & $9(1)$ & $-8(1)$ \\
\hline $\mathrm{F}(2)$ & $75(2)$ & $61(2)$ & $37(1)$ & $10(1)$ & $-4(1)$ & $-9(2)$ \\
\hline $\mathrm{F}(3)$ & $114(4)$ & $81(3)$ & $29(2)$ & $4(2)$ & $39(2)$ & $19(3)$ \\
\hline$C(31 X)$ & $34(3)$ & $33(2)$ & $31(2)$ & $6(2)$ & $9(2)$ & $21(2)$ \\
\hline$C(30 X)$ & $45(3)$ & $28(2)$ & $27(3)$ & $-1(2)$ & $11(2)$ & $13(2)$ \\
\hline$C(29 X)$ & $36(4)$ & $16(3)$ & $18(3)$ & $0(2)$ & $9(3)$ & $6(3)$ \\
\hline$C(28 X)$ & $37(6)$ & $36(5)$ & $22(4)$ & $-2(4)$ & $10(4)$ & 19(4) \\
\hline$F(1 X)$ & $96(6)$ & $42(4)$ & $87(5)$ & $23(4)$ & $67(5)$ & $0(4)$ \\
\hline$F(2 X)$ & $75(2)$ & $61(2)$ & $37(1)$ & $10(1)$ & $-4(1)$ & $-9(2)$ \\
\hline$F(3 X)$ & $89(6)$ & $33(3)$ & $32(3)$ & $13(3)$ & $10(3)$ & $29(4)$ \\
\hline$C(32)$ & $34(1)$ & $26(1)$ & $46(1)$ & $-7(1)$ & $10(1)$ & $4(1)$ \\
\hline C(33) & $53(2)$ & $52(2)$ & $65(2)$ & $-31(2)$ & $4(2)$ & $5(1)$ \\
\hline$C(34)$ & $75(2)$ & $43(2)$ & $68(2)$ & $-9(1)$ & $43(2)$ & $5(2)$ \\
\hline
\end{tabular}




$\begin{array}{lllllll}\mathrm{C}(35) & 43(2) & 32(1) & 72(2) & -5(1) & 12(1) & 16(1) \\ \mathrm{C}(36) & 24(1) & 20(1) & 39(1) & 0(1) & 7(1) & 4(1) \\ \mathrm{C}(37) & 40(1) & 29(1) & 41(1) & 1(1) & 10(1) & -4(1) \\ \mathrm{C}(38) & 38(1) & 32(1) & 58(2) & 3(1) & 11(1) & -9(1) \\ \mathrm{C}(39) & 31(1) & 32(1) & 54(2) & 2(1) & -4(1) & -3(1) \\ \mathrm{C}(40) & 36(1) & 37(1) & 39(1) & 6(1) & -2(1) & -1(1) \\ \mathrm{C}(41) & 28(1) & 30(1) & 40(1) & 5(1) & 5(1) & -2(1) \\ \mathrm{C}(42) & 28(1) & 22(1) & 38(1) & -5(1) & 6(1) & 0(1) \\ \mathrm{C}(43) & 36(1) & 35(1) & 53(2) & 8(1) & 5(1) & -4(1) \\ \mathrm{C}(44) & 58(2) & 49(2) & 56(2) & 13(1) & 13(1) & -17(1) \\ \mathrm{C}(45) & 51(2) & 51(2) & 65(2) & -7(2) & 26(2) & -22(1) \\ \mathrm{C}(46) & 30(1) & 44(2) & 68(2) & -17(1) & 14(1) & -10(1) \\ \mathrm{C}(47) & 28(1) & 30(1) & 44(1) & -10(1) & 4(1) & -1(1)\end{array}$

Table S30. Hydrogen coordinates $\left(\mathrm{x10}^{4}\right)$ and isotropic displacement parameters $\left(\AA^{2} \times 10^{3}\right)$ for $\mathrm{C}_{47} \mathrm{H}_{60} \mathrm{CuF}_{3} \mathrm{~N}_{2} \mathrm{OSi}\left(\mathrm{C}_{6} \mathrm{H}_{14}\right)_{0.5}$

\begin{tabular}{lcccc}
\hline & $x$ & $y$ & $z$ & $U(e q)$ \\
& & & \\
$H(2)$ & 6055 & 7130 & 8695 & 26 \\
$H(3)$ & 5814 & 8364 & 7813 & 27 \\
$H(6)$ & 8127 & 4779 & 8994 & 40 \\
$H(7)$ & 7255 & 3716 & 8705 & 42 \\
$H(8)$ & 6002 & 3945 & 7972 & 36 \\
$H(10)$ & 7719 & 6877 & 8399 & 42 \\
$H(11 A)$ & 8748 & 6876 & 9572 & 115 \\
$H(11 B)$ & 7978 & 6550 & 9795 & 115 \\
$H(11 C)$ & 8632 & 5921 & 9689 & 115 \\
$H(12 A)$ & 8319 & 6178 & 7485 & 97 \\
$H(12 B)$ & 8939 & 6689 & 8141 & 97 \\
$H(12 C)$ & 8874 & 5725 & 8245 & 97 \\
$H(13)$ & 5210 & 5894 & 7213 & 36 \\
$H(14 A)$ & 4177 & 5130 & 7489 & 58
\end{tabular}




\begin{tabular}{|c|c|c|c|}
\hline $\mathrm{H}(14 \mathrm{~B})$ & 4768 & 4457 & 7955 \\
\hline $\mathrm{H}(14 \mathrm{C})$ & 4782 & 5356 & 8328 \\
\hline $\mathrm{H}(15 \mathrm{~A})$ & 4607 & 4946 & 6191 \\
\hline $\mathrm{H}(15 \mathrm{~B})$ & 5492 & 5066 & 6177 \\
\hline $\mathrm{H}(15 \mathrm{C})$ & 5228 & 4270 & 6591 \\
\hline $\mathrm{H}(18)$ & 5093 & 8788 & 4518 \\
\hline $\mathrm{H}(19)$ & 6098 & 9698 & 4585 \\
\hline $\mathrm{H}(20)$ & 7145 & 9696 & 5698 \\
\hline $\mathrm{H}(22)$ & 4911 & 7390 & 6113 \\
\hline $\mathrm{H}(23 \mathrm{~A})$ & 4525 & 6530 & 4951 \\
\hline $\mathrm{H}(23 \mathrm{~B})$ & 4947 & 7116 & 4429 \\
\hline $\mathrm{H}(23 \mathrm{C})$ & 5442 & 6622 & 5199 \\
\hline $\mathrm{H}(24 \mathrm{~A})$ & 3685 & 7596 & 5224 \\
\hline $\mathrm{H}(24 \mathrm{~B})$ & 4020 & 8440 & 5635 \\
\hline $\mathrm{H}(24 \mathrm{C})$ & 4042 & 8244 & 4702 \\
\hline $\mathrm{H}(25)$ & 7324 & 8512 & 7535 \\
\hline$H(26 A)$ & 8253 & 9556 & 7775 \\
\hline$H(26 B)$ & 7959 & 9864 & 6845 \\
\hline $\mathrm{H}(26 \mathrm{C})$ & 7408 & 9932 & 7473 \\
\hline $\mathrm{H}(27 \mathrm{~A})$ & 8563 & 8218 & 7331 \\
\hline $\mathrm{H}(27 \mathrm{~B})$ & 7922 & 7663 & 6751 \\
\hline $\mathrm{H}(27 \mathrm{C})$ & 8270 & 8431 & 6373 \\
\hline $\mathrm{H}(31 \mathrm{~A})$ & 7982 & 4676 & 6650 \\
\hline $\mathrm{H}(31 \mathrm{~B})$ & 7078 & 4480 & 6461 \\
\hline $\mathrm{H}(30 \mathrm{~A})$ & 6936 & 4665 & 5076 \\
\hline $\mathrm{H}(30 \mathrm{~B})$ & 7844 & 4646 & 5157 \\
\hline H(29) & 8005 & 5900 & 5749 \\
\hline $\mathrm{H}(31 \mathrm{C})$ & 7491 & 4537 & 6738 \\
\hline $\mathrm{H}(31 \mathrm{D})$ & 6762 & 4203 & 6059 \\
\hline $\mathrm{H}(30 \mathrm{C})$ & 7578 & 4499 & 5057 \\
\hline $\mathrm{H}(30 \mathrm{D})$ & 8049 & 5083 & 5771 \\
\hline $\mathrm{H}(29 \mathrm{X})$ & 6405 & 5224 & 5086 \\
\hline $\mathrm{H}(31 \mathrm{E})$ & 7302 & 4536 & 6575 \\
\hline $\mathrm{H}(31 \mathrm{~F})$ & 6790 & 4224 & 5713 \\
\hline $\mathrm{H}(30 \mathrm{E})$ & 7847 & 4668 & 5103 \\
\hline
\end{tabular}




\begin{tabular}{|c|c|c|c|c|}
\hline $\mathrm{H}(30 \mathrm{~F})$ & 8183 & 5136 & 5957 & 34 \\
\hline H(29Y) & 6650 & 5288 & 5144 & 42 \\
\hline $\mathrm{H}(33 \mathrm{~A})$ & 7687 & 2068 & 5316 & 87 \\
\hline $\mathrm{H}(33 \mathrm{~B})$ & 8250 & 1300 & 5395 & 87 \\
\hline $\mathrm{H}(33 \mathrm{C})$ & 7714 & 1414 & 6032 & 87 \\
\hline $\mathrm{H}(34 \mathrm{~A})$ & 9554 & 2922 & 6111 & 86 \\
\hline $\mathrm{H}(34 \mathrm{~B})$ & 9372 & 2197 & 5454 & 86 \\
\hline $\mathrm{H}(34 \mathrm{C})$ & 8817 & 2974 & 5354 & 86 \\
\hline $\mathrm{H}(35 \mathrm{~A})$ & 9584 & 1916 & 7241 & 74 \\
\hline $\mathrm{H}(35 \mathrm{~B})$ & 8867 & 1320 & 7203 & 74 \\
\hline $\mathrm{H}(35 \mathrm{C})$ & 9404 & 1206 & 6566 & 74 \\
\hline $\mathrm{H}(37)$ & 9347 & 4164 & 6695 & 44 \\
\hline $\mathrm{H}(38)$ & 10320 & 4898 & 7547 & 51 \\
\hline $\mathrm{H}(39)$ & 10552 & 4754 & 8974 & 49 \\
\hline $\mathrm{H}(40)$ & 9782 & 3888 & 9540 & 47 \\
\hline $\mathrm{H}(41)$ & 8797 & 3154 & 8691 & 40 \\
\hline $\mathrm{H}(43)$ & 8341 & 1846 & 8298 & 50 \\
\hline $\mathrm{H}(44)$ & 7482 & 1227 & 8965 & 65 \\
\hline $\mathrm{H}(45)$ & 6163 & 1427 & 8483 & 64 \\
\hline $\mathrm{H}(46)$ & 5703 & 2232 & 7332 & 56 \\
\hline $\mathrm{H}(47)$ & 6555 & 2867 & 6672 & 42 \\
\hline $\mathrm{H}(1 \mathrm{~S} 1)$ & 9785 & 6844 & 6340 & 231 \\
\hline $\mathrm{H}(1 \mathrm{~S} 2)$ & 9794 & 7016 & 5398 & 231 \\
\hline $\mathrm{H}(1 \mathrm{~S} 3)$ & 9056 & 6606 & 5621 & 231 \\
\hline $\mathrm{H}(2 \mathrm{~S} 1)$ & 10511 & 5903 & 5909 & 194 \\
\hline $\mathrm{H}(2 \mathrm{~S} 2)$ & 9779 & 5497 & 6130 & 194 \\
\hline $\mathrm{H}(3 \mathrm{~S} 1)$ & 9981 & 5732 & 4578 & 163 \\
\hline $\mathrm{H}(3 \mathrm{~S} 2)$ & 9256 & 5312 & 4808 & 163 \\
\hline
\end{tabular}

Table S31. Torsion angles $\left[{ }^{\circ}\right]$ for $\mathrm{C}_{47} \mathrm{H}_{60} \mathrm{CuF}_{3} \mathrm{~N}_{2} \mathrm{OSi}\left(\mathrm{C}_{6} \mathrm{H}_{14}\right)_{0.5}$

$\begin{array}{lc}\mathrm{C}(36)-\mathrm{Si}(1)-\mathrm{O}(1)-\mathrm{C}(31) & -30.5(3) \\ \mathrm{C}(42)-\mathrm{Si}(1)-\mathrm{O}(1)-\mathrm{C}(31) & 91.8(3) \\ \mathrm{C}(32)-\mathrm{Si}(1)-\mathrm{O}(1)-\mathrm{C}(31) & -150.3(3)\end{array}$




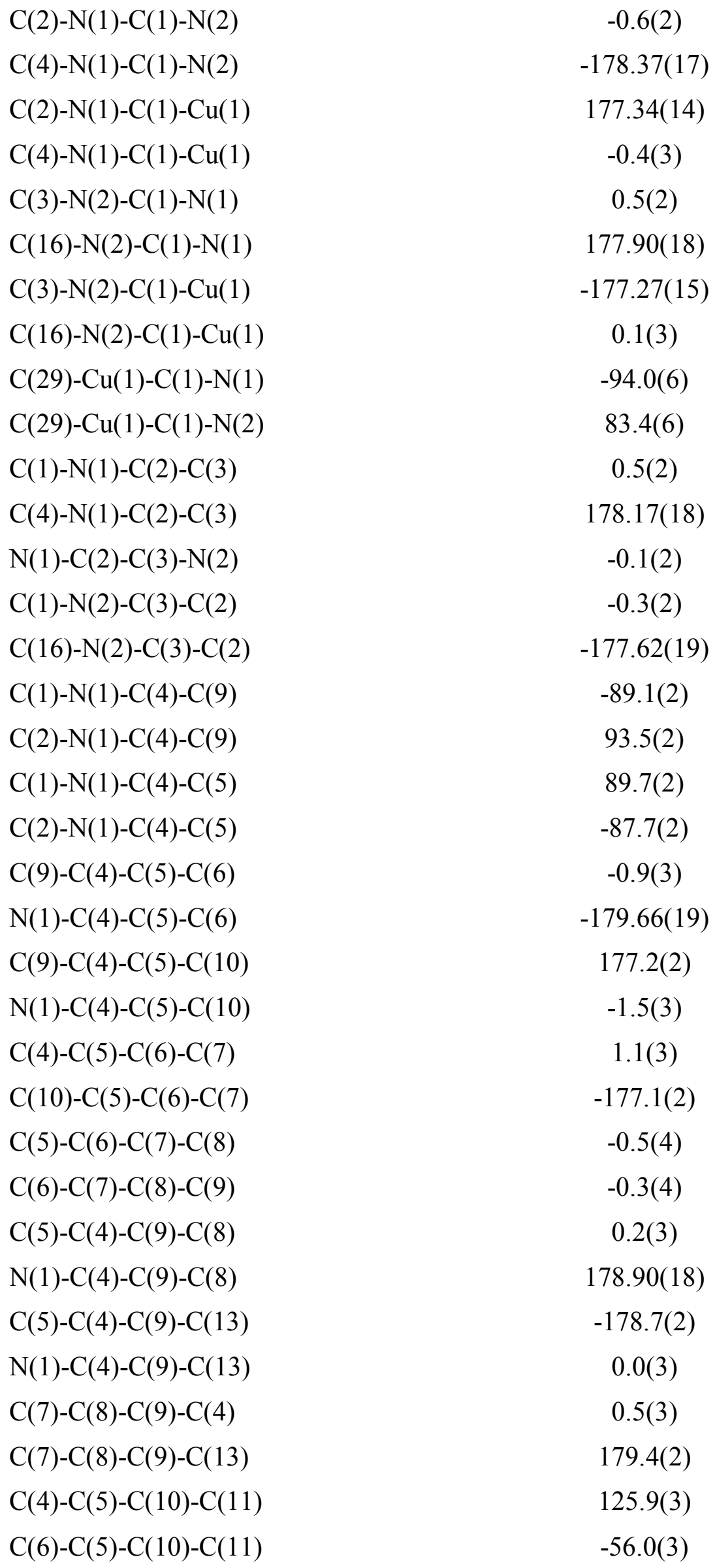




\begin{tabular}{|c|c|}
\hline$C(4)-C(5)-C(10)-C(12)$ & $-109.4(3)$ \\
\hline$C(6)-C(5)-C(10)-C(12)$ & $68.7(3)$ \\
\hline$C(4)-C(9)-C(13)-C(14)$ & $-122.0(2)$ \\
\hline$C(8)-C(9)-C(13)-C(14)$ & $59.1(3)$ \\
\hline$C(4)-C(9)-C(13)-C(15)$ & $113.6(2)$ \\
\hline$C(8)-C(9)-C(13)-C(15)$ & $-65.2(3)$ \\
\hline$C(1)-N(2)-C(16)-C(17)$ & $85.3(2)$ \\
\hline$C(3)-N(2)-C(16)-C(17)$ & $-97.7(2)$ \\
\hline$C(1)-N(2)-C(16)-C(21)$ & $-96.6(2)$ \\
\hline $\mathrm{C}(3)-\mathrm{N}(2)-\mathrm{C}(16)-\mathrm{C}(21)$ & $80.5(3)$ \\
\hline$C(21)-C(16)-C(17)-C(18)$ & $0.7(3)$ \\
\hline $\mathrm{N}(2)-\mathrm{C}(16)-\mathrm{C}(17)-\mathrm{C}(18)$ & $178.75(19)$ \\
\hline$C(21)-C(16)-C(17)-C(22)$ & $179.8(2)$ \\
\hline $\mathrm{N}(2)-\mathrm{C}(16)-\mathrm{C}(17)-\mathrm{C}(22)$ & $-2.2(3)$ \\
\hline$C(16)-C(17)-C(18)-C(19)$ & $-0.1(3)$ \\
\hline $\mathrm{C}(22)-\mathrm{C}(17)-\mathrm{C}(18)-\mathrm{C}(19)$ & $-179.2(2)$ \\
\hline $\mathrm{C}(17)-\mathrm{C}(18)-\mathrm{C}(19)-\mathrm{C}(20)$ & $-0.2(4)$ \\
\hline$C(18)-C(19)-C(20)-C(21)$ & $0.0(4)$ \\
\hline$C(17)-C(16)-C(21)-C(20)$ & $-0.9(3)$ \\
\hline $\mathrm{N}(2)-\mathrm{C}(16)-\mathrm{C}(21)-\mathrm{C}(20)$ & $-179.0(2)$ \\
\hline$C(17)-C(16)-C(21)-C(25)$ & $-178.8(2)$ \\
\hline $\mathrm{N}(2)-\mathrm{C}(16)-\mathrm{C}(21)-\mathrm{C}(25)$ & $3.1(3)$ \\
\hline$C(19)-C(20)-C(21)-C(16)$ & $0.6(4)$ \\
\hline$C(19)-C(20)-C(21)-C(25)$ & $178.5(3)$ \\
\hline$C(16)-C(17)-C(22)-C(23)$ & $-99.8(3)$ \\
\hline$C(18)-C(17)-C(22)-C(23)$ & $79.3(3)$ \\
\hline$C(16)-C(17)-C(22)-C(24)$ & $137.2(2)$ \\
\hline $\mathrm{C}(18)-\mathrm{C}(17)-\mathrm{C}(22)-\mathrm{C}(24)$ & $-43.8(3)$ \\
\hline$C(16)-C(21)-C(25)-C(26)$ & $-144.1(2)$ \\
\hline$C(20)-C(21)-C(25)-C(26)$ & $38.1(4)$ \\
\hline$C(16)-C(21)-C(25)-C(27)$ & $91.9(3)$ \\
\hline$C(20)-C(21)-C(25)-C(27)$ & $-85.8(3)$ \\
\hline $\mathrm{Si}(1)-\mathrm{O}(1)-\mathrm{C}(31)-\mathrm{C}(30)$ & $152.3(6)$ \\
\hline $\mathrm{O}(1)-\mathrm{C}(31)-\mathrm{C}(30)-\mathrm{C}(29)$ & $-165.8(6)$ \\
\hline $\mathrm{C}(31)-\mathrm{C}(30)-\mathrm{C}(29)-\mathrm{C}(28)$ & $-179.7(7)$ \\
\hline
\end{tabular}




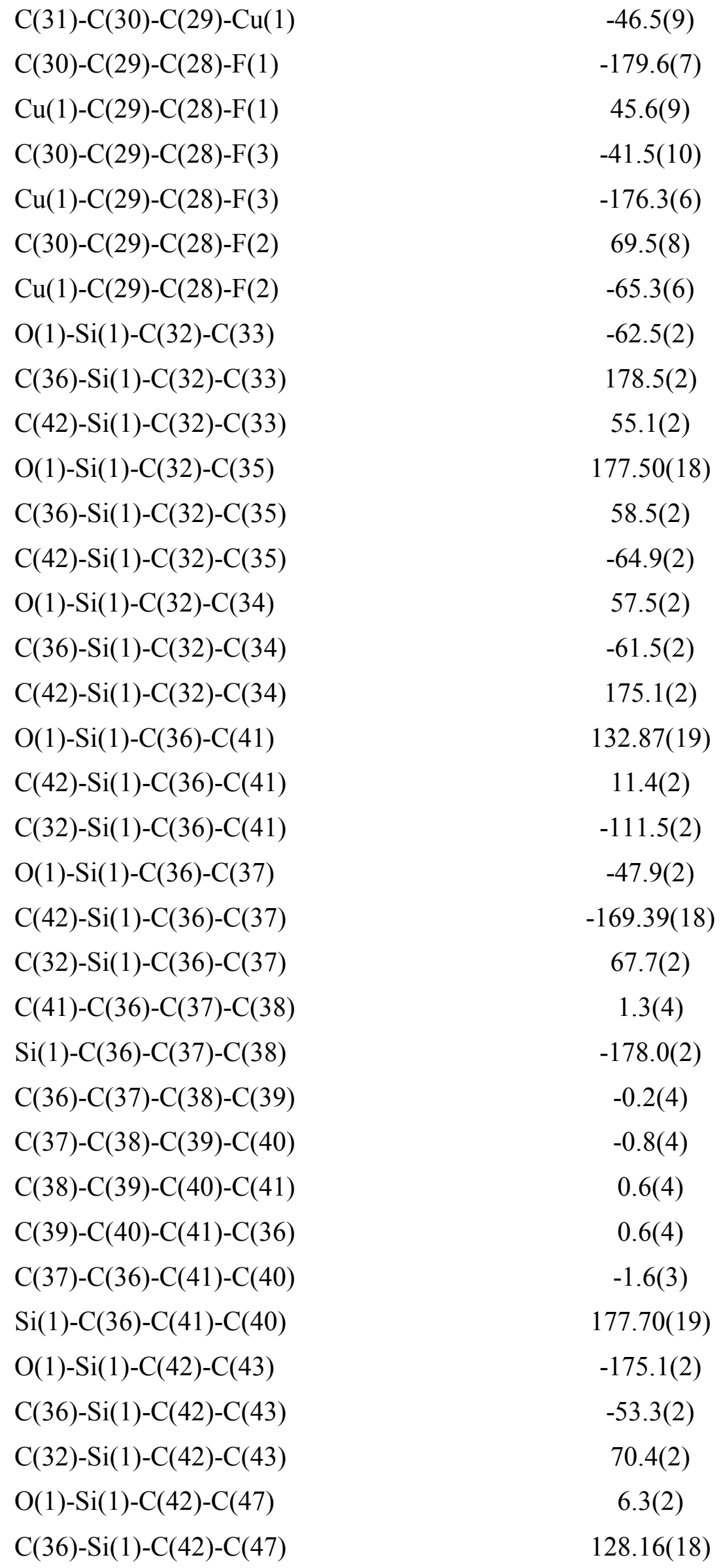


$\mathrm{C}(32)-\mathrm{Si}(1)-\mathrm{C}(42)-\mathrm{C}(47)$

$\mathrm{C}(47)-\mathrm{C}(42)-\mathrm{C}(43)-\mathrm{C}(44)$

$\mathrm{Si}(1)-\mathrm{C}(42)-\mathrm{C}(43)-\mathrm{C}(44)$

$\mathrm{C}(42)-\mathrm{C}(43)-\mathrm{C}(44)-\mathrm{C}(45)$

$\mathrm{C}(43)-\mathrm{C}(44)-\mathrm{C}(45)-\mathrm{C}(46)$

$\mathrm{C}(44)-\mathrm{C}(45)-\mathrm{C}(46)-\mathrm{C}(47)$

$\mathrm{C}(45)-\mathrm{C}(46)-\mathrm{C}(47)-\mathrm{C}(42)$

$\mathrm{C}(43)-\mathrm{C}(42)-\mathrm{C}(47)-\mathrm{C}(46)$

$\mathrm{Si}(1)-\mathrm{C}(42)-\mathrm{C}(47)-\mathrm{C}(46)$

$\mathrm{C}(1 \mathrm{~S})-\mathrm{C}(2 \mathrm{~S})-\mathrm{C}(3 \mathrm{~S})-\mathrm{C}(3 \mathrm{~S}) \# 1$
$-108.15(19)$

$-1.5(4)$

179.9(2)

$0.8(5)$

$0.4(5)$

$-0.8(4)$

$0.1(4)$

$1.0(3)$

179.66(19)

179.0(9)

16. NMR Spectra 
Paioti, et al.; Supporting Information, Part I; Page S144

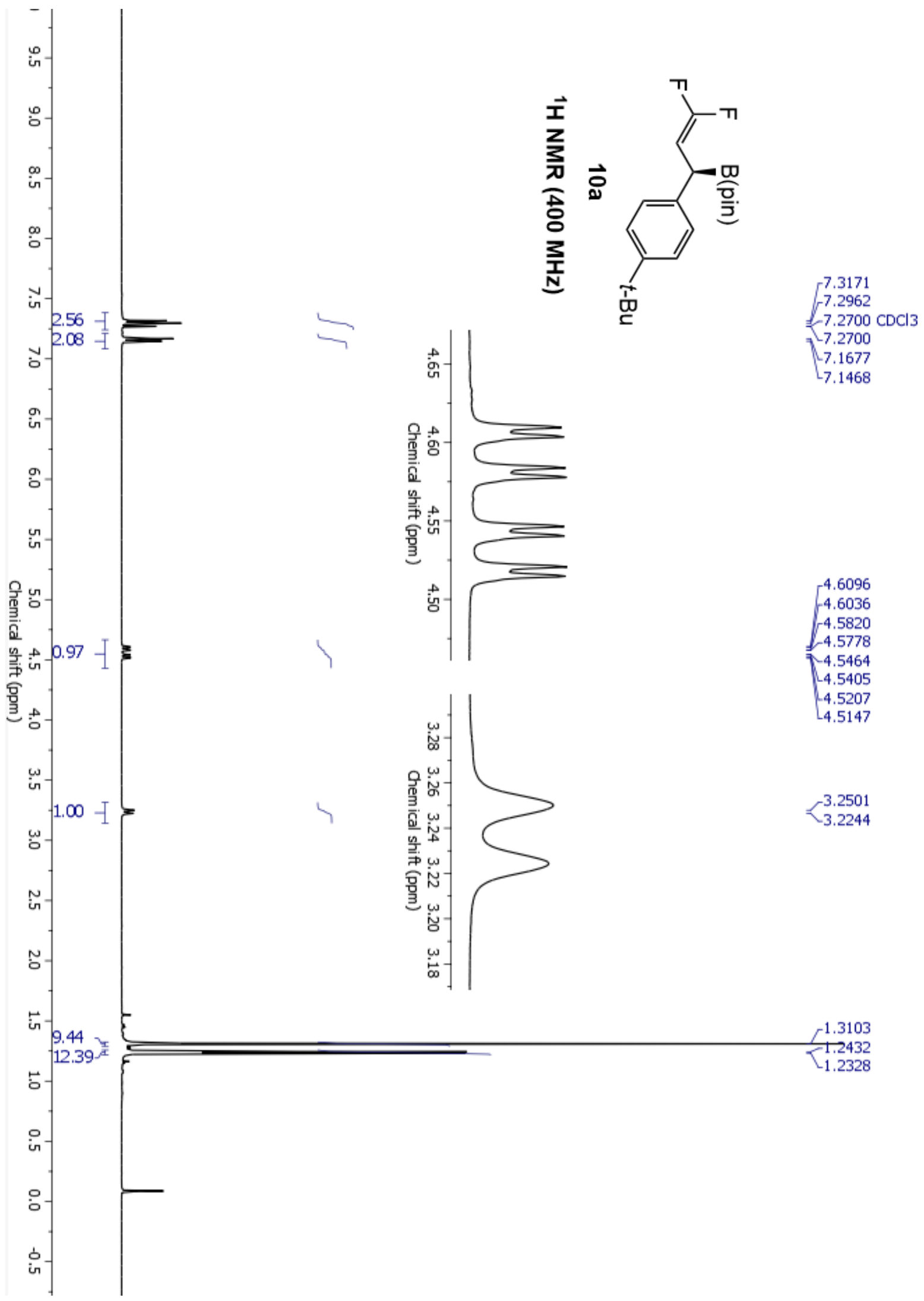




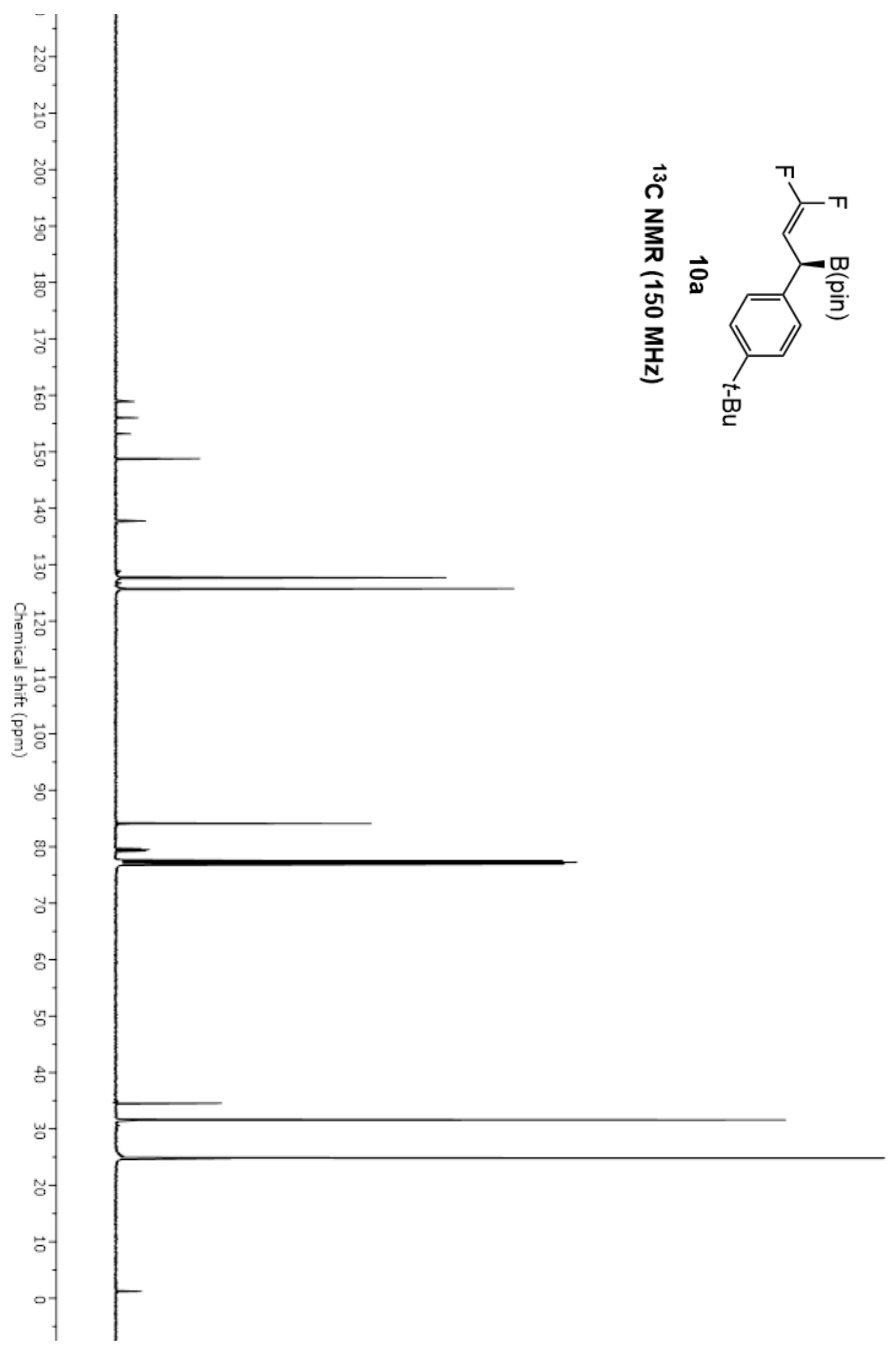




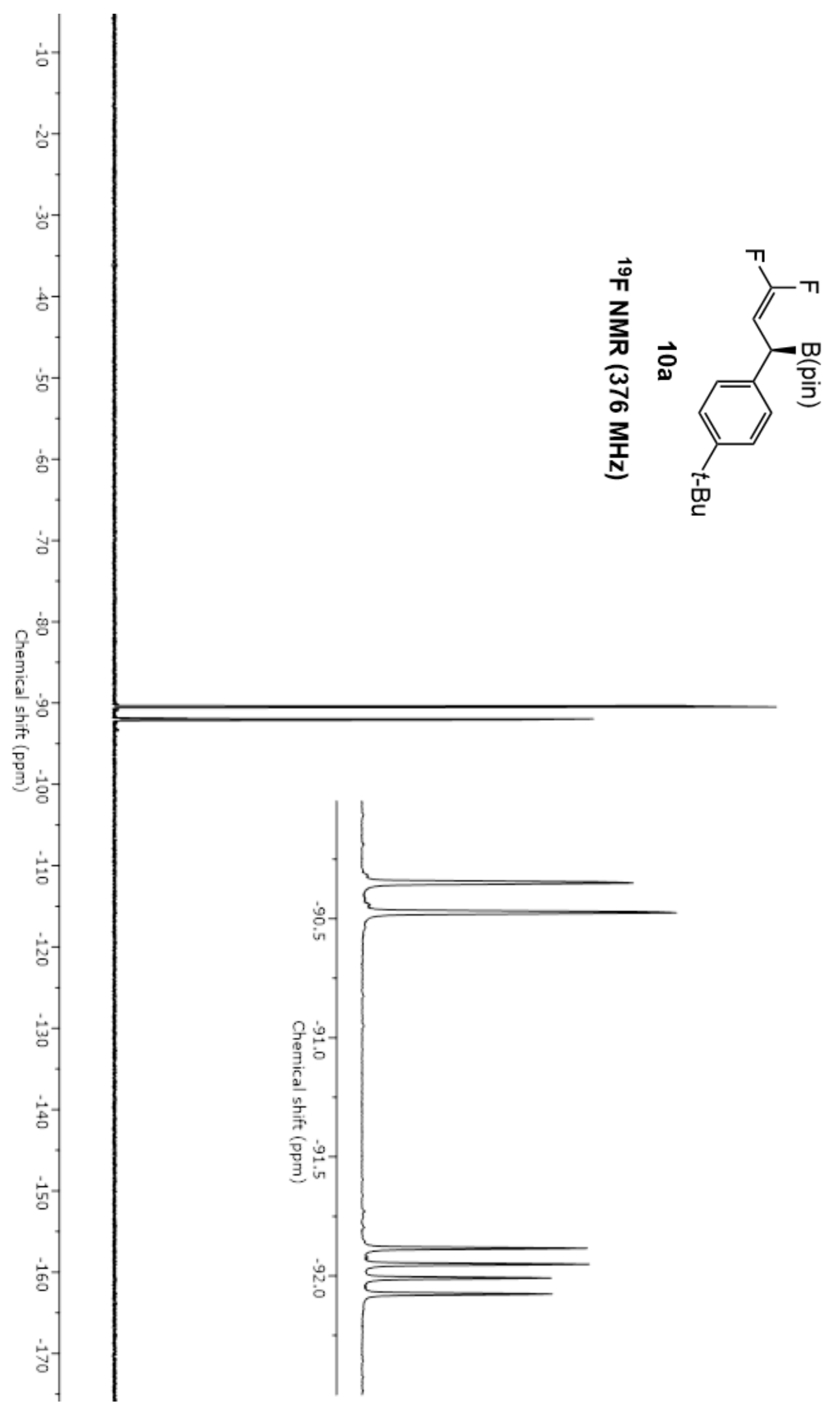




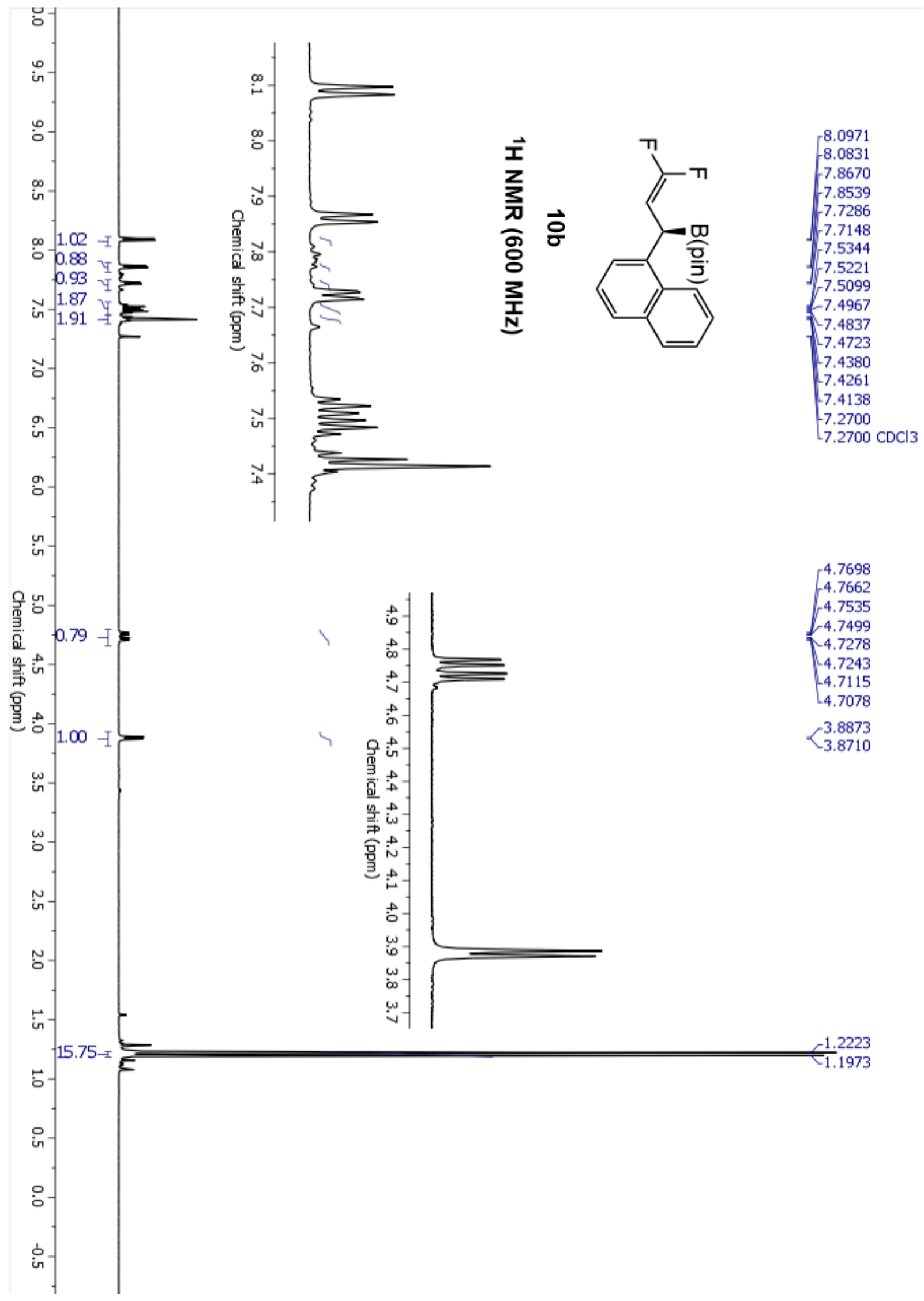




$$
k^{\prime \prime}
$$




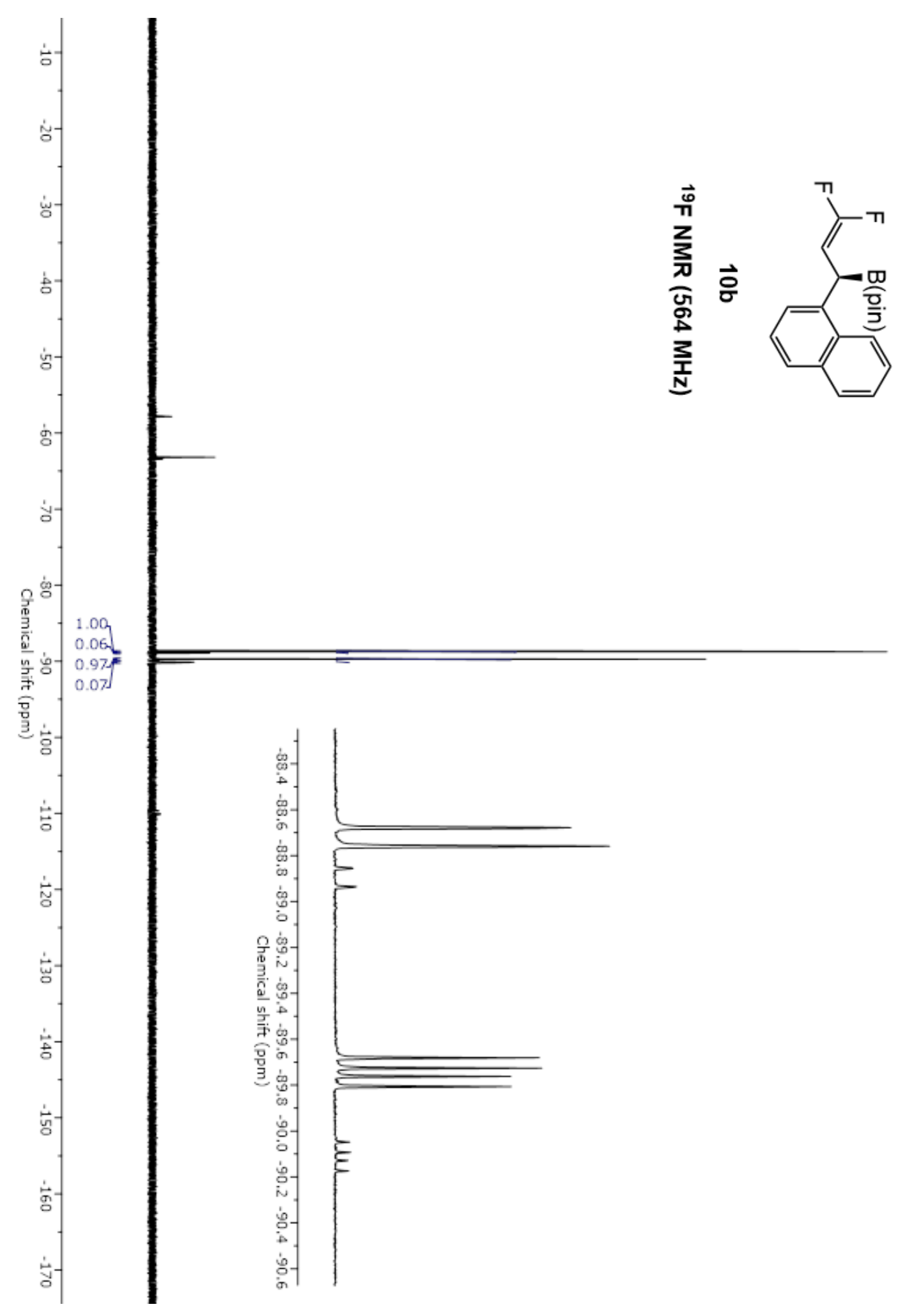




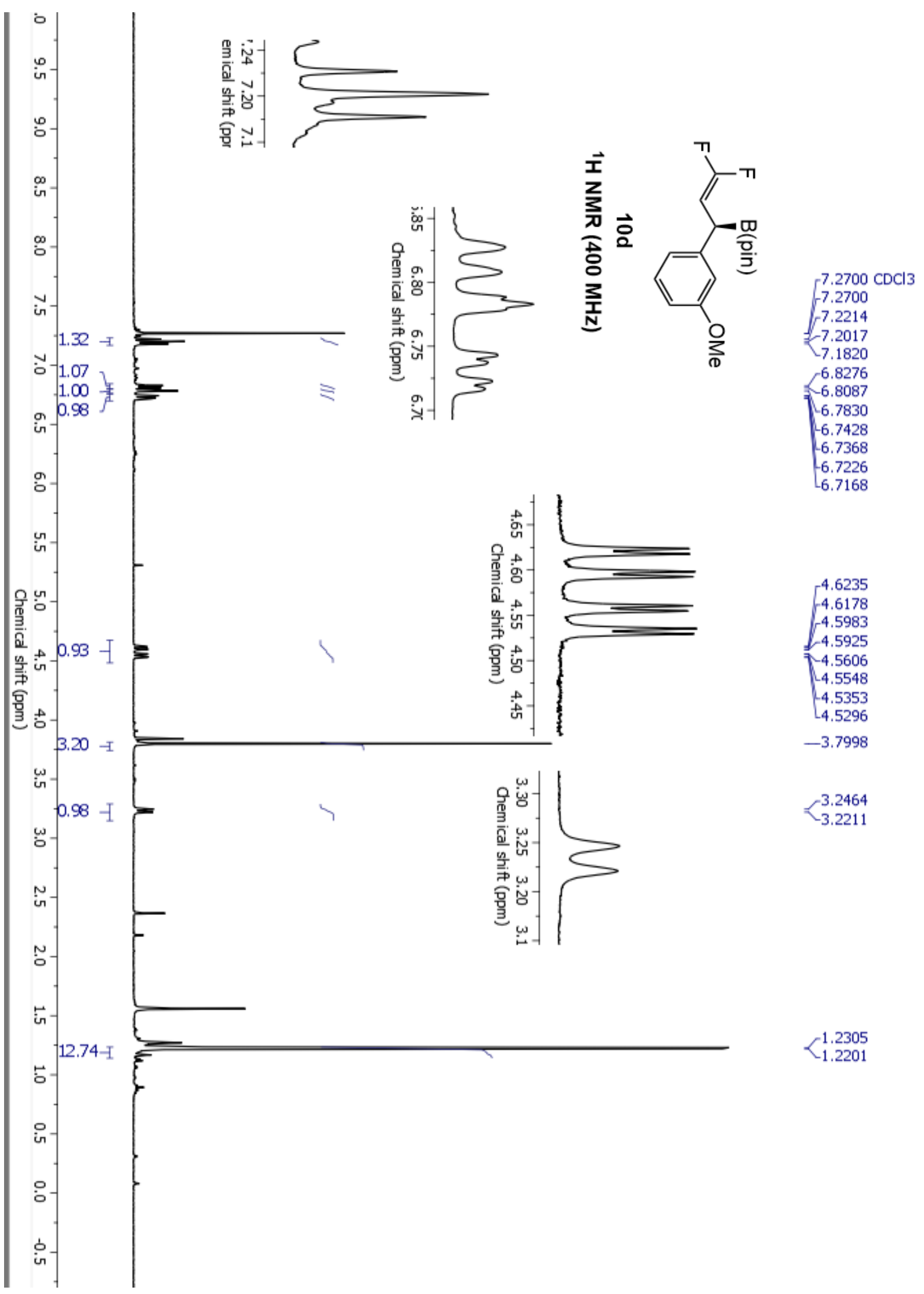


Paioti, et al.; Supporting Information, Part I; Page S151

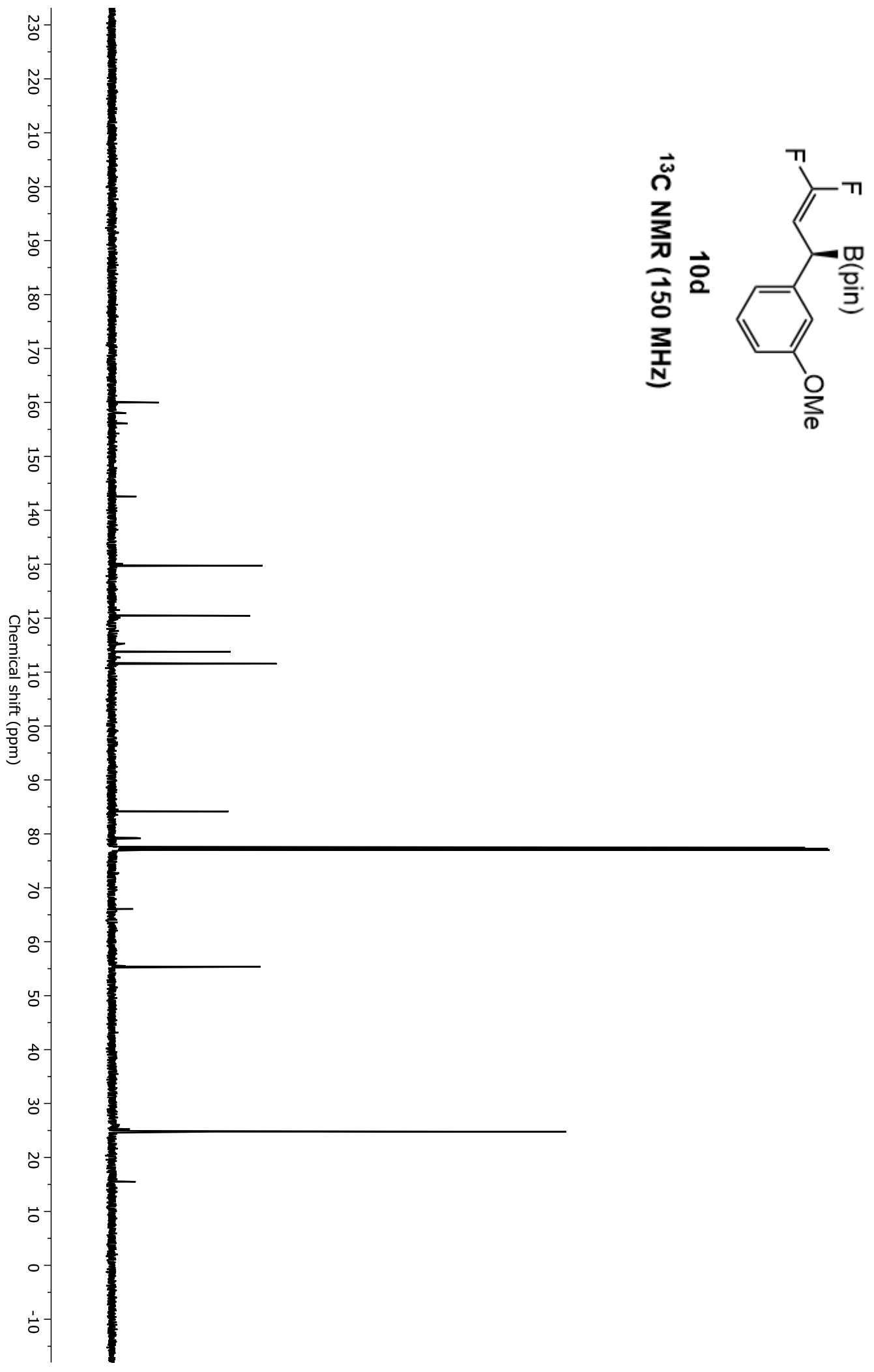




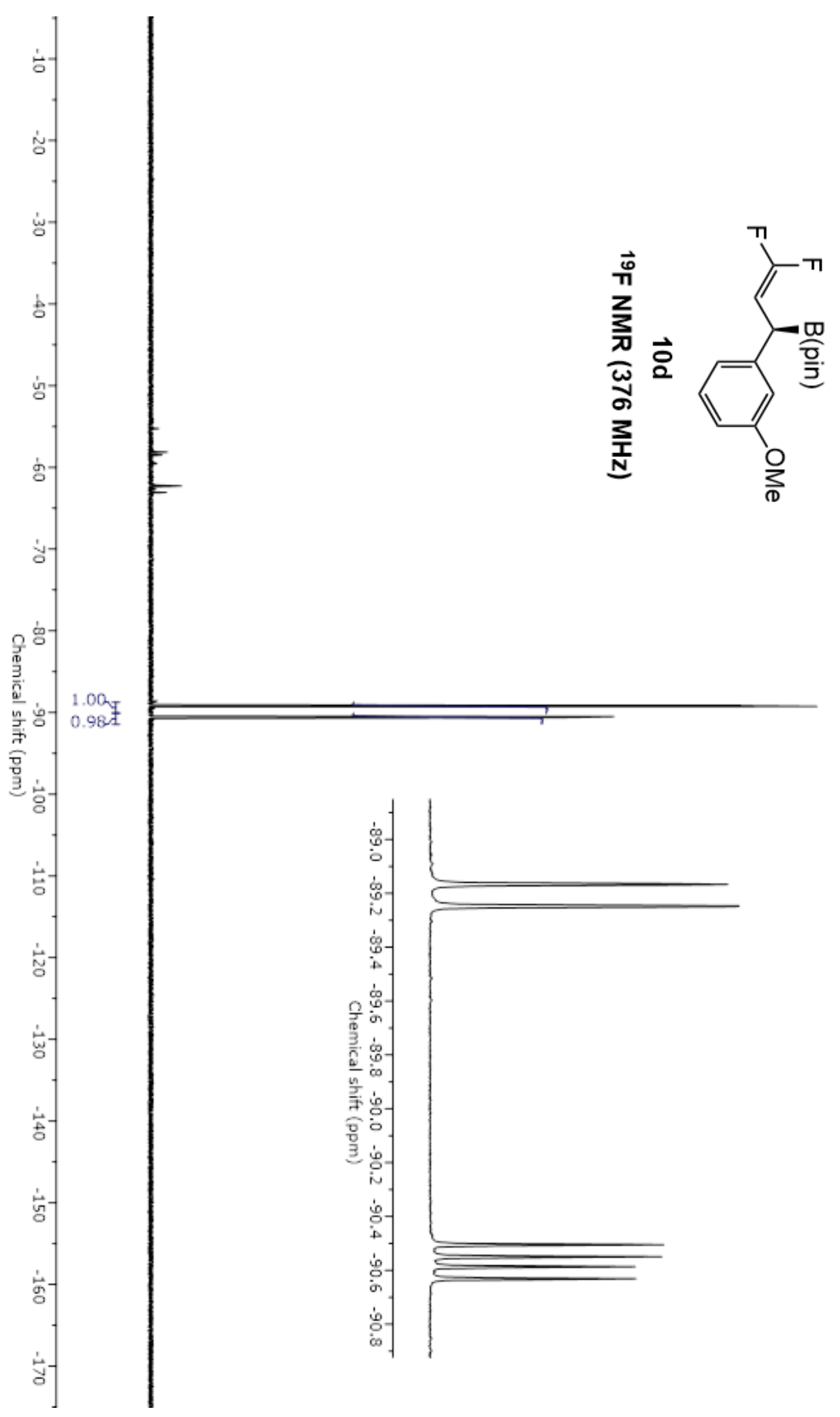


Paioti, et al.; Supporting Information, Part I; Page S153

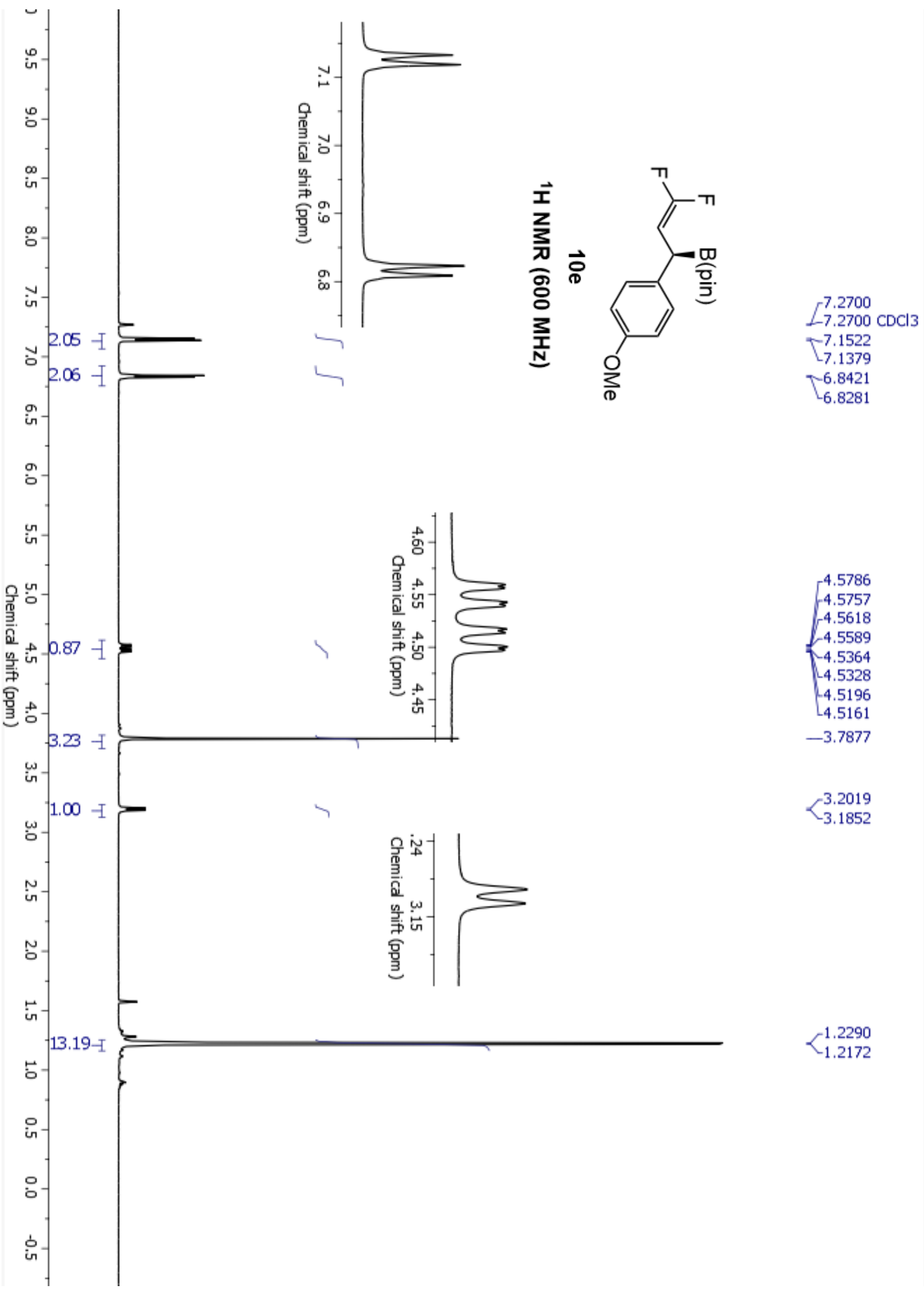




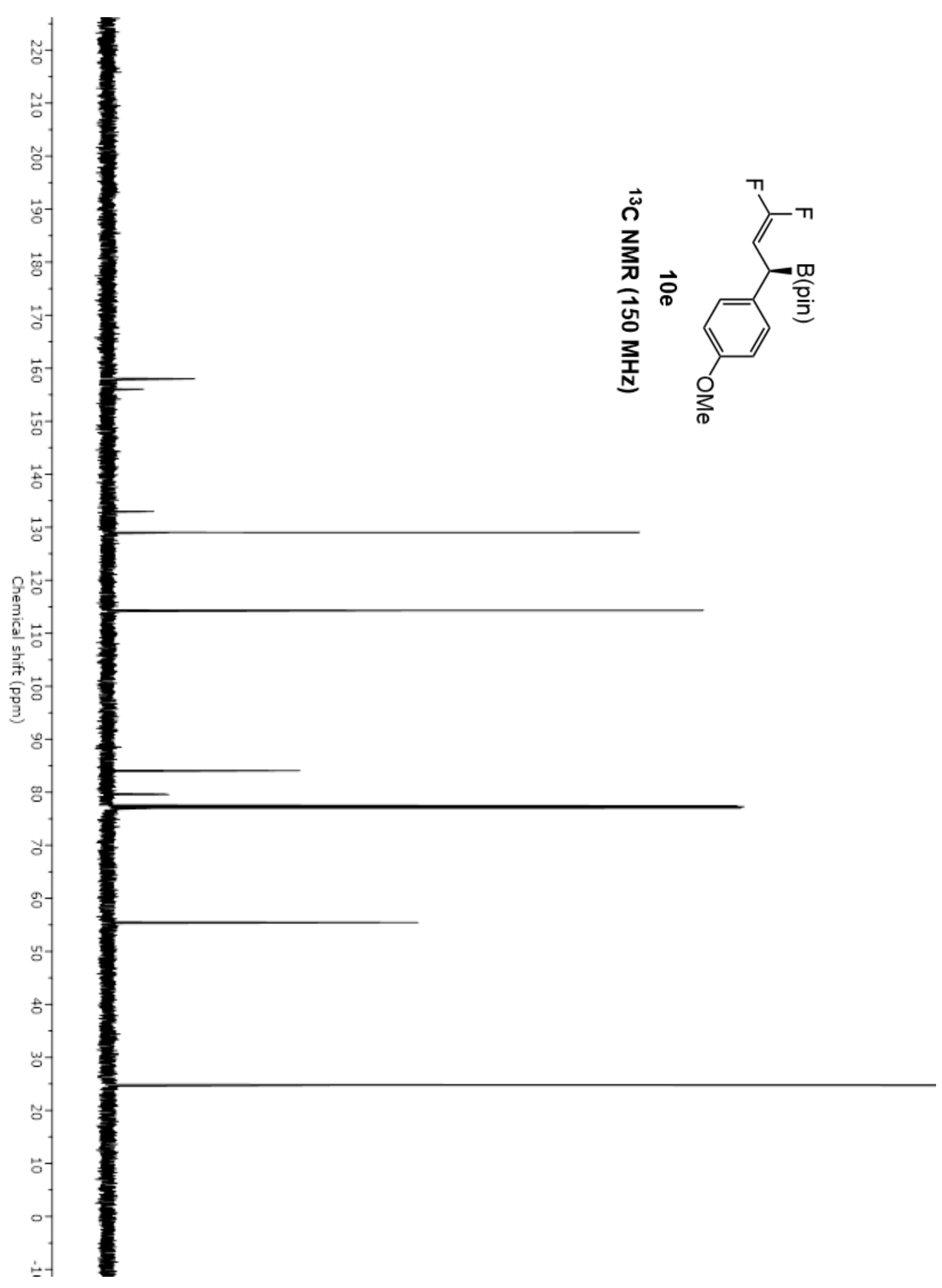




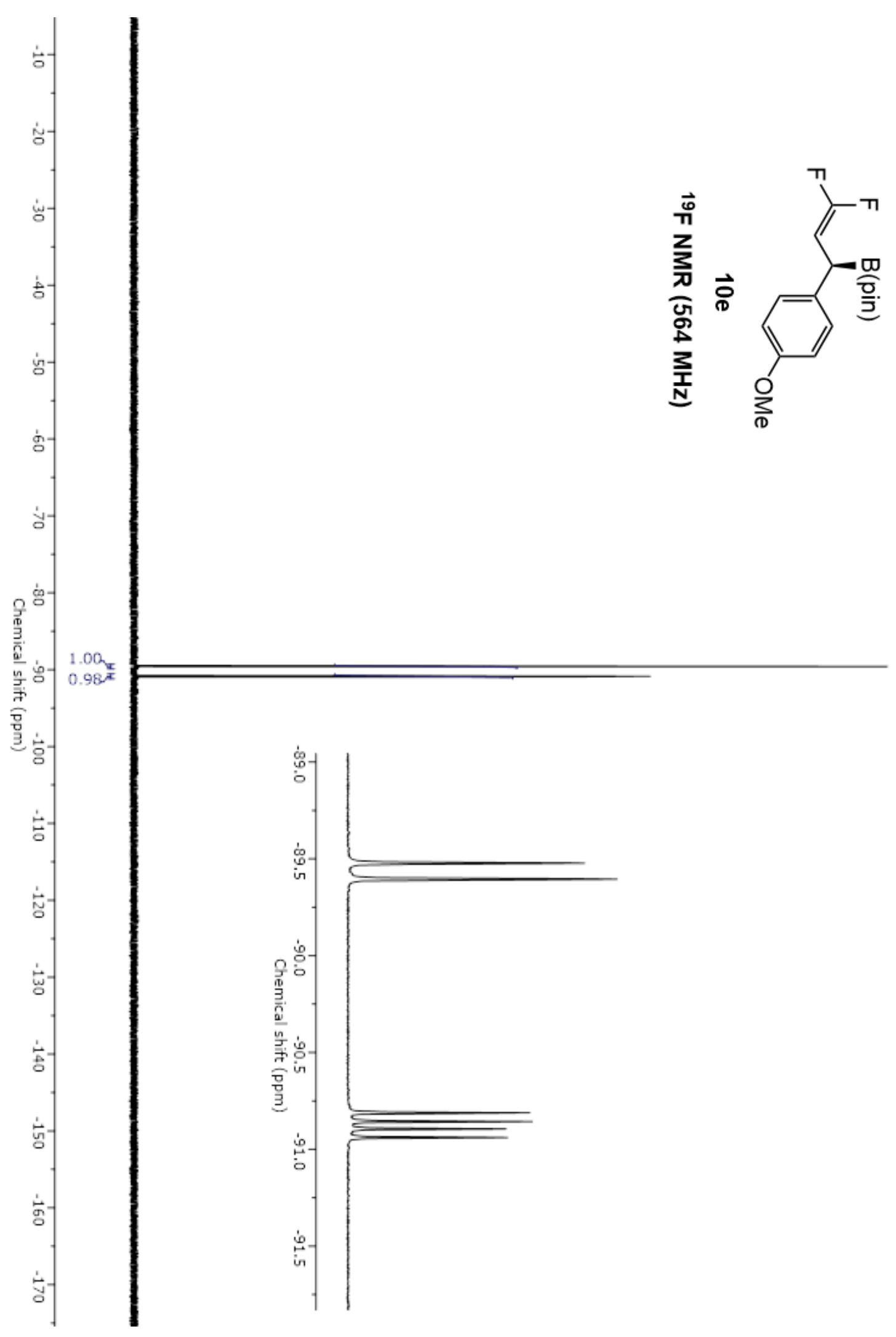




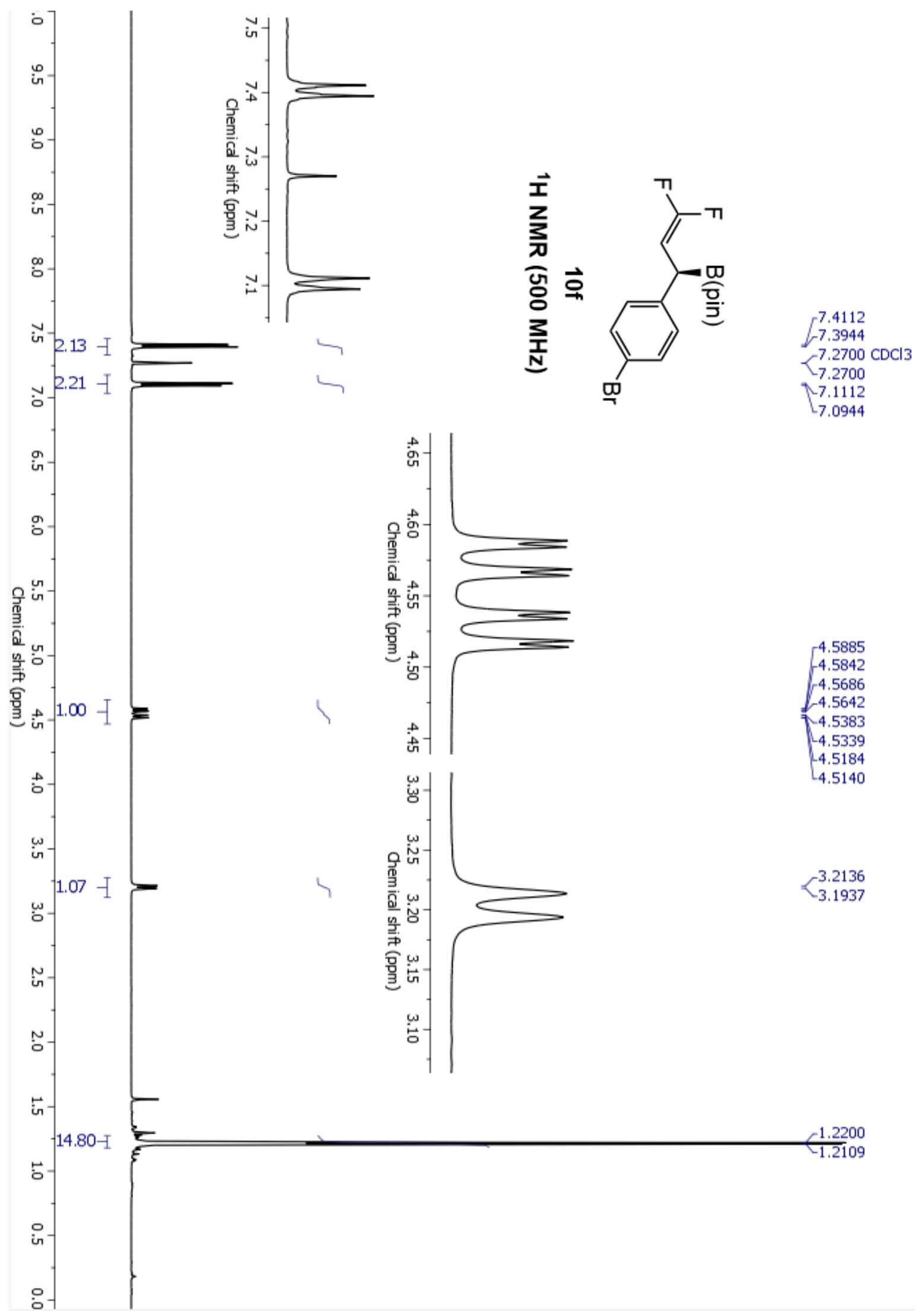




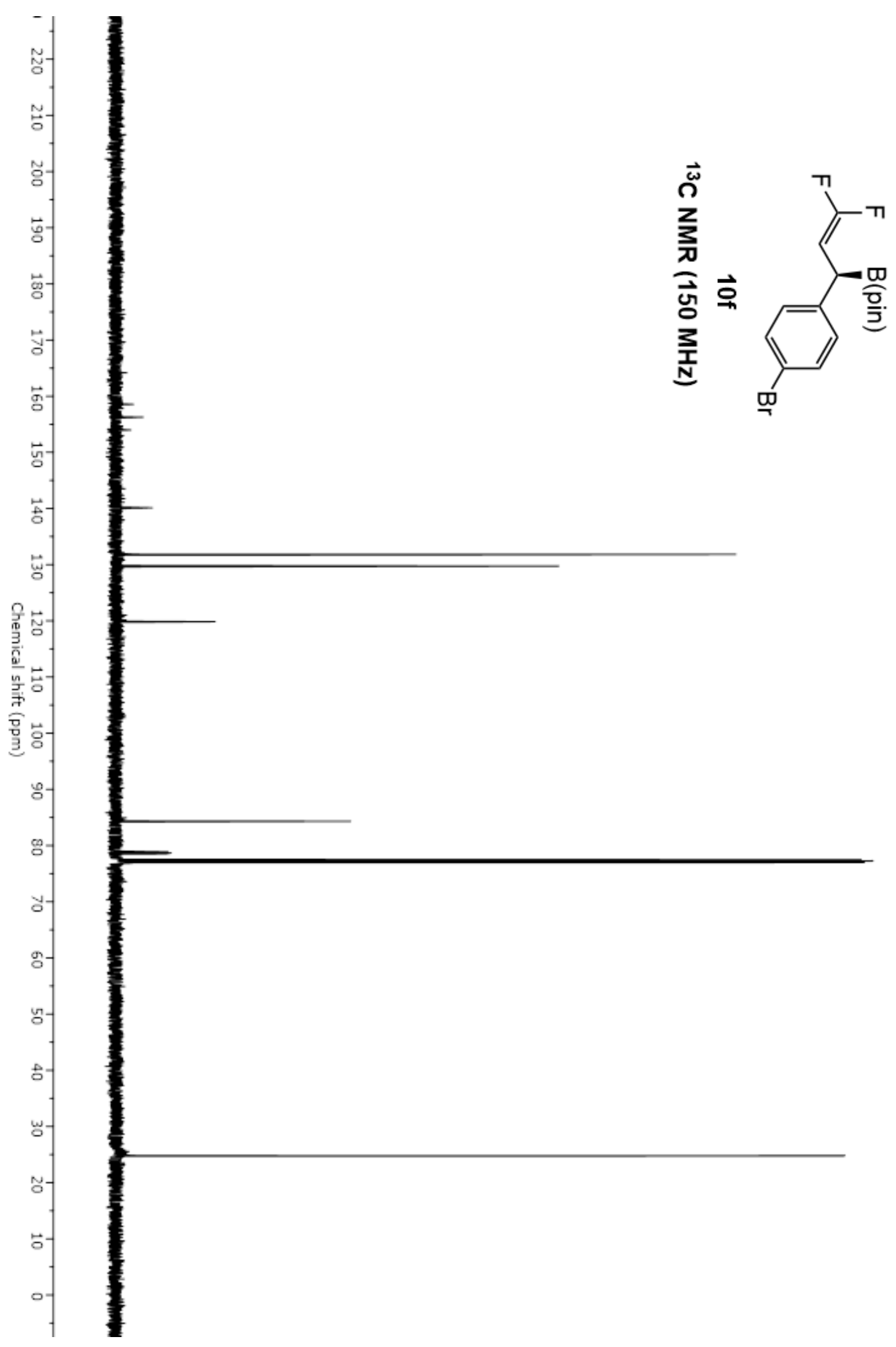




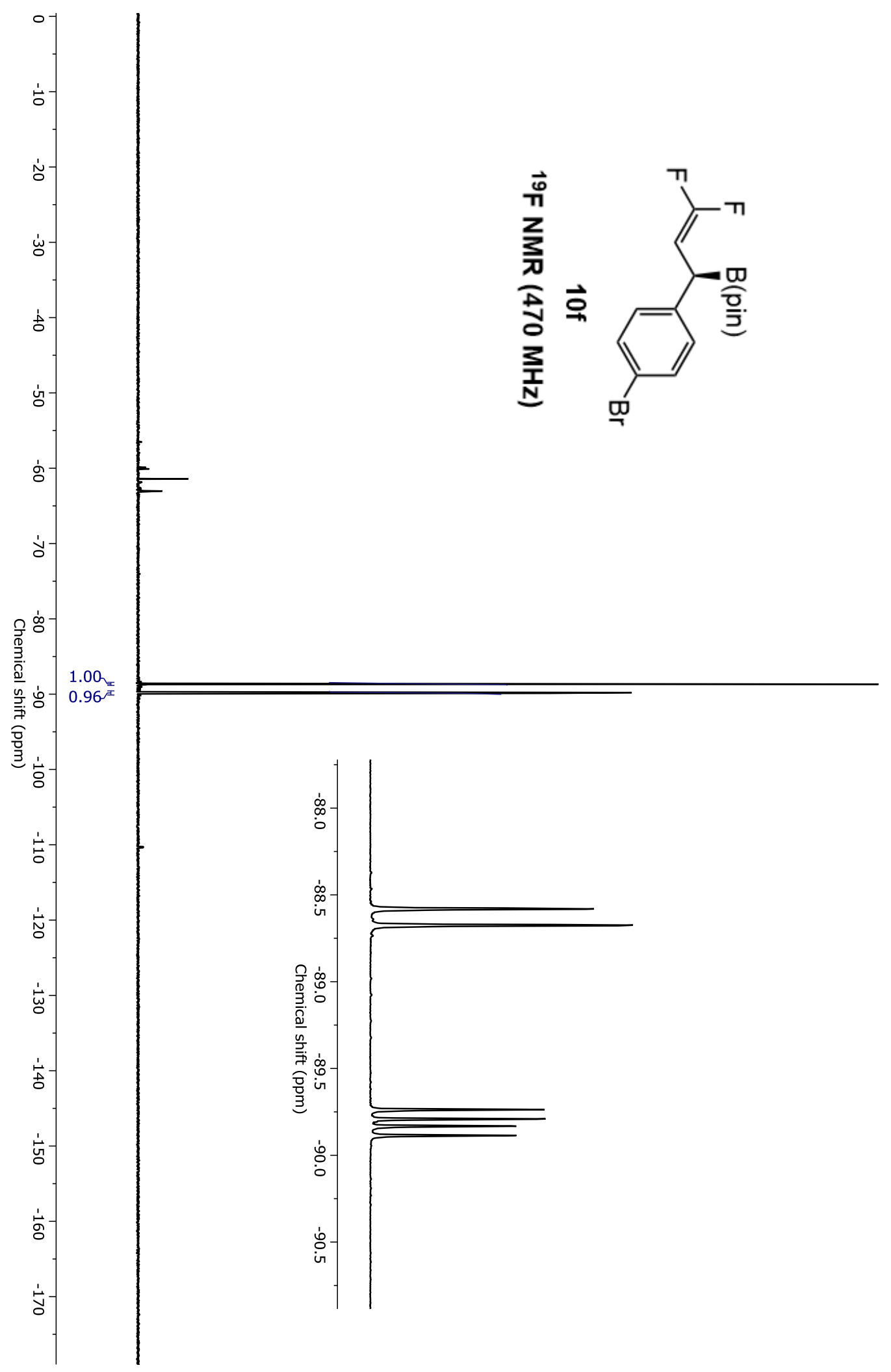




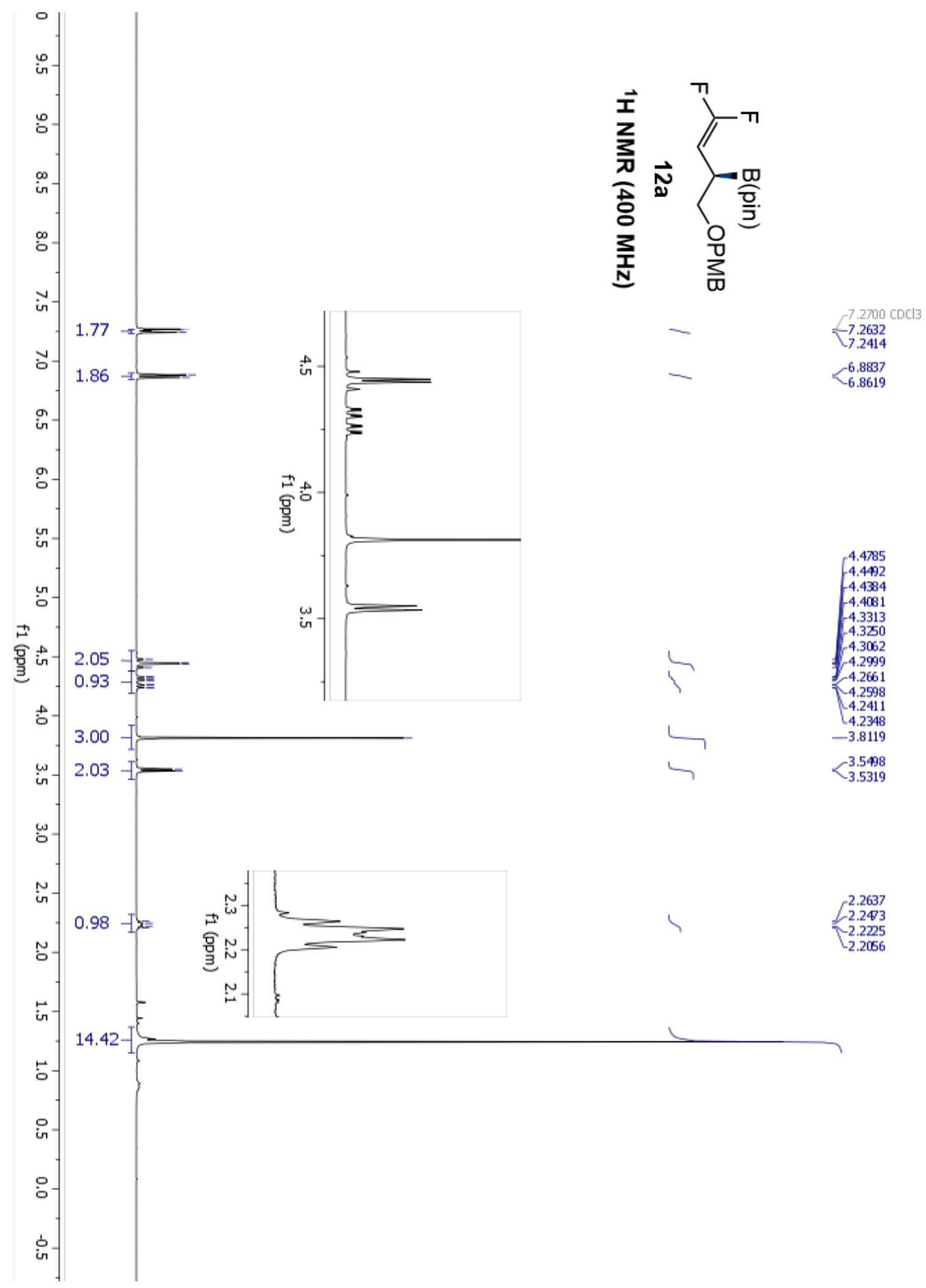




$$
\frac{1}{=}
$$




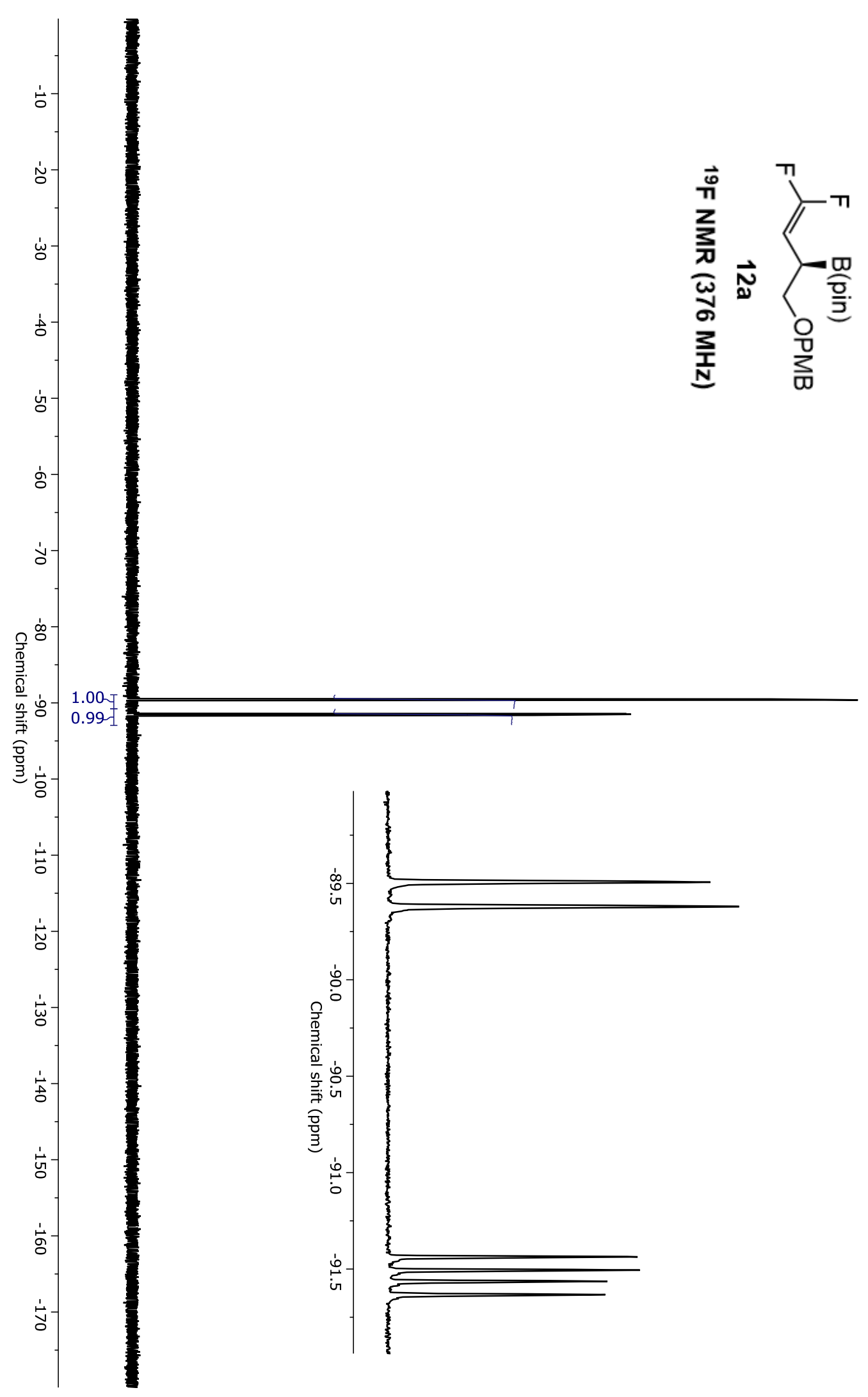




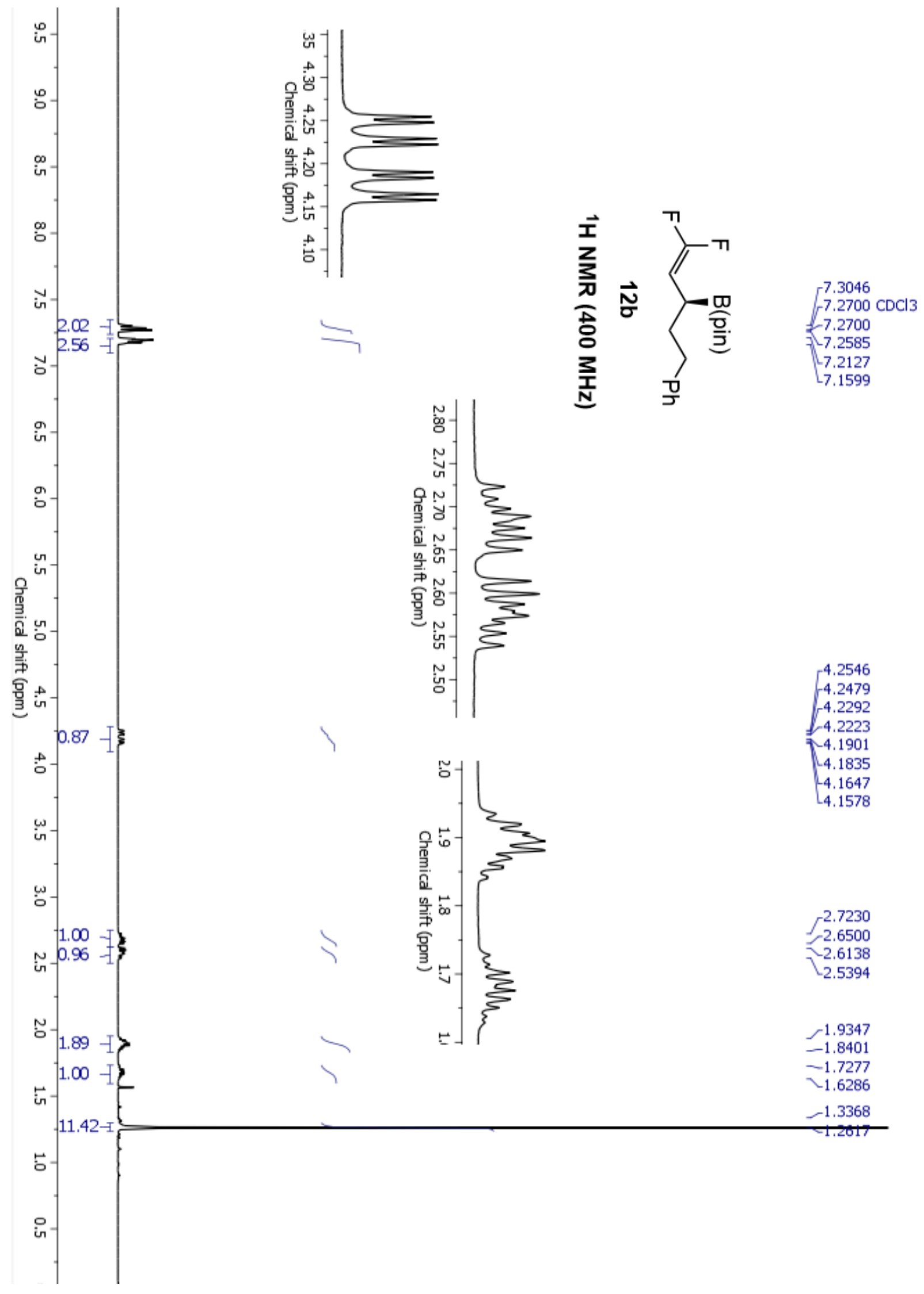




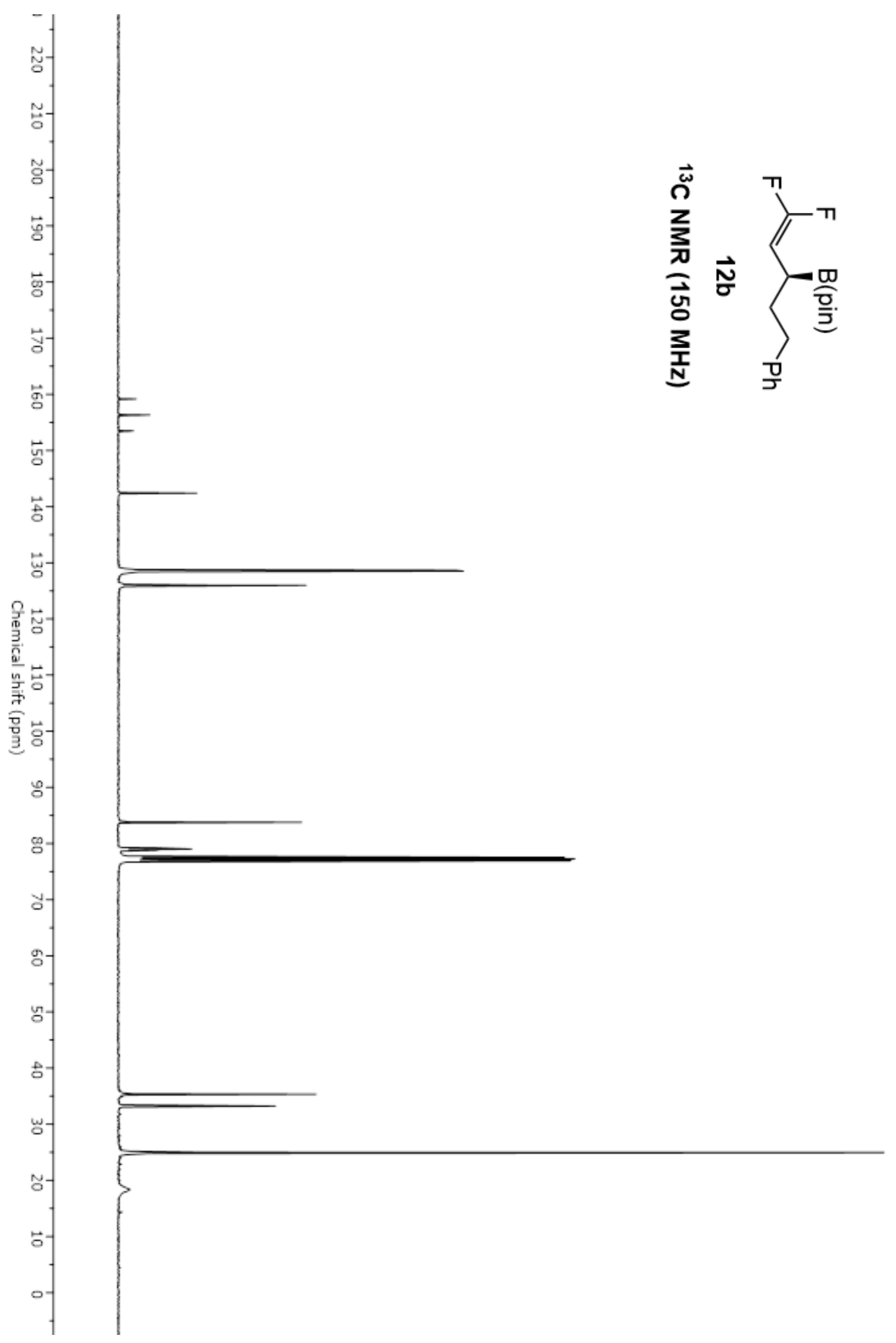




$$
1
$$




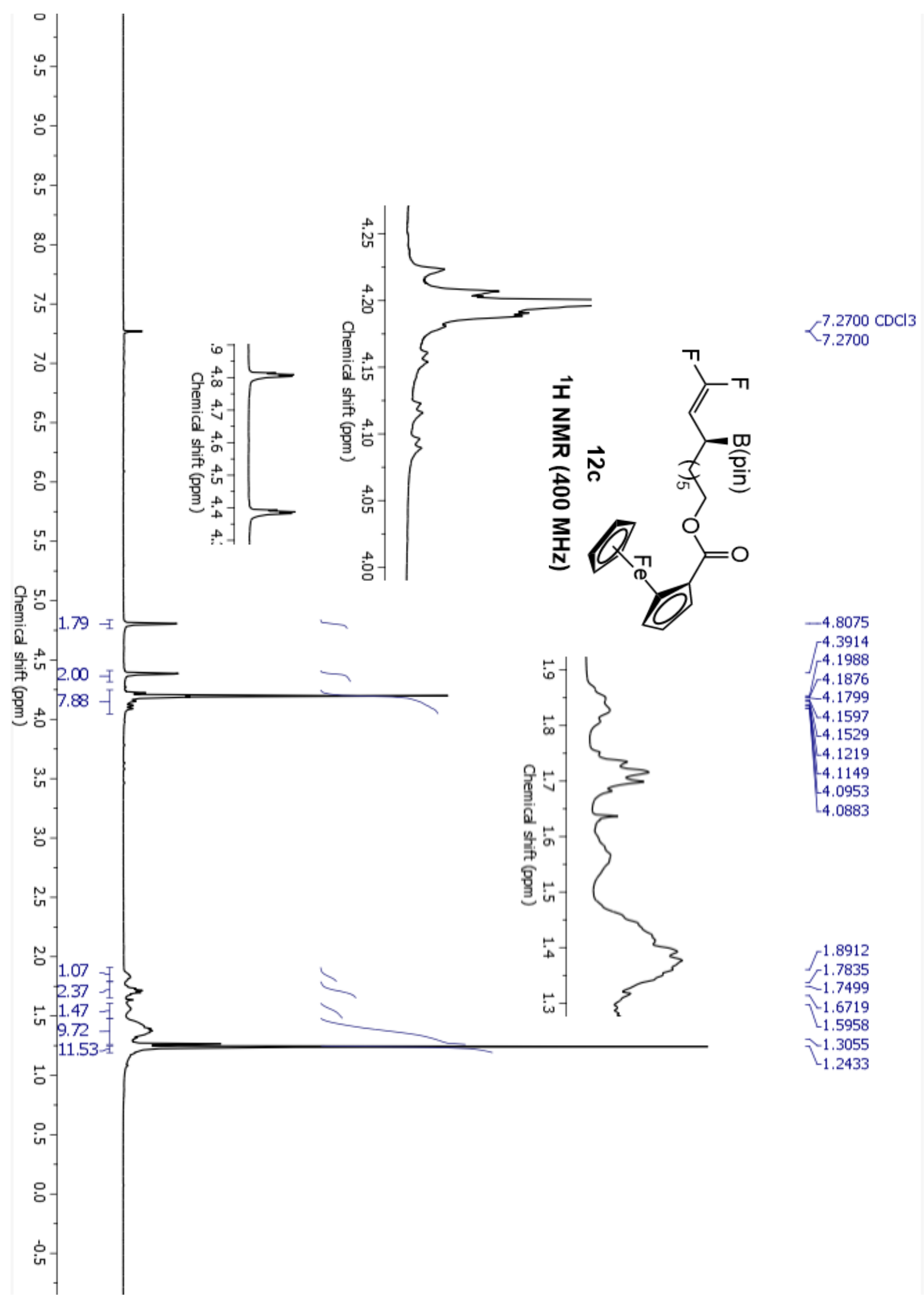


Paioti, et al.; Supporting Information, Part I; Page S166

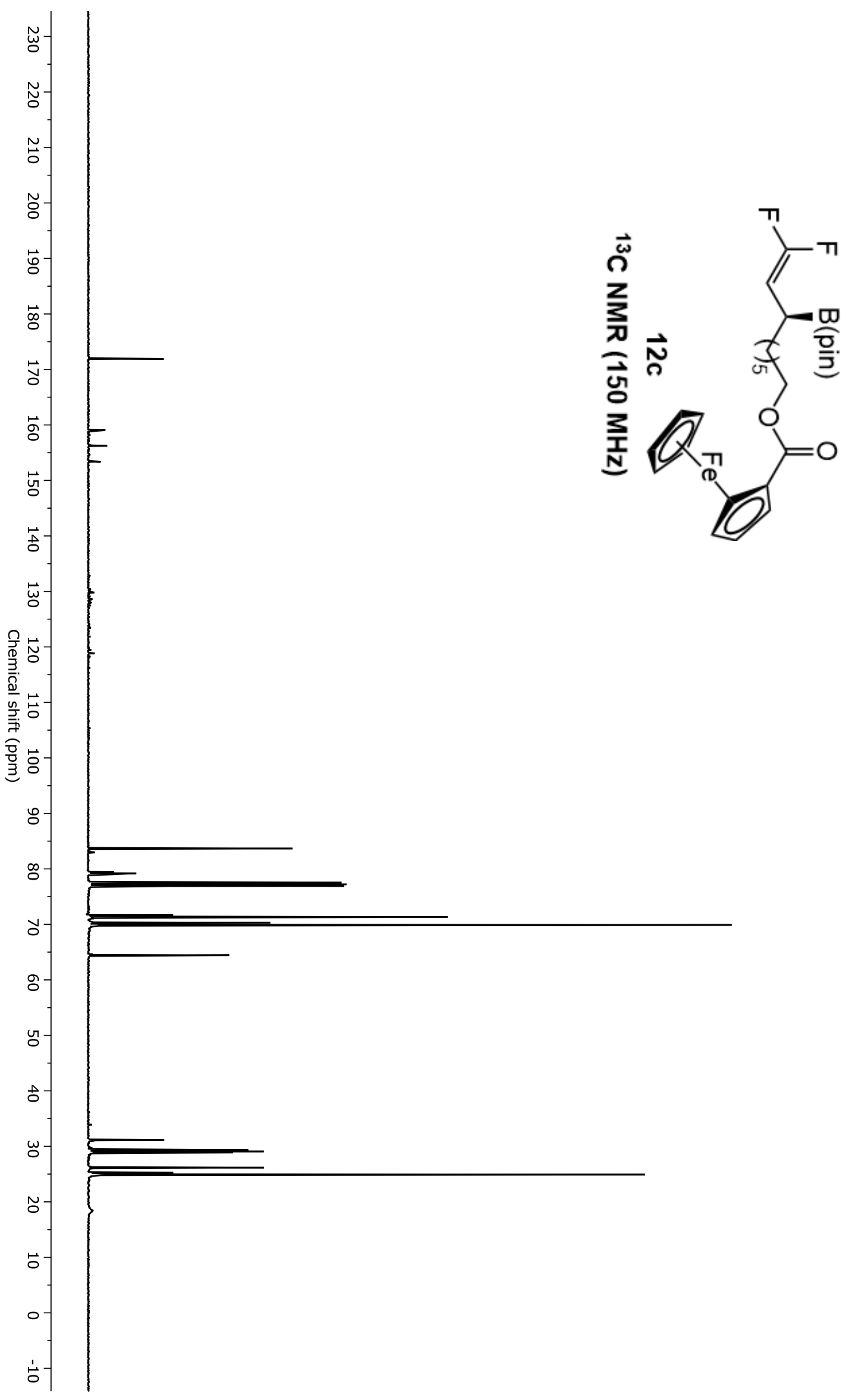




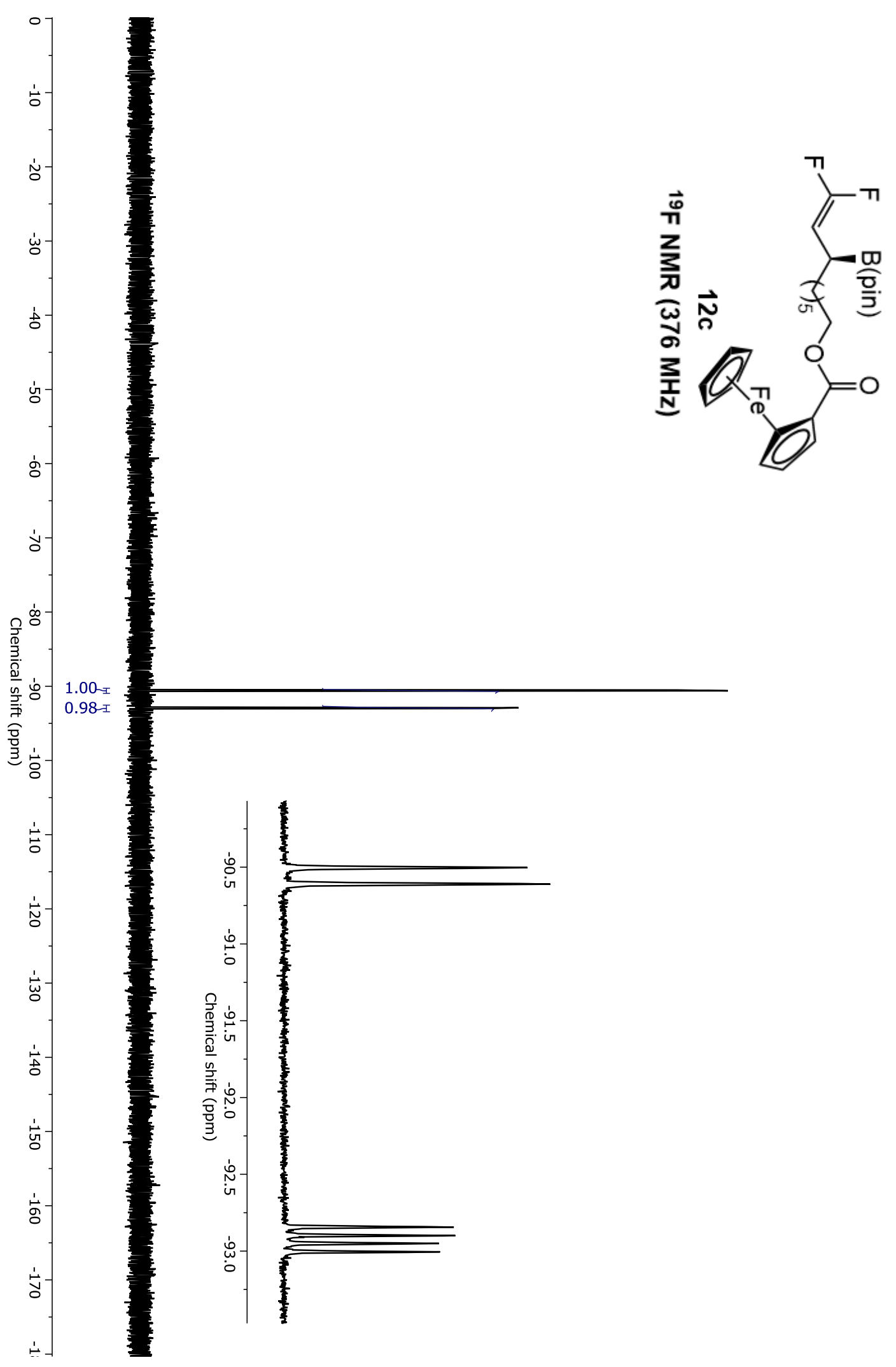




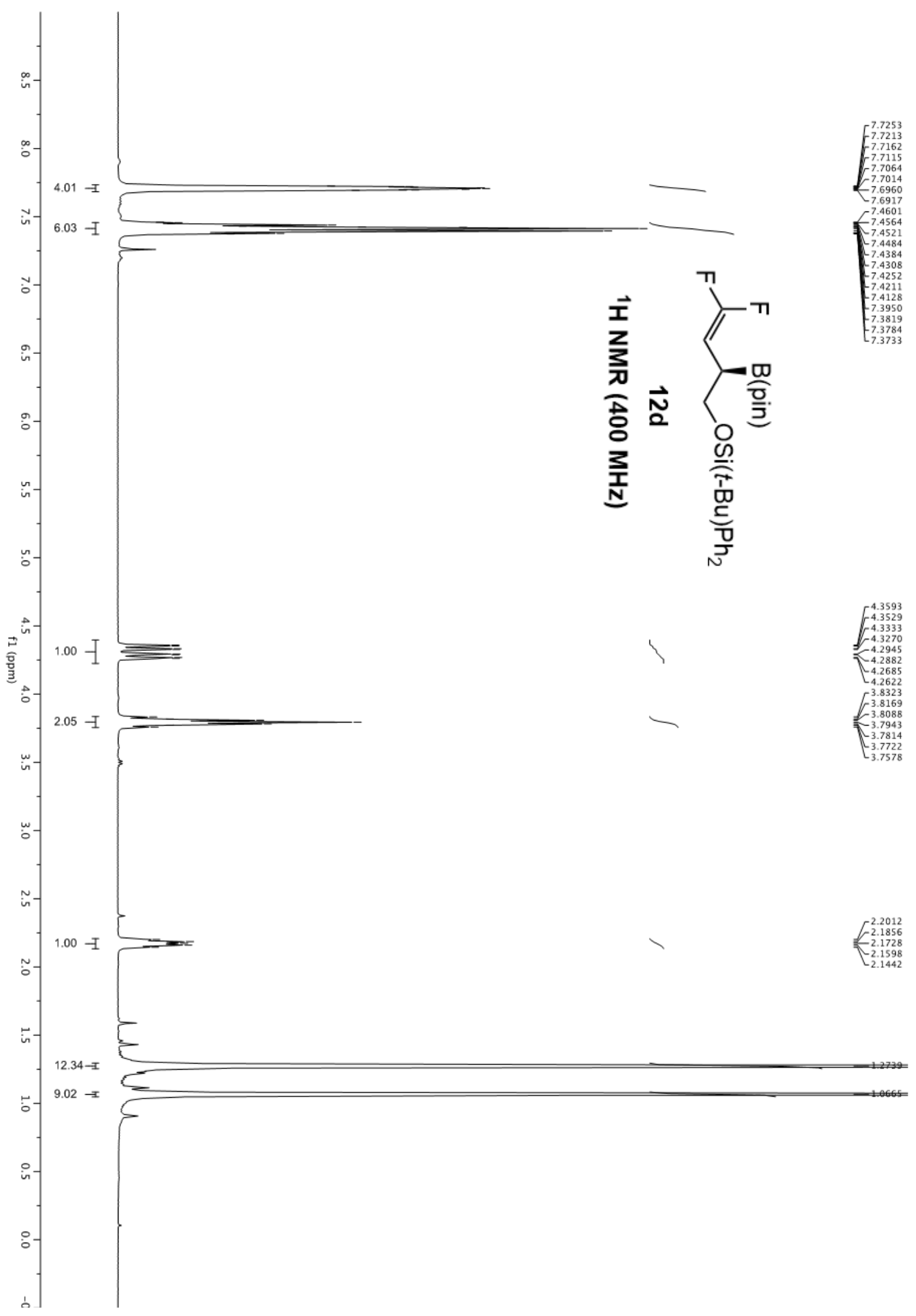




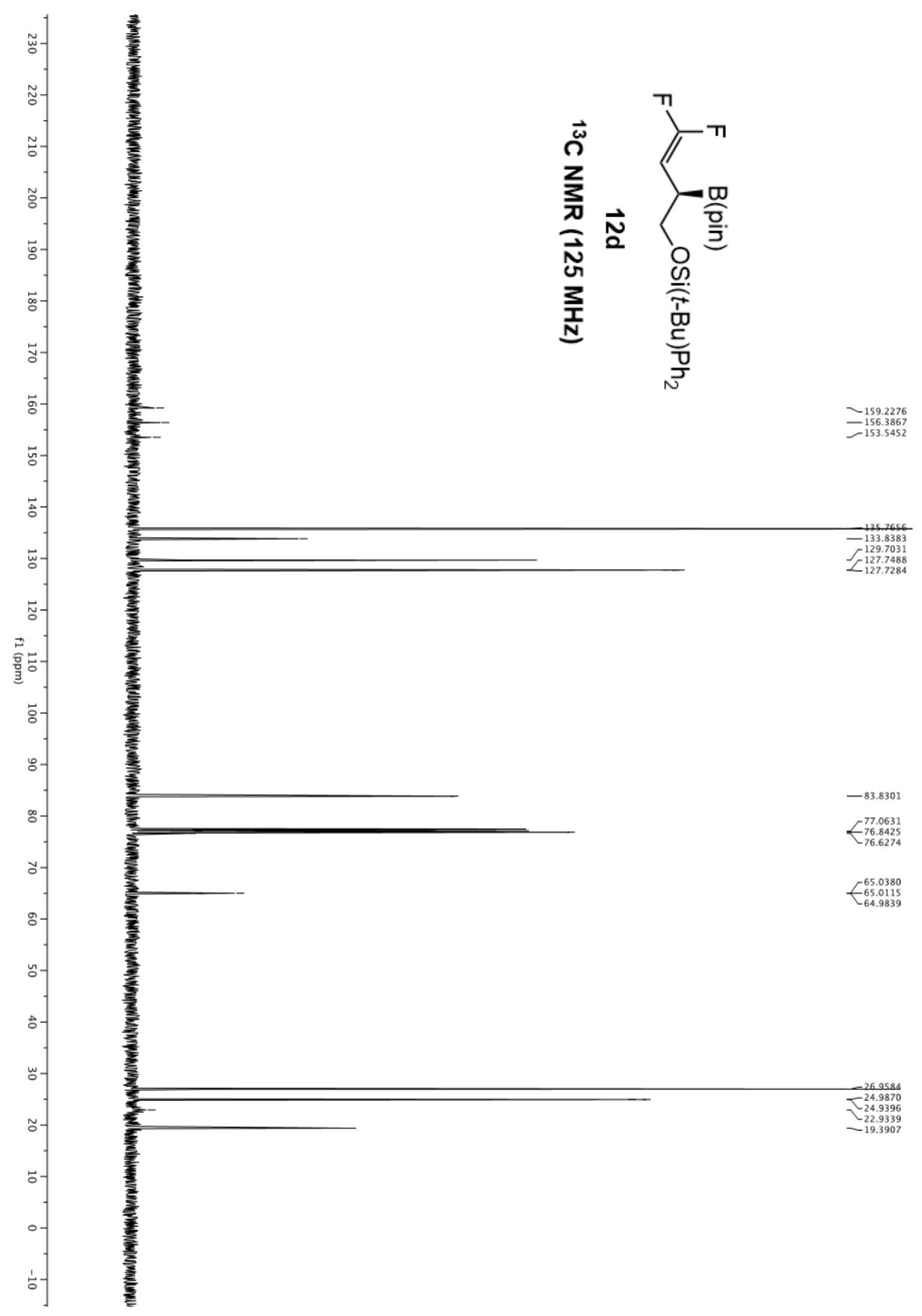




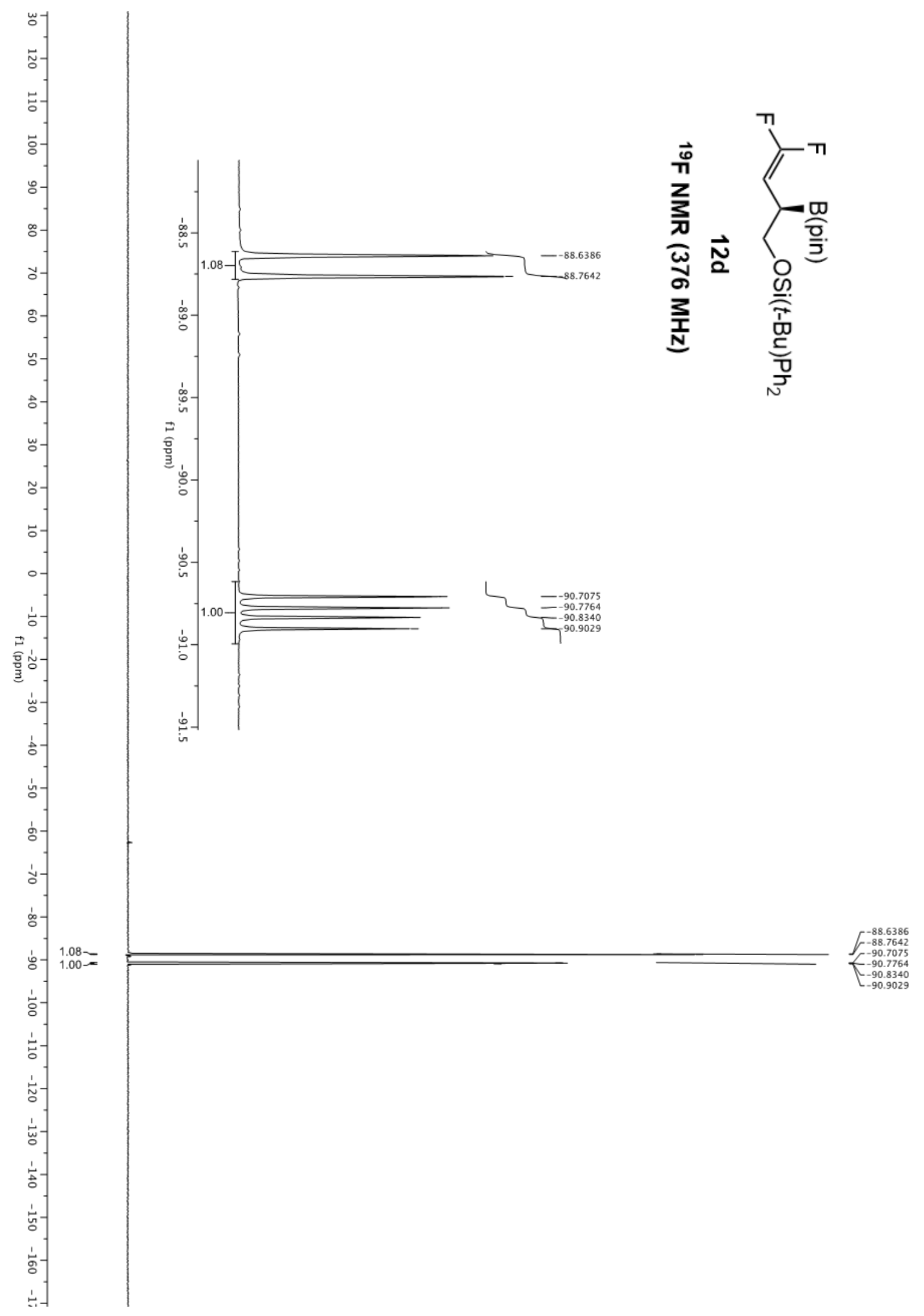




$$
{ }_{5}^{5}
$$




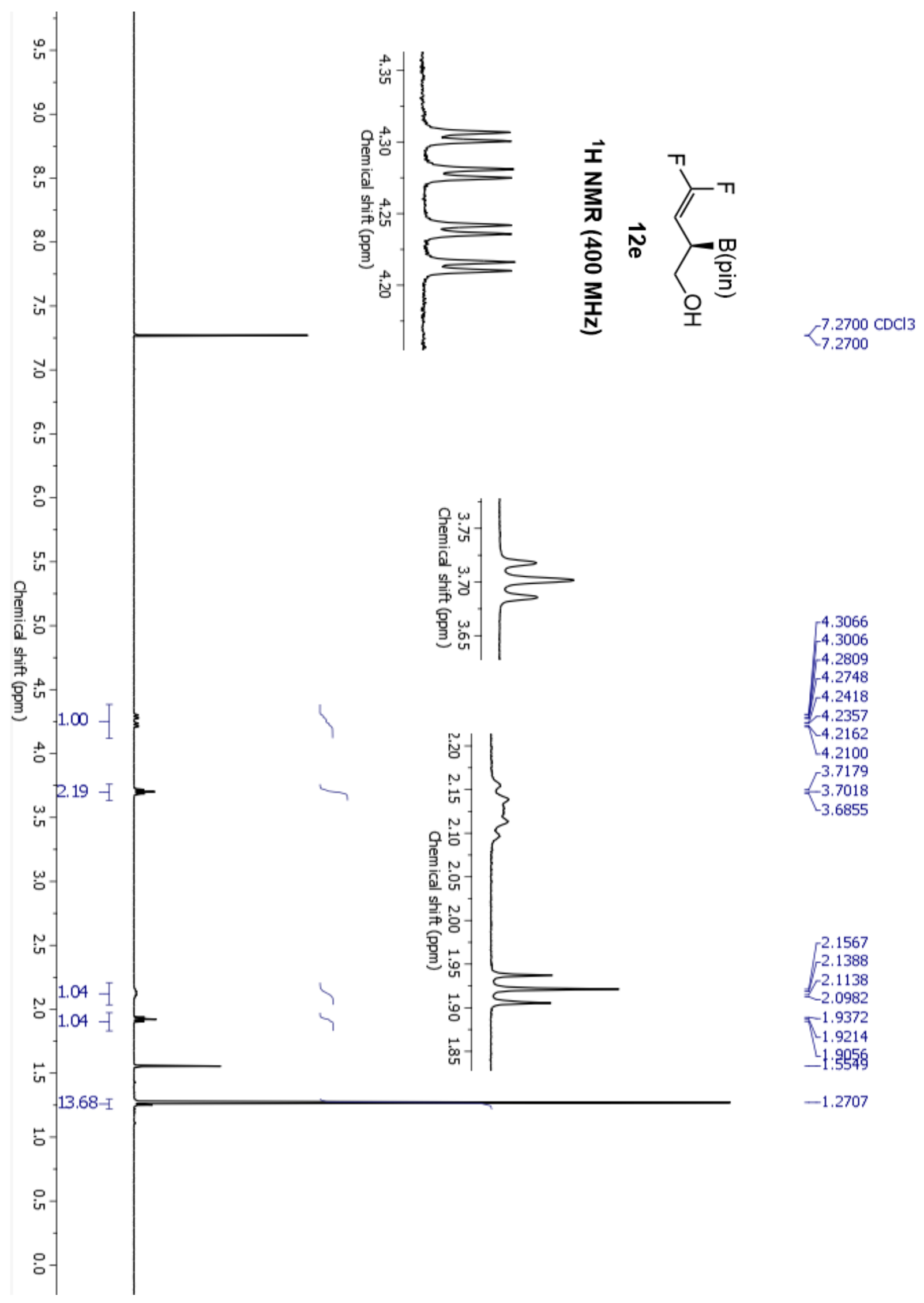




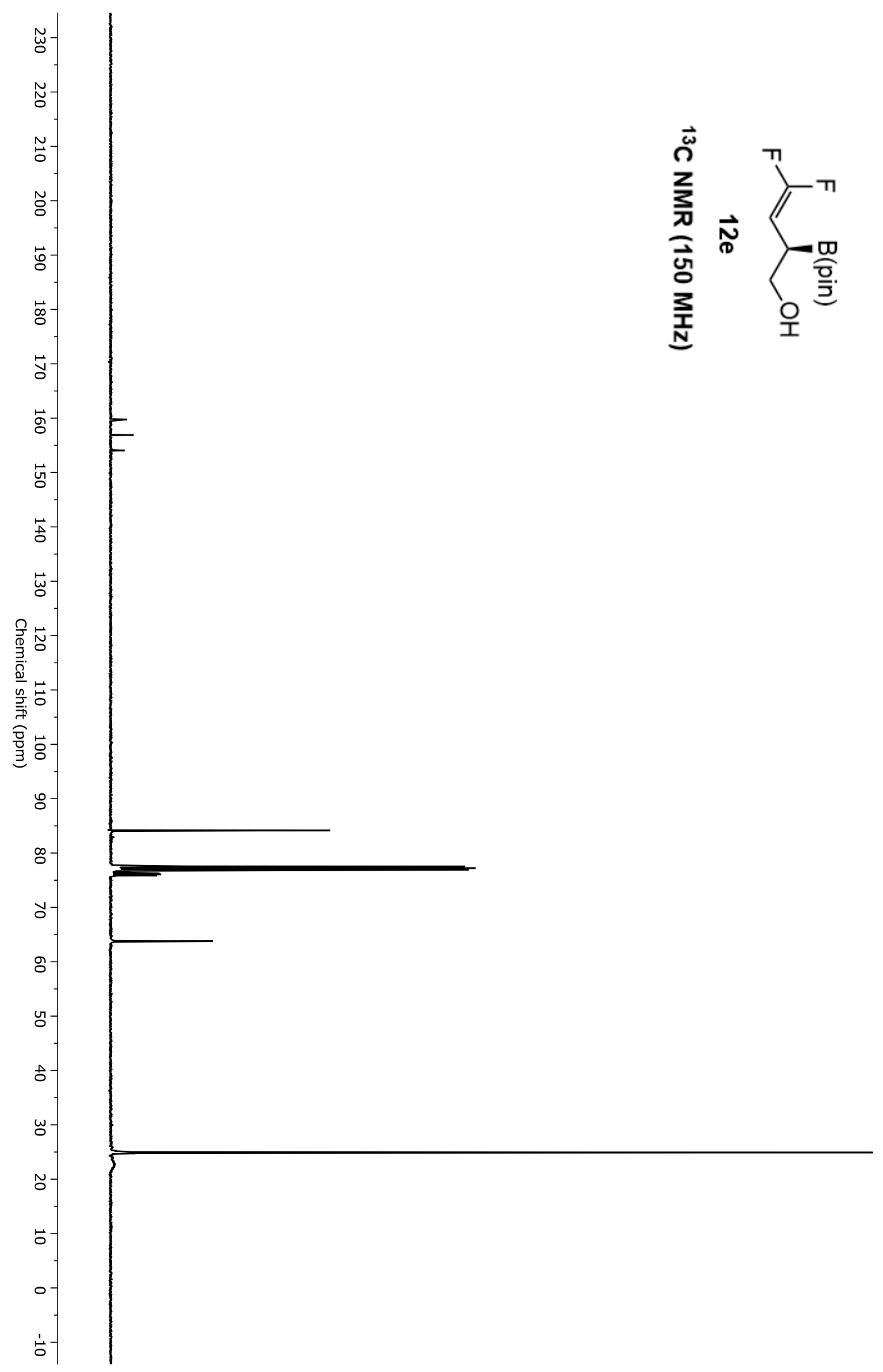




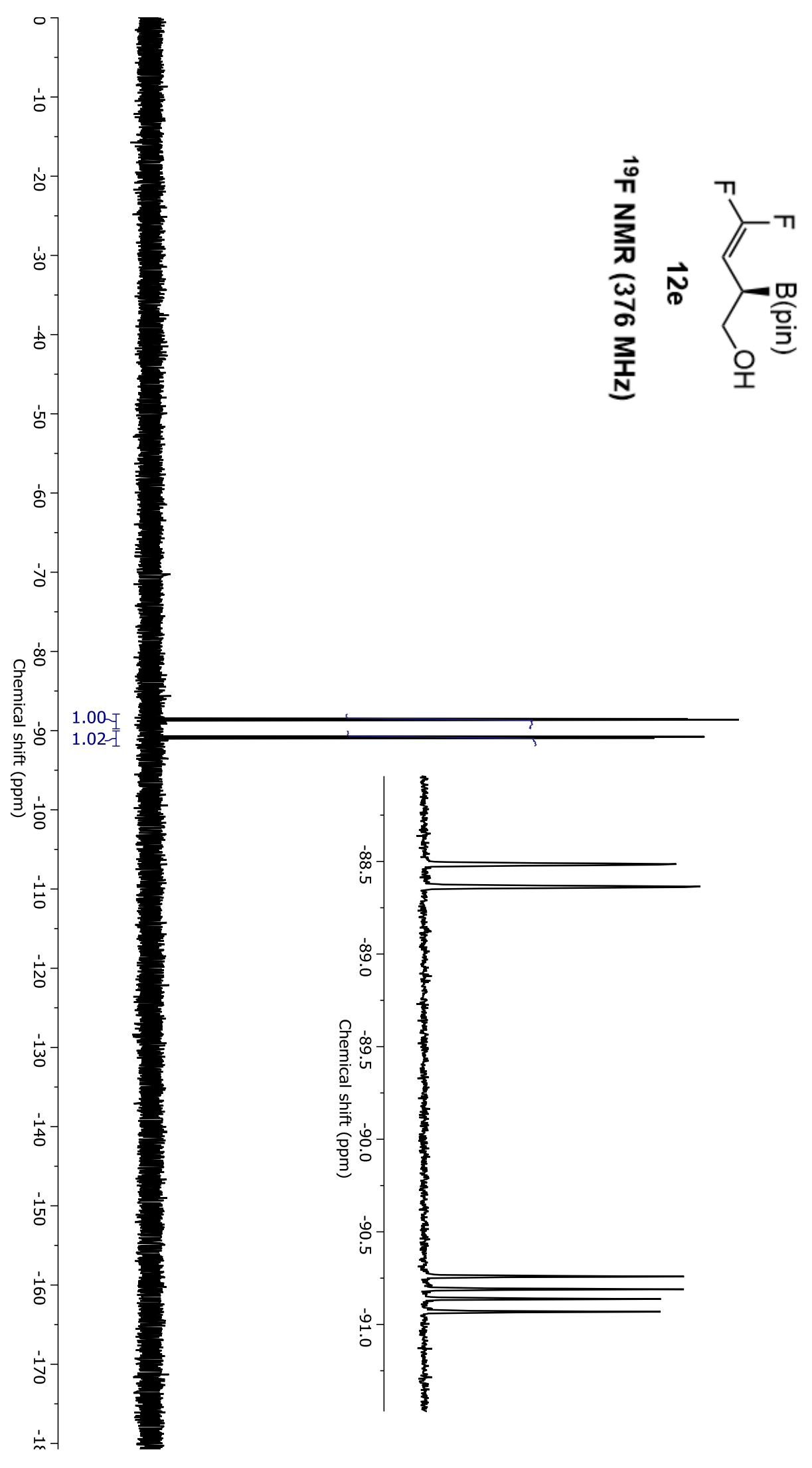




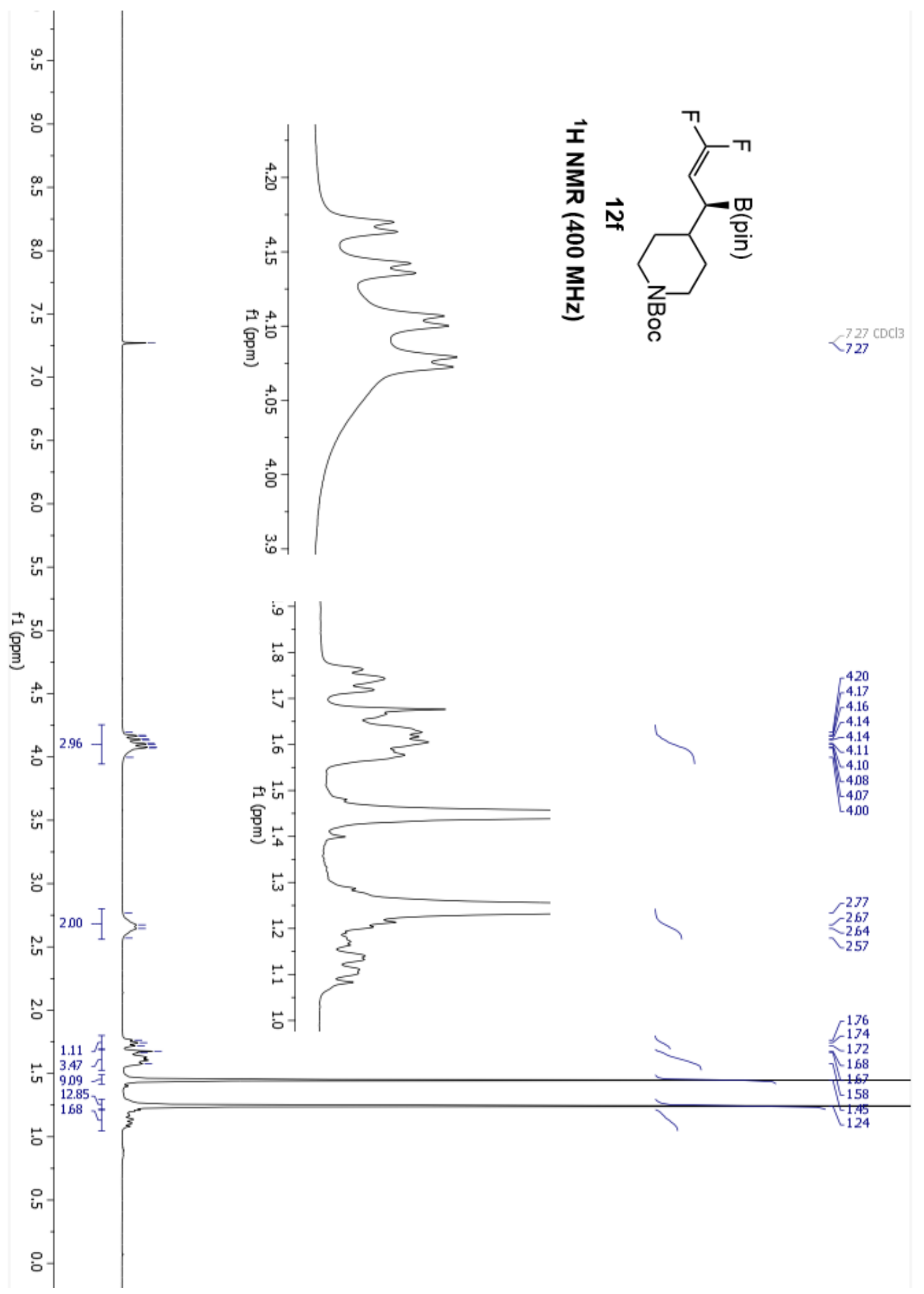




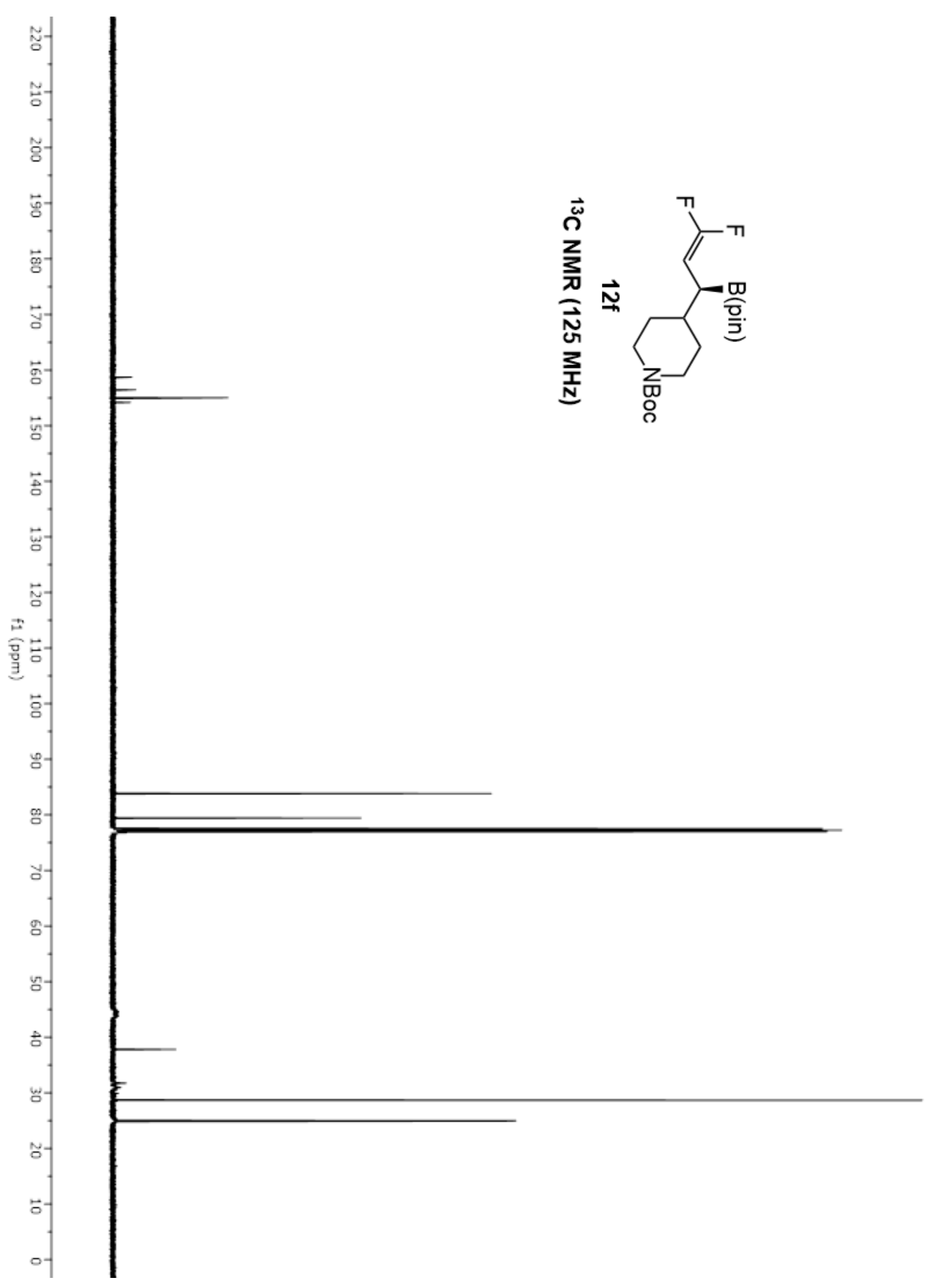


Paioti, et al.; Supporting Information, Part I; Page S177

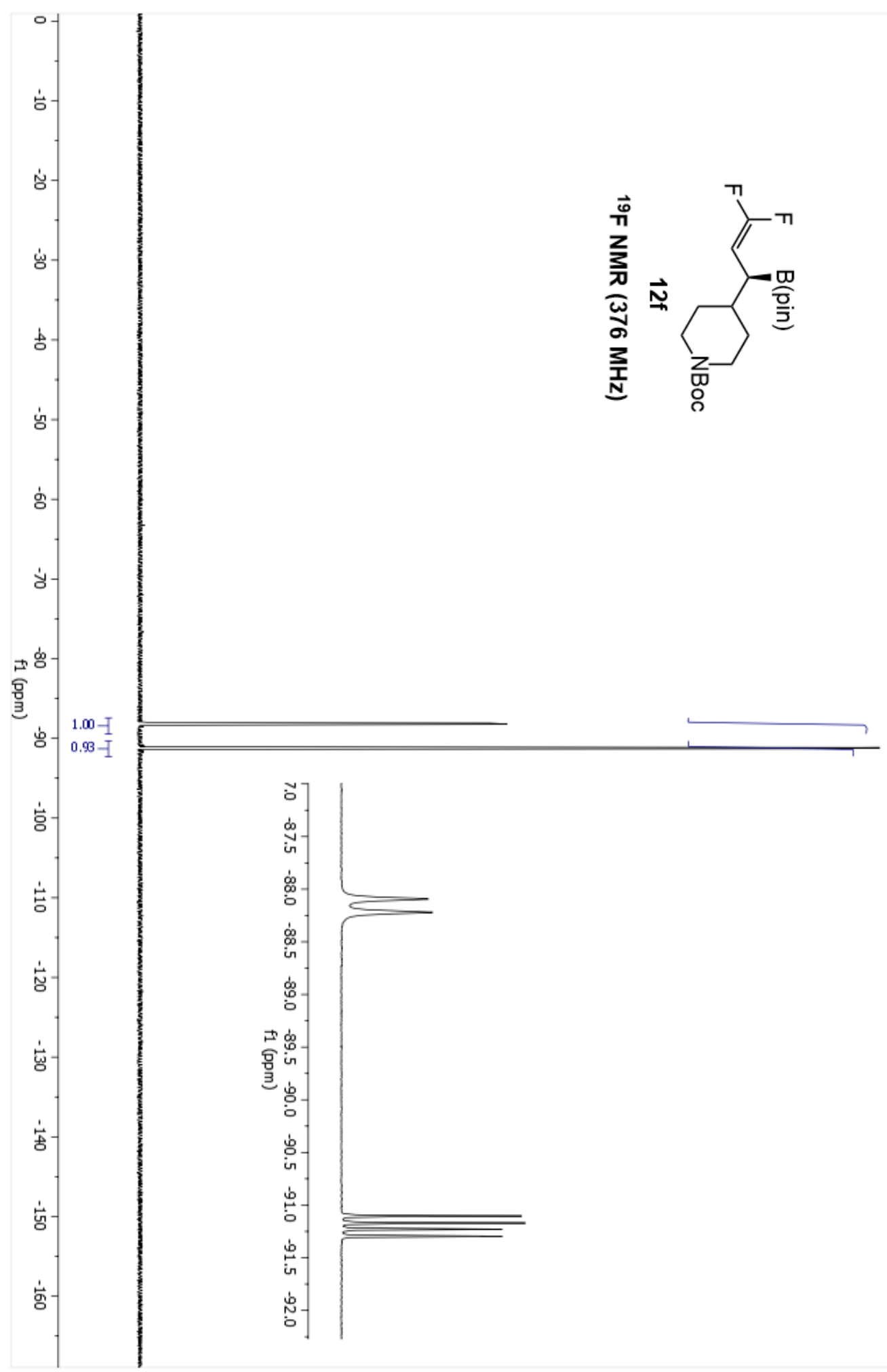


Paioti, et al.; Supporting Information, Part I; Page S178

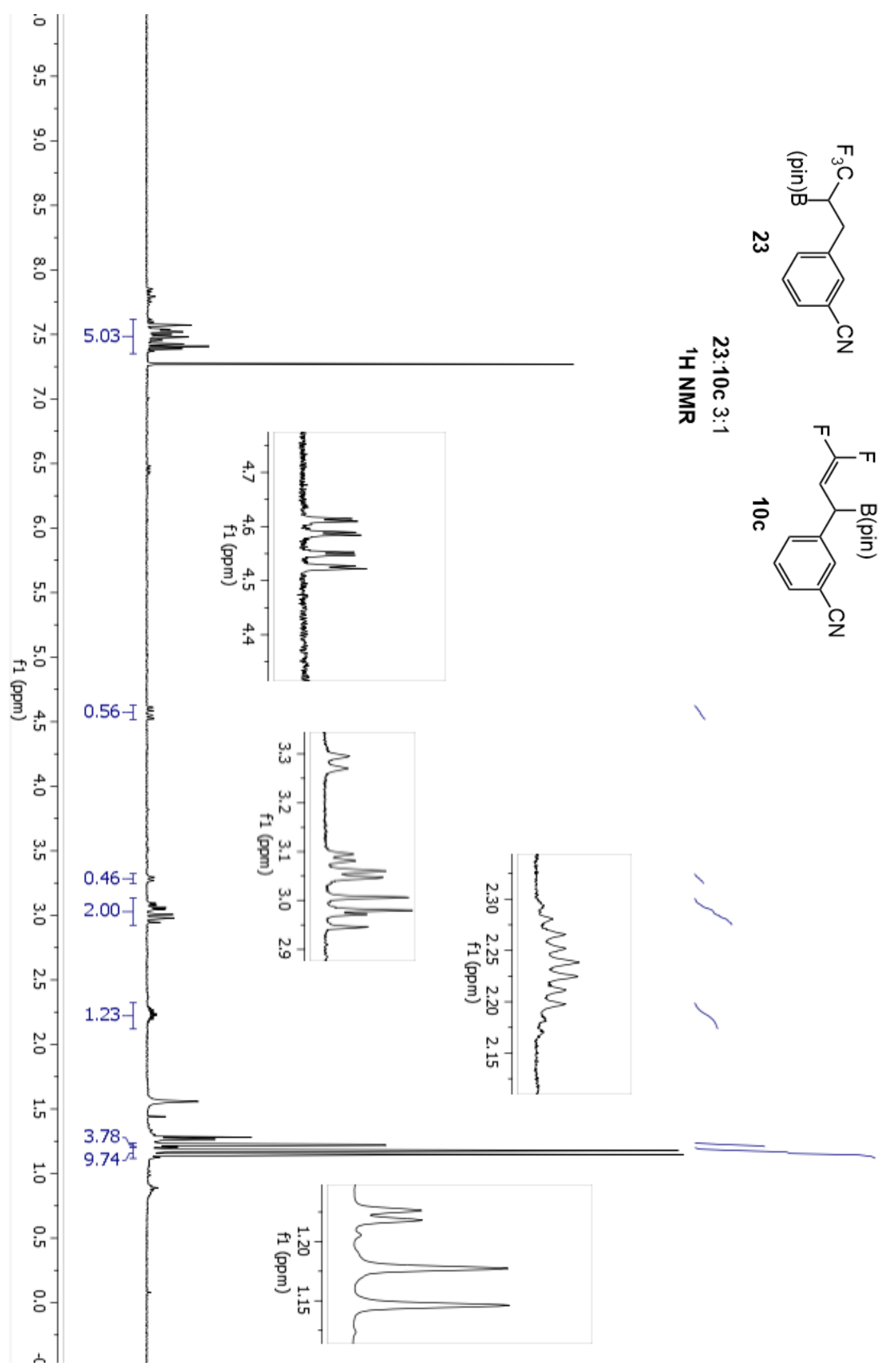



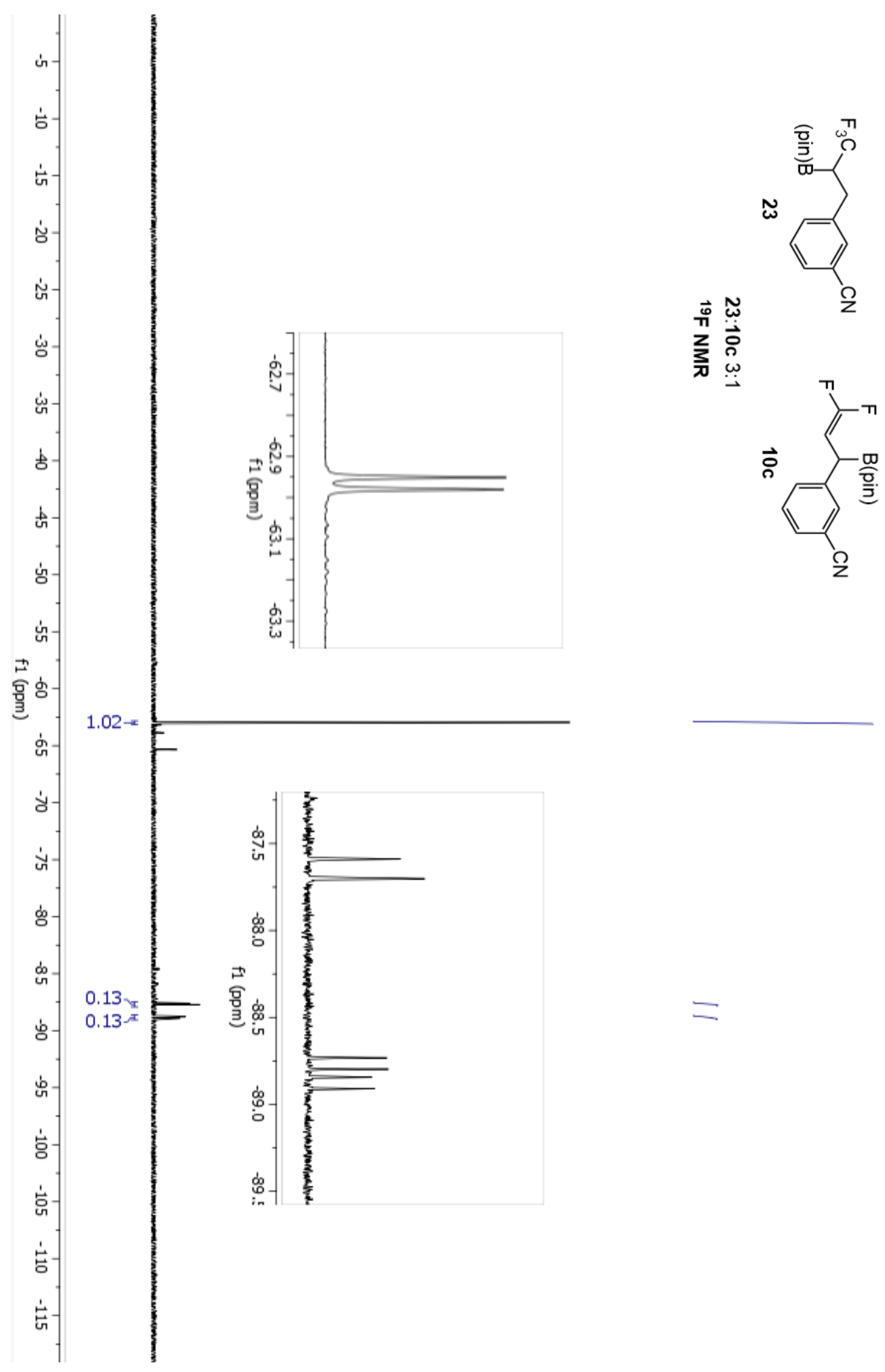
Paioti, et al.; Supporting Information, Part I; Page S180

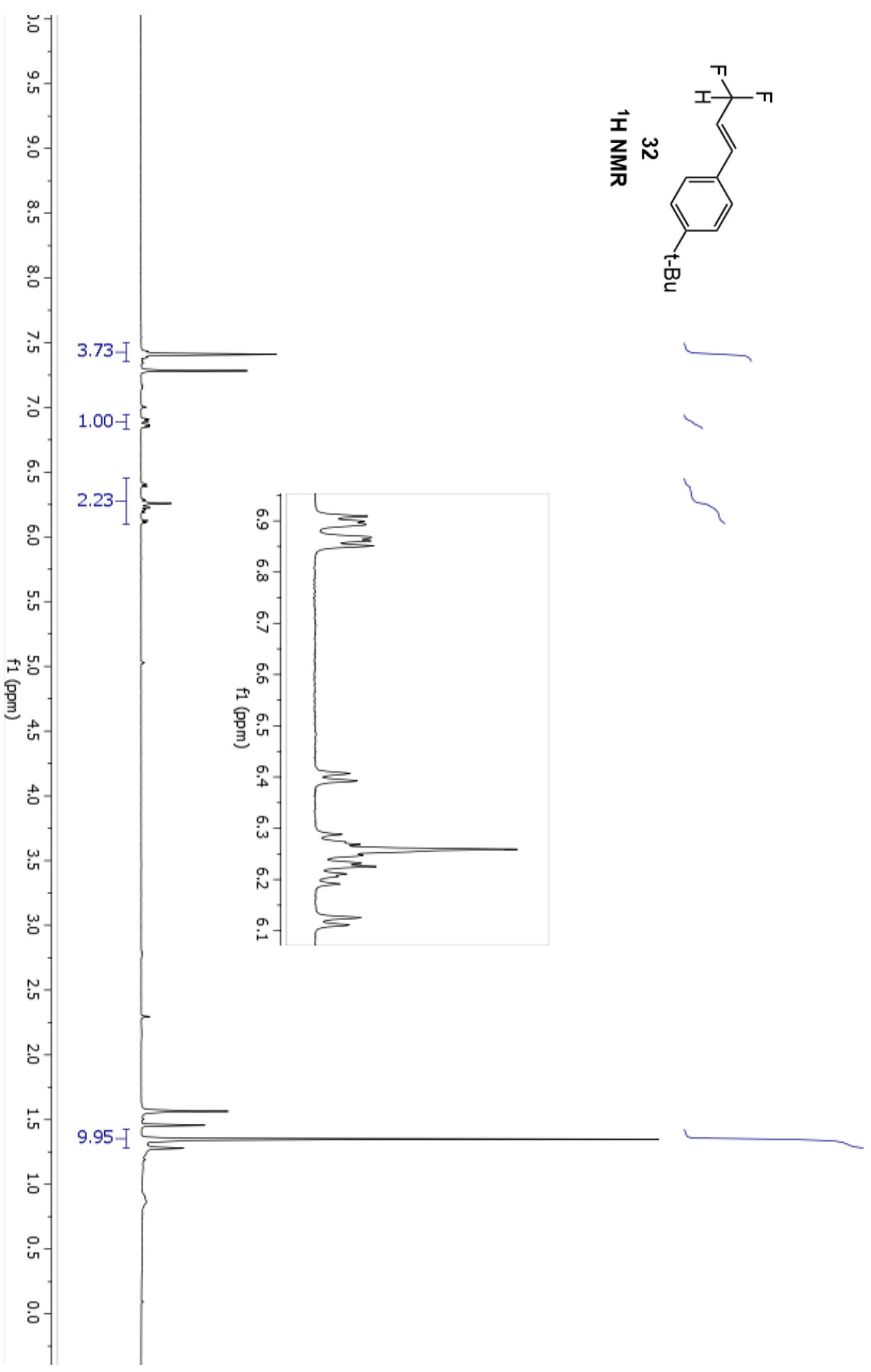




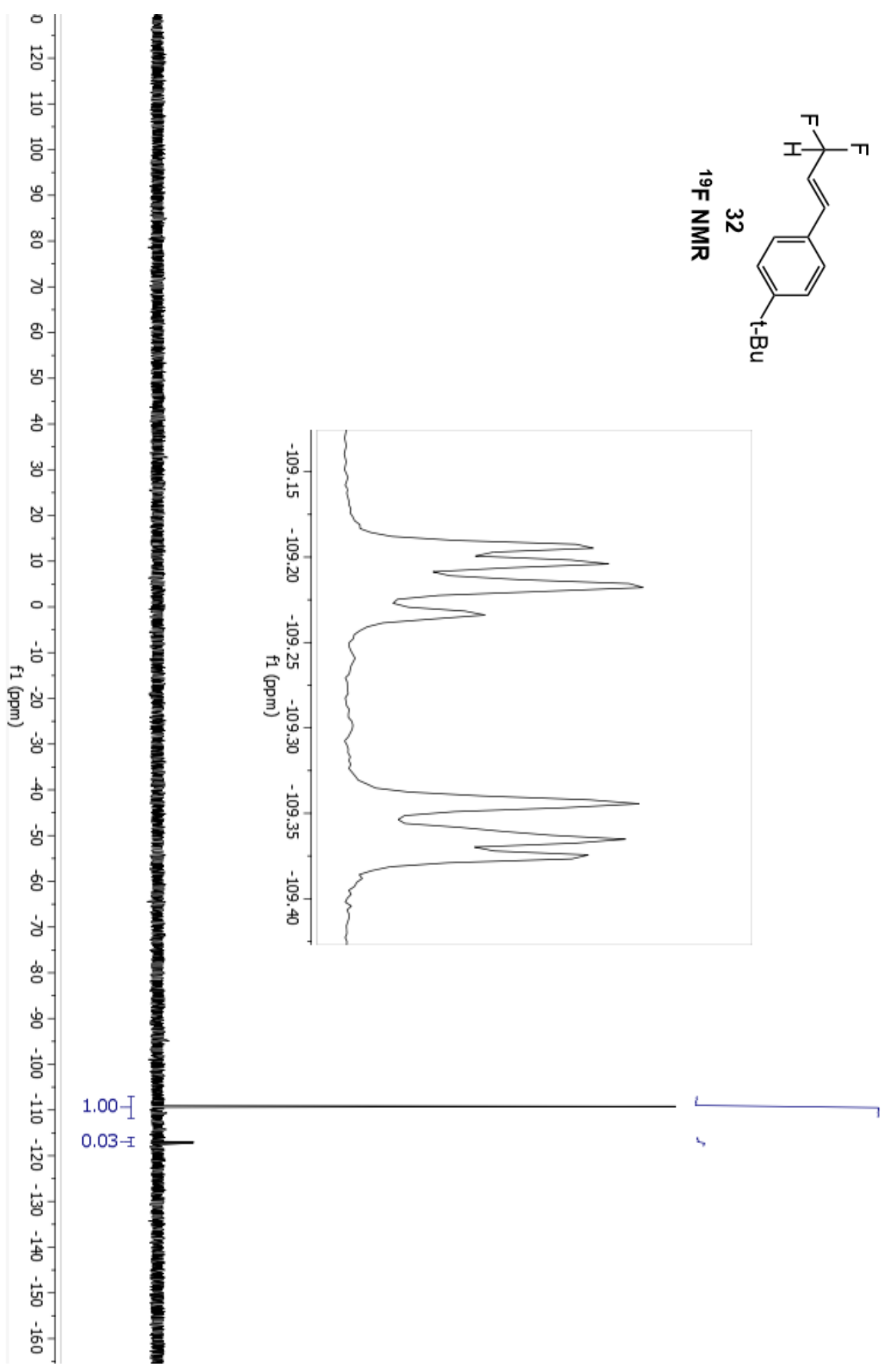


Paioti, et al.; Supporting Information, Part I; Page S182

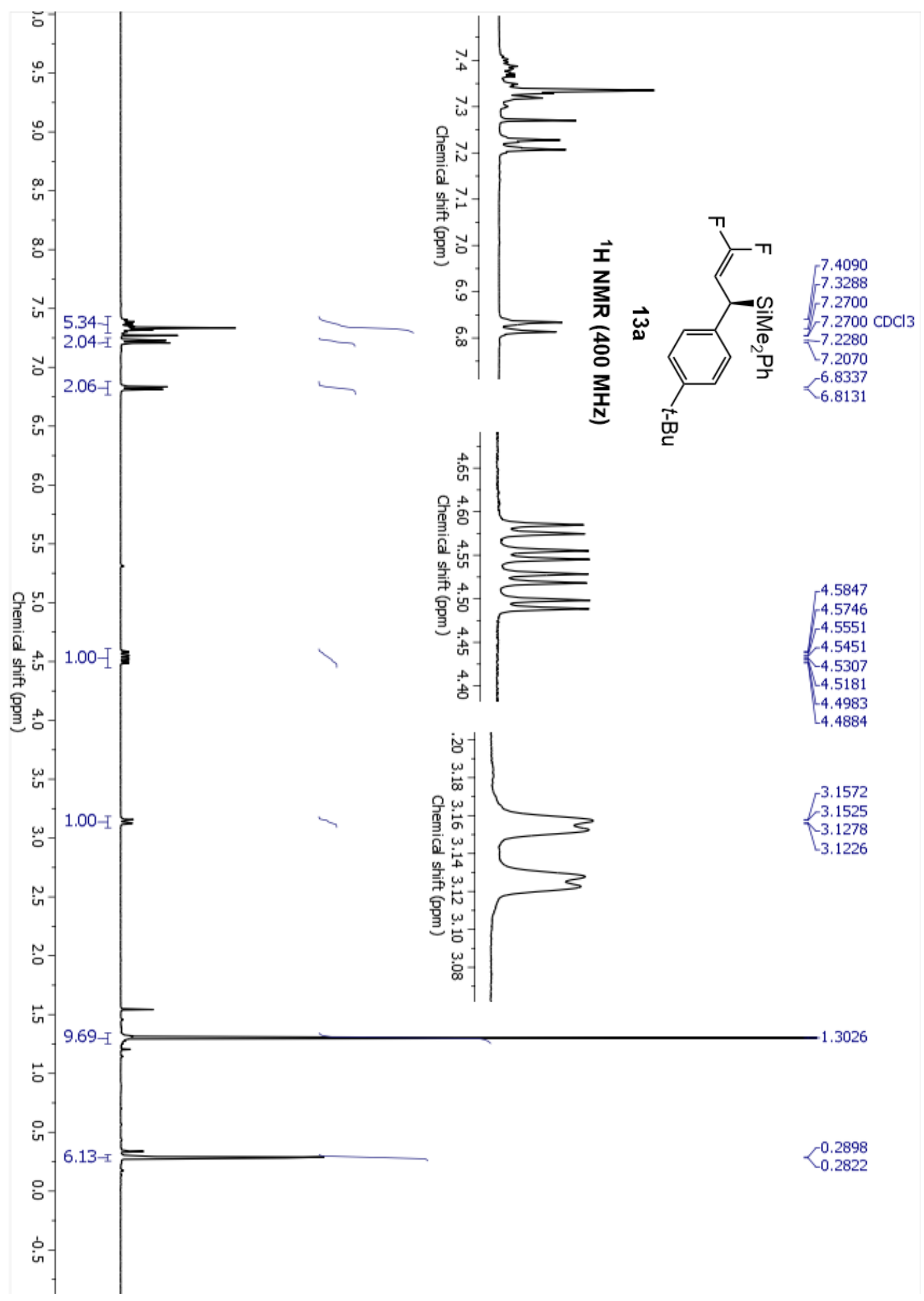




$$
E^{\prime \prime}
$$




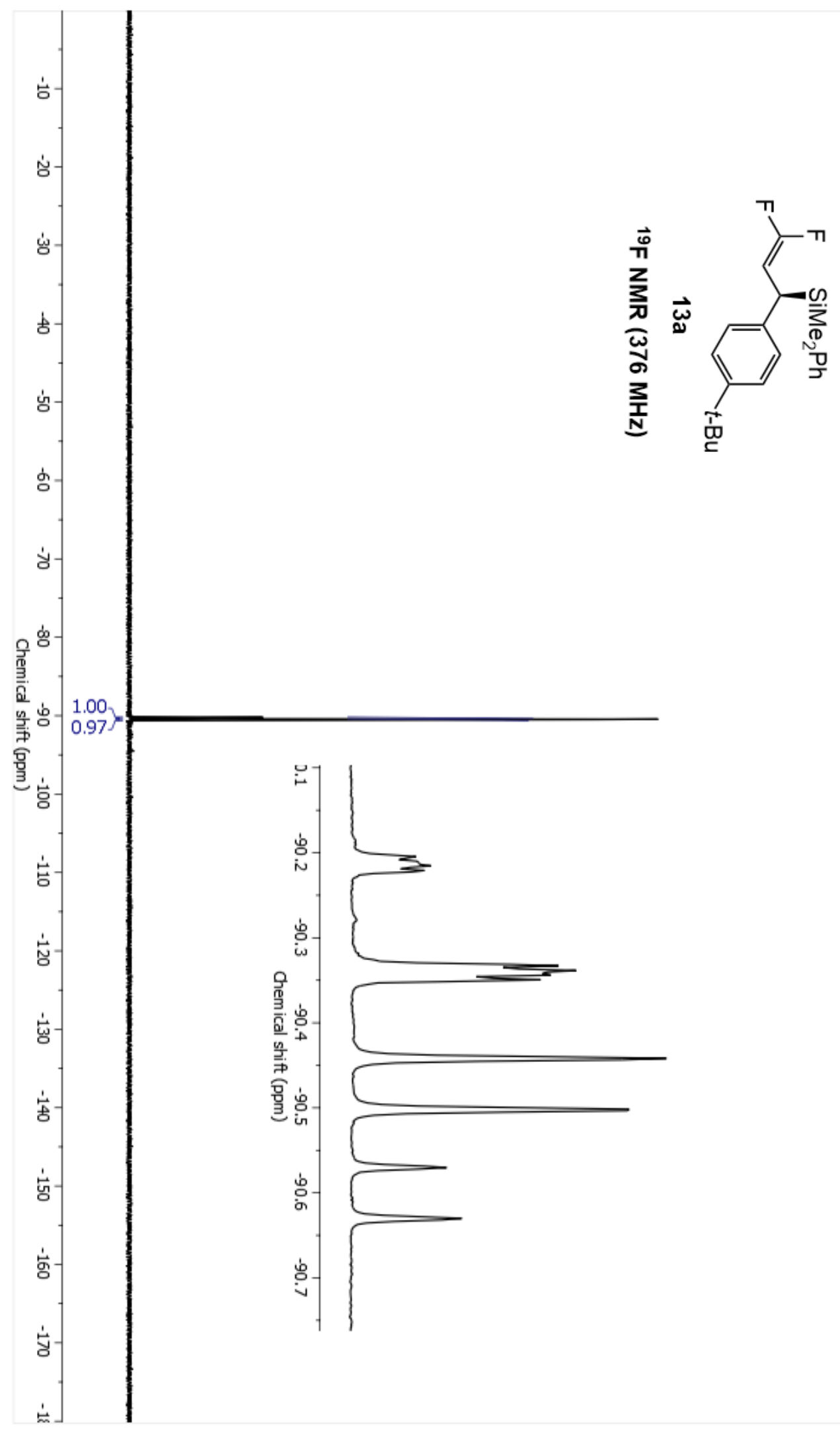




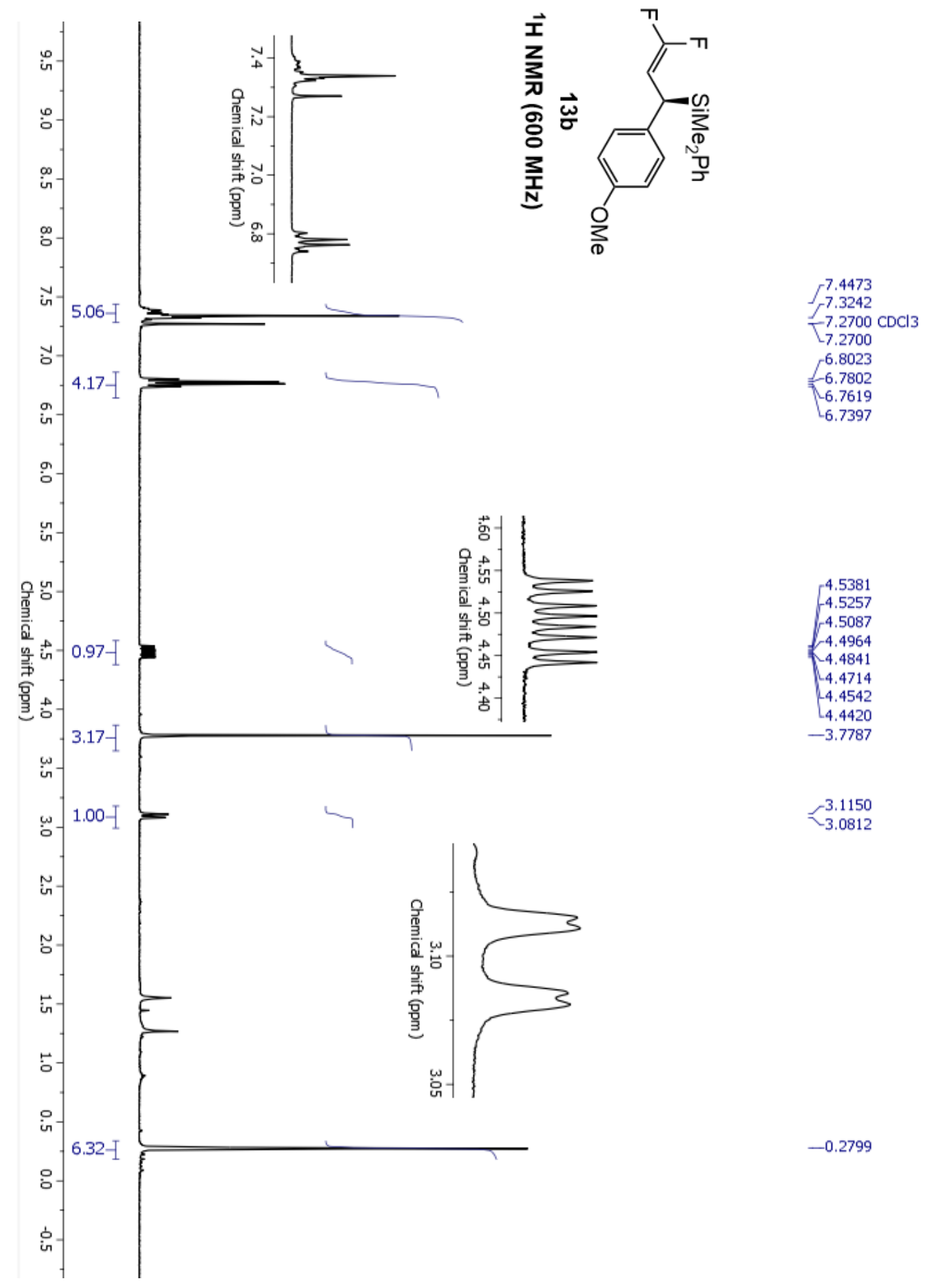




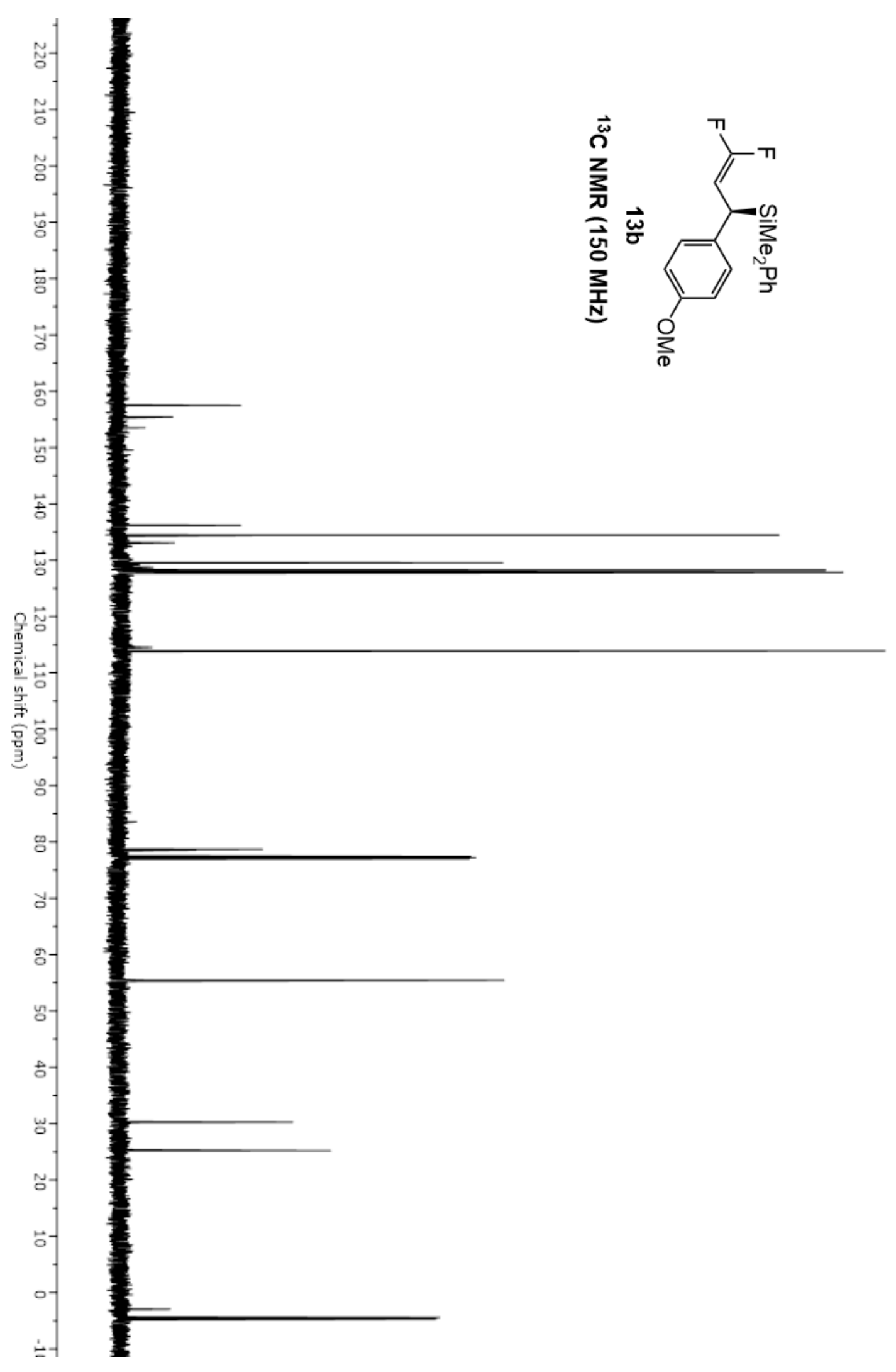




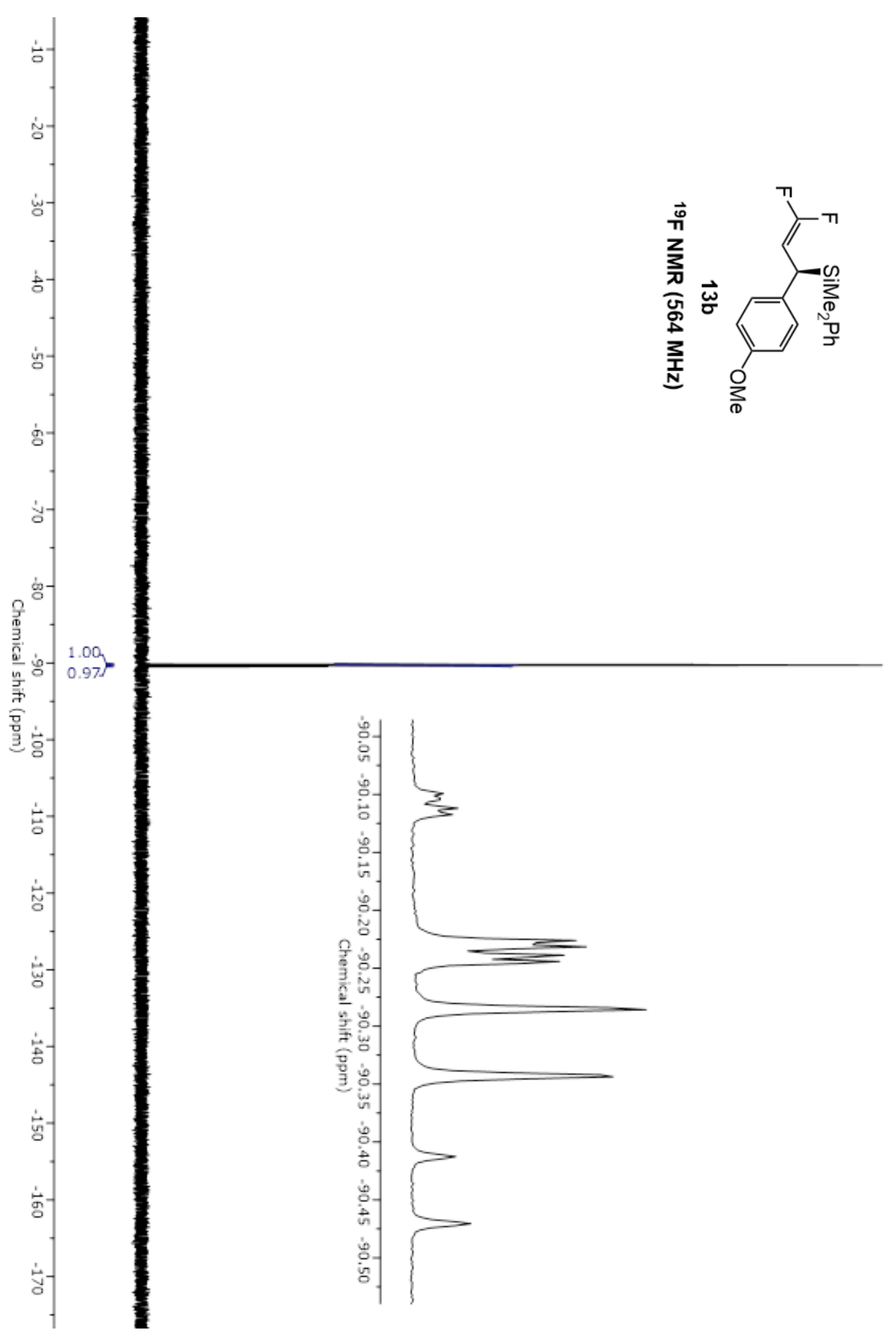




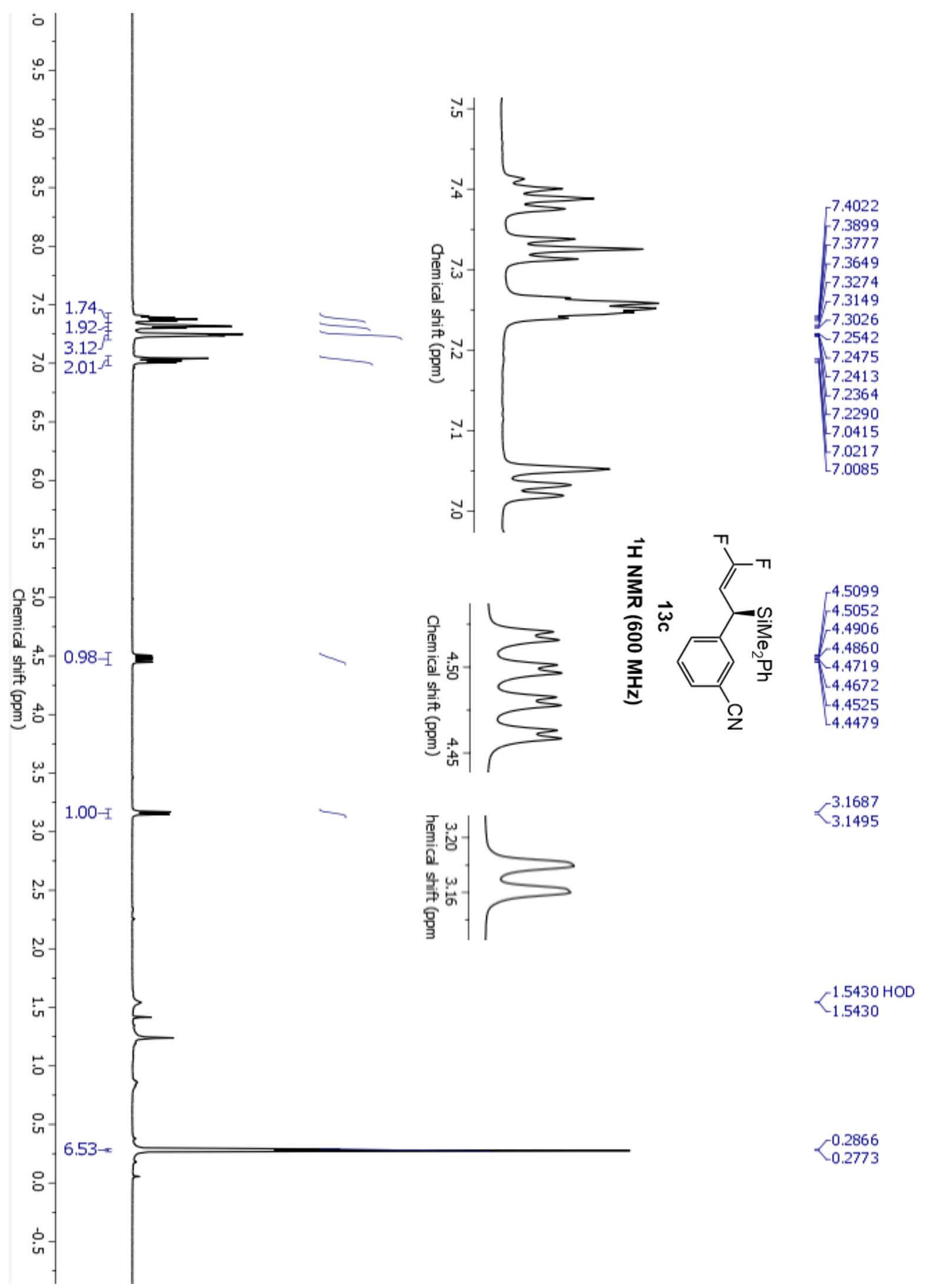




$$
E^{\prime \prime}
$$




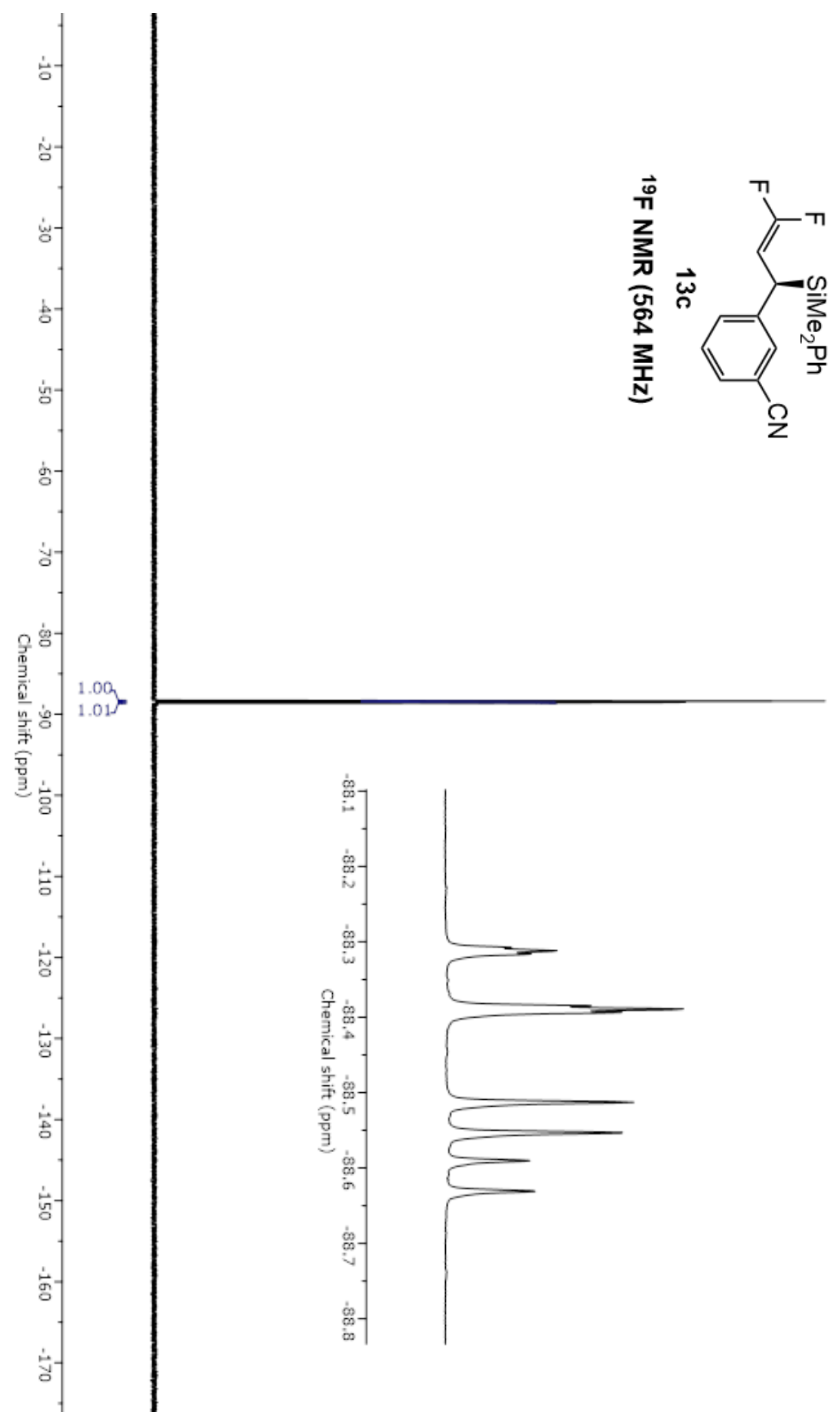




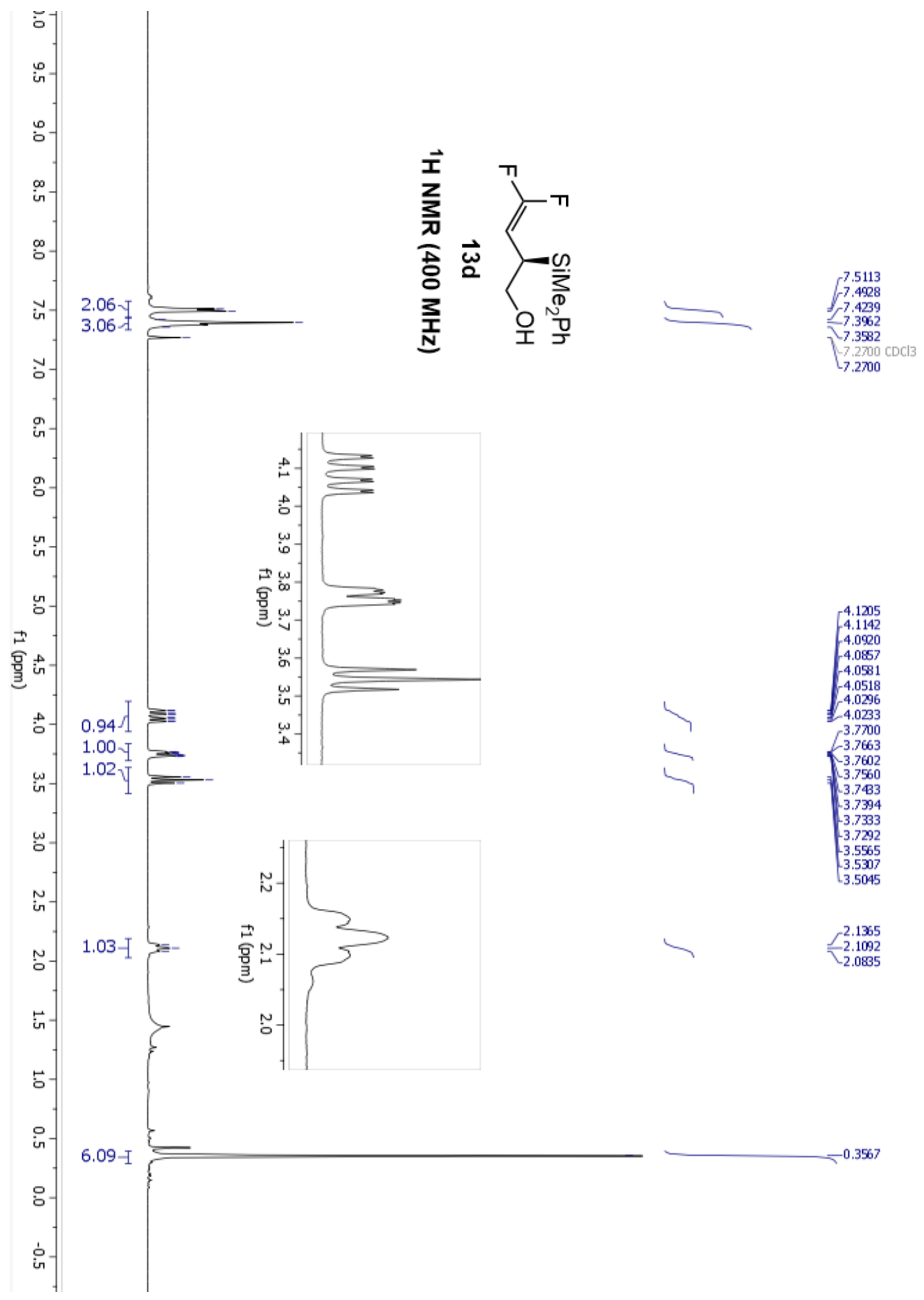




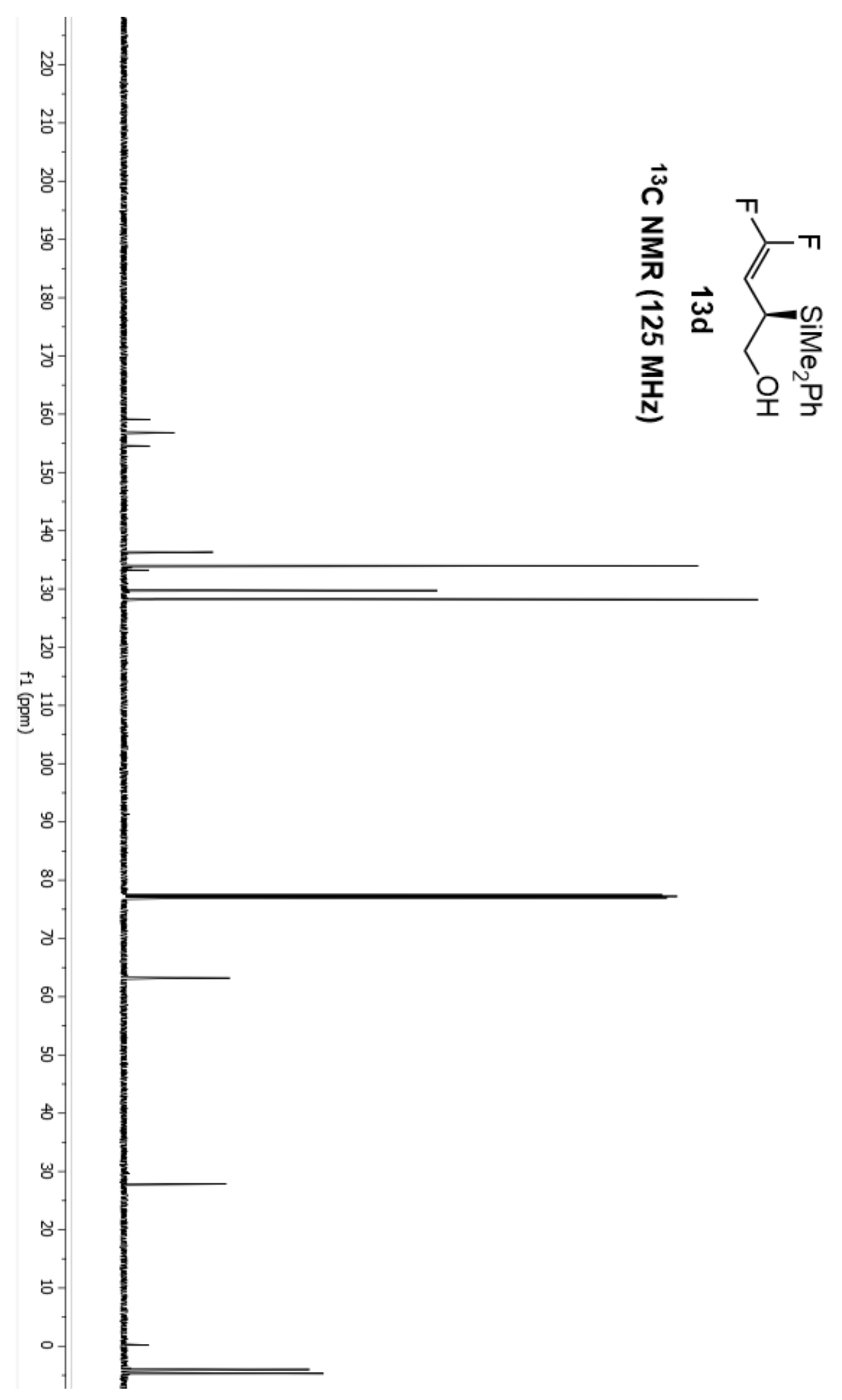


Paioti, et al.; Supporting Information, Part I; Page S193

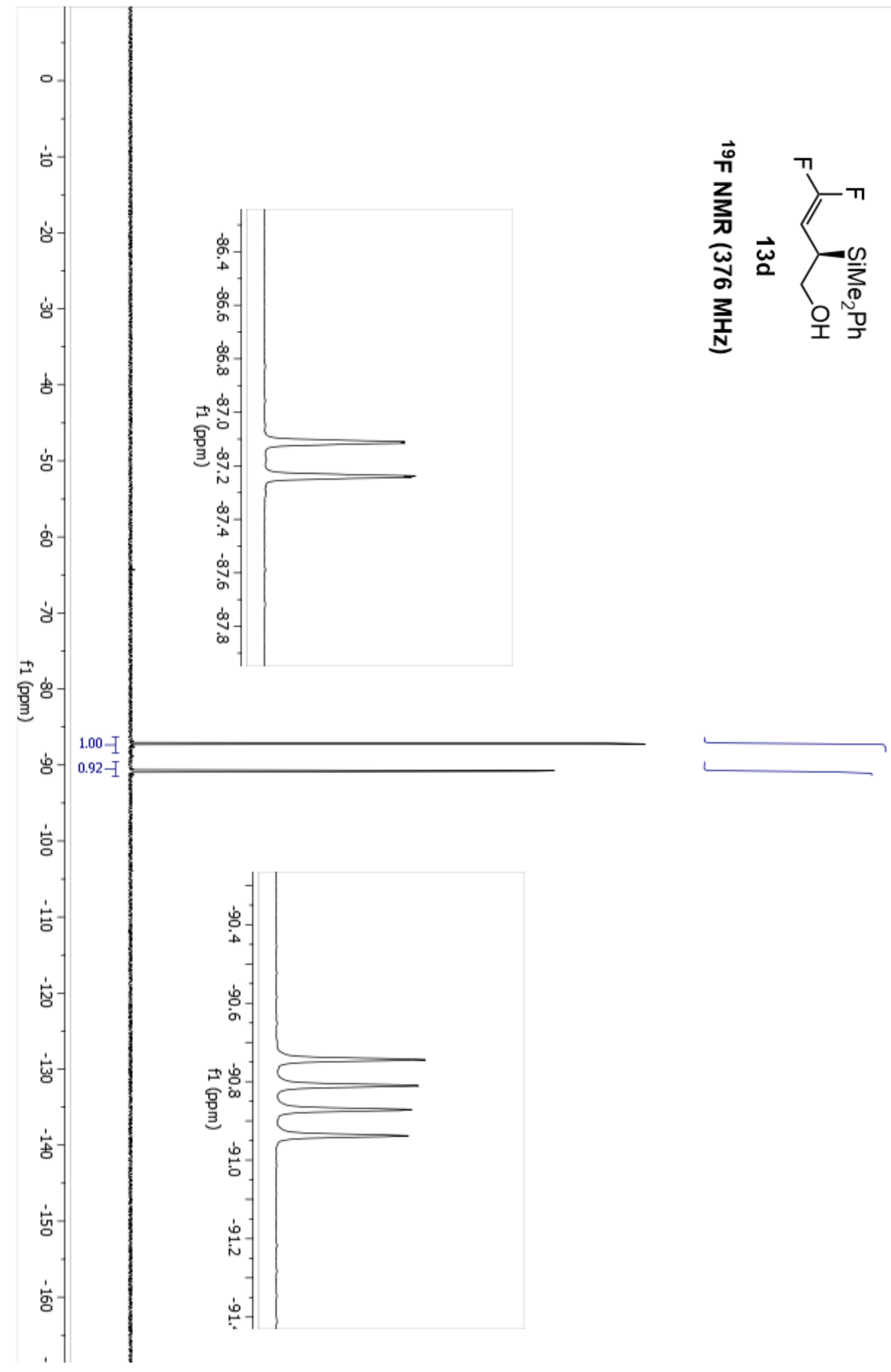




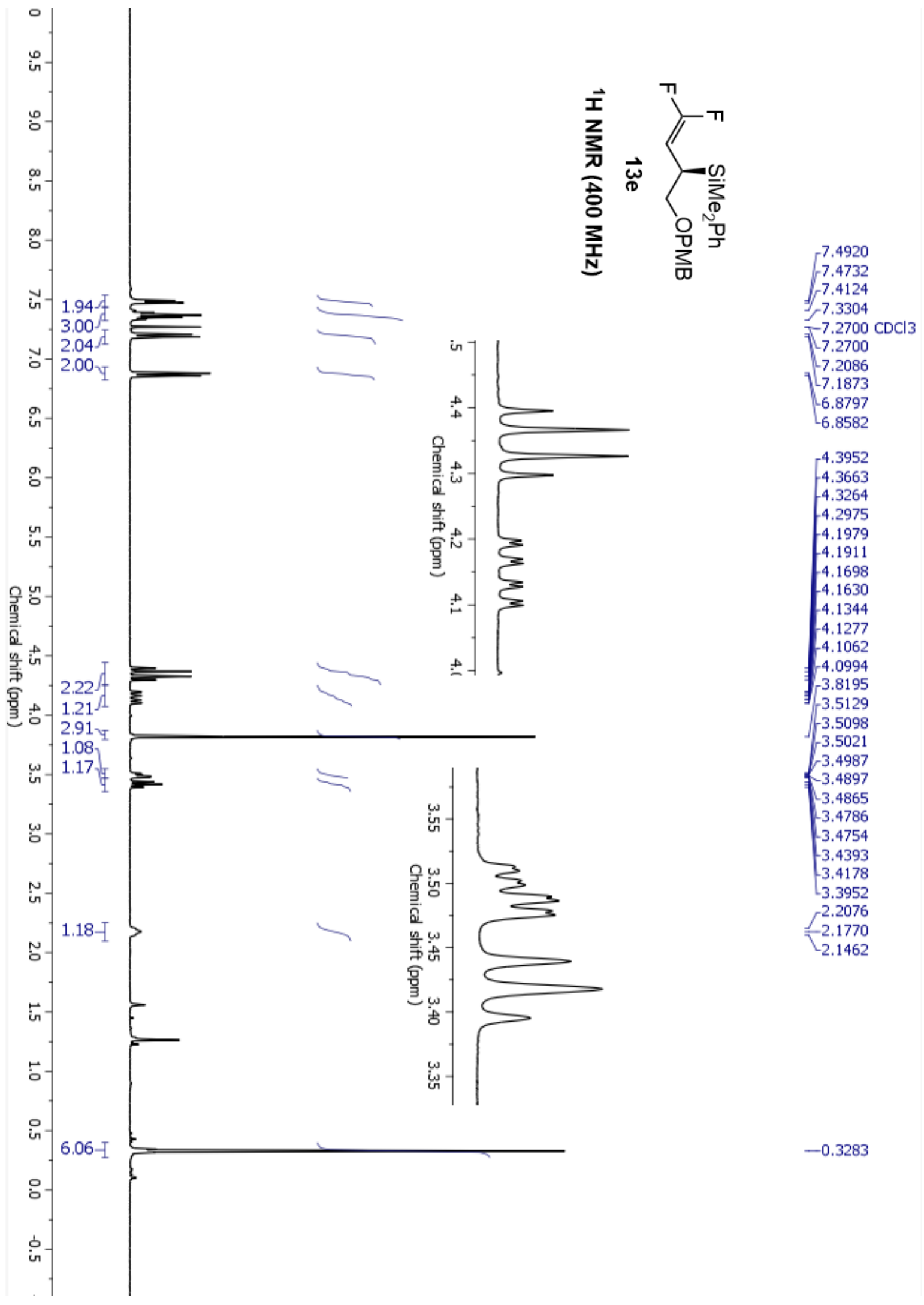




$$
k^{\prime \prime}
$$




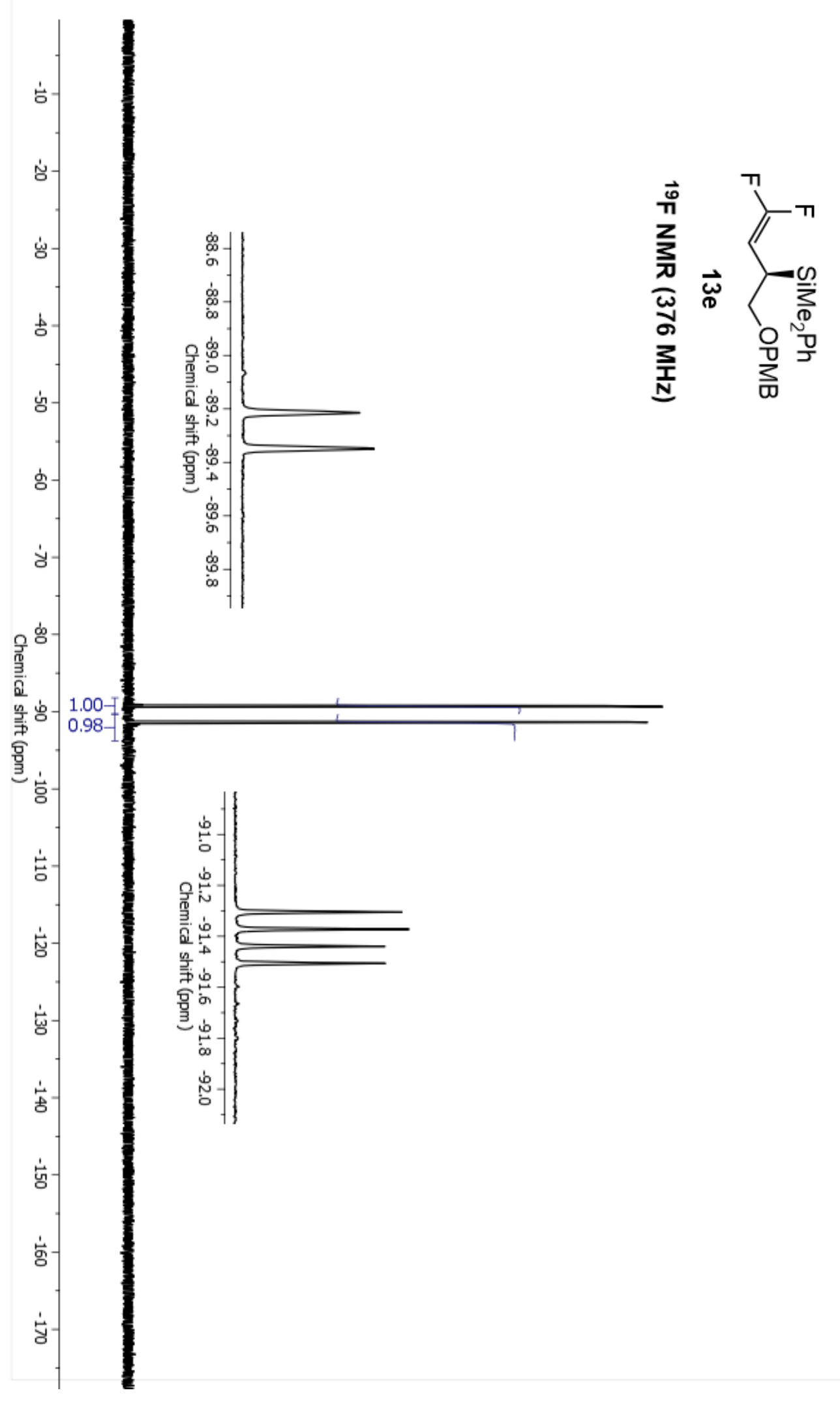


Paioti, et al.; Supporting Information, Part I; Page S197

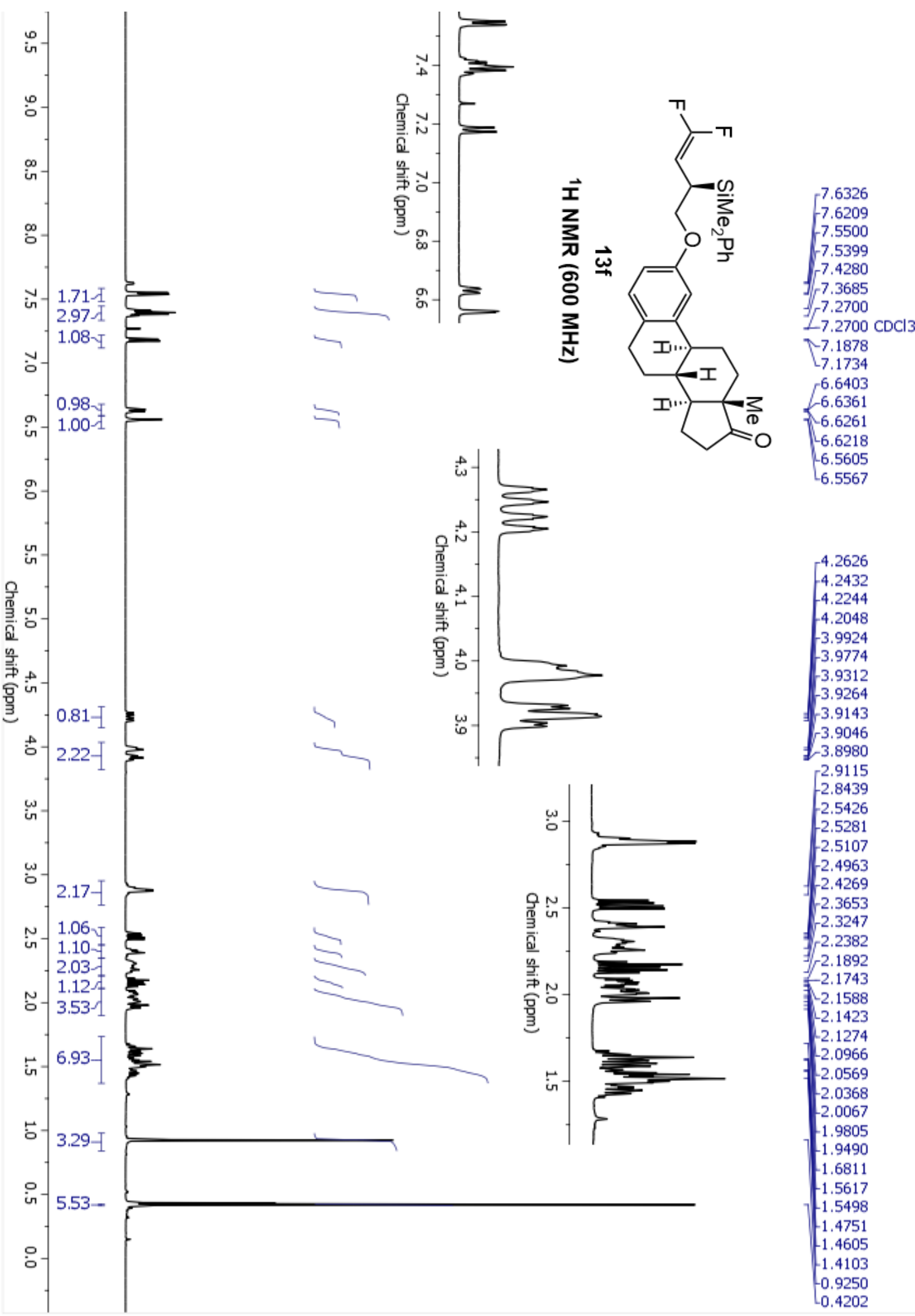




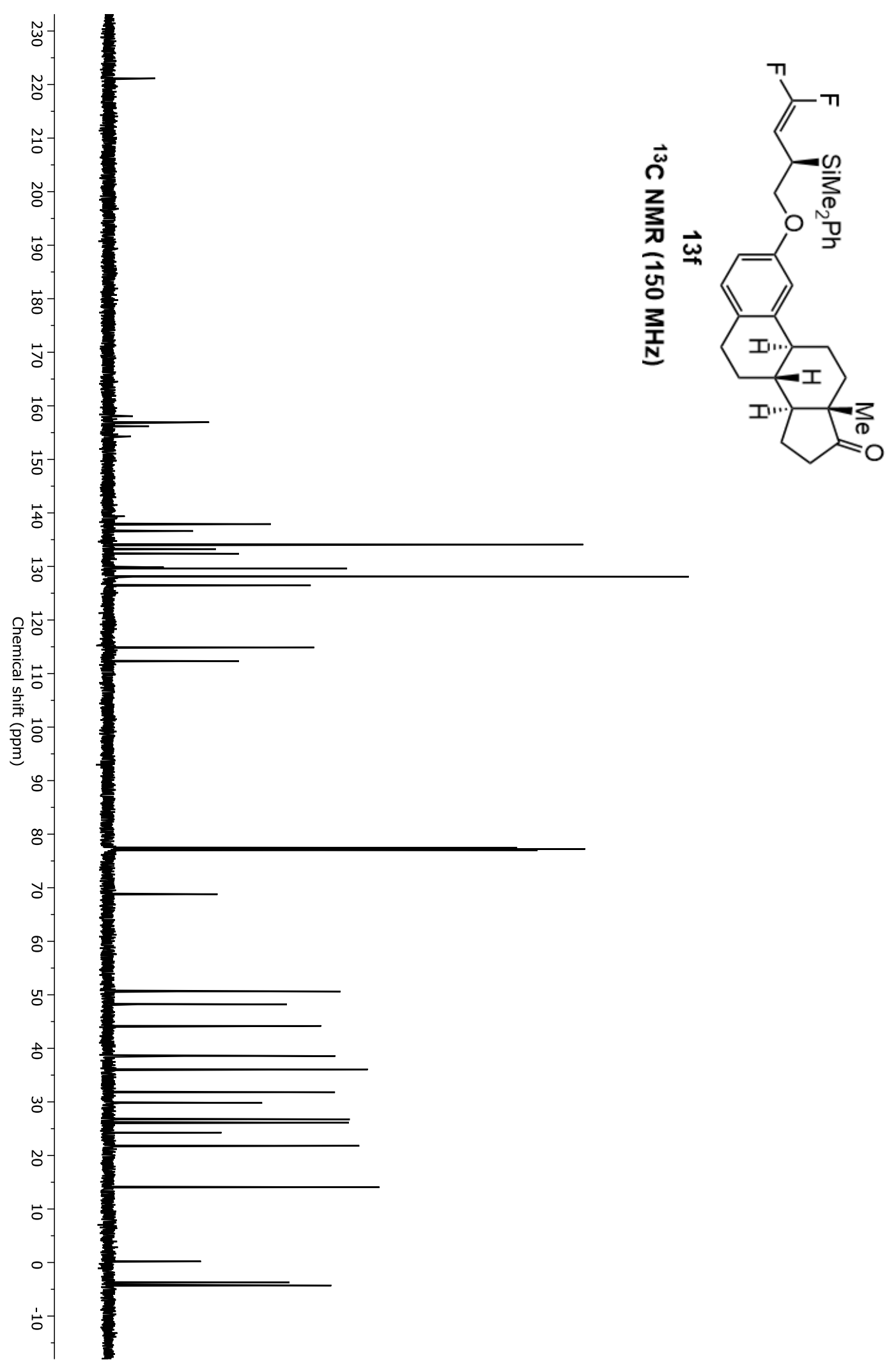




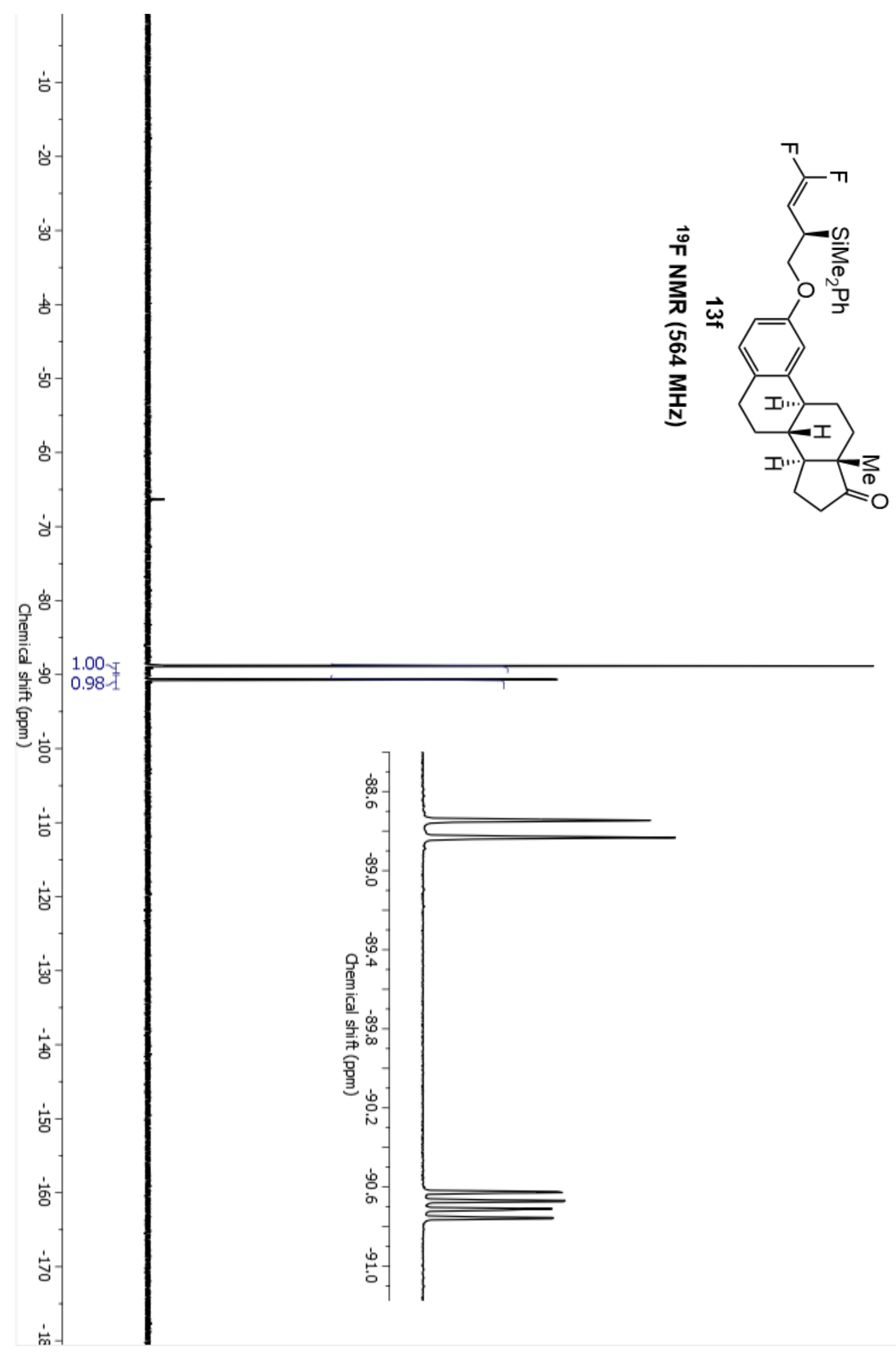


Paioti, et al.; Supporting Information, Part I; Page S200

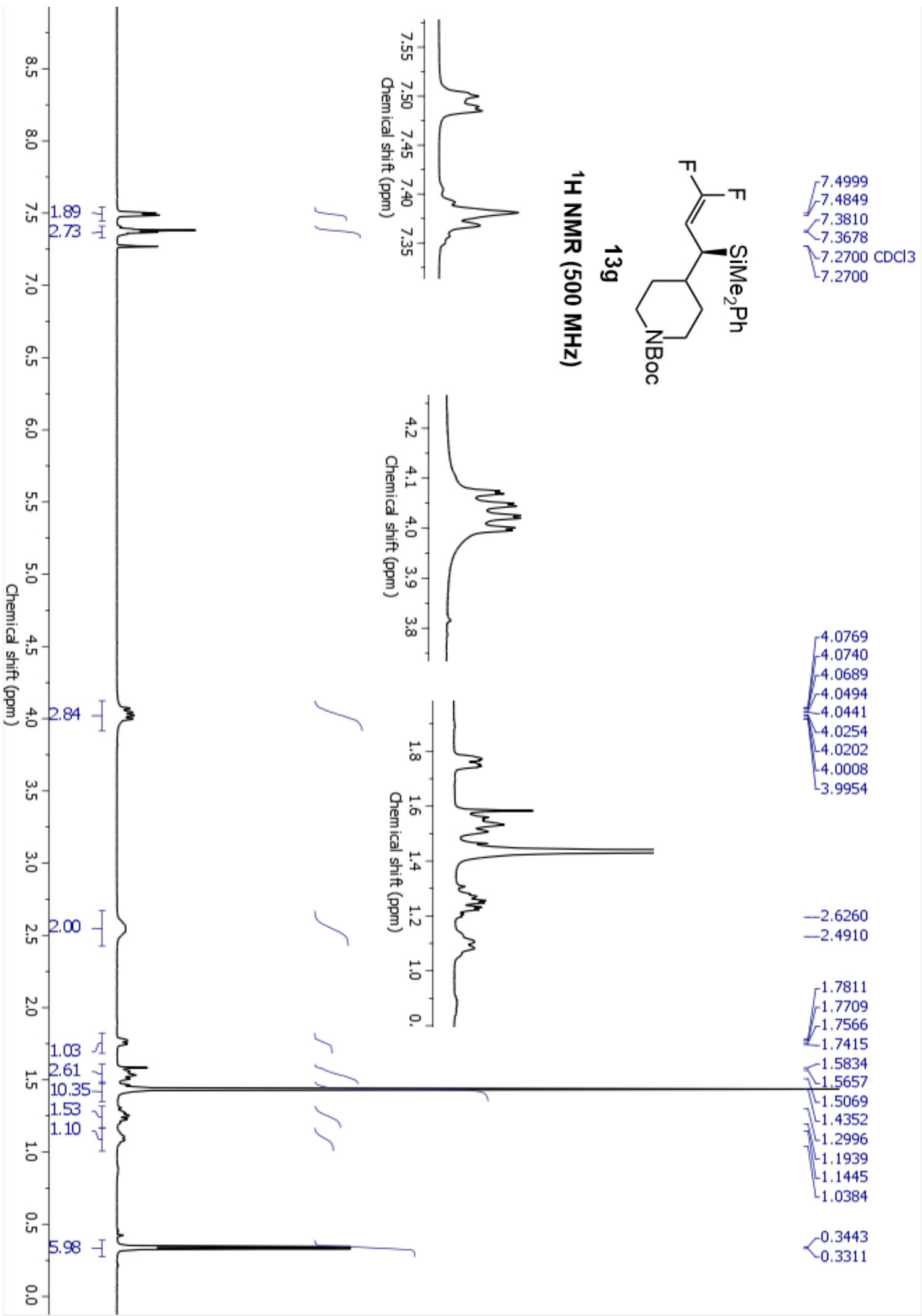




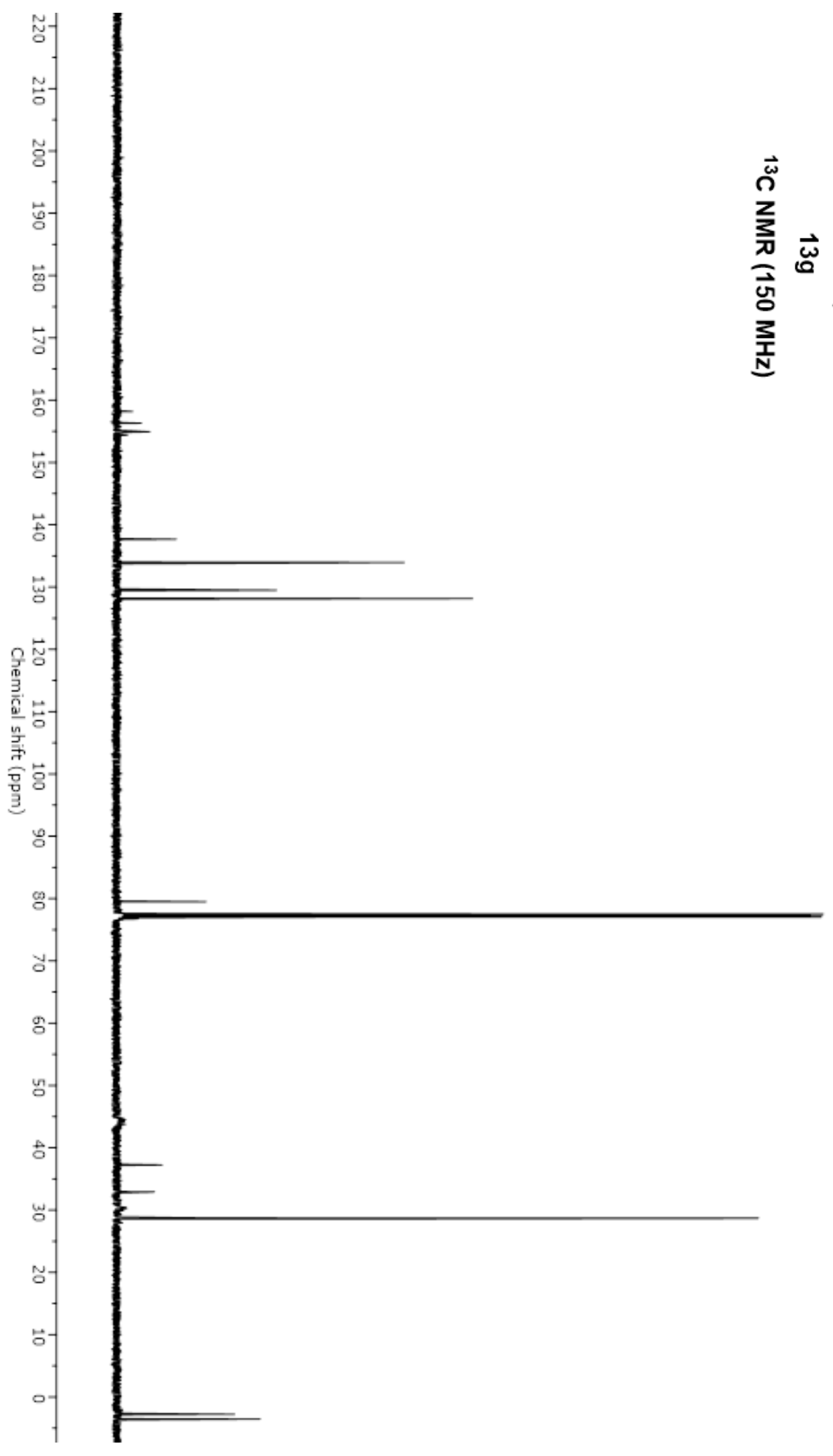




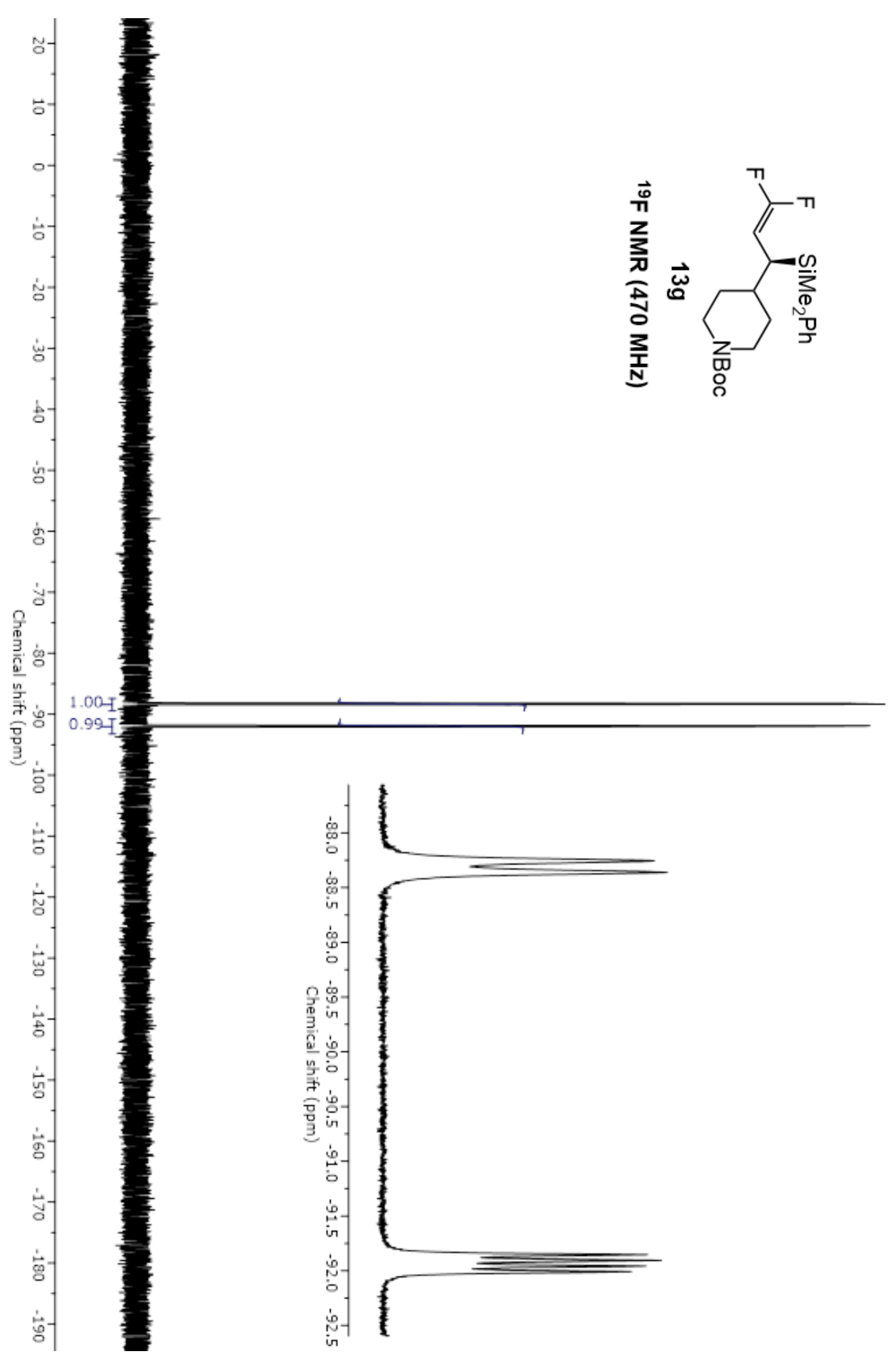




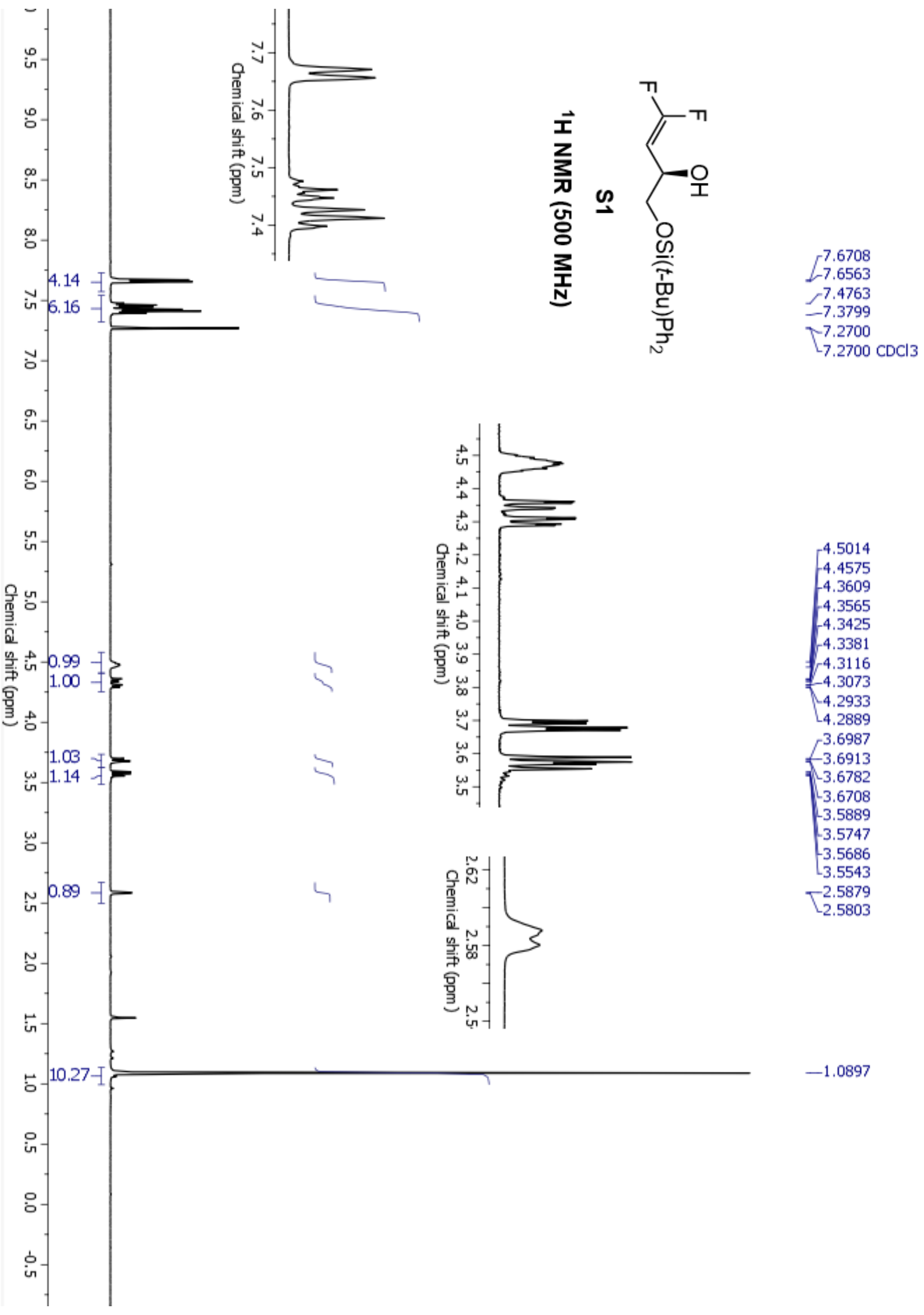




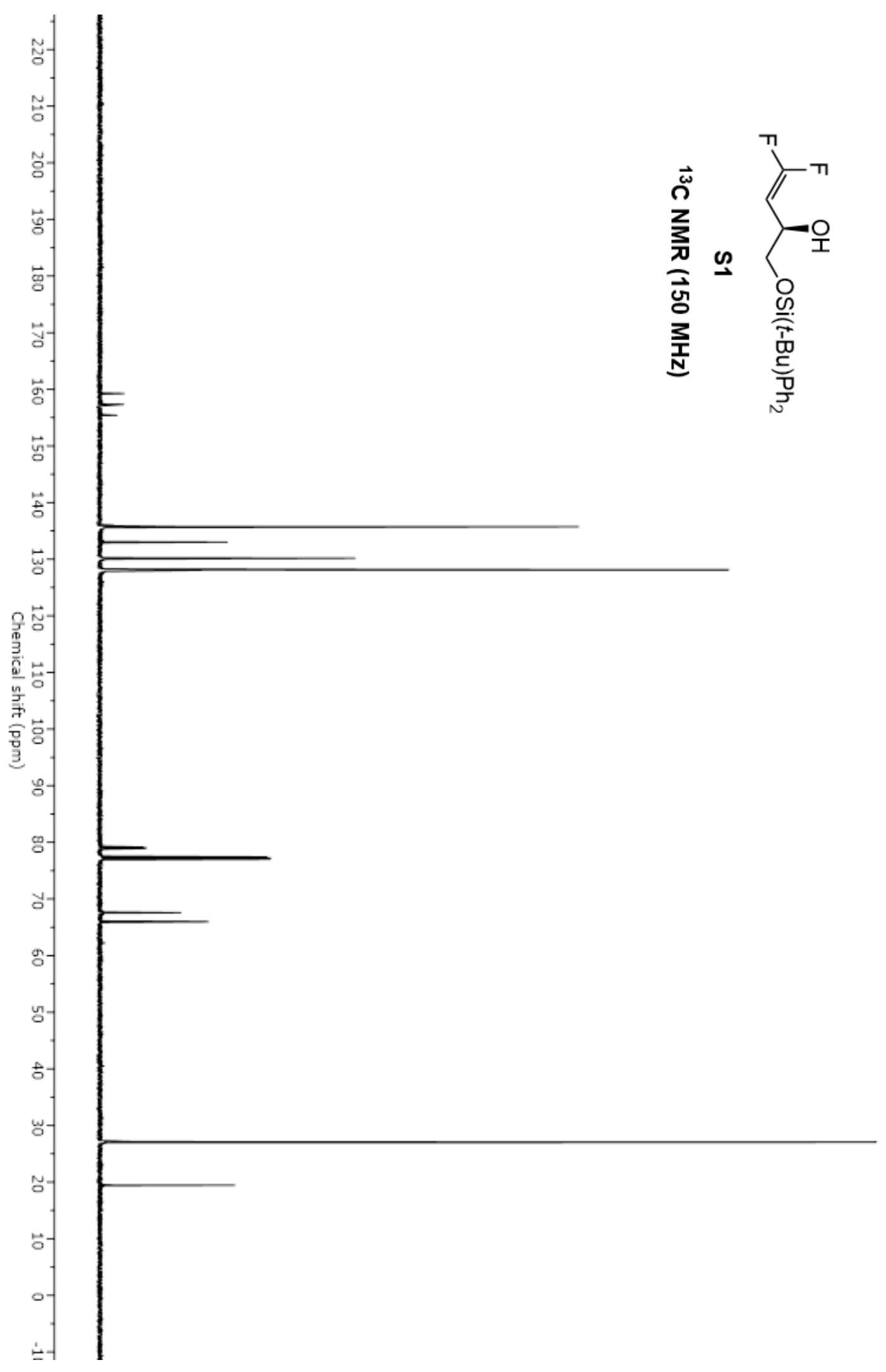




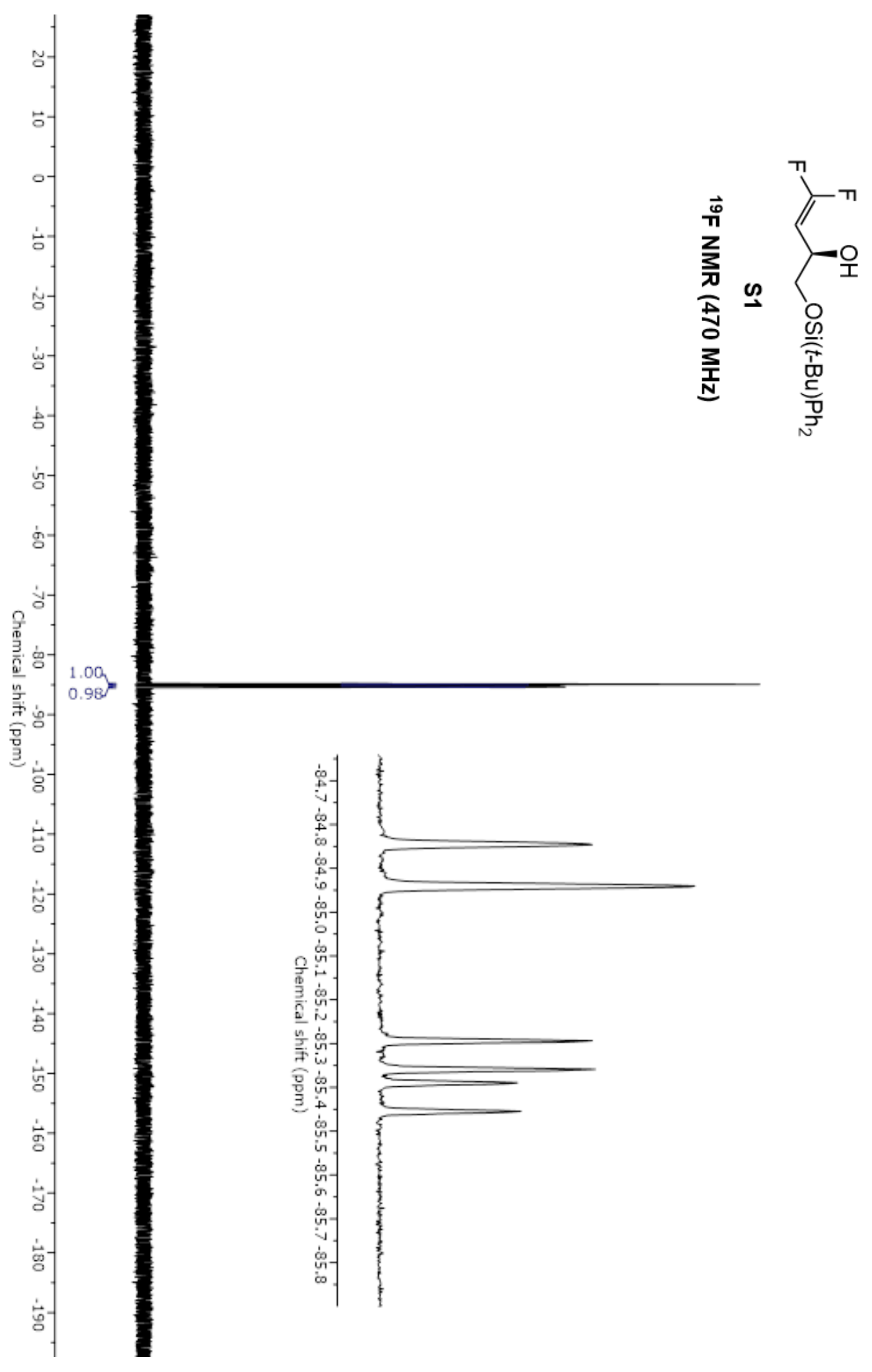




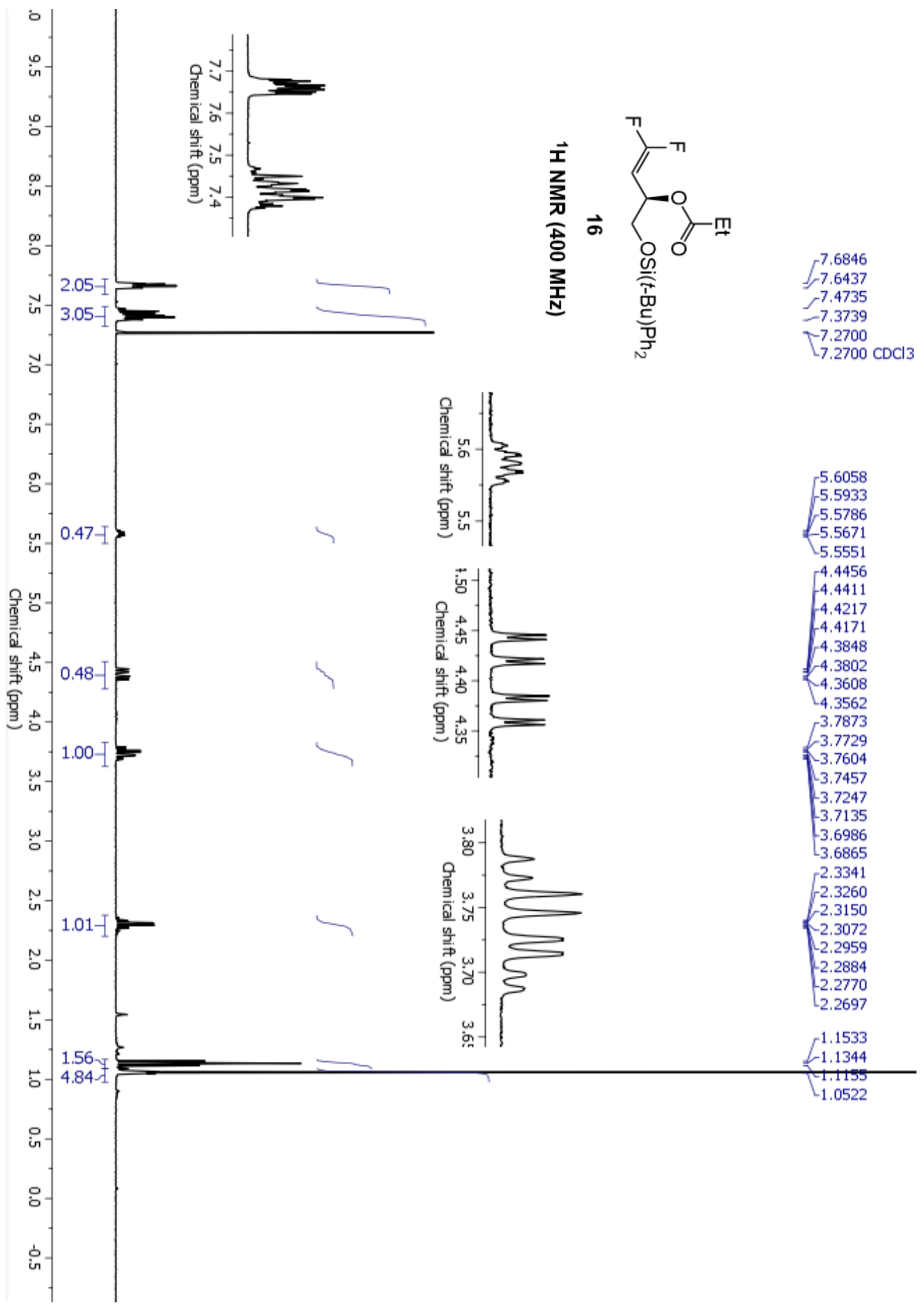


Paioti, et al.; Supporting Information, Part I; Page S207

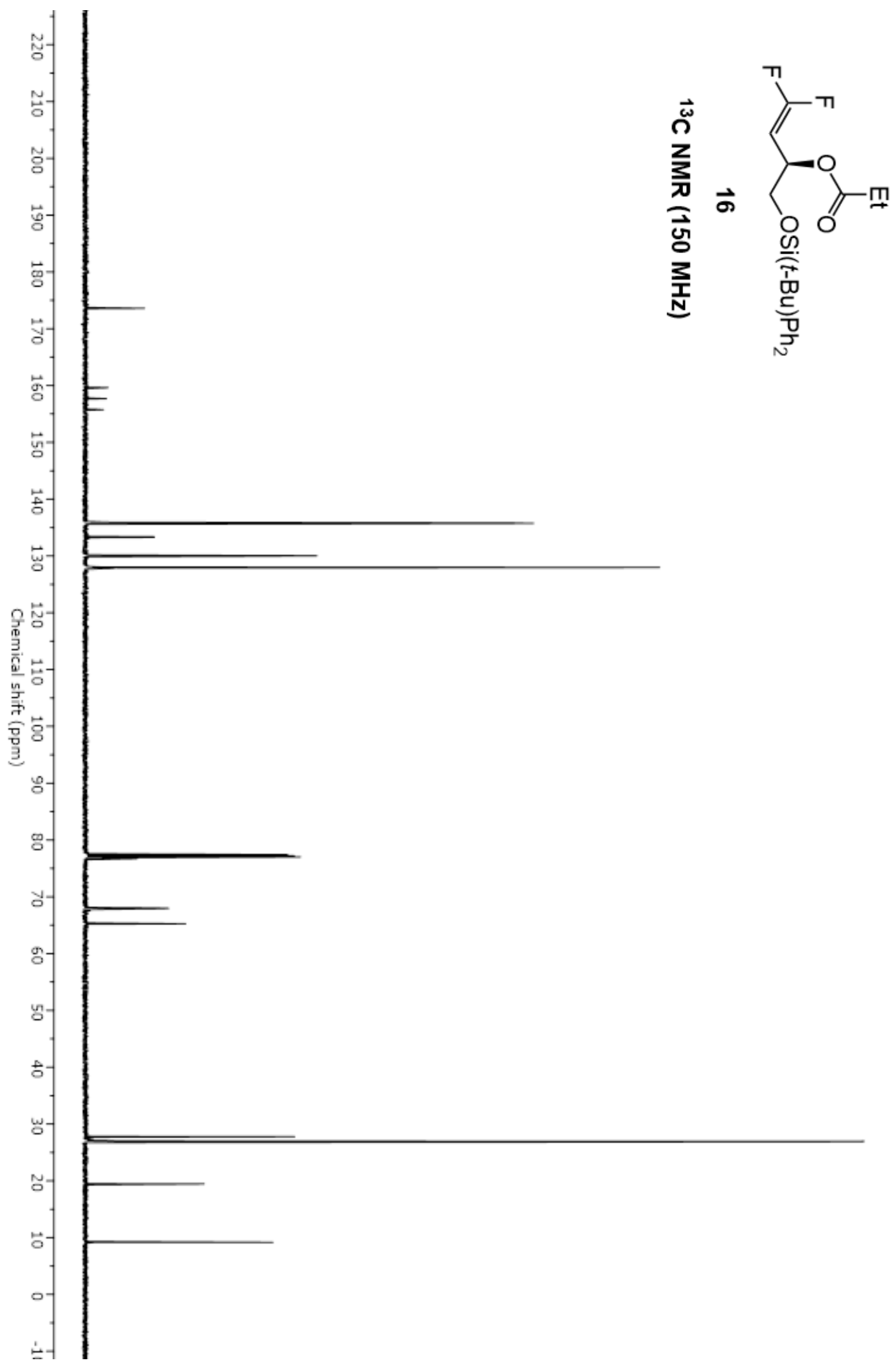




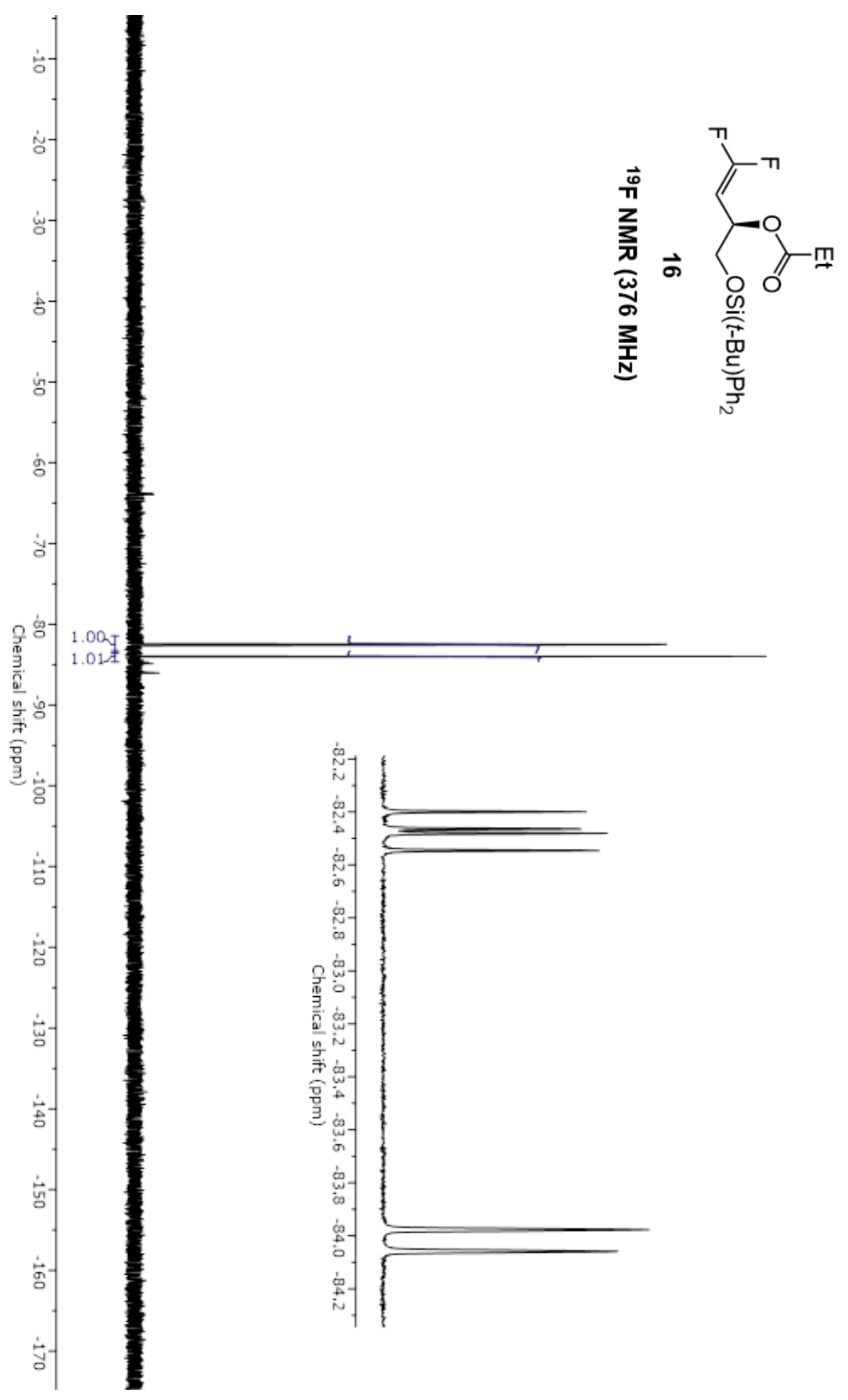




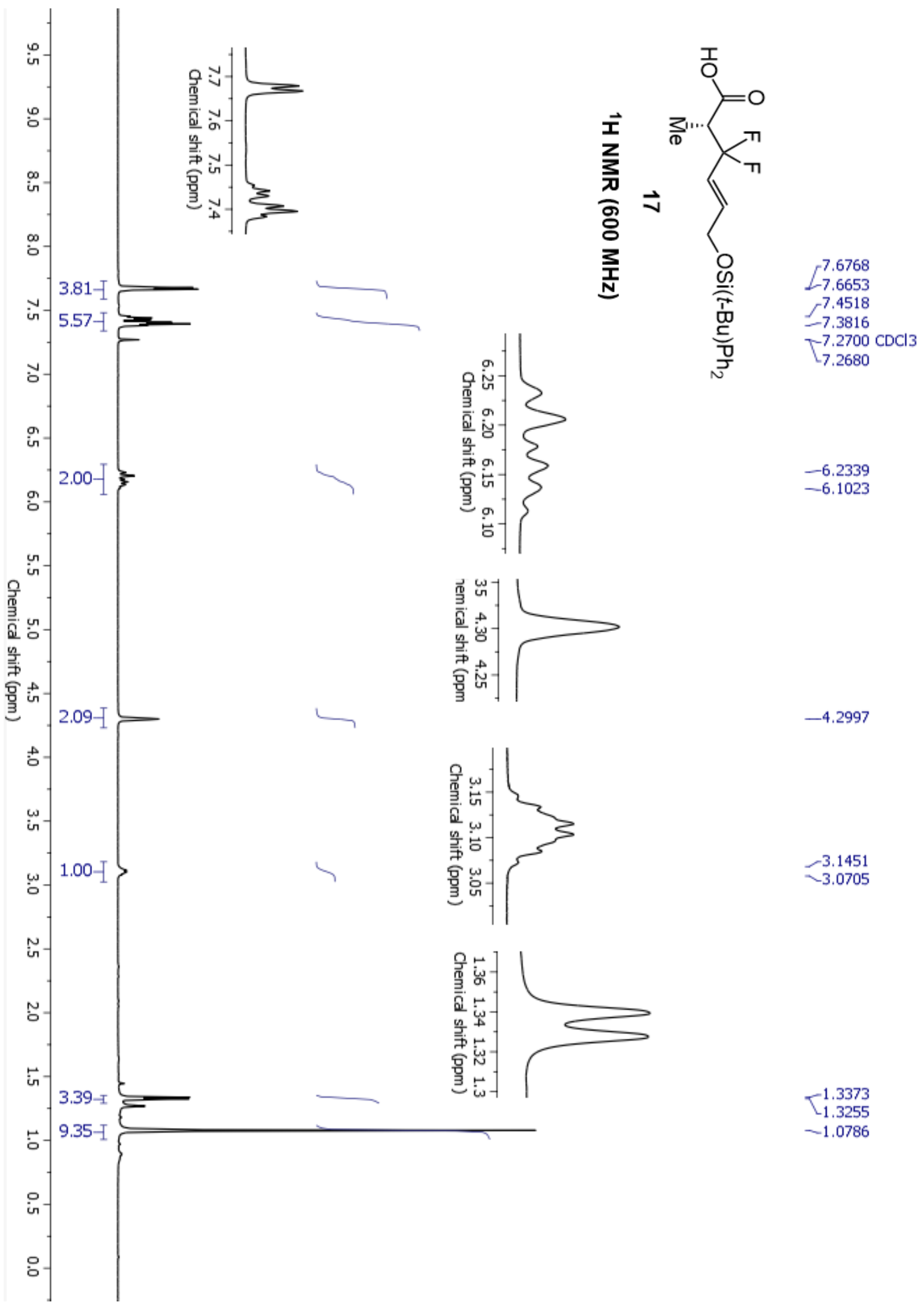


Paioti, et al.; Supporting Information, Part I; Page S210

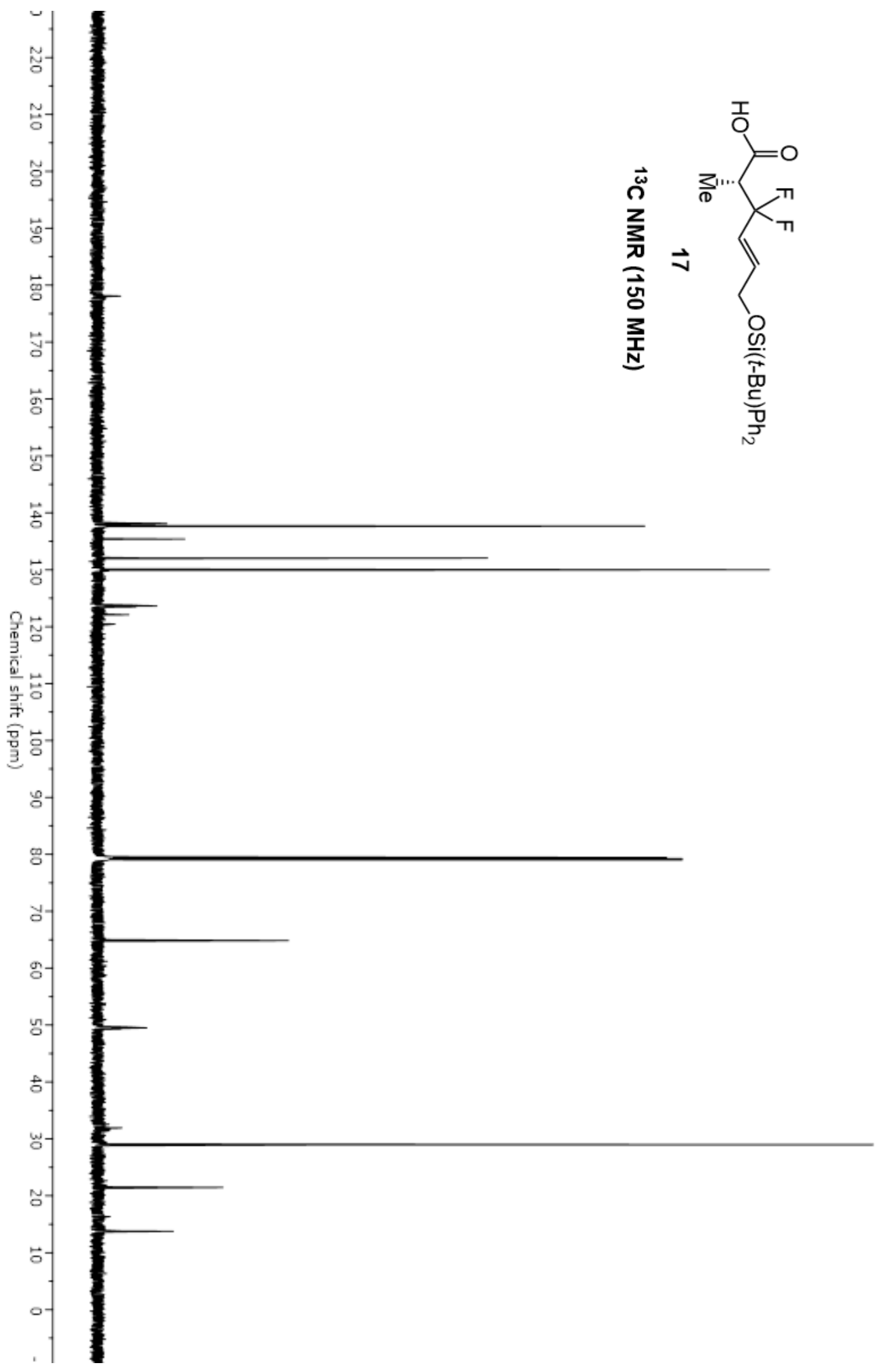




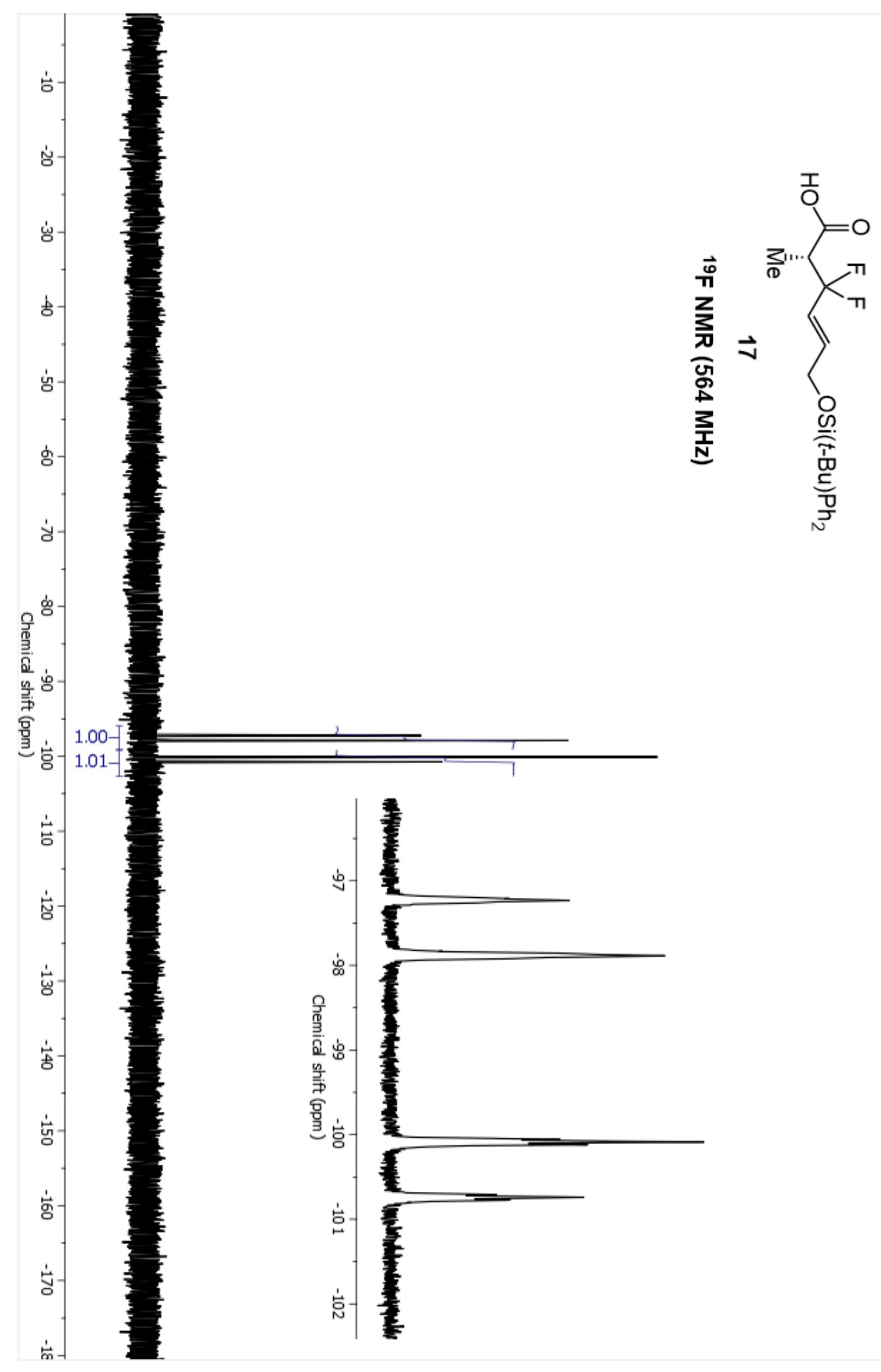




$$
\begin{aligned}
& 1 \\
& =1 \\
& =1
\end{aligned}
$$


Paioti, et al.; Supporting Information, Part I; Page S213

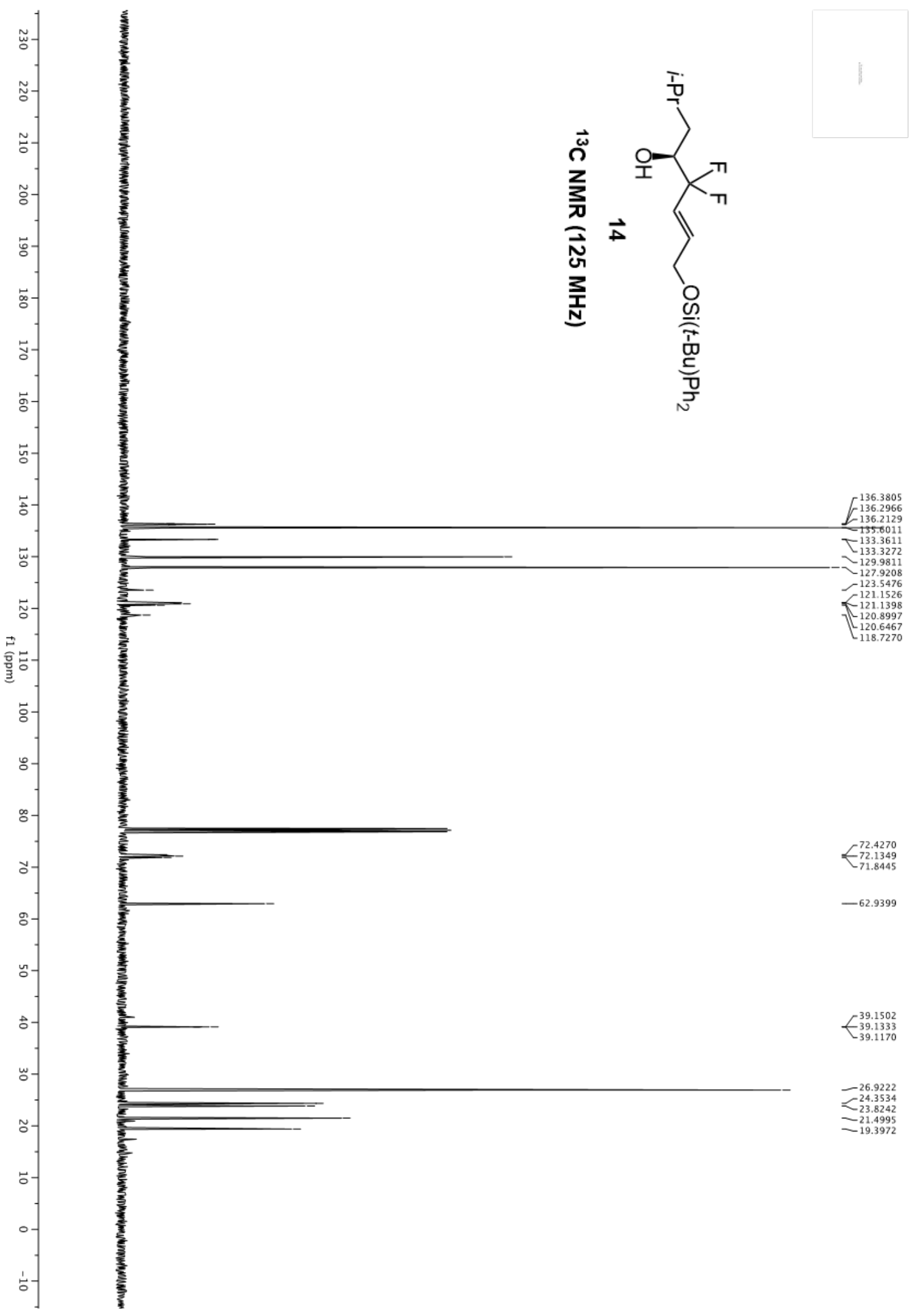




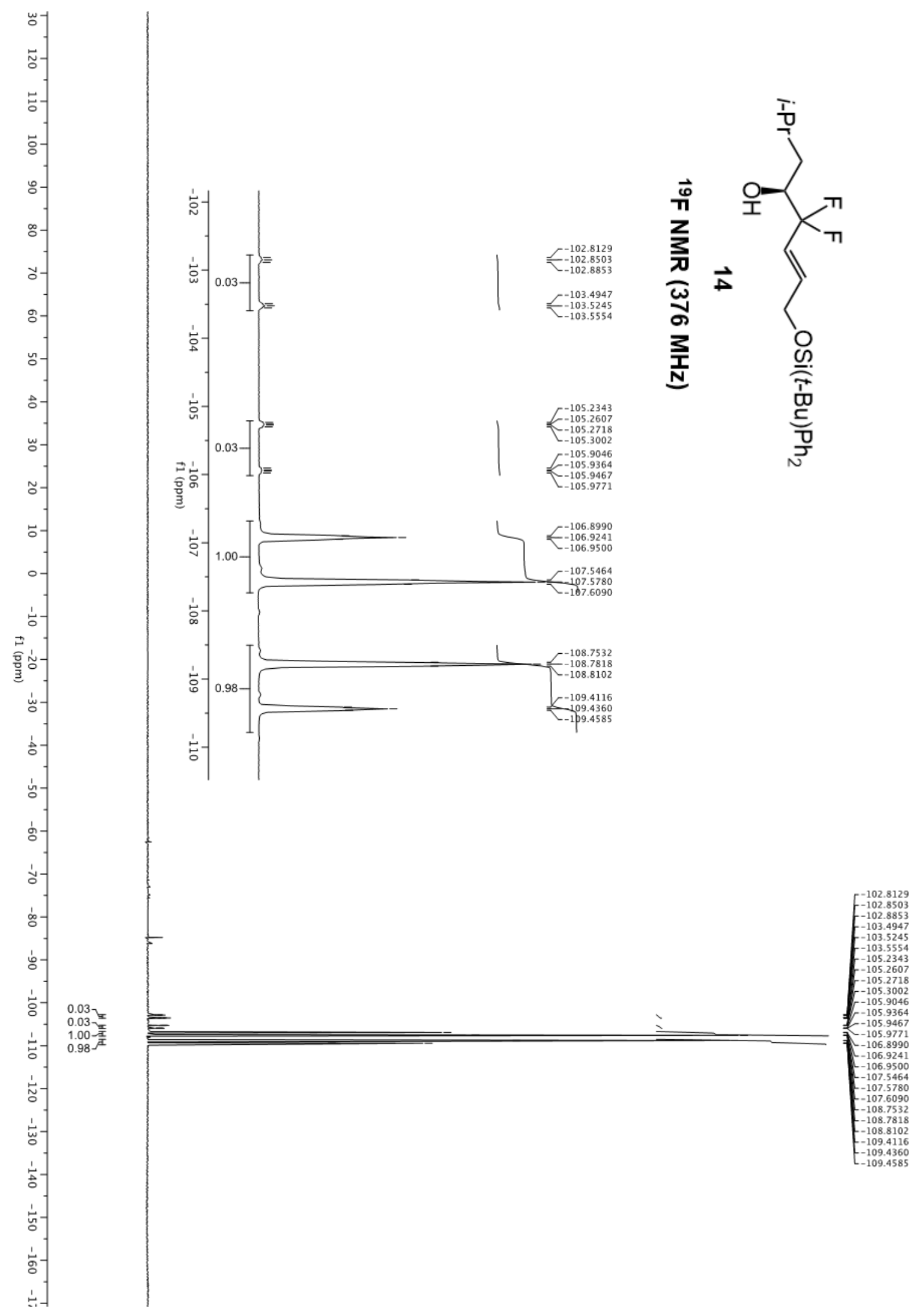


Paioti, et al.; Supporting Information, Part I; Page S215

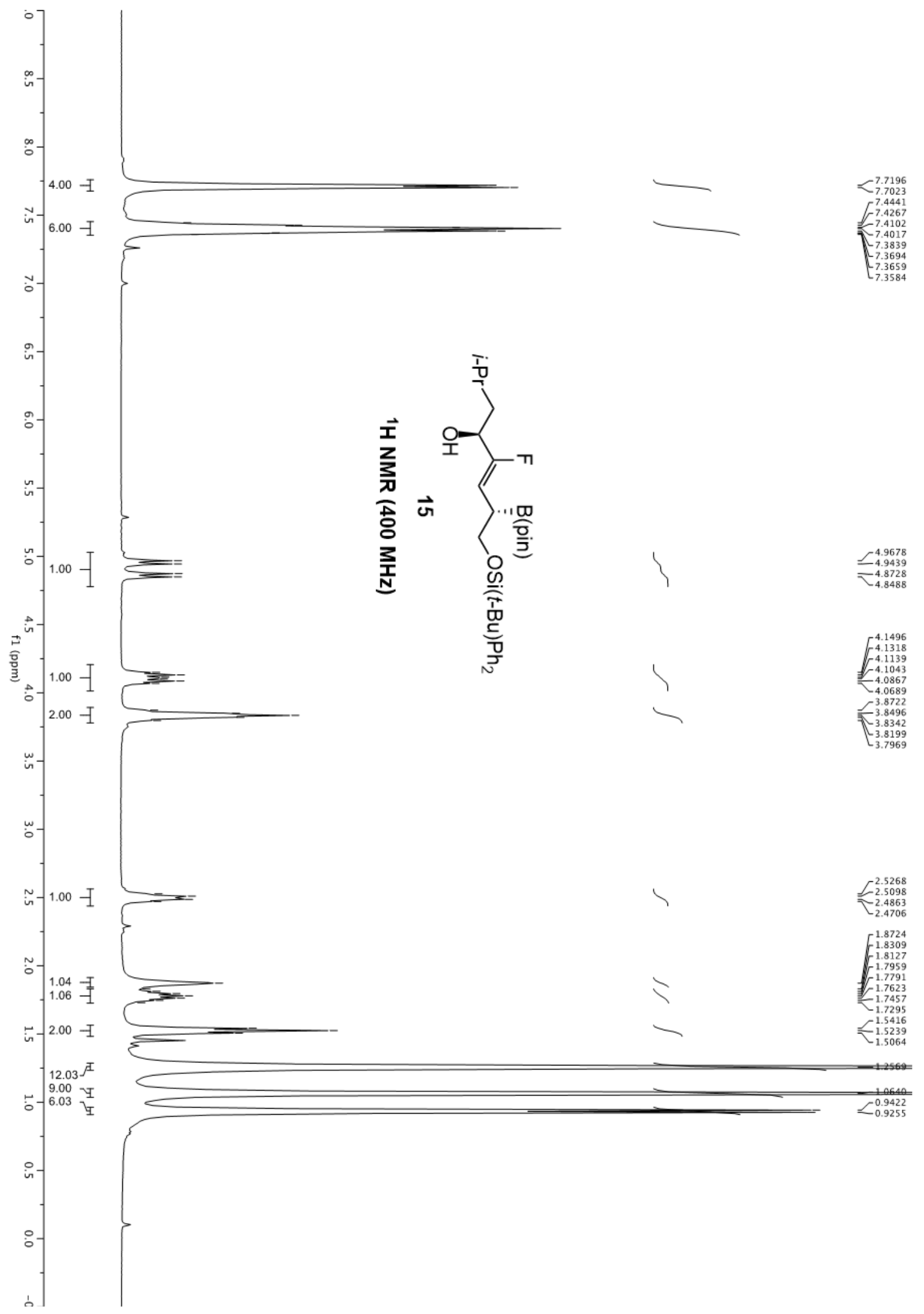




$$
\underline{E}
$$




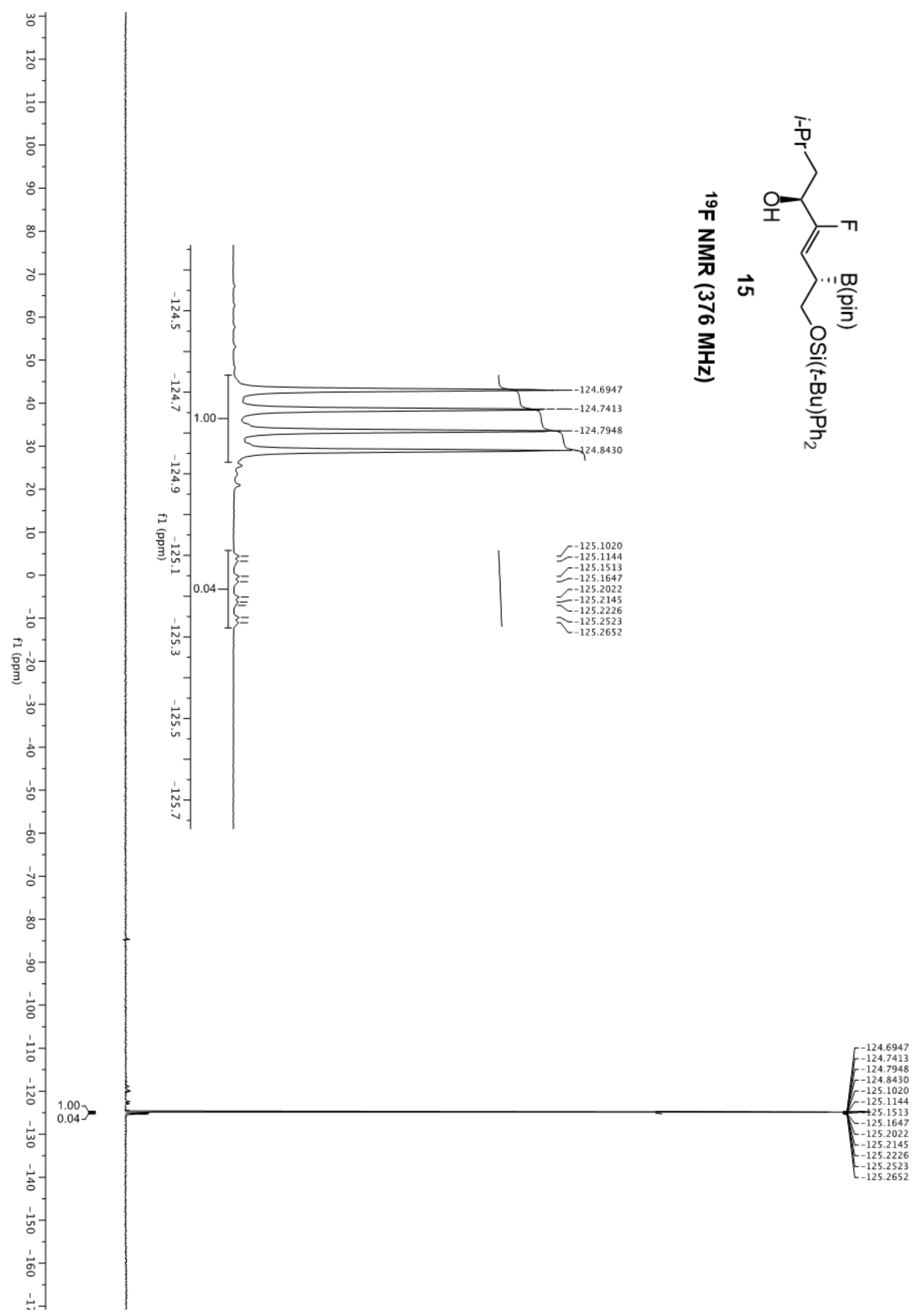


Paioti, et al.; Supporting Information, Part I; Page S218

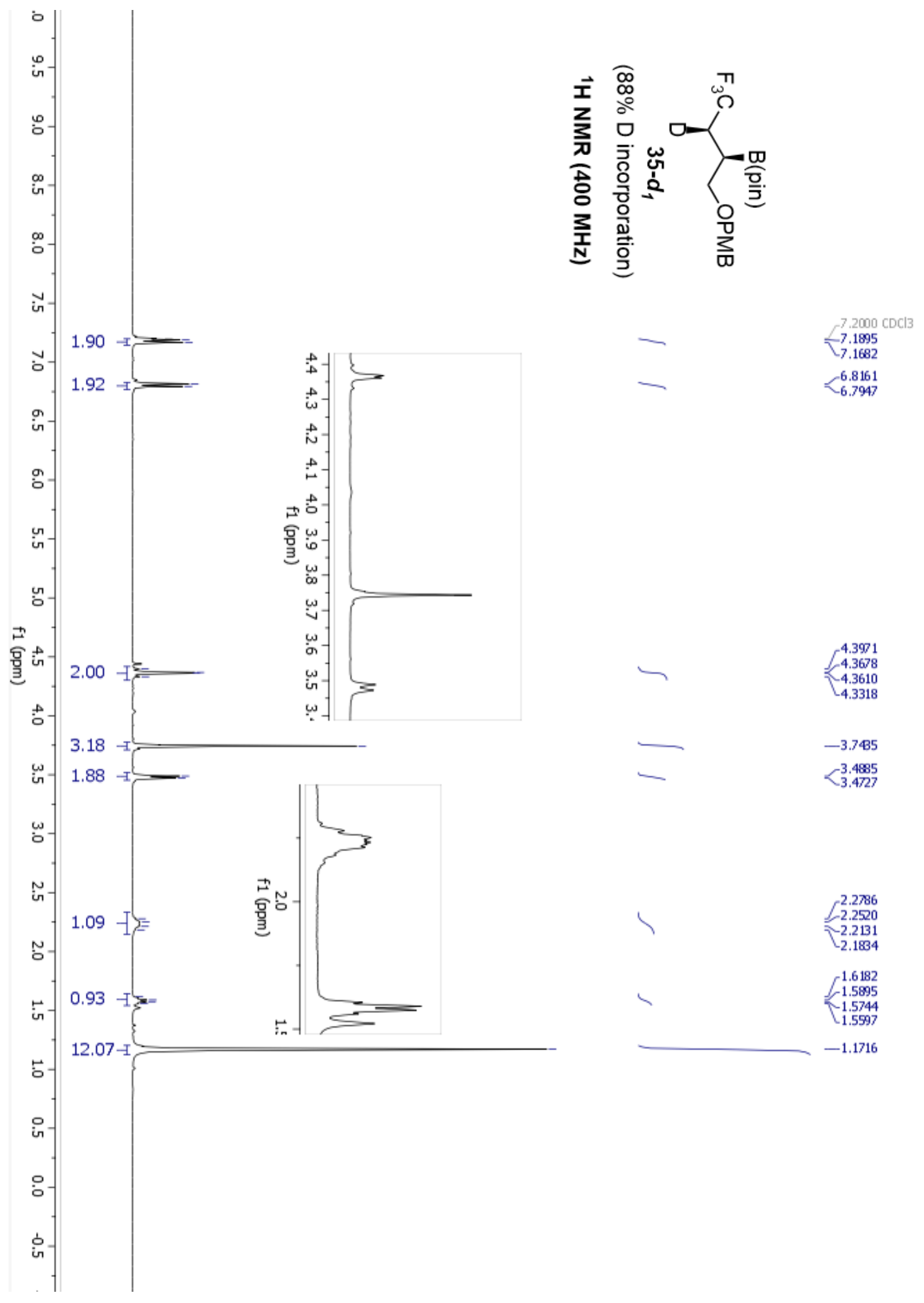




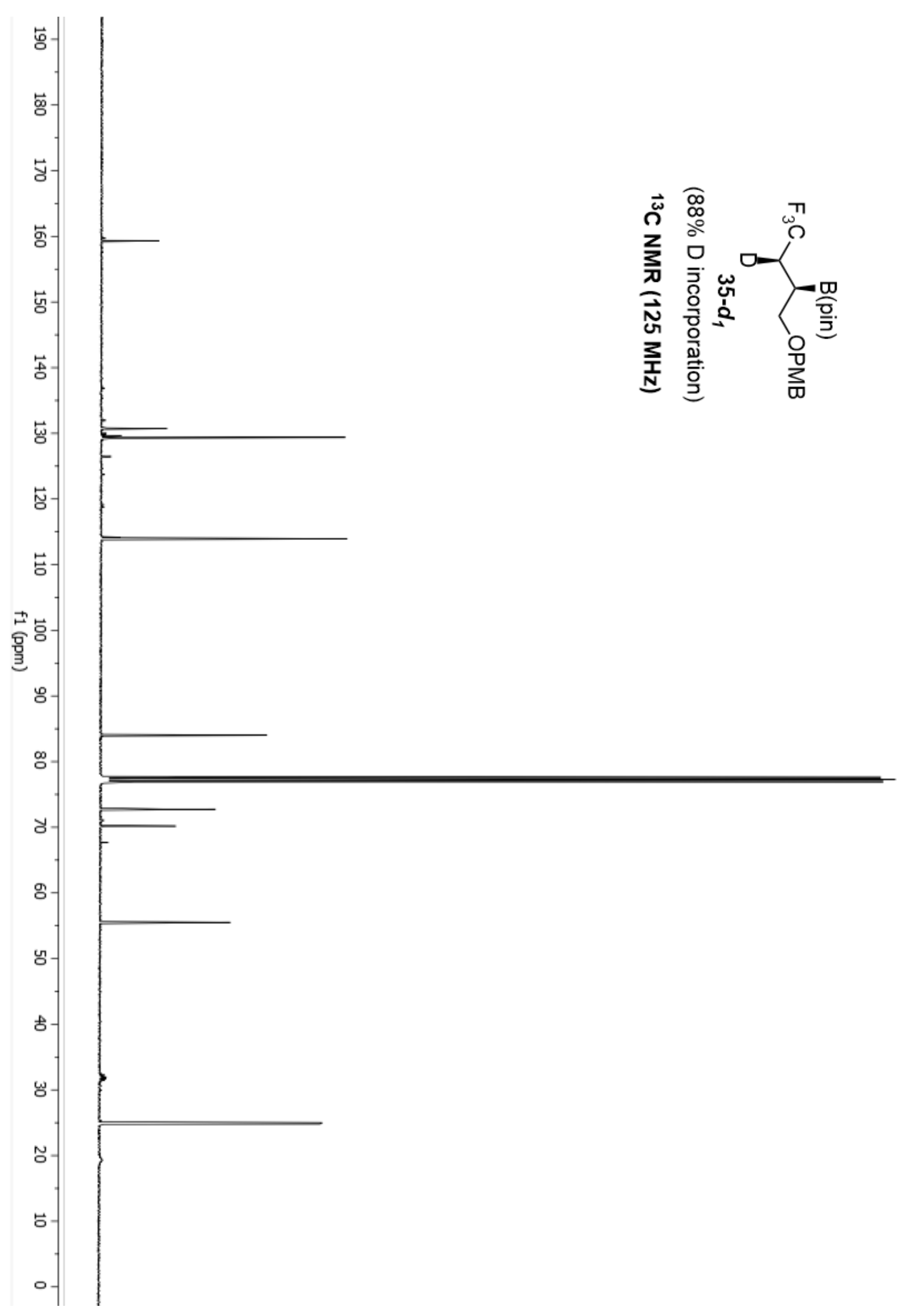




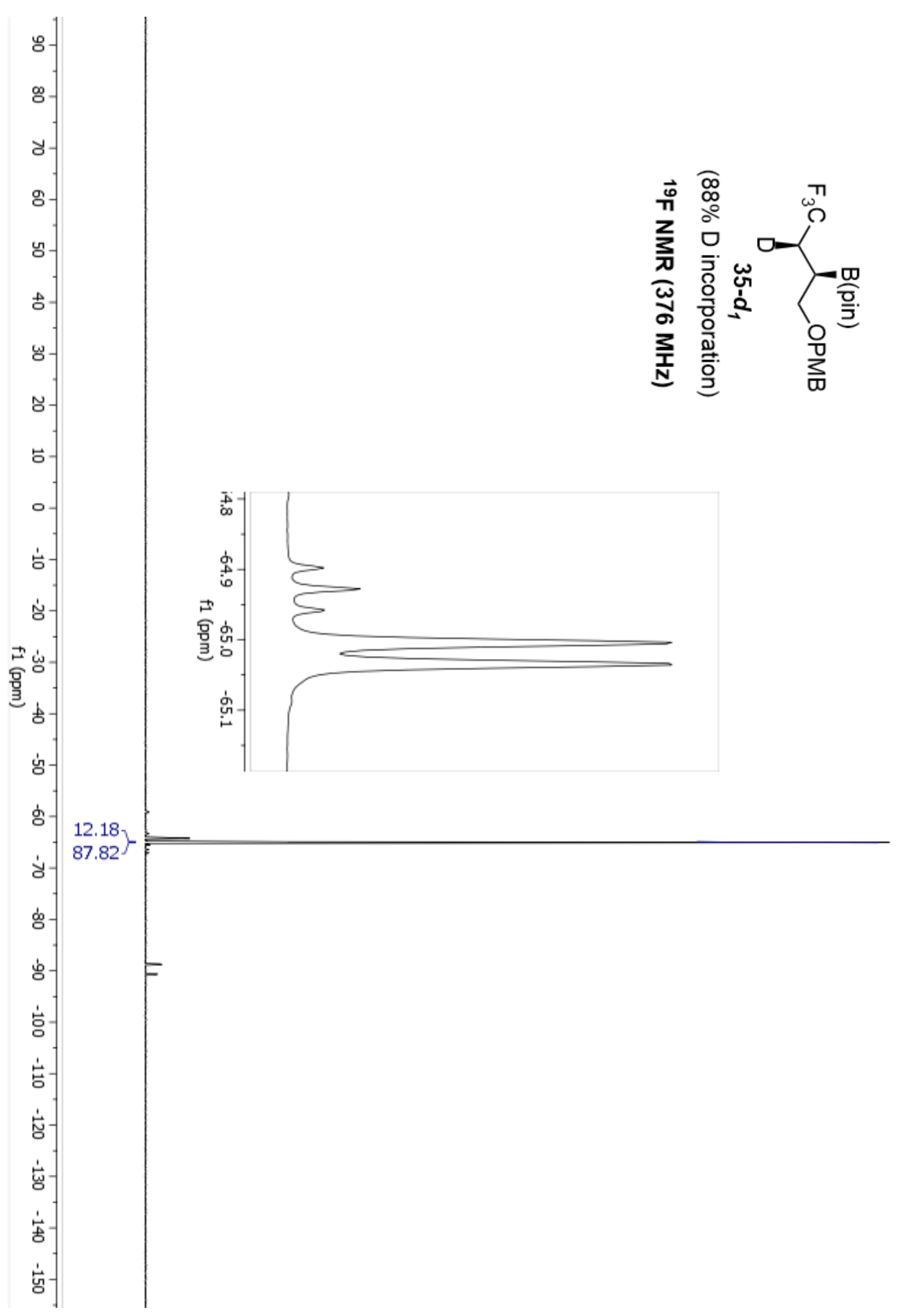




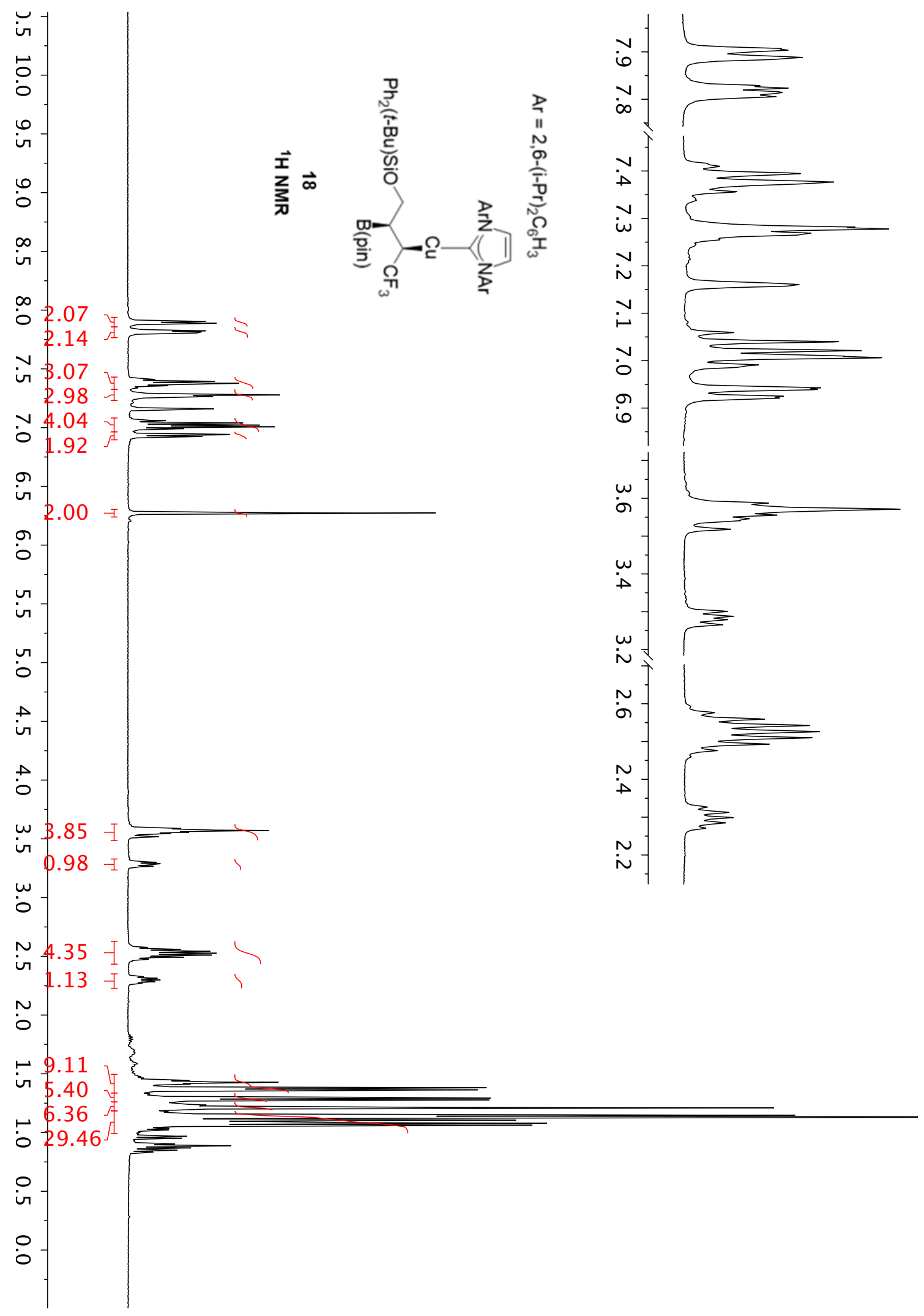




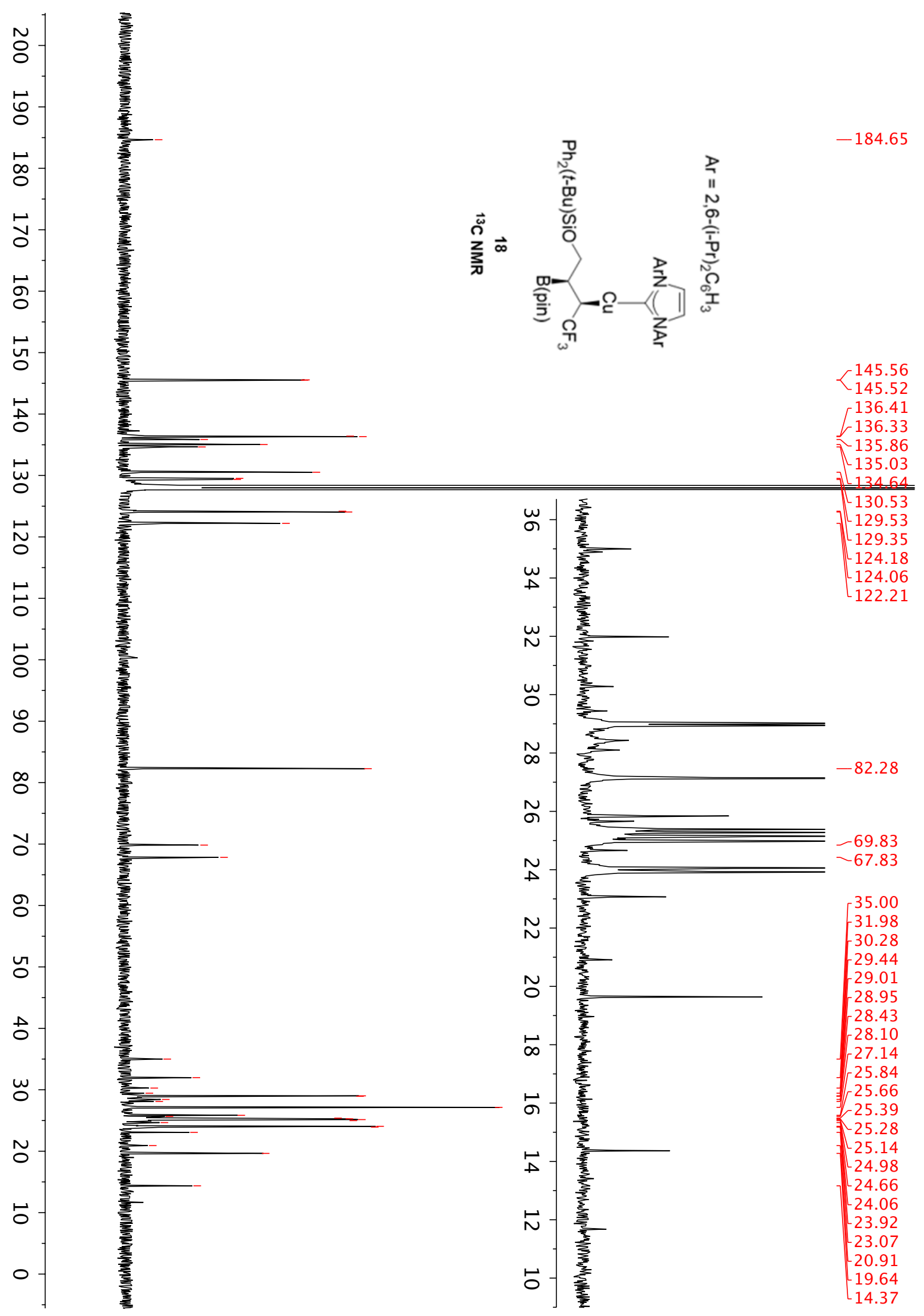


Paioti, et al.; Supporting Information, Part I; Page S223

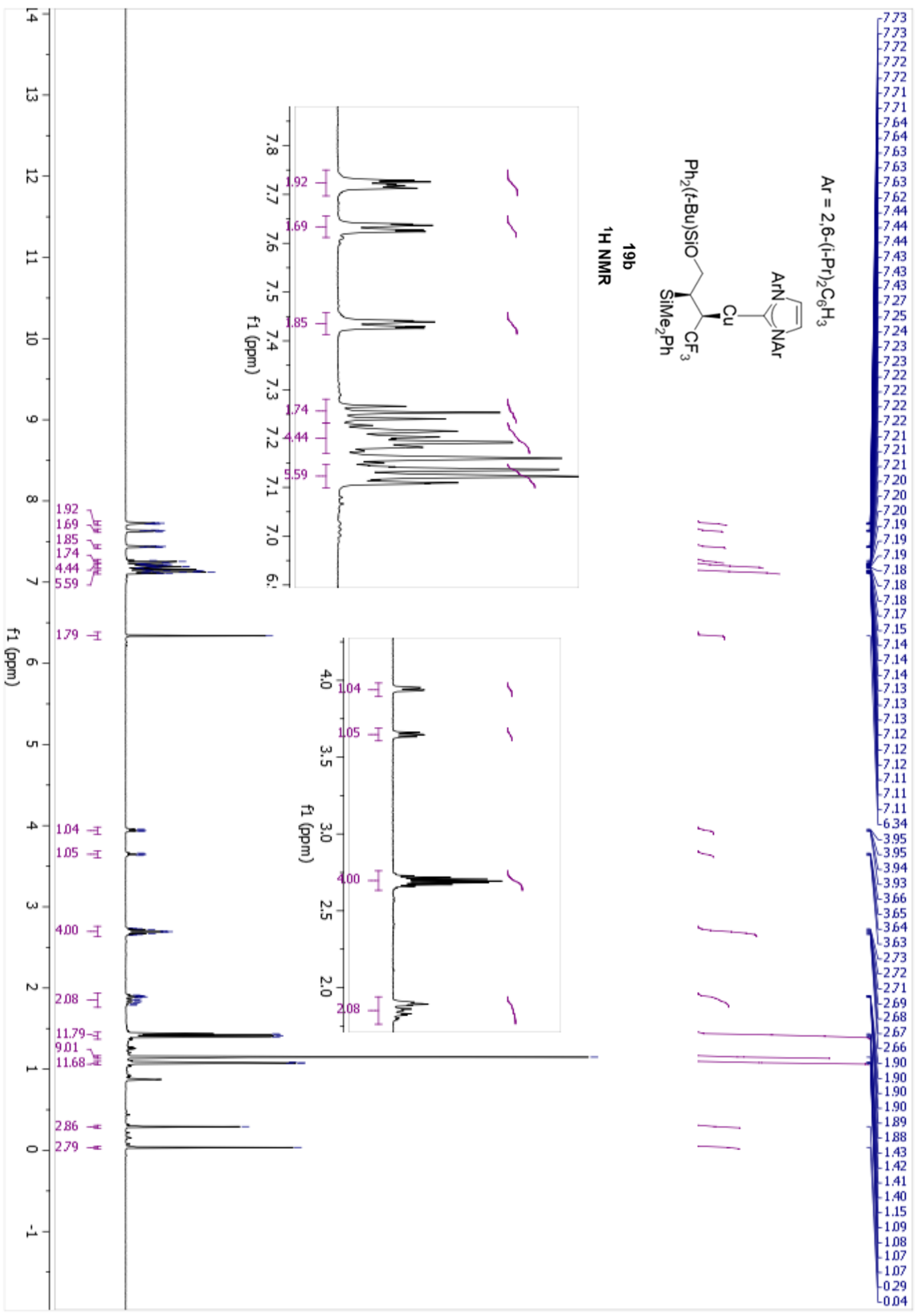


Paioti, et al.; Supporting Information, Part I; Page S224

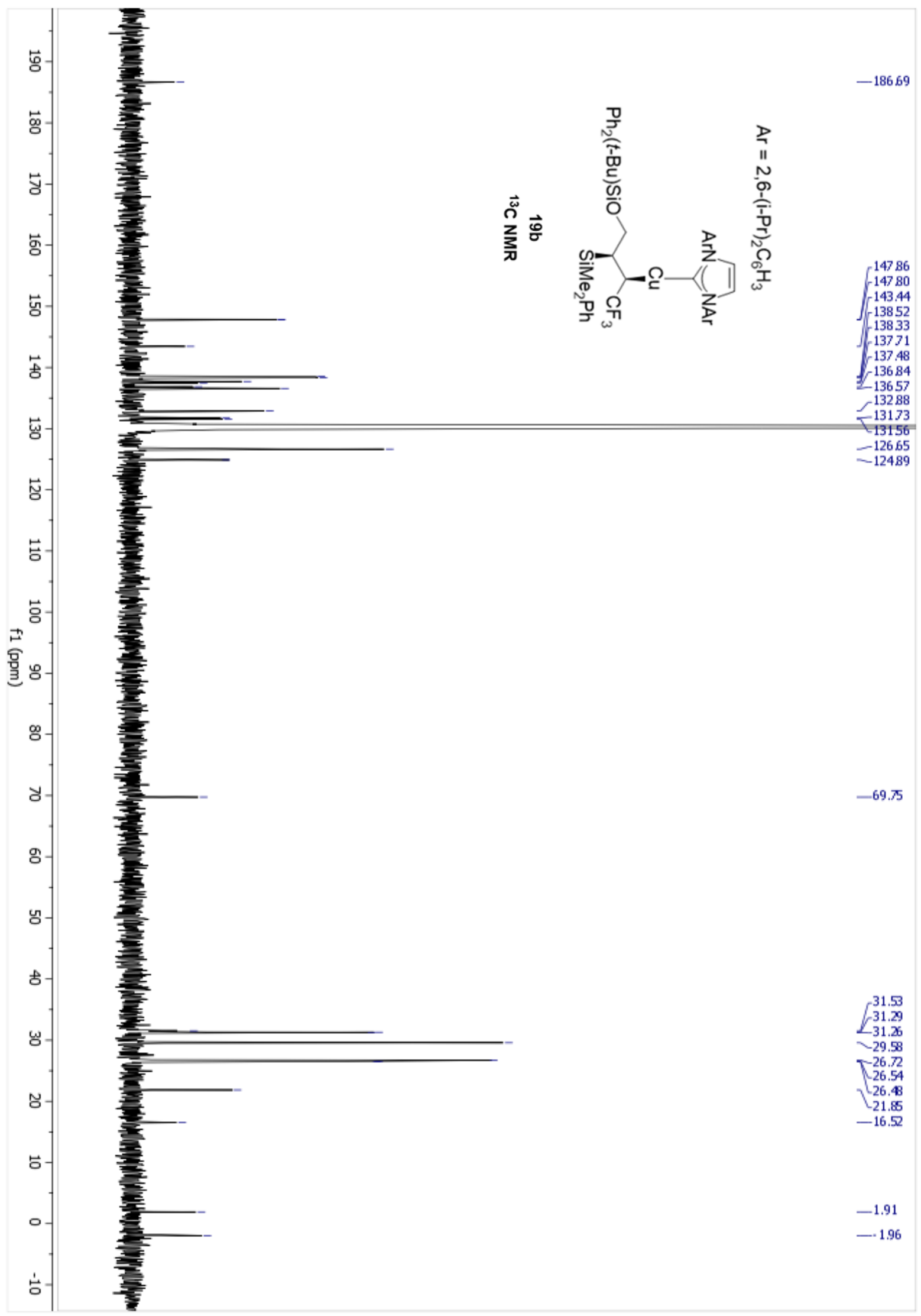


Paioti, et al.; Supporting Information, Part I; Page S225

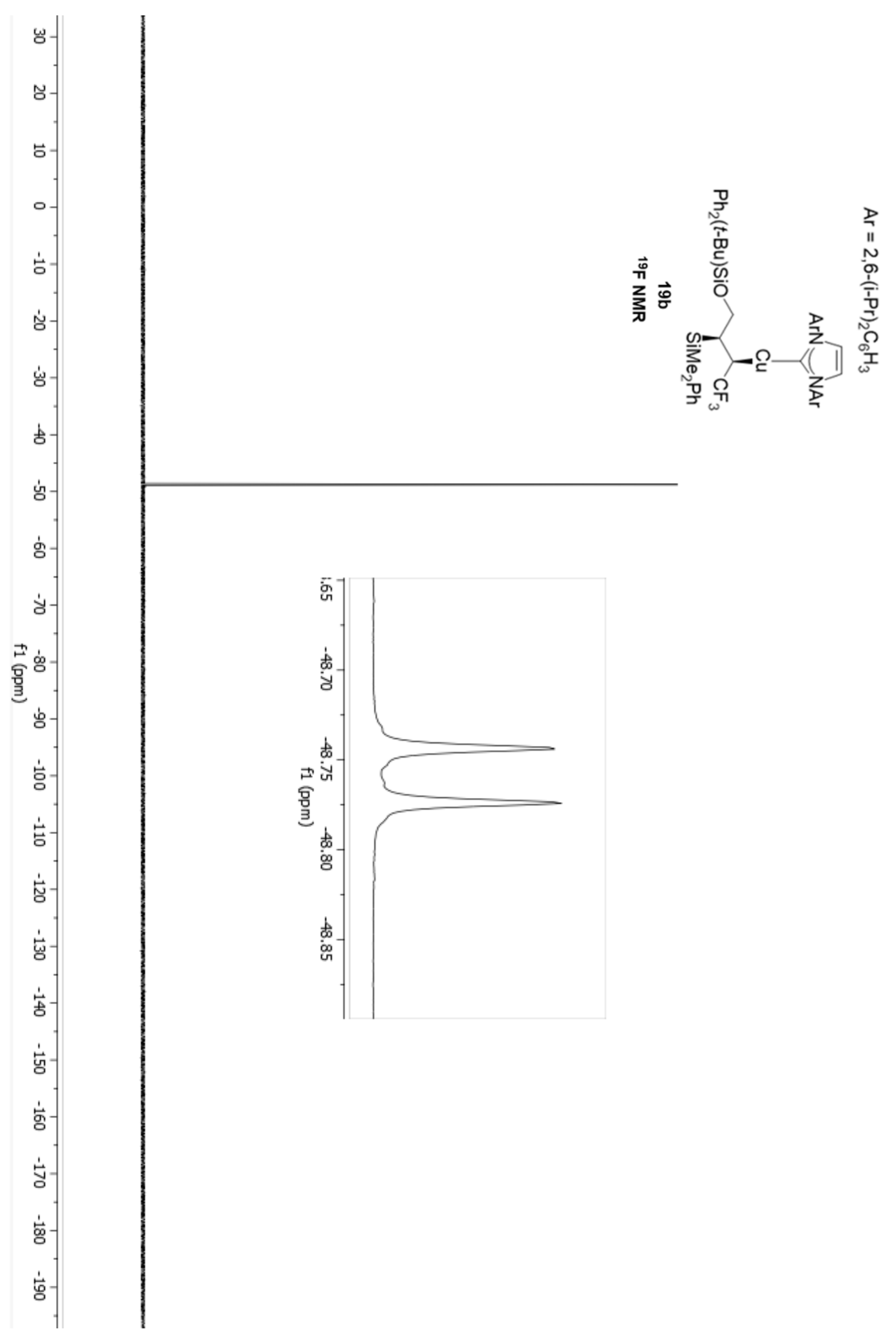


Paioti, et al.; Supporting Information, Part I; Page S226

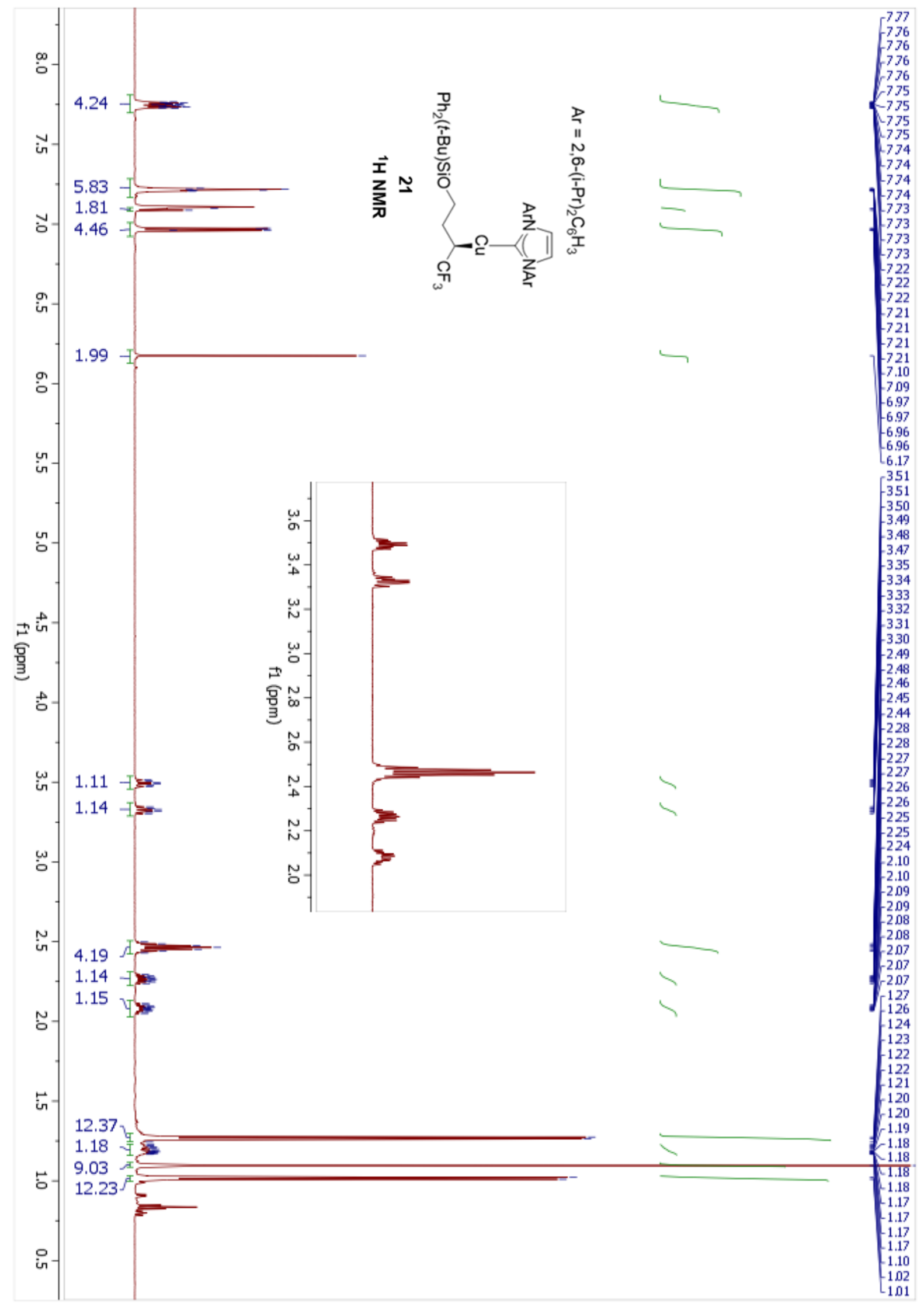


Paioti, et al.; Supporting Information, Part I; Page S227

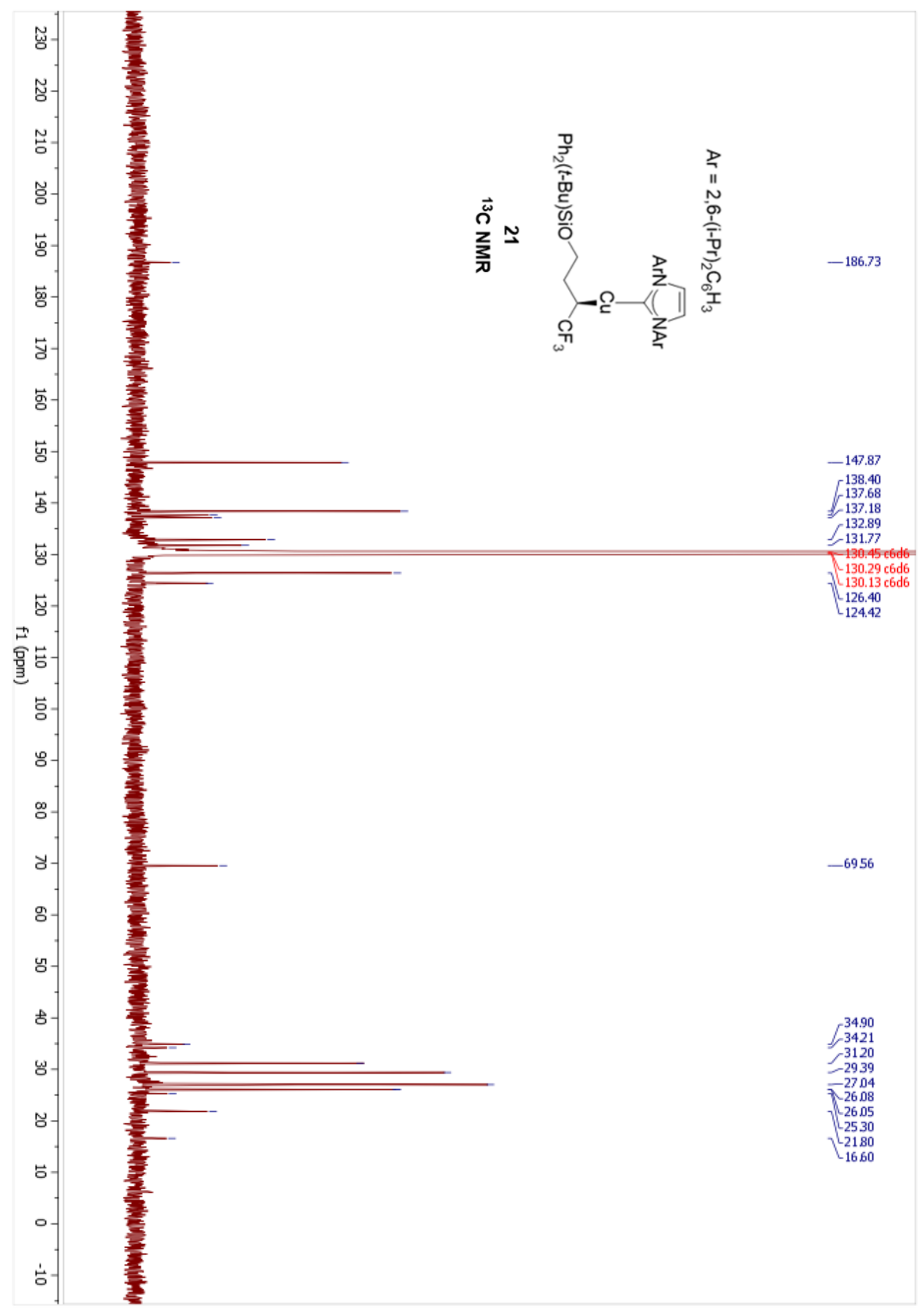




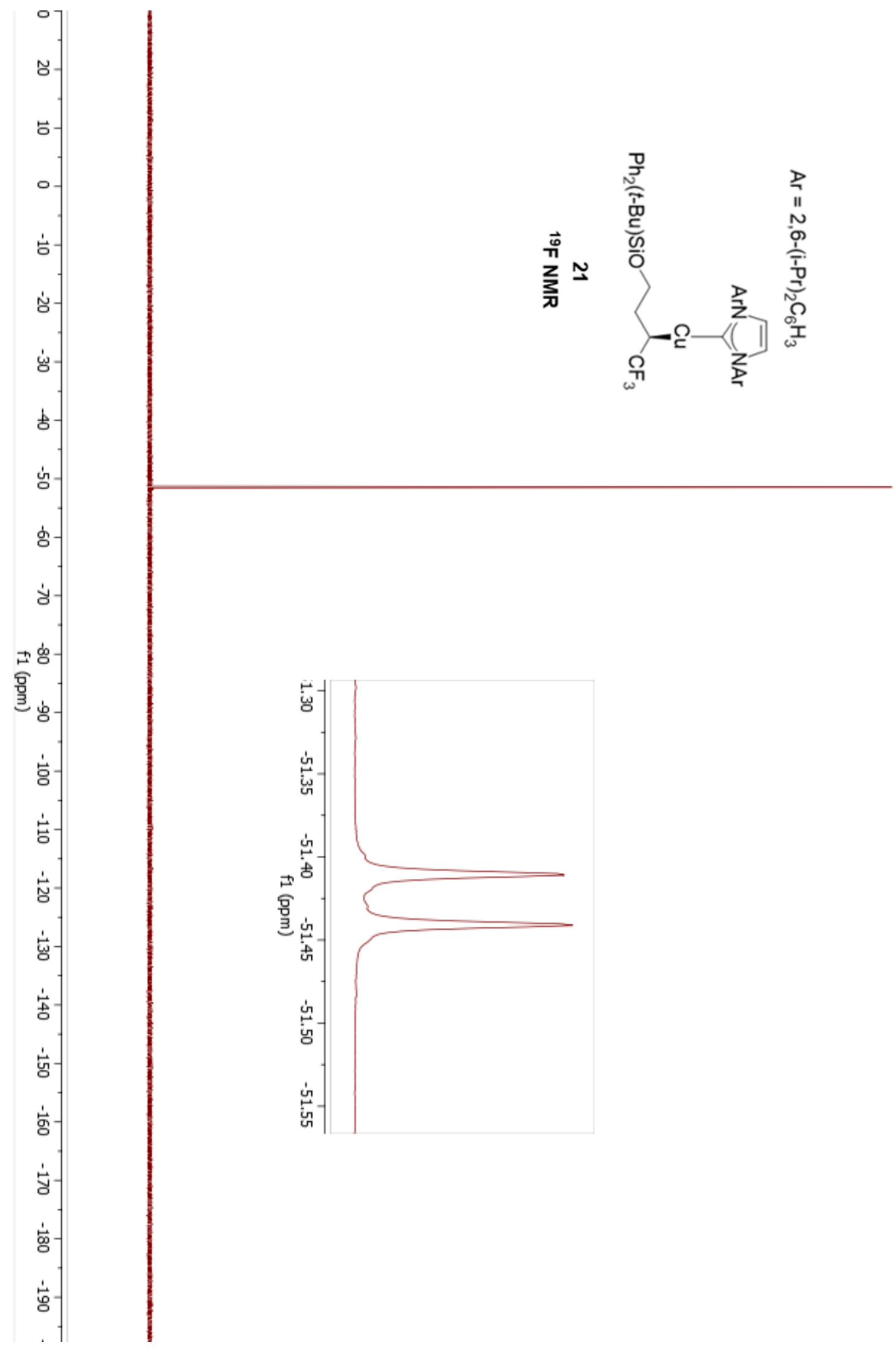




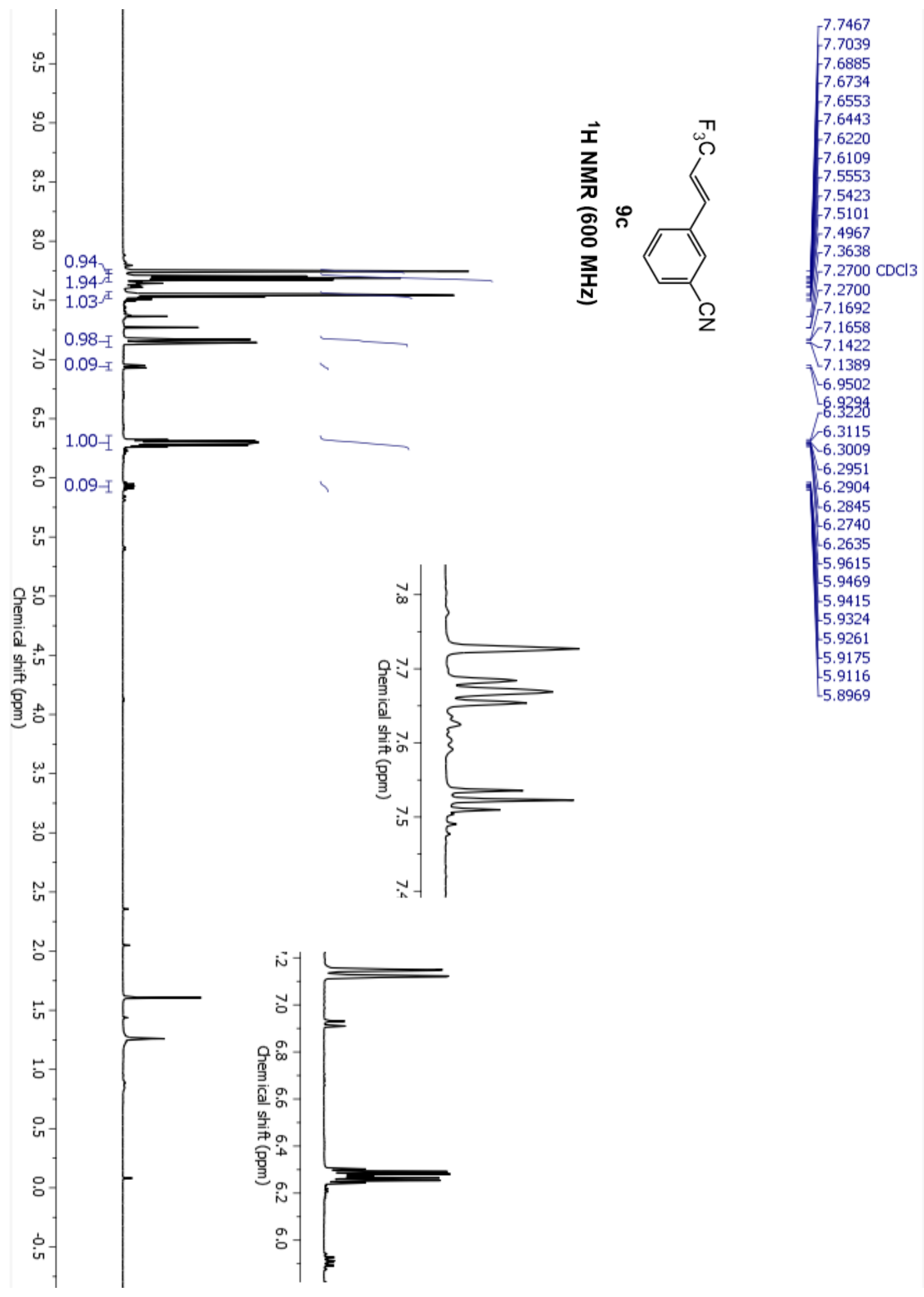




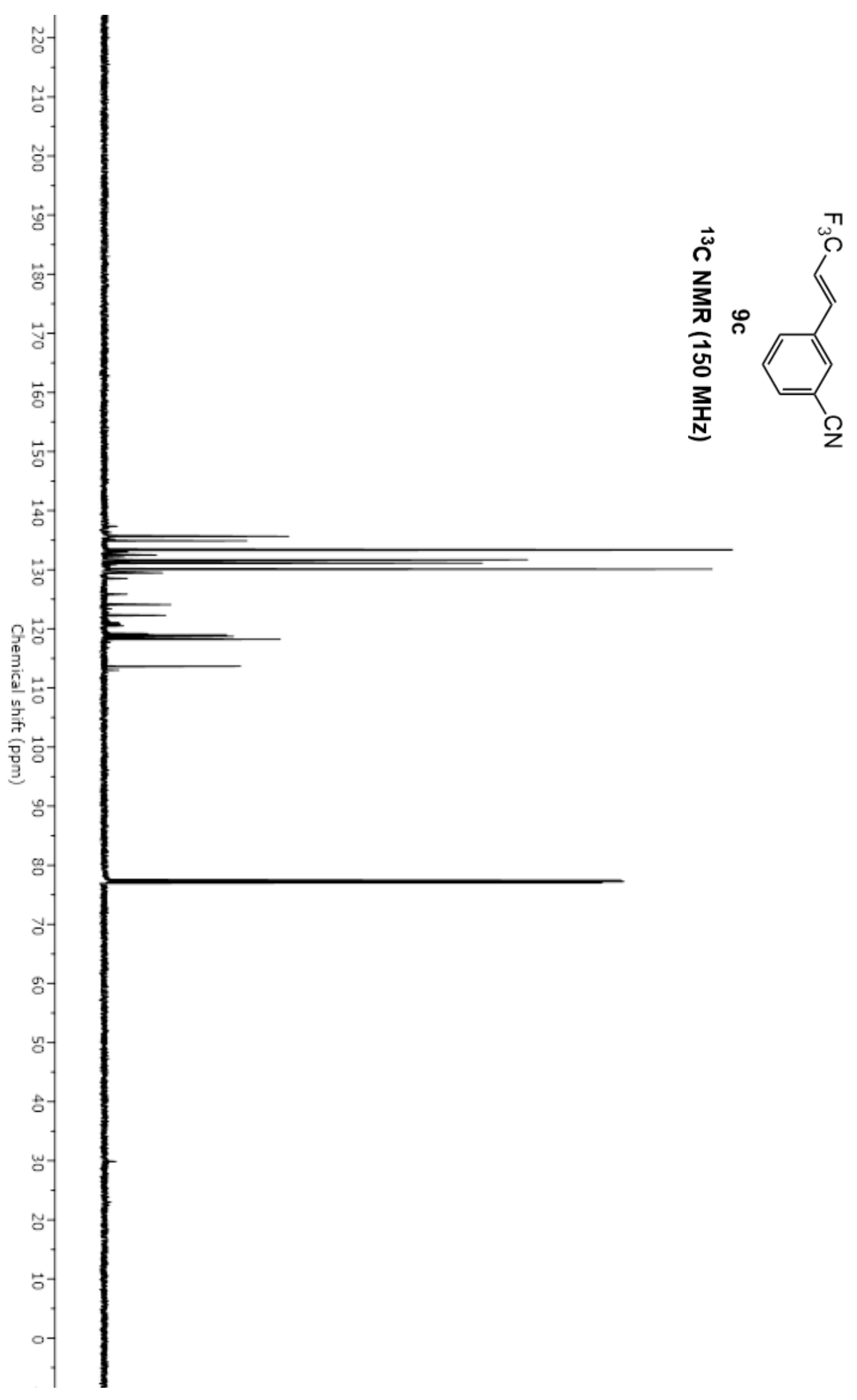


Paioti, et al.; Supporting Information, Part I; Page S231

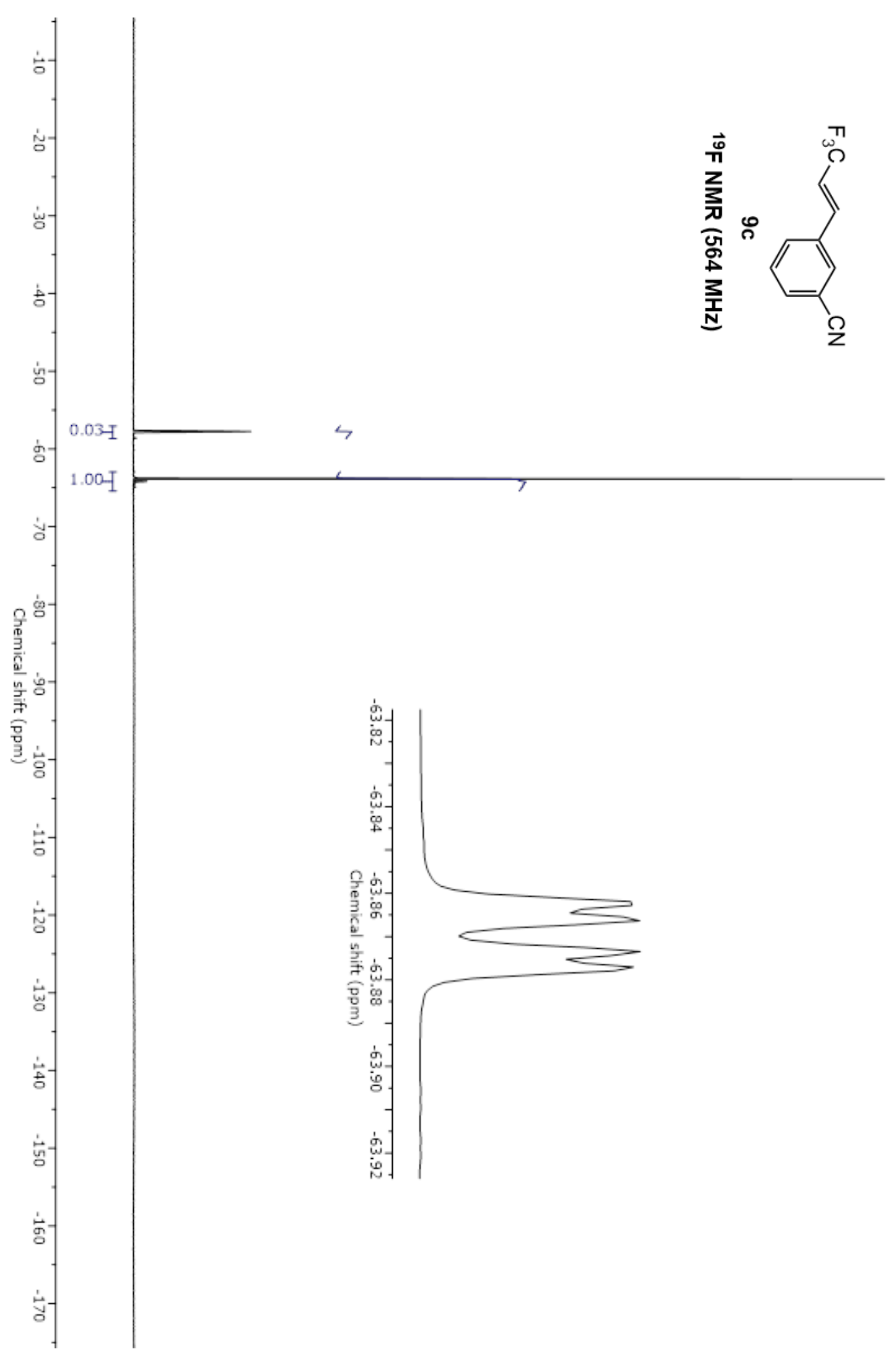


Paioti, et al.; Supporting Information, Part I; Page S232

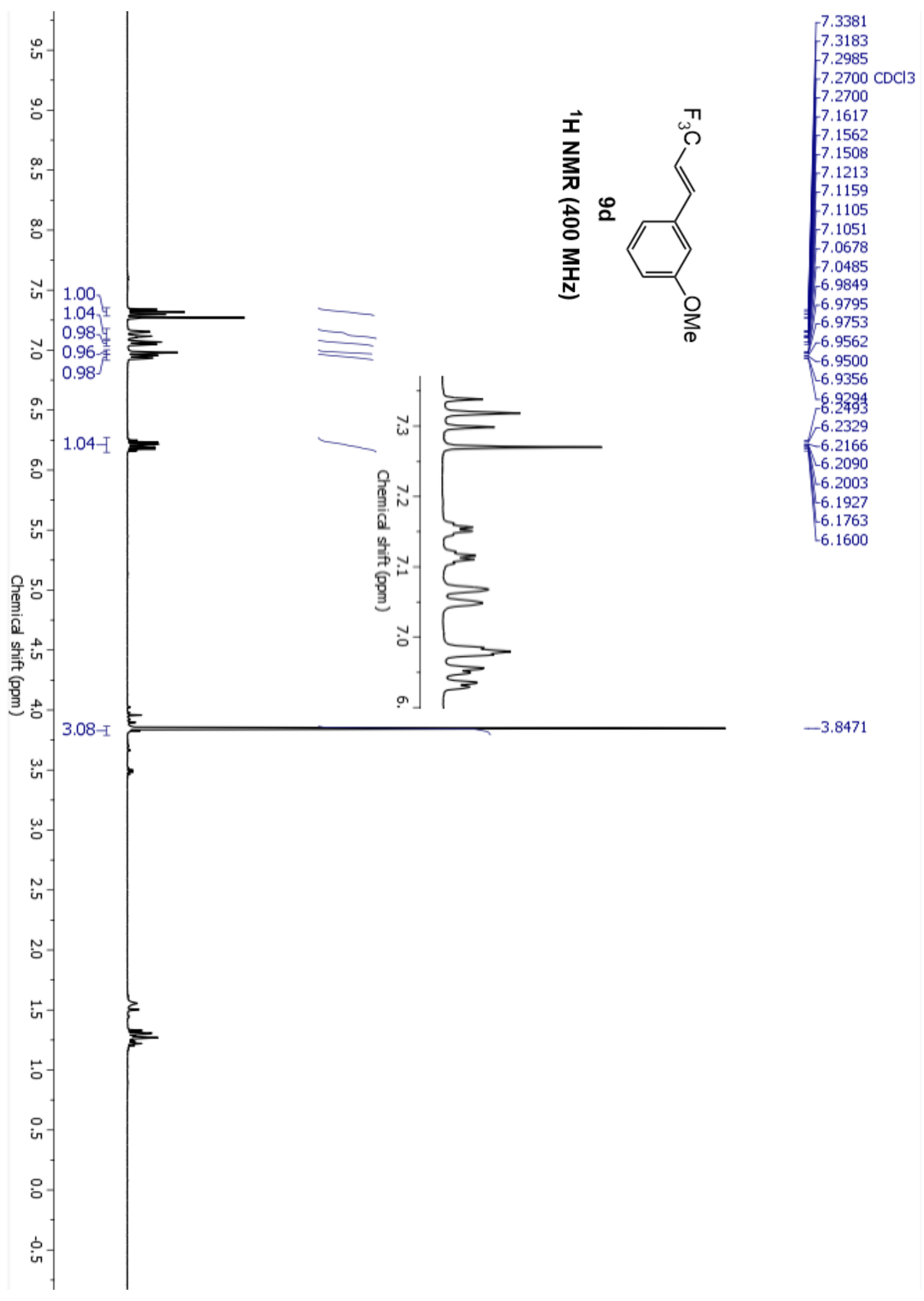




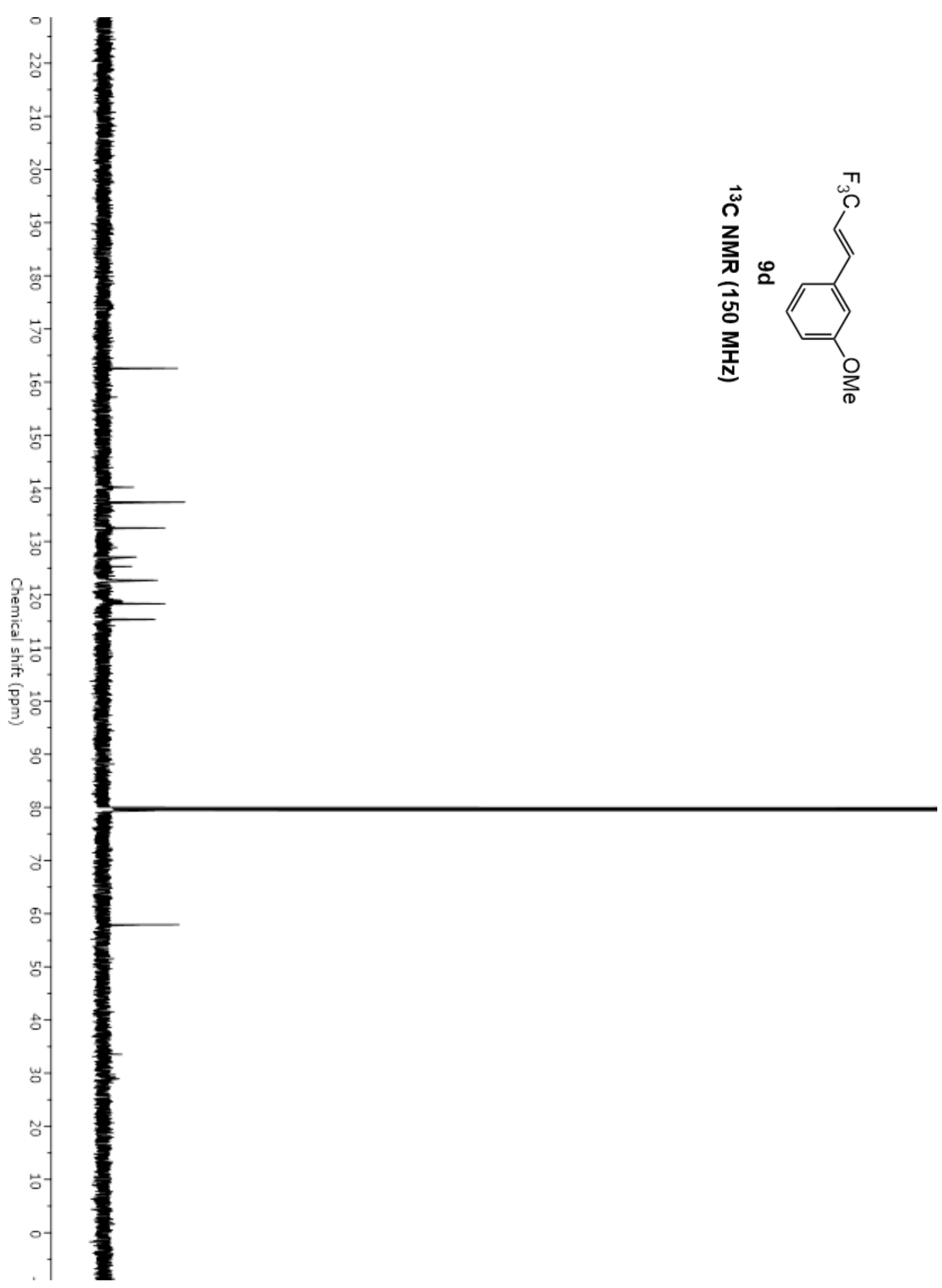


Paioti, et al.; Supporting Information, Part I; Page S234

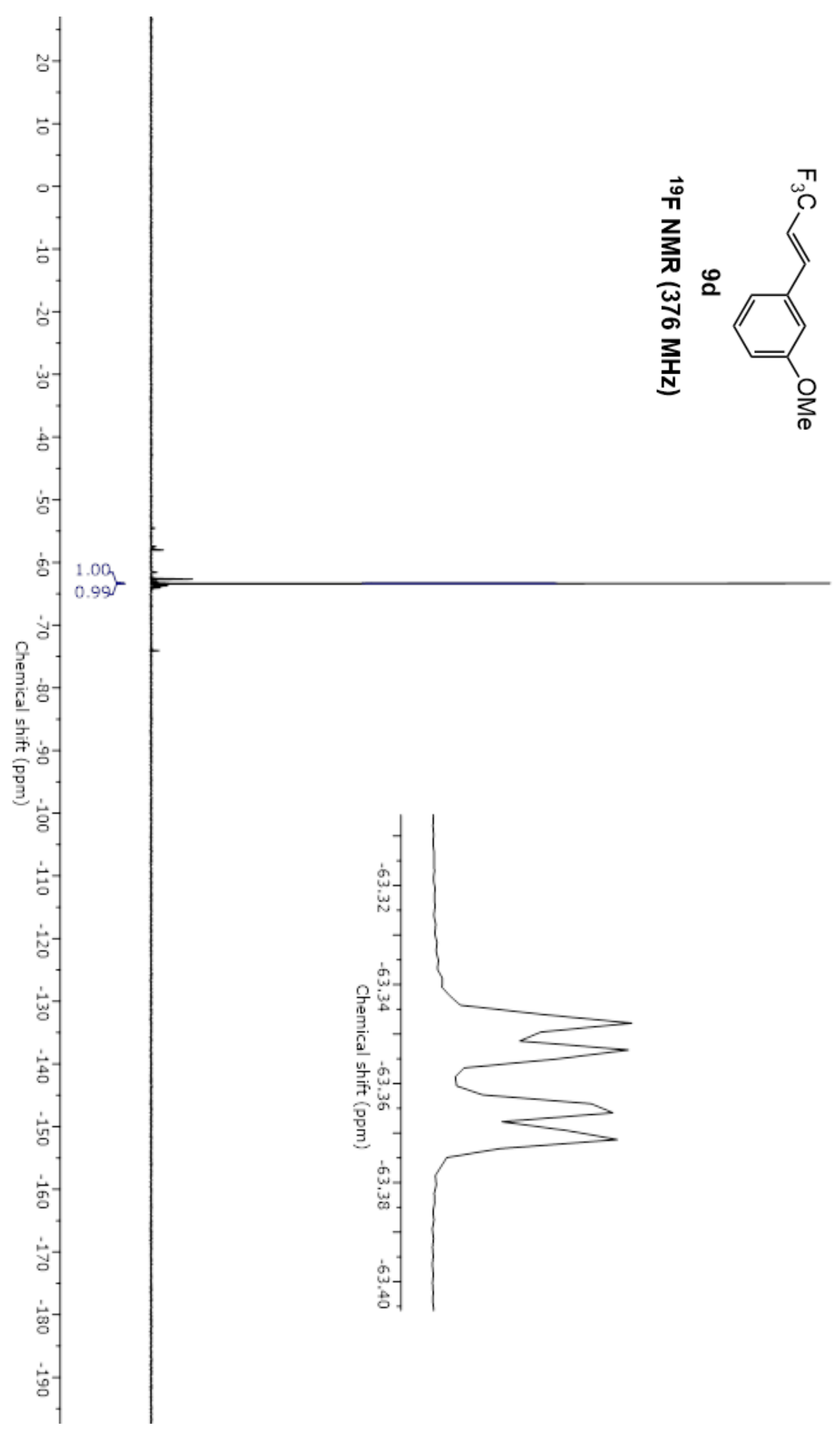




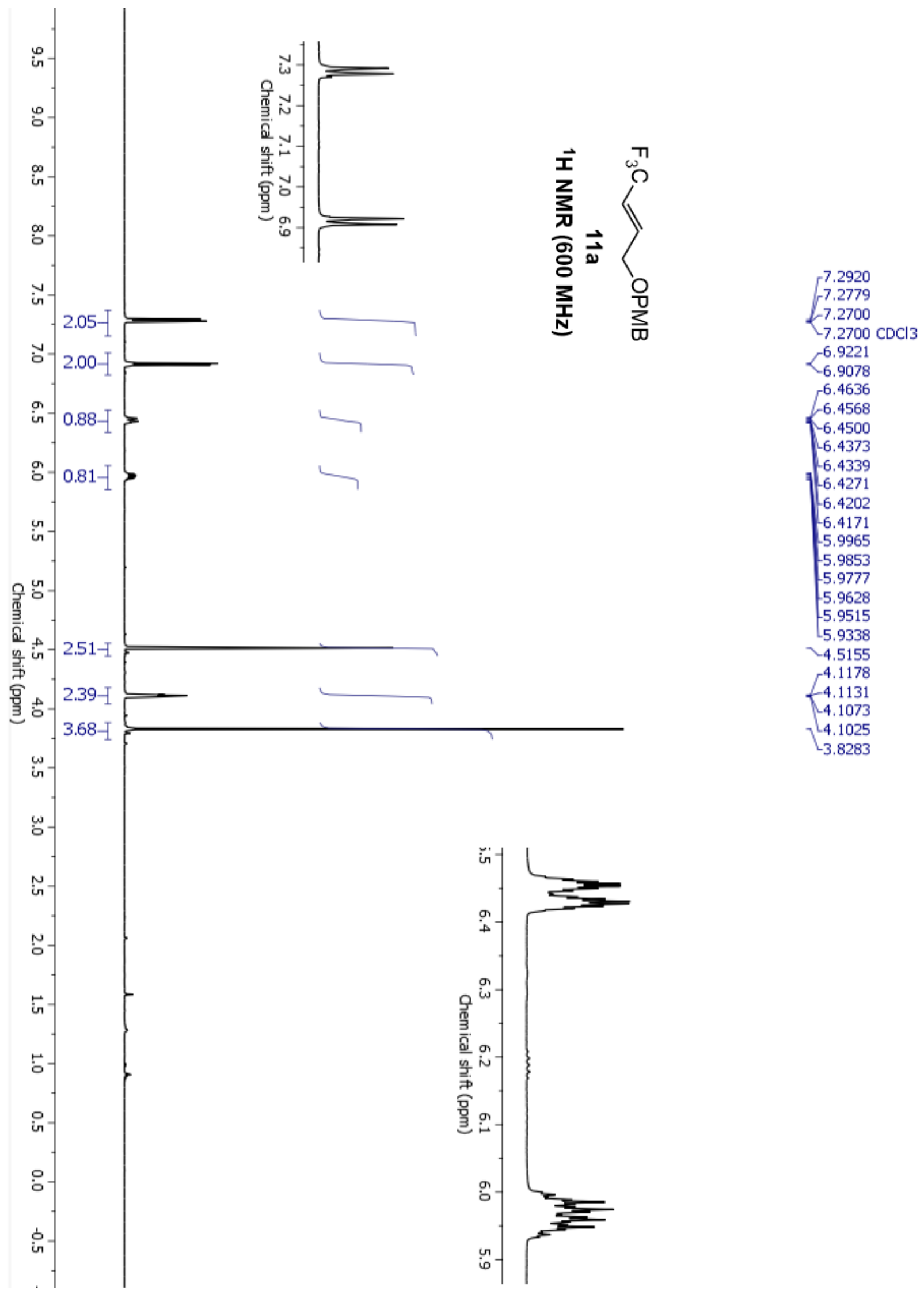


Paioti, et al.; Supporting Information, Part I; Page S236

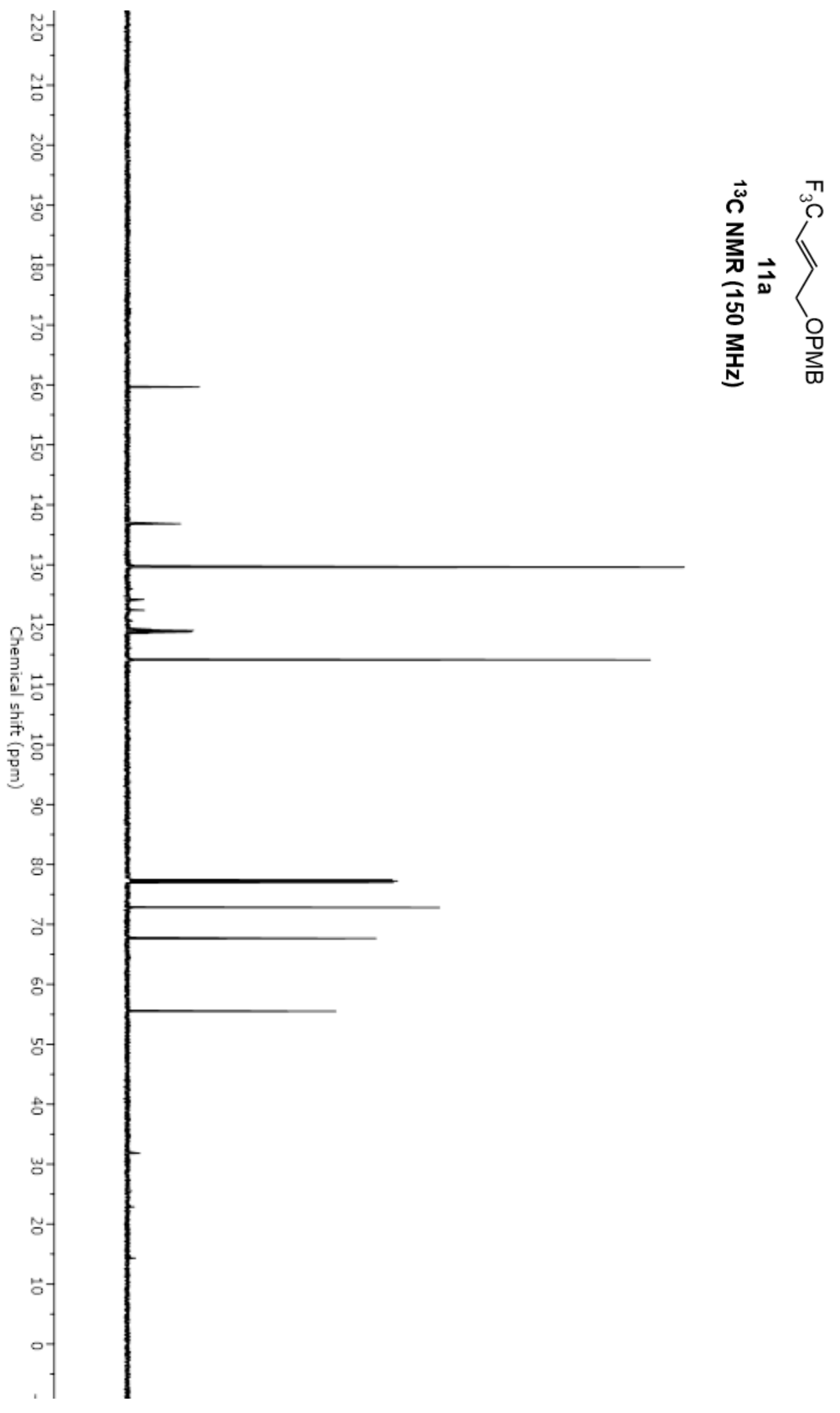


Paioti, et al.; Supporting Information, Part I; Page S237

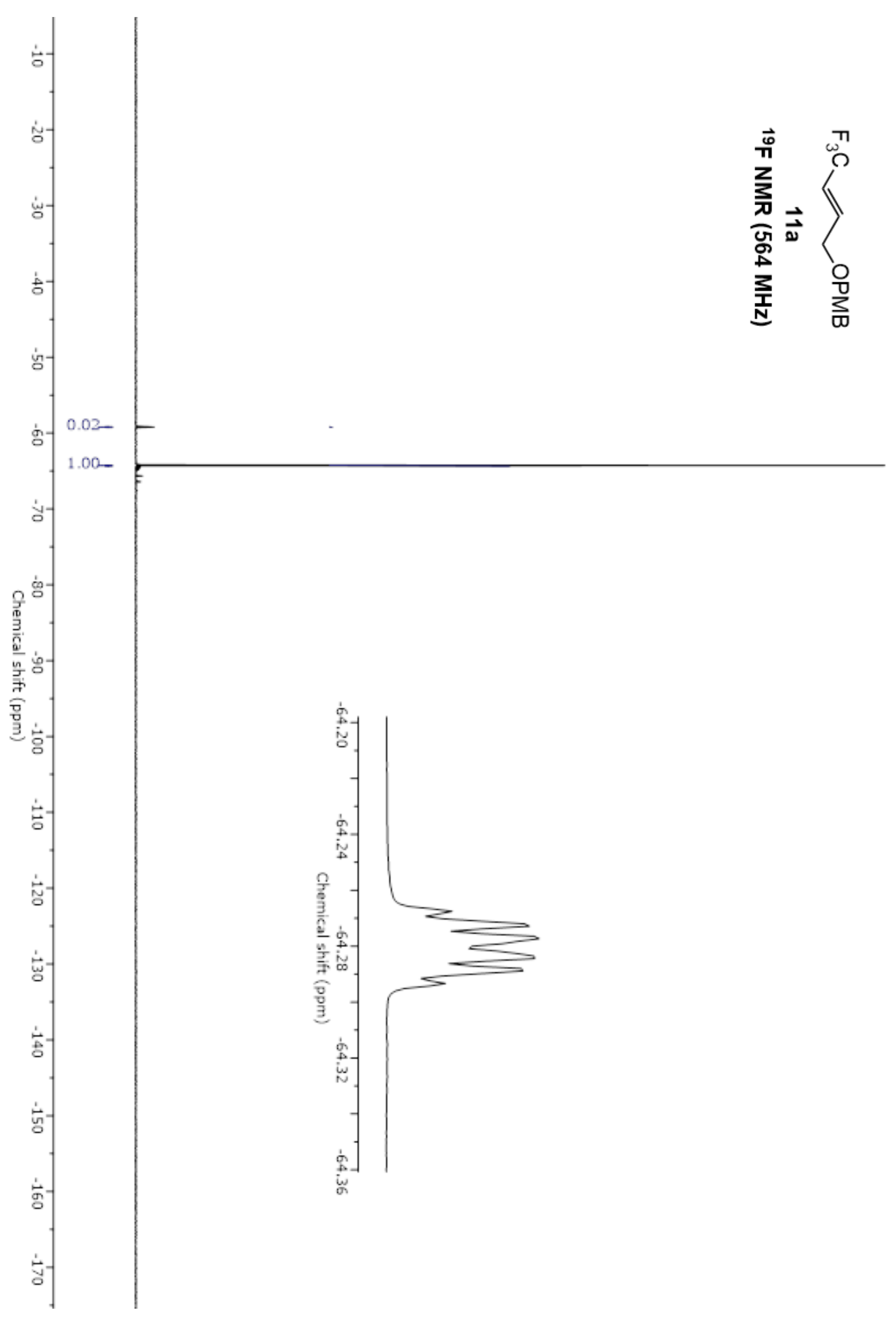




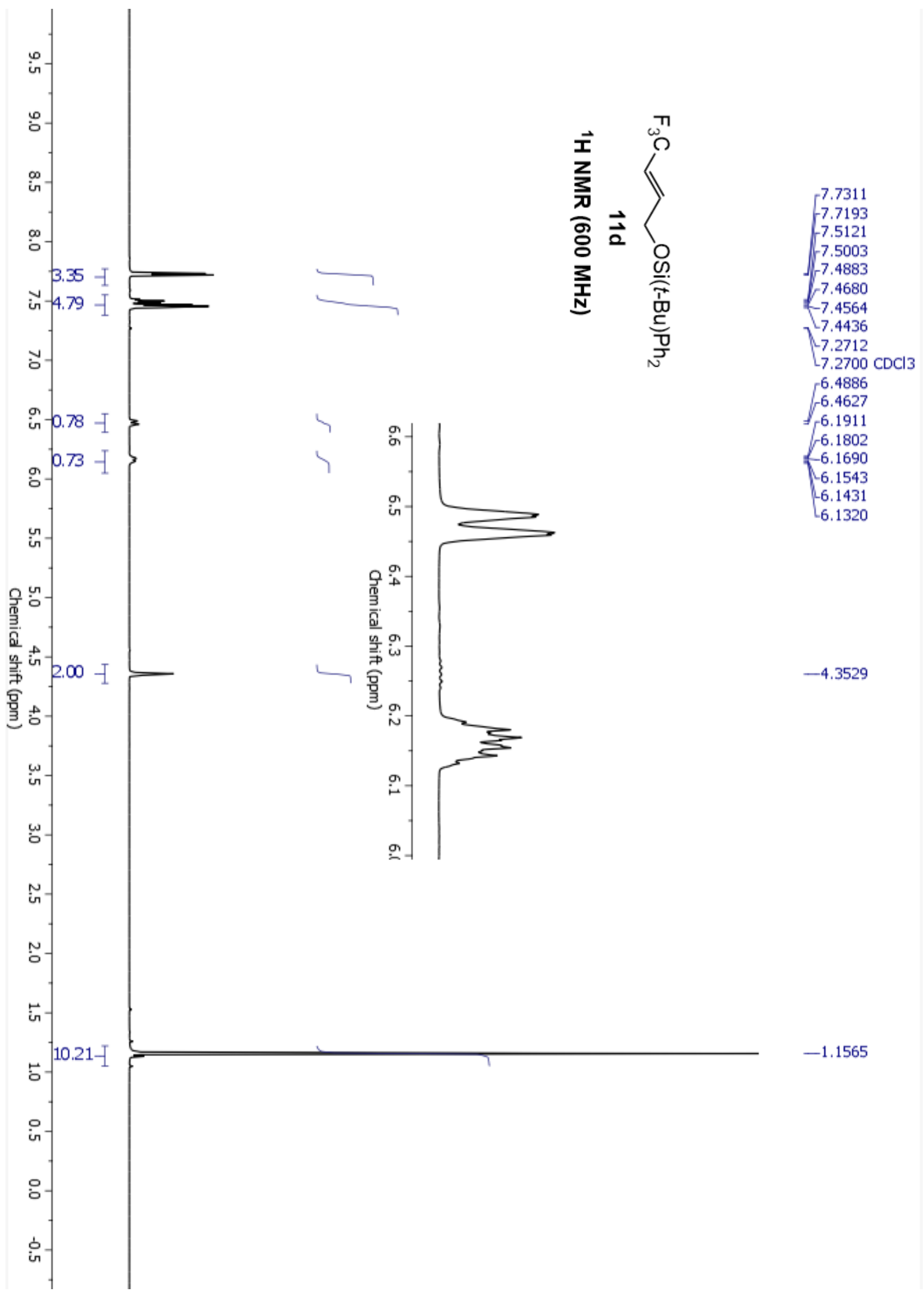


Paioti, et al.; Supporting Information, Part I; Page S239

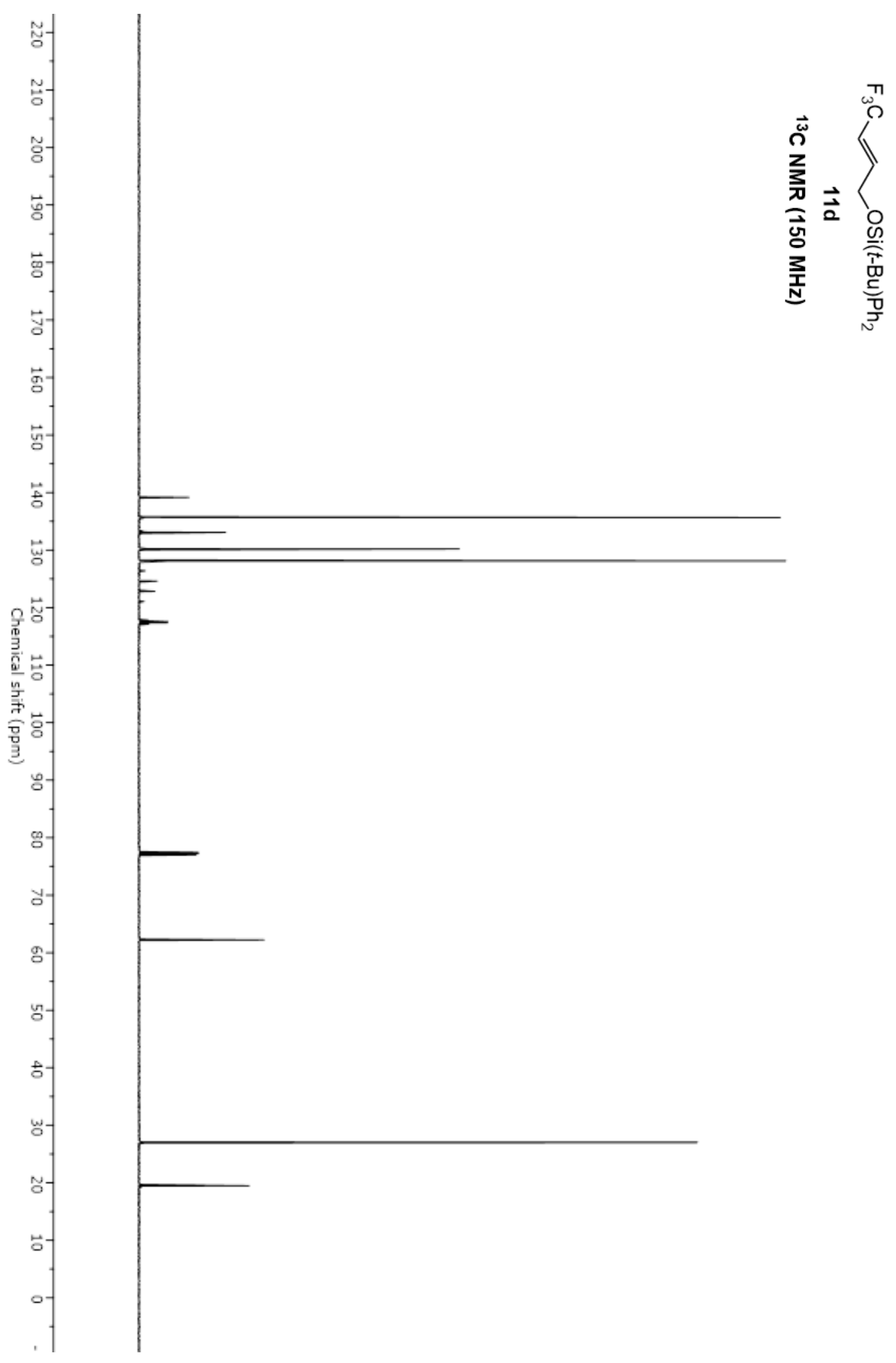




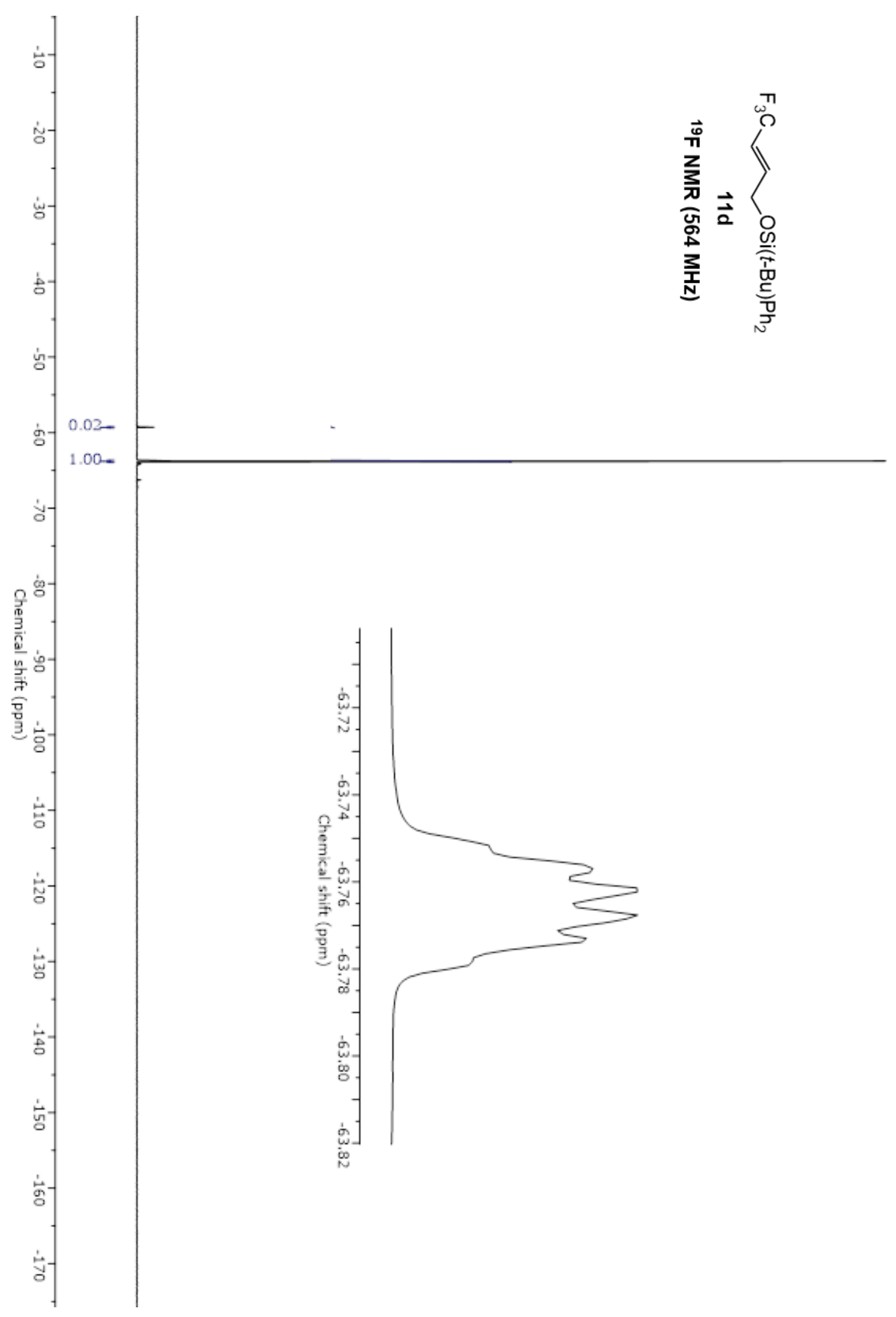




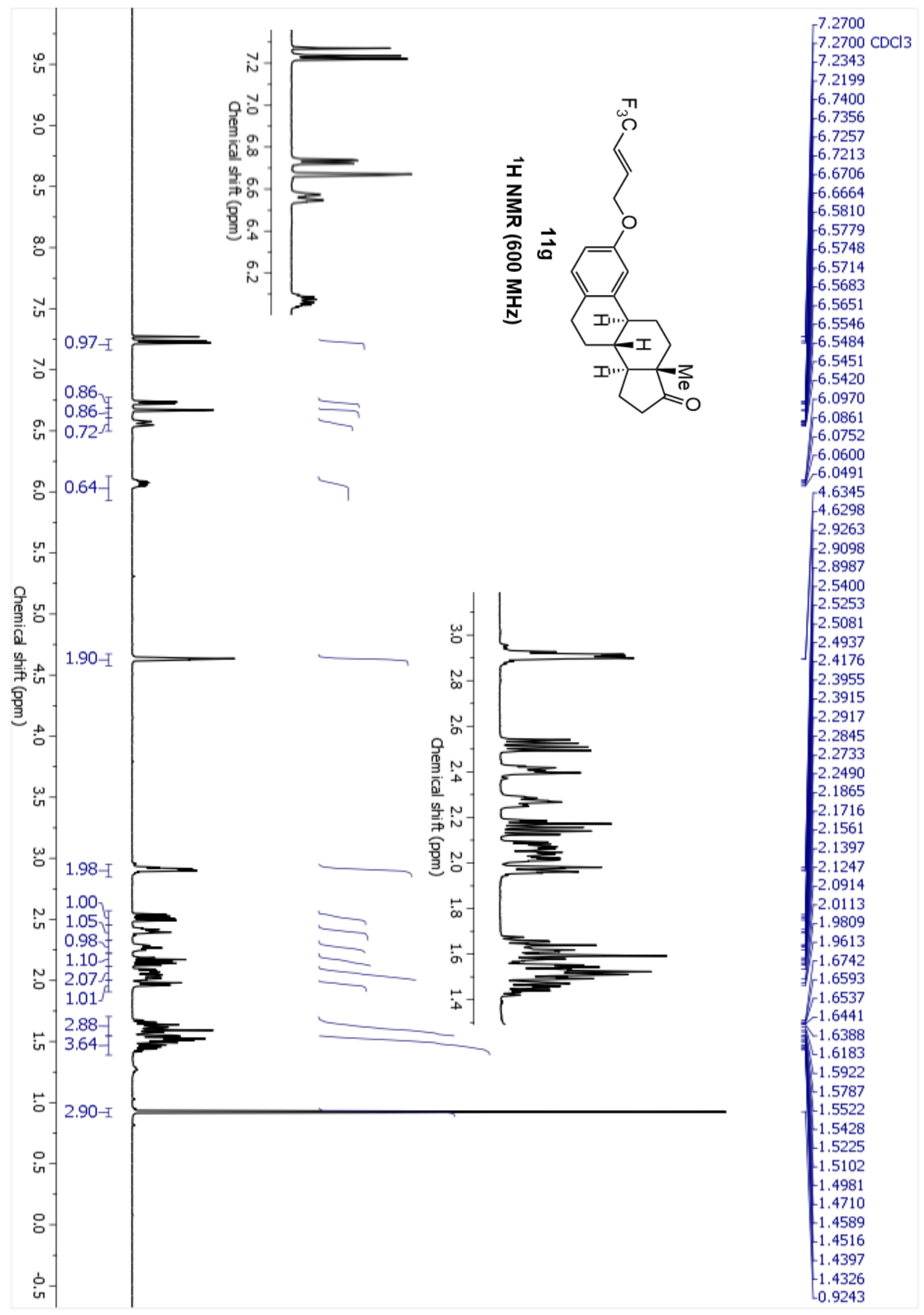


Paioti, et al.; Supporting Information, Part I; Page S242

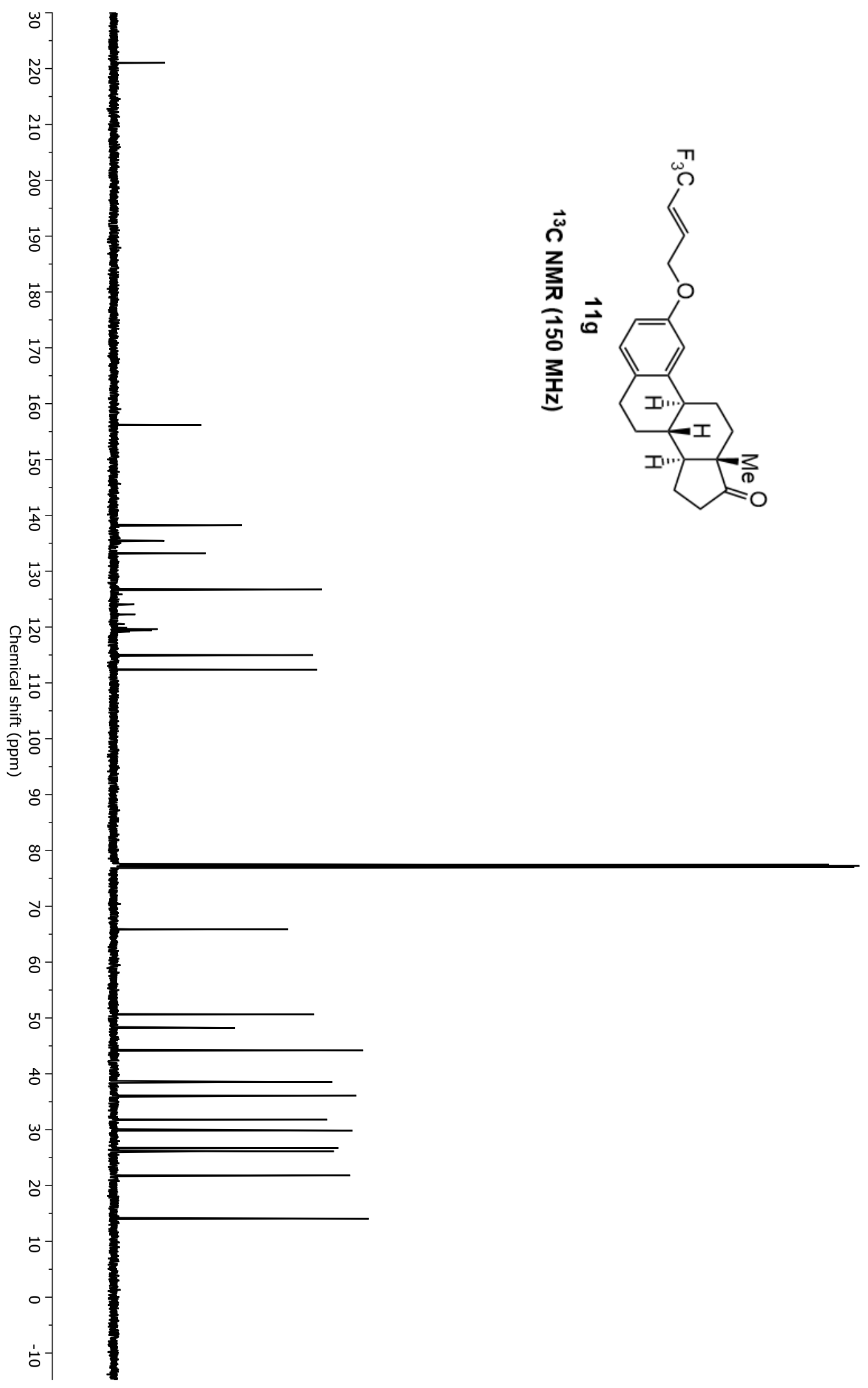


Paioti, et al.; Supporting Information, Part I; Page S243

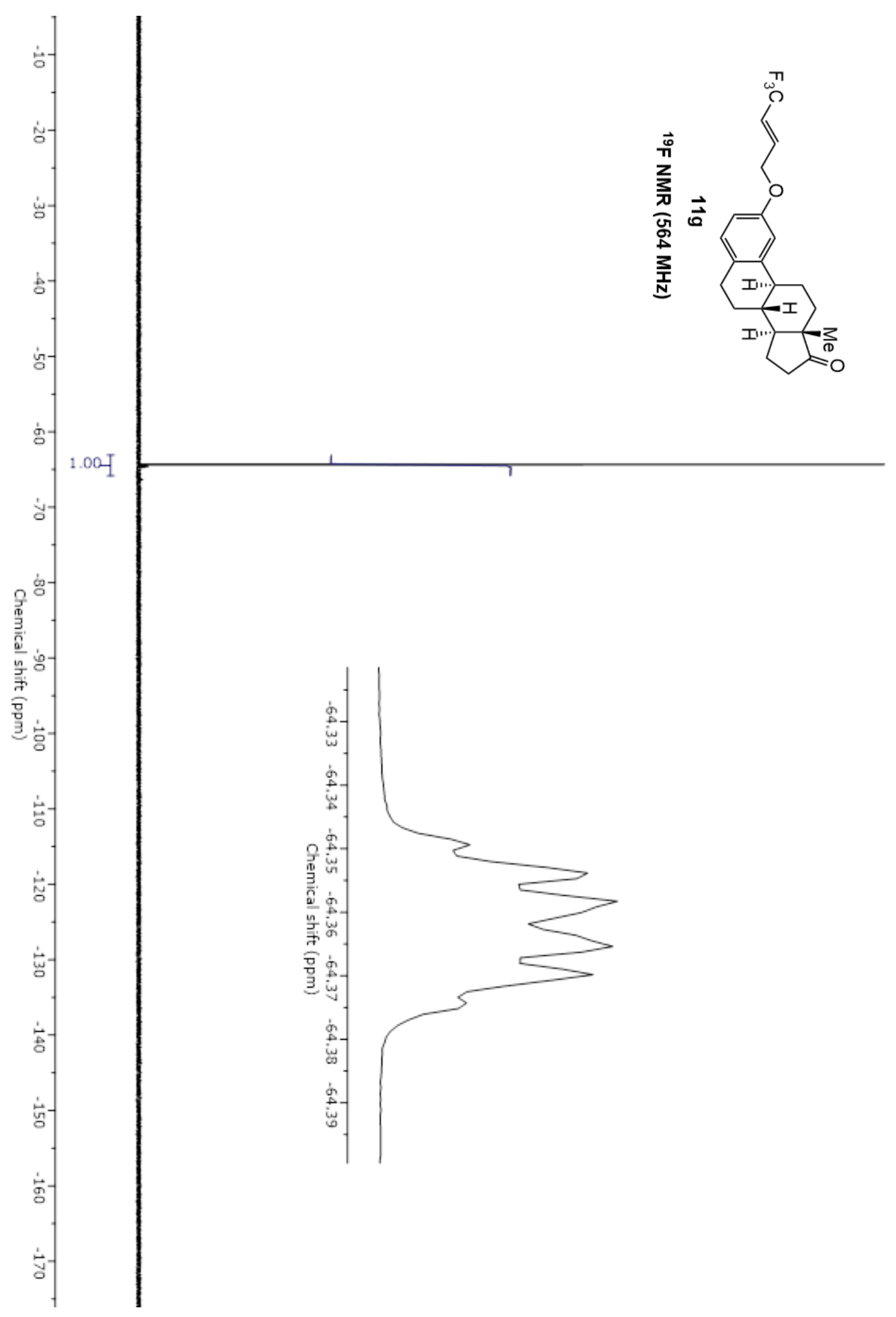




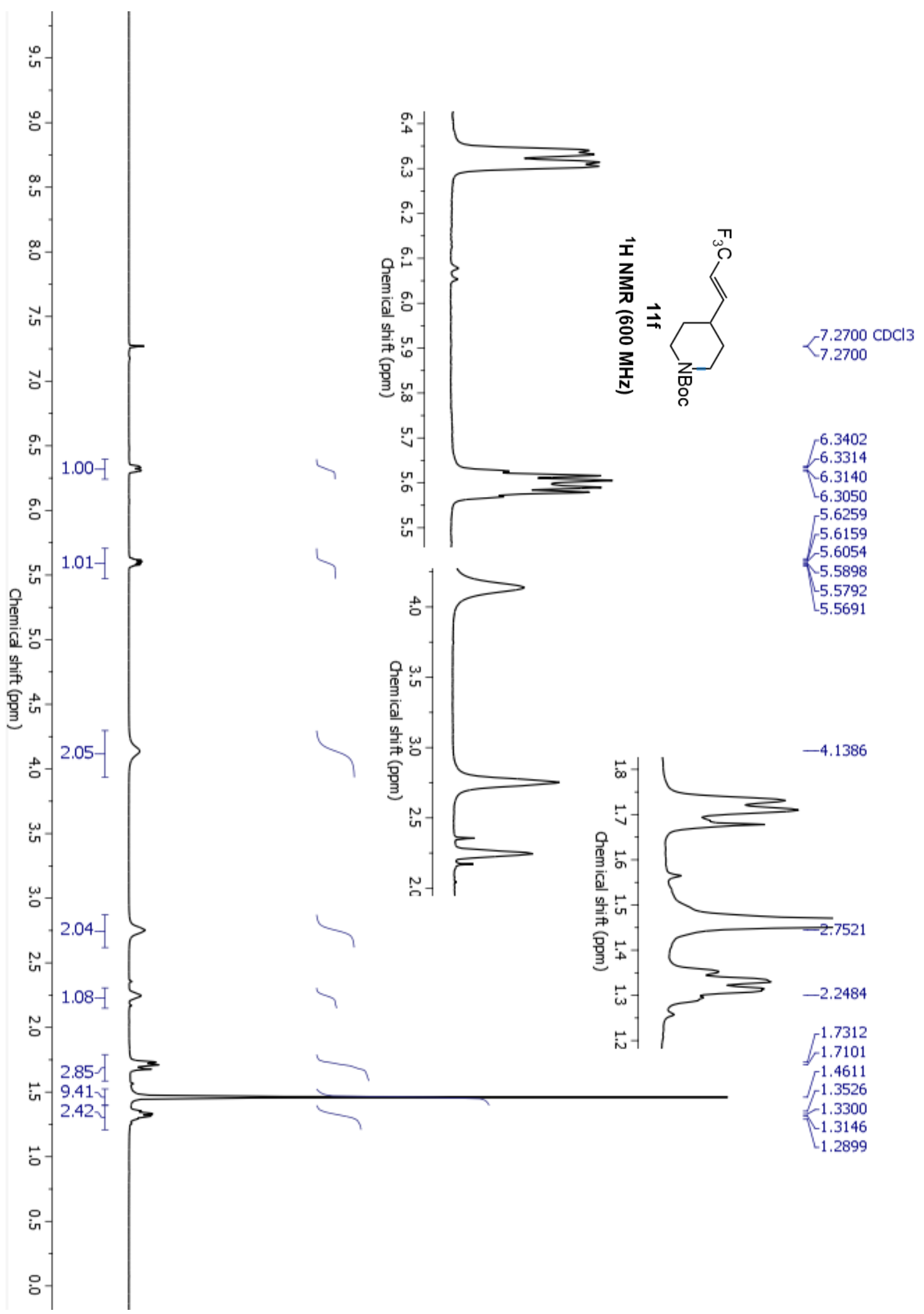


Paioti, et al.; Supporting Information, Part I; Page S245

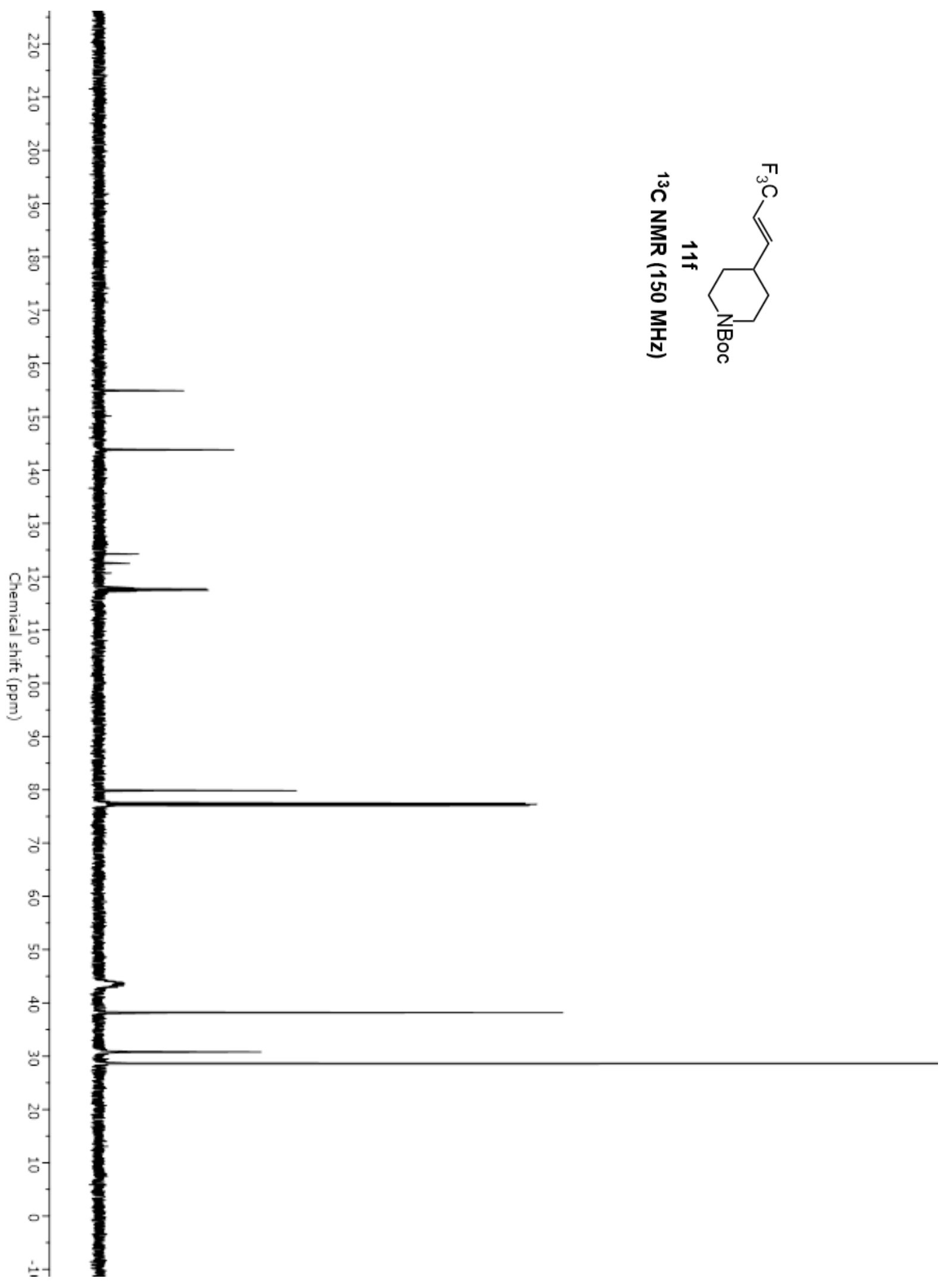


Paioti, et al.; Supporting Information, Part I; Page S246

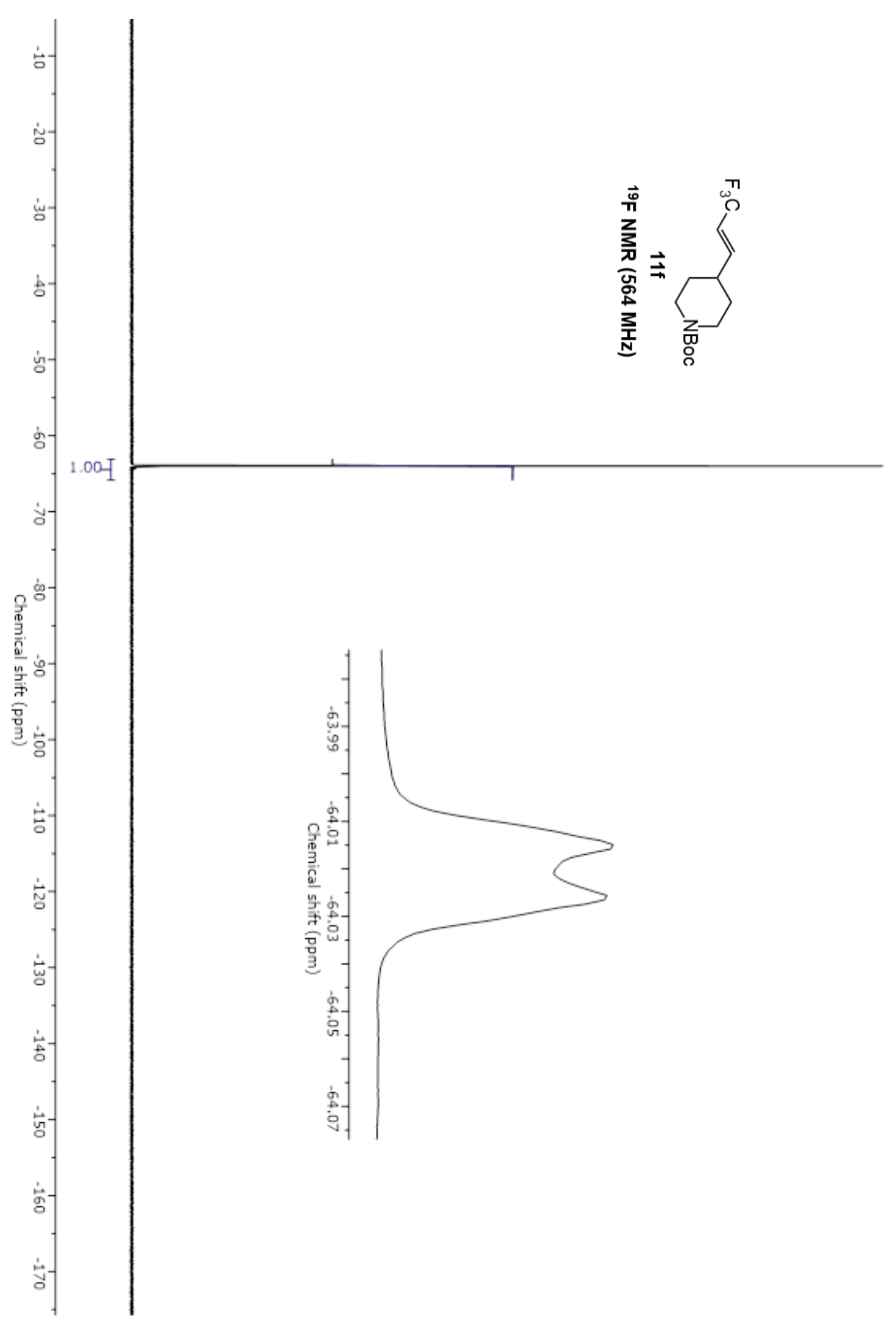




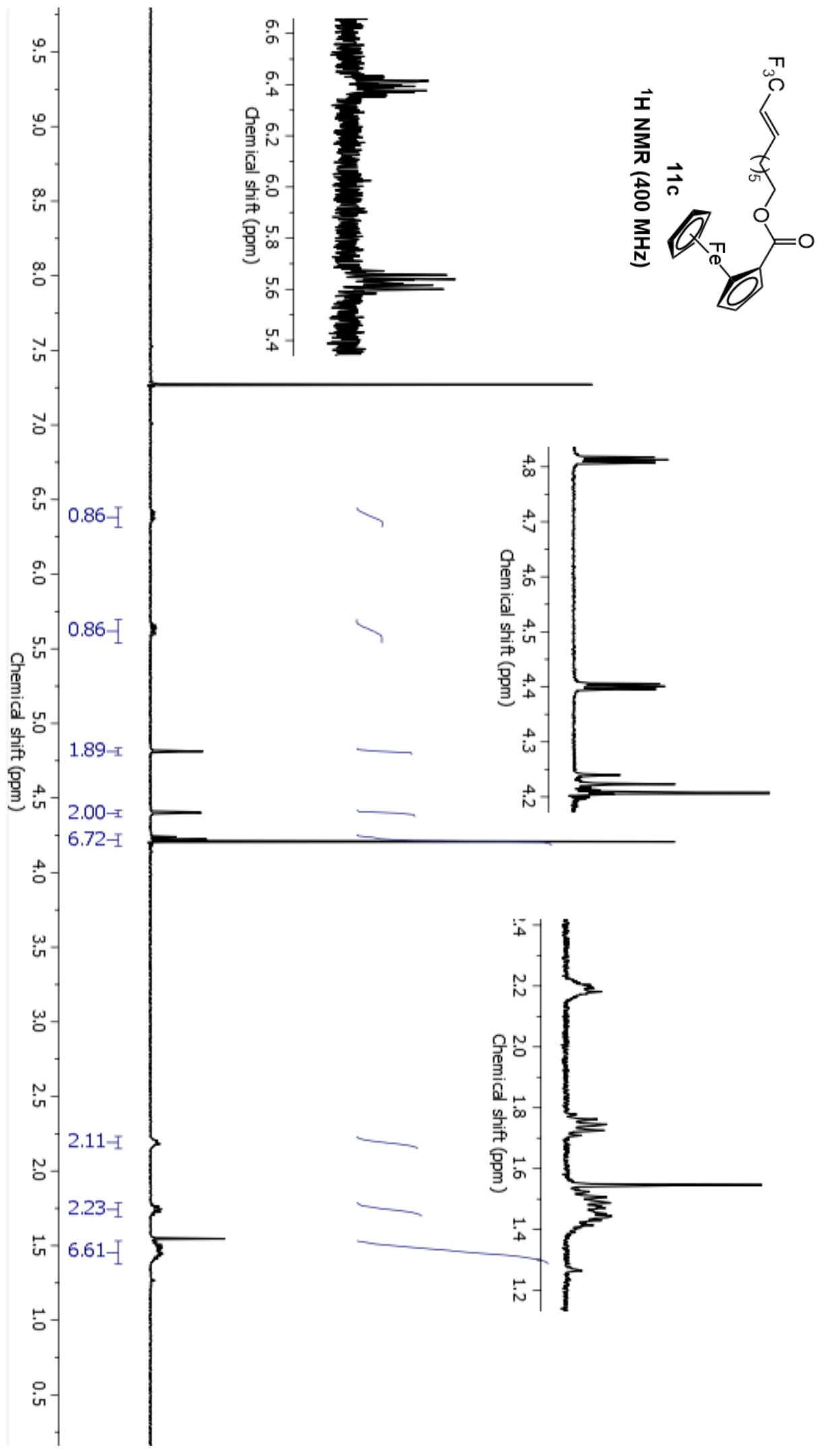

$-7.2700$

$-6.4319$

$-6.4276$

$-6.4220$

$-6.4155$

$-6.4099$

$-6.4044$

$-6.3986$

$-6.3931$

$-6.3874$

$-6.3819$

$-6.3759$

6.3707

$-6.3663$

$-6.3593$

6.3531

5.6716

5.6595

$-5.6556$

5.6514

$-5.6435$

$-5.6396$

$-5.6355$

$-5.6198$

$-5.6163$

$-5.6120$

$-5.6044$

$-5.6003$

$-5.5962$

$-5.5844$

$-4.8174$

$-4.8127$

$-4.8076$

$-4.4057$

$-4.4007$

$-4.3959$

$-4.2397$

$-4.2231$

$-4.2172$

$-4.2142$

$-4.2049$

$-4.2015$

$-4.2000$

4. 4.1952

$-2.2057$

2.1581

$-1.7793$

$-1.7620$

$-1.7453$

$-1.7254$

$-1.7079$

$-1.5307$

1.4036 


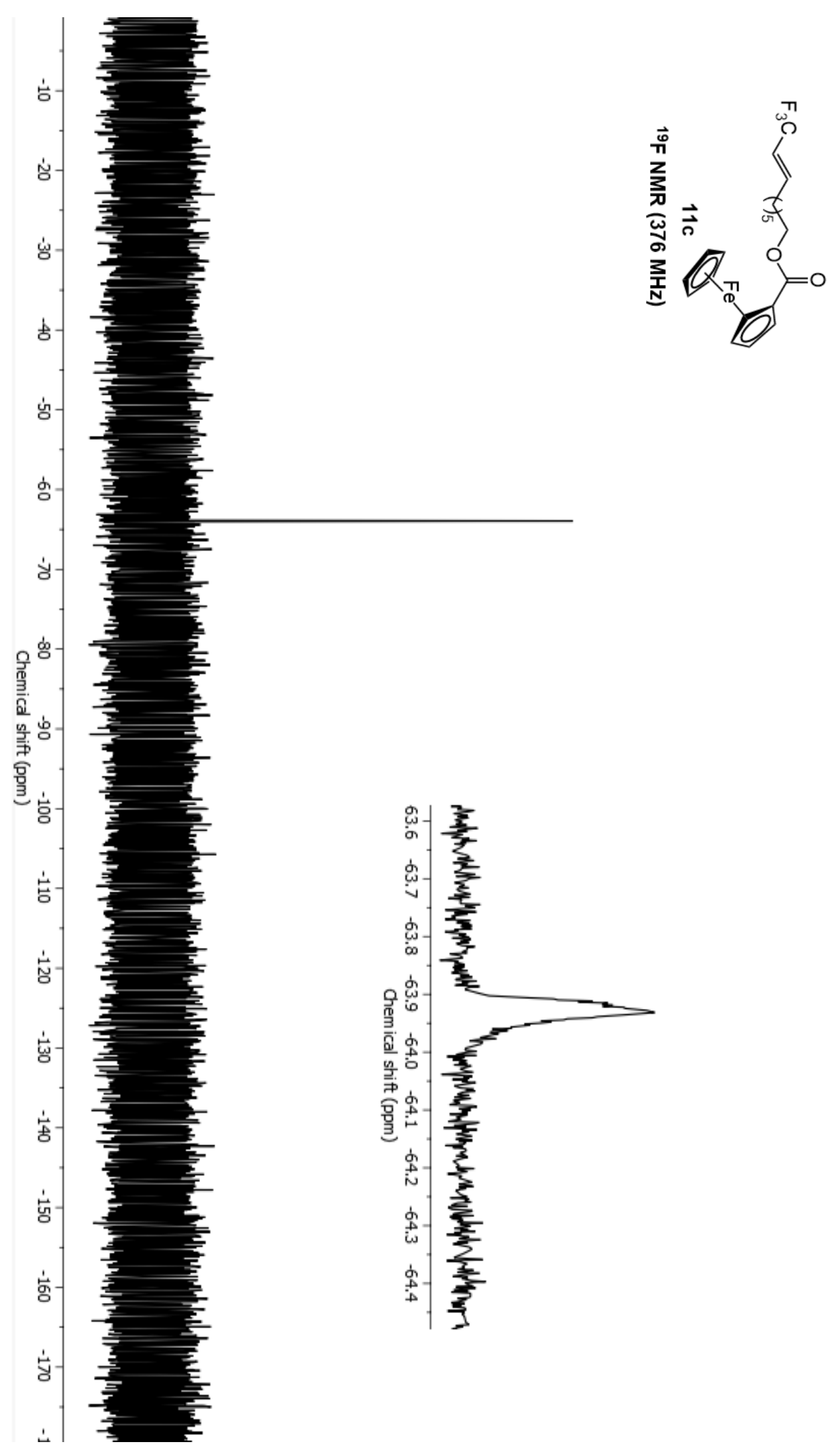


Paioti, et al.; Supporting Information, Part I; Page S249

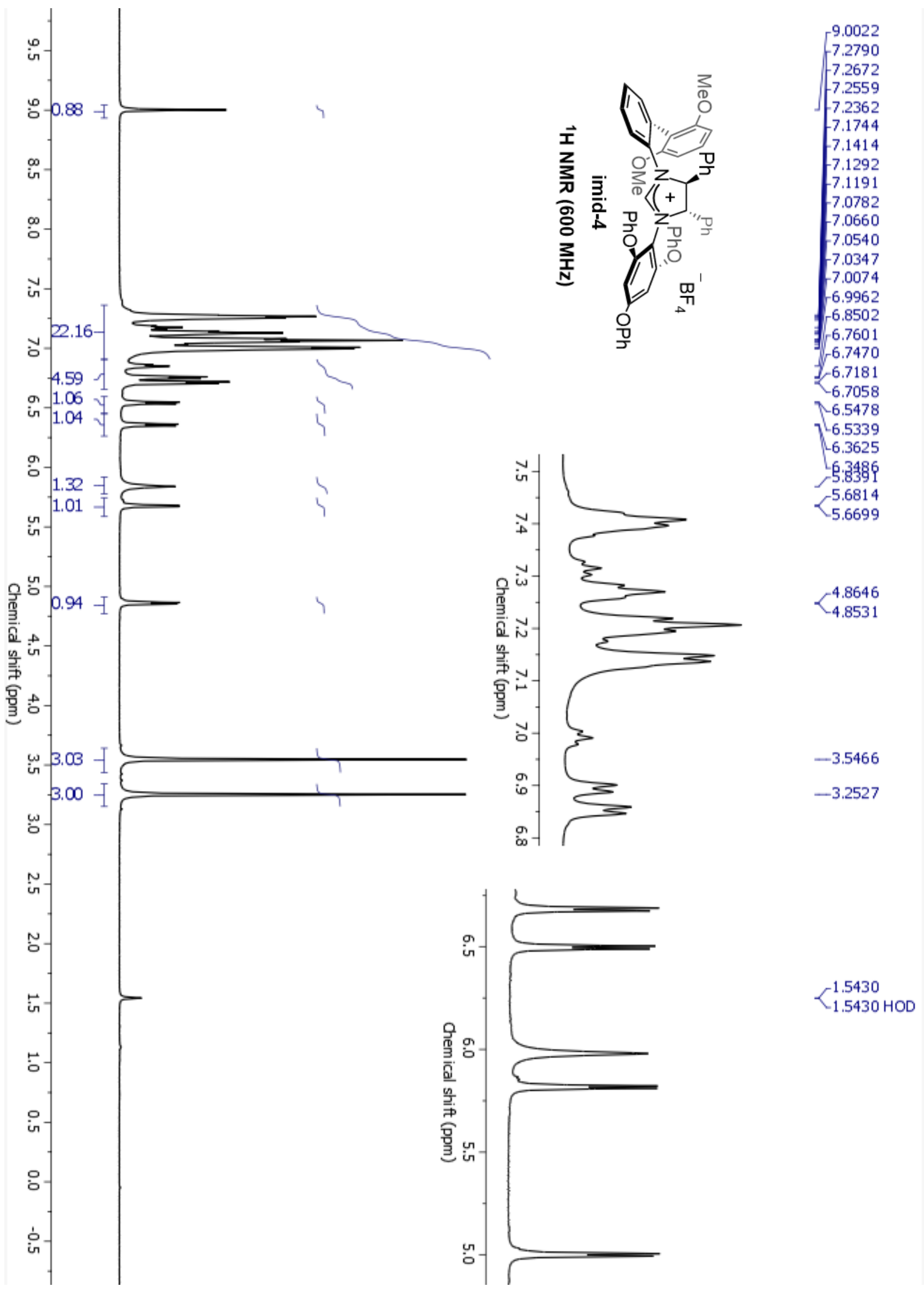


Paioti, et al.; Supporting Information, Part I; Page S250

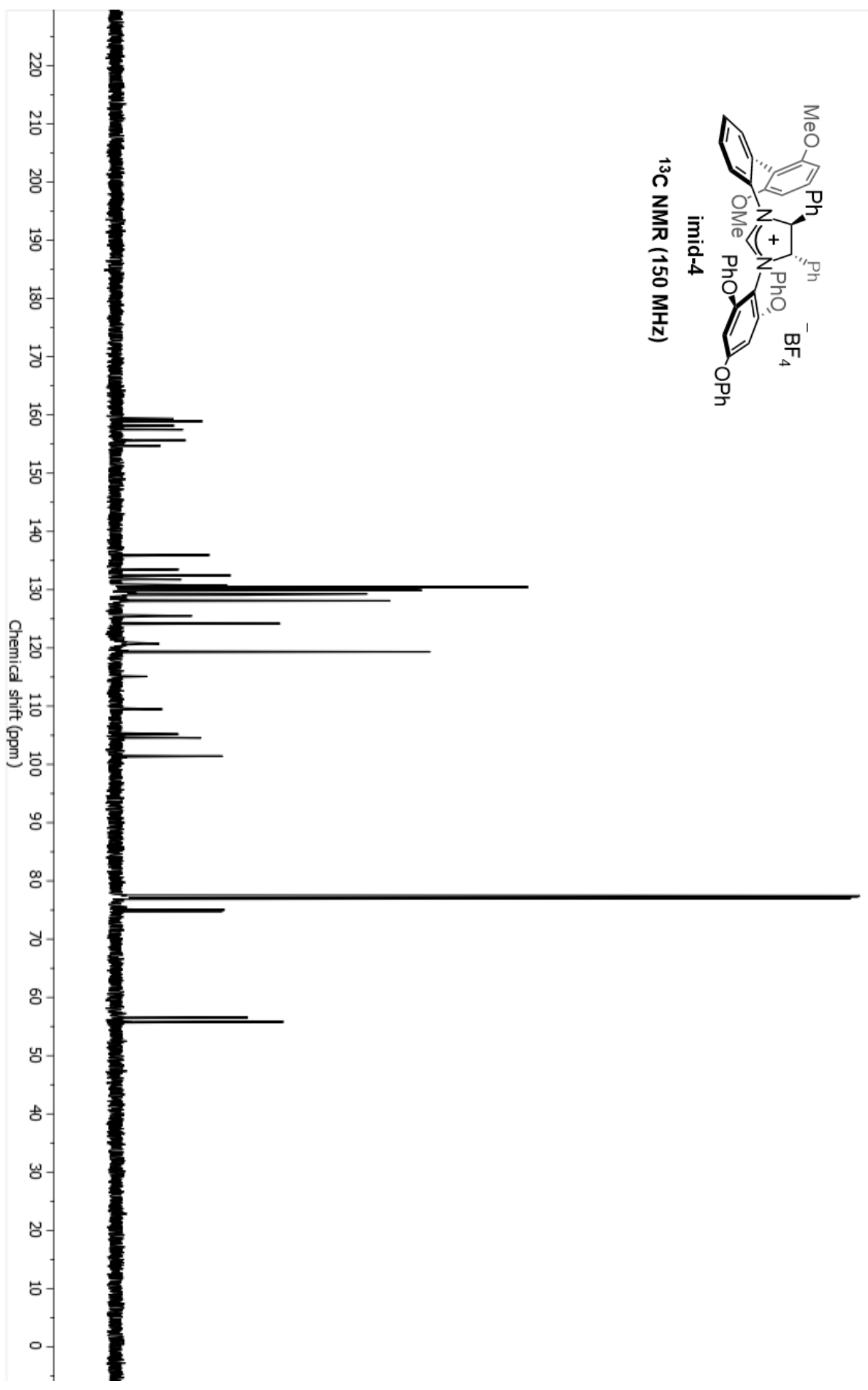




\section{References}

(1) Omote, M.; Tanaka, M.; Ikeda, A.; Nomura, S.; Tarui, A.; Sato, K.; Ando, A. Simple synthesis of $\beta$ trifluoromethylstyrenes using (E)-trimethyl-(3,3,3-trifluoroprop-1-enyl)silane. Org. Lett. 2012, 14, 2286-2289.

(2) Kathiravan, S.; Nicholls, I. A. Palladium catalyzed vinyltrifluoromethylation of aryl halides through decarboxylative cross-coupling with 2-(trifluoromethyl)acrylic acid. Org. Lett. 2015, 17, 1874-1877.

(3) (a) Wang, P.; Pu, X.; Zhao, Y.; Wang, P.; Li, Z.; Zhu, C.; Shi, Z. Enantioselective copper-catalyzed defluoroalkylation using arylboronate-activated alkyl Grignard reagents. J. Am. Chem. Soc. 2018, 140, 9061-9065. (b) Yin, J.; Li, Y.; Zhang, R.; Jin, K.; Duan, C. Copper/silver-mediated decarboxylative trifluoromethylation of $\alpha, \beta$-unsaturated carboxylic acids with $\mathrm{CF}_{3} \mathrm{SO}_{2} \mathrm{Na}$. Synthesis 2014, 46, 607-612.

(4) (a) Coombs, J. R.; Zhang, L.; Morken, J. P. Synthesis of vinyl boronates from aldehydes by a practical boronwittig reaction. Org. Lett. 2015, 17, 1708. (b) Morimoto, H.; Tsubogo, T.; Litvinas, N. D.; Hartwig J. F. A broadly applicable copper reagent for trifluoromethylations and perfluoroalkylations of aryl iodides and bromides. Angew. Chem., Int. Ed. 2011, 50, 3793-3798.

(5) Pereira, S.; Srebnik, M. Hydroboration of Alkynes with Pinacolborane Catalyzed by $\mathrm{HZrCp} \mathrm{Cl}_{2} \mathrm{Cl}$ Organometallics. 1995, 14, 3127.

(6) Hemelaere, R.; Desroches, J.; Paquin, J.-F. Introduction of the 4,4,4-trifluorobut-2-ene chain exploiting a regioselective Tsuji-Trost reaction catalyzed by palladium nanoparticles. Org. Lett., 2015, 17, 1770-1773.

(7) Copper-alkoxide complexes were prepared according to a previously disclosed procedure. See: Uehling, M. R.; Suess, A. M.; Lalic, G. Copper-catalyzed hydroalkylation of terminal alkynes. J. Am. Chem. Soc. 2015, 137, $1424-1427$.

(8) Kojima, R. Akiyama, S.; Ito, H. A copper(I)-catalyzed enantioselective $\gamma$-boryl substitution of trifluoromethylsubstituted alkenes: synthesis of enantioenriched $\gamma, \gamma$-difluoroallylboronates. Angew. Chem.; Int. Ed. 2018, 57 , $7196-7199$. 